\title{
ResearchOnline@JCU
}

This file is part of the following reference:

Webb, Adam Douglas (2003) From banded iron-

formation to iron ore: geochemical and mineralogical constraints from across the Hamersley Province, Western Australia. PhD thesis, James Cook University.

Access to this file is available from:

http://researchonline.jcu.edu.au/34808/

If you believe that this work constitutes a copyright infringement, please contact ResearchOnline@jcu.edu.au and quote http://researchonline.jcu.edu.au/34808/ 
FROM BANDED IRON-FORMATION TO IRON ORE: GEOCHEMICAL AND MINERALOGICAL CONSTRAINTS FROM ACROSS THE HAMERSLEY PROVINCE, WESTERN AUSTRALIA

Thesis submitted by

Adam Douglas Webb BSc (Hons) (UNSW)

in June 2003

For the degree of Doctor of Philosophy

in the School of Earth Sciences

James Cook University 


\section{STATEMENT OF ACCESS}

\section{Declaration}

I, the undersigned, author of this work, understand that James Cook University will make this thesis available for use within the University Library and, via the Australian Digital Theses network, for use elsewhere. I understand that, as an unpublished work, a thesis has significant protection under the Copyright Act and I do not wish to place any further restriction on access to this work.

Adam Douglas Webb

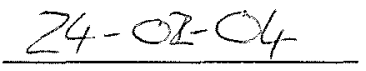

Date 


\section{ELECTRONIC COPY}

\section{Declaration}

I, the undersigned, the author of this work, declare that the electronic copy of this thesis provided to the James Cook University Library is an accurate copy of the print thesis submitted, within the limits of the technology available.

Adam Douglas Webb

$24-02-04$

Date 


\section{STATEMENT OF SOURCES}

\section{Declaration}

I declare that this thesis is my own work and has not been submitted in any form for another degree or diploma at any university or other institution of tertiary education. Information derived from the published or unpublished work of others has been acknowledged in the text and a list of references is given.

Adam Douglas Webb

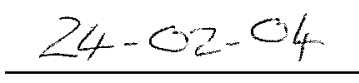

Date 


\section{ABSTRACT}

Three giant iron ore deposits - Mt. Whaleback, Mt. Tom Price and Paraburdoo occur in deformed parts of the southern Hamersley Province, where banded ironformation (BIF) of the Dales Gorge Member has been has been converted to martite and microplaty hematite. The genesis of these high-grade hematite ores has remained controversial, in part because no study has systematically documented variations on the chemistry and mineralogy of stratigraphically equivalent rocks from undeformed and unmineralized strata in the north, through deformed but unmineralized strata in the south, and into the ore deposits. This study examines the powder colour, chemistry, mineralogy and petrography of 270 samples of the Dales Gorge Member and surrounding shales from several locations across the southeastern Hamersley Province, including Mt. Whaleback.

On the basis of these analyses, samples of BIF and shale can each be categorized into four groups. Unaltered BIF consists of sub-equal portions of $\mathrm{SiO}_{2}$ and $\mathrm{Fe}_{2} \mathrm{O}_{3}$ and moderate amounts of $\mathrm{MgO}, \mathrm{CaO}$ and loss on ignition (LOI). Compared to these rocks, weathered $\mathrm{BIF}$ has significantly higher $\mathrm{SiO}_{2}$, but lower $\mathrm{MgO}, \mathrm{CaO}$ and LOI. Likewise, oxidized $\mathrm{BIF}$ from Mt. Whaleback has lower $\mathrm{MgO}, \mathrm{CaO}$ and LOI, but interestingly it has higher $\mathrm{Fe}_{2} \mathrm{O}_{3}$ than unaltered $\mathrm{BIF}$. In striking contrast to all $\mathrm{BIF}$, iron ore is relatively enriched in $\mathrm{Fe}_{2} \mathrm{O}_{3}$ and depleted in all other major elements particularly $\mathrm{SiO}_{2}$.

As for chemistry, the mineralogy of BIF varies significantly across the Hamersley Province. Unaltered BIF is largely composed of fine-grained chert and euhedral magnetite, although fine-grained siderite, stilpnomelane, ankerite, dolomite, minnesotaite, and riebeckite are significant in some samples. Weathered BIF contains hematite instead of magnetite (martite) and goethite pseudomorphs of carbonates and silicates. Chert remains unaltered. Oxidized BIF from Mt. Whaleback similarly consists of martite and chert, however it does not contain any goethite. Instead these rocks contain abundant microplaty hematite nucleated on martite euhedra or within small voids left by the dissolution of gangue. In comparison to all BIF, iron ore lacks chert and is composed entirely of martite in a porous network of microplaty hematite. 
Profound differences in chemistry also occur between shales. Unaltered black shale predominantly consists of $\mathrm{SiO}_{2}$ and $\mathrm{Fe}_{2} \mathrm{O}_{3}$ with relatively high contents of $\mathrm{Al}_{2} \mathrm{O}_{3}$, $\mathrm{MgO}, \mathrm{CaO}, \mathrm{K}_{2} \mathrm{O}$ and LOI. Compared to these rocks altered black shale at Mt. Whaleback has slightly lower $\mathrm{SiO}_{2}$ and $\mathrm{Fe}_{2} \mathrm{O}_{3}$ and significantly higher $\mathrm{Al}_{2} \mathrm{O}_{3}$. Red shale from Mt. Whaleback contains less $\mathrm{SiO}_{2}, \mathrm{MgO}$, and $\mathrm{CaO}$ and higher $\mathrm{Fe}_{2} \mathrm{O}_{3}$ and $\mathrm{Al}_{2} \mathrm{O}_{3}$ than all black shales. In striking contrast to these rocks two Mt. McRae Shale samples from core located deep within the Mt. Whaleback pit are significantly enriched in $\mathrm{MgO}$ and $\mathrm{CaO}$ and depleted in $\mathrm{SiO}_{2}$.

Unaltered black shales have highly variable mineralogies, consisting of very finegrained stilpnomelane, K-feldspar and quartz with subordinate amounts of siderite, dolomite, ankerite, muscovite, biotite, pyrite and chlorite. Altered black shales contain abundant chlorite and muscovite instead of stilpnomelane, K-feldspar and carbonates. Red shales are entirely composed of very fine hematite plates and kaolinite. The two shale samples from deep within the Mt. Whaleback pit consist predominantly of fine- to medium-grained dolomite cut by numerous chlorite and ferroan-dolomite/ankerite veins. Spatially associated with many of these veins are large porphyroblasts of finegrained ferroan-dolomite and ankerite.

Profound chemical and mineralogical changes between unaltered rocks and their altered equivalents suggest that after early diagenesis, low-grade metamorphism converted clays in black shales to stilpnomelane and talc. Coincident with, or following these changes, reduced metamorphic fluids altered phyllosilicates and K-feldspar in these rocks to chlorite and muscovite around Mt. Whaleback. These metamorphic fluids did not significantly affect BIF. However, subsequent acidic and oxidizing fluids around Mt. Whaleback converted magnetite to martite and dissolved carbonates and silicates from BIF. In black shales, these fluids also dissolved quartz and converted chlorite and muscovite to hematite and kaolinite respectively. Late in the paragenetic sequence, oxidized BIF was converted to highly porous high-grade hematite ore by the dissolution of silica. Mass and volume change calculations coupled with detailed thickness measurements indicates ore genesis was a process not requiring iron addition. 
However, the significant increase in microplaty hematite growth between oxidized BIF and iron ore suggests $\mathrm{mm}$ - to $\mathrm{cm}$-scale (or m-scale?) mobilization and precipitation of iron. The paragenetic sequence for mineralization is probably more complicated as carbonate-rich, silica-poor shales deep within Mt. Whaleback and previously described magnetite-siderite rich assemblages at Mt. Tom Price suggest a stage involving carbonate replacement of silica prior to oxidation. During or after ore genesis weathered BIF developed from the interaction of unaltered BIF with acidic, oxidizing fluids associated with typical supergene weathering.

An internally consistent and testable model that explains rocks at both deposits, as well as the limited geochemical and mineralogical data at Paraburdoo, can be proposed. Rocks at all three deposits experienced regional metamorphism, although the grade was less at Mt. Tom Price and Paraburdoo. Hydrothermal fluids followed by heated meteoric fluids then locally affected rocks at all three deposits, forming carbonate-rich "BIF and shale" and, ultimately, high-grade hematite ore. Substantial northward flow of acidic, oxygenated fluids sometime during or after mineralization converted BIF, including carbonate-rich "BIF" to altered martite-rich BIF. The distinct lack of abundant carbonate-rich silica-poor rocks at Mt. Whaleback compared to Mt. Tom Price and similarities between oxidized BIF from Mt. Whaleback to equivalent sequences outside the deposit suggest this oxidation was more pervasive in the southeast. It is possible, and likely that formation of these particular giant, martite-microplaty hematite rich deposits was dependent on both a phase of silica loss and a phase of oxidation during or soon after extensional deformation at ca. $2200 \mathrm{Ma}$. Initial access of deepseated silica undersaturated fluids to parts of extensional faults triggering silica loss, may have created initial chemical porosity that subsequently allowed focusing of oxidized, surface-derived fluids. 


\section{ACKNOWLEDGMENTS}

Many people have assisted in the completion of this thesis, and I would like to thank them all for their valuable contributions, both professional and personal.

BHP Billiton Iron Ore is thanked for their extensive field support and unlimited access to data and material at Mt. Whaleback, particularly Simon Hewson, Peter Waters, Mal Kneeshaw, Peter Croft and Mawson Croaker. Sharon Ness, Elvy Grigolato, Darren Mylea, Alan Chappell and Kevin Blake of the James Cook University Advanced Analytical Centre are thanked for their help with XRF, XRD and microprobe analyses. Thanks must also go to Helen Waldron of Becquerel Laboratories for her assistance with Instrumental Neutron Activation analyses and John Bradley of the Geological Survey of Western Australia for access to core DDH-47A. I gratefully acknowledge the financial support of an ARC large grant to N.H.S. Oliver and G.R. Dickens and Australian Institute of Nuclear Sciences and Engineering (AINSE) grants $01 / 204 \mathrm{~S}$ and $02 / 036$ for sponsoring this work.

I am especially indebted to the guidance and help of my supervisors, Jerry Dickens and Nick Oliver, and thank them for the opportunity to undertake this project. Their infectious enthusiasm and unsurpassed dedication as supervisors, as well as their energetic outlook on anything geological was inspirational. Thanks also to the rest of the staff in the School of Earth Sciences for their help and assistance throughout my time at James Cook University.

Special thanks to my friends within the School of Earth Sciences, in particular everyone in EGRU, whom over many years made the whole $\mathrm{PhD}$ experience an enjoyable one. More specifically I would like to thank Matthew Brown for his friendship and for all the great times in the field and Roger Mustard for all things piscatorial. I wish everyone the best for the future. Thanks must also go to my family for their tireless encouragement throughout my whole academic career and for believing that I would get there one day. Finally and most importantly, I thank Annette; your love, support and understanding have been my lifeline and a huge source of motivation. Without doubt you helped me through this. 


\section{TABLE OF CONTENTS}

Statement of access ii

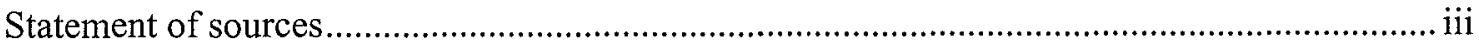

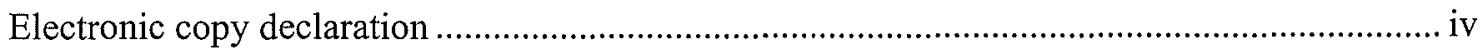

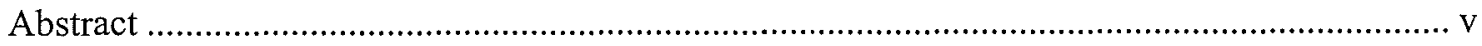

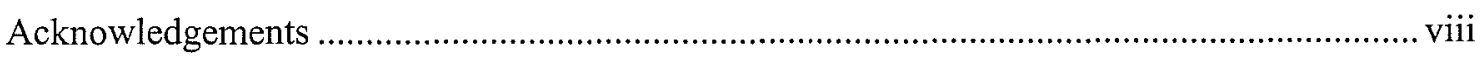

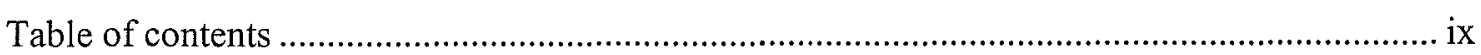

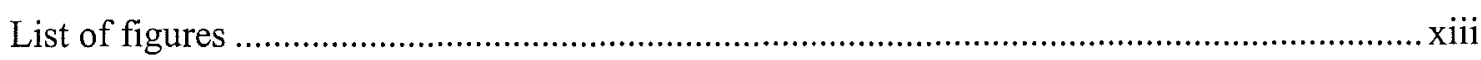

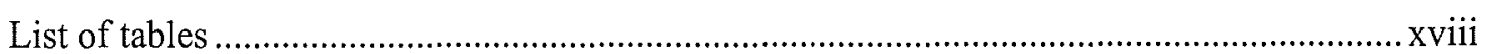

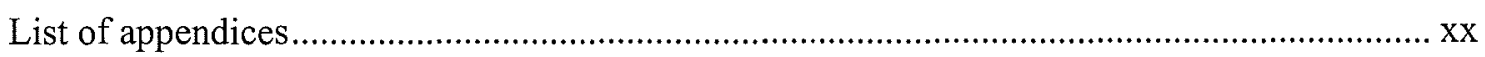

\section{Chapter 1: Introduction}

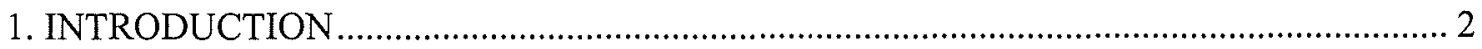

1.1. Martite-microplaty hematite ores of the Hamersley Province............................................ 2

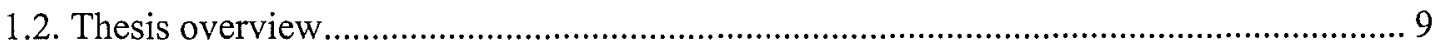

Chapter 2: Major element chemistry and mineralogy of the Proterozoic Dales Gorge Member and surrounding shales at Wittenoom and Mt. Whaleback, Hamersley Province, Western Australia

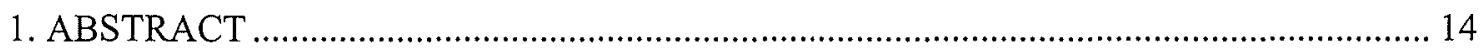

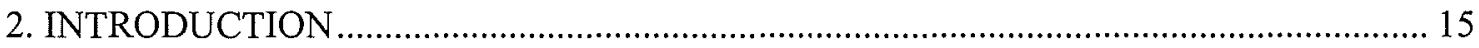

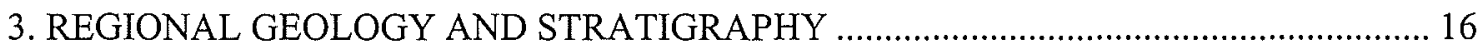

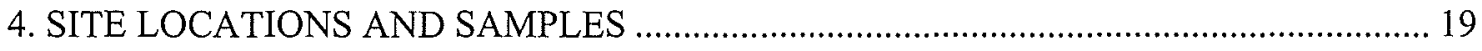

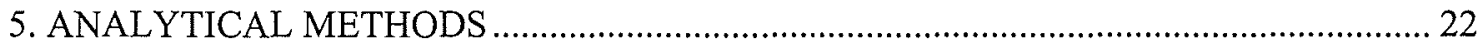

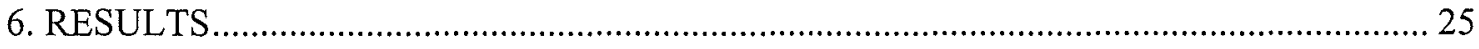

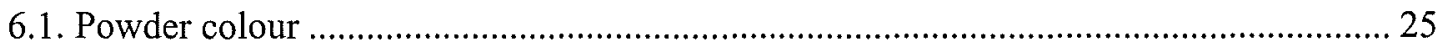

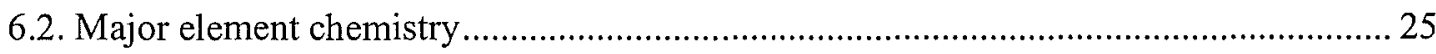

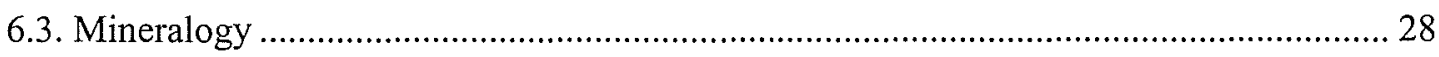

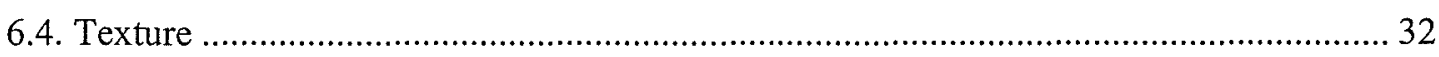

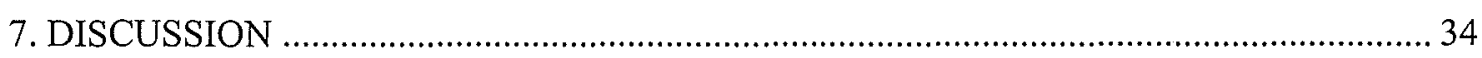

7.1. Chemical comparisons across the Hamersley Province ................................................... 34

7.2. Mineralogical comparisons across the Hamersley Province ……................................... 39

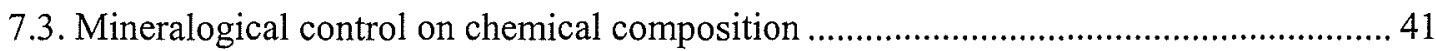


7.4. Causes of chemical and mineralogical variation ............................................................ 44

7.5. Chemical and mineralogical paragenesis ....................................................................... 49

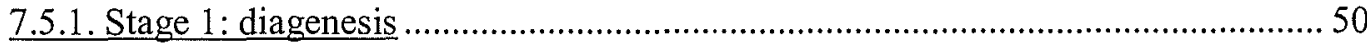

7.5.2. Stage 2: low-grade regional metamorphism.......................................................... 50

7.5.3. Stage 3: medium-grade regional metamorphism ............................................. 51

(black shale to altered black shale)

7.5.4. Stage 4: pervasive oxidation (BIF to altered BIF:...............................................5

altered black shale to red shale)

7.5.5. Stage 5: silica dissolution and microplaty hematite formation ............................ 53 (altered BIF to iron ore)

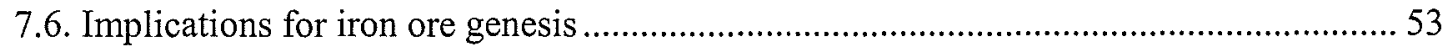

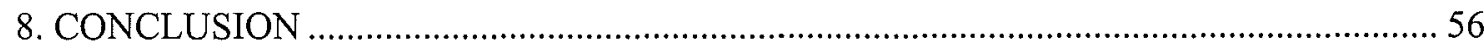

Chapter 3: Oxidation and weathering of banded iron-formation across the Hamersley Province, Western Australia

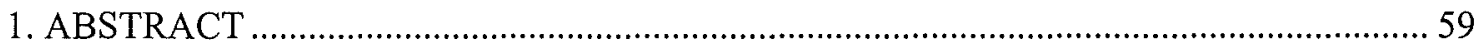

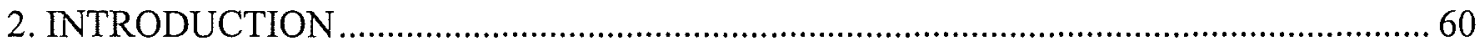

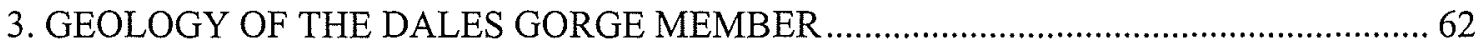

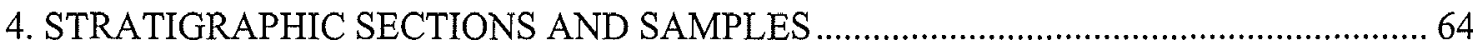

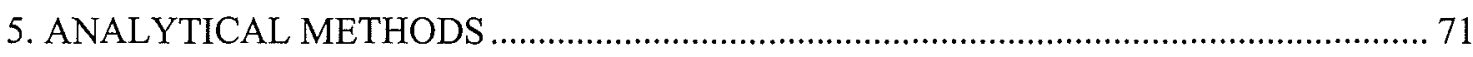

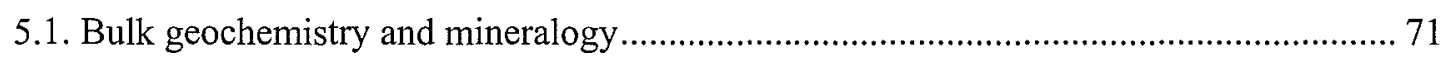

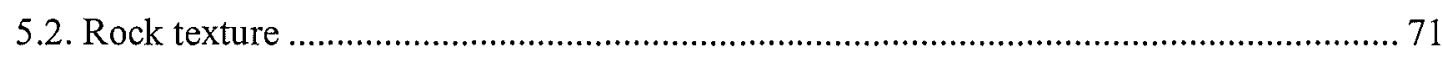

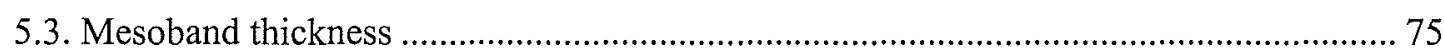

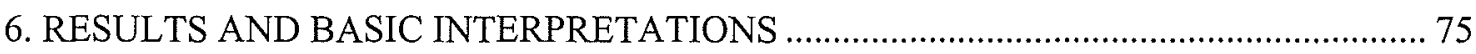

6.1. General BIF variability across the southeastern Hamersley Province ............................ 75

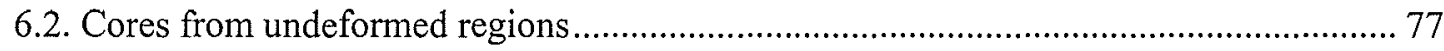

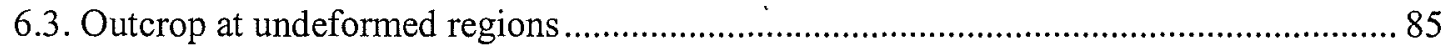

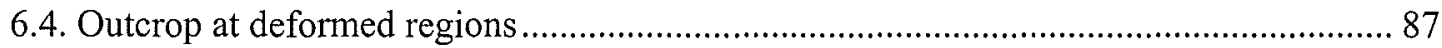

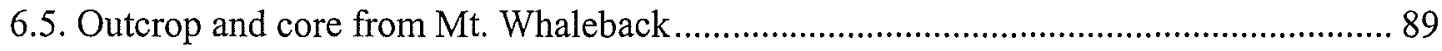

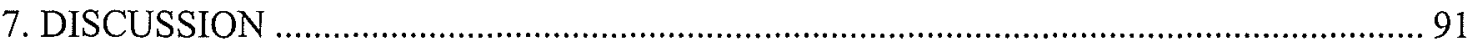

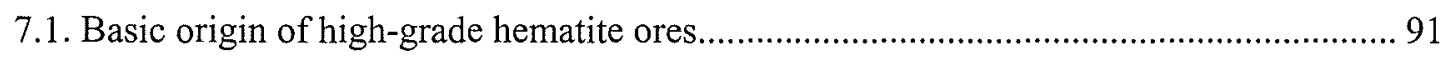

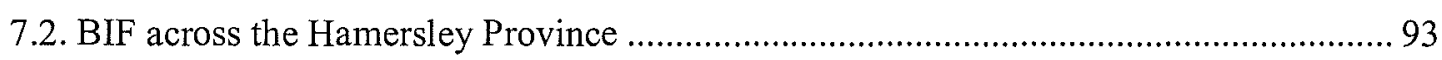

7.3. Possible chemical reactions to explain different BIF across the southeast ..................... 94

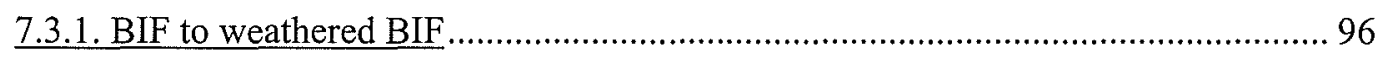

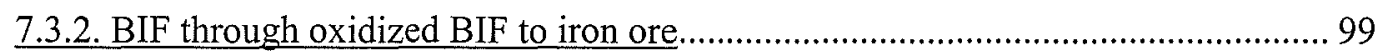

7.4. Fundamental problems with current ore formation models......................................... 102 


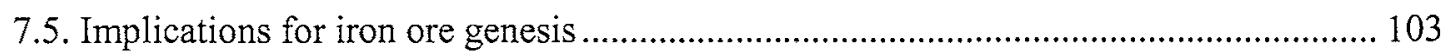

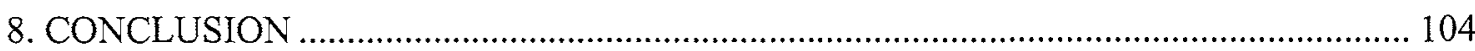

Chapter 4: Carbonate alteration of the upper Mt. McRae Shale beneath the martitemicroplaty hematite ore deposit at Mt. Whaleback, Western Australia

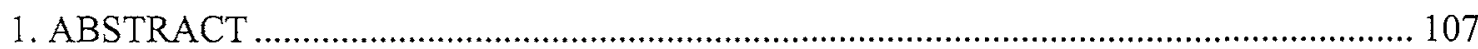

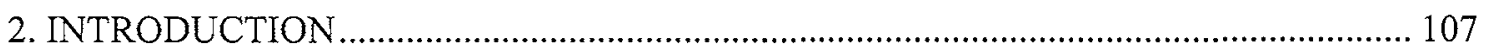

3. GEOLOGICAL BACKGROUND AND CORE DDH-409 ….......................................... 111

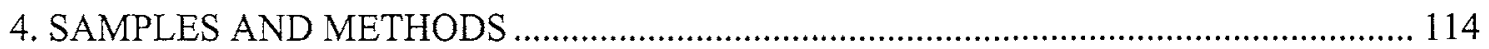

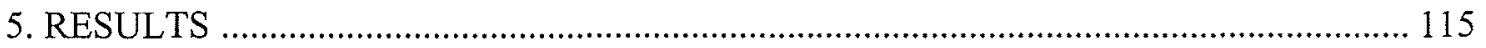

5.1. Bulk chemistry and mineralogy of Mt. McRae Shale in DDH-409 ............................ 115

5.2. Petrography of the Upper Mt. McRae Shale across the Hamersley Province ............... 117

5.3. Chlorite and carbonate composition........................................................................... 125

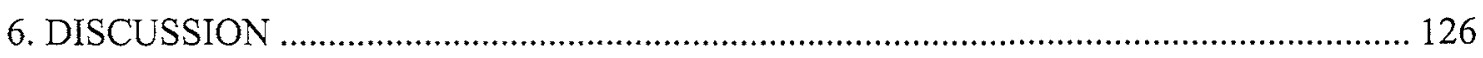

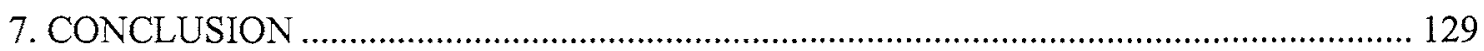

Chapter 5: Trace element characteristics and mass-volume changes associated with the alteration of banded iron-formation and shale across the Hamersley Province,

\section{Western Australia}

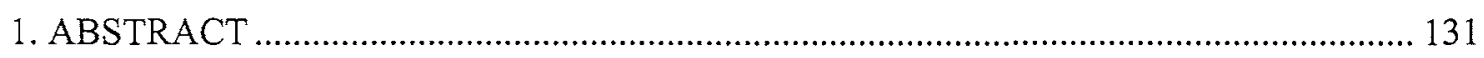

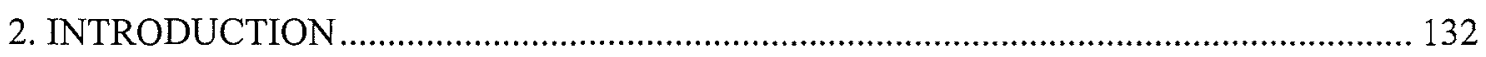

3. GEOLOGICAL VARIATION ACROSS THE HAMERSLEY PROVINCE...................... 134

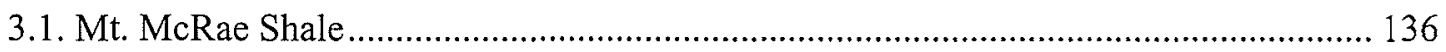

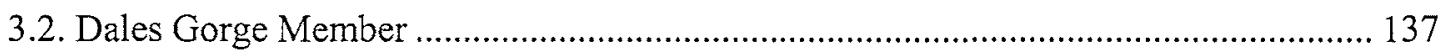

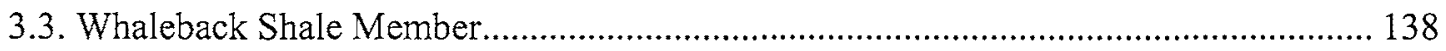

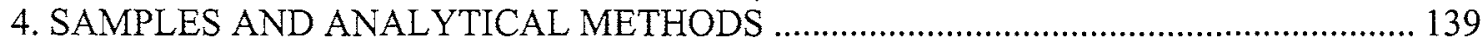

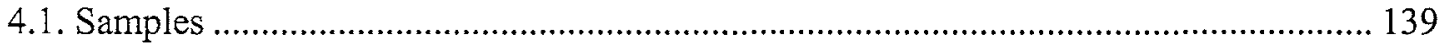

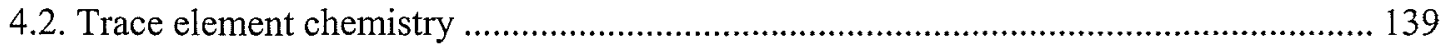

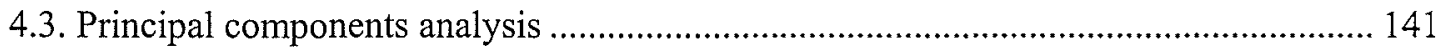

4.4. Stratigraphic thickness changes and bulk rock densities.......................................... 142

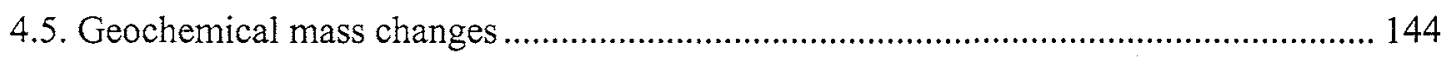

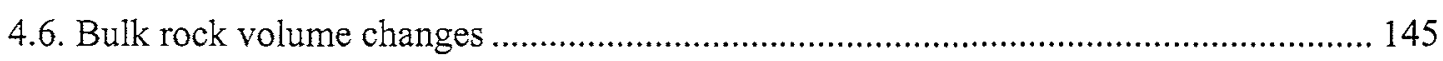

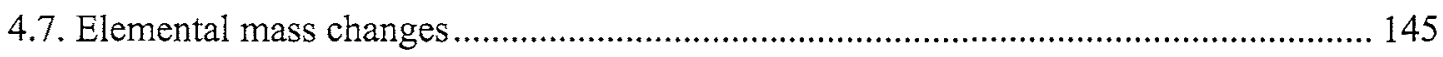

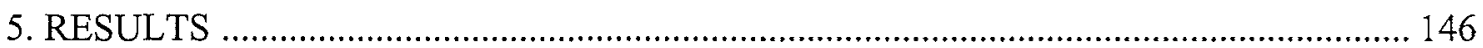


5.1. Element variability across the Hamersley Province 146

5.1.1. Core and outcrop from undeformed regions 146

5.1.2. Outcrop from deformed regions 150

5.1.3. Core and outcrop from Mt. Whaleback 151

5.2. Rare earth elements 152

5.3. Principal component analysis 155

5.4. Dales Gorge Member thickness variations across the Hamersley Province. 158

5.5. Bulk rock density variations across the Hamersley Province. 160

5.6. Mass-volume changes 162

5.6.1. Weathering of banded iron-formation 162

5.6.2. Oxidation of banded iron-formation 164

5.6.3. Conversion of black shale to altered black shale 169

5.6.4. Conversion of altered black shale to red shale 169

5.6.5. Altered black shale to reddish-green shale ....................................................... 171

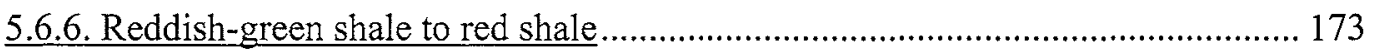

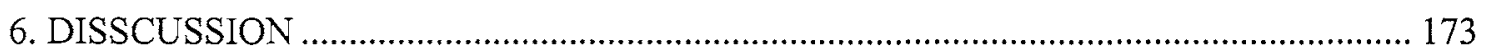

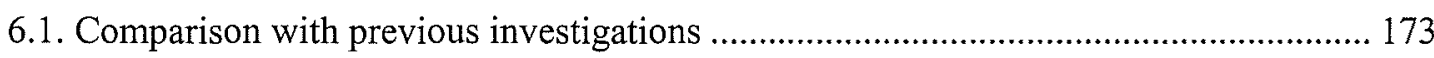

6.2. Mineralogical control on chemical composition ....................................................... 176

6.3. Rare earth element variation and implications for BIF and shale genesis..................... 178

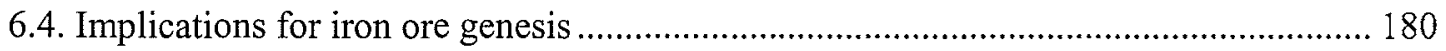

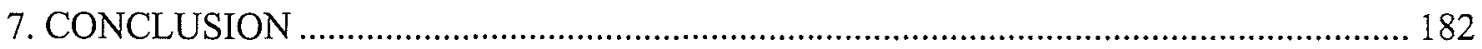

Chapter 6: Summary: A general geochemical model for explaining altered banded iron-formation, altered shales and martite-microplaty hematite ores in the Hamersley Province

1. THE BASIC TRANSITION FROM BIF TO IRON ORE 185

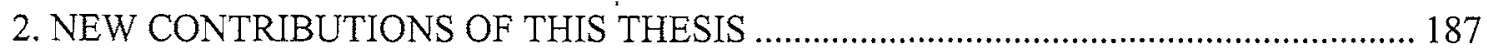

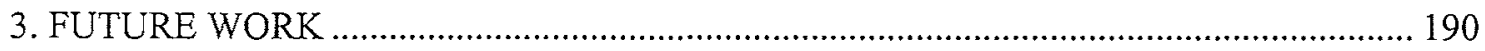

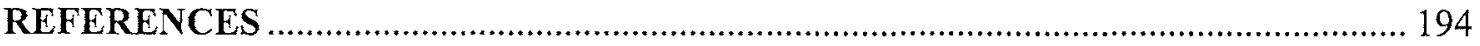




\section{LIST OF FIGURES}

\section{Chapter 1: Introduction}

Fig. 1.1. Location and regional geology of the study area. 2

Fig. 1.2. Hamersley Province stratigraphy. 3

Fig. 1.3. Dales Gorge Member at (a) Wittenoom Gorge and (b) Mt. Whaleback. 4

Fig. 1.4. Comparison of chert and iron oxide mesobands in DB16 across the Hamersley 5 Province

Fig. 1.5. Schematic diagram showing how BIF and shale layers change across the 10 Hamersley Province.

\section{Chapter 2: Major element chemistry and mineralogy of the Proterozoic Dales Gorge Member and surrounding shales at Wittenoom and Mt. Whaleback, Hamersley Province, Western Australia}

Fig. 2.1. Location and regional geology of the Hamersley Province. 16

$\begin{array}{ll}\text { Fig. 2.2. Stratigraphic columns of the Hamersley Group. } & 17\end{array}$

Fig. 2.3. Detailed log of diamond DDH-47A. 20

Fig. 2.4. (a) Surface geological map of Mt. Whaleback. (b) Locations of sampled 21 diamond drill holes and mine faces within the Mt. Whaleback pit.

Fig. 2.5. (a) Photograph of mine face B at Mt. Whaleback. (b) Schematic diagram of 25 mine face $B$ showing sample locations, rock unit colour and lithology.

Fig. 2.6. Ternary diagrams showing the distribution of $\mathrm{SiO}_{2}, \mathrm{Al}_{2} \mathrm{O}_{3}, \mathrm{Fe}_{2} \mathrm{O}_{3}, \mathrm{MgO}$ and $\mathrm{K}_{2} \mathrm{O}$ for samples collected across the Hamersley Province. (a) Northern Hamersley samples. (b) Mt. Whaleback pit samples. (c) The relationship of significant mineral phases to the bulk analyses.

Fig. 2.7. XRD traces of representative rock types from $\mathrm{DDH}-47 \mathrm{~A} *$ and $\mathrm{Mt}$. Whaleback pit. (a) BIF, altered BIF, and iron ore. (b) Black shale, altered black shale, and red shale.

Fig. 2.8. Photomicrographs of BIF mesobands across the Hamersley Province. (a) Chert and magnetite in unaltered BIF from DDH-47A*. (b) Chert and martite in altered BIF from Mt. Whaleback pit. (c) Hematite textures in high-grade iron ore from Mt. Whaleback pit.

Fig. 2.9. Ternary diagram illustrating that shale samples from Paraburdoo and Mt. Tom 38 Price may represent mixtures of shale and chert-siderite bands.

Fig. 2.10. Isocon diagrams showing the representative mass changes between shales at 48 Mt. Whaleback.

Fig. 2.11. Schematic paragenetic sequence for BIF and shale. 
Fig. 2.12. Schematic cross-sections showing the evolution of hematite ore at Mt. 55 Whaleback.

\section{Chapter 3: Oxidation and weathering of banded iron-formation across the Hamersley Province, Western Australia}

Fig. 3.1. (a) Location and simplified geology of the Hamersley Province. (b) Outcrop of Brockman Iron Formation across the southeastern Hamersley Province, showing sample locations.

Fig. 3.2. Stratigraphic column of the Hamersley Group, showing detailed stratigraphy of the Dales Gorge Member.

Fig. 3.3. Detailed log of DDH-JG1.

Fig. 3.4. Geological map of the upper reaches of Bee Gorge showing sample locations. 68

Fig. 3.5. Schematic cross-sections of gorges from deformed regions across the southeastern Hamersley Province. (a) Weeli Wolli Spring. (b) Mt. Robinson. (c) Pamelia Hill. (d) Fourth West Gorge. (e) Cathedral Gorge.

Fig. 3.6. Comparison of chert and iron oxide mesobands in DB16 across the Hamersley Province. (a) Wittenoom Gorge to Mt. Whaleback BIF and iron ore. (b) Bee Gorge to Mt. Robinson to Fourth West Gorge.

Fig. 3.7. Ternary diagrams showing the distribution of $\mathrm{SiO}_{2}, \mathrm{Fe}_{2} \mathrm{O}_{3} \mathrm{~T}, \mathrm{MgO}, \mathrm{CaO}$ and LOI for BIF samples collected across the Hamersley Province. (a) Wittenoom Gorge and Mt. Whaleback. (b) Gorges across the southeast. (c) The relationship of significant mineral phases to the bulk chemical analyses.

Fig. 3.8. Photomicrographs of various minerals in unaltered BIF from the northern Hamersley Province.

Fig. 3.9. Photomicrographs of magnetite and its various altered forms in 81 stratigraphically equivalent BIF samples across the Hamersley Province.

Fig. 3.10. Photomicrographs of stratigraphically equivalent chert and magnetite 82 mesobands across the Hamersley Province.

Fig. 3.11. Photomicrographs of representative gangue minerals in unaltered BIF.

Fig. 3.12. Photomicrographs of common chert textures in altered BIF across the 86 Hamersley Province.

Fig. 3.13. Photomicrographs of goethite pseudomorphs of siderite, stilpnomelane and riebeckite.

Fig. 3.14. Photomicrographs of microplaty hematite laths in altered BIF from Fourth 90 West Gorge and Mt. Whaleback.

Fig. 3.15. Schematic paragenetic sequences for BIF and across the Hamersley Province.

(a) Unaltered BIF to weathered BIF; (b) Unaltered BIF to oxidized BIF to high-grade hematite ore. 


\section{Chapter 4: Carbonate alteration of the upper Mt. McRae Shale beneath the martite- microplaty hematite ore deposit at Mt. Whaleback, Western Australia}

Fig. 4.1. Simplified map of the Hamersley Province showing location, regional 108 geology, location of major martite-microplaty hematite deposits and a summary of the lower Hamersley Group stratigraphy.

Fig. 4.2. Schematic diagram showing the relative stratigraphic position of the Mt. 109 McRae Shale and the different rock types sampled at Wittenoom Gorge and Mt. Whaleback.

Fig. 4.3. Schematic cross-section representing the "hypogene" step in the formation of a martite-microplaty hematite deposit and showing the relative positions of carbonate altered rocks.

Fig. 4.4. (a) Surface geologic plan of the Mt. Whaleback iron ore deposit. (b) 112 Geological cross-section 4720E, showing the location of DDH-409. (c) Detailed log of DDH-409 showing general geology and sample locations.

Fig. 4.5. Ternary diagrams showing the distribution of $\mathrm{SiO}_{2}, \mathrm{Al}_{2} \mathrm{O}_{3}, \mathrm{Fe}_{2} \mathrm{O}_{3} \mathrm{~T}, \mathrm{MgO}$ and $\mathrm{CaO}$ for shale samples collected from $\mathrm{DDH}-409$ and the relationship of significant mineral phases to the bulk analyses.

Fig. 4.6. XRD trace of D4096 from DDH-409. clino = clinochlore; dol = dolomite; 119 hem $=$ hematite.

Fig. 4.7. Photomicrographs of common textures found in Mt. McRae Shale across the 120 Hamersley Province.

Fig. 4.8. Photomicrographs of Mt. McRae Shale from the Mt. Whaleback pit.

Fig. 4.9. Photomicrographs of reddish green shale from Mt. Whaleback pit.

Fig. 4.10. Ternary diagram showing compositions of carbonates in Mt. McRae Shale 126 determined from DDH-409.

\section{Chapter 5: Trace element characteristics and mass-volume changes associated with the alteration of banded iron-formation and shale across the Hamersley Province, Western Australia}

Fig. 5.1. (a) Location and simplified geology of the Hamersley Province showing the location of the three major high-grade hematite ore deposits. (b) General geology of the southeastern Hamersley Province, showing outcrop of Brockman Iron Formation, sample locations and localities of measured stratigraphic sections.

Fig. 5.2. Stratigraphic column of the Hamersley Group, showing detailed stratigraphy 135 of the Dales Gorge Member and relative stratigraphic thicknesses.

Fig. 5.3. Ternary diagrams showing the distribution of $\mathrm{Ba}, \mathrm{Co}, \mathrm{Pb}, \mathrm{Sr}$ and $\mathrm{Cr}$ for $\mathrm{DB}-146$ macroband samples collected across the Hamersley Province.

Fig. 5.4. Whole rock trace element contents (ppm) versus whole rock $Y$ contents (ppm) 147 for shales across the Hamersley Province. (a) Nb-Y. (b) Zr-Y. (c) Ni-Y. (d) 
Zn-Y. (e) Rb-Y. (f) Ba-Y.

Fig. 5.5. REE patterns of selected BIF samples collected across the Hamersley 152 Province.

Fig. 5.6. The REE patterns of shale across the Hamersley Province.

Fig. 5.7. Folded DS-macroband (DS16) in high-grade hematite ore showing the effects 160 of $\mathrm{D}_{2}$ folding on shale layers.

Fig. 5.8. Isocon diagrams showing the representative element changes between (a) unaltered BIF and weathered BIF; (b) unaltered BIF and oxidized BIF (Fourth West Gorge); (c) unaltered BIF and oxidized BIF (Mt. Whaleback); (d) oxidized BIF and high-grade hematite ore.

Fig. 5.9. Major element mass changes for specific volume losses during the alteration 165 of BIF across the Hamersley Province.

Fig. 5.10. Possible porosity range of high-grade hematite ore.

Fig. 5.11. Volume losses associated with the conversion of Mt. Whaleback BIF to high- 167 grade hematite ore of varying porosities.

Fig. 5.12. $\mathrm{SiO}_{2}$ and $\mathrm{Fe}_{2} \mathrm{O}_{3} \mathrm{~T}$ mass changes associated with the oxidation of $\mathrm{BIF}$ at Mt. 168 Whaleback to high-grade hematite ore.

Fig. 5.13. Isocon diagrams showing the representative changes between (a) unaltered black shale and altered black shale (major element oxides); (b) unaltered black shale and altered black shale (trace elements); (c) altered black shale and red shale (major element oxides); (d) altered black shale and red shale (trace elements).

Fig. 5.14. Major element oxide mass changes for specific volume losses during the alteration of shale across the Hamersley Province.

Fig. 5.15. Isocon diagrams showing the representative changes between (a) altered black shale and reddish-green shale (major element oxides); (b) altered black shale and reddish-green shale (trace elements); (c) reddish-green shale and red shale (major element oxides); (d) reddish-green shale and red shale (trace elements).

Fig. 5.16. REE patterns of average BIF and shale across the Hamersley Province and 179 some potential sources of REEs.

Fig. 5.17. Cartoons representing possible models for oxidized BIF to high-grade 181 hematite ore transitions.

Chapter 6: A general geochemical model for explaining altered banded ironformation, altered shales and martite-microplaty hematite ores in the Hamersley Province

Fig. 6.1. (a) Plan view of Mt. Whaleback pit, showing geology and sample locations. 187

(b) Generic cross-section of Mt. Whaleback, showing general distribution of the different rock types analysed in this study. 
Fig. 6.2. Schematic cross-sections showing the evolution of mineralization and 189 alteration at Mt. Whaleback,

Fig. 6.3. Schematic cross-sections showing the regional evolution of mineralization 191 and relative position of altered rock across the Hamersley Province.

Fig. 6.4. Solubility characteristics of silica in water. 


\section{LIST OF TABLES}

\section{Chapter 2: Major element chemistry and mineralogy of the Proterozoic Dales Gorge Member and surrounding shales at Wittenoom and Mt. whaleback, Hamersley Province, Western Australia}

Table 2.1. Major element oxide contents of the standard and replicate samples. 23

Table 2.2. Average major element oxide contents and standard deviations of rocks from Wittenoom and Mt. Whaleback.

Table 2.3. (a) Semi-quantified mineralogy of rocks from the northern Hamersley Province. (b) Semi-quantified mineralogy of rocks from the Mt. Whaleback pit.

Table 2.4. (a) Average composition of DB-macrobands from the Hamersley Province. (b) Average composition of DS-macrobands from the Hamersley Province.

Table 2.5. Formulas and major element oxide contents of significant minerals found in 42 rocks across the Hamersley Province.

Table 2.6. Estimated mineral mixtures to best explain average major element chemistry.

Table 2.7. Possible reactions for the alteration of BIF and black shale from the 46 Hamersley Province.

Chapter 3: Oxidation and weathering of banded iron-formation across the Hamersley Province, Western Australia

Table 3.1. Sample locations across the Hamersley Province.

Table 3.2. Average major element oxide contents and standard deviations of Dales 72 Gorge Member BIF across the Hamersley Province.

Table 3.3. Semi-quantified mineralogy of BIF macrobands across the Hamersley 73 Province.

Table 3.4. Mesoband characteristics of Dales Gorge Member BIF across the Hamersley Province.

Table 3.5. Petrographic groups across the Hamersley Province.

Table 3.6. Formulas and major element oxide contents of significant minerals found in 95 rocks across the Hamersley Province.

Table 3.7. Possible reactions for the alteration of BIF from across the Hamersley 97 Province

\section{Chapter 4: Carbonate alteration of the upper Mt. McRae Shale beneath the martite- microplaty hematite ore deposit at Mt. Whaleback, Western Australia}

Table 4.1. Description and major element composition of rocks from the Mt. McRae 116 Shale at DDH-409 (Mt. Whaleback). 
Table 4.2. Semi-quantified mineralogy of rocks from the Mt. McRae Shale at DDH-409 118 (Mt. Whaleback).

Table 4.3. Representative microprobe analyses of silicate and carbonate minerals in Mt. 125 McRae Shale from DDH-409 (Mt. Whaleback).

\section{Chapter 5: Trace element characteristics and mass-volume changes associated with the alteration of banded iron-formation and shale across the Hamersley Province, Western Australia}

Table 5.1. Analytical precision (a) XRF, (b) INAA, (c) Rock density.

Table 5.2. Average trace element contents and standard deviations of rocks across the 148 Hamersley Province.

Table 5.3. Average rare earth element contents and standard deviations of rocks across 154 the Hamersley Province.

Table 5.4. (a) Principal Component Analysis matrix for BIF across the Hamersley 156 Province. (b) Principal Component Analysis matrix* for shales across the Hamersley Province.

Table 5.5. Average thickness changes of Dales Gorge Member macrobands across the 159 Hamersley Province.

Table 5.6. Average mineralogy and density of rocks across the Hamersley Province.

Table 5.7. (a) Average trace element composition of BIF across the Hamersley Province. 174 (b) Average trace element composition of shale across the Hamersiey Province. 


\section{LIST OF APPENDICES}

\section{Appendix 1}

Appendix 1.1. (a) Outcrop of Brockman Iron Formation across the southeastern 206 Hamersley Province, showing sample locations and position of the Mt. Whaleback iron ore deposit. (b) Locations of sampled diamond drill holes and mine faces within the Mt. Whaleback pit.

Appendix 1.2. Sample locations across the Hamersley Province.

Appendix 1.3. Geological map of the upper reaches of Bee Gorge showing sample 208 locations.

Appendix 1.4. Detailed log of DDH-47A.

Appendix 1.5. Detailed log of DDH-JG1.

Appendix 1.6. Geological map of Mt. Robinson showing location of sampled section.

Appendix 1.7. Schematic cross-sections of gorges from deformed regions across the southeastern Hamersley Province

Appendix 1.8. Detailed logs of sampled Mt. Whaleback pit diamond drill holes. (a) 213 DDH-229. (b) DDH-257. (c) DDH-324.

Appendix 1.9. Detailed logs of sampled Mt. Whaleback pit diamond drill holes. (a) 214 DDH-73. (b) DDH-86. (c) DDH-409.

Appendix 1.10. Mine face A at Mt. Whaleback. (a) East facing photograph with shale units labeled according to the BHPBIO classification scheme. (b) Schematic diagram showing sample locations.

Appendix 1.11. Mine face B at Mt. Whaleback. (a) West facing photograph with rock 216 units labeled according to the BHPBIO classification scheme. (b) Schematic diagram showing sample locations, colour and lithology.

Appendix 1.12. Schematic diagrams of fresh mine faces at Mt. Whaleback showing sample locations, colour and lithology. (a) Face C. (b) Face D. (c) Face E.

\section{Appendix 2}

Appendix 2.1. Measured and reported stratigraphic thicknesses of Dales Gorge Member 219 macrobands across the Hamersley Province.

\section{Appendix 3}

Appendix 3.1. Description and major element composition of rocks at Wittenoom Gorge 221 and Mt. Whaleback.

Appendix 3.2. Trace element composition of rocks across the Hamersley Province.

Appendix 3.3. Rare earth element contents of rocks across the Hamersley Province. 
Appendix 3.4. Statistical summary of Dales Gorge Member BIF across the Hamersley 239 Province.

Appendix 3.5. Statistical summary of shale across the Hamersley Province.

\section{Appendix 4}

Appendix 4.1. Semi-quantified mineralogy of rocks from the Hamersley Province.

Appendix 4.2. Photomicrographs of miscellaneous minerals in unaltered BIF

\section{Appendix 5}

Appendix 5.1. Average chemical composition of silicate minerals in BIF from the Dales 248 Gorge Member.

Appendix 5.2. Average chemical composition of carbonate minerals in BIF from the 249 Dales Gorge Member.

Appendix 5.3. Microprobe data for silicates and carbonates in unaltered BIF from the 250 northern Hamersley Province.

Appendix 5.4. Chemical composition of silicate and carbonate minerals in Mt. McRae 254 Shale from Mt. Whaleback.

\section{Appendix 6}

Appendix 6.1. Rock densities across the Hamersley Province.

\section{Appendix 7}

Appendix 7.1. Elemental mass changes as a function of volume and porosity for the 260 alteration of BIF across the Hamersley Province.

Appendix 7.2. Elemental mass changes as a function of volume for the alteration of shale 264 across the Hamersley Province.

\section{Appendix 8}

Appendix 8.1. Catalogue of James Cook University sample numbers. 
CHAPTER 1

INTRODUCTION 


\section{INTRODUCTION}

\subsection{Martite-microplaty hematite ores of the Hamersley Province}

The Hamersley Province of Western Australia (Fig. 1.1) contains numerous economic deposits of iron ore (e.g., Morris, 1985; Harmsworth et al., 1990) where Proterozoic banded iron-formation (BIF) composed predominantly of magnetite and chert layers has been converted to oxidized iron minerals. Collectively, these deposits produce approximately $160 \mathrm{Mt} /$ year of iron ore and provide Australia with a major export commodity (Department of Mineral and Petroleum Resources, WA, 2001). Many of these bedded orebodies consist of martite (a hematite pseudomorph of magnetite) and goethite, and formed from the Marra Mamba and Brockman Iron Formations (Fig. 1.2) by deep supergene enrichment of precursor BIFs (Harmsworth et

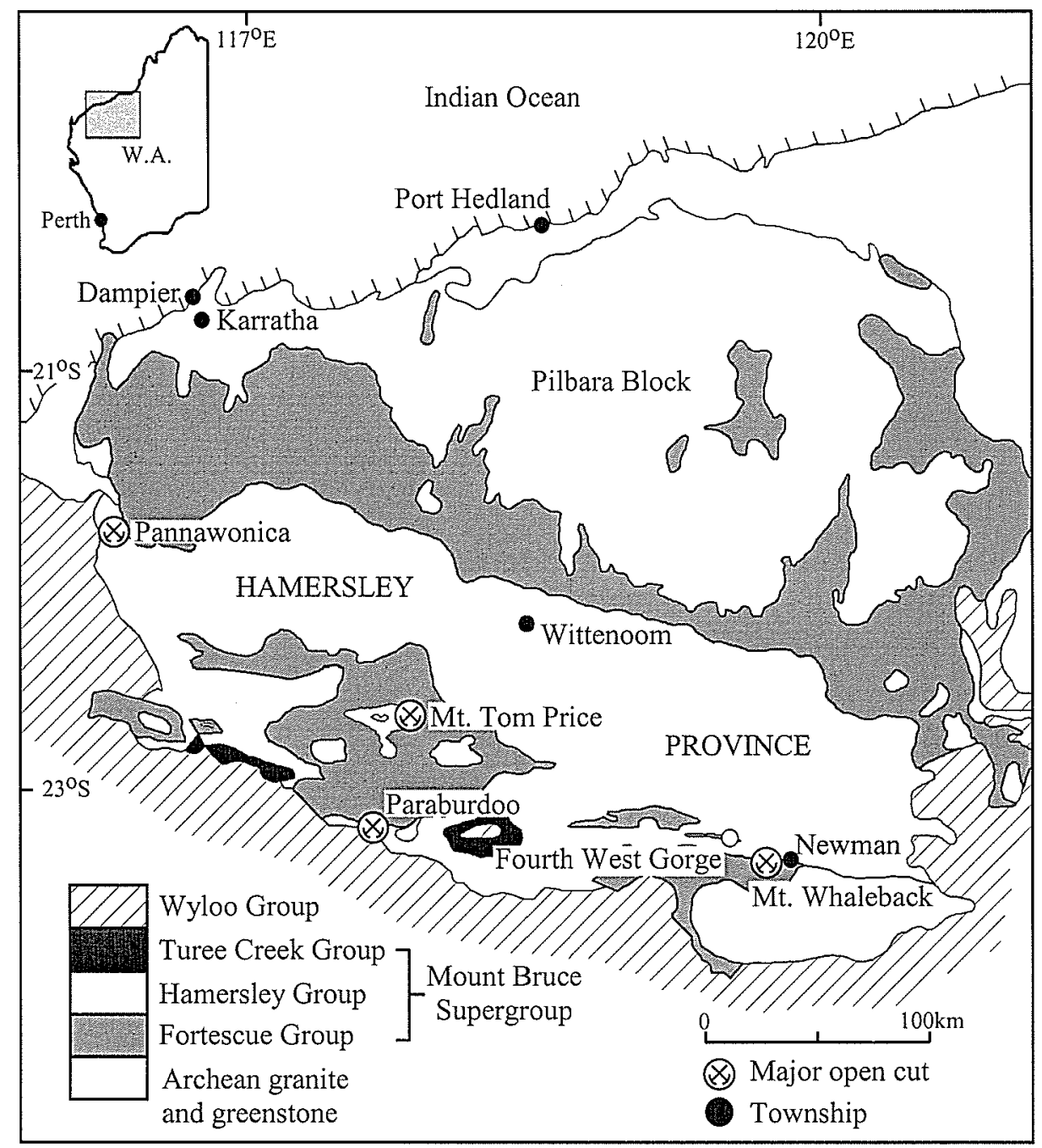

Figure 1.1. Location and regional geology of the Hamersley Province (modified from Trendall and Blockley, 1970), showing positions of major high-grade hematite ore deposits. 


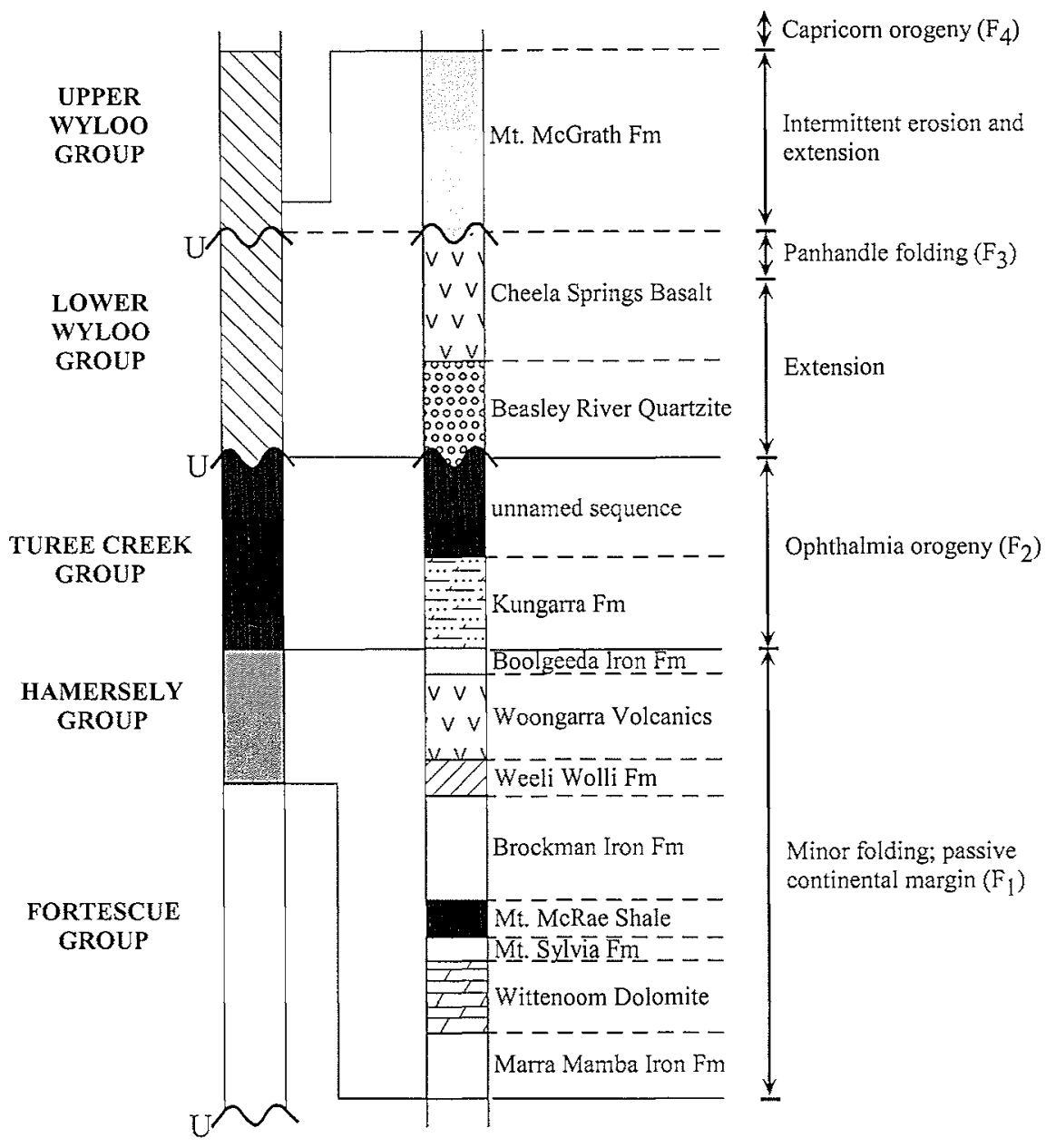

Figure 1.2. Summary stratigraphic column of Hamersley Province rocks, showing detailed stratigraphy of the Hamersley, Turee Creek and Wyloo Groups and approximate timing of the major deformation events. $\mathrm{Fm}=$ Formation; $\mathrm{U}=$ major unconformity.

al., 1990; Morris, 1985). During this process magnetite was oxidized to martite, silicates and carbonates were oxidized and hydrated to goethite, while remaining gangue was leached without replacement. These orebodies form deposits up to hundreds of million of tonnes and are laterally very extensive, although they rarely extend to depths $>100 \mathrm{~m}$ (Morris, 1980; Harmsworth et al., 1990). Because martitegoethite orebodies typically lack any evidence of metamorphism, are related to present day erosion surfaces, and contain abundant hydrous iron oxides, they are generally accepted as resulting from Cretaceous supergene enrichment of unaltered BIF (Morris, 1980; Harmsworth et al., 1990).

The second main type of bedded iron ores (e.g., Mt. Whaleback, Mt. Tom Price and Paraburdoo) occur in the south of the Hamersley Province where BIF layers have been folded, faulted and altered to mixtures of martite and fine-grained platy hematite 
(microplaty hematite) (Figs. 1.1-1.4). These ores are characterised by well-preserved primary banding (although there is some loss of internal textures) (Fig. 1.4) and relatively little goethite. They can be enormous in size (Mt. Whaleback, >1500 Mt) and often extend to great depths $(>400 \mathrm{~m})$. High-grade martite-microplaty hematite orebodies are nearly all confined to the lowermost unit of the Brockman Iron Formation, the Dales Gorge Member (Fig. 1.2). The origins of these economically important "high-grade" deposits remain controversial (e.g., Dalstra et al., 2002a; Kneeshaw and Kepert, 2002; Morris, 2002a; Taylor et al., 2002).

a) Wittenoom Gorge

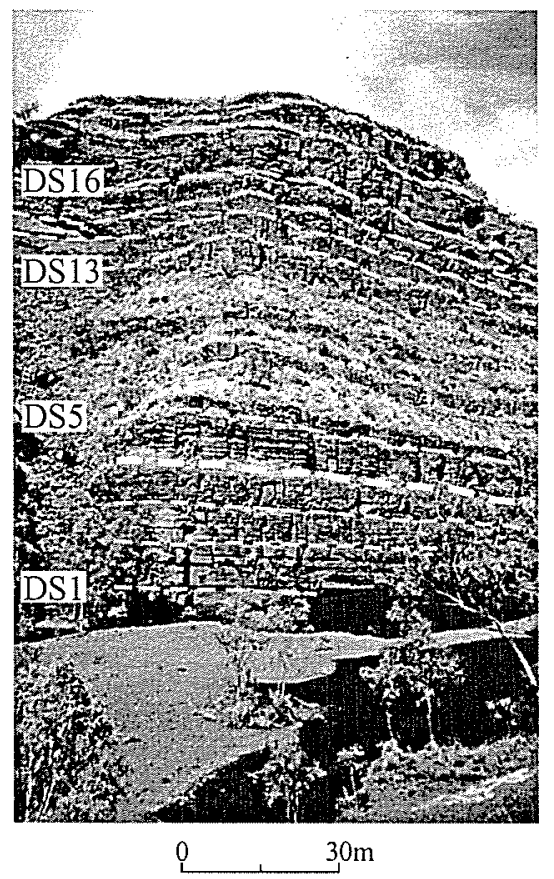

b) Mt. Whaleback (fresh pit face)

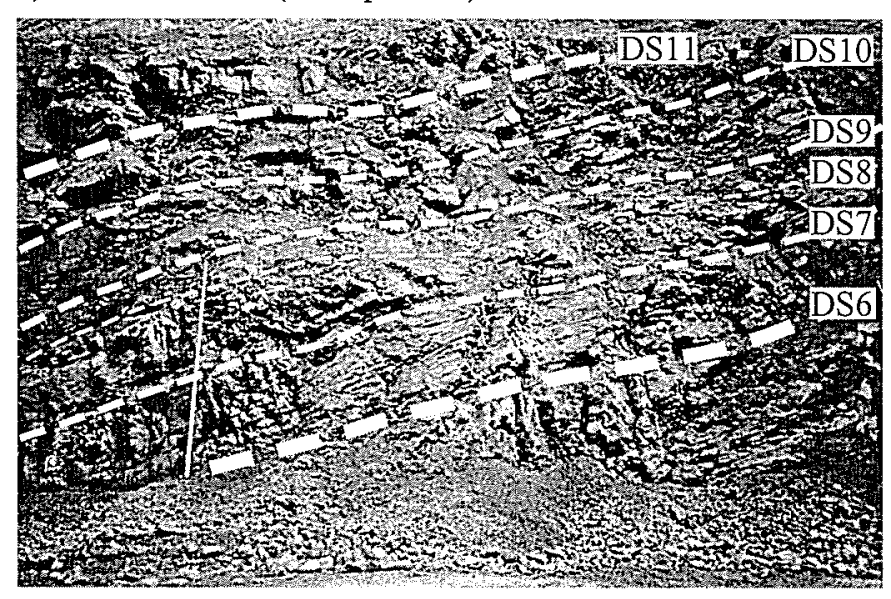

0 $5 \mathrm{~m}$

Figure 1.3. Dales Gorge Member in outcrop at (a) Wittenoom Gorge and (b) Mt. Whaleback pit. Note relatively unaltered flat-lying BIF (DB) and shale (DS) (dotted lines) layers at Wittenoom Gorge and deformed mineralized equivalents at Mt. Whaleback. 


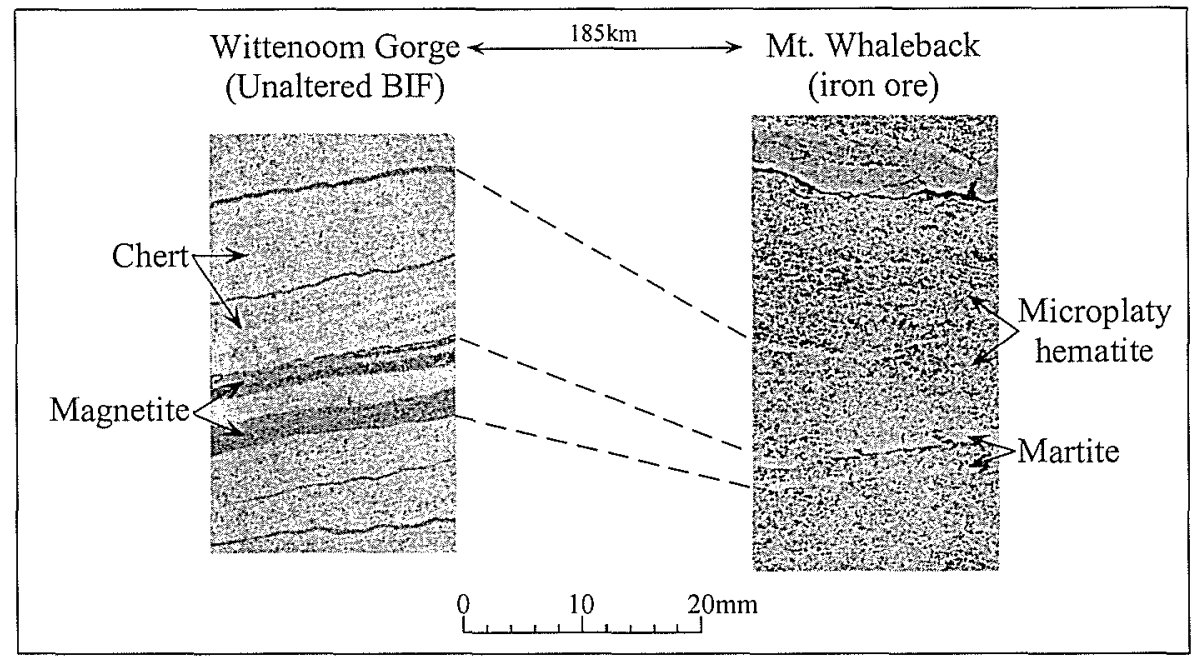

Figure 1.4. Comparison of chert and iron oxide mesobands in BIF macroband 16 (DB16) of the Dales Gorge Member between Wittenoom Gorge (sample 473, DDH-47A, undeformed and unmineralized) to Mt. Whaleback (sample E24C, fresh mine face, deformed and mineralized). Note that similar spacing between iron-oxide mesobands suggests it may be possible to correlate mesobands from the Dales Gorge Member over considerable distances.

Originally high-grade martite-microplaty hematite ores were thought to be supergene orebodies related to Tertiary weathering (Macleod, 1966), however later work incorporating detailed mineralogy and geological history (e.g., Morris, 1980, 1985) suggested they were Precambrian. Supergene enrichment followed by metamorphism is the most widely cited explanation for the genesis of these ores (Morris, 1980, 1985, 1993; Morris et al., 1980; Harmsworth et al., 1990). According to this "supergene-metamorphic" model, original BIF layers of magnetite and chert were uplifted during the Ophthalmian Orogeny $\left(\mathrm{D}_{2}\right)$ (ca. 2.45 to $2.2 \mathrm{Ga}$ ) (Martin et al., 1998) and exposed to subsurface weathering that, over a protracted period of time, simultaneously oxidized magnetite to martite, and replaced chert with goethite. The supergene goethite was subsequently dehydrated to microplaty hematite during post-2.0 Ga burial metamorphism under the lower Wyloo Group (Morris, 1985). The timing of mineralization for this model has been broadly constrained by the presence of microplaty hematite clasts in conglomerates of the Mt. McGrath Formation at the base of the upper Wyloo Group (>2.0 Ga) (Fig. 1.2). These conglomerates are the basal sequence to a major sedimentary basin that is deformed by the Capricorn Orogeny (ca.1.8 to $1.6 \mathrm{Ga}$ ) (Thorne and Seymour, 1991), implying, at the very least, an orerelated cycle of burial, exhumation and erosion prior to this deformation. To account 
for the exceptional depth of mineralization at places like Mt. Whaleback ( $>400 \mathrm{~m})$, the model also appeals to a special combination of fluid seepage down former fault zones and electrochemical cells involving BIF and groundwater (Morris et al., 1980). Importantly, the supergene-metamorphic model for iron ore genesis suggests that any evidence of hydrothermal alteration at the high-grade hematite deposits is absent.

Recent papers (e.g., Findlay, 1994; Martin et al., 1998; Barley, et al., 1999; Oliver and Dickens, 1999; Powell et al., 1999; Taylor et al., 2001) have highlighted several problems with this supergene model. For example, detrital microplaty hematite clasts in conglomerates of the Beasley River Quartzite at the base of the lower Wyloo Group $(>2.2 \mathrm{Ga})$ (Fig. 1.2) suggest that some orebodies formed well before the deposition of the McGrath Formation, possibly even during late stages of Ophthalmian deformation (Martin et al., 1998). This questions the timing of the supergene-metamorphic model that requires a long period of surficial exposure between deposition of the Turee Creek and Wyloo Groups (Martin et al., 1998). Another problem is that silica-poor, magnetite-rich ore at Mt. Tom Price suggests that BIF may have been leached of silica prior to oxidation (Taylor et al., 2001). Recent work (e.g., Powell et al., 1999; Brown et al., in press) has also demonstrated that peak metamorphism predated formation of the deposits. Consequently, alternative models for high-grade hematite ore genesis have been forwarded.

A "diagenetic boudinage model" (Findlay, 1994) proposes mechanical separation of $\mathrm{Fe}$ and $\mathrm{Si}$ with minimal fluid involvement, through large-scale boudinage of BIF during an early extensional phase $\left(D_{1}\right)$ prior to the Ophthalmian Orogeny. However, this model cannot be the primary explanation for iron ore genesis as the main orebody at Mt. Whaleback clearly crosscuts (and postdates) early extensional features as well as fold structures associated with contractional phases of the Ophthalmian Orogeny (Powell et al., 1999). Moreover, no massive silica bodies have been found adjacent to any of the orebodies and any evidence for the substantial metasomatic replacement of gangue by iron is limited.

A "deep hypogene model" (Li et al., 1993) proposes that fluids from underlying 
basalts ascended along faults and reacted with BIF during Palaeoproterozoic compression (i.e., Ophthalmian Orogeny). Such fluids predominantly leached non-iron components from the rocks, although metasomatic replacement of gangue by hematite also occurred. A relatively similar model was suggested for the high-grade hematite ores of Minas Gerais, Brazil (Dorr, 1965). In this model heated basinal brines related to regional metamorphism replaced quartz with hematite scavenged from surrounding iron formation. Although a "deep hypogene model" is consistent with the tectonic and stratigraphic history of the Hamersley Province, it is unclear how oxidized and silicadepleted ore can be deposited from deep and presumably ređucing fluids.

A "syntectonic-meteoric model" (Powell et al., 1999; Oliver and Dickens, 1999) proposes that surface-derived fluids penetrated BIF layers during active foreland, foldand-thrust belt formation of the Ophthalmian Orogeny. As these fluids descended and warmed, they removed silica and oxidized magnetite-rich BIFs to hematite. This model is analogous to the proposed formation of Mississippi Valley-type lead-zinc deposits of the central United States (Oliver, 1986), and combines key aspects of the "supergene" and "deep hypogene" models. In particular, ore formation involved the oxidation of BIF layers by surface derived fluids at relatively high temperatures during or soon after the Ophthalmian Orogeny. Oliver and Dickens (1999) presented and discussed field examples from Fourth West Gorge (Fig. 1.1) that show silica dissolution and iron oxidation fronts apparently caused by high-temperature fluids. However, it is possible that these small-scale examples of microplaty hematite have a different genesis to the giant martite-microplaty hematite orebodies.

A "hypogene-meteoric model" (Barley et al., 1999; Taylor et al., 2001) proposes that hot fluids formed silica-poor, magnetite-siderite assemblages in original BIF, and descending meteoric fluids subsequently oxidized and leached this modified BIF. The initial hypogene stage in this model was developed to explain an extensive alteration zone deep within Mt. Tom Price where silica-bearing minerals in BIF and surrounding shales have been replaced by Fe- and Mg-rich carbonates and silicates. A similar deepseated carbonate alteration zone has also been documented beneath the Giles Mini 
deposit in the southeastern Hamersley Province (Dalstra et al., 2002b). However, no such zone has been documented at the biggest martite-microplaty hematite deposit in the Hamersley Province, Mt. Whaleback (Kneeshaw and Kepert, 2002), suggesting that either carbonate alteration is unimportant to high-grade iron ore formation or that any evidence for this alteration has been removed (Taylor et al., 2001; Dalstra et al., 2002a, b).

A major problem with distinguishing between these or other possible models for the genesis of high-grade martite-microplaty hematite ores in the Hamersley Province is the paucity of basic information concerning the transformation of BIF to iron ore. The composition and structure of equivalent BIF and shale horizons vary dramatically between undeformed areas in the north and deformed areas in the south surrounding the ore deposits (Fig. 1.3) (Trendall and Blockley, 1970; Ewers and Morris, 1981; Taylor et al., 2001). Moreover, this study shows there are colour transitions between black and red shales within the Mt. Whaleback pit. These observations suggest profound changes in chemistry and mineralogy, perhaps related to iron mineralization. However, the cause and identity of these changes remains unclear because there has been no systematic study of the Dales Gorge Member and surrounding shales across the Hamersley Province. While numerous investigations have focused on the geochemical origins of Hamersley BIF (e.g., Holland, 1973; Trendall and Blockley, 1970; Trendall and Pepper, 1976; Ewers, 1983; Morris and Horwitz, 1983; Anbar and Holland, 1992; Morris, 1993; Alibert and McCulloch, 1993; Barley et al., 1997; Canfield, 1998), only limited information exists regarding the colour, chemistry and mineralogy of rocks from the Dales Gorge Member, especially in the south or around orebodies (Ewers and Morris, 1981). It is unclear how these rock properties vary from an undeformed area without mineralization, through a deformed area without mineralization, to a deformed area with mineralization. The exhaustive textural analysis of BIF and hematite ores by Morris (1985) cannot be fully utilized until this layer-correlated rock data has been collected. 


\subsection{Thesis overview}

The principal aim of this study is to determine the bulk chemical composition, mineralogy and petrography of rock samples from similar stratigraphic horizons of the Dales Gorge Member and surrounding shales across the Hamersley Province with the idea that this can establish a framework for understanding the transformation of BIF to high-grade hematite ore. The four main sections that comprise this thesis (Chapters 2-5, outlined below) are intended as stand-alone bodies of work suitable for publication in peer-reviewed journals, although this format leads to some repetition, especially in the early parts of each chapter. For the ease of reading, the text and figures have been separated into Volume I and Volume II, respectively, the references have been collated into a single list at the end of Volume I, and tables and appendices have been placed in Volume II.

Chapter 2 documents and discusses the powder colour, major element chemistry and mineralogy of the Dales Gorge Member and surrounding shales from three diamond drill holes (DDHs) near Wittenoom and five DDHs and six fresh mine faces within the Mt. Whaleback mine near Newman. On the basis of chemical and mineralogical differences, at least three distinct types of rock can be found in stratigraphically equivalent BIF horizons (Fig. 1.5); unaltered BIF, altered BIF and iron ore. Unaltered BIF is largely composed of fine-grained chert and euhedral magnetite, although finegrained siderite, stilpnomelane, ankerite, dolomite, minnesotaite and riebeckite are significant in some samples. Altered BIF consists of martite and chert and typically surrounds the Mt. Whaleback ore deposit. Iron ore lacks any chert and is composed entirely of martite within a porous network of microplaty hematite. Three distinct types of rock can also be found in stratigraphically equivalent shale horizons (Fig. 1.5); unaltered black shale, altered black shale and red shale. Unaltered black shale consists of very fine-grained stilpnomelane, K-feldspar and quartz with subordinate amounts of siderite, dolomite, ankerite, muscovite, biotite, pyrite and chlorite. Altered black shale contains abundant chlorite and muscovite and red shale is entirely composed of very fine hematite plates and kaolinite. Compositional differences between stratigraphically 
equivalent BIF and shale samples suggest several stages of alteration, including a pervasive oxidation step. Importantly, the altered BIF surrounding Mt. Whaleback clearly indicates that magnetite oxidation may occur independently of silica removal. Much of this chapter has been published in Chemical Geology (Webb et al., 2003).

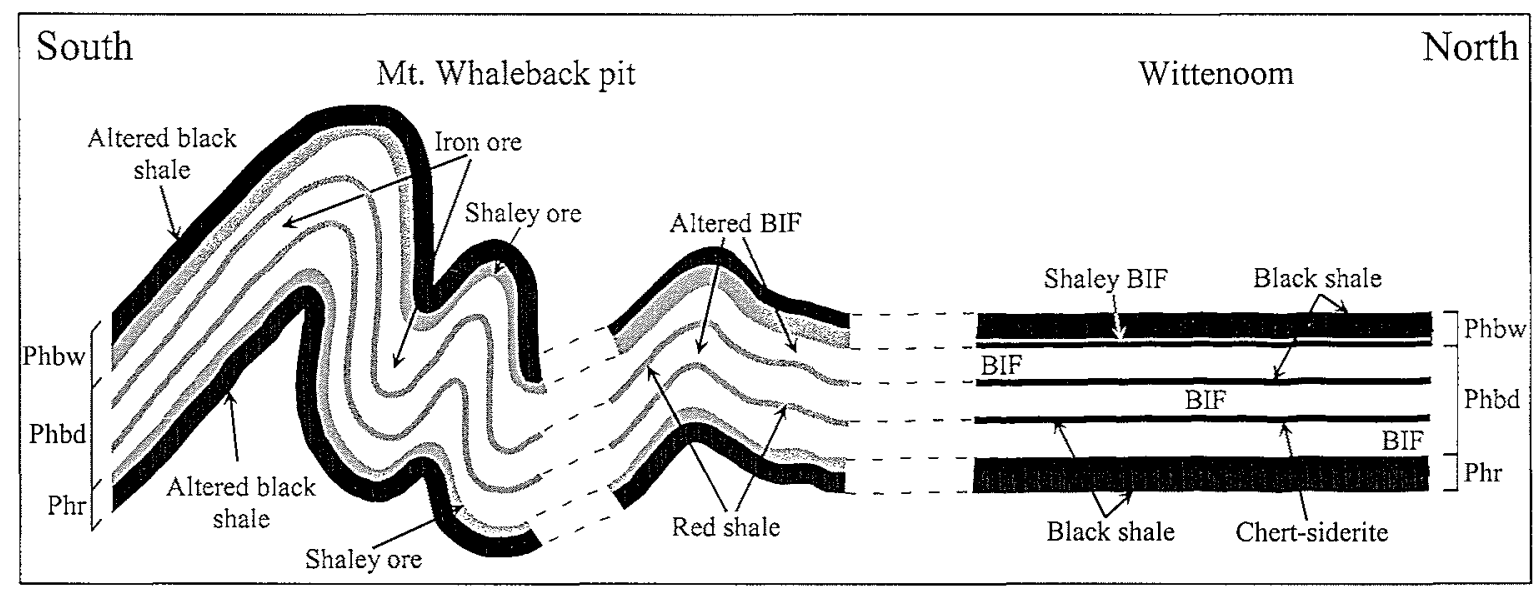

Figure 1.5. Schematic diagram showing the relative stratigraphic position of the different rock types sampled from DDH-47A* at Wittenoom Gorge and Mt. Whaleback pit. Note that this diagram does not portray the complex thickness and porosity changes of the units from north to south caused by deformation and ore genesis (see Chapter 5). Phbw = Whaleback Shale Member; Phbd = Dales Gorge Member; Phr = Mt. McRae Shale.

Current efforts towards a coherent model for iron ore genesis are stymied because with available data BIF surrounding the two largest deposits - Mt. Whaleback and Mt. Tom Price - has been altered differently. The simplest explanation for the contrasting assemblages is that large volumes of oxidizing water have passed through the rocks at Mt. Whaleback. Such fluids may have affected areas between the two deposits. Chapter 3 therefore examines and discusses the chemistry, mineralogy and petrography of stratigraphically equivalent BIF samples from the Dales Gorge Member at several locations across the southeastem Hamersley Province in order to better understand variations in BIF composition especially in and around Mt. Whaleback. On the basis of differences between samples, BIF can be categorized into four groups. One rock type from Mt. Whaleback consists of chert, martite and microplaty hematite. These rocks are not associated with supergene weathering as they lack goethite and contain abundant microplaty hematite. Similarities between these "oxidized" rocks associated with iron ore and equivalent sequences outside of the deposit suggest substantial lateral flow of 
acidic, oxygenated fluids sometime during or after mineralization.

The altered BIF documented and discussed in Chapters 2 and 3 cannot be adequately explained by the supergene-metamorphic model. Given the other problems with this model, this work favors a hypogene-meteoric model for iron ore genesis. Based on the presence of silica-poor carbonate-enriched rocks deep within the Mt. Tom Price and Giles Mini deposits hypogene leaching of silica by alkaline, carbonate-rich fluids, followed by subsequent oxidation has been recently proposed (Barley et al., 1999; Dalstra et al., 2002; Taylor et al., 2001). However, no such rocks have been identified at Mt. Whaleback by the present study (Chapters 2 and 3), or by others (Kneeshaw and Kepert, 2002). Chapter 4 examines the chemistry, mineralogy and petrography of samples of the Mt. McRae Shale collected from several key locations across the Hamersley Province, including within drill core at Mt. Whaleback. DDH409 was drilled into folded parts of the upper Mt. McRae Shale beneath high-grade hematite ore along the Mt. Whaleback fault - a similar setting to carbonate-altered shales at the Mt. Tom Price and Giles Mini deposits. Compared to other shales described in Chapter 2, two samples from DDH-409 are enriched in $\mathrm{MgO}$ and $\mathrm{CaO}$, depleted in $\mathrm{SiO}_{2}$ and contain coarse-grained carbonate phenocrysts not seen in other shales. These differences indicate that carbonate-bearing fluids may have altered pockets of deeply buried rocks at Mt. Whaleback. This alteration differs significantly from that related to regional metamorphism and most likely represents hydrothermal alteration similar to the first mineralization phase observed at Mt. Tom Price.

Chapters 2-4 reveal that profound chemical, mineralogical and petrographical differences exist between stratigraphically equivalent rocks across the Hamersley Province. A series of chemical reactions and processes are proposed in these chapters to explain these changes. However, quantification of the absolute mass changes occurring during the alteration of rocks across the Hamersley Province are hampered by the high variability within the chemical dataset and the lack of key trace elements (e.g., minor and rare earth elements) needed to fully assess the geochemical processes.

Chapter 5 determines the mass changes associated with the alteration of rocks 
across the Hamersley Province using trace element chemistry and calculated massvolume changes in conjunction with already determined major element/paragenetic studies. Importantly, the data confirms that the crucial ore-forming step is silica loss and not widespread iron metasomatism.

Chapter 6 synthesizes the ideas and concepts developed in the previous chapters. The primary purpose of the chapter is to summarize and highlight results of this thesis, and then use these results to develop a general model for the formation of high-grade hematite ores. Future research avenues are also suggested. 
CHAPTER 2

MAJOR ELEMENT CHEMISTRY AND MINERALOGY OF THE PROTEROZOIC DALES GORGE MEMBER AND SURROUNDING SHALES AT WITTENOOM AND MT. WHALEBACK, HAMERSLEY PROVINCE, WESTERN AUSTRALIA 


\section{ABSTRACT}

Several major iron ore deposits occur in deformed regions of the Hamersley Province, Western Australia, where banded iron-formation (BIF) of the Dales Gorge Member has been converted to martite and microplaty hematite. The genesis of these high-grade hematite ores remains controversial, in part because no study has systematically documented variations on the chemistry and mineralogy of stratigraphically equivalent rocks from undeformed regions into the deposits. In this study, 177 samples of the Dales Gorge Member and surrounding shales were collected from the type section near Wittenoom and the Mt. Whaleback mine near Newman. The powder colour, chemistry and mineralogy of these samples were then examined. Profound chemical and mineralogical changes suggest that after early diagenesis, lowgrade metamorphism converted clays in black shales to stilpnomelane and talc. Coincident with or following these changes, reduced metamorphic fluids altered phyllosilicates and $\mathrm{K}$-feldspar in these rocks to clinochlore and muscovite around $\mathrm{Mt}$. Whaleback. These metamorphic fluids did not significantly affect BIF. However, subsequent acidic and oxidizing fluids around Mt. Whaleback converted magnetite to martite and dissolved carbonates and silicates from BIF. In black shales, these fluids also dissolved quartz and converted clinochlore and muscovite to hematite and kaolinite respectively. At some time in the paragenetic sequence, BIF or altered BIF was converted to highly porous, high-grade hematite ore (or a precursor of such ore) by the dissolution of $\mathrm{Si}$, a process not requiring iron addition. These observations in and around Mt. Whaleback suggest that BIF was oxidized separately from silica removal, so it is inferred that ore formation requires at least two steps. Regionally, the alteration sequence is probably more complicated because rocks described at Mt. Tom Price show a stage involving carbonate replacement of silica prior to oxidation that is not evident at Mt. Whaleback. Also, the oxidation stage could (at least in part) have formed by weathering sometime since the Proterozoic. In any case, (1) no single process can produce all of the altered rocks at Mt. Whaleback, (2) oxidation of magnetite to hematite can occur independently of silica removal or replacement, and (3) the complete 
mineralization postdates metamorphism. It is assumed that the same set of processes generated the high-grade hematite ores at Mt. Tom Price and Mt. Whaleback. Thus, with available data, a model explaining differences between these two deposits requires either a local carbonate addition step at Mt. Tom Price unrelated to ore formation, or the complete removal of previous carbonate-magnetite BIF at $\mathrm{Mt}$. Whaleback, perhaps during the oxidation stage.

\section{INTRODUCTION}

The southern Hamersley Province (Fig. 2.1) hosts several large orebodies (Mt. Whaleback, Mt. Tom Price and Paraburdoo) where BIF of the Dales Gorge Member has been folded, faulted and altered to mixtures of martite and microplaty hematite (Figs. 1.2-1.4). As introduced in Chapter 1, several models have been forwarded to explain the genesis of these high-grade hematite ores (e.g., Morris, 1980, 1985; Morris et al., 1980; Harmsworth et al., 1990; Li et al., 1993; Findlay, 1994; Barley et al., 1999; Oliver and Dickens, 1999; Powell et al., 1999; Taylor et al., 2001). A major problem in assessing these models is the paucity of basic information concerning the transformation of BIF to iron ore (Fig. 2.2). The composition and structure of BIF and shale horizons vary dramatically between undeformed areas in the north and deformed areas in the south (Trendall and Blockley, 1970; Ewers and Morris, 1981). Such observations suggest profound changes in chemistry and mineralogy, perhaps related to mineralization. Surprisingly, however, while numerous investigations have focused on the geochemical origins of Hamersley BIF (e.g., Holland, 1973; Trendall and Blockley, 1970; Trendall and Pepper, 1976; Anbar and Holland, 1992; Alibert and McCulloch, 1993; Barley et al., 1997; Canfield, 1998), only limited information exists regarding the colour, chemistry or mineralogy of bulk rocks from the Dales Gorge Member, especially in the south or around orebodies (i.e., Ewers and Morris, 1981; Taylor et al., 2001). Indeed, other than initial work by Ewers and Morris (1981), there has been no systematic study of chemical and mineralogical variations between undeformed and unmineralized sequences in the north and deformed and mineralized sequences in the 
south. This critical gap is partly filled in this chapter, which documents and discusses the major element chemistry and mineralogy of the Dales Gorge Member and surrounding shales at two key locations, the type section near Wittenoom and the giant iron ore mine at Mt. Whaleback.

\section{REGIONAL GEOLOGY AND STRATIGRAPHY}

The $2.5 \mathrm{~km}$ thick Hamersley Group covers $\sim 40,000 \mathrm{~km}^{2}$ of the Hamersley Province of the southern Pilbara Craton (Fig. 2.1). The group consists of BIF, shale, carbonates, and volcanics that were deposited in a marine environment during the Late Archaean and Palaeoproterozoic ca. 2.6 to 2.45 Ga (Barley et al., 1997; Trendall et al., 1998). Rocks of the Hamersley Group are horizontal to shallow dipping in the north (e.g., at Wittenoom), but are spectacularly folded in the southeast (e.g., at Mt. Whaleback) primarily as a consequence of the Ophthalmian $\left(\mathrm{D}_{2}\right)$ ca. 2.45-2.2 Ga (Martin et al., 1998), and Capricorn orogenies $\left(\mathrm{D}_{4}\right)$ ca. 1.8 to $1.6 \mathrm{Ga}$ (Thorne and

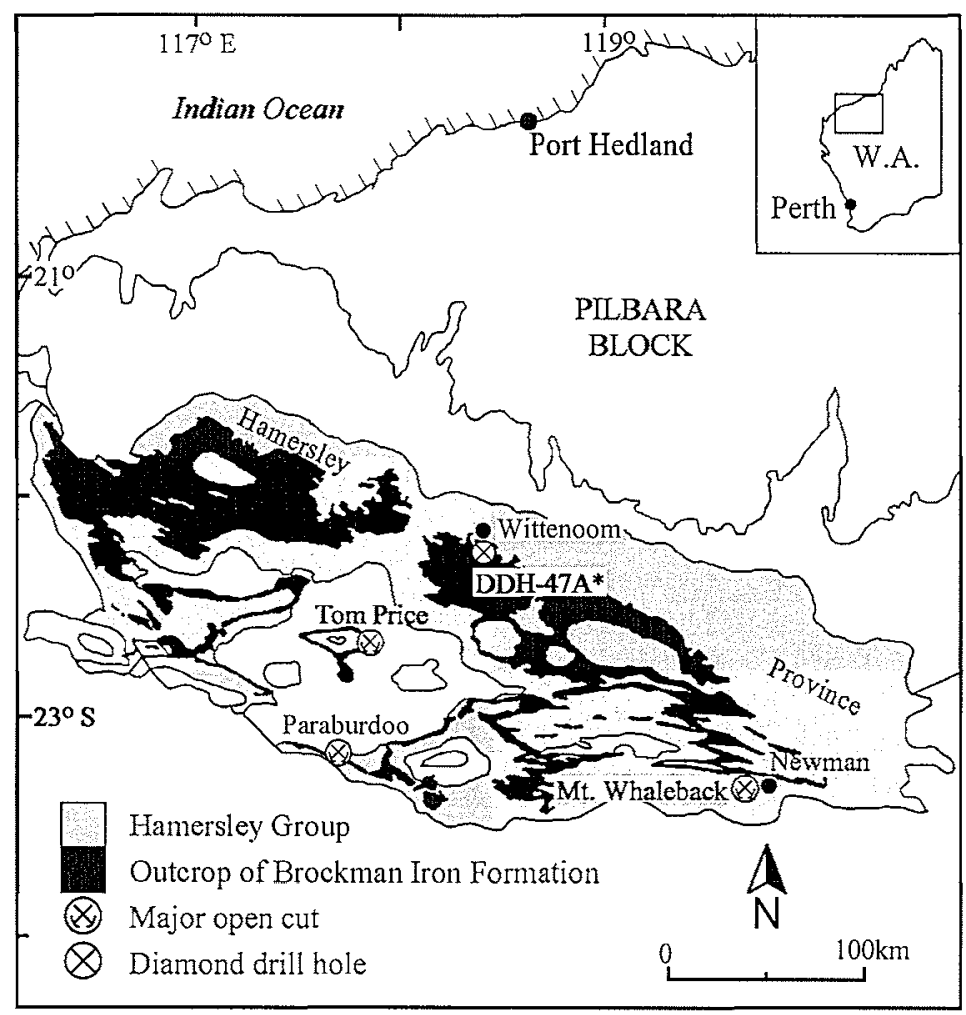

Figure 2.1. Location and regional geology of the Hamersley Province, showing outcrop of Brockman Iron Formation (modified from Trendall and Blockley, 1970), sample locations and positions of major microplaty hematite ore deposits. 
Seymour, 1991), the first of which involved the northward collision of the Yilgarn Craton into the southern Pilbara margin (Tyler and Thorne, 1990; Thorne and Seymour, 1991; Powell et al., 1999). Note that a third generation of folds (Panhandle folding, $\mathrm{D}_{3}$ ) in the western part of the province interacts with earlier Ophthalmian folds to produce a characteristic dome and basin structural pattern (Taylor et al., 2001).

The Hamersley Group has been divided into eight formations (Fig. 2.2) on the basis of lithology (Macleod, 1966; Trendall and Blockley, 1970; Trendall, 1983). In this chapter, the focus is on the three rock units that host and surround most of the highgrade hematite ore at Mt. Whaleback, Mt. Tom Price and Paraburdoo. These units, from bottom to top, are the Mt. McRae Shale Formation, and the Dales Gorge Member and Whaleback Shale Member of the Brockman Iron Formation (Fig. 2.2).

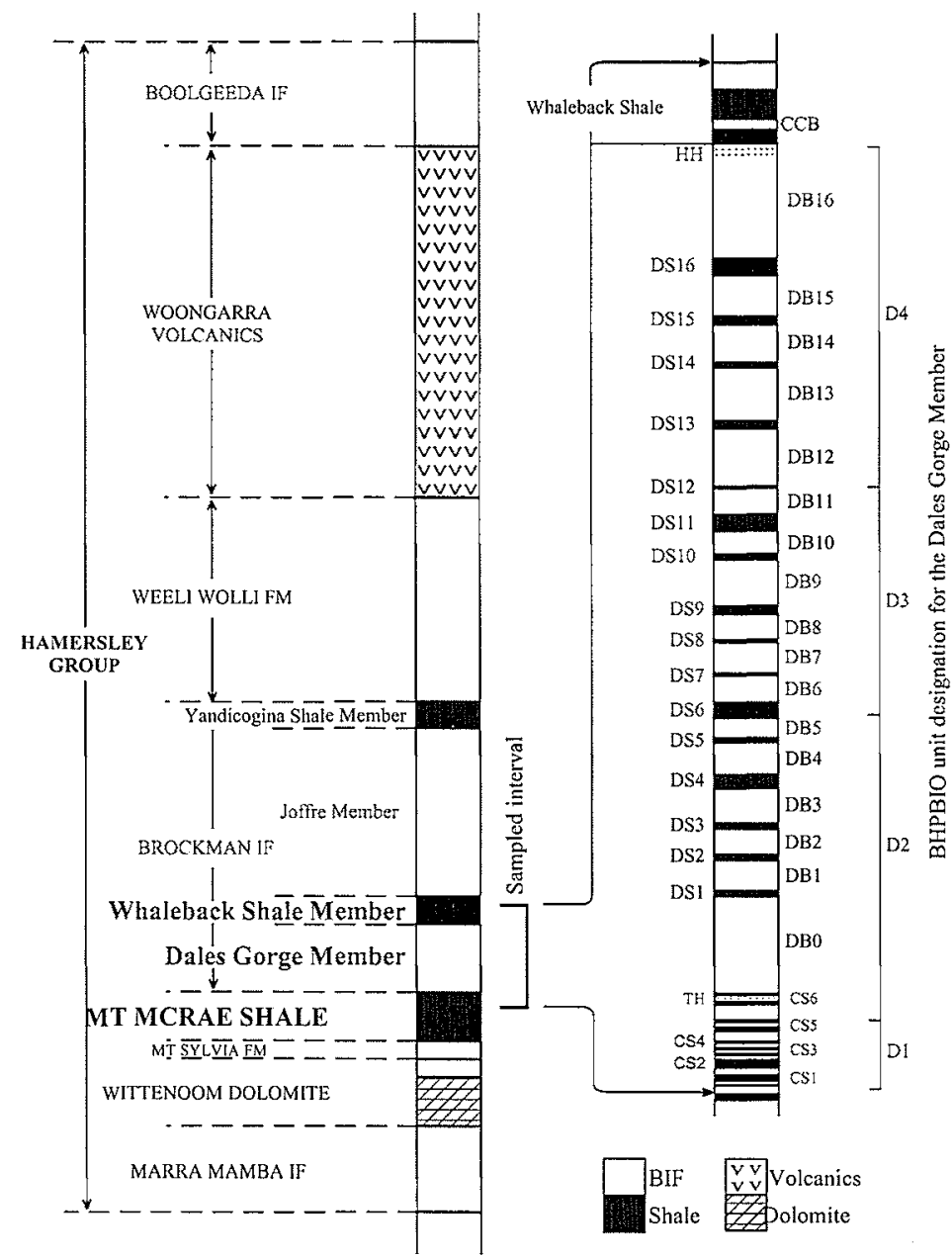

Figure 2.2. Stratigraphic columns of the Hamersley Group, showing detailed stratigraphy of the upper Mt. McRae Shale, Dales Gorge Member and Whaleback Shale Member (modified from Harmsworth et al., 1990). Note the internal lithological nomenclature used by BHPBIO for the Dales Gorge Member. CCB = Central Chert Band; CS = Colonial Chert shale bands; $\mathrm{DB}=$ Dales Gorge Member BIF macrobands; DS = Dales Gorge Member shale macrobands; FM = Formation; HH = Huleatt's Holes; IF = Iron Formation; $\mathrm{TH}=$ Trendall's bed of holes. 
The Mt. McRae Shale is $\sim 100 \mathrm{~m}$ thick in the north where it is composed of thinly bedded black shale, chert, carbonates and cherty BIF (Trendall and Blockley, 1970). The uppermost 10-15 $\mathrm{m}$ (the Colonial Chert Member) are particularly enriched in BIF and are clearly identified in the field by two sets of twin shale bands (CS5 and CS6) (Fig. 2.2). At Mt. Whaleback and Mt. Tom Price, the Mt. McRae Shale also consists of black shale, chert, carbonates and cherty BIF, although the upper Colonial Chert Member is typically mineralized (Ewers and Morris, 1981; Harmsworth et al., 1990). For this reason, and in contrast to other workers (e.g., Trendall and Blockley, 1970; Morris, 1985), BHP Billiton Iron Ore (BHPBIO) geologists include the top 5-10 $\mathrm{m}$ of the Mt. McRae Shale as part of the overlying, Fe-rich Dales Gorge Member (D1, Fig. 2.2).

The Dales Gorge Member is $~ 145 \mathrm{~m}$ thick in the north and hosts large parts of the Mt. Whaleback, Mt. Tom Price and Paraburdoo ore deposits in the south (Fig. 2.1). The overall unit is composed of 17 BIF (DB) and 16 shale (DS) m-scale macrobands (Fig. 2.2) that persist laterally throughout the entire province, including the orebodies (Trendall and Blockley, 1968, 1970; Ewers and Morris, 1981). These 33 macrobands are consecutively numbered from the base of the unit so that DB1-DB17 straddle DS1DS16 (Fig. 2.2). In the north, unweathered DB-macrobands consist of BIF and unweathered DS-macrobands consist predominantly of black shale, chert and carbonate (Trendall and Blockley, 1970; Ewers and Morris, 1981). Chert and carbonate layers, commonly known as chert-siderite bands, typically lie between the black shales and BIF units (Trendall and Blockley, 1970). In the deformed and mineralized terrains of mine pits, DB-macrobands predominantly consist of hematite whereas DS-macrobands consist of red shale (Morris, 1980; Barley et al., 1999; Taylor et al., 2001).

The Whaleback Shale Member is $\sim 65 \mathrm{~m}$ thick in undeformed regions (Trendall and Blockley, 1970). Similar to the Mt. McRae Shale, this member mostly consists of black shale, chert and carbonates (Trendall and Blockley, 1970). However, it also contains cherty BIF, especially towards the base (Trendall and Blockley, 1970). At Mt. Whaleback, the lower third of the Whaleback Shale can form low-grade shaley ore 
(Ewers and Morris, 1981, p.1930).

\section{SITE LOCATIONS AND SAMPLES}

One hundred and seventy-seven rock samples were collected from the Mt. McRae Shale, Dales Gorge Member and Whaleback Shale Member (Appendix 3). These samples were collected from three diamond drill holes (DDHs) near Wittenoom (59 samples) and five DDHs (49 samples) and six fresh mine faces (69 samples) within the Mt. Whaleback pit. These samples and their locations are briefly discussed below; detailed photographs, logs and maps of sample locations at Mt. Whaleback are presented in Appendix 1.

DDH-47A, DDH-EC10 and DDH-Y1 were cored within $25 \mathrm{~km}$ of Wittenoom by the Australian Blue Asbestos Co. between 1961 and 1966 (Trendall and Blockley, 1968). Stacked cores from these holes, currently stored at the Geological Survey of Western Australia (GSWA) core repository in Perth, and collectively referred to as DDH-47A*, constitute the type section for the Dales Gorge and Whaleback Shale Members. A continuous photographic record and log of the Dales Gorge portion of DDH-47A* has been published (Trendall and Blockley, 1968). As the Whaleback Shale Member and uppermost Mt. McRae Shale were not examined by these authors in detail, the core was relogged from $\sim 25 \mathrm{~m}$ above to $\sim 2 \mathrm{~m}$ below the Dales Gorge Member (Fig. 2.3). The 59 samples from DDH-47A* include representative samples from most DB- and DS-macrobands as well as Dales Gorge chert-siderite bands and surrounding Mt. McRae and Whaleback shales. Samples were typically $5-10 \mathrm{~cm}$ thick.

Five working faces in the Mt Whaleback pit (Fig. 2.4) were extensively sampled in 1999 because they appeared unaffected by surface weathering, and because they had straightforward stratigraphy. In addition, four of these faces contained intervals of BIF or black shale rather than exclusively hematite ore and red shale. The five faces $(A-E)$ were located on mine benches 23, 24, and 25. The latter face is documented here (Fig. 2.5) whereas the others are presented in Appendix 1. Thirteen red shale samples collected from a single mine face in 1997 and given to this project with a stratigraphic 


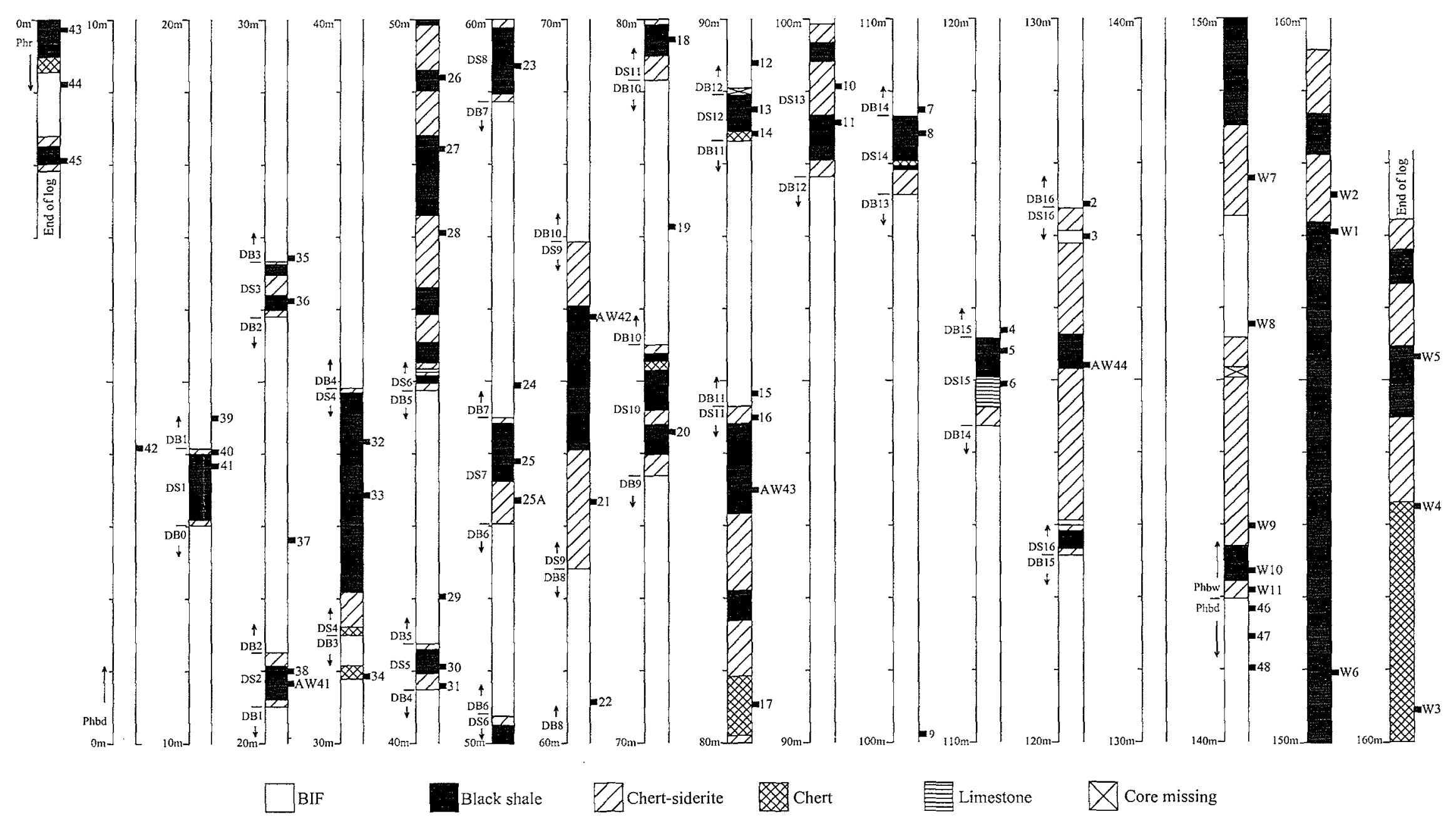

Figure 2.3. Detailed log of diamond drill hole (DDH) 47A*, Wittenoom region. Note that shale macrobands (DS) are composed of black shale and chert-siderite bands. Black ticks on the right side of the columns indicate sample location and the corresponding sample names are prefixed by "47" in Appendix 3. Left-hand scale (in metres) refers to distances above the base of the Dales Gorge Member (similar to Trendall and Blockley, 1968). Phbw = Whaleback Shale Member; Phbd = Dales Gorge Member; DB = Dales Gorge Member BIF macrobands; DS = Dales Gorge Member shale macrobands; Phr = Mt. McRae Shale. 
$\log$ but without a location are included as face O. Five sets of cores from BHPBIO holes DDH-73, DDH-86, DDH-229, DDH-257 and DDH-324 were also sampled (Appendix 1). These five holes were located in rocks that now comprise the main pit (Fig. 2.4). The 118 total samples at Mt. Whaleback include 50 samples from DB- and DS-macrobands, 43 samples from the Whaleback Shale Member, and 25 samples from the Mt. McRae Shale. Layers corresponding to chert-siderite bands were not clearly identified in the pit. Samples from pit faces were $10-15 \mathrm{~cm}$ thick, whereas those from mine drill cores were $5-10 \mathrm{~cm}$ thick.
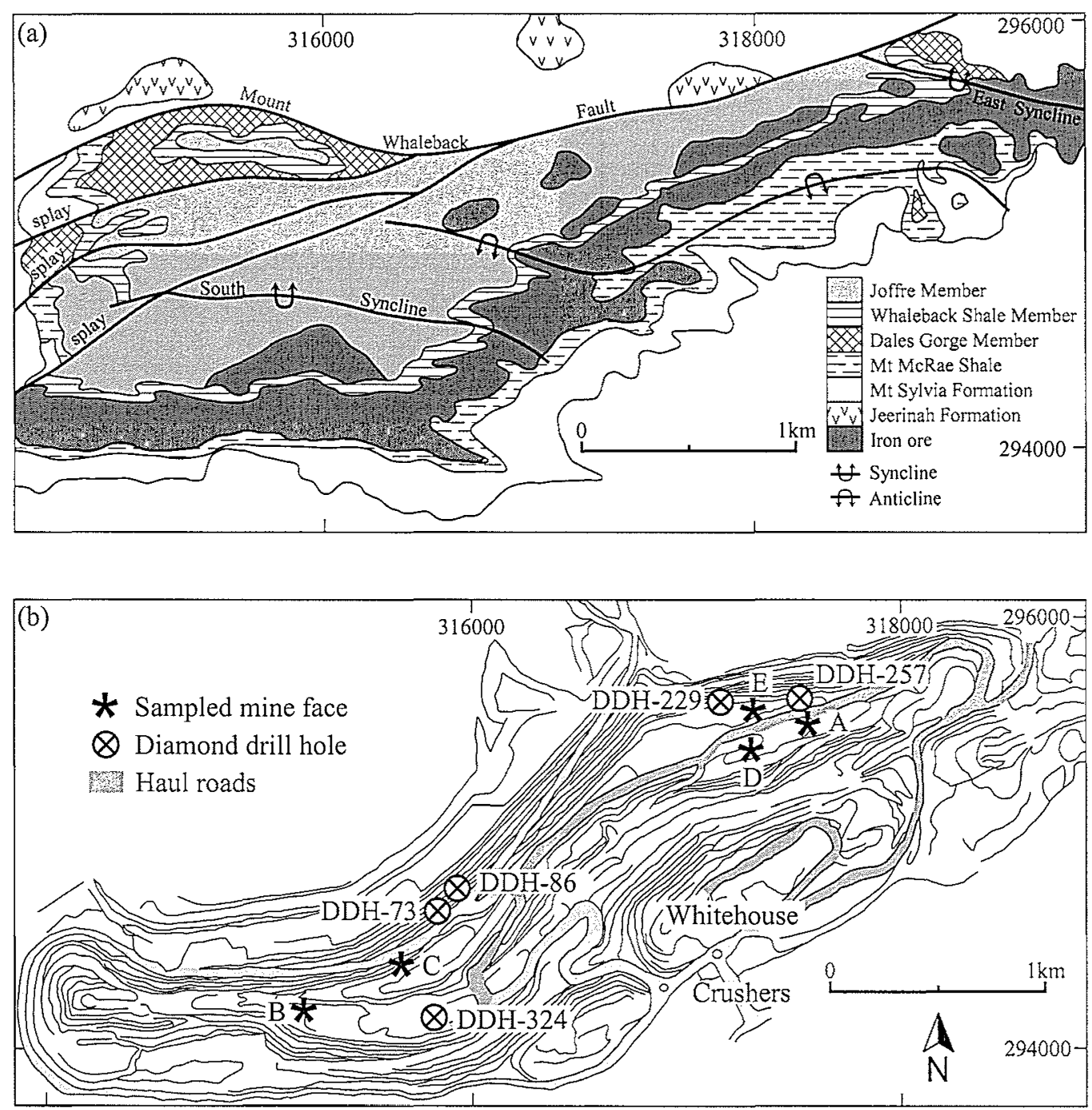

Figure 2.4. Simplified geologic and mine plans of Mt. Whaleback. (a) Surface geological map of Mt. Whaleback prior to mining (from Harmsworth et al., 1990). (b) Locations of sampled diamond drill holes and mine faces within the Mt. Whaleback pit (circa 1997) (after Ronaszeki, 1997). Letters adjacent to face locations correspond to those in Appendix 1 and sample locations in Appendix 3. Phbd $=$ Dales Gorge Member; Phbj = Joffre Member; DDH = diamond drill hole. Note: see Figure 6.1 for generalised crosssection of Mt. Whaleback. 


\section{ANALYTICAL METHODS}

Each sample was crushed in a clean tungsten carbide bowl using a Rocklabs tema mill. The colour of the crushed samples was determined using a Munsell colour chart. Splits were then examined for major element chemistry and mineralogy at the James Cook University Advanced Analytical Centre (JCU-AAC).

Approximately $10 \mathrm{~g}$ of each sample was weighed into a porcelain crucible and heated at $1000^{\circ} \mathrm{C}$ for 10 hours to determine loss on ignition (LOI). One split of $\sim 0.6 \mathrm{~g}$ of each roasted sample was then made into a quenched pressed glass disk and analysed for major elements using a Siemens SRS-3000 X-ray fluorescence (XRF) spectrometer (Appendix 3). Major element oxide contents were obtained by comparing peak positions and intensities to traces of geological standards. Eighty analyses of five different pressed glass disks of the geological standard AGV-1 consistently gave major element oxide contents that were within $1 \%$ of consensus values (Table 2.1). For three samples, 4747 (BIF), E24C (iron ore) and 4718 (black shale), five new splits were prepared and analysed to evaluate precision. All major element oxide contents for these replicates were within $0.5 \%$ (absolute) of the first analysis (Table 2.1). A critical check on the quality of XRF analyses is that the sum of major element oxides and LOI is $100 \%$. For the entire sample suite, this sum averaged $100.2 \%$ with a standard deviation of $0.5 \%$. Major elements are reported as oxide weight percents because this is compatible with all previous work on rocks of the Hamersley Province (Trendall and Blockley, 1970; Ewers and Morris, 1981; Alibert and McCulloch, 1993). Iron contents are reported as total $\mathrm{Fe}_{2} \mathrm{O}_{3}\left(\mathrm{Fe}_{2} \mathrm{O}_{3} \mathrm{~T}\right)$ because $\mathrm{Fe}(\mathrm{II})$ and $\mathrm{Fe}(\mathrm{III})$ were not distinguished.

Twenty-five samples from the northern Hamersley Province and 29 samples from the Mt. Whaleback pit were selected for X-ray diffraction (XRD) analysis (Appendix 4). A second split of homogenized sample $(\sim 2.0 \mathrm{~g})$ was lightly pressed into a plastic holder and analysed using a Siemens D5000 X-ray diffractometer (XRD). Mineralogical phases were identified using software (Eva) that searches and matches diffraction patterns to reference patterns. Semi-quantitative phase analysis of the XRD patterns was undertaken using SIROQUANT Version 2.0. This software package uses 
Table 2.1. Major element oxide contents of the standard and replicate samples (wt\%)

\begin{tabular}{|c|c|c|c|c|c|c|c|c|c|c|c|c|c|c|}
\hline \multirow{3}{*}{$\begin{array}{l}\text { Element } \\
\text { Oxide } \\
\mathrm{SiO}_{2}\end{array}$} & \multirow[t]{2}{*}{ Line } & \multicolumn{4}{|c|}{ AGV-1 } & \multicolumn{3}{|c|}{4747 (BIF) } & \multicolumn{3}{|c|}{ E24C (Iron Ore) } & \multicolumn{3}{|c|}{4718 (Black shale) } \\
\hline & & \multicolumn{2}{|c|}{ Certified* } & \multicolumn{2}{|c|}{ Analysed $(n=80)$} & \multirow{2}{*}{$\frac{\text { Reported }}{43.8}$} & \multicolumn{2}{|c|}{ Repeats $(n=5)$} & \multirow{2}{*}{$\begin{array}{c}\text { Reported } \\
0.21\end{array}$} & \multicolumn{2}{|c|}{ Repeats $(n=5)$} & \multirow{2}{*}{$\frac{\text { Reported }}{42.5}$} & \multicolumn{2}{|c|}{ Repeats ( $n=5$ ) } \\
\hline & $\mathrm{KA} 1,2$ & 58.8 & $(0.28)$ & 58.8 & $(0.6)$ & & 43.2 & $(0.06)$ & & 0.37 & $(0.17)$ & & 42.7 & $(0.66)$ \\
\hline $\mathrm{TiO}_{2}$ & $\mathrm{KAl}, 2$ & 1.05 & $(0.05)$ & 1.05 & $(0.02)$ & 0.01 & 0.02 & $(0.01)$ & 0.02 & 0.03 & $(0.01)$ & 0.01 & 0.28 & $(0.01)$ \\
\hline $\mathrm{Al}_{2} \mathrm{O}_{3}$ & $\mathrm{KAl}, 2$ & 17.2 & $(0.15)$ & 17.2 & $(0.20)$ & 0.36 & 0.64 & $(0.23)$ & 0.07 & 0.16 & $(0.05)$ & 5.75 & 5.47 & $(0.09)$ \\
\hline $\mathrm{Fe}_{2} \mathrm{O}_{3}$ & $\mathrm{KAl}, 2$ & 6.77 & $(0.17)$ & 6.76 & $(0.08)$ & 40.6 & 40.9 & $(0.42)$ & 99.9 & 99.2 & $(0.45)$ & 29.6 & 29.8 & $(0.13)$ \\
\hline $\mathrm{MnO}$ & $\mathrm{KAl}, 2$ & 0.09 & $(0.01)$ & 0.10 & $(0.01)$ & 0.23 & 0.23 & $(0.01)$ & 0.10 & 0.11 & $(0.00)$ & 0.13 & 0.12 & $(0.00)$ \\
\hline $\mathrm{MgO}$ & $\mathrm{KA} 1,2$ & 1.53 & $(0.10)$ & 1.50 & $(0.04)$ & 3.18 & 3.13 & $(0.03)$ & - & - & - & 9.33 & 8.88 & $(0.16)$ \\
\hline $\mathrm{CaO}$ & $\mathrm{KAl}, 2$ & 4.94 & $(0.14)$ & 4.92 & $(0.06)$ & 3.32 & 3.11 & $(0.03)$ & 0.03 & 0.21 & $(0.05)$ & 0.68 & 0.66 & $(0.01)$ \\
\hline $\mathrm{Na}_{2} \mathrm{O}$ & $\mathrm{KA} 1,2$ & 4.26 & $(0.11)$ & 4.18 & $(0.09)$ & - & 0.13 & $(0.12)$ & - & - & - & 0.50 & 0.72 & $(0.45)$ \\
\hline $\mathrm{K}_{2} \mathrm{O}$ & $\mathrm{KAl}, 2$ & 2.92 & $(0.08)$ & 3.01 & $(0.02)$ & 0.48 & 0.51 & $(0.01)$ & 0.01 & 0.03 & $(0.00)$ & 1.98 & 1.93 & $(0.04)$ \\
\hline $\mathrm{P}_{2} \mathrm{O}_{5}$ & $\mathrm{KAl}, 2$ & 0.49 & $(0.04)$ & 0.49 & $(0.01)$ & 0.08 & 0.07 & $(0.00)$ & 0.02 & 0.01 & $(0.00)$ & 0.09 & 0.12 & $(0.00)$ \\
\hline $\mathrm{S}$ & $\mathrm{KAl}, 2$ & & & 0.02 & $(0.00)$ & 0.02 & 0.02 & $(0.00)$ & - & 0.01 & $(0.02)$ & 0.18 & 0.10 & $(0.10)$ \\
\hline LOI & & & & & & 8.30 & 8.37 & $(0.01)$ & 0.20 & 0.22 & $(0.00)$ & 8.56 & 9.06 & $(0.01)$ \\
\hline SUM & & 98.0 & $(1.0)$ & 99.7 & $(0.68)$ & 100.4 & 100.302 & $(0.29)$ & 100.5 & 100.3 & $(0.49)$ & 99.9 & 100.1 & $(0.50)$ \\
\hline
\end{tabular}

Notes: *Ref: Gladney et al., 1992; $n=$ number of analyses; standard deviations in brackets; '-' = below detection; blank = not reported. 
the full-profile Rietveld method of refining the shape of calculated XRD patterns against the profile of a measured pattern (Taylor, 1991). The SIROQUANT program does not contain a calculated XRD pattern for the chlorite mineral clinochlore. Therefore an XRD pattern from another chlorite mineral, chamosite, was used, and this trace was fitted to measured XRD traces by adjusting unit cell parameters.

Three polished thin sections were prepared and examined using reflected and transmitted light microscopy to illustrate petrographic differences between BIF units across the Hamersley Province. The samples chosen were 477 from DDH-47A* (BIF, DB14), D73C from Mt. Whaleback (BIF, DB16), and E24C from Mt. Whaleback (iron ore, DB16). Photomicrographs of these samples were taken using a Leica DMR photomicroscope. The petrography of other BIF and iron ore samples as well as shale samples are presented in Chapters 3 and 4.

\section{RESULTS}

\subsection{Powder colour}

Powdered samples of the Hamersley Group display a considerable range in colour (Appendix 3). Near Wittenoom, BIF and "black" shale are grey and olive grey, respectively, whereas chert-siderite bands and cherty BIF samples are white and light grey, respectively. BIF and "black" shale from the Mt. Whaleback pit are commonly weak red and very dark grey, respectively. However, some samples of the Mt. McRae Shale and Whaleback Shale Member at Mt. Whaleback are truly black. In striking contrast, DB- and DS-macrobands from mineralized areas of the pit are dusky red and red, respectively. Shaley ore is typically dark red.

The overall colour trend is one where green and grey rock units in the northern Hamersley Province change to red rocks in and around the Mt. Whaleback pit. These colour transitions can be observed at the macroscopic scale on certain pit faces where the Mt. McRae Shale and Whaleback Shale Member are grey away from the orebody but reddish grey to dark red close to the orebody (e.g., Fig. 2.5). 
a)

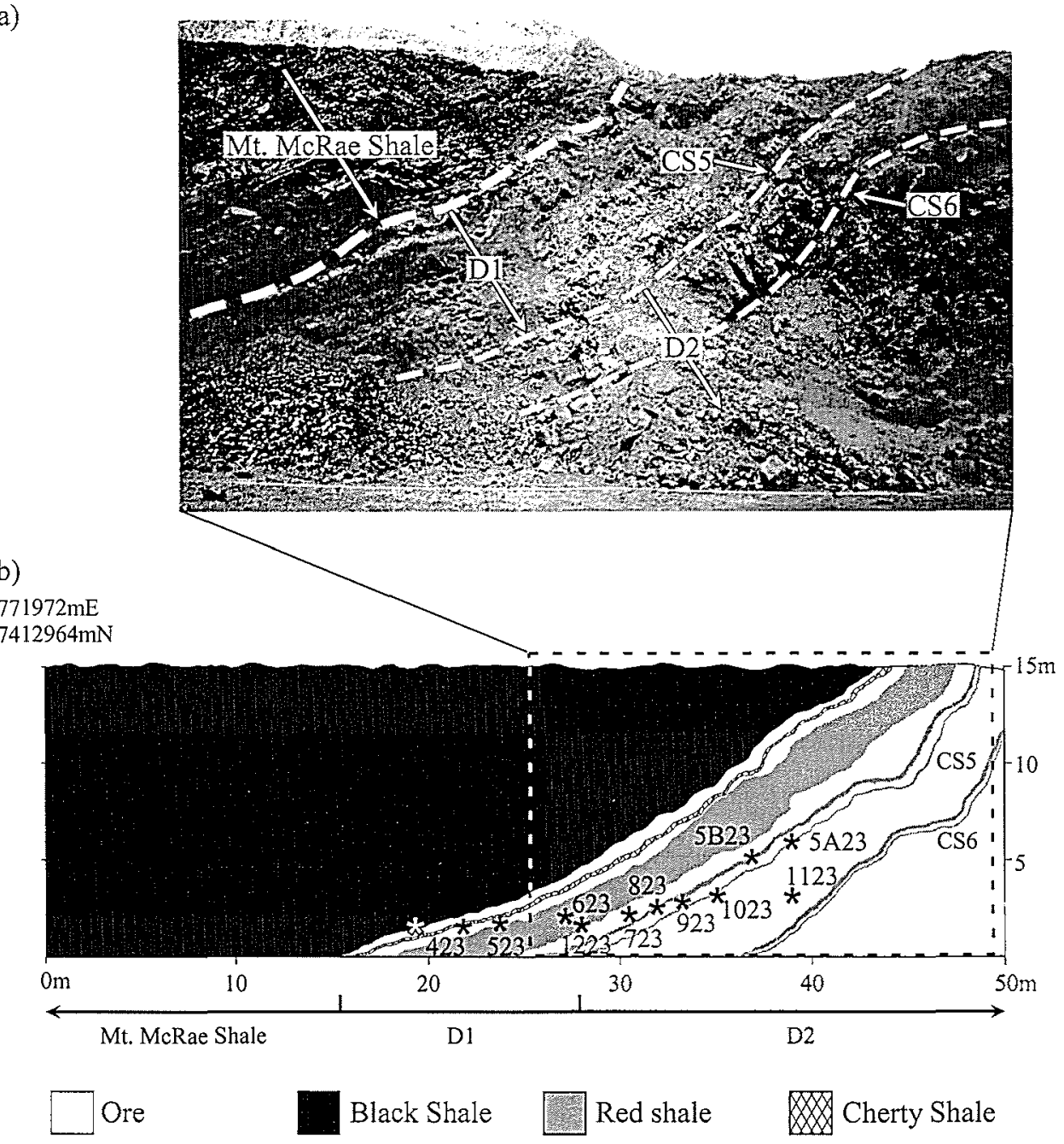

Figure 2.5. Mine face B at Mt. Whaleback. (a) West facing photograph with rock units labelled according to the BHPBIO classification scheme (Fig. 2.2). (b) Schematic diagram showing sample locations (stars), colour and lithology. Note the colour transition from black, away from the orebody, to red, close to the orebody.

\subsection{Major element chemistry}

Rocks from the Hamersley Province (Fig. 2.6) have an exceptionally wide range in major element composition as exemplified by mean contents and standard deviations

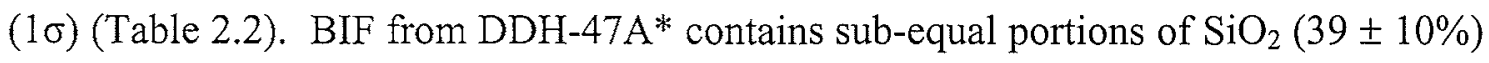
and $\mathrm{Fe}_{2} \mathrm{O}_{3} \mathrm{~T}(48 \pm 8.5 \%)$, although $\mathrm{MgO}(2.6 \pm 0.8 \%), \mathrm{CaO}(1.9 \pm 1.7 \%)$ and LOI $(7.0 \pm$ $5.9 \%$ ) contents are moderately high. Contents of $\mathrm{Al}_{2} \mathrm{O}_{3}, \mathrm{MnO}, \mathrm{Na}_{2} \mathrm{O}, \mathrm{K}_{2} \mathrm{O}, \mathrm{P}_{2} \mathrm{O}_{5}$ and $\mathrm{S}$ are $<0.3 \%$. BIF at Mt. Whaleback also consists mostly of $\mathrm{SiO}_{2}(41 \pm 14 \%)$ and $\mathrm{Fe}_{2} \mathrm{O}_{3} \mathrm{~T}$ $(58 \pm 14 \%)$, although $\mathrm{Fe}$ is significantly higher. However, $\mathrm{MgO}, \mathrm{CaO}$ and $\mathrm{LOI}$ (as well as all other element oxides) are $<0.6 \%$. In contrast to all BIF, iron ore consists almost entirely of $\mathrm{Fe}_{2} \mathrm{O}_{3} \mathrm{~T}(98 \pm 1.0 \%)$. 

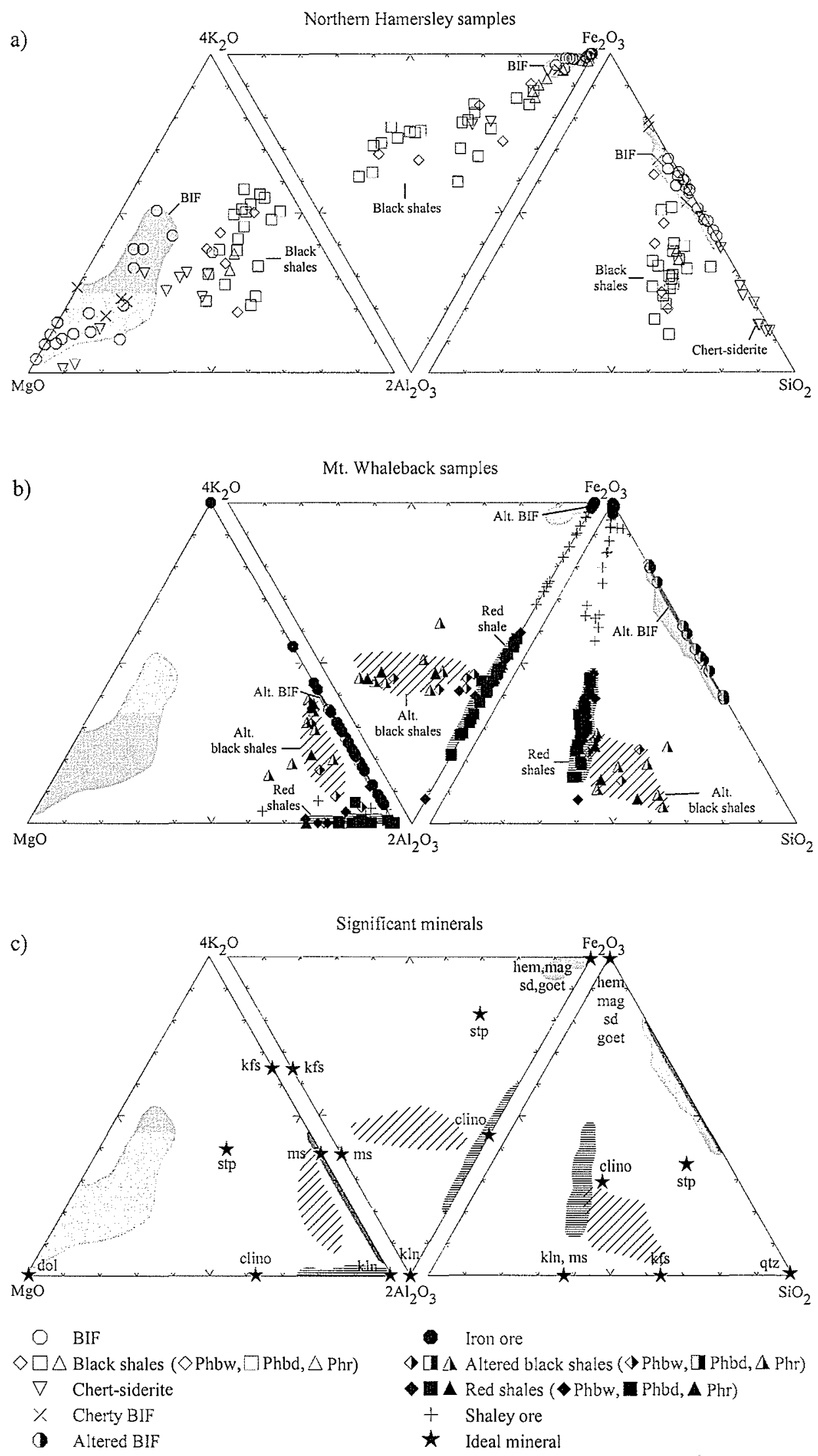

Figure 2.6.Ternary diagrams showing the distribution of $\mathrm{SiO}_{2}, \mathrm{Al}_{2} \mathrm{O}_{3}, \mathrm{Fe}_{2} \mathrm{O}_{3}, \mathrm{MgO}$ and $\mathrm{K}_{2} \mathrm{O}$ for samples collected across the Hamersley Province. (a) Northern Hamersley samples (DDH-47A*). (b) Mt. Whaleback pit samples. (c) The relationship of significant mineral phases to the bulk analyses. Phbw $=$ Mt. Whaleback Shale Member. Phbd = Dales Gorge Menber, Phr = Mt. McRae Shale; Alt. = altered; clino $=$ clinochlore; dol $=$ dolomite; goet $=$ goethite; hem $=$ hematite; $\mathrm{kln}=$ kaolinite; $\mathrm{kfs}=\mathrm{K}$-feldspar; mag = magnetite; $m s=$ muscovite; $q \mathrm{tz}=$ quartz; $\mathrm{sd}=$ siderite; $\mathrm{stp}=$ stilpnomelane. 
Table 2.2. Average major element oxide contents and standard deviations of rocks from Wittenoom and Mt. Whaleback (wt\%)

\begin{tabular}{|c|c|c|c|c|c|c|c|c|c|c|c|c|c|c|c|c|c|c|c|c|c|c|c|c|c|c|c|}
\hline \multirow[t]{2}{*}{ Rocks } & \multirow[t]{2}{*}{$\mathbf{n}$} & \multicolumn{2}{|c|}{$\mathrm{SiO}_{2}$} & \multicolumn{2}{|c|}{$\mathrm{TiO}_{2}$} & \multicolumn{2}{|c|}{$\mathrm{Al}_{2} \mathrm{O}_{3}$} & \multicolumn{2}{|c|}{$\mathrm{Fe}_{2} \mathrm{O}_{3} \mathrm{~T}$} & \multicolumn{2}{|c|}{ MnO } & \multicolumn{2}{|c|}{ MgO } & \multicolumn{2}{|c|}{$\mathrm{CaO}$} & \multicolumn{2}{|c|}{$\mathrm{Na}_{2} \mathrm{O}$} & \multicolumn{2}{|c|}{$\mathrm{K}_{2} \mathrm{O}$} & \multicolumn{2}{|c|}{$\mathrm{P}_{2} \mathrm{O}_{5}$} & \multicolumn{2}{|c|}{$\mathbf{S}$} & \multicolumn{2}{|c|}{ LOI } & \multicolumn{2}{|c|}{ SUM } \\
\hline & & avg & sd & avg & sd & avg & sd & avg & sd & avg & sd & avg & sd & avg & sd & avg & sd & avg & sd & avg & sd & avg & sd & avg & sd & avg & sd \\
\hline \multicolumn{28}{|c|}{ Wittenoom samples (DDH-47A*) } \\
\hline $\mathrm{BIF}$ & 19 & 39.20 & 9.91 & 0.04 & 0.12 & 0.25 & 0.36 & 48.48 & 8.46 & 0.10 & 0.13 & 2.63 & 0.85 & 1.91 & 1.75 & 0.04 & 0.12 & 0.31 & 0.36 & 0.22 & 0.17 & 0.07 & 0.14 & 6.99 & 5.93 & 100.2 & 0.40 \\
\hline Black shale & 27 & 39.14 & 8.11 & 0.35 & 0.23 & 7.00 & 2.98 & 26.02 & 7.72 & 0.24 & 0.16 & 6.86 & 233 & 4.05 & 3.99 & 0.22 & 0.20 & 3.98 & 2.32 & 0.13 & 0.12 & 0.53 & 0.48 & 11.40 & 5.39 & 99.9 & 0.50 \\
\hline Whaleback & 5 & 30.29 & 6.64 & 0.21 & 0.09 & 5.86 & 2.38 & 27.34 & 13.01 & 0.44 & 0.14 & 7.88 & 2.10 & 5.95 & 4.82 & 0.04 & 0.10 & 3.05 & 1.79 & 0.17 & 0.09 & 0.54 & 0.70 & 18.18 & 4.60 & 100.0 & 0.60 \\
\hline Dales Gorge & 20 & 41.05 & 7.41 & 0.36 & 0.22 & 7.42 & 3.20 & 25.20 & 6.50 & 0.20 & 0.13 & 6.49 & 2.44 & 3.86 & 3.87 & 0.25 & 0.19 & 4.34 & 2.47 & 0.13 & 0.13 & 0.53 & 0.44 & 10.09 & 4.46 & 99.9 & 0.48 \\
\hline Mt. McRae & 2 & 42.13 & 2.69 & 0.63 & 0.45 & 5.72 & 0.45 & 30.92 & 0.57 & 0.10 & 0.02 & 7.99 & 0.04 & 1.18 & 1.30 & 0.46 & 0.04 & 2.60 & 0.54 & 0.05 & 0.01 & 0.56 & 0.62 & 7.66 & 0.83 & 100.0 & 0.88 \\
\hline Chert-siderite & 9 & 61.17 & $15: 13$ & 0.03 & 0.02 & 0.64 & 0.38 & 19.15 & 8.59 & 0.22 & 0.10 & 3.09 & 1.79 & 2.55 & 1.60 & 0.02 & 0.05 & 0.32 & 0.23 & 0.13 & 0.06 & 0.09 & 0.09 & 12.14 & 5.49 & 99.5 & 0.23 \\
\hline Cherty BIF & 4 & 25.77 & 12.83 & 0.02 & 0.01 & 0.54 & 0.50 & 58.05 & 19.74 & 0.10 & 0.16 & 5.11 & 4.38 & 0.67 & 0.33 & 0.00 & 0.00 & 0.48 & 0.41 & 0.26 & 0.18 & 0.02 & 0.03 & 9.36 & 13.54 & $100: 4$ & 0.19 \\
\hline
\end{tabular}

\section{Mt. Whaleback pit samples}

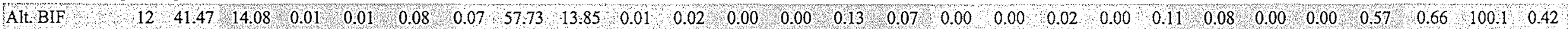

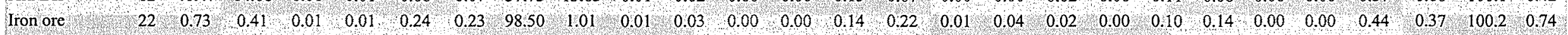

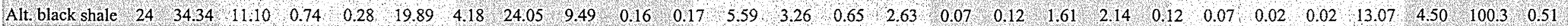
$\begin{array}{lllllllllllllllllllllllllllll}\text { Whaleback } & 14 & 30.70 & 7.55 & 0.80 & 0.27 & 21.48 & 2.82 & 28.76 & 7.66 & 0.16 & 0.08 & 5.28 & 2.02 & 0.11 & 0.05 & 0.10 & 0.15 & 0.75 & 1.53 & 0.12 & 0.07 & 0.02 & 0.01 & 12.21 & 2.90 & 100.5 & 0.41\end{array}$ $\begin{array}{lllllllllllllllllllllllllllll}\text { Dales Gorge } & 2 & 29.10 & 1.87 & 1.13 & 0.01 & 22.85 & 1.26 & 27.84 & 3.43 & 0.27 & 0.14 & 7.26 & 0.73 & 0.10 & 0.01 & 0.00 & 0.00 & 0.02 & 0.00 & 0.09 & 0.02 & 0.00 & 0.00 & 11.45 & 1.06 & 100.1 & 0.11\end{array}$

$\begin{array}{lllllllllllllllllllllllllllllllll}\text { Mt. McRae } & 8 & 42.02 & 14.02 & 0.56 & 0.19 & 16.36 & 4.54 & 14.85 & 6.30 & 0.15 & 0.27 & 5.70 & 5.12 & 1.74 & 4.55 & 0.02 & 0.06 & 3.50 & 2.11 & 0.11 & 0.06 & 0.04 & 0.02 & 14.99 & 6.67 & 100.2 & 0.59\end{array}$

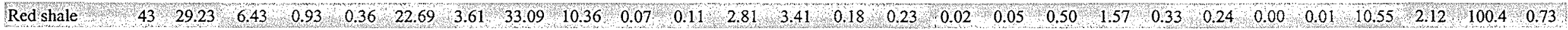
$\begin{array}{llllllllllllllllllllllllllllllllll}\text { Whaleback } & 13 & 27.72 & 5.27 & 0.74 & 0.34 & 21.87 & 3.84 & 35.12 & 10.37 & 0.08 & 0.09 & 4.25 & 3.99 & 0.13 & 0.04 & 0.01 & 0.05 & 0.20 & 0.47 & 0.27 & 0.19 & 0.00 & 0.01 & 10.25 & 1.98 & 100.6 & 0.97\end{array}$ $\begin{array}{llllllllllllllllllllllllllllll}\text { Dales Gorge } & 21 & 29.17 & 4.43 & 0.98 & 0.29 & 23.69 & 3.95 & 32.99 & 9.85 & 0.06 & 0.06 & 1.84 & 2.27 & 0.14 & 0.03 & 0.02 & 0.06 & 0.07 & 0.18 & 0.34 & 0.23 & 0.00 & 0.01 & 11.08 & 1.72 & 100.4 & 0.64\end{array}$ $\begin{array}{llllllllllllllllllllllllllllllllll}\text { Mt. McRae } & 9 & 31.55 & 10.78 & 1.09 & 0.44 & 21.57 & 1.40 & 30.39 & 12.01 & 0.10 & 0.21 & 3.01 & 4.30 & 0.37 & 0.48 & 0.00 & 0.00 & 1.95 & 3.08 & 0.41 & 0.31 & 0.00 & 0.00 & 9.74 & 2.97 & 100.2 & 0.47\end{array}$

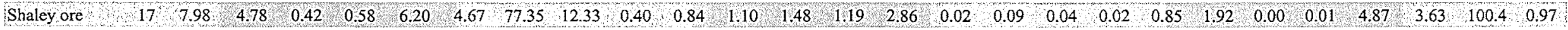
Total 118

Notes: Alt. = altered; $\mathrm{BIF}=$ banded iron-formation; $\mathrm{n}=$ number of samples in the group; avg $=$ average; $\mathrm{sd}=$ one standard deviation. 
Profound differences in chemistry also occur between black and red shales. Black shale from DDH-47A* predominantly consists of $\mathrm{SiO}_{2}(39 \pm 8.1 \%)$ and $\mathrm{Fe}_{2} \mathrm{O}_{3} \mathrm{~T}(26 \pm$ $7.7 \%)$, with relatively high contents of $\mathrm{Al}_{2} \mathrm{O}_{3}(7.0 \pm 3.0 \%), \mathrm{MgO}(6.9 \pm 2.3 \%), \mathrm{CaO}(4.0$ $\pm 4.0 \%), \mathrm{K}_{2} \mathrm{O}(4.0 \pm 2.3 \%)$ and LOI $(11 \pm 5.4 \%)$. Black shales of the Mt. McRae Shale and Dales Gorge Member in the north are broadly similar in major element composition whereas shales of the Whaleback Shale Member contain lower $\mathrm{SiO}_{2}$ and slightly higher $\mathrm{CaO}$ and LOI. Black shales at Mt. Whaleback have slightly lower $\mathrm{SiO}_{2}(34 \pm 11 \%)$ and $\mathrm{Fe}_{2} \mathrm{O}_{3} \mathrm{~T}(24 \pm 9.5 \%)$, but much greater $\mathrm{Al}_{2} \mathrm{O}_{3}(20 \pm 4.2 \%)$. These shales also have significant $\mathrm{MgO}(5.3 \pm 3.3 \%), \mathrm{K}_{2} \mathrm{O}(1.6 \pm 2.1 \%)$ and LOI $(13 \pm 4.5 \%)$ but low $\mathrm{CaO}$ $(<1.0 \%)$. Black shales of the Dales Gorge and Whaleback Shale Members in the pit are broadly similar in composition whereas shales of the Mt. McRae Shale contain higher $\mathrm{SiO}_{2}$ and $\mathrm{K}_{2} \mathrm{O}$ and lower $\mathrm{Al}_{2} \mathrm{O}_{3}, \mathrm{Fe}_{2} \mathrm{O}_{3} \mathrm{~T}$ and $\mathrm{MgO}$. Red shales from the pit consist mostly of $\mathrm{SiO}_{2}(29 \pm 6.4 \%), \mathrm{Fe}_{2} \mathrm{O}_{3} \mathrm{~T}(33 \pm 10 \%)$, and $\mathrm{Al}_{2} \mathrm{O}_{3}(23 \pm 3.6 \%)$, although $\mathrm{MgO}$ $(2.8 \pm 3.4 \%)$ is moderately high.

Three sets of samples cannot be classified as BIF, ore, or shale. Chert-siderite bands in $\mathrm{DDH}-47 \mathrm{~A}^{*}$ contain high $\mathrm{SiO}_{2}(61 \pm 15 \%)$, moderate $\mathrm{Fe}_{2} \mathrm{O}_{3} \mathrm{~T}(19 \pm 8.6)$ and significant $\mathrm{MgO}(3.1 \pm 1.8 \%), \mathrm{CaO}(2.5 \pm 1.6 \%)$ and LOI $(12 \pm 5.5 \%)$. Notably, $\mathrm{Al}_{2} \mathrm{O}_{3}$ and $\mathrm{K}_{2} \mathrm{O}$ are $<1 \%$ in these bands. Cherty BIF of the Whaleback Shale Member in $\mathrm{DDH}-47 \mathrm{~A}^{*}$ contains relatively high $\mathrm{Fe}_{2} \mathrm{O}_{3} \mathrm{~T}(58 \pm 20 \%)$ and $\mathrm{SiO}_{2}(26 \pm 13 \%)$ with moderate $\mathrm{MgO}(5.1 \pm 4.4 \%)$. Shaley ores of the Whaleback Shale Member at Mt. Whaleback contain relatively high $\mathrm{Fe}_{2} \mathrm{O}_{3} \mathrm{~T}(77 \pm 12 \%)$ and moderate $\mathrm{SiO}_{2}(8.0 \pm 4.8 \%)$ and $\mathrm{Al}_{2} \mathrm{O}_{3}(6.2 \pm 4.7 \%)$.

\subsection{Mineralogy}

Seventeen different minerals were found in excess of $1 \%$ (Table 2.3). These are: quartz, magnetite, hematite, stilpnomelane, siderite, dolomite, ankerite, K-feldspar, muscovite, biotite, pyrite, clinochlore, goethite, talc, kaolinite, apatite and pyrophyllite. However, only one to three phases dominate (>10\%) most samples (Fig. 2.7). 
Table 2.3a. Semi-quantified mineralogy of rocks from the northern Hamersley Province.

\begin{tabular}{|c|c|c|c|c|c|c|c|c|c|c|c|c|c|c|c|c|c|c|c|c|}
\hline Sample & Unit & Desciption & Powder Colour & $\begin{array}{l}\text { Qtz } \\
(\%)\end{array}$ & $\begin{array}{c}\text { Mag } \\
(\%)\end{array}$ & $\begin{array}{l}\text { Hem } \\
(\%)\end{array}$ & $\begin{array}{l}\text { Stp } \\
(\%)\end{array}$ & $\begin{array}{c}\mathrm{Sd} \\
(\%)\end{array}$ & $\begin{array}{l}\text { Dol } \\
(\%)\end{array}$ & $\begin{array}{c}\text { Ank } \\
(\%)\end{array}$ & $\begin{array}{l}\text { Kfs } \\
(\%)\end{array}$ & $\begin{array}{l}\text { Ms } \\
(\%)\end{array}$ & $\begin{array}{l}\text { Bio } \\
(\%)\end{array}$ & $\begin{array}{c}\text { Py } \\
(\%)\end{array}$ & $\begin{array}{c}\text { Clino } \\
(\%)\end{array}$ & $\begin{array}{l}\text { Goet } \\
(\%)\end{array}$ & $\begin{array}{l}\text { Tle } \\
(\%)\end{array}$ & $\begin{array}{l}\text { Kln } \\
(\%)\end{array}$ & $\begin{array}{l}\text { Apa } \\
(\%)\end{array}$ & $\begin{array}{l}\text { Pyr } \\
(\%)\end{array}$ \\
\hline 4748 & $\overline{\mathrm{DB} 16}$ & $\mathrm{BIF}$ & light grey & 35 & 17 & & & 38 & & & & & & & & & 10 & & & \\
\hline 477 & DB14 & $\mathrm{BIF}$ & grey & 39 & 48 & & & 13 & & & & & & & & & & & & \\
\hline 4715 & DB11 & $\mathrm{BIF}$ & grey & 49 & 23 & & & 22 & & & & & & & & & 5 & & & \\
\hline 4719 & DB10 & $\mathrm{BIF}$ & dark grey & 34 & 57 & & 3 & & & & & & & & & & 6 & & & \\
\hline 4722 & DB8 & BIF & grey & 33 & 39 & & 7 & 7 & & 8 & & & & & & & 4 & & & \\
\hline 4735 & DB3 & BIF & grey & 38 & 32 & & 4 & 19 & & 7 & & & & & & & & & & \\
\hline 4739 & DB1 & $\mathrm{BIF}$ & grey & 28 & 40 & & 10 & 9 & & 9 & & & & & & & 5 & & & \\
\hline 4742 & DB0 & $\mathrm{BIF}$ & dark grey & 41 & 50 & & 4 & & & 2 & & & & & & & 3 & & & \\
\hline $47 W 1$ & Whale & black shale & grey & 14 & & & & & 41 & & 14 & 4 & & & 26 & & & & & \\
\hline $47 \mathrm{~W} 10$ & Whale & black shale & olive grey & 5 & & & 30 & 34 & 13 & & 8 & & 9 & & & & & & & \\
\hline AW44 & DS16 & black shale & olive grey & 12 & & & 24 & & & 48 & 16 & & & & & & & & & \\
\hline 475 & DS15 & black shale & light grey & 4 & & & 26 & & 17 & & 24 & & 28 & & & & & & & \\
\hline AW43 & DS11 & black shale & dark grey & 7 & & & 16 & & & & 56 & & & & 21 & & & & & \\
\hline AW42 & DS9 & black shale & dark grey & 27 & & & & & & & 48 & & & 7 & 18 & & & & & \\
\hline 4723 & DS8 & black shale & grey & 2 & & & 53 & & 3 & & 2 & & & & 41 & & & & & \\
\hline 4730 & DS5 & black shale & olive grey & & & & 55 & & 6 & & & & 39 & & & & & & & \\
\hline 4733 & DS4 & black shale & olive & 35 & & & 36 & 21 & 8 & & & & & & & & & & & \\
\hline AW41 & DS2 & black shale & light grey & & & & 40 & & & 34 & 26 & & & & & & & & & \\
\hline 4738 & DS2 & black shale & grey & 1 & & & 34 & & 5 & & 45 & & 15 & & & & & & & \\
\hline 4743 & McRae & black shale & olive grey & & & & 87 & & & & & 13 & & & & & & & & \\
\hline 4710 & DS13 & chert-siderite & light grey & 57 & & & 5 & 33 & 4 & & & 2 & & & & & & & & \\
\hline 4721 & DS9 & chert-siderite & white & 75 & & & & 22 & 2 & & & & & & & & & & & \\
\hline $47 W 2$ & Whale & chert-siderite & light grey & 29 & & & & 62 & 5 & & & & & & & & 3 & & & \\
\hline $47 \mathrm{~W} 8$ & Whale & cherty BIF & grey & 11 & 72 & & 5 & & & & & 5 & & & & & 6 & & 1 & \\
\hline $47 \mathrm{~W} 7$ & Whale & cherty BIF & light grey & 12 & 2 & & 10 & 71 & & & 6 & & & & & & & & & \\
\hline
\end{tabular}

Notes: Whale $=$ Whaleback Shale Member; McRae $=$ Mt. McRae Shale; BIF $=$ banded iron-formation; ank $=$ ankerite; apa $=$ apatite; bio $=$ biotite; clino $=$ clinochlore; dol $=$ dolomite;

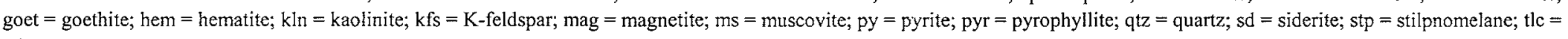
talc. 
Table 2.3b. Semi-quantified mineralogy of rocks from the Mt. Whaleback pit.

\begin{tabular}{|c|c|c|c|c|c|c|c|c|c|c|c|c|c|c|c|c|c|c|c|c|}
\hline Sample & Unit & Desciption & Powder Colour & $\begin{array}{l}\text { Qtz } \\
(\%)\end{array}$ & $\begin{array}{c}\text { Mag } \\
(\%)\end{array}$ & $\begin{array}{c}\mathrm{Hem} \\
(\%)\end{array}$ & $\begin{array}{l}\text { Stp } \\
(\%)\end{array}$ & $\begin{array}{l}\mathrm{Sd} \\
(\%)\end{array}$ & $\begin{array}{l}\text { Dol } \\
(\%)\end{array}$ & $\begin{array}{c}\text { Ank } \\
(\%)\end{array}$ & $\begin{array}{l}\text { Kfs } \\
(\%)\end{array}$ & $\begin{array}{l}\text { Ms } \\
(\%)\end{array}$ & $\begin{array}{l}\text { Bio } \\
(\%)\end{array}$ & $\begin{array}{l}\text { Py } \\
(\%)\end{array}$ & $\begin{array}{l}\text { Clino } \\
(\%)\end{array}$ & $\begin{array}{l}\text { Kln } \\
(\%)\end{array}$ & $\begin{array}{c}\text { Goet } \\
(\%)\end{array}$ & $\begin{array}{l}\text { Tle } \\
(\%)\end{array}$ & $\begin{array}{c}\text { Apa } \\
(\%)\end{array}$ & $\begin{array}{l}\text { Pyr } \\
(\%)\end{array}$ \\
\hline D73A & $\mathrm{DB} 16$ & Alt. BIF & weak red & 60 & & 40 & & & & & & & & & & & & & & \\
\hline D73C & DB16 & Alt. BIF & weak red & 39 & & 61 & & & & & & & & & & & & & & \\
\hline D73D & DB16 & Alt. BIF & weak red & 41 & & 59 & & & & & & & & & & & & & & \\
\hline D86C & DB16 & Alt. BIF & brown & 24 & & 65 & & & & & & & & & & & 11 & & & \\
\hline D86D & DB16 & Alt. BIF & weak red & 48 & & 52 & & & & & & & & & & & & & & \\
\hline D86E & $\mathrm{DB} 16$ & Alt. BIF & yellowish red & 40 & & 45 & & & & & & & & & & & 15 & & & \\
\hline D86F & DB16 & Alt. BIF & yellowish red & 44 & & 45 & & & & & & & & & & & 11 & & & \\
\hline AW24 & Whale & Alt. black shale & very dark grey & 10 & & 20 & & & & & & & & & 70 & & & & & \\
\hline AW 18 & McRae & Alt. black shale & black & & & & & & & & & 6 & & & 94 & & & & & \\
\hline $\mathrm{AW} 21$ & McRae & Alt. black shale & black & 30 & & & & & & & & 29 & & 26 & 16 & & & & & \\
\hline $\mathrm{RC}$ & McRae & Alt. black shale & very dark grey & 22 & & & & & & & & 25 & & & 53 & & & & & \\
\hline $125 \mathrm{E}$ & McRae & Alt. black shale & black & 10 & & & & & & & & 60 & & & 30 & & & & & \\
\hline $225 \mathrm{E}$ & McRae & Alt. black shale & brown & 21 & & 5 & & & 4 & & & 34 & & & 27 & 15 & & & & \\
\hline AW27 & Whale & red shale & dark reddish brown & & & 49 & & & & & & & & & 8 & 43 & & & & \\
\hline AW31 & Whale & red shale & reddish brown & & & 40 & & & & & & & & & 16 & 44 & & & & \\
\hline AW36 & Whale & red shale & reddish grey & & & 36 & & & & & & & & & 18 & 46 & & & & \\
\hline D86B & DS16 & red shale & red & & & 48 & & & & & & & & & 11 & 41 & & & & \\
\hline AWI4 & DSi6 & red shale & red & & & 43 & & & & & & & & & & 57 & & & & \\
\hline AW 10 & $\mathrm{DS} 12$ & red shale & red & & & 22 & & & & & & & & & & 78 & & & & \\
\hline AW6 & DS9 & red shale & red & & & 54 & & & & & & & & & 6 & 40 & & & & \\
\hline AW1 & DS4 & red shale & red & & & 44 & & & & & & & & & 39 & 17 & & & & \\
\hline AW 29 & Whale & iron ore & dusky red & & & 98 & & & & & & & & & & 2 & & & & \\
\hline $\mathrm{E} 24 \mathrm{C}$ & DB16 & iron ore & weak red & & & 100 & & & & & & & & & & & & & & \\
\hline AW15 & McRae & iron ore & dusky red & & & 99 & & & & & & & & & & 1 & & & & \\
\hline AW22 & Whale & shaley ore & dark reddish brown & & & 85 & & & & & & & & & & 15 & & & & \\
\hline AW28 & Whale & shaley ore & dark yellowish brown & & & 5 & & & & & & & & & & 18 & 74 & & & 4 \\
\hline AW34 & Whale & shaley ore & dark red & & & 73 & & & & & & & & & & 6 & & & 21 & \\
\hline AW39 & Whale & shaley ore & reddish grey & & & 87 & & & & & & & & & & 13 & & & & \\
\hline $\mathrm{D} 73 \mathrm{~F}$ & DS16 & shaley ore & reddish brown & & & 57 & & & & & & & & & & 40 & & & & 3 \\
\hline
\end{tabular}

Notes: Alt. $=$ altered; mineral abbreviations as in Table 2.3a. 

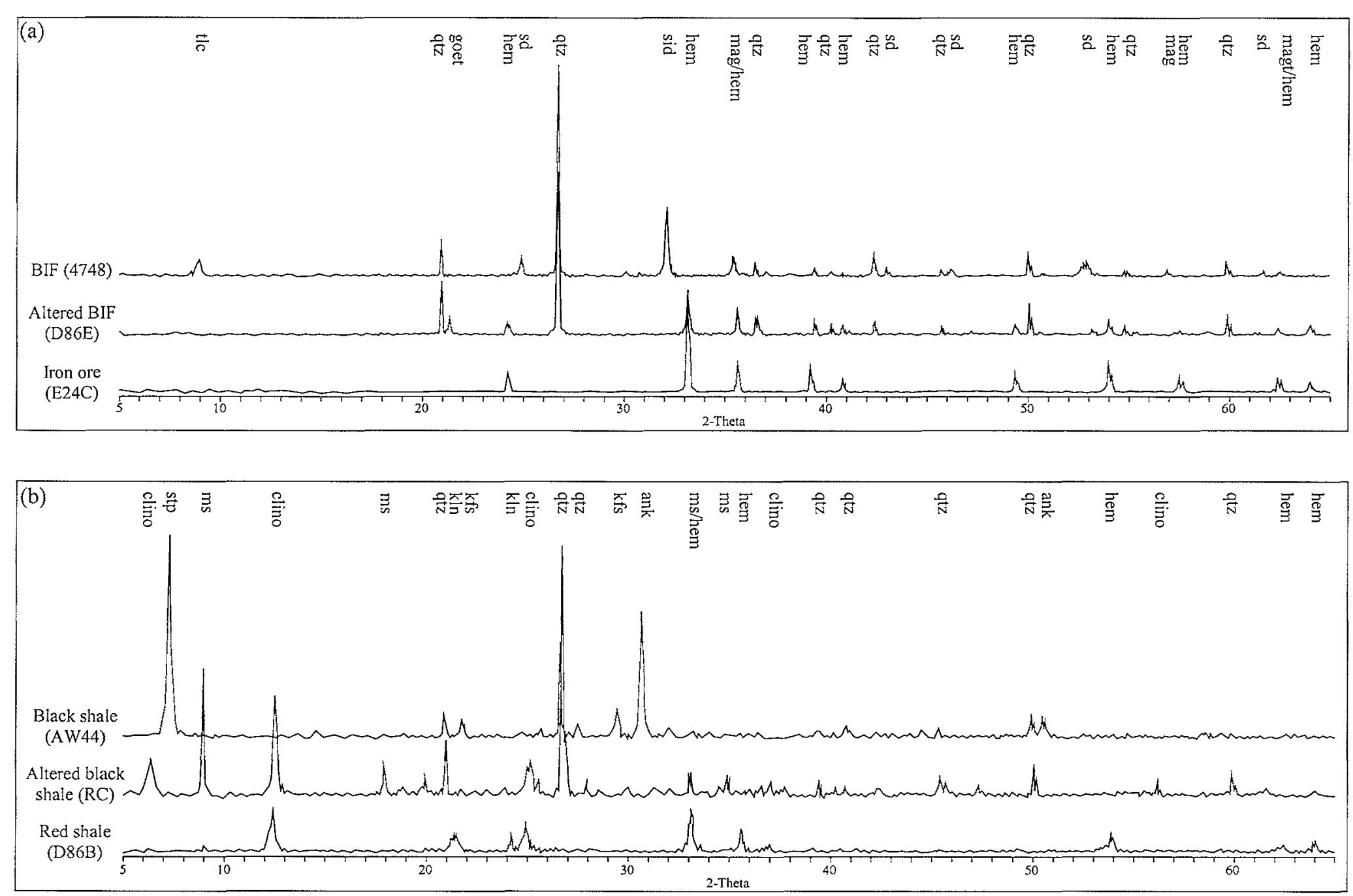

Figure 2.7. XRD traces of representative rock types from DDH-47A* and Mt. Whaleback pit. (a) BIF, altered BIF, and iron ore. (b) Black shale, altered black shale, and red shale. ank = ankerite; clino = clinochlore; goet = goethite; hem = hematite; $\mathrm{kln}=$ kaolinite; $\mathrm{kfs}=\mathrm{K}-\mathrm{feldspar}$; mag $=$ magnetite; $\mathrm{ms}=$ muscovite; $\mathrm{qt}=$ quartz; $\mathrm{sd}=$ siderite; $\mathrm{stp}=$ stilpnomelane; tlc = talc. 
As for major element chemistry, significant mineralogical differences occur between $\mathrm{BIF}$ and iron ore. BIF samples from $\mathrm{DDH}-47 \mathrm{~A}^{*}$ are largely, though never exclusively, comprised of quartz and magnetite (Fig. 2.7a). Siderite is also a significant component in most of these rocks, particularly in samples with relatively low magnetite. Stilpnomelane, ankerite and talc were also identified in one or more samples. BIF around Mt. Whaleback consists entirely of hematite and quartz (Figs. 2.7a), though goethite is present in some samples; these rocks do not contain magnetite, carbonates or silicates. In contrast to all BIF, iron ore at Mt. Whaleback is almost entirely hematite (Figs. 2.7a).

Striking mineralogical differences also occur between black and red shales (Fig. 2.7b). Black shales from DDH-47A* have highly variable mineralogies, consisting of stilpnomelane, K-feldspar and quartz with subordinate amounts of siderite, dolomite, ankerite, muscovite, biotite, pyrite and clinochlore. However, some samples lack stilpnomelane, K-feldspar or quartz. In contrast, black shales around Mt. Whaleback are mostly comprised of clinochlore, muscovite and quartz, although hematite, pyrite and kaolinite are significant in some samples. Red shales around Mt. Whaleback are entirely composed of hematite, kaolinite and clinochlore.

Chert-siderite, cherty BIF and shaley ore contain the same minerals as BIF, ore and shale but in different proportions. Chert-siderite bands are comprised of quartz and siderite with accessory stilpnomelane, dolomite, muscovite, kaolinite, jarosite and riebeckite. Cherty BIF from DDH-47A* is also dominated by quartz, although siderite and magnetite can be significant. Stilpnomelane, dolomite, K-feldspar, muscovite, talc and apatite occur in minor amounts. Shaley ore at Mt. Whaleback is mostly hematite but contains moderate amounts of kaolinite. Goethite and apatite are also significant components in two samples of shaley ore while pyrophyllite is an accessory mineral in two others.

\subsection{Texture}

The texture of BIF and iron ore in the Hamersley Province can vary significantly 
(Trendall and Blockley, 1970; Grubb, 1971; Ayres, 1972; Morris, 1980, 1985). Although the three samples examined in this study do not represent the full range of textures, they highlight some key differences between BIF, altered BIF and iron ore (Fig. 2.8).
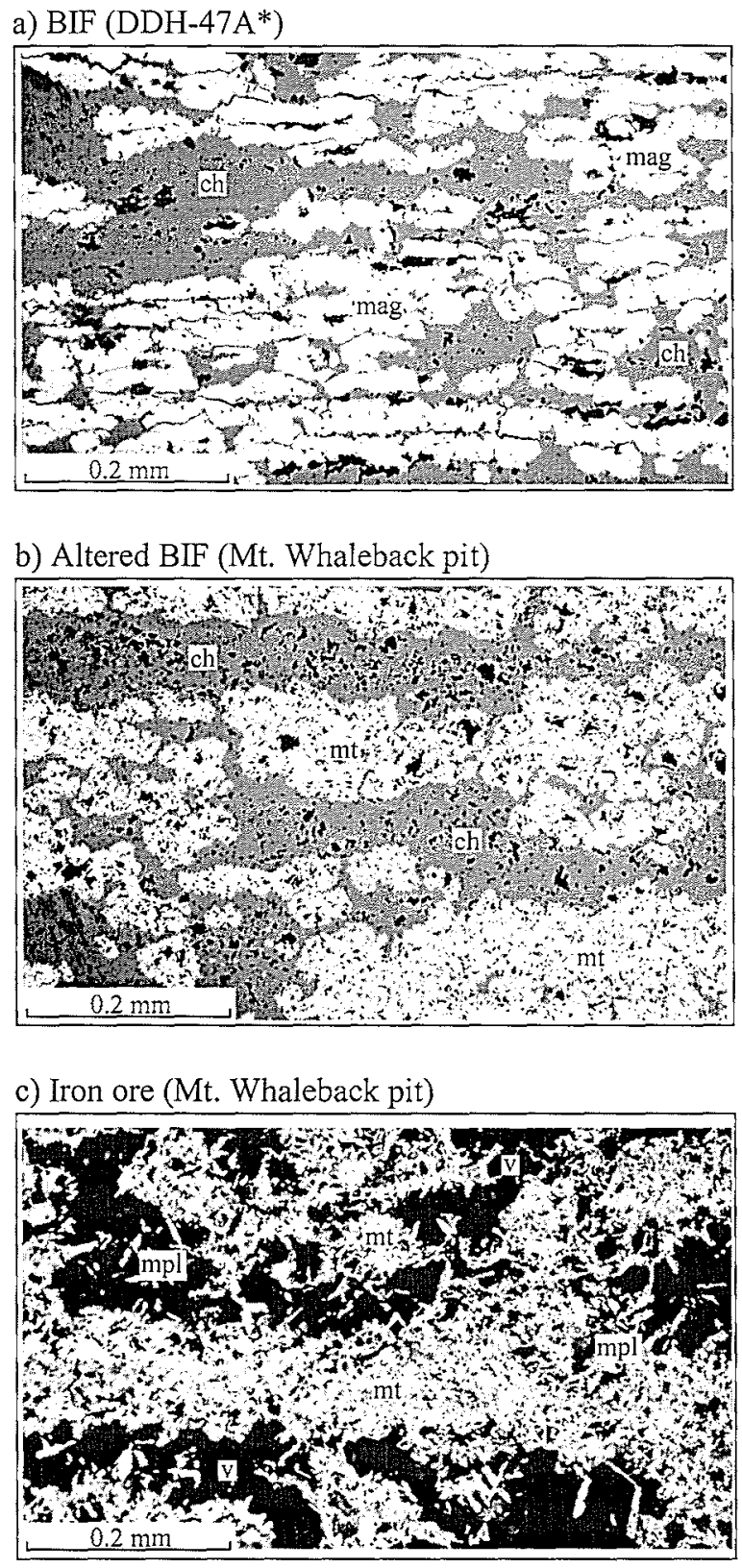

Figure 2.8. Photomicrographs of BIF mesobands across the Hamersley Province. Reflected polarized light. (a) Chert and magnetite euhedra in unaltered BIF from DDH-47A*. (sample 477). Note discontinuous bands of magnetite aggregates. (b) Chert and martite in altered BIF from Mt. Whaleback pit (sample D73C). Note the preservation of original magnetite euhedra and aggregates by martite. (c) Hematite textures in high-grade iron ore from Mt. Whaleback pit (sample E24C). Note abundant microplaty hematite laths overgrowing and possibly replacing martite grains. $\mathrm{ch}=\mathrm{chert}$; mag = magnetite; $\mathrm{mt}=$ martite; $\mathrm{mpl}=$ microplaty hematite $\mathrm{v}=$ voids. 
BIF from the north predominantly consists of alternating mm-scale layers of euhedral magnetite and fine-grained chert, although subhedral to euhedral shaped carbonates and silicates are commonly scattered throughout (Fig. 2.8a). In altered BIF from Mt. Whaleback, original magnetite has been totally oxidized to martite and all carbonates and silicates have been leached without replacement (Fig. 2.8b). The pore space created by leaching of gangue has not been replaced in the sample examined here (i.e., there are significant voids where these minerals presumably existed), nor was microplaty hematite observed. Additionally, chert remains unaffected, exhibiting similar characteristics to that in unaltered equivalents. In contrast to all BIF, iron ore consists entirely of martite and anhedral hematite in a porous network of randomly orientated fine-grained platy hematite (Fig. 2.8c).

\section{DISCUSSION}

\subsection{Chemical comparisons across the Hamersley Province}

As emphasized by others (e.g., Trendall and Blockley, 1970; Trendall and Pepper, 1976; Ewers and Morris, 1981; Gole, 1981; Alibert and McCulloch, 1993), the chemistry of BIF from the northern Hamersley Province is fairly predictable. Table 2.4a lists oxide contents of DB-macrobands determined in this study and by previous investigators. Compared to some analyses (Trendall and Blockley, 1970; Trendall and Pepper, 1976; Ewers and Morris, 1981; Taylor et al., 2001), BIF samples in this study, like those of Alibert and McCulloch (1993), have less $\mathrm{SiO}_{2}$, slightly higher LOI and a large range in composition (i.e., large standard deviations). These differences probably reflect the number and size of samples in different studies because it is difficult to obtain small, yet representative samples of chert and magnetite banding. Clearly, variations in BIF composition decrease with increasing sample size (Trendall and Pepper, 1976; Ewers and Morris, 1981). To overcome sampling biases, Trendall and Blockley (1970) calculated a theoretical BIF composition using estimated thicknesses and compositions of individual centimeter scale BIF mesobands. The average BIF composition determined here is remarkably similar to this "theoretical BIF" 
Table 2.4a. Average composition of DB-macrobands from the Hamersley Province.

\begin{tabular}{|c|c|c|c|c|c|c|c|c|c|c|c|c|c|c|c|c|c|c|c|}
\hline \multirow[t]{2}{*}{$\begin{array}{l}\text { Element } \\
\text { Oxide }\end{array}$} & \multicolumn{2}{|c|}{$\begin{array}{l}\text { Wittenoom }^{(1)} \\
\quad(n=19)\end{array}$} & \multicolumn{3}{|c|}{ Wittenoom $^{(2)}$} & \multicolumn{2}{|c|}{$\begin{array}{l}\text { Wittenoom } \\
\qquad(\mathrm{n}=5)\end{array}$} & \multicolumn{2}{|c|}{$\begin{array}{l}\text { Wittenoom }^{(4)} \\
(\mathrm{n}=11)\end{array}$} & \multicolumn{2}{|c|}{$\begin{array}{l}\text { Turner Syncline } \mathrm{e}^{(5)} \\
\quad(\mathrm{n}=12)\end{array}$} & \multicolumn{2}{|c|}{$\begin{array}{l}\text { Paraburdoo } \\
(\mathrm{n}=17)\end{array}$} & \multicolumn{2}{|c|}{$\begin{array}{l}\text { Mt. Whaleback }{ }^{(7)} \\
\quad(n=12)\end{array}$} & \multicolumn{2}{|c|}{$\begin{array}{l}\text { Mt. Tom Price } e^{(8)} \\
\quad(n=2)\end{array}$} & \multicolumn{2}{|c|}{$\begin{array}{c}\text { Mt. Tom Price }{ }^{(9)} \\
(\mathrm{n}=4)\end{array}$} \\
\hline & avg & sd & avg & sd & etical & avg & sd & avg & sd & avg & sd & avg & sd & avg & sd & avg & sd & avg & sd \\
\hline $\mathrm{SiO}_{2}$ & 39.20 & 9.91 & 49.44 & 4.73 & 41.09 & 43.05 & 1.46 & 37.24 & 14.13 & 44.72 & 3.01 & 43.26 & 1.97 & 41.47 & 14.08 & 30.59 & 3.54 & 5.54 & 5.39 \\
\hline $\mathrm{TiO}_{2}$ & 0.04 & 0.12 & 0.03 & 0.01 & 0.04 & 0.02 & 0.01 & 0.01 & 0.00 & 0.01 & 0.01 & 0.01 & 0.01 & 0.01 & 0.01 & 0.01 & 0.00 & 0.01 & 0.01 \\
\hline $\mathrm{Al}_{2} \mathrm{O}_{3}$ & 0.25 & 0.36 & 0.46 & 0.54 & 0.29 & 0.19 & 0.09 & 0.19 & 0.08 & 0.44 & 0.33 & 0.09 & 0.07 & 0.08 & 0.07 & 0.18 & 0.03 & 0.37 & 0.22 \\
\hline $\mathrm{Fe}_{2} \mathrm{O}_{3} \mathrm{~T}$ & 48.48 & 8.46 & 41.11 & 4.84 & 48.87 & 49.44 & 1.76 & 55.08 & 15.52 & 46.82 & 5.90 & 46.17 & 2.39 & 57.73 & 13.85 & 51.07 & 1.02 & 66.02 & 3.76 \\
\hline $\mathrm{MnO}$ & 0.10 & 0.13 & 0.02 & 0.00 & & 0.05 & 0.02 & 0.04 & 0.02 & & & 0.05 & 0.02 & 0.01 & 0.02 & 0.52 & 0.03 & & \\
\hline $\mathrm{MgO}$ & 2.63 & 0.85 & 2.31 & 0.27 & 2.09 & 1.92 & 0.32 & 2.04 & 0.80 & 1.96 & 0.67 & 2.66 & 0.41 & 0.00 & 0.00 & 4.22 & 0.49 & 6.35 & 0.89 \\
\hline $\mathrm{CaO}$ & 1.91 & 1.75 & 1.96 & 0.45 & 2.10 & 1.65 & 0.32 & 1.61 & 2.08 & 1.73 & 0.71 & 1.67 & 0.31 & 0.13 & 0.07 & 3.83 & 1.54 & 8.60 & 3.81 \\
\hline $\mathrm{Na}_{2} \mathrm{O}$ & 0.04 & 0.12 & 0.37 & 0.45 & 0.08 & 0.45 & 0.40 & 1.04 & 2.16 & & & 0.03 & 0.04 & 0.00 & 0.00 & 0.06 & 0.06 & & \\
\hline $\mathrm{K}_{2} \mathrm{O}$ & 0.31 & 0.36 & 0.12 & 0.02 & 0.07 & 0.23 & 0.13 & 0.13 & 0.12 & & & 0.01 & 0.01 & 0.02 & 0.00 & 0.07 & 0.02 & 0.15 & 0.14 \\
\hline $\mathrm{P}_{2} \mathrm{O}_{5}$ & 0.22 & 0.17 & 0.27 & 0.11 & 0.11 & 0.19 & 0.01 & 0.24 & 0.14 & 0.20 & 0.03 & 0.22 & 0.03 & 0.11 & 0.08 & 0.36 & 0.06 & 0.29 & 0.07 \\
\hline S & 0.07 & 0.14 & 0.05 & 0.02 & & 0.04 & 0.01 & & & 0.07 & 0.06 & 0.03 & 0.01 & 0.00 & 0.00 & 0.04 & 0.02 & 0.14 & 0.10 \\
\hline LOI* $^{*}$ & 6.99 & 5.93 & 4.13 & 1.09 & 5.25 & 3.39 & 0.16 & 4.37 & 2.80 & 3.83 & 2.80 & 4.12 & 0.89 & 0.57 & 0.66 & 7.79 & 0.87 & 13.50 & 5.49 \\
\hline Sum & 100.24 & 0.40 & 100.13 & 0.11 & 99.99 & 100.06 & 0.09 & 99.96 & 3.42 & & & 98.30 & 0.28 & 100.13 & 0.42 & 98.64 & 0.40 & & \\
\hline
\end{tabular}

Notes: $(1)=$ this study, table $2.2 ;(2)=$ Trendall and Blockley $(1970)$, table 17 , nos 3 and $4 ;(3)=$ Trendall and Pepper $(1976)$, table 3 , nos $3,5,7,9$ and 11 , table 5 , no $2 ;(4)=$ Alibert and McCulloch (1993), table 1; (5) = Taylor et al. (2001), appendix $1 ;(6)=$ Ewers and Morris (1981), table $1 ;(7)=$ this study, table 2.2; (8) = Ewers and Morris (1981), table 3; (9) = Taylor et al. (2001), appendices 5A \& B. * LOI includes loss of $\mathrm{CO}_{2}$ and $\mathrm{H}_{2} \mathrm{O}$ and gain from oxidation of $\mathrm{Fe}(\mathrm{II}) ; \mathrm{n}=$ number of samples; avg = average; sd = one standard deviation; blank = not reported. 
Table 2.4b. Average composition of DS-macrobands from the Hamersley Province.

\begin{tabular}{|c|c|c|c|c|c|c|c|c|c|c|c|c|c|c|c|c|c|c|}
\hline \multirow[t]{2}{*}{$\begin{array}{l}\text { Element } \\
\text { Oxide }\end{array}$} & \multicolumn{2}{|c|}{$\begin{array}{l}\text { Wittenoom }^{(1)} \\
\qquad(\mathrm{n}=20)\end{array}$} & \multicolumn{2}{|c|}{$\begin{array}{l}\text { Wittenoom }^{(2)} \\
\qquad(\mathrm{n}=4)\end{array}$} & \multicolumn{2}{|c|}{$\begin{array}{l}\text { Wittenoom }^{(3)} \\
\qquad(\mathrm{n}=6)\end{array}$} & \multicolumn{2}{|c|}{$\begin{array}{l}\text { Wittenoom }^{(4)} \\
(\mathrm{n}=11)\end{array}$} & \multicolumn{2}{|c|}{$\begin{array}{l}\text { Turner Syncline } \\
\qquad(\mathrm{n}=11)\end{array}$} & \multicolumn{2}{|c|}{$\begin{array}{c}\text { Paraburdoo }^{(6)} \\
\quad(n=16)\end{array}$} & \multicolumn{2}{|c|}{$\begin{array}{l}\text { Mt. Whaleback }{ }^{(7)} \\
\quad(n=24)\end{array}$} & \multicolumn{2}{|c|}{$\begin{array}{l}\text { Mt. Tom Price }{ }^{(8)} \\
\qquad(\mathrm{n}=2)\end{array}$} & \multicolumn{2}{|c|}{$\begin{array}{l}\text { Mt. Tom Price } \\
\quad(n=4)\end{array}$} \\
\hline & avg & sd & avg & sd & avg & sd & avg & sd & avg & sd & avg & sd & avg & sd & avg & sd & avg & sd \\
\hline $\mathrm{iO}_{2}$ & 41.00 & 7.40 & 46.87 & 4.07 & 39.07 & 10.50 & 41.19 & 7.97 & 45.43 & 5.31 & 47.67 & 5.98 & 34.34 & 11.10 & 41.09 & 0.40 & 25.15 & 10.36 \\
\hline $\mathrm{TiO}_{2}$ & 0.40 & 0.23 & 0.37 & 0.10 & 0.13 & 0.04 & 0.29 & 0.12 & 0.12 & 0.10 & 0.10 & 0.07 & 0.74 & 0.28 & 0.19 & 0.04 & 0.24 & 0.11 \\
\hline $\mathrm{Al}_{2} \mathrm{O}_{3}$ & 7.40 & 3.20 & 9.44 & 4.28 & 2.78 & 0.87 & 6.72 & 2.78 & 3.83 & 3.15 & 2.01 & 1.27 & 19.89 & 4.18 & 3.87 & 0.86 & 7.23 & 3.91 \\
\hline $\mathrm{Fe}_{2} \mathrm{O}_{3} \mathrm{~T}$ & 25.00 & 6.50 & 22.68 & 7.65 & 24.60 & 6.47 & 25.74 & 6.45 & 32.67 & 9.60 & 25.80 & 4.10 & 24.05 & 9.49 & 35.01 & 4.93 & 35.92 & 8.75 \\
\hline $\mathrm{MnO}$ & 0.21 & 0.10 & 0.11 & 0.08 & 0.25 & 0.06 & 0.24 & 0.14 & & & 0.24 & 0.09 & 0.16 & 0.17 & 0.25 & 0.06 & & \\
\hline $\mathrm{hgO}$ & 6.50 & 2.40 & 4.54 & 2.15 & 4.05 & 1.36 & 6.93 & 2.19 & 3.16 & 1.10 & 5.45 & 1.46 & 5.59 & 3.26 & 7.22 & 1.63 & 11.65 & 2.97 \\
\hline $\mathrm{CaO}$ & 3.90 & 3.90 & 0.22 & 0.26 & 9.14 & 10.69 & 3.53 & 2.53 & 3.18 & 3.47 & 3.18 & 1.77 & 0.65 & 2.63 & 0.50 & 0.05 & 5.14 & 4.07 \\
\hline $\mathrm{Na}_{2} \mathrm{O}$ & 0.20 & 0.19 & 0.34 & 0.33 & 0.09 & 0.06 & 0.21 & 0.15 & & & 0.02 & 0.01 & 0.07 & 0.12 & 0.15 & 0.07 & & \\
\hline $\mathrm{K}_{2} \mathrm{O}$ & 4.30 & 2.50 & 5.21 & 4.66 & 2.29 & 0.99 & 3.59 & 2.46 & & & 0.17 & 0.43 & 1.61 & 2.14 & 1.90 & 0.62 & & \\
\hline $\mathrm{P}_{2} \mathrm{O}_{5}$ & 0.13 & 0.12 & 0.23 & 0.16 & 0.14 & 0.04 & 0.11 & 0.04 & 0.17 & 0.05 & 0.17 & 0.07 & 0.12 & 0.07 & 0.21 & 0.04 & 0.18 & 0.08 \\
\hline & 0.51 & 0.40 & 1.49 & 1.08 & 0.54 & 0.19 & 0.81 & 0.49 & 0.43 & 0.25 & 0.36 & 0.37 & 0.02 & 0.02 & 0.28 & 0.01 & 0.35 & 0.20 \\
\hline LOI* & 10.00 & 4.50 & 9.27 & 6.18 & 17.12 & 6.59 & 10.22 & 3.53 & 9.86 & 3.45 & 13.89 & 2.82 & 13.07 & 4.50 & 8.28 & 2.52 & 12.95 & 3.30 \\
\hline Sum & 99.90 & 0.50 & 100.05 & 0.16 & 99.97 & 0.15 & 99.94 & 0.31 & & & 98.69 & 0.68 & 100.30 & 0.51 & 98.62 & 0.54 & & \\
\hline
\end{tabular}

Notes: $(1)=$ this study, table $2.2 ;(2)=$ Trendall and Blockley $(1970)$, table 15 , nos. 1-3, table 16 , no. 3; (3) $=$ Trendall and Pepper $(1976)$, table 3, nos 1, 2, 4, 6,8 and 10; (4) $=$ Alibert and McCulloch (1993), table 1; (5) = Taylor et al (2001), appendix 1; $(6)=$ Ewers and Morris $(1981)$, table $1 ;(7)=$ altered black shale, this study, table $2.2 ;(8)=$ Ewers and Morris $(1981)$ table 3; (9) = Taylor et al. (2001), appendices 5A \& B. ${ }^{*}$ The LOI includes loss of $\mathrm{CO}_{2}$ and $\mathrm{H}_{2} \mathrm{O}$ and gain from oxidation of $\mathrm{Fe}(\mathrm{II}) ; \mathrm{n}=$ number of samples; avg $=$ average; sd $=$ one standard deviation; blank $=$ not reported. 
composition (Table 2.4a), presumably because a sufficiently large number of samples were analysed.

It has often been stated that the chemistry of BIF does not vary across the Hamersley Province (e.g., Trendall and Blockley, 1970; Trendall and Pepper, 1976; Morris and Horwitz, 1983; Morris, 1985), although remarkably few analyses have come from rocks away from the vicinity of Wittenoom. This view is incorrect as BIF around the major hematite orebodies can have a significantly different chemistry. For example, relative to BIF from near Wittenoom, BIF at Mt. Whaleback has significantly higher $\mathrm{Fe}_{2} \mathrm{O}_{3} \mathrm{~T}$ but lower $\mathrm{MgO}, \mathrm{CaO}$, and LOI (Table 2.4a; Figs. 2.6a, b). These differences are real and relate to mineralogical changes, despite the large standard deviations in $\mathrm{Fe}_{2} \mathrm{O}_{3} \mathrm{~T}$. Thus BIF at Mt. Whaleback is referred to as "altered". Ewers and Morris (1981) also noted significant variations in the chemistry of BIF across the Hamersley Province. In particular, they suggested, albeit with only two samples, that DBmacrobands at $\mathrm{Mt}$. Tom Price were altered and contained less $\mathrm{SiO}_{2}$ and more $\mathrm{Fe}_{2} \mathrm{O}_{3} \mathrm{~T}$ than DB-macrobands from near Paraburdoo or Wittenoom (Table 2.4a). However, in contrast to Mt. Whaleback, their altered BIF contained excess $\mathrm{MgO}, \mathrm{CaO}$ and LOI. Taylor et al. (2001) have also analysed altered magnetite-rich BIF from Mt. Tom Price, demonstrating even lower $\mathrm{SiO}_{2}$ and higher $\mathrm{Fe}_{2} \mathrm{O}_{3} \mathrm{~T}, \mathrm{CaO}, \mathrm{MgO}$ and LOI (Table 2.4a).

The black DS-macrobands from cores near Wittenoom broadly correspond in chemistry to those examined by some investigators but generally contain more $\mathrm{Al}_{2} \mathrm{O}_{3}$ and $\mathrm{K}_{2} \mathrm{O}$ and less LOI than certain "shale" samples from Wittenoom, Paraburdoo or the Turner Syncline near Mt. Tom Price (Table 2.4b). Given the sub-meter interlayering of shales and chert-siderite in DS-macrobands (Trendall and Blockley, 1970) (Fig. 2.3), it is strongly suspected that Trendall and Pepper (1976), Ewers and Morris (1981) and Taylor et al. (2001) have incorporated other rock types into their "shale" samples (Fig. 2.9). Especially note that Ewers and Morris (1981) sampled 0.41 and $0.54 \mathrm{~m}$ thick intervals of DS5, Trendall and Pepper (1976) sampled entire DS-macrobands, and Taylor et al. (2001) sampled whole 1 to $2 \mathrm{~m}$ intervals from a percussion drill hole. Such "bulk" sampling at DDH-47A* would definitely mix shale and chert-siderite bands 


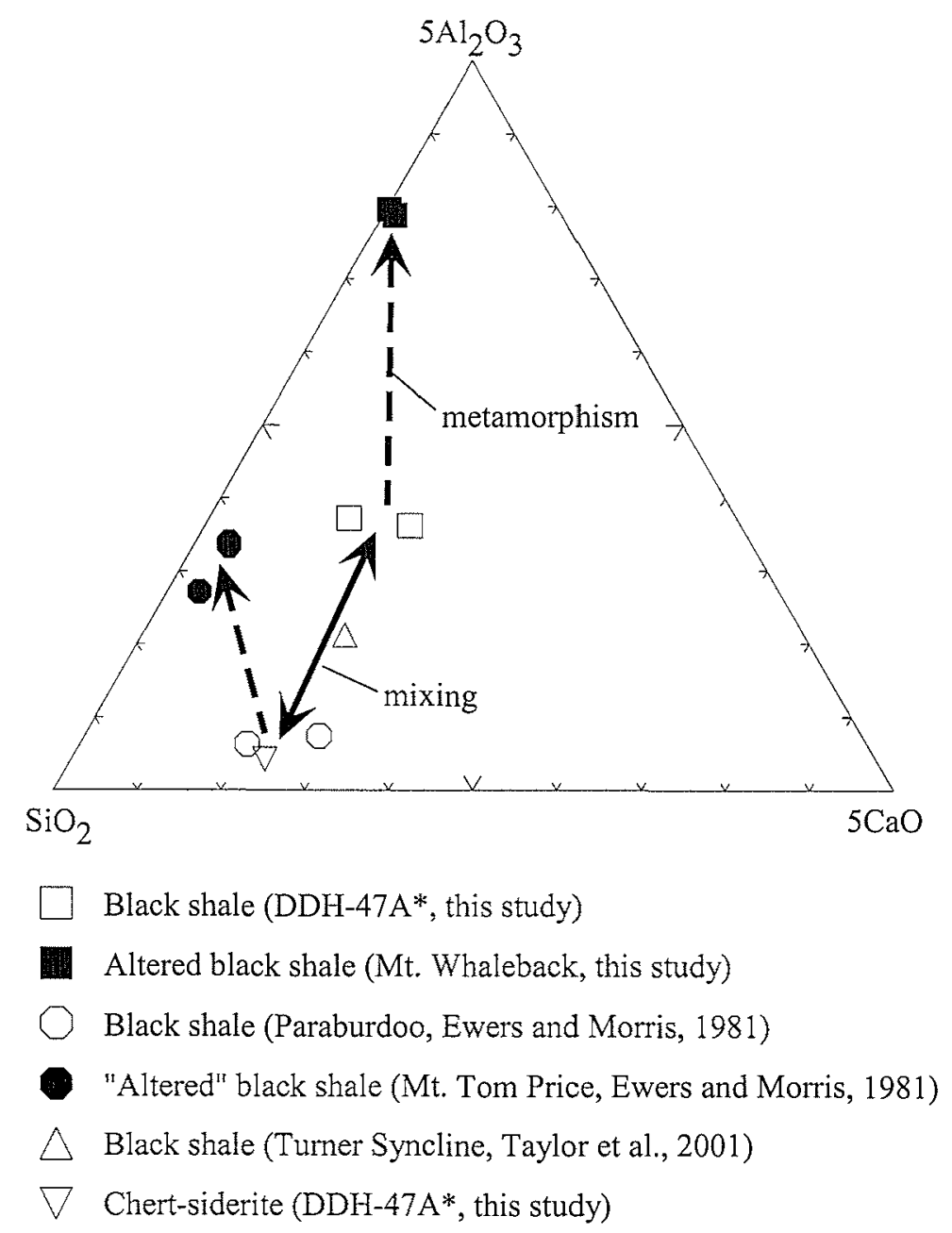

Figure 2.9. Ternary diagram of $\mathrm{SiO}_{2}, \mathrm{Al}_{2} \mathrm{O}_{3}$ and $\mathrm{CaO}$ illustrating that relative to black shales from this study, shale samples from Paraburdoo and Tom Price (Ewers and Morris, 1981; Taylor et al., 2001) may represent mixtures of shale and chert-siderite bands. Solid arrow represents a mixing line between black shale and chert-siderite; dashed arrows represent metamorphism of these black shales. Note how the chemical differences between Mt. Whaleback and Mt. Tom Price "altered" black shales (this study and Ewers and Morris, 1981) are most likely due to mixing of chert-siderite bands in the latter rocks and not metamorphism.

(Fig. 2.3). In the latter case, mixing of shale and BIF bands might also occur.

Several workers (LaBerge, 1966; Trendall and Blockley, 1970; Ewers and Morris, 1981) have suggested that the m-scale, fairly regularly spaced DS-macrobands represent lithified volcanic ash beds even though such horizons in modern basins are typically $<1 \mathrm{~m}$ thick and irregularly spaced with log-normal thickness distributions (e.g., Cao et al., 1995). Black shales of the very thick Mt. McRae Shale, undoubtedly deposited through non-volcanic processes, are compositionally similar to those of the Dales Gorge Member (Table 2.2). This comparison strongly suggests that the DS-macrobands have a primarily siliciclastic rather than volcanic origin. However, the DS-macrobands 
contain apparent glass shards (LaBerge, 1966), and excess $\mathrm{Fe}_{2} \mathrm{O}_{3} \mathrm{~T}$ compared to other Archean Shales (e.g., Cameron and Garrels, 1980; Wronkiewicz et al., 1987) that may indicate a volcanic component. The compositional differences between the Whaleback Shale Member and the previously mentioned shale units may be due to higher abundances of carbonates, such as dolomite, in the Whaleback Shale Member (Table $2.3 b)$.

Because of significant chemical differences between black shales at Wittenoom and Mt. Whaleback (Table 2.4b; Figs. 2.6a, b), the black shales at Mt. Whaleback are referred to as "altered". Ewers and Morris (1981) analysed "altered" black shales at Mt. Tom Price. Similar to their unaltered black shales from Paraburdoo, their shales from Mt. Tom Price had much higher $\mathrm{Fe}_{2} \mathrm{O}_{3} \mathrm{~T}$ and lower $\mathrm{Al}_{2} \mathrm{O}_{3}$ than altered black shales at Mt. Whaleback (Table 2.4b). This discrepancy may again indicate inclusion of chertsiderite bands (Fig. 2.9). On the other hand, shales from Mt. Tom Price with low $\mathrm{SiO}_{2}$ and high $\mathrm{MgO}$ and $\mathrm{CaO}$ (Table 2.4b) may reflect carbonates added during metasomatism (Barley et al., 1999; Taylor et al., 2001).

Chert-siderite bands from cores near Wittenoom contain higher $\mathrm{SiO}_{2}$ and LOI and lower $\mathrm{Fe}_{2} \mathrm{O}_{3} \mathrm{~T}$ than adjacent $\mathrm{BIF}$ samples (Fig. 2.6a). They also contain significantly higher $\mathrm{SiO}_{2}$ and lower $\mathrm{Al}_{2} \mathrm{O}_{3}$ and $\mathrm{K}_{2} \mathrm{O}$ than interlayered black shales. Incorporation of these bands into shales will indeed cause the observed chemical differences between samples of this study and those presented by other workers (Fig. 2.9). Chert-siderite bands or altered equivalents were not found at Mt. Whaleback. Presumably, some process has destroyed these assemblages near the deposit.

From a chemical perspective, cherty BIF at Wittenoom is a mixture of mostly unaltered BIF and minor unaltered black shale (Fig. 2.6a). Shaley ore at Mt. Whaleback probably represents mineralized cherty BIF because it comes from mineralized portions of the lower Whaleback Shale Member.

\subsection{Mineralogical comparisons across the Hamersley Province}

As for chemistry, the mineralogy of BIF varies profoundly across the Hamersley 
Province. Previous workers have used microscope petrography and XRD to determine the mineralogy of BIF from near Wittenoom and Paraburdoo (Trendall and Blockley, 1970; Grubb, 1971; Ewers and Morris, 1981). These samples consisted of quartz and magnetite with minor amounts of carbonates, talc, stilpnomelane, riebeckite, chlorite and apatite. The BIF at Paraburdoo also contained significant hematite. Thus, the mineralogy of BIF samples at DDH-47A* is broadly similar to that identified previously, although no hematite, riebeckite or apatite was found (Table 2.3a; Fig. 2.7a). However, the latter two minerals have a heterogeneous distribution in BIF (Trendall and Blockley, 1970; Grubb, 1971; Ewers and Morris, 1981).

A particularly intriguing observation is that altered BIF at Mt. Whaleback contains hematite (as martite) instead of magnetite, and lacks carbonates and aluminosilicates (Table 2.3a; Fig. 2.7a). Ewers and Morris (1981) suggested that altered BIF at Mt. Tom Price consists of, in order of abundance, quartz and magnetite with lesser carbonates, stilpnomelane, talc and apatite, while Taylor et al. (2001) indicated that altered BIF at Mt. Tom Price consists mostly of quartz deficient magnetite-siderite or hematiteankerite assemblages. In any case, altered BIFs are mineralogically different at Mt. Tom Price and Mt. Whaleback. Instead, with available information, altered BIF at Mt. Whaleback best compares with BIF at Paraburdoo.

The mineralogy of black shales from DDH-47A* is similar to that determined by some investigators (Trendall and Blockley, 1970; Morris and Horwitz, 1983). However, it differs from that of black shale samples from Paraburdoo, which contain significant quartz, siderite and ankerite (Ewers and Morris, 1981). As inferred from the chemistry, their samples probably included chert-siderite bands.

Unlike black shales at Wittenoom, altered black shales at Mt. Whaleback contain abundant clinochlore and muscovite instead of stilpnomelane, K-feldspar and carbonates. The one sample of "altered" DS5 from Mt. Tom Price lacked K-feldspar but contained stilpnomelane without clinochlore or muscovite (Ewers and Morris, 1981). Interestingly, their supposedly unaltered black shales from near Paraburdoo had significant chlorite and minor mica. It is speculated that these are more specifically 
clinochlore and muscovite, so they have a similar mineralogy to altered black shales at Mt. Whaleback.

\subsection{Mineralogical control on chemical composition}

The overall abundance and compositions of minerals should dictate the powdered colour and major element chemistry of most rocks, including BIF and shales. Thirteen of the 17 minerals identified occur in multiple samples at significant levels (>5\%) (Table 2.3). These minerals include ankerite, clinochlore, dolomite, goethite, hematite, K-feldspar, kaolinite, magnetite, muscovite, quartz, siderite, stilpnomelane, and talc. For 11 of these minerals, a standard chemical formula can be assumed (Table 2.5). However, stilpnomelane and clinochlore have solid solution series. To obtain their formula, a basic chemical formula (Deer et al., 1992) was iteratively adjusted until the chemistry of multiple samples containing these minerals was accounted for (Table 2.5). It is assumed these two minerals have the same chemical composition in all samples.

The relative proportions of the dominant 13 minerals (Table 2.6; Fig. 2.6c) dictate differences in the powder colour and chemistry of BIF and shale units. BIF samples from DDH-47A* are essentially mixtures of quartz and magnetite, with $\mathrm{SiO}_{2}$ and $\mathrm{Fe}_{2} \mathrm{O}_{3} \mathrm{~T}$ contents and grey to dark grey powder colour reflecting the relative abundance of these phases (Table 2.6; Fig. 2.6c). Moderate siderite and minor stilpnomelane, ankerite and talc contribute small quantities of $\mathrm{Fe}_{2} \mathrm{O}_{3} \mathrm{~T}, \mathrm{MgO}, \mathrm{CaO}$ and LOI that dilute $\mathrm{SiO}_{2}$ and $\mathrm{Fe}_{2} \mathrm{O}_{3} \mathrm{~T}$ contents. Quartz abundance also controls the $\mathrm{SiO}_{2}$ content of altered $\mathrm{BIF}$ at Mt. Whaleback. However, hematite and sometimes goethite control the $\mathrm{Fe}_{2} \mathrm{O}_{3} \mathrm{~T}$ content and give a weak red powder colour. The lack of aluminosilicates and carbonates in altered BIF results in low contents of all other oxides and LOI. As iron ore is mostly hematite with minor kaolinite, these rocks contain $>98 \% \mathrm{Fe}_{2} \mathrm{O}_{3} \mathrm{~T}$ and $<2 \%$ $\mathrm{SiO}_{2}$ and $\mathrm{Al}_{2} \mathrm{O}_{3}$ and exhibit a dusky red to dark red powder colour.

Variations in the relative abundances of stilpnomelane, K-feldspar, quartz and clinochlore control the $\mathrm{SiO}_{2}, \mathrm{Al}_{2} \mathrm{O}_{3}, \mathrm{Fe}_{2} \mathrm{O}_{3} \mathrm{~T}, \mathrm{MgO}$ and $\mathrm{K}_{2} \mathrm{O}$ contents of black shales from DDH-47A* (Table 2.6; Fig. 2.6c). Moderate amounts of siderite, dolomite and 
Table 2.5. Formulas and major element oxide contents (wt\%) of significant minerals found in rocks across the Hamersley Province

\begin{tabular}{|c|c|c|c|c|c|c|c|c|c|c|c|c|c|c|c|}
\hline Mineral & Formula & $\mathrm{SiO}_{2}$ & $\mathrm{Al}_{2} \mathrm{O}_{3}$ & $\mathrm{FeO}$ & $\mathrm{Fe}_{2} \mathrm{O}_{3}$ & $\mathrm{Fe}_{2} \mathrm{O}_{3} \mathrm{~T}$ & $\mathrm{CaO}$ & $\mathrm{Na}_{2} \mathrm{O}$ & $\mathrm{K}_{2} \mathrm{O}$ & MgO & $\mathrm{TiO}_{2}$ & $P_{2} \mathrm{O}_{5}$ & $\mathrm{SO}_{3}$ & LOI & Total \\
\hline Ankerite & $\mathrm{CaFe}\left(\mathrm{CO}_{3}\right)_{2}$ & - & - & 33.3 & - & 37.0 & 26.0 & - & - & - & - & - & - & 37.7 & 100.0 \\
\hline Clinochlore & $\mathrm{Fe}_{2} \mathrm{Mg}_{3} \mathrm{Al}_{2} \mathrm{Si}_{3} \mathrm{O}_{10}(\mathrm{OH})_{8} *$ & 29.1 & 16.5 & 23.2 & - & 25.8 & - & - & - & 19.5 & - & - & - & 9.00 & 100.0 \\
\hline Dolomite & $\mathrm{CaMg}\left(\mathrm{CO}_{3}\right)_{2}$ & - & - & - & - & - & 30.4 & - & - & 21.9 & - & - & - & 47.7 & 100.0 \\
\hline Goethite & $\mathrm{FeO}(\mathrm{OH})$ & - & - & - & 89.9 & 89.9 & - & - & - & - & - & - & - & 10.1 & 100.0 \\
\hline Hematite & $\mathrm{Fe}_{2} \mathrm{O}_{3}$ & - & - & - & 100 & 100 & - & - & - & - & - & - & - & - & 100.0 \\
\hline K-Feldspar & $\mathrm{KAISi}_{3} \mathrm{O}_{8}$ & 64.8 & 18.3 & - & - & - & - & - & 16.9 & - & - & - & - & - & 100.0 \\
\hline Kaolinite & $\mathrm{Al}_{2} \mathrm{Si}_{2} \mathrm{O}_{5}(\mathrm{OH})_{4}$ & 46.6 & 39.5 & - & - & - & - & - & - & - & - & - & - & 13.9 & 100.0 \\
\hline Magnetite & $\mathrm{Fe}_{3} \mathrm{O}_{4}$ & - & - & 31.0 & 69.0 & 103 & - & - & - & - & - & - & - & -3.50 & 100.0 \\
\hline Muscovite & $\mathrm{KAl}_{2} \mathrm{Si}_{3} \mathrm{AlO}_{10}(\mathrm{OH})_{2}$ & 45.3 & 38.4 & - & - & - & - & - & 11.8 & - & - & - & - & 4.52 & 100.0 \\
\hline Quartz & $\mathrm{SiO}_{2}$ & 100 & - & - & - & - & - & - & - & - & - & - & - & - & 100.0 \\
\hline Siderite & $\mathrm{FeCO}_{3}$ & - & - & 62.0 & - & 68.9 & - & - & - & - & - & - & - & 31.1 & 100.0 \\
\hline Stilpnomelane & $\mathrm{K}_{5} \mathrm{Fe}_{33} \mathrm{Mg}_{15} \mathrm{Si}_{64} \mathrm{Al}_{8} \mathrm{O}_{168}(\mathrm{OH})_{45} \cdot 12 \mathrm{H}_{2} \mathrm{O}^{*}$ & 48.6 & 5.15 & 30.0 & - & 33.3 & - & - & 2.97 & 7.64 & - & - & - & 2.40 & 100.0 \\
\hline Talc & $\mathrm{Mg}_{3} \mathrm{Si}_{4} \mathrm{O}_{10}(\mathrm{OH})_{2}$ & 63.4 & - & - & - & - & - & - & - & 31.9 & - & - & - & 4.75 & 100.0 \\
\hline
\end{tabular}

Notes: *The formula of these minerals was determined by first calculating their modal abundance in samples enriched in these minerals and then iterativley adjusting their basic formula (Deer et al., 1998) until the chemistry of these samples was accounted for. 
Table 2.6. Estimated mineral mixtures to best explain average major element chemistry (wt\%)

\begin{tabular}{|c|c|c|c|c|c|c|c|c|c|c|}
\hline Mineral & Abundance (\%) & $\mathrm{SiO}_{2}$ & $\mathrm{Al}_{2} \mathrm{O}_{3}$ & $\mathrm{FeO}$ & $\mathrm{Fe}_{2} \mathrm{O}_{3}$ & $\mathrm{Fe}_{2} \mathrm{O}_{3} \mathrm{~T}$ & $\mathrm{CaO}$ & $\mathrm{K}_{2} \mathrm{O}$ & $\mathrm{MgO}$ & LOI \\
\hline \multicolumn{11}{|l|}{$B I F$} \\
\hline Magnetite & 37 & & & 11 & 26 & 38 & & & & -1 \\
\hline Quartz & 34 & 34 & & & & & & & & \\
\hline Siderite & 13 & & & 8 & & 9 & & & & 4 \\
\hline Stp & 6 & 3 & 0.3 & 2 & & 2 & & 0.2 & 0.5 & 0.1 \\
\hline Ankerite & 6 & & & 2 & & 2 & 2 & & & 2 \\
\hline Talc & 4 & 3 & & & & & & & 1 & 0.2 \\
\hline Total & 100 & 39 & 0.3 & 23 & 26 & 51 & 2 & 0.2 & 1.7 & 5 \\
\hline \multicolumn{11}{|l|}{ Altered BIF } \\
\hline Hematite & 52 & & & & 52 & 52 & & & & \\
\hline Quartz & 41 & 41 & & & & & & & & \\
\hline Goethite & 7 & & & & 6 & 6 & & & & 1 \\
\hline Total & 100 & 41 & & & 6 & 6 & & & & 1 \\
\hline \multicolumn{11}{|l|}{ Iron ore } \\
\hline Hematite & 98 & & & & 98 & 98 & & & & \\
\hline Kaolinite & 2 & 1 & 1 & & & & & & & 0.3 \\
\hline Total & 100 & 1 & 1 & & 98 & 98 & & & & 0.3 \\
\hline \multicolumn{11}{|l|}{ Black shale } \\
\hline Stilp & 45 & 22 & 2 & 13 & & 15 & & 1 & 3 & 1 \\
\hline $\mathrm{Kfs}$ & 20 & 13 & 4 & & & & & 3 & & \\
\hline Quartz & 12 & 12 & & & & & & & & \\
\hline Siderite & 13 & & & 8 & & 9 & & & & 4 \\
\hline Dolomite & 10 & & & & & & 3 & & 2 & 5 \\
\hline Total & 100 & 47 & 6 & 22 & & 24 & 3 & 5 & 6 & 10 \\
\hline \multicolumn{11}{|c|}{ Altered black shale } \\
\hline Clinochlore & 65 & 19 & 11 & 15 & & 17 & & & 13 & 6 \\
\hline Muscovite & 25 & 11 & 10 & & & & & 3 & & 1 \\
\hline Quartz & 10 & 10 & & & & & & & & \\
\hline Total & 100 & 40 & 20 & 15 & & 17 & & 3 & 13 & 7 \\
\hline \multicolumn{11}{|l|}{ Red Shale } \\
\hline Kaolinite & 54 & 25 & 21 & & & & & & & 8 \\
\hline Hematite & 34 & & & & 34 & 34 & & & & \\
\hline Clinochlore & 12 & 3 & 2 & 3 & & 3 & & & 2 & 1 \\
\hline Total & 100 & 29 & 23 & 3 & 34 & 37 & & & 2 & 9 \\
\hline \multicolumn{11}{|l|}{ Chert-siderite } \\
\hline Quartz & 65 & 65 & & & & & & & & \\
\hline Siderite & 27 & & & 17 & & 19 & & & & 8 \\
\hline Dolomite & 8 & & & & & & 2 & & 2 & 4 \\
\hline Total & 100 & 65 & & 17 & & 19 & 2 & & 2 & 12 \\
\hline \multicolumn{11}{|l|}{ Cherty BIF } \\
\hline Siderite & 44 & & & 27 & & 30 & & & & 14 \\
\hline Magnetite & 25 & & & 8 & 17 & 26 & & & & -1 \\
\hline Quartz & 22 & 22 & & & & & & & & \\
\hline Stp & 9 & 4 & 0.5 & 3 & & 3 & & 0.3 & 0.2 & 1 \\
\hline Total & 31 & 26 & 0.5 & 3 & 0 & 3 & & 0.3 & 0.2 & 1 \\
\hline \multicolumn{11}{|l|}{ Shaley Ore } \\
\hline Hematite & 80 & & & & & 80 & & & & \\
\hline Kaolinite & 20 & 9 & 8 & & & & & & & 3 \\
\hline Total & 100 & 9 & 8 & & & 80 & & & & 3 \\
\hline
\end{tabular}

Notes: $\mathrm{BIF}=$ banded iron-formation; $\mathrm{Kfs}=\mathrm{K}$-feldspar; $\mathrm{Stp}=$ stilpnomelane. 
ankerite also contribute small quantities of $\mathrm{Fe}_{2} \mathrm{O}_{3} \mathrm{~T}, \mathrm{CaO}$ and LOI. For altered black shales at Mt. Whaleback, differences in clinochlore, muscovite and quartz dictate the $\mathrm{SiO}_{2}$ content, while differences in the first two minerals control $\mathrm{Al}_{2} \mathrm{O}_{3}, \mathrm{Fe}_{2} \mathrm{O}_{3} \mathrm{~T}, \mathrm{MgO}$, $\mathrm{K}_{2} \mathrm{O}$ and LOI contents. The olive grey to very dark grey powder colour of black shale and altered black shale is essentially controlled by variations in stilpnomelane and clinochlore respectively. However, the lighter coloured powders tend to contain higher abundances of quartz, K-feldspar or carbonates. The proportion of hematite generally determines the $\mathrm{Fe}_{2} \mathrm{O}_{3} \mathrm{~T}$ content and red powder colour of red shales, while kaolinite and clinochlore abundances drive variations in $\mathrm{SiO}_{2}, \mathrm{Al}_{2} \mathrm{O}_{3}, \mathrm{MgO}$ and $\mathrm{LOI}$ contents.

The relative abundance of quartz and siderite dictates the $\mathrm{SiO}_{2}$ and $\mathrm{Fe}_{2} \mathrm{O}_{3} \mathrm{~T}$ contents and white to light grey powder colour of chert-siderite bands. Minor amounts of dolomite contribute small quantities of $\mathrm{MgO}, \mathrm{CaO}$ and $\mathrm{LOI}$. The absence of silicates such as stilpnomelane results in the low $\mathrm{Al}_{2} \mathrm{O}_{3}$ and $\mathrm{K}_{2} \mathrm{O}$ contents of these bands.

Similar to BIF at Wittenoom, quartz and magnetite abundance control the $\mathrm{SiO}_{2}$ and $\mathrm{Fe}_{2} \mathrm{O}_{3} \mathrm{~T}$ contents and powder colour of cherty BIF. However, variations in the amount of siderite also influence the $\mathrm{Fe}_{2} \mathrm{O}_{3} \mathrm{~T}$ content as well as LOI. Minor stilpnomelane contributes small amounts of $\mathrm{Al}_{2} \mathrm{O}_{3}, \mathrm{MgO}$ and LOI to these rocks. Hematite abundance determines the $\mathrm{Fe}_{2} \mathrm{O}_{3} \mathrm{~T}$ content and red colour of shaley ore samples from $\mathrm{Mt}$. Whaleback with kaolinite influencing the $\mathrm{SiO}_{2}, \mathrm{Al}_{2} \mathrm{O}_{3}$ and LOI contents.

\subsection{Causes of chemical and mineralogical variation}

It is assumed here, as in previous works (Trendall and Blockley, 1970; Ewers and Morris, 1981), that laterally continuous units of the Dales Gorge Member and surrounding shales were originally deposited as sediment horizons with the same chemistry and mineralogy across the Hamersley Province. Despite arguments to the contrary (Ewers, 1983), m-scale sediment horizons of significantly different composition can occur in modern ocean basins. As an intriguing though imperfect analog, consider deposition of siliciclastic and chemical components off the present 
northeast Australian margin. Here, because of changes in eustatic sea level and sediment supply though the late Pleistocene, m-scale horizons dominated by shale alternate with thicker horizons dominated by carbonate across at least $31000 \mathrm{~km}^{2}$ (Dunbar et al., 2000). In the Hamersley Province, it is also assumed that precursor sediments were similar in chemical composition to BIF and shale currently found in $\mathrm{DDH}-47 \mathrm{~A}^{*}$ because this hole lies in the flat, least deformed part of the province. Given these assumptions, differences in the chemistry and mineralogy of equivalent BIF and shale units across the Province represent a series of post-depositional chemical reactions (Table 2.7).

Two simple sets of reactions can explain the changes in DB-macrobands between Wittenoom and Mt. Whaleback (Table 2.7), although their appropriateness and relative timing are equivocal. In the first set of reactions, magnetite and siderite in unaltered BIF oxidize to hematite, while talc and stilpnomelane dissolve (Table 2.7, reactions 14). Although the oxidation of magnetite results in minimal change to major element oxide contents, the oxidation of siderite and the dissolution of talc release $\mathrm{HCO}_{3}{ }^{-} \mathrm{Mg}^{2+}$, $\mathrm{K}^{+}$and $\mathrm{H}_{4} \mathrm{SiO}_{4}$. The lack of aluminosilicates and $\mathrm{Al}_{2} \mathrm{O}_{3}$ in altered $\mathrm{BIF}$ indicates a change in mass through loss of $\mathrm{Al}$, addition of $\mathrm{Fe}$, or both. Isocon plots using immobile trace elements provide one means to evaluate such mass changes (Grant, 1986). Such diagrams are discussed in Chapter 5. It is noted here, though, that the thickness of altered BIF horizons are similar or less than unaltered equivalents, suggesting that $\mathrm{Fe}_{2} \mathrm{O}_{3} \mathrm{~T}$ contents in altered $\mathrm{BIF}$ increased, at least partly, through the loss of $\mathrm{MgO}, \mathrm{CaO}$, $\mathrm{Al}_{2} \mathrm{O}_{3}$, LOI and minor amounts of $\mathrm{SiO}_{2}$. In the second set of reactions, quartz in altered BIF dissolves (Table 2.7, reaction 5). This reaction would result in considerable mass loss, evident as a large increase in porosity or a decrease in volume between equivalent layers of altered BIF and iron ore. Although either expectation is difficult to quantify with information presented so far, several workers (Blockley 1969; Jones et al. 1973; Harmsworth et al. 1990; Taylor et al., 2001) have suggested that 40 to $50 \%$ of precursor $\mathrm{BIF}$ volume can be lost upon iron ore formation. Clearly, however, high-grade hematite ore can also be very porous (Morris, 1985; Taylor et al., 2001; Fig. 2.8c). Importantly, 
Table 2.7. Possible reactions for the alteration of BIF and black shale from the Hamersley Province

\section{Unaltered BIF $\rightarrow$ altered BIF}

1. Oxidation of magnetite to hematite

$4 \mathrm{Fe}_{3} \mathrm{O}_{4(\mathrm{~s})}+\mathrm{O}_{2(\mathrm{aq})} \rightarrow 6 \mathrm{Fe}_{2} \mathrm{O}_{3(\mathrm{~s})}$

2. Oxidation of siderite to hematite

$4 \mathrm{FeCO}_{3(\mathrm{~s})}+4 \mathrm{H}_{2} \mathrm{O}_{(\mathrm{l})}+\mathrm{O}_{2(\mathrm{aq})} \rightarrow 2 \mathrm{Fe}_{2} \mathrm{O}_{3(\mathrm{~s})}+4 \mathrm{HCO}_{3 \text { (aq) }}^{-}+4 \mathrm{H}^{+}$

3. Stilpnomelane dissolution

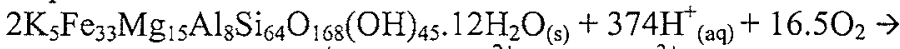

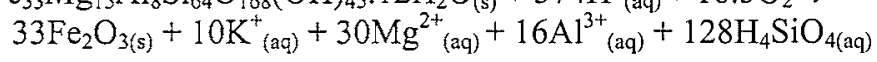

4. Talc dissolution

$\mathrm{Mg}_{3} \mathrm{Si}_{4} \mathrm{O}_{10}(\mathrm{OH})_{2(\mathrm{~s})}+6 \mathrm{H}^{+}$(aq) $+4 \mathrm{H}_{2} \mathrm{O}_{(\mathrm{l})} \rightarrow 3 \mathrm{Mg}^{2+}{ }_{(\mathrm{aq})}+4 \mathrm{H}_{4} \mathrm{SiO}_{4(\mathrm{aq})}$

\section{Altered BIF $\rightarrow$ iron ore}

5. Quartz dissolution

$\mathrm{SiO}_{2(\mathrm{~s})}+2 \mathrm{H}_{2} \mathrm{O}_{(\mathrm{l})} \rightarrow \mathrm{H}_{4} \mathrm{SiO}_{4(\mathrm{aq})}$

\section{Unaltered black shale $\rightarrow$ altered black shale}

6. Incongruent hydrolysis of stilpnomelane to clinochlore

$2 \mathrm{~K}_{5} \mathrm{Fe}_{33} \mathrm{Mg}_{15} \mathrm{Al}_{8} \mathrm{Si}_{64} \mathrm{O}_{168}(\mathrm{OH})_{45} \cdot 12 \mathrm{H}_{2} \mathrm{O}_{(\mathrm{s})}+110 \mathrm{H}_{2} \mathrm{O}_{(\mathrm{l})}+122 \mathrm{H}^{+}(\mathrm{aq}) \rightarrow$

$8 \mathrm{Fe}_{2} \mathrm{Mg}_{3} \mathrm{Al}_{2} \mathrm{Si}_{3} \mathrm{O}_{10}(\mathrm{OH})_{8(\mathrm{~s})}+10 \mathrm{~K}_{(\mathrm{aq})}^{+}+6 \mathrm{Mg}^{2+}{ }_{(\mathrm{aq})}+50 \mathrm{Fe}^{2+}{ }_{(\mathrm{aq})}+104 \mathrm{H}_{4} \mathrm{SiO}_{4(\mathrm{aq})}$

7. Incongruent hydrolysis of $K$-feldspar to muscovite $3 \mathrm{KAlSi}_{3} \mathrm{O}_{8(\mathrm{~s})}+12 \mathrm{H}_{2} \mathrm{O}_{(1)}+2 \mathrm{H}_{(\mathrm{aq})}^{+} \rightarrow \mathrm{KAl}_{3} \mathrm{Si}_{3} \mathrm{O}_{10}(\mathrm{OH})_{2(\mathrm{~s})}+2 \mathrm{~K}_{(\mathrm{aq})}^{+}+6 \mathrm{H}_{4} \mathrm{SiO}_{4(\mathrm{aq})}$

8. Siderite dissolution

$\mathrm{FeCO}_{3(\mathrm{~s})}+\mathrm{H}_{(\mathrm{aq})}^{+} \rightarrow \mathrm{Fe}^{2+}{ }_{(\mathrm{aq})}+\mathrm{HCO}_{3(\mathrm{aq})}^{-}$

9. Dolomite dissolution

$\mathrm{CaMg}\left(\mathrm{CO}_{3}\right)_{2(\mathrm{~s})}+2 \mathrm{H}^{+}{ }_{(\mathrm{aq})} \rightarrow \mathrm{Ca}_{(\mathrm{aq})}^{2+}+\mathrm{Mg}_{(\mathrm{aq})}^{2+}+2 \mathrm{HCO}_{3}^{-}(\mathrm{aq})$

\section{Altered black shale $\rightarrow$ red shale}

10. Incongruent hydrolysis of clinochlore to kaolinite + hematite $2 \mathrm{Fe}_{2} \mathrm{Mg}_{3} \mathrm{Al}_{2} \mathrm{Si}_{3} \mathrm{O}_{10}(\mathrm{OH})_{8(\mathrm{~s})}+20 \mathrm{H}_{(\mathrm{aq})}^{+}+3 \mathrm{O}_{2(\mathrm{aq})} \rightarrow$

$$
2 \mathrm{Al}_{2} \mathrm{Si}_{2} \mathrm{O}_{5}(\mathrm{OH})_{4(\mathrm{~s})}+6 \mathrm{Mg}^{2+}{ }_{(\mathrm{aq})}+2 \mathrm{Fe}_{2} \mathrm{O}_{3(\mathrm{~s})}+2 \mathrm{H}_{4} \mathrm{SiO}_{4(\mathrm{aq})}+10 \mathrm{H}_{2} \mathrm{O}_{(\mathrm{l})}
$$

11. Incongruent hydrolysis of muscovite to kaolinite

$$
2 \mathrm{KAl}_{3} \mathrm{Si}_{3} \mathrm{O}_{10}(\mathrm{OH})_{2(\mathrm{~s})}+3 \mathrm{H}_{2} \mathrm{O}_{(\mathrm{l})}+2 \mathrm{H}_{(\mathrm{aq})}^{+} \rightarrow 3 \mathrm{Al}_{2} \mathrm{Si}_{2} \mathrm{O}_{5}(\mathrm{OH})_{4(\mathrm{~s})}+2 \mathrm{~K}_{\text {(aq) }}^{+}
$$

12. Quartz dissolution

$$
\mathrm{SiO}_{2(\mathrm{~s})}+2 \mathrm{H}_{2} \mathrm{O}_{(\mathrm{l})} \rightarrow \mathrm{H}_{4} \mathrm{SiO}_{4(\mathrm{aq})}
$$

\section{Chert-siderite diagenesis}

13. Denitrification

$$
5 \mathrm{CH}_{2} \mathrm{O}_{(\mathrm{s})}+4 \mathrm{NO}_{3(\mathrm{aq})}^{-} \rightarrow 2 \mathrm{~N}_{2(\mathrm{~g})}+4 \mathrm{HCO}_{3(\mathrm{aq})}^{-}+\mathrm{CO}_{2(\mathrm{~g})}+3 \mathrm{H}_{2} \mathrm{O}_{(1)}
$$

14. Magnetite to siderite (metal oxide reduction)

$$
2 \mathrm{Fe}_{3} \mathrm{O}_{4(\mathrm{~s})}+\mathrm{CH}_{2} \mathrm{O}_{(\mathrm{s})}+3 \mathrm{CO}_{2(\mathrm{~g})}+4 \mathrm{H}^{+}{ }_{(\mathrm{aq})} \rightarrow 2 \mathrm{Fe}^{2+}{ }_{(\mathrm{aq})}+4 \mathrm{FeCO}_{3(\mathrm{~s})}+3 \mathrm{H}_{2} \mathrm{O}_{(\mathrm{l})}
$$

Note: See figure 2.11 for plausible paragenetic sequence. 
the formation of high-grade hematite ore can be achieved without significant Fe addition (see also Taylor et al., 2001).

A relatively straightforward set of reactions can also explain the transformation of black shale through altered black shale to red shale (Table 2.7 ). In one set of reactions, stilpnomelane and $\mathrm{K}$-feldspar form clinochlore and muscovite, while siderite and dolomite dissolve (Table 2.7, reactions 6-9). These reactions release significant $\mathrm{H}_{4} \mathrm{SiO}_{4}$, $\mathrm{Fe}^{2+}, \mathrm{Mg}^{2+}, \mathrm{Ca}^{2+}, \mathrm{K}^{+}$and $\mathrm{HCO}_{3}^{-}$. An isocon plot using constant $\mathrm{A} 1$, Ti and $\mathrm{Y}$ mass concurs with these expected losses, suggesting that 50 to $60 \%$ of shale mass can be lost during this step (Fig. 2.10a). Thus, the great enrichment of $\mathrm{Al}_{2} \mathrm{O}_{3}$ content in altered black shale at Mt. Whaleback most likely results through significant loss of $\mathrm{SiO}_{2}$, $\mathrm{Fe}_{2} \mathrm{O}_{3} \mathrm{~T}, \mathrm{MgO}, \mathrm{CaO}, \mathrm{K}_{2} \mathrm{O}$ and LOI. Such a mass loss may also explain the substantial thinning of shale units at Mt. Whaleback. In the second set of reactions, clinochlore and muscovite in altered black shale form kaolinite and hematite while quartz dissolves (Table 2.7, reactions 10-12). Given the mineral proportions of altered black shale (Table 2.6), these reactions release only moderate $\mathrm{H}_{4} \mathrm{SiO}_{4}, \mathrm{Mg}^{2+}, \mathrm{K}^{+}$and $\mathrm{H}_{2} \mathrm{O}$. An isocon plot assuming immobile $\mathrm{Ti}$ and $\mathrm{Y}$ agrees with these losses, suggesting that an additional $\sim 18 \%$ of shale mass is lost during red shale formation (Fig. 2.10b). Therefore, $\mathrm{Al}_{2} \mathrm{O}_{3}$ and $\mathrm{Fe}_{2} \mathrm{O}_{3} \mathrm{~T}$ contents likely increase in red shale through the loss of $\mathrm{SiO}_{2}, \mathrm{MgO}, \mathrm{K}_{2} \mathrm{O}$ and LOI. However, as for the $\mathrm{BIF}$ reactions, the $\mathrm{Fe} / \mathrm{Al}$ ratio rises significantly after the second step, indicating a loss of $\mathrm{Al}$ or relative gain in $\mathrm{Fe}$. Assuming that $\mathrm{Ti}$ and $\mathrm{Y}$ are immobile during the second step, the isocon plot (Fig. 2.10b) supports a gain in Fe.

Both sets of reactions for altering BIF and the second set of reactions for altering shale require oxidizing, acidic waters. These reactions can also proceed at relatively low temperatures. In contrast, reducing, acidic waters are probably necessary to remove the significant amounts of $\mathrm{Fe}^{2+}$ during conversion of black shale to altered black shale. However, these waters need not be hot because stilpnomelane can decompose to clinochlore at relatively low temperatures provided that surrounding fluids have a low $\mathrm{pH}$ or $\mathrm{a}_{\mathrm{K}+}$ (Miyano and Klein, 1989). 
a)

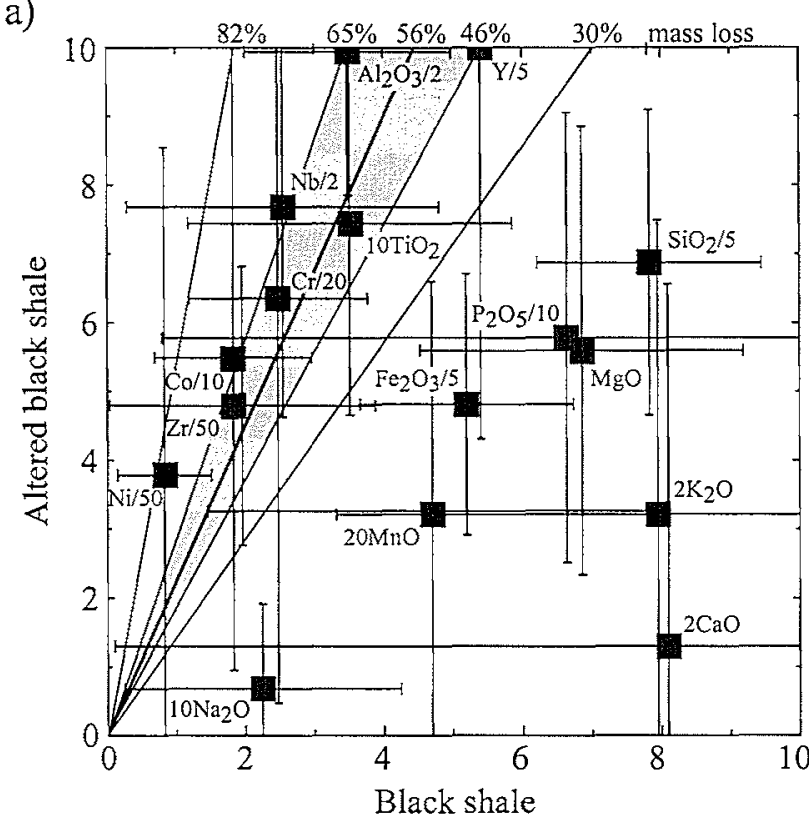

b)

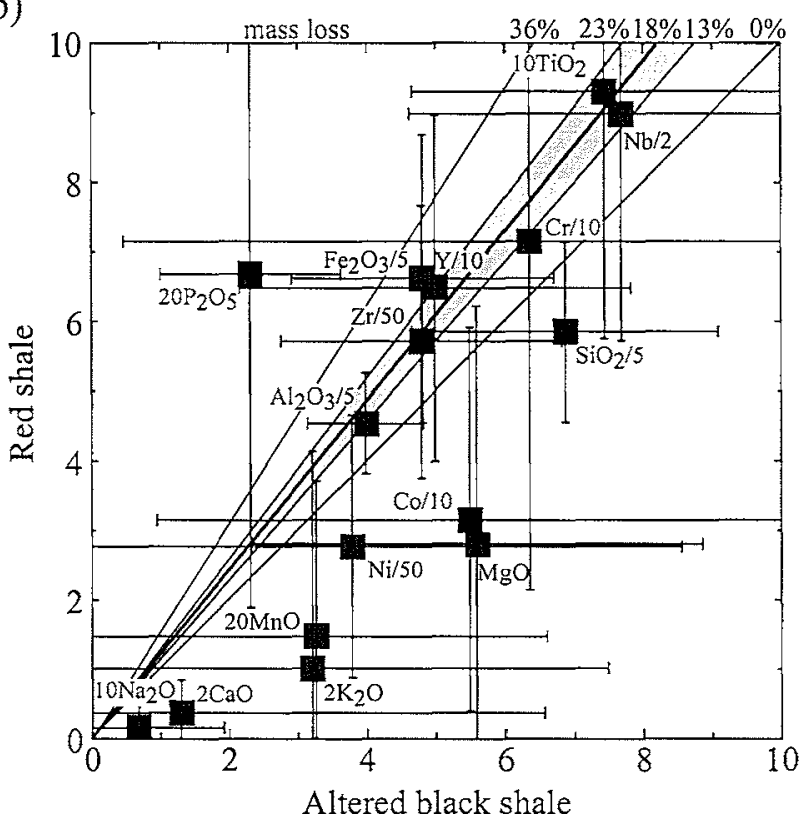

Figure 2.10. Isocon diagrams (after Grant, 1986) showing the representative changes between shales at Mt. Whaleback. (a) black shale (average composition) and altered black shale (average composition); (b) altered black shale (average composition) and red shale (average composition). Major element data is calculated from table 2.2 and trace element data is from Chapter 5. Major element oxides are plotted as $\mathrm{wt} \%$, while trace elements are plotted in $\mathrm{ppm}$. Individual elements were multiplied or divided by a factor that conveniently placed them on a scaled diagram from 0 to 10 . In both figures dark gray areas represent the broadest range of possible isocons for assumed near-immobile elements $\mathrm{Al}$, Ti and $\mathrm{Y}$, which are most commonly found to be immobile in low- to med-T systems. The central lines represent a "best-fit" isocon through these elements. Light gray areas represent the broadest range of possible isocons taking into account most of their standard deviations. The ranges of mass losses implied for the indicated isocons are shown along the edges. 
Although the reactions discussed above are reasonable, they may not correctly describe the complete processes. In particular, the peak metamorphic conditions recorded by mineral assemblages increases from prehnite-pumpellyite facies in the north to epidote-actinolite (lower greenschist) facies in the south (Smith et al., 1982). Stilpnomelane in the north probably reflects low-grade metamorphism of original clay minerals such as montmorillonite (LaBerge, 1966; Grubb, 1971; Miyano, 1982). Thus, clinochlore in the south may reflect a higher grade metamorphism of the same original clay assemblages. In this case, a direct metasomatic reaction of stilpnomelane to clinochlore may not have occurred. Furthermore, magnetite-carbonate rich BIF at Mt. Tom Price (Taylor et al., 2001) suggests that mineralization might be more complex, with Si removed from BIF before oxidation occurred.

A simple set of reactions (Table 2.7 , reactions 13,14 ) can also explain chertsiderite bands adjacent to or within black shale (Fig. 2.3). In marine environments with high $\mathrm{Fe}^{3+}$ and low sulphur contents, diagenesis of organic matter can proceed through metal oxide reduction to form siderite (e.g., Taylor and Curtis, 1995). Although siderite formed by this reaction often has anomalously high $\delta^{13} \mathrm{C}$ in modern environments because of methanogenesis (e.g., Mozley and Burns, 1993; Rodriguez et al., 2000), the opposite might be expected in Archean environments with excess Fe and limited methane production (Walker, 1984). Such an anomalous enrichment of ${ }^{12} \mathrm{C}$ is found in chert-siderite bands of the Dales Gorge Member (Becker and Clayton, 1972; Walker, 1984).

\subsection{Chemical and mineralogical paragenesis}

Based on key field relationships, mineralogy and consistency of plausible reaction paths, some rocks of the Hamersley Province must have experienced at least five stages of alteration (Fig. 2.11): (1) early diagenesis, (2) low-grade regional metamorphism, (3) higher-grade regional metamorphism, (4) oxidation, and (5) silica dissolution. The first two stages are briefly noted for completeness, although others have discussed them previously. 


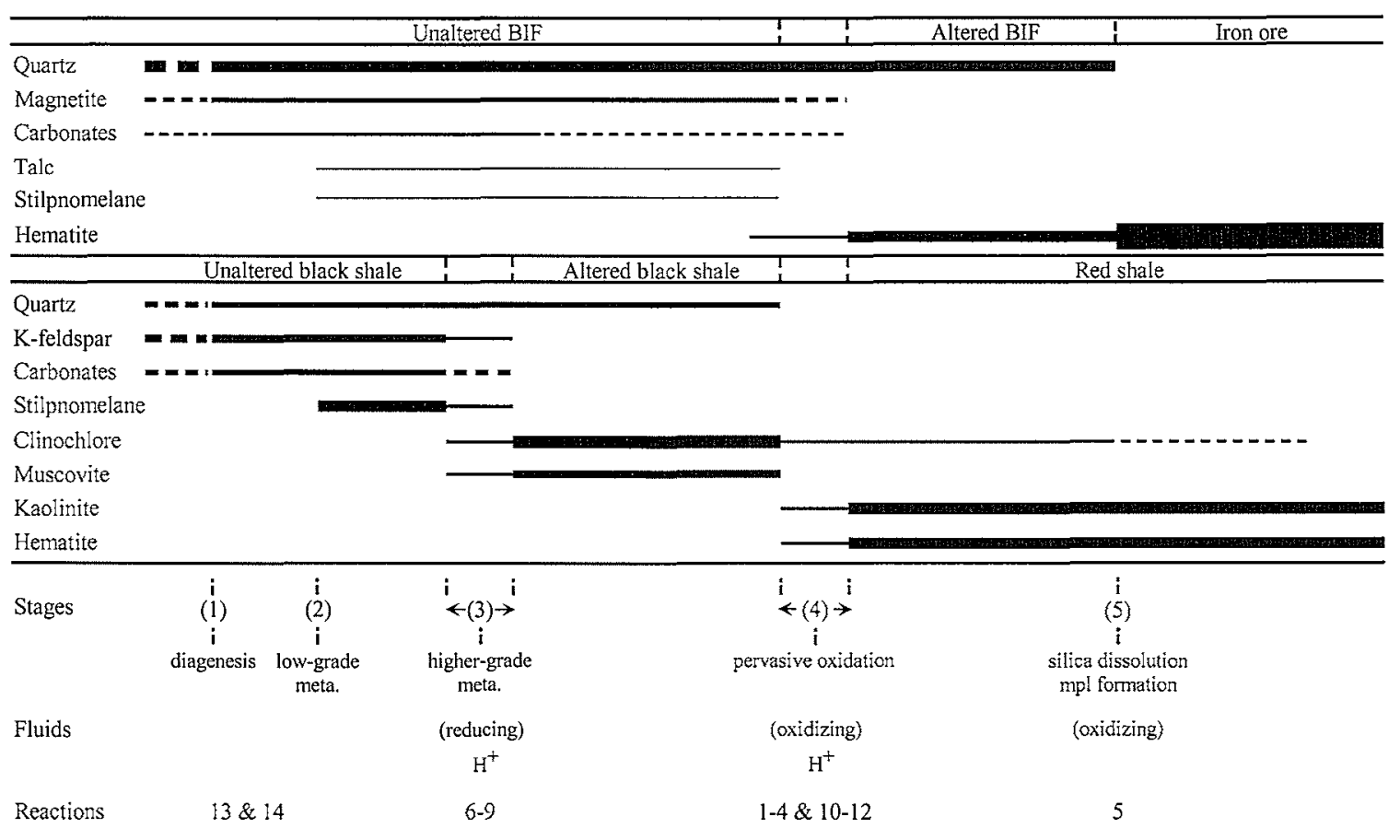

Figure 2.11. Schematic paragenetic sequence for BIF and shale across the Hamersley Province. Line thicknesses represent relative mineral abundance; dotted lines represent areas of gradational change. Reaction numbers correspond to the reactions listed in table 2.7 . meta $=$ metamorphism; $\mathrm{mpl}=$ microplaty hematite.

\subsubsection{Stage 1: diagenesis}

Previously documented textural observations and chemical processes suggest that most of the minerals occurring in unaltered BIF and black shale are not primary precipitates; rather they probably represent secondary phases formed during early diagenesis (e.g., LaBerge, 1966; Trendall and Blockley, 1970; Grubb, 1971; Ayers, 1972; Garrels et al., 1973; Ewers and Morris, 1981; Miyano, 1982; Morris, 1993). For example, quartz and primary hematite probably represent low temperature recrystallization of silica and iron oxyhyroxides in shallow sediment (Grubb, 1971; Ayers, 1972; French, 1973; Morris, 1993). Siderite may also have formed during metal oxide reduction of organic matter.

\subsubsection{Stage 2: low-grade regional metamorphism}

The presence of prehnite, pumpellyite, epidote and actinolite in mafic rocks of the underlying Fortescue Group, suggests that regional metamorphism has affected most 
rocks of the Hamersley Province (Smith, et al., 1982). In particular, stilpnomelane, talc and magnetite in BIF at Wittenoom likely represent metamorphic products of precursor phases such as montmorillonite, greenalite and hematite respectively (LaBerge, 1966; Ayers, 1972; French, 1973; Miyano, 1982; Morris, 1980; 1993).

\subsubsection{Stage 3: medium-grade regional metamorphism (black shale to altered black} shale)

Black shales at Mt. Whaleback contain clinochlore and muscovite without stilpnomelane, K-feldspar or carbonates (Table 2.3b). Some clinochlore-rich, carbonate-poor black shales also occur adjacent to unaltered BIF in DDH-47A*, although they contain K-feldspar (Table 2.3a). Assuming K-feldspar typically alters at higher temperatures and pressures than stilpnomelane (Miyano, 1982), these observations collectively suggest that acidic, mildly reducing fluids (Table 2.7) have affected rocks across the Hamersley Province prior to oxidation of BIF and more pervasively in the south. Importantly, such fluids would not dissolve quartz or affect the chemistry of BIF except removal of minor constituents. Both inferences are consistent with observations (Tables 2.2a, 2.3a, 2.3b). Smith et al. (1982) have indicated that metamorphic grade increases to the south. Although these authors suggest that depth of burial controls metamorphic grade across the Hamersley Province, the higher grades in the south are most likely related to increased deformation associated with the Ophthalmian Orogeny $\left(\mathrm{D}_{2}\right)$ (Tyler, 1994). Because regional metamorphism often involves flow of acidic and mildly reducing fluids (e.g., Helgeson, 1967; Bowers and Helgeson, 1983a), the conversion of black shale to altered black shale may relate to $\mathrm{D}_{2}$ metamorphism. In this case, the alteration of stages 2 and 3 would roughly coincide in time. Unlike rocks from the northern Hamersley Province, BIF layers around Newman contain numerous bedding parallel veins composed of quartz and hematite that formed during the Ophthalmian Orogeny (Brown et al., in press). The loss of $\mathrm{H}_{4} \mathrm{SiO}_{4}$ and $\mathrm{Fe}^{2+}$ during black shale alteration (Table 2.7) may provide the requisite material for these veins. 


\subsubsection{Stage 4: pervasive oxidation (BIF to altered BIF; altered black shale to red} shale)

Altered BIF and iron ore at Mt. Whaleback coexist with red shale, suggesting a common process has affected all three rock types. The simplest explanation for the altered BIF and red shale is that original BIF and altered black shale have reacted with large quantities of acidic, oxygenated fluids (Table 2.7). With BIF, such fluids would oxidize magnetite to hematite, and dissolve carbonates and silicates. Similarly, with altered black shale, such fluids would transform clinochlore to hematite and kaolinite, muscovite to kaolinite, and dissolve quartz.

Deep weathering with meteoric water could provide the necessary fluids to drive this pervasive oxidation of rocks in and around Mt., Whaleback. There are, however, several problems with this explanation. First, despite complete conversion of magnetite to martite, the altered BIF around Mt. Whaleback has the hardness and millimetre to centimetre layering of original BIF, a finding inconsistent with typical supergene weathering. Moreover, on pit faces at Mt. Whaleback, altered black shale of the Mt. McRae Member grades into red shale and altered BIF of the Dales Gorge Member, even when the units are overturned (Fig. 2.5). Instead of fluids percolating from above, field observations suggest bedding parallel (lateral) fluid flow along more permeable BIF units with egression into thin but not thick shale horizons. Regardless of process, there are two problems with understanding this pervasive oxidation: (1) red shales have lost quartz but adjacent altered BIF units contain abundant quartz (Tables 2.3a, 2.3b; Fig. 2.11), and (2) altered BIF has lost $\mathrm{Al}$, an element generally considered immobile during reaction with acidic, oxygenated fluids (Goldschmidt, 1958; Sugitani et al., 1996; Panahi et al., 2000). These observations suggest local variations in fluid chemistry restricted to specific rock units, although these differences cannot be appreciated with available data. Interestingly, abundant shear hosted veins composed of quartz, stilpnomelane and riebeckite $\left(\mathrm{Na}_{2}(\mathrm{Fe}, \mathrm{Mg})_{5} \mathrm{Si}_{8} \mathrm{O}_{22}(\mathrm{OH})_{2}\right)$ formed in $\mathrm{BIF}$ units around Newman during post- $\mathrm{D}_{2}$ extension (Brown et al., in press). As these veins necessitate transport of $\mathrm{H}_{4} \mathrm{SiO}_{4}, \mathrm{Mg}^{2+}$ and $\mathrm{Al}^{3+}$, they may relate to and provide a post-Ophthalmian 
age for stage 4 oxidation.

\subsubsection{Stage 5: silica dissolution and microplaty hematite formation (altered BIF to iron}

ore)

From a chemical and mineralogical perspective, quartz represents the only difference between altered BIF and high-grade hematite ore. Thus, dissolution of the quartz in altered BIF provides a simple explanation for ore genesis. However, a significant portion of hematite in the ore at Mt. Whaleback occurs as microplaty hematite whereas that in altered BIF is mostly martite (Fig. 2.8b). Hence, in addition to silica removal, some process must have precipitated microplaty hematite, presumably from a solution or a precursor Fe-rich phase. One possible process is discussed below in light of the recent work at the Mt. Tom Price and Giles Mini deposits (Barley et al., 1999; Taylor et al., 2001; Dalstra et al., 2002b). Uncertainties in the relative timing of stages 4 and 5 are also noted.

\subsection{Implications for ore genesis}

The widely cited supergene model for high-grade hematite ore genesis has, as a first step, shallow, meteoric fluids affecting primary, unaltered BIF by simultaneously oxidizing magnetite to martite and replacing quartz with hydrous iron oxides (Morris, 1985; Harmsworth et al., 1990). In a second step, deep burial upgrades the hydrous iron oxides to microplaty hematite (Morris, 1985; Harmsworth et al., 1990). The results presented here demonstrate that mineralization at Mt. Whaleback and alteration across the Hamersley Province is more complex. In particular, (1) oxidation of magnetite to martite in BIF can occur independently of silica removal, (2) rocks at Mt. Whaleback have been chemically altered multiple times so that surrounding BIF may have been significantly altered prior to and after ore genesis and, (3) oxidation, including mineralization, occurred after formation of altered black shales, which probably formed during peak metamorphism $\left(D_{2}\right)$.

Recent examinations at the Mt. Tom Price and Giles Mini deposits have 
documented areas where "BIF" is composed of magnetite and siderite and juxtaposed with quartz-hematite-carbonate veins and carbonate-enriched shales (Barley et al., 1999; Taylor et al., 2001; Dalstra et al., 2002b). To explain these findings, these authors have invoked a four-stage paragenesis for mineralization. First, high temperature, carbonaterich fluids (i.e., hydrothermal conditions) replaced silica with siderite, leaving carbonate-rich BIF and shales with some iron silicates. For the BIF assemblages, heated meteoric fluids then oxidized the magnetite and siderite to martite, microplaty hematite and ankerite. Continued oxidation by cooling meteoric fluids leached remaining carbonates and silicates, leaving a highly porous ore. Finally, supergene weathering with cold, oxidizing meteoric fluids destroyed remaining minor components such as apatite.

Rocks at Mt. Whaleback presented in this chapter do not conform to this paragenetic sequence. In particular, no carbonate-rich rocks were found (although Chapter 4 indicates they may exist). Indeed, except for one shale sample, no magnetite or carbonate minerals were documented in any rock sample collected at Mt. Whaleback (Table 2.3b).

There are three possible explanations for these differences. First, the carbonaterich "BIF" and shale at Mt. Tom Price never formed at Mt. Whaleback. In this case, these rocks do not reflect a necessary process on the path to high-grade hematite ore. Second, these rocks exist at Mt. Whaleback but have not yet been found. Given the enormous size of the Mt. Whaleback deposit, carbonate-rich BIF, shales and "hydrothermal" veins could lie below the current pit and beyond the depths of examined drill cores. Third, one or more processes have affected rocks at either location during or after ore genesis, altering key rocks of the paragenetic sequence.

It is difficult to rigorously argue for or against any of these possibilities with the data presented so far. However, an internally consistent and testable model that explains both deposits, as well as the limited geochemical and mineralogical data at Paraburdoo, can be forwarded (Fig. 2.12). Rocks at all three deposits experienced regional metamorphism during $\mathrm{D}_{2}$, although the grade was less at Mt. Tom Price and 


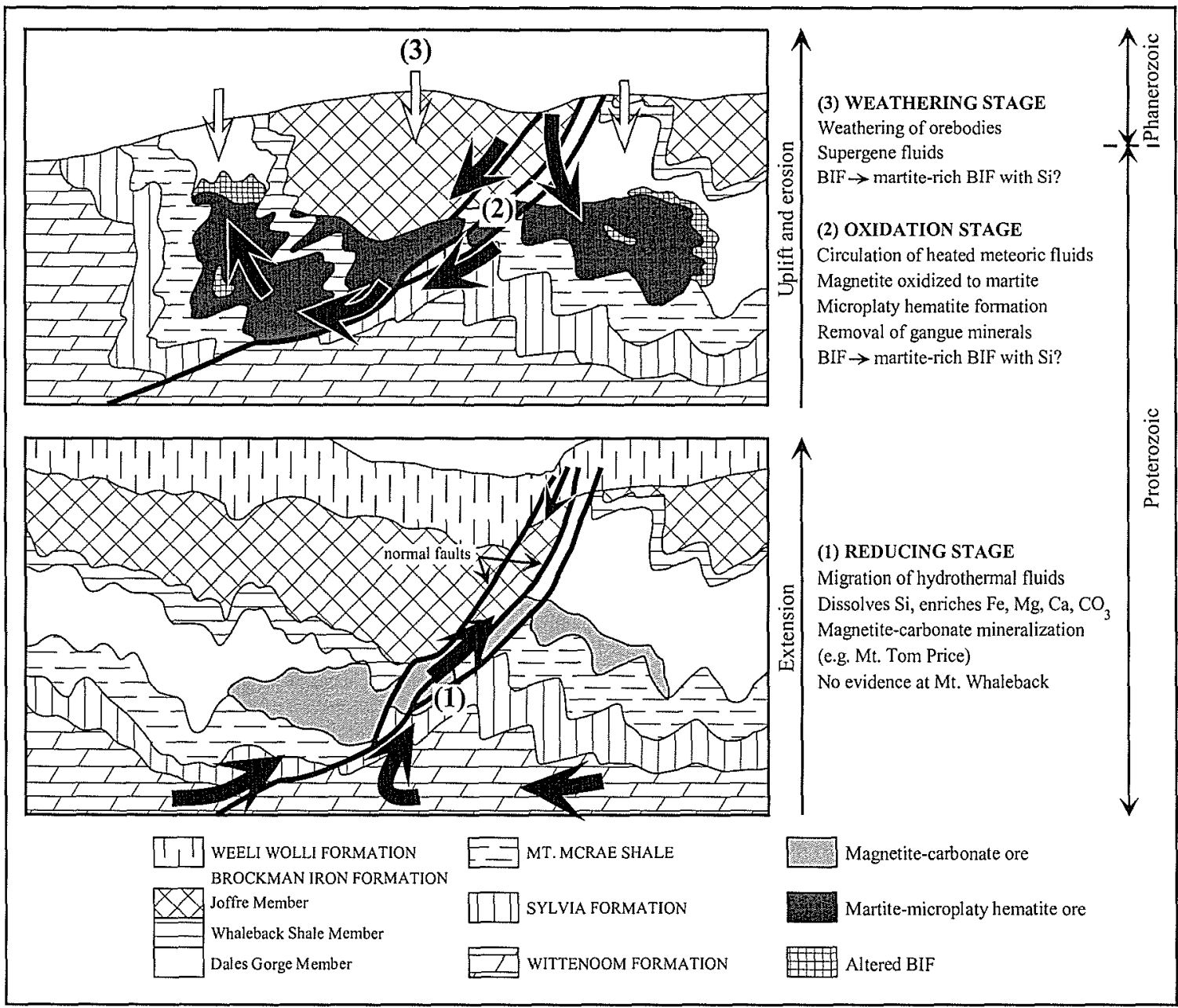

Figure 2.12. Schematic cross-sections showing the evolution of hematite ore at Mt. Whaleback (modified from Taylor et al., 2001). Note that altered BIF developed either from deep-seated oxidation of unaltered $\mathrm{BIF}$ (syn/post-mineralization) or from weathering sometime since the Proterozoic. Also note the total overprinting of magnetite-carbonate rich rocks (identified at Mt. Tom Price but not Mt. Whaleback) by high-grade hematite ore.

Paraburdoo. Hydrothermal fluids followed by heated meteoric fluids then locally affected rocks at all three deposits, forming carbonate-rich BIF. Substantial northward flow of acidic, oxygenated fluids sometime during or after carbonate replacement converted carbonate-rich BIF and surrounding unaltered BIF to altered high-grade hematite ore and martite-rich BIF across the south (i.e., at Mt. Whaleback and Paraburdoo). This step also converted altered black shales to red shales.

There are several tests of this model. First, BIF in the southern Hamersley Province away from Mt. Whaleback should be composed of martite and silica without carbonates as this proposed step involved large-scale lateral flow of oxidized fluids. Second, remnants of carbonate-rich rocks and veins should exist below the high-grade 
hematite ore at Mt. Whaleback. Third, high temperature fluids might have affected other rocks near Mt. Whaleback during or immediately after $\mathrm{D}_{2}$. Recent fluid inclusion work has shown that some quartz veins near Mt. Whaleback precipitated at high temperature during or immediately after $\mathrm{D}_{2}$ (Oliver and Dickens, 1999; Powell et al., 1999; Brown et al., in press). The first two expectations are assessed in the next two chapters.

\section{CONCLUSION}

Several models have been proposed to explain the origin of giant high-grade hematite ore deposits in the southern Hamersley Province. Most of these models invoke profound changes in chemistry and mineralogy, a view consistent with the dramatic variation in colour between equivalent rock units in undeformed areas of the north and deformed areas of the south. Chemical differences indeed occur between rocks in the north and south, and these changes reflect variations in the relative proportions of 13 dominant minerals. Assuming that original BIF and shale were similar in composition, relatively straightforward chemical reactions can explain the observed differences in chemistry and mineralogy. In conjunction with key field relationships, the reaction paths also indicate that some rocks have experienced at least five stages of alteration: (1) diagenesis, (2) low-grade regional metamorphism, (3) higher-grade regional metamorphism in the south, (4) pervasive oxidation, and (5) silica dissolution and highgrade hematite formation. Recently described carbonate-rich, silica-poor rocks at Mt. Tom Price (Barley et al., 1999; Taylor et al., 2001) suggest this alteration sequence is probably more complex. Nonetheless, three important conclusions stem from the work in this chapter: (1) no single process can produce all of the altered rocks at Mt. Whaleback, (2) oxidation of magnetite to martite can occur independently of silica removal or replacement, and (3) full mineralization, which involves oxidation postdates peak metamorphism and the formation of altered black shales. The "supergenemetamorphic" model for the formation of high-grade hematite ore deposits, which involves simultaneous oxidation of magnetite and removal of silica during surficial 
weathering, needs re-evaluation. An alternative model, which incorporates the above results, is presented in Chapter 6. 
CHAPTER 3

OXIDATION AND WEATHERING OF BANDED IRON-FORMATIUN ACROSS THE SOUTHEASTERN HAMERSLEY PROVINCE, WESTERN

AUSTRALIA 


\section{ABSTRACT}

High-grade hematite ores of the southern Hamersley Province, Western Australia, can be found in deformed sequences of the Dales Gorge Member where magnetite and chert in banded iron-formation (BIF) macrobands have been converted to martite and microplaty hematite. The origin of these ore deposits remains highly controversial, in part because the rocks and analyses used to support (or reject) various genetic models represent incomplete data sets. In particular, no study has systematically examined the composition and texture of weathered and unweathered BIF macrobands from deformed and mineralized regions, deformed and unmineralized regions, and undeformed and unmineralized regions, so the full range of processes affecting BIF remains unclear. The chemistry, mineralogy and petrography of BIF macrobands within the Dales Gorge Member at nine locations across the southeastern Hamersley Province are examined in this investigation. On the basis of this work, rocks within original BIF macrobands can be categorized into four groups. Unaltered BIF contains sub-equal portions of $\mathrm{SiO}_{2}$ and $\mathrm{Fe}_{2} \mathrm{O}_{3}$ and moderate amounts of $\mathrm{MgO}, \mathrm{CaO}$ and loss on ignition (LOI). This chemistry is largely controlled by variations in chert and magnetite, although siderite, stilpnomelane, ankerite, dolomite, minnesotaite, and riebeckite have minor influence. Weathered BIF has significantly higher $\mathrm{SiO}_{2}$, but lower $\mathrm{MgO}, \mathrm{CaO}$ and LOI and contains hematite instead of magnetite (martite) and goethite pseudomorphs of carbonates and silicates. Oxidized BIF predominantly consists of $\mathrm{SiO}_{2}$ and $\mathrm{Fe}_{2} \mathrm{O}_{3}$, although $\mathrm{Fe}_{2} \mathrm{O}_{3}$ is higher than unaltered BIF. These rocks contain martite and chert with microplaty-hematite laths nucleating off iron oxide layers or crystallizing within small voids left from the dissolution of gangue. In striking contrast to all BIF, iron ore is enriched in $\mathrm{Fe}_{2} \mathrm{O}_{3}$ and depleted in all other major elements particularly $\mathrm{SiO}_{2}$. These rocks are characterised by martite layers in a porous network of randomly orientated microplaty hematite laths. Chemical and mineralogical differences between unaltered BIF and altered equivalents can be explained by a series of relatively straightforward equations. These reactions suggest most altered rocks developed from the interaction of BIF with acidic, oxidizing fluids related to either weathering or mineralization. 
Importantly, the widely accepted supergene-metamorphic model for iron ore genesis cannot explain BIF in and around Mt. Whaleback as these rocks have been oxidized prior to silica loss. Regionally this sequence may be more complicated as rocks from Mt. Tom Price show an earlier stage involving carbonate replacement of silica prior to oxidation. Assuming this alteration is pre-ore, the most plausible explanation for differences between Mt. Whaleback and Mt. Tom Price is that some process has completely removed any evidence of reduced rocks at the former location. Similarities between oxidized BIF from Mt. Whaleback to equivalent sequences outside the deposit suggest substantial lateral flow of pervasive, acidic, oxygenated fluids across the region sometime during or after mineralization.

\section{INTRODUCTION}

In the northeast Hamersley Province, Western Australia (Fig. 3.1), Proterozoic banded-iron formation (BIF) primarily comprising mm- to cm-scale layers (mesobands) of magnetite and chert forms thick, laterally extensive, sub-horizontal sequences (Trendall and Blockley, 1968). To the south, where these sequences have been folded and faulted, some set of processes has converted the mesobands to oxidized iron minerals in numerous locations, producing a range of economic iron-ore deposits (Harmsworth et al., 1990). The BIF mesobands in many of the deposits now consist of martite (a hematite pseudomorph of magnetite) and goethite, which likely reflects the effects of supergene alteration (Morris, 1980, 1985; Harmsworth et al., 1990). By contrast, BIF mesobands in the most prominent ore bodies - Mt. Whaleback, Mt. Tom Price, and Paraburdoo - now consist of martite and microplaty hematite (a habit of finegrained, elongated plates). Although supergene emrichment followed by metamorphism remains a widely cited explanation for these "high-grade hematite ores" (Morris, 1980; 1985, 1998, 2002; Harmsworth et al., 1990; Kneeshaw et al., 2002), recent investigations (Martin et al., 1998; Barley et al., 1999; Oliver and Dickens, 1999; Powell et al., 1999; Taylor et al., 2001) have highlighted fundamental problems with this interpretation. On the basis of chemical and mineralogical analyses of rocks 

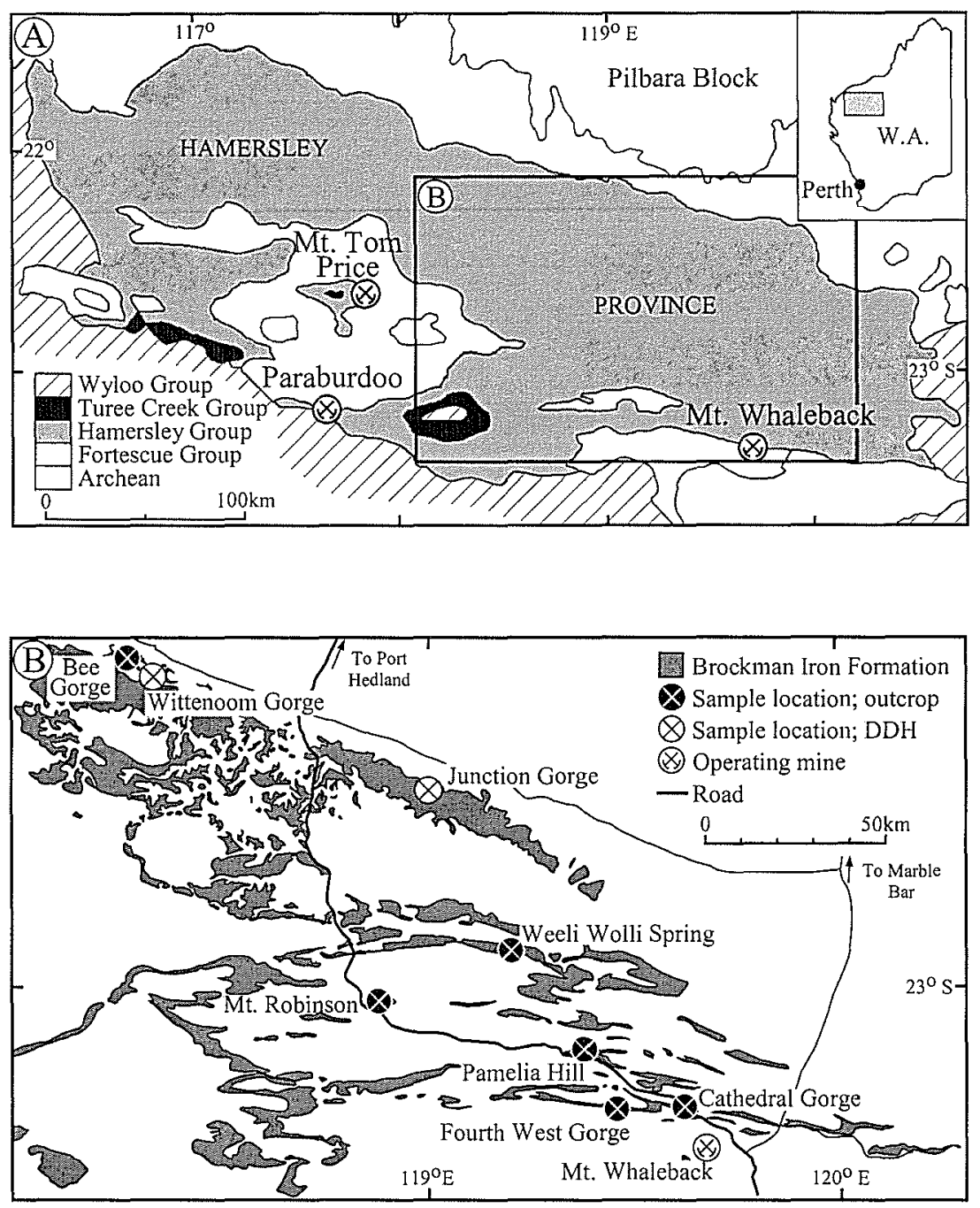

Figure 3.1. Location and simplified geology of the Hamersley Province. (a) Locations of major high-grade hematite ore deposits. Outlined area is enlarged in (b). (b) Outcrop of Brockman Iron Formation across the southeastern Hamersley Province (modified from Trendall and Blockley, 1970), showing sample locations and position of the Mt. Whaleback iron ore deposit. DDH $=$ Diamond Drill Hole.

surrounding the deposits, these authors have generally suggested an origin that involves, at least in part, upward egression of hot, reducing fluids.

Current efforts toward a coherent model for the formation of high-grade hematite ores in the Hamersley Province are stymied because, with available data and rock descriptions, mesobands of Dales Gorge Member BIF surrounding the two largest deposits have been altered differently. Around parts of the orebody at Mt. Tom Price, magnetite-chert BIF can be found along with a series of assemblages where one or both layers have been remineralized (Ewers and Morris, 1981; Barley et al., 1999; Taylor et al., 2001). These modified rocks include magnetite-siderite BIF, martite-ankerite BIF, 
and an unusual "jasperoidal BIF" composed of martite, microplaty hematite and chert. Several investigators have suggested that the first two of these rock assemblages reflect requisite steps for high-grade hematite ore formation (Barley et al., 1999; Taylor et al., 2001). However, despite intensive field and core sampling, all BIF documented at Mt. Whaleback to date (excluding ore) consists of martite and chert (Chapter 2), and it is unclear whether this "altered BIF" is the same rock as the jasperoidal BIF at Mt. Tom Price.

The apparently contrasting BIF assemblages surrounding the Mt. Tom Price and Mt. Whaleback deposits might be explained by differences in the lithological descriptions or processes unrelated to ore formation (e.g., weathering, basinal fluid reactions) that have affected rocks at one or both locations. When evaluating such explanations, a major problem is that very few papers have integrated rock composition and mineral texture, although both change during weathering, metamorphism and ore formation (e.g., Morris, 1985; Chapter 2). Moreover, despite numerous investigations of BIF from the Hamersley Province (e.g., the above references), almost all studies to date have examined rocks from undeformed sequences near Wittenoom or highly deformed sequences immediately adjacent to major ore deposits. This sampling necessarily precludes a good understanding of regional-scale processes that could affect BIF macrobands before or after ore formation. In this paper, the chemistry, mineralogy and petrography of stratigraphically equivalent BIF are examined at several locations (Fig. 3.1), including deformed sequences away from the high-grade hematite ore deposits. The purpose is to develop a systematic understanding of how and why the composition and texture of BIF can vary across the southeastern Hamersley Province.

\section{GEOLOGY OF THE DALES GORGE MEMBER}

The Hamersley Group consists of marine sedimentary and volcanic rocks deposited in the Late Archean (ca. 2.6 to $2.45 \mathrm{Ga}$ ) that currently cover $\sim 40,000 \mathrm{~km}^{2}$ of the southern Pilbara Craton, Western Australia (Figs. 3.1, 3.2). Rocks of this group are gently folded in the north but strongly deformed in the south due to multiple north-south 


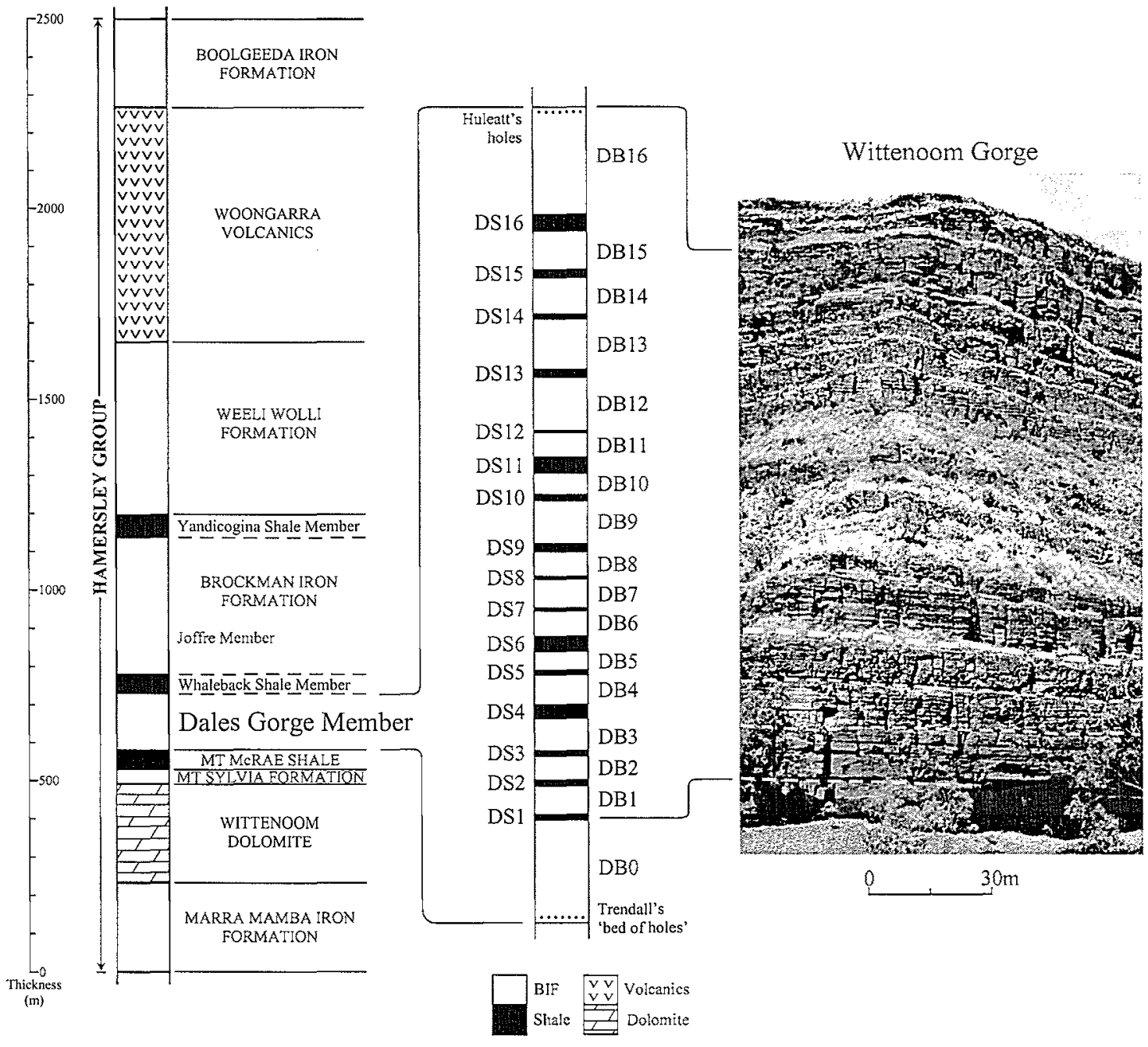

Figure 3.2. Stratigraphic column of the Hamersley Group, showing detailed stratigraphy of the Dales Gorge Member (modified from Harmsworth et al., 1990) and alternating BIF and shale macrobands (mscale) in outcrop at Wittenoom Gorge. Note how in outcrop shale layers (white dotted lines) are recessive and covered by vegetation and the middle, shale-dominated section of the Dales Gorge Member (DS6DS12) tends to form a single slope in which individual macrobands cannot be easily recognized. Also note that Huleates's holes and Trendall's bed of holes indicate the top and bottom of the Dales Gorge Member respectively. DB $=$ Dales Gorge Member BIF macroband; DS = Dales Gorge Member shale macroband.

collisions of the Yilgarn and Pilbara Cratons between 2.4 and 1.6 Ga (Tyler and Thorne, 1990; Martin et al., 1998; Powell et al., 1999; Brown et al., in press).

The Dales Gorge Member (Phbd) was deposited ca. $2470 \pm 4$ Ma (Trendall et al., 1990) and hosts most of the high-grade hematite ore at Mt. Whaleback and Mt. Tom Price, and a large fraction of this ore at Paraburdoo (e.g., Harmsworth et al., 1990). Throughout the province, this member consists of $17 \mathrm{BIF}$ (DB) and 16 shale (DS) metre-scale macrobands consecutively numbered from the base, with DB0 forming the 
bottom and DB16 forming the top (Trendall and Blockley, 1968) (Fig. 3.2). At the $\sim 145 \mathrm{~m}$ type-section near Wittenoom (Figs. 3.1, 3.2), the DB-macrobands characteristically comprise alternating mesobands of chert, iron oxides (predominantly magnetite), carbonates and silicates, whereas the intervening DS-macrobands typically comprise shale surrounded by chert and siderite (Trendall and Blockley, 1970; Chapter 2). The Mt. McRae Shale (Phr) and the Whaleback Shale Member (Phbw) underlie and overlie the Dales Gorge Member, respectively.

A remarkable aspect of the Dales Gorge Member is its lateral continuity (Trendall and Blockley, 1968, 1970; Morris, 1985). Given adequate exposure, individual macrobands can be correlated across the Hamersley Province, from relatively undeformed and unmineralized sequences in the north, to deformed sequences in the south, including those hosting major ore deposits (Trendall and Blockley, 1968, 1970; Ewers and Morris, 1981). Various authors (Trendall and Blockley, 1970; Morris, 1985) have suggested that even mesobands can be traced for many $\mathrm{km}$, a view supported below. Importantly, the ability to correlate over considerable distances enables the collection of stratigraphically equivalent samples from widely separated locations.

\section{STRATIGRAPHIC SECTIONS AND SAMPLES}

In Chapter 2, 53 samples of Dales Gorge Member BIF were collected from drill cores at Wittenoom Gorge and drill cores and mine faces at Mt. Whaleback. For this study, 85 additional samples of Dales Gorge Member BIF were chiseled from seven sections in the southeastern Hamersley Province that lie between Wittenoom Gorge and Mt. Whaleback (Table 3.1; Fig. 3.1; Appendix 1). These sections include diamond drill hole (DDH) JG1 at Junction Gorge (3 samples) and outcrops at Bee Gorge (6 samples), Weeli Wolli Spring (12 samples), Mt. Robinson (16 samples), Pamelia Hill (14 samples), Cathedral Gorge (17 samples) and Fourth West Gorge (17 samples) (Table 3.1; Fig. 3.1). The seven sections were chosen because they are widely separated, stratigraphically simple, and weathered and deformed differently. These new sections are briefly discussed here because they have not been documented in the literature. A 
Table 3.1. Sample locations across the Hamersley Province

\begin{tabular}{lccccclll}
\hline Site name & Easting $(\mathrm{m})$ & Northing $(\mathrm{m})$ & Map sheet* & 1 & 2 & Stratigraphy intersected/exposed & Deformation \\
\hline Junction Gorge & 706010 & 7502490 & Roy Hill SF50-12 & & X & DS1 to DS3 & gentle \\
Bee Gorge & 629980 & 7535390 & Mt. Bruce SF50-11 & X & & Wittenoom Dolomite to Whaleback Shale & gentle \\
Weeli Wolli Spring & 725720 & 7463780 & Roy Hill SF50-12 & X & & Mt. McRae Shale to Whaleback Shale & moderate \\
Mt. Robinson & 689660 & 7450760 & Newman SF50-16 & X & Upper Mt. McRae Shale to DB16 & moderate \\
Pamelia Hill & 746920 & 7436150 & Newman SF50-16 & X & Upper Mt. McRae Shale to DB17 & weak-moderate \\
Cathedral Gorge & 767990 & 7423890 & Newman SF50-16 & X & Mt. Sylvia Fm to Weeli Wolli Fm & moderate-strong \\
Fourth West Gorge & 757960 & 7422890 & Newman SF50-16 & X & Mt. McRae Shale to Whaleback Shale & moderate-strong \\
\hline
\end{tabular}

Notes: Eastings and northings relate to Zone 50 Australian Map Grid; * = 1:250 000 scale; 1 = surface exposure; 2 = diamond drill core; $D B=$ 
complete set of maps and cross-sections showing general geology and sample locations are given in Appendix 1.

Junction Gorge cuts gently folded rocks of the upper Dales Gorge Member in the northeastern part of the Hamersley Province (Trendall and Blockley, 1970). In general, creeks in the vicinity have incised to DB16. However, lower macrobands to DB12 are exposed in several east-west trending anticlines (Trendall and Blockley, 1970). In 1966, the Australian Blue Asbestos Pty. Ltd. cored DDH-JG1 at the Aspinall prospect (Trendall and Blockley, 1970). These cores, currently stored at the Geological Survey of Western Australia (GSWA) core repository in Perth, intersect the lowermost seven macrobands (Fig. 3.3). The three samples were $5-10 \mathrm{~cm}$ thick quarter-rounds from DB1, DB2 and DB3.

Bee Gorge incises the Dales Gorge Member $\sim 12 \mathrm{~km}$ west of Wittenoom (Fig. 3.1). The most pronounced structure in this area is the broad Garden Gorge Anticline (Trendall and Blockley, 1970), the southern limb bringing macrobands down to creek level at dips $10-15^{0} \mathrm{SW}$ (Fig. 3.4). Although the lower macrobands outcrop poorly, the upper macrobands (DS10-DB16) can be clearly identified in cliff exposures. The six samples were $10-15 \mathrm{~cm}$ thick from the centres of DB10-DB14 and DB16.

Weeli Wolli Spring bisects the northern limb of the Weeli Wolli Anticline $\sim 80 \mathrm{~km}$ northwest of Newman (Fig. 3.1). Most of the Dales Gorge Member outcrops at this location (Fig. 3.5a). Macrobands dip $45-55^{\circ} \mathrm{NE}$ in the upper part of the section, but are turned more horizontally by E-W trending folds in the lower the part of the section. The upper and lower BIF macrobands at Weeli Wolli Spring characteristically form clearly defined layers. However, the middle macrobands (DS6-DS10), which contain more shale, could not be sampled confidently. The 12 samples were $15-20 \mathrm{~cm}$ thick from the centres of DB0-DB6 and DB12-DB16.

Mt. Robinson protrudes above surrounding plains $\sim 100 \mathrm{~km}$ west-northwest of Newman (Fig. 3.1). From the campground along the Great Northern Highway, a prominent gorge transects this mountain, exposing the entire Dales Gorge Member (Fig. 3.5b, Appendix 1). Deformation is moderate and most stratigraphic units dip towards 


\section{DDH-JG1}

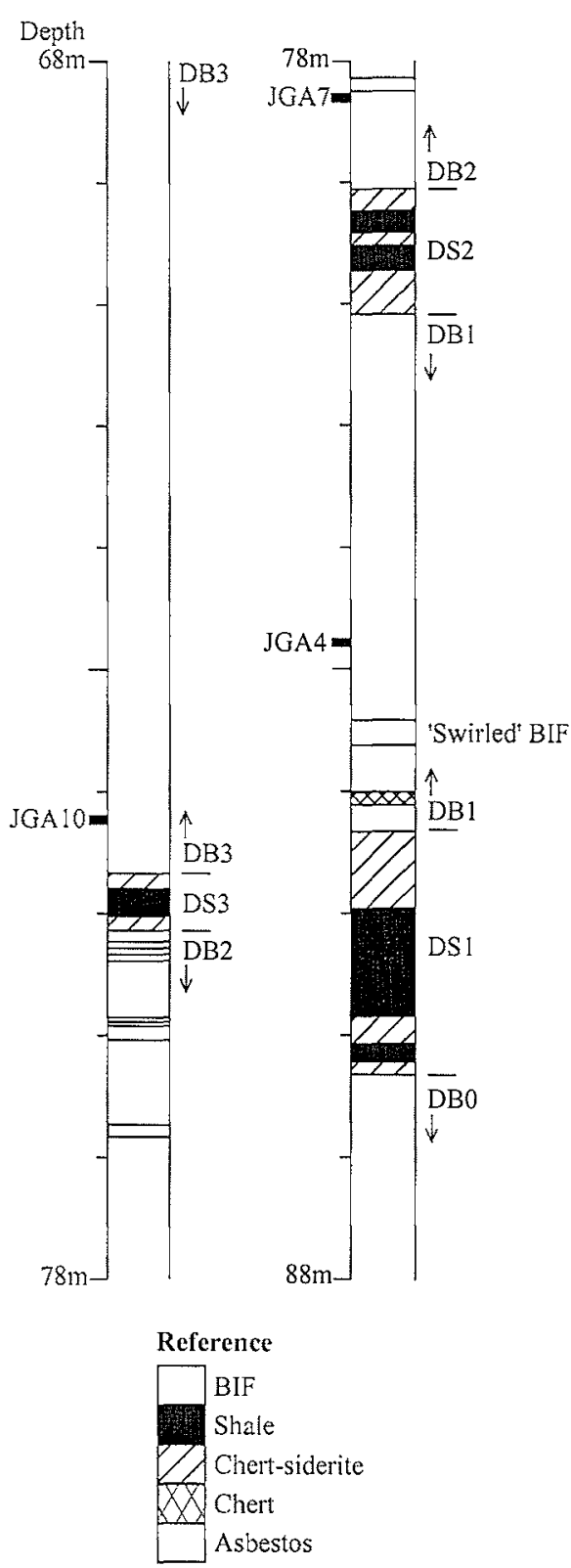

Figure 3.3. Detailed log of DDH-JG1. Note that shale macrobands are composed of both black shale and chert-siderite bands. Sample names and locations are on the left side of the columns. Phbd = Dales Gorge Member; $\mathrm{DB}=$ Dales Gorge Member BIF macroband; DS = Dales Gorge Member shale macroband. 


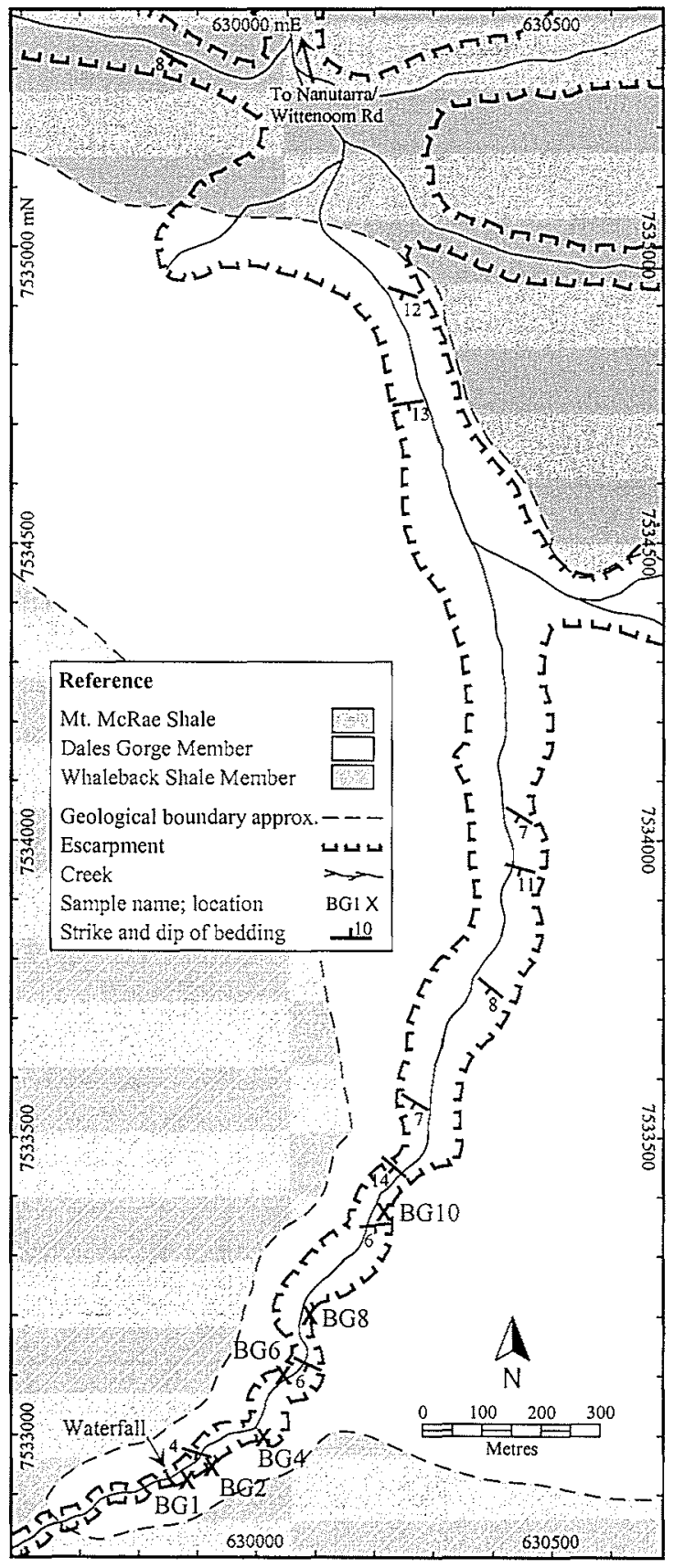

Figure 3.4. Geological map of the upper reaches of Bee Gorge showing sample locations (crosses). 

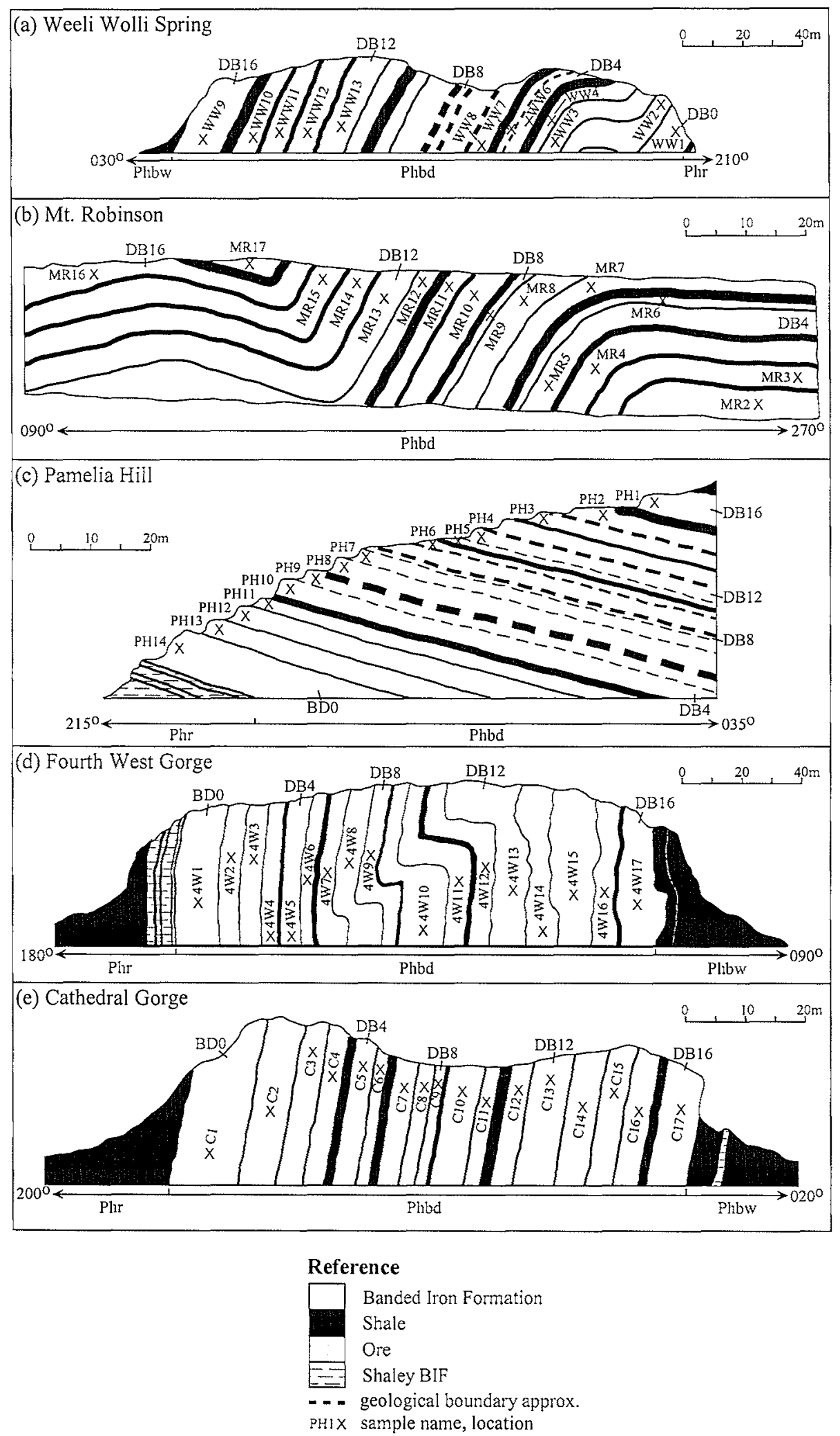

Figure 3.5. Schematic cross-sections of gorges from deformed regions across the southeastern Hamersley Province showing general geology and sample locations (crosses). (a) Weeli Wolli Spring; (b) Mt. Robinson; (c) Pamelia Hill; (d) Fourth West Gorge; (e) Cathedral Gorge. Phr = Mt. McRae Shale; Phbd = Dales Gorge Member; DB = Dales Gorge Member BIF macroband; Phbw = Whaleback Shale Member. 
the north, although at a wide range of angles. An E-W trending syncline also affects upper parts of the gorge. The 16 samples were $10-15 \mathrm{~cm}$ thick from the centres of DB0DB9 and DB11-DB16.

Pamelia Hill parallels the Great Northern Highway approximately halfway between Mt. Robinson and Newman (Fig. 3.1). Rocks of this hill form the southern limb of a broad NW-SE trending syncline and generally dip $20-40^{\circ}$ NE. Of the several south trending gorges that cut this ridge, one gorge towards the westem end exposes most of the Dales Gorge Member (Fig. 3.5c). Although middle units (DB8-DS9) are covered by scree, the remaining DB-macrobands can be clearly identified and sampled. The 14 samples were $15-20 \mathrm{~cm}$ thick from the centres of DB0-DB7, DB10-DB12 and DB14-DB16.

Fourth West Gorge bisects the northern limb of an overturned E-W trending anticline $\sim 25 \mathrm{~km}$ west-northwest of Newman (Fig. 3.1). The Dales Gorge Member in this area is sub-vertical with an E-W strike, although the middle macrobands (DB6DB12) have been refolded (Fig. 3.5d). All DB-macrobands are well exposed in prominent cliffs, although the DS-macrobands are extensively weathered. The 17 samples were $15-20 \mathrm{~cm}$ thick from the centres of each DB-macroband.

The Great Northern Highway passes through Cathedral Gorge $\sim 20 \mathrm{~km}$ northwest of Newman (Fig. 3.1). The gorge cuts through the southern, overturned limb of the Newman Syncline and, similar to Fourth West Gorge, exposes a sub-vertical section of the Dales Gorge Member that strikes approximately E-W (Fig. 3.5e). All DBmacrobands are prominent as they alternate with the relatively thin, highly weathered DS-macrobands. The 17 samples were $15-20 \mathrm{~cm}$ thick from the centres of each DBmacroband.

In a general sense, rocks from the new sections come from three different environments. Junction Gorge samples represents unweathered BIF from an undeformed region. Bee Gorge samples represent weathered BIF from an undeformed region. Samples from the remaining sections represent weathered BIF from deformed regions, where deformation varies from moderate (Pamelia Hill) to intense (Fourth 
West Gorge).

\section{ANALYTICAL METHODS}

\subsection{Bulk geochemistry and mineralogy}

Portions of all 85 BIF samples were crushed with a tungsten carbide-plated hydraulic press and powdered in a clean tungsten carbide bowl using a Rocklabs tema mill. Splits of these homogenized samples were then examined at the James Cook University Advanced Analytical Centre for major element chemistry by X-ray fluorescence (XRF) and bulk mineralogy by X-ray diffraction (XRD).

For XRF analyses, splits of all 85 samples were prepared and analysed according to procedures outlined in Chapter 2. For the entire suite of samples, the sum of major element oxides and loss on ignition (LOI) averaged $99.9 \%$ with a standard deviation of $0.42 \%$ (Table 3.2). As in Chapter 2, major element contents are reported as oxide weight percents and iron is reported as total $\mathrm{Fe}_{2} \mathrm{O}_{3}\left(\mathrm{Fe}_{2} \mathrm{O}_{3} \mathrm{~T}\right)$.

For XRD analyses, a $\sim 1.0 \mathrm{~g}$ split from 25 samples was prepared and analysed according to methods described in Chapter 2. Results are presented in table 3.3.

\subsection{Rock texture}

To assess textural variations in $\mathrm{BIF}$ across the region, 59 polished thin-sections were prepared from 50 rock samples using standard techniques (e.g., Adams et al., 1984, p.97-98). Thirty-two of these samples came from the seven stratigraphic sections described above: Junction Gorge (2 samples), Bee Gorge (4 samples), Weeli Wolli Spring (4 samples), Mt. Robinson (6 samples), Pamelia Hill (5 samples), Fourth West Gorge ( 3 samples) and Cathedral Gorge ( 8 samples). The other 18 rock samples came from DDH-47A at Wittenoom Gorge (8 samples) and two DDHs (4 samples) and three fresh mine faces (6 samples) within the Mt. Whaleback pit. These samples were examined previously for major element chemistry and bulk mineralogy in Chapter 2 but with minimal textural information.

Of the thin-sections, one set was made specifically to evaluate the lateral 
Table 3.2. Average major element oxide contents and standard deviations of Dales Gorge Member BIF across the Hamersley Province

\begin{tabular}{|c|c|c|c|c|c|c|c|c|c|c|c|c|c|c|}
\hline Rocks & n & $\mathrm{SiO}_{2}$ & $\mathrm{TiO}_{2}$ & $\mathrm{Al}_{2} \mathrm{O}_{3}$ & $\mathrm{Fe}_{2} \mathrm{O}_{3} \mathrm{~T}$ & $\mathrm{MnO}$ & $\mathrm{MgO}$ & $\mathrm{CaO}$ & $\mathrm{Na}_{2} \mathrm{O}$ & $\mathbf{K}_{2} \mathrm{O}$ & $\mathrm{P}_{2} \mathrm{O}_{5}$ & $\mathrm{SO}_{3}$ & LOI & SUM \\
\hline & & $\begin{array}{c}\text { avg sd } \\
(w+\%)\end{array}$ & $\begin{array}{c}\text { avg sd } \\
(\mathrm{w}+\%)\end{array}$ & $\begin{array}{l}\text { avg sd } \\
(\mathrm{wt} \%)\end{array}$ & $\begin{array}{c}\text { avg sd } \\
(\mathrm{wt} \%)\end{array}$ & $\begin{array}{c}\text { avg su } \\
(\mathrm{w}+\%)\end{array}$ & $\begin{array}{c}\text { avg sd } \\
(w 1 \%)\end{array}$ & $\begin{array}{c}\text { avg sd } \\
(w+\%)\end{array}$ & $\begin{array}{c}\text { avg sd } \\
(w t \%)\end{array}$ & $\begin{array}{c}\text { avg sd } \\
(\mathrm{wt} \%)\end{array}$ & $\begin{array}{c}\text { avg sd } \\
(\mathrm{w}+\%)\end{array}$ & $\begin{array}{l}\text { avg sd } \\
(\mathrm{wt} \%)\end{array}$ & $\begin{array}{c}\text { avg sd } \\
(w+\%)\end{array}$ & $\begin{array}{c}\text { avg sd } \\
(w \% \%)\end{array}$ \\
\hline
\end{tabular}

Northern Hamersley Province

Bif

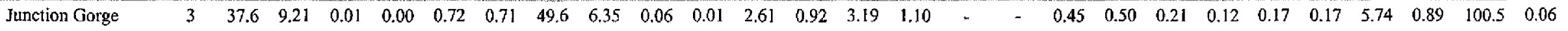
$\begin{array}{lllllllllllllllllllllllllllll}\text { Wittenoom* } & 19 & 39.2 & 9.91 & 0.04 & 0.12 & 0.25 & 0.36 & 48.5 & 8.46 & 0.10 & 0.13 & 2.63 & 0.85 & 1.91 & 1.75 & 0.04 & 0.12 & 0.31 & 0.36 & 0.22 & 0.17 & 0.07 & 0.14 & 6.99 & 5.93 & 100.2 & 0.40 & 0\end{array}$

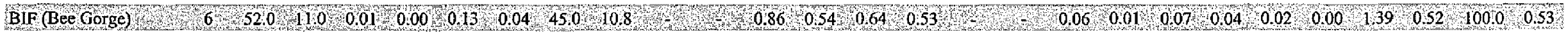
Southeastern Hamerslep Province

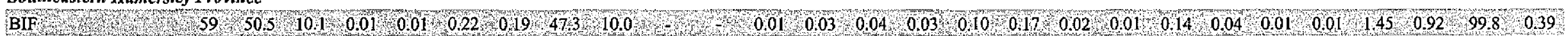
$\begin{array}{lllllllllllllllllllllllllllllllllll}\text { Wecli Wolli Spring } & 12 & 43.3 & 7.43 & 0.01 & 0.01 & 0.19 & 0.09 & 54.1 & 6.69 & - & - & 0.01 & 0.04 & 0.07 & 0.05 & 0.23 & 0.17 & 0.03 & 0.01 & 0.15 & 0.03 & 0.01 & 0.01 & 1.93 & 0.64 & 100.0 & 0.65\end{array}$ $\begin{array}{llllllllllllllllllllllllllllll}\text { Mt. Robinson } & 16 & 51.0 & 14.1 & 0.02 & 0.00 & 0.26 & 0.16 & 45.7 & 13.6 & - & - & 0.16 & - & 0.03 & 0.01 & 0.24 & 0.12 & 0.02 & 0.01 & 0.15 & 0.04 & 0.01 & 0.01 & 2.29 & 0.95 & 99.6 & 0.29\end{array}$ $\begin{array}{lllllllllllllllllllllllllllllllll}\text { Pamelia Hill } & 14 & 48.5 & 5.92 & 0.02 & 0.00 & 0.18 & 0.1 \text { I } & 49.6 & 6.15 & - & - & - & - & 0.02 & 0.01 & - & - & 0.01 & 0.00 & 0.16 & 0.05 & 0.01 & 0.00 & 1.38 & 0.50 & 99.9 & 0.17\end{array}$ $\begin{array}{lllllllllllllllllllllllllllllll}\text { Cathedral Gorge } & 17 & 54.3 & 8.55 & 0.02 & 0.00 & 0.32 & 0.28 & 43.4 & 8.91 & - & - & 0.12 & - & 0.04 & 0.02 & 0.21 & 0.08 & 0.02 & 0.02 & 0.15 & 0.03 & 0.02 & 0.03 & 1.53 & 0.56 & 99.9 & 0.34 & 0.03 & \end{array}$ $\begin{array}{llllllllllllllllllllllllllllllll}\text { Fourth West Gorge } & 17 & 52.9 & 9.30 & 0.01 & 0.01 & 0.15 & 0.15 & 46.1 & 9.28 & - & - & - & - & 0.04 & 0.02 & 0.10 & 0.24 & 0.02 & 0.02 & 0.11 & 0.01 & 0.01 & 0.01 & 0.32 & 0.14 & 99.8 & 0.40\end{array}$ Mi. Whaleback pit*

W BIF

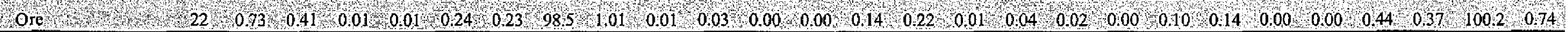
Notes: $\mathrm{n}=$ number of samples in the group; avg = average; $\mathrm{sd}=$ one standard deviation; ' - ' = below detection; $\mathrm{Fe}_{2} \mathrm{O}_{3} \mathrm{~T}=$ total iron. *Average major element oxice contents for samples from Wittenoom (DDH-47A) and Mt. Whaleback pit is from Chapter 2. 
Table 3.3. Semi-quantified mineralogy of BIF macrobands across the Hamersley Province.

\begin{tabular}{|c|c|c|c|c|c|c|c|c|c|c|c|c|c|}
\hline Sample & Unit & Location & $\begin{array}{l}\text { Qtz } \\
(\%)\end{array}$ & $\begin{array}{l}\text { Mag } \\
(\%)\end{array}$ & $\begin{array}{c}\text { Hem } \\
(\%)\end{array}$ & $\begin{array}{l}\text { Stp } \\
(\%)\end{array}$ & $\begin{array}{c}\text { Sd } \\
(\%)\end{array}$ & $\begin{array}{l}\text { Ank } \\
(\%)\end{array}$ & $\begin{array}{l}\text { Dol } \\
(\%)\end{array}$ & $\begin{array}{l}\text { Min } \\
(\%)\end{array}$ & $\begin{array}{l}\text { Rbk } \\
(\%)\end{array}$ & $\begin{array}{l}\text { Goet } \\
(\%)\end{array}$ & $\begin{array}{l}\text { Kln } \\
(\%)\end{array}$ \\
\hline \multicolumn{14}{|c|}{ Northern Hamersley Province } \\
\hline \multicolumn{14}{|c|}{ Banded Iron Formation } \\
\hline $4748 *$ & $\mathrm{DB} 16$ & Wittenoom & 35 & 17 & & & 38 & & & 10 & & & \\
\hline $477^{*}$ & DB14 & Wittenoom & 39 & 48 & & & 13 & & & & & & \\
\hline $4715^{*}$ & DB 11 & Wittenoom & 49 & 23 & & & 22 & & & 5 & & & \\
\hline $4719^{*}$ & DB10 & Wittenoom & 34 & 57 & & 3 & & & & 6 & & & \\
\hline $4722^{*}$ & DB8 & Wittenoom & 33 & 39 & & 7 & 7 & 8 & & 4 & & & \\
\hline $4735^{*}$ & DB3 & Wittenoom & 38 & 32 & & 4 & 19 & 7 & & & & & \\
\hline $4739 *$ & $\mathrm{DB} 1$ & Wittenoom & 28 & 40 & & 10 & 9 & 9 & & 5 & & & \\
\hline $4742^{*}$ & $\mathrm{DBO}$ & Wittenoom & 41 & 50 & & 4 & & 2 & & 3 & & & \\
\hline JGA 10 & DB3 & Junction Gorge & 21 & 49 & & 17 & 4 & 10 & & & & & \\
\hline JGA4 & DB1 & Iunction Gorge & 45 & 15 & 19 & 2 & 10 & 7 & & 3 & & & \\
\hline BG1 & $\mathrm{DB} 15$ & Bee Gorge & 56 & & 30 & & & & & & & 14 & \\
\hline $\mathrm{BG} 2$ & DB14 & Bee Gorge & 56 & 36 & & & & & & 5 & & 3 & \\
\hline BG4 & DB13 & Bee Gorge & 42 & 45 & & 3 & 2 & & 3 & 4 & 2 & & \\
\hline $\mathrm{BG} 10$ & DB10 & Bee Gorge & 33 & 21 & 36 & & & & & 3 & & 9 & \\
\hline \multicolumn{14}{|c|}{ Southeastern Hamersley Province } \\
\hline \multicolumn{14}{|c|}{ Banded Iron Formation } \\
\hline WWo & $\mathrm{DB} 16$ & Weeli Wolli & 43 & 0 & 50 & & & & & & & 7 & \\
\hline WW13 & DB12 & Weeli Wolli & 48 & 0 & 32 & & & & & & & 21 & \\
\hline WWG & $\mathrm{DB} 4$ & Weeli Wolli & 31 & 0 & 53 & & & & & & & 16 & \\
\hline WW3 & $\mathrm{DB} 2$ & Weeli Wolli & 42 & 0 & 39 & & & & & & & 19 & \\
\hline WW1 & DBO & Weeli Wolli & 51 & 0 & 29 & & & & & & & 21 & \\
\hline MRI7 & DBI6 & Mt. Robinson & 44 & 0 & 35 & & & & & & & 21 & \\
\hline MR13 & $\mathrm{DB} 12$ & Mt. Robinson & 43 & 0 & 31 & & & & & & & 26 & \\
\hline MR1 & DBO & Mt. Robinson & 67 & 0 & 19 & & & & & & & 15 & \\
\hline PHI & $\mathrm{DB} 16$ & Pamelia Hill & 43 & 11 & 32 & & & & & & & 15 & \\
\hline PH6 & $\mathrm{DB} 10$ & Pamelia Hill & 56 & 0 & 24 & & & & & & & 20 & \\
\hline $\mathrm{PH} 14$ & DBO & Pamelia Hill & 36 & 0 & 54 & & & & & & & 11 & \\
\hline $\mathrm{C} 17$ & $\mathrm{DB} 16$ & Cathedral Gorge & 51 & 0 & 35 & & & & & & & 14 & \\
\hline $\mathrm{CI} 1$ & DB10 & Cathedral Gorge & 56 & 0 & 19 & & & & & & & 25 & \\
\hline $\mathrm{Cl}$ & $\mathrm{DBO}$ & Cathedral Gorge & 56 & 0 & 37 & & & & & & & 8 & \\
\hline $4 W 10$ & DBS & Fourth West Gorge & 36 & 5 & 59 & & & & & & & & \\
\hline $4 W 7$ & DB6 & Fourth West Gorge & 50 & 3 & 47 & & & & & & & & \\
\hline $4 W 6$ & DB5 & Fourth West Gorge & 66 & 3 & 31 & & & & & & & & \\
\hline $4 W_{2}$ & DB 1 & Fourth West Gorge & 38 & 1 & 61 & & & & & & & & \\
\hline $4 W I$ & DBO & Fourth West Gorge & 59 & 0 & 41 & & & & & & & & \\
\hline \multicolumn{14}{|c|}{ Mt. Whaleback pit* } \\
\hline \multicolumn{14}{|c|}{ Bunded Iron Formation } \\
\hline D73A & DB16 & $\mathrm{DDH}-73$ & 60 & & 40 & & & & & & & & \\
\hline $\mathrm{D} 73 \mathrm{C}$ & DB16 & $\mathrm{DDH}-73$ & 39 & & 61 & & & & & & & & \\
\hline D73D & $\mathrm{DB} 16$ & DDH-73 & 41 & & 59 & & & & & & & & \\
\hline D866 & DB 16 & DDH-86 & 24 & & 65 & & & & & & & 11 & \\
\hline D860 & DB16 & DDH-86 & 48 & & 52 & & & & & & & & \\
\hline D86E & $\mathrm{DB} 16$ & DDH-86 & 40 & & 45 & & & & & & & 15 & \\
\hline D86F & DB 16 & $\mathrm{DDH}-86$ & 44 & & 45 & & & & & & & 11 & \\
\hline \multicolumn{14}{|c|}{ Iron Ore } \\
\hline $\mathrm{E} 24 \mathrm{C}$ & $\mathrm{DB} 16$ & Mine face & & & 100 & & & & & & & & \\
\hline $\mathrm{B} 25 \mathrm{E}$ & DB 11 & Mine face & & & 98 & & & & & & & & 2 \\
\hline 5BEDC & DB5 & Mine face & & & 99 & & & & & & & & 1 \\
\hline
\end{tabular}

Notes: $\mathrm{DB}=$ Dales Gorge Member BIF macroband; ank = ankerite; dol = dolomite; goet = goethite; hern = hematite; $\mathrm{kln}=$ kaolinite; mag = magnetite; $\min =$ minnesotaite; gtz = quartz; $\mathrm{rbk}=$ riebeckite; sd = siderite; stp $=$ stilpnomelane; *Samples and mineralogical data from Chapter 2 . 
continuity of mesobands and mineralogical changes in the same $\mathrm{cm}$-scale horizons across the province. The samples for this work were taken from the middle of DB16 in the nine sections that contained this stratigraphic interval. Correlation between samples was achieved by subjectively assessing the similarity of mesoband sequences (Fig. 3.6).
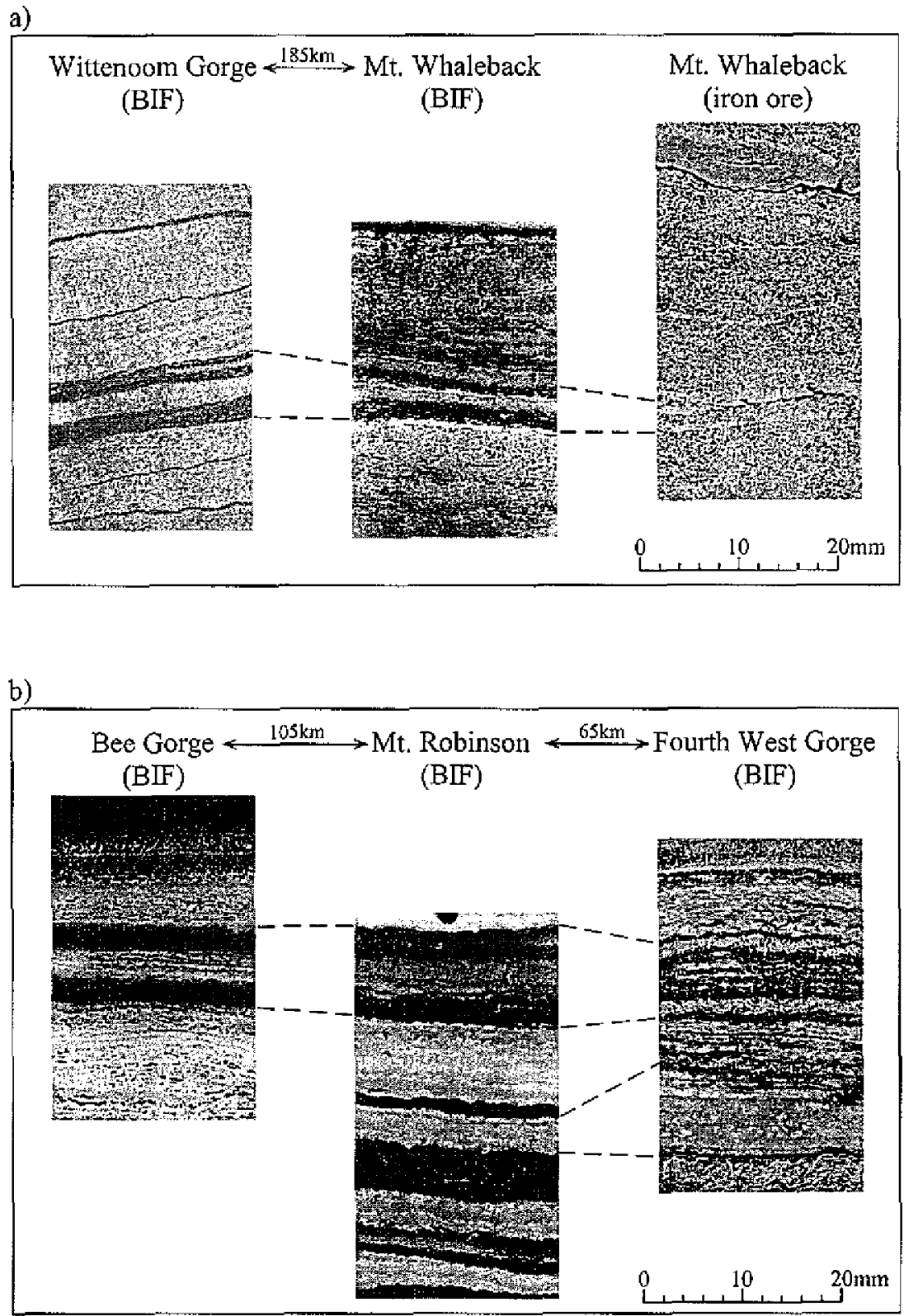

Figure 3.6. Comparison of chert and iron oxide mesobands in DB16 across the Hamersley Province. (a) Wittenoom Gorge (sample 473, DDH-47A, unweathered and undeformed) to Mt. Whaleback BIF and iron ore (samples A24C \& E24C, fresh mine faces, unweathered and strongly deformed). (b) Bee Gorge (sample BG1, outcrop, weathered and undeformed) to Mt. Robinson (sample MR17, outcrop, weathered and moderately deformed) to Fourth West Gorge (4W17, outcrop, altered and strongly deformed). Note that despite thickness changes and the various affects of alteration and deformation it is still possible to correlate BIF horizons (at the $\mathrm{cm}$ scale) between several sections across the southeastern Hamersley Province. 
All thin sections were examined using reflected and transmitted light microscopy. Photomicrographs of selected samples were taken using a Leica DMR photomicroscope. Some BIF samples contain carbonate (as determined by XRD and microscopy). Simple chemical etching and staining techniques were used to optically distinguish between possible carbonate minerals in these samples. The Alizarin Red S dye was used to differentiate calcite and dolomite, while potassium ferricyanide was used to differentiate ferroan and non-ferroan carbonates (Dickson, 1965). Staining solutions were prepared following the procedures of Adams et al. (1984, p.99).

\subsection{Mesoband thickness}

The composition and thickness of each mesoband was recorded for each hand specimen and prepared thin-section. Similar to Trendall and Blockley (1970), only mesobands $>1 \mathrm{~mm}$ across were recorded. The results were tabulated to get average volumetric abundances and thicknesses for each type of mesoband in Dales Gorge BIF (Table 3.4). Errors in thickness were minimized by consistently cutting all rocks perpendicular to layering. Nevertheless, these results are somewhat subjective, especially when one considers that the thickness of mesobands can change over short horizontal distances (Trendall and Blockley, 1970).

\section{RESULTS AND BASIC INTERPRETATIONS}

\subsection{General BIF variability across the southeastern Hamersley Province}

BIF of the Dales Gorge Member looks different across the southeastern Hamersley Province. Even in hand-specimens, BIF from various cores and gorges can be readily distinguished. This variability is easily appreciated by comparing thinsections of stratigraphically equivalent mesobands from different sections (Fig. 3.6).

In thin-sections and hand-specimens from cores from Wittenoom and Junction Gorges, chert- and iron oxide-rich mesobands are whitish-grey and grey, respectively. These mesobands commonly become light-brown and reddish brown in samples from outcrops, except at Fourth West Gorge, where they are whitish-grey and dark grey. In 
Table 3.4. Mesoband characteristics of Dales Gorge Member BIF across the Hamersley Province

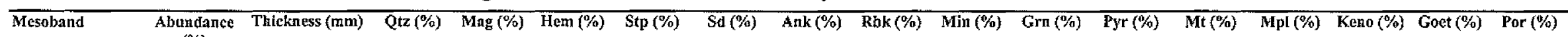
$\frac{(\%)}{\text { Northern Hamersley Province }}$

Cores (DDHJGI and DDH-47A*)

$\begin{array}{lllllllllllllllllll}\text { Chert } & 51 & 8.4 & 1-53 & 77 & 70-90 & 5 & 1-10 & 2 & 0-5 & 3 & 0-2 & 9 & 5-20 & 2 & 0-5 & 2 & 0-5 \\ \text { Chert-matrix } & 23 & 7.6 & 1-26 & 28 & 15-70 & 43 & 10-70 & <1 & 0-7 & 10 & 1-20 & 15 & 0-40 & 2 & 0-5 & 1 & 0-2 & 1\end{array}$

Chert-matrix

Magnetite

Stilpmomelans

Misc.

Hem

Min

Ank/sd

Outcrop (Bee Gorge)

Chert

Chert-matrix

Martite

Goethite

$\begin{array}{ll}23 & 7.6 \\ 12 & 3.8\end{array}$

Hematite

$\begin{array}{cccccccccccccccc}3-6 & 9 & 3.15 & 73 & 70-95 & 7 & 0-30 & 8 & 0-25 & 2 & 0-20 & 1 & 0-2 & <1 & 0-1\end{array}$

Outcrop (Weeli Woll Spring, Mt. Robinson, Pameilo Hill, Cathedral Gorge)

$\begin{array}{llllllllll}\text { Chert } & 59 & 6.9 & 1-19 & 83 & 70-95 & - & - & 4 & 0-15 \\ \text { Chert-matrix } & 19 & 10.9 & 6-17 & 55 & 30-70 & - & - & 15 & 5-60\end{array}$

$\begin{array}{lllllllllll}\text { Martite } & 14 & 3.5 & 1-6 & 10 & 5-40 & - & 8 & 5-30\end{array}$

Goethite

$\begin{array}{lllllllcc}6 & 5.4 & 1-12 & 11 & 5-35 & - & - & 1 & 0-5 \\ 2 & 8.5 & 1-36 & 10 & 0-15 & - & - & 70 & 60-80\end{array}$

Outcrop (Fourth West Gorge)

Chert

$\begin{array}{lllllll}1-3 & 15 & 10-45 & 10 & 0-20 & 70 & 45-85\end{array}$

$\begin{array}{cccccc}5 & 0-5 & 60 & 40-60 & 7 & 5-10 \\ 75 & 50-80 & 15 & 5-20 & 2 & 0-5\end{array}$

Chert-mat ix

Hematite

$\begin{array}{llllll}3 & 6.2 & 3-9 & 95 & 75-98 & - \\ 82 & 8.9 & 1-16 & 84 & 70-95 & -\end{array}$

Mt. Whate

Mt. Whaleback pit ${ }^{\star}$

Banded Iron Fomation

Chert

Chert-matrix

Martite

$\begin{array}{ccccccccc}9 & 9.3 & 2-20 & 78 & 70-85 & - & - & 2 & 1-5 \\ 78 & 10.8 & 1-30 & 56 & 30-65 & - & - & 15 & 5-55\end{array}$

Hematite

Massive hermatite

$\begin{array}{llll}6.4 & 1-15 & 5 & 0-12\end{array}$

Porous hematite

\begin{tabular}{lll}
12 & 3.2 & $2-11$ \\
88 & 4.6 & $2-16$ \\
\hline
\end{tabular}

$\begin{array}{lll}85 & 75-95 & -\end{array}$

Notes: avg = average; ank = ankerite; goet $=$ goethite; grn = greenalite; hem = primary hematite; keno = kenomagnetite, mag = magnetite; min = minnesotaite; mpl = microplaty hematite; mt = martite; por = 
altered BIF around Mt. Whaleback, the chert- and iron oxide-rich mesobands are dusky red and dark grey, respectively. All mesobands in iron ore from Mt. Whaleback are distinctly grey to dark grey.

\subsection{Cores from undeformed regions}

Similar to BIF from drill cores near Wittenoom Gorge (Chapter 2), bulk samples of BIF from DDH-JG1 at Junction Gorge contain sub-equal portions of $\mathrm{SiO}_{2}(38 \pm$ $9.2 \%)$ and $\mathrm{Fe}_{2} \mathrm{O}_{3} \mathrm{~T}(49 \pm 6.4 \%)$, and moderate amounts of $\mathrm{MgO}(2.6 \pm 0.9 \%), \mathrm{CaO}(3.2$ $\pm 1.1 \%$ ) and LOI $(5.7 \pm 0.9 \%$ ) (Table 3.2; Fig. 3.7). For cores at Wittenoom, this chemical composition reflects a specific mineralogy, which consists mostly of quartz and magnetite with subordinate quantities of hematite, stilpnomelane, siderite, ankerite and minnesotaite (Chapter 2). The same is true for BIF from DDH-JG1 (Table 3.3).

The minerals in BIF from cores at Wittenoom and Junction Gorges are generally distributed into mesobands of chert, chert-matrix, magnetite, carbonate and stilpnomelane (Table 3.4; Fig. 3.6). Chert mesobands are largely comprised of finegrained quartz (usually $>70 \%$ ) with subordinate amounts of magnetite, hematite, stilpnomelane, siderite, ankerite and riebeckite. They are generally the thickest (1-33 $\mathrm{mm}$ ) and most abundant mesoband type, typically occupying more than $50 \%$ of hand samples by volume. Chert-matrix mesobands refer to those mm-cm scale layers where sub-equal amounts of quartz and iron-bearing minerals are interspersed (Trendall and Blockley, 1970). In cores at Wittenoom and Junction Gorges, magnetite is the dominant iron-bearing mineral of these mesobands, although hematite occurs in lesser quantities. Stilpnomelane, siderite, ankerite, riebeckite, minnesotaite and greenalite were also identified in one or more layers. Although usually slightly thinner than chert mesobands (1-26 mm), chert-matrix mesobands are the second most abundant, so they often form about 20 to $30 \%$ of the rock by volume. Magnetite mesobands mostly contain magnetite (usually $>70 \%$ ) with small $(0-10 \%)$ amounts of chert, hematite, siderite, ankerite, stilpnomelane and riebeckite. They are the thimnest mesoband type (3-6 mm), usually comprising 10 to $15 \%$ of hand samples by volume. Relatively rare 

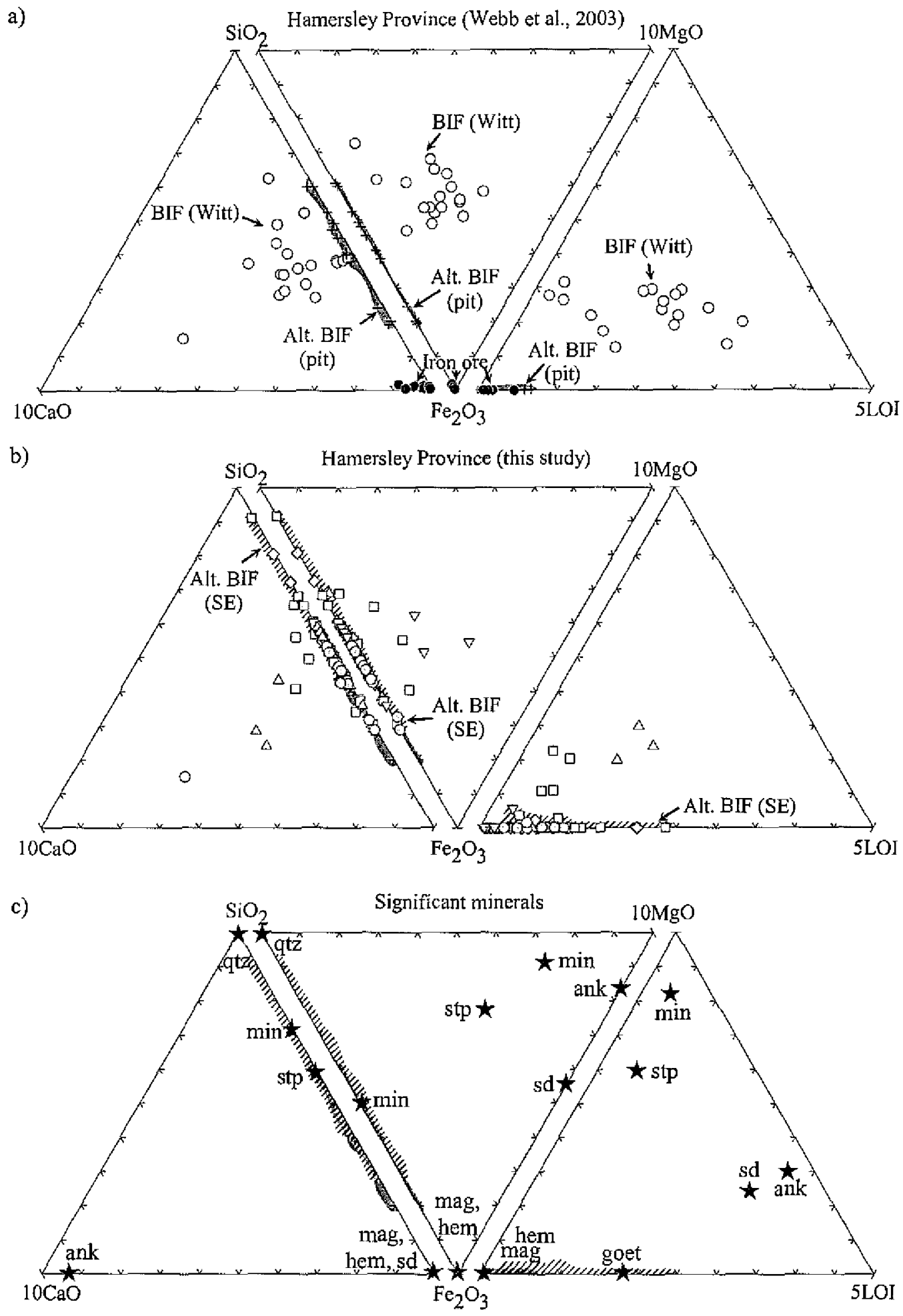

$\begin{array}{ll}\text { Undeformed, utaltered BIF } & \\ \text { O Wittenoom Gorge } & \square \text { Mt. Robinson } \\ \triangle \text { Junction Gorge } & \triangle \text { Pamelia Hil! } \\ \text { Undeformed, altered BIF } & \triangle \text { Cathedral Gorge } \\ \square \text { Bee Gorge } & \nabla \text { Fourth West Gorge } \\ \text { Deformed, altered BIF } & +M \mathrm{Mt} \text {. Whaleback BIF } \\ \bigcirc \text { Weeli Woili Spring } & \text { Mt. Whaieback iron ore }\end{array}$

Figure 3.7. Ternary diagrams showing the distribution of $\mathrm{SiO}_{2}, \mathrm{Fe}_{2} \mathrm{O}_{3} \mathrm{~T}, \mathrm{MgO}, \mathrm{CaO}$ and $\mathrm{LOI}$ for $\mathrm{BIF}$ samples collected across the Hamersley Province. (a) Wittenoom Gorge (DDH-47A) and Mt. Whaleback samples (Chapter 2). (b) Gorges across the southeastern Hamersley Province (this study). (c) The relationship of significant mineral phases to the bulk chemical analyses. Alt. $=$ altered; $\mathrm{SE}=$ southeastern Hamersley Province; Witt $=$ Wittenoom Gorge $(\mathrm{DDH}-47 \mathrm{~A})$; ank = ankerite; goet = goethite; hem = hematite; mag = magnetite; qtz = quartz; $\mathrm{sd}=$ siderite; stp = stilpnomelane. 
siderite and stilpnomelane mesobands are mostly comprised of their respective minerals, with relatively minor amounts of chert, magnetite, ankerite and silicates. On average these mesobands have similar thicknesses (1-15 mm).

Quartz is the dominant mineral in unaltered BIF from Wittenoom and Junction Gorges. It commonly occurs as a mosaic of roughly spherical, often interlocking grains, which are referred to as "incipient chert" because it not a primary mineral (Grubb, 1971; Ayres, 1972; Ewers, 1983; Morris, 1993) but can be found in even the most unaltered BIF samples (French, 1973; Ewers and Morris, 1981). The grains range from 1-80 $\mu \mathrm{m}$ in diameter, but typically average about $10-20 \mu \mathrm{m}$ (Fig. 3.8a). In chert and chert-matrix mesobands, incipient chert aggregates concentrate into chert-rich microbands (mm-scale layers). However, in other mesobands, incipient chert grains are randomly dispersed throughout the matrix (Fig. 3.8b). Coarser-grained quartz (up to $0.5 \mathrm{~mm}$ in length) is also present in pressure shadows adjacent to iron-oxide microbands (Fig. 3.8c) and within thin layer-parallel or crosscutting veins.

Magnetite is the dominant iron oxide in unaltered BIF and generally occurs as octahedral-shaped crystals ranging from 10-500 $\mu \mathrm{m}$ across (Fig. 3.9a). In chert, chertmatrix and magnetite mesobands, it characteristically occurs as subhedral to euhedral shaped aggregates in well-defined microbands and mesobands (Fig. 3.10a). By contrast, in siderite and stilpnomelane mesobands, it is dispersed as individual grains or small aggregates in discontinuous layers (Fig. 3.8d). Magnetite can be found in association with all phases and commonly crosscuts or overgrows hematite (Fig. 3.9a), siderite and stilpnomelane.

Hematite in unaltered BIF varies from anhecral grains and aggregates to euhedral plates and laths. The anhedral crystals range from 1-15 $\mu \mathrm{m}$ across and randomly occur throughout chert and chert-matrix mesobands (Fig. 3.8e). Coarser-grained, interlocking crystals of 20-150 $\mu \mathrm{m}$ across can also form mesobands, which may alternate with magnetite layers of similar thickness. The hematite plates and laths range from 5-100 $\mu \mathrm{m}$ in length, and usually occur in chert mesobands as thin layers of randomly orientated laths (Fig. 3.8f). These cigar-shaped laths are similar to secondary 

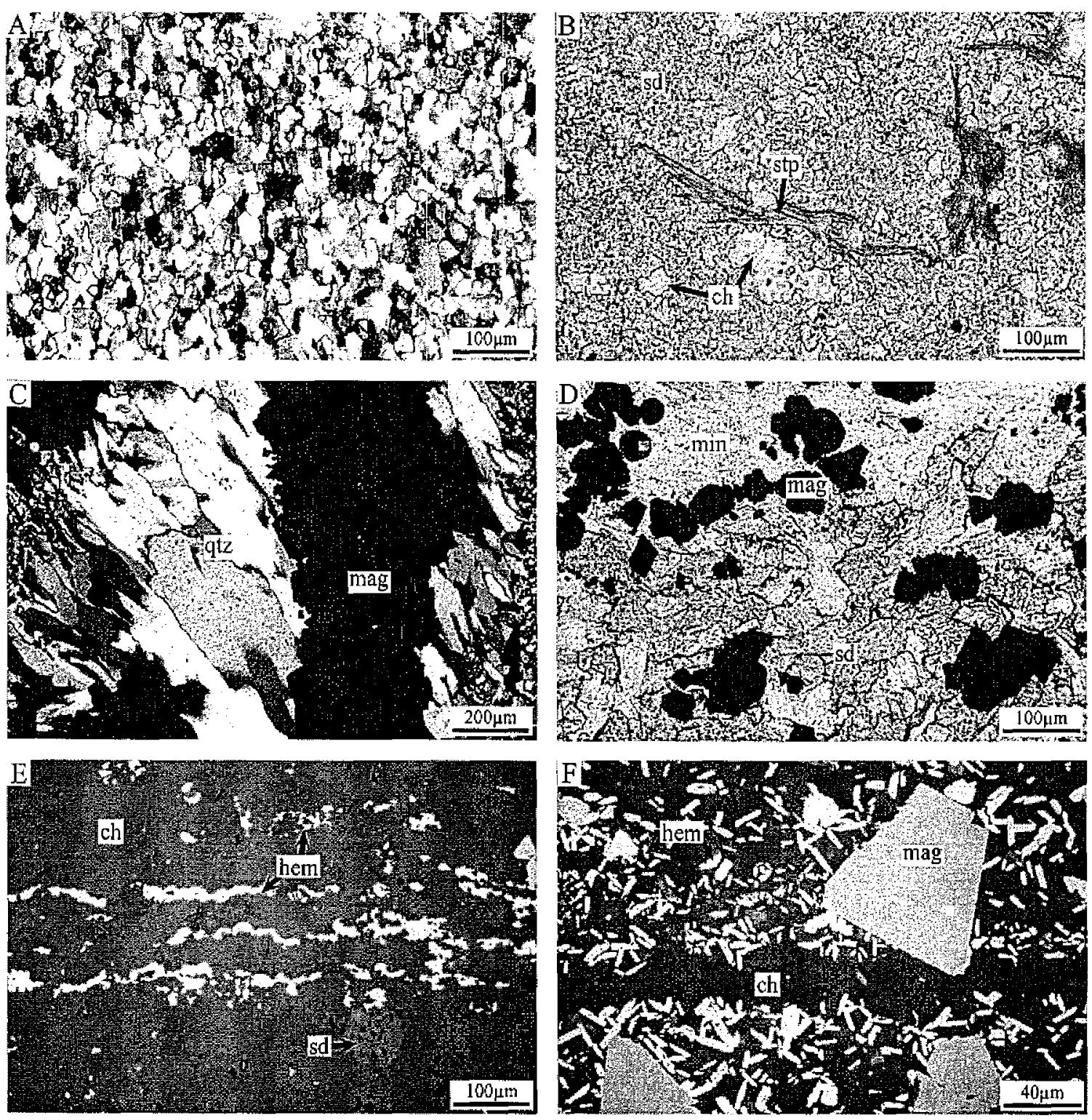

Figure 3.8. Photomicrographs of various minerals in unaltered BIF from the northern Hamersley Province. (a) Fine-grained mosaic chert (sample 473, Wittenoom Gorge). Crossed polarized light. (b) Scattered chert (ch) grains in siderite (sd) mesoband. Note aggregate of stilpnomelane (stp) laths (sample 4722, Wittenoom Gorge). Plane polarized light. (c) Coarse-grained quartz (qtz) adjacent magnetite (mag) microband in chert-matrix mesoband (sample 4742, Wittenoom Gorge). Crossed polarized light. (d) Scattered magnetite (mag) euhedra in siderite (sd) and minnesotaite (min) mesoband (sample 4722 , Wittenoom Gorge). Plane polarized light. (e) Small anhedral hematite grains and aggregates (hem) in chert (ch) mesoband (sample JGA10, Junction Gorge). Reflected polarized light. (f) Microbands of randomly orientated fine-grained hematite laths (hem) in chert (ch) mesoband (sample 4737, Wittenoom Gorge). Note magnetite euhedra (mag) overgrowing individual crystals. Plane polarized light. 

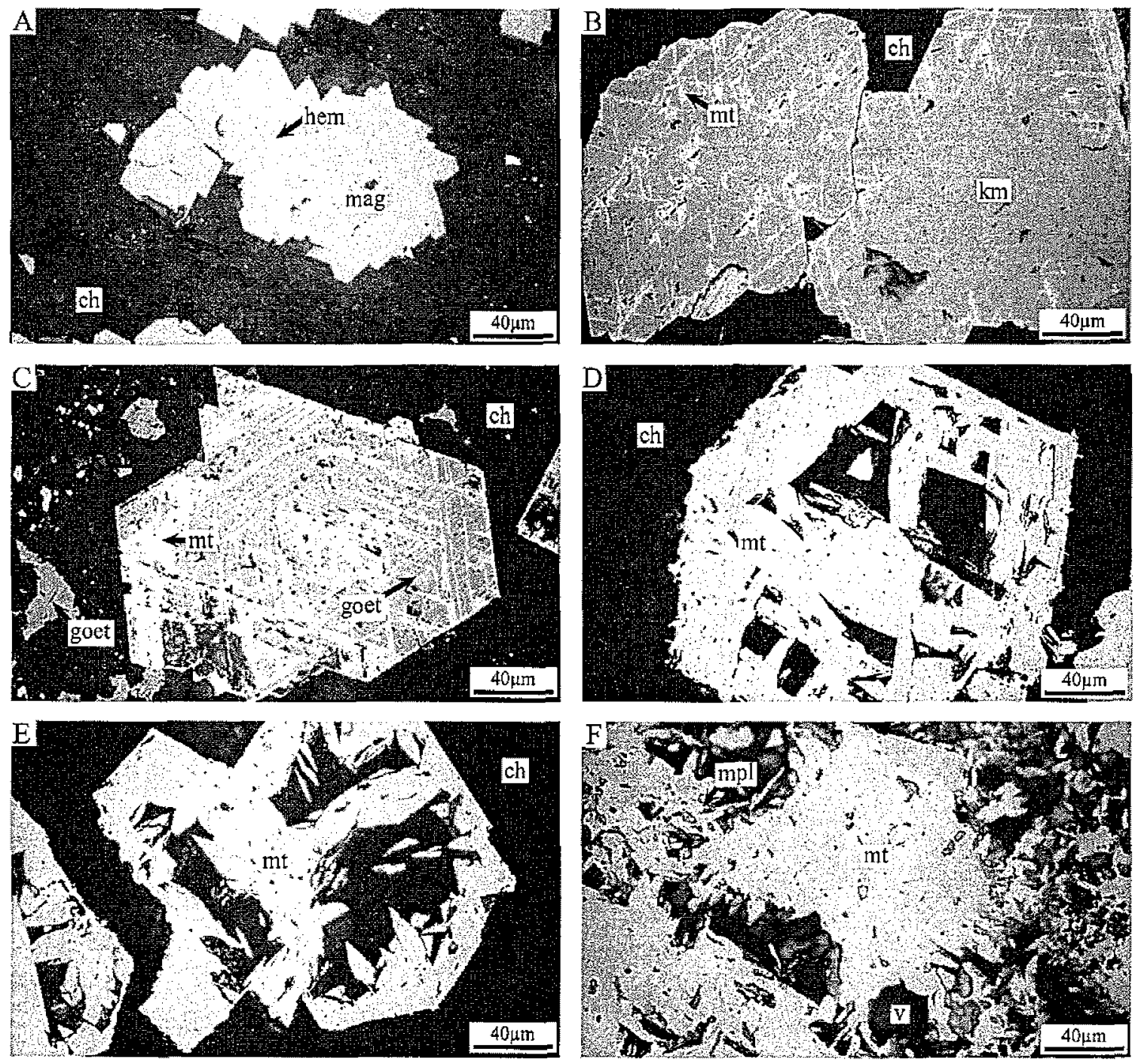

Figure 3.9. Photomicrographs of magnetite and its various altered forms in stratigraphically equivalent BIF samples across the Hamersley Province. Reflected polarized light. (a) Magnetite (mag) euhedra in unaltered BIF from Wittenoom Gorge (sample 473), the original texture of figures b-f. Note the small hematite (hem) inclusion. (b) Kenomagnetite $(\mathrm{km})$ and martite lamella (mt) replacing magnetite in weathered BIF from Bee Gorge (sample BGl). (c) Martite (mt) and goethite (goet) replacement of magnetite in weathered BIF from Mt. Robinson (sample MR17). (d) Coarse skeletal martite in oxidized BIF from Fourth West Gorge (sample 4W17). Note lack of kenomagnetite and goethite. (e) Skeletal martite grain in oxidized BIF from Mt. Whaleback (sample A24C). Note how it is basically made up of relatively coarse hematite plates (see subtle colour changes). (f) Subhedral martite grain in high-grade hematite ore from Mt. Whaleback (sample E24C). Note microplaty hematite laths (mpl) nucleating from the margins of martite (mt) grains. $v=$ voids. 

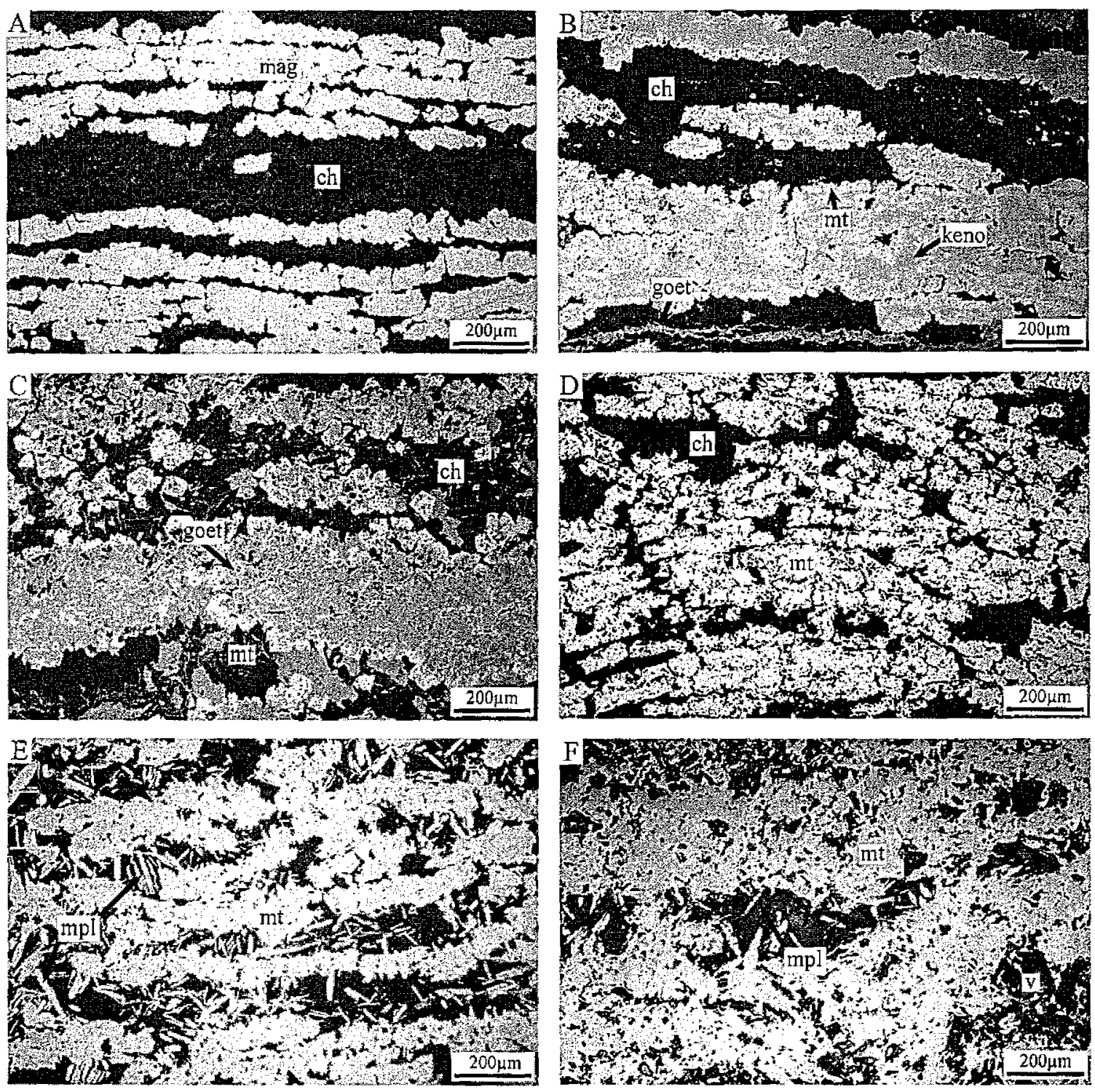

Figure 3.10. Photomicrographs of stratigraphically equivalent chert mesobands across the Hamersley Province. Reflected polarized light. (a) Unaltered, undeformed BIF (sample 473, Wittenoom Gorge). (b) Weathered, undeformed BIF (sample BG1, Bee Gorge). (c) Weathered, moderate deformed BIF (sample MR17, Mt. Robinson). (d) Oxidized, strongly deformed BIF (sample 4W17, Fourth West Gorge). (e) Oxidized, strongly deformed BIF (sample A24C, Mt. Whaleback). (f) Mt. Whaleback iron ore (sample E24C). Note: the massive appearance of magnetite (mag) in unaltered BIF from Wittenoom Gorge; martite (mt), kenomagnetite (keno) and goethite pseudomorphing magnetite microbands in weathered BIF from Bee Gorge and Mt. Robinson; the absence of kenomagnetite and goethite in BIF from Fourth West Gorge and Mt. Whaleback; the overgrowth of martite $(\mathrm{mt})$ grains by microplaty hematite laths $(\mathrm{mpl})$ in rocks from Mt. Whaleback; an increase in the relative abundance of iron oxide minerals in rocks from Fourth West Gorge and Mt. Whaleback. 
microplaty hematite found in altered BIF and ore (see below). However, they are sometimes cut by euhedral magnetite suggesting they developed relatively early.

Siderite is the most abundant carbonate mineral in BIF samples from Wittenoom and Junction Gorges. It characteristically occurs as $20-60 \mu \mathrm{m}$ diameter subhedral to euhedral crystals within chert, chert-matrix and carbonate mesobands (Fig. 3.11a). Individual grains are commonly disseminated throughout these layers, although some may form aggregates. In carbonate mesobands, fine-grained siderite typically develops an interlocking mosaic of roughly equidimensional grains (Fig. 3.8d). Coarser-grained varieties of siderite are also relatively common and range from anhedral to subhedral grains and aggregates in chert, chert-matrix, carbonate and minnesotaite mesobands, to euhedral grains in stilpnomelane layers (Fig. 3.11b) and fibrous quartz veins. Although siderite is associated with most minerals, it usually occurs with quartz and stilpnomelane (Figs. 3.11a, b, c).

Ankerite in unaltered BIF typically occurs as coarse euhedral thombs or tabular plates. Individual crystals are normally disseminated throughout chert, chert-matrix, magnetite and stilpnomelane mesobands, although mosaics of interlocking crystals develop in carbonate-rich layers. Less common varieties of ankerite include hollow quartz-filled rhombs (Fig. 3.11d), coarse-grained subhedral rhombs and elongated anhedral laths $(\sim 500-600 \mu \mathrm{m}$ in length) that appear to replace stilpnomelane (Fig. $3.11 b)$.

Stilpnomelane is the most dominant silicate mineral in unaltered BIF, and occurs as fine-grained fibrous or micaceous crystals $5-30 \mu \mathrm{m}$ in length. It is distinctly pleochroic and ranges in colour from pale green-brown (ferrostilpnomelane) to yellowbrown (ferristilpnomelane) (Trendall and Blockley, 1970; Grubb, 1971; Miyano, 1982). Typically, stilpnomelane crystals form massive sheaflike aggregates or interlocking lath networks where individual grain boundaries are barely discernible (Fig. 3.11e). However, small-radiating structures can also be found in chert and chert-matrix mesobands. Stilpnomelane is usually associated with chert, siderite and magnetite and is sometimes replaced by coarse-grained subhedral to euhedral siderite and ankerite 

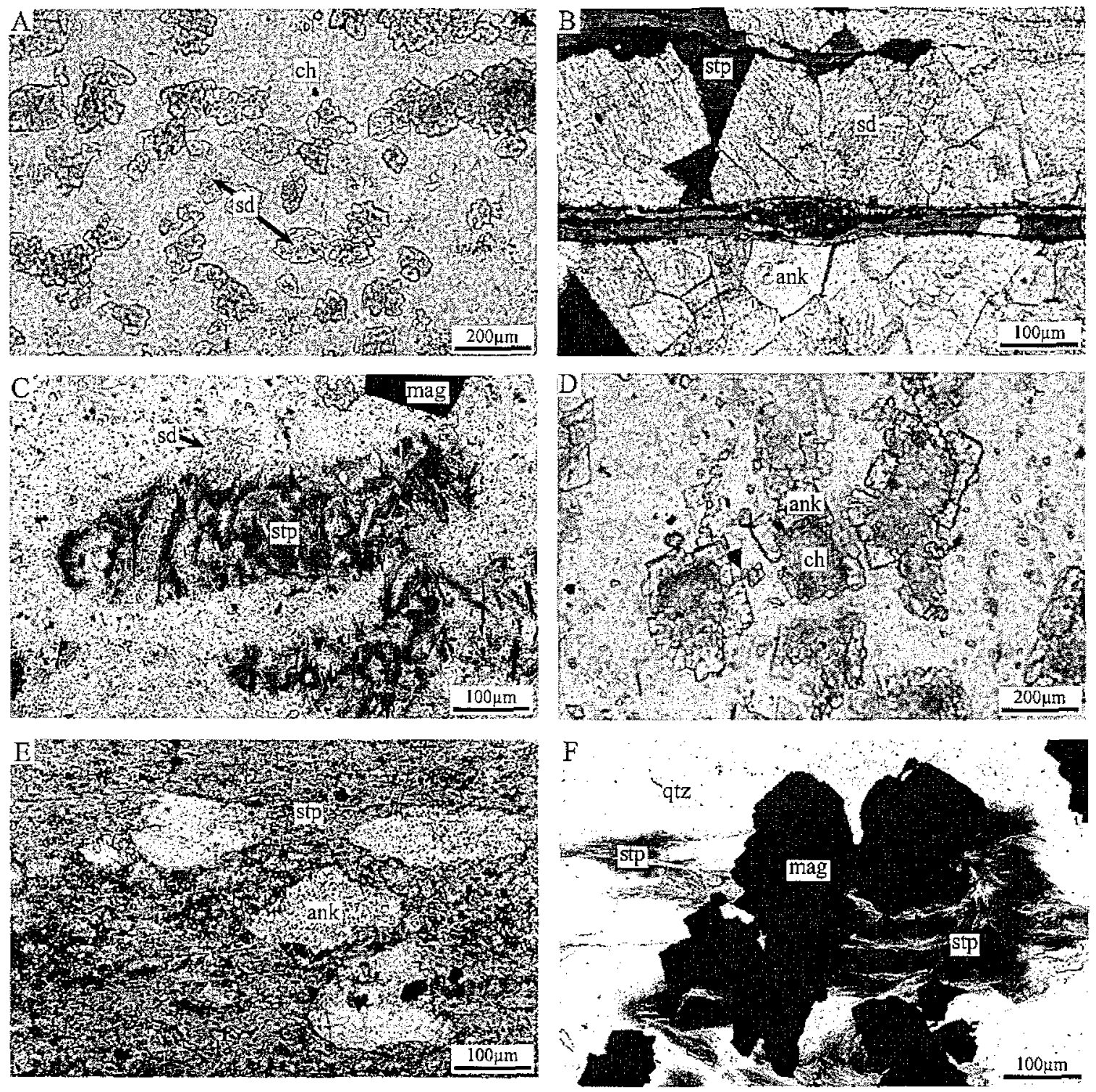

Figure 3.11. Photomicrographs of representative gangue minerals in unaltered BIF. (a) Fine-grained siderite disseminated in chert-natrix mesoband (sample 4715, Wittenoom Gorge). Plane polarized light. (b) Coarse-grained subhedral to euhedral siderite (sd) and ankerite (ank) crosscutting and possibly replacing fine-grained stilpnomelane (stp) (sample 479, Wittenoom Gorge). Plane polarized light. (c) Stilpnomelane (stp) replacing fine-grained siderite (sd) in chert mesoband (sample JGA7, Junction Gorge). Plane polarized light. (d) Hollow, coarse-grained ankerite (ank) rhombs (sample 4742, Wittenoom Gorge). Note centres of chert (ch). Plane polarized light. (e) Fine-grained stilpnomelane (stp) mesoband being partially replaced by coarse-grained subhedral siderite (sd) and ankerite (ank) (sample 479, Wittenoom Gorge). Plane polarized light. (f) Thin lamellae aggregates of stilpnomelane (stp) associated with reciystallized quartz (qtz) in pressure shadows adjacent to iron-oxide layers (sample JGA4, Junction Gorge). Plane polarized light. 
(Figs, $3.1 \mathrm{lb}, \mathrm{e})$. Large $(<250 \mu \mathrm{m}$ in length), lathlike aggregates of stilpnomelane were also found with coarse-grained quartz in pressure shadows surrounding iron oxide layers and within carbonate mesobands (Figs. 3.8b, 3.11f).

Riebeckite, greenalite, and minnesotaite can also be found in BIF. These relatively uncommon silicate minerals are not discussed here, although some representative examples are documented in Appendix 4.

\subsection{Outcrop at undeformed regions}

Similar to cores from Wittenoom and Junction Gorges, bulk samples of BIF from outcrops at Bee Gorge consist mostly of $\mathrm{SiO}_{2}(52 \pm 11 \%)$ and $\mathrm{Fe}_{2} \mathrm{O}_{3} \mathrm{~T}(45 \pm 11 \%)$ (Table 3.2; Fig. 3.7). However, in contrast to the cores, all other major element oxides and LOI are $<1 \%$. This somewhat different composition reflects the mineralogy, which consists mostly of quartz, kenomagnetite, martite and goethite with only minor amounts of minnesotaite, siderite, dolomite and riebeckite (Table 3.3). Kenomagnetite is a metastable lacunar spinel phase between magnetite and maghemite, and can be identified in BIF by its distinctive pinkish-grey to brown zonal nature (Morris, 1985).

Minerals at Bee Gorge are generally distributed into mesobands of chert, chertmatrix, martite and goethite (Table 3.4). Chert and chert-matrix mesobands are very similar to those in unaltered BIF from cores at Wittenoom and Junction Gorges, except they contain goethite, martite and kenomagnetite. Stilpnomelane, siderite, riebeckite and minnesotaite were identified in these mesobands at Bee Gorge, although they seem to be less abundant than from cores at Wittenoom and Junction Gorges. Interestingly, although the chert mesobands have similar thicknesses at Wittenoom, Junction and Bee Gorges, the chert matrix mesobands appear to be slightly thicker at Bee Gorge (4-34 $\mathrm{mm}$ ). Martite mesobands predominantly consist of martite and kenomagnetite, although goethite, quartz and primary hematite can be significant. They are relatively thin (1-6 $\mathrm{mm}$ ) and make up less than $10 \%$ of hand specimens by volume. Goethite mesobands consist almost entirely of goethite with accessory martite, quartz, primary hematite and kenomagnetite. Their distribution and thickness (I-8 mm) are similar to those of 
carbonate and stilpnomelane mesobands in unaltered BIF.

Quartz in BIF from Bee Gorge has the same texture as incipient chert from equivalent, unaltered sequences at Wittenoom and Junction Gorges (Fig. 3.12a). However, the magnetite grains are typically pseudomorphed by mixtures of martite and kenomagnetite (Fig. 3.9b). Martite is best recognised as an angular network of crisscrossing light-grey hematite lamellae. Despite this alteration, altered magnetite equivalents can be found as subhedral to euhedral shaped grains in well-defined and discontinuous microbands (Fig. 3.10b).

In striking contrast to unaltered BIF, carbonates and silicates in BIF from Bee Gorge are partially or totally replaced by goethite (Fig. 3.13a), or leached to voids without replacement (Fig. 3.13b). Goethite often preserves the original crystal structures, so that it is possible to identify the original gangue mineral (e.g., compare Figs. 3.11a, 3.13a).
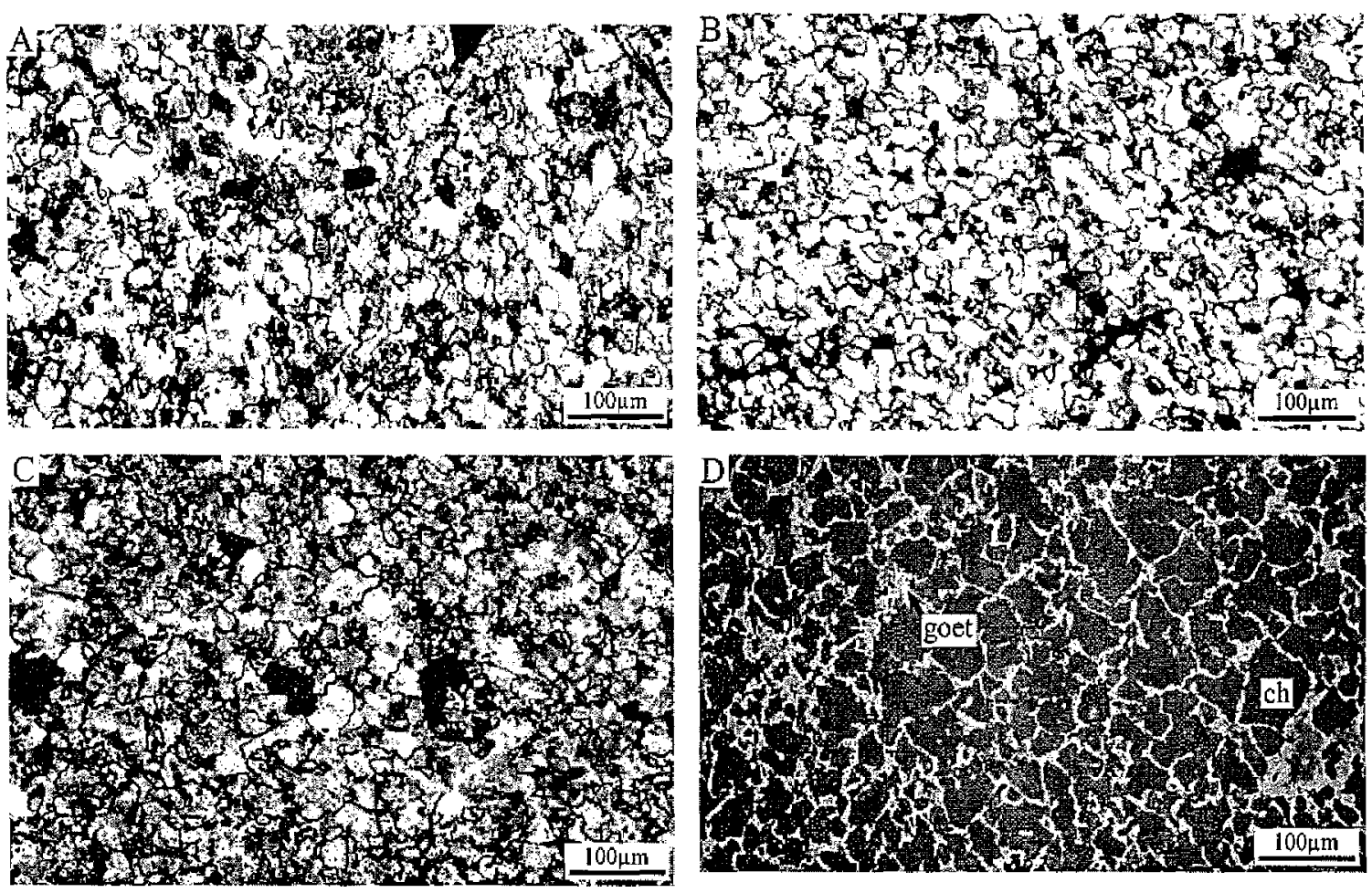

Figure 3.12. Photomicrographs of common chert textures in altered BIF across the Hamersley Province. (a) Fine-grained chert mesoband in weathered BIF from the undeformed north (sample BG1, Bee Gorge). Note: compare to figure 3.8a. Crossed polarized light. (b) Fine-grained mosaic chert in weathered BIF from moderately deformed regions (sample MR17, Mt. Robinson). Crossed polarized light. (c) Relatively unaltered mosaic chert, in oxidized, strongly deformed BIF from Fourth West Gorge (sample 4W17). Crossed polarized light. (d) Partial replacement of chert (ch) by goethite (goet) in weathered, moderately deformed BIF from Mt, Robinson (sample MR17). Reflected polarized light. 

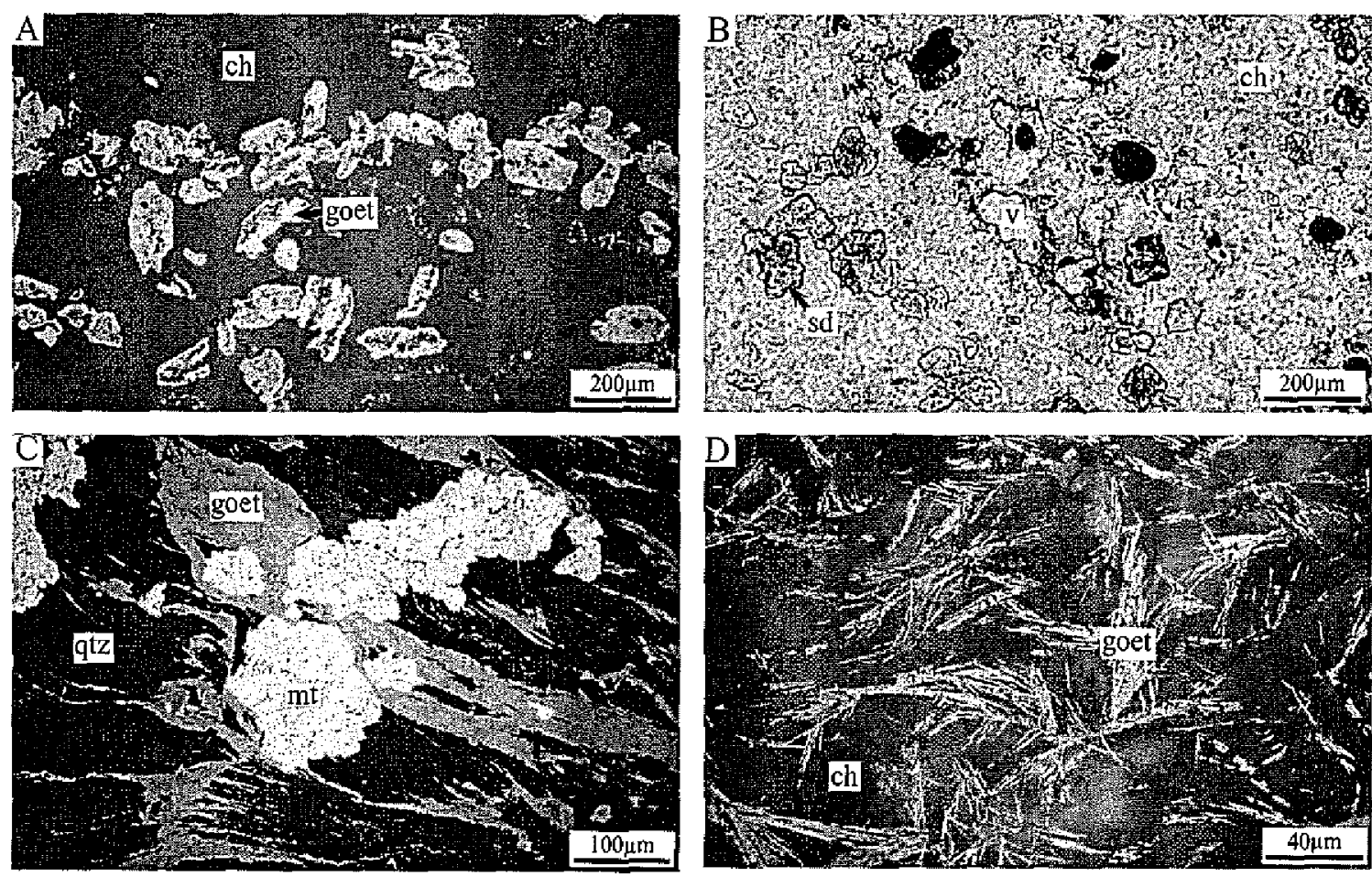

Figure 3.13. (a) Goethite (goet) pseudomorphs of siderite in chert-matrix mesoband from weathered Bee Gorge BIF (sample BG4). Reflected polarized light. Compare to figure 3.11a. (b) Partial dissolution of siderite grains without replacement in weathered Bee Gorge BIF (sample DB2). Plane polarized light. (c) Goethite (goet) pseudomorphs of stilpnomelane associated with recrystallized quartz (qtz) (sample PH14, Pamelia Hill). Reflected polarized light. Compare to figure 3.11f. (d) Goethite pseudomorphs of scattered riebeckite laths in weathered BIF from Cathedral Gorge (sample C17). Reflected polarized light.

\subsection{Outcrop at deformed regions}

BIF from deformed regions in the southeast Hamersley Province are broadly similar in composition to each other and to BIF from Bee Gorge (Table 3.2; Fig. 3.7). Collectively, the 76 samples of BIF from Weeli Wolli Spring, Mt. Robinson, Pamelia Hill, Cathedral Gorge and Fourth West Gorge consist mostly of $\mathrm{SiO}_{2}(50.5 \pm 10.1 \%)$ and $\mathrm{Fe}_{2} \mathrm{O}_{3} \mathrm{~T}(47.3 \pm 10.0 \%)$ with all other element oxide contents less than or equal to $0.3 \%$. It is difficult to assess whether differences in average $\mathrm{SiO}_{2}$ and $\mathrm{Fe}_{2} \mathrm{O}_{3} \mathrm{~T}$ contents between gorges are significant because of the intrinsic problems of collecting representative BIF samples (e.g., Ewers and Morris, 1980; Chapter 2). In fact, only one clear chemical difference emerges when comparing BIF in these outcrops: samples from Fourth West Gorge have an average LOI content of $0.32 \%$, whereas samples from the other gorges have average LOT contents $>1.38 \%$ (Table 3.2). Except for Fourth West Gorge, the bulk chemistry reflects a mineralogy comprising mostly quartz, martite, 
kenomagnetite and goethite (Table 3.3). At Fourth West Gorge, BIF contains minor magnetite and microplaty hematite instead of the latter two phases. The significant lack of goethite in these rocks possibly explains the lower LOI content.

Similar to Bee Gorge, the minerals are distributed into chert, chert-matrix, martite, and goethite mesobands (Table 3.4). Chert mesobands are largely comprised of quartz, primary hematite and martite with significant amounts of kenomagnetite and goethite, except at Fourth West Gorge. These mesobands typically make up to $50 \%$ of bulk samples by volume, and have a thickness $(1-19 \mathrm{~mm})$ that matches equivalent layers in unaltered BIF. The chert-matrix mesobands, with significantly less quartz, again appear to be significantly thicker $(6-36 \mathrm{~mm})$ than at Wittenoom and Junction Gorges. Martite mesobands are mostly comprised of martite and kenomagnetite with minor amounts of quartz, primary hematite and goethite. They form approximately $14 \%$ of bulk BIF samples, and are relatively thin (1-6 mm) like magnetite mesobands from cores of undeformed regions. Goethite mesobands, occurring at all of the gorges but Fourth West Gorge, are dominantly composed of goethite with minor amounts of quartz, martite and kenomagnetite. These mesobands have a similar thickness (1-12 mm) to carbonate and stilpnomelane mesobands at Wittenoom and Junction Gorges, but average about $6 \%$ of bulk samples by volume.

Quartz in BIF from the deformed southeast has similar textural characteristics to incipient chert in unaltered equivalents (e.g., Figs. 3.12b, c). Original coarse-grained and fibrous quartz is also preserved within pressure shadows and small veinlets (Fig. 3.13c). However, in several samples from Mt. Robinson, quartz was partially replaced by goethite (Fig. $3.12 \mathrm{~d}$ ).

With the exception of Fourth West Gorge, the magnetite has been oxidized to mixtures of kenomagnetite and martite. Many grains have also been partially hydrated to fine-grained goethite (Figs. 3.9c, 3.10c). Textural relationships indicate that the goethite either directly replaces magnetite, or more probably develops from the hydration of kenomagnetite (Morris, 1985). Magnetite in BIF from Fourth West Gorge has been totally replaced by martite (Figs. 3.9d, 3.10d); kenomagnetite and goethite are 
generally absent. Individual grains that were magnetite are also more subhedral at Fourth West Gorge, and many exhibit coarse skeletal textures (Fig. 3.9d).

Primary hematite and pseudomorphs of magnetite (martite, kenomagnetite and goethite) are the dominant iron oxide minerals in BIF from most gorges in the deformed southeast. However, in Fourth West Gorge, where samples almost invariably lack kenomagnetite and goethite, microplaty hematite with plates up to $400 \mu \mathrm{m}$ long is fairly common. These laths typically nucleate off martite grains and aggregates (Fig. 3.10e), although small crystals have also crystallized within voids left by the dissolution of gangue minerals (Figs. 3.14a, b). Replacement relationships involving microplaty hematite and goethite or kenomagnetite were not observed in any sample.

With the exception of Fourth West Gorge, all carbonates and silicates in BIF have been totally replaced by goethite. This process perfectly replaces the original crystal so that distinction between the different types of gangue minerals can still be made confidently (Figs. 3.13c, d). Carbonates and silicates are typically leached without replacement at Fourth West Gorge.

\subsection{Outcrop and core from Mt. Whaleback}

Altered BIF from core and fresh mine faces at Mt. Whaleback (Fig. 3.1) have broadly similar chemistry to BIF from outcrops at Bee Gorge and across the southeast; it is dominantly $\mathrm{SiO}_{2}(41.5 \pm 14.1 \%)$ and $\mathrm{Fe}_{2} \mathrm{O}_{3} \mathrm{~T}(54.7 \pm 13.8 \%)$ with all other element oxide contents and LOI $\quad 0.3 \%$ (Table 3.2; Fig. 3.7). In contrast to all BIF samples of the Hamersley Province, iron ore consists almost entirely of $\mathrm{Fe}_{2} \mathrm{O}_{3} \mathrm{~T}(98.5 \pm 1.0 \%)$. The chemical composition of both rock types is reflected in their mineralogy (Chapter 2). Altered BIF comprises largely quartz, martite and microplaty hematite, whereas iron ore is mostly martite and microplaty hematite (Table 3.3).

The minerals are distributed into mesobands of chert, chert-matrix and martite in altered BIF, and massive hematite and porous hematite in iron ore (Table 3.4). The chert, chert-matrix and martite mesobands are similar in thickness and composition to those at Fourth West Gorge. Each consists of variable proportions of quartz and martite 

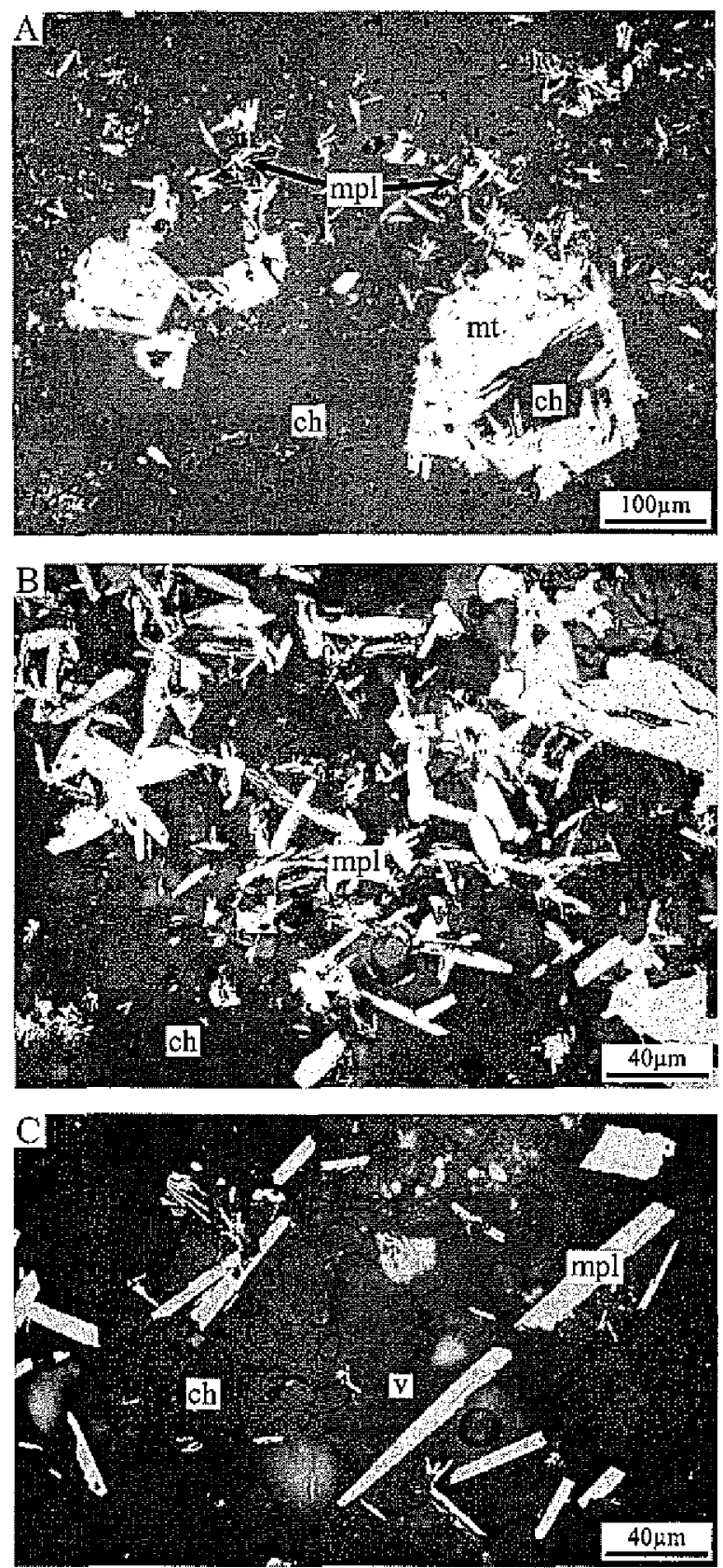

Figure 3.14. Photomicrographs of microplaty hematite laths in altered BIF from Fourth West Gorge and Mt. Whaleback. Reflected polarized light. (a) Fine-grained microplaty hematite laths (mpl) in chert matrix mesoband. Note laths nucleating off martite (mt) grain (sample 4W16). (b) Network of microplaty hematite laths ( $\mathrm{mpl}$ ) in chert-matrix mesoband (sample 4W12). (c) Microplaty hematite (mpl) laths in voids (v) left by the dissolution of chert (ch), in oxidized, strongly deformed BIF from Mt. Whaleback (sample A24C). Note total absence of goethite. Reflected polarized light.

with lesser amounts of primary hematite and microplaty hematite. The main difference is that chert and chert-matrix mesobands occupy about $10 \%$ and $80 \%$ of the volume of altered BIF at Mt. Whaleback, respectively, suggesting that some of the chert bands elsewhere have been converted to chert-matrix mesobands through the addition of hematite. In iron ore, massive hematite mesobands are largely martite with minor 
microplaty hematite, whereas porous hematite mesobands comprise sub-equal portions of martite and microplaty hematite. A fundamental observation regarding iron ore is that average mesobands, massive hematite and porous hematite, are relatively thin $(<16 \mathrm{~mm})$, indicating a volume loss beyond that associated with porosity. Interestingly, Taylor et al, (2001) record a volume loss of $\sim 40 \%$ and porosity increase of $\sim 30 \%$.

Quartz in altered BIF from Mt. Whaleback exhibits similar textures to that in BIF away from the deposit. Although quartz has been partially leached and/or replaced by microplaty hematite in a few cases (Fig. 3.8f), there is no evidence of infilling by secondary silica (or any other minerals) in these rocks. In contradiction to recently published statements (Morris, 2002), BIF around Mt. Whaleback can clearly contain incipient chert, martite and microplaty hematite together at small scale. In fact, almost all BIF around Mt. Whaleback appears to have this composition.

Magnetite has been converted to martite in altered BIF and iron ore from Mt. Whaleback (Figs. 3.9e-f, 3.10e-f). This conversion essentially maintains the original shape of magnetite, although many crystals exhibit coarse skeletal textures (Fig. 3.9e) or microplaty hematite overgrowths (Figs. 3.10e-f). Microplaty hematite commonly forms a network of interlocking laths that nucleate off martite grains and aggregates (Figs. 3.9f, 3.10e-f). However, in altered BIF, microplaty hematite can also occur within voids left by dissolution of gangue minerals (Fig. 3.14c).

\section{DISCUSSION}

\subsection{Basic origin of high-grade hematite ores}

The basic origin of the high-grade hematite ore deposits of the Hamersley Province appears partly resolved. Magnetite mesobands of original BIF have been altered to martite, while chert, chert matrix, stilpnomelane and carbonate mesobands have been replaced by porosity and microplaty hematite. This is supported here by two observations. First, the similar sizes, shapes and distribution patterns between magnetite and martite, as well as observed direct replacement relationships (e.g., Figs. $3.10 \mathrm{a}, \mathrm{e}$, and $\mathrm{f}$ ), indicate that martite replaced magnetite. Second, mesoband thicknesses 
of unaltered BIF are comparable to mesoband thicknesses of altered equivalents. There is no evidence to suggest that high-grade hematite ores formed through physical separation of magnetite and chert (cf. Findlay, 1994).

However, a major open issue is how the silica dissolution and iron oxidation occurred. Two testable models have emerged over the past two decades. The widely cited "supergene-metamorphic" model (Morris, 1980, 1985, 1998; Harmsworth et al., 1990) suggests the following three-step process. Uplift during the Ophthalmian Orogeny ca. 2.45-2.2 Ga brought BIF units to near the surface. During prolonged nearsurface exposure and supergene enrichment, magnetite layers in BIF were oxidized to martite, and iron derived from the weathering of overlying BIF migrated downwards to structurally favourable sites where it replaced chert layers in BIF with goethite. Subsequent burial metamorphism sometime after the Ophthalmian Orogeny upgraded the goethite to microplaty hematite.

Alternatively, the "hypogene-meteoric" model invokes a four-stage paragenesis for mineralization. First, high temperature, Fe-carbonate charged fluids at hydrothermal conditions replaced chert with carbonate, leaving a modified BIF composed of magnetite and carbonate with some iron silicates. Heated meteoric fluids then oxidized these assemblages to martite, microplaty hematite and ankerite. Cooling meteoric fluids subsequently leached remaining carbonates and silicates, leaving a highly porous ore. Finally, supergene weathering with cold, oxidizing meteoric fluids destroyed remaining minor components such as apatite. The critical observation in support of this model has been the finding of magnetite-siderite BIF juxtaposed with quartz-hematite-carbonate veins and carbonate-altered shales (Barley et al., 1999; Taylor et al., 2001).

A limitation to the development of a well-constrained and testable ore genesis model is that almost all previous work has examined either unaltered Dales Gorge Member rocks from the northern Hamersley Province or altered equivalents in and around the major ore deposits. Essentially no effort has been placed toward understanding Dales Gorge Member rocks between these two regions and the full range of processes that can affect BIF. Furthermore very few investigations have studied 
rocks from the largest low Phosphorous Brockman iron ore deposit, Mt. Whaleback, and most did not integrate rock composition and mineral texture.

\subsection{BIF across the Hamersley Province}

This work has examined BIF of the Dales Gorge Member across the southeastern Hamersley Province in an attempt to document the full range of alteration processes that can affect these rocks. The most fundamental observation from the analyses is that BIF of the Dales Gorge Member can, on the basis of chemistry, mineralogy and petrography, be categorized into at least four rock types: unaltered BIF, weathered BIF, oxidized BIF, and iron ore (Table 3.5 ).

Table 3.5. Petrographic groups across the Hamersley Province

\begin{tabular}{lcccc}
\hline Mineral & \multicolumn{1}{c}{ Unaltered BIF } & Weathered BIF & Oxidized BIF & Iron ore \\
\hline Chert & $\mathrm{S}$ & $\mathrm{S}$ & $\mathrm{S}$ & \\
Magnetite & $\mathrm{S}$ & $\mathrm{t}$ & & \\
Anhedral hematite & $\mathrm{t}$ & $\mathrm{t}$ & $\mathrm{t}$ & $\mathrm{t}$ \\
Siderite & $\mathrm{a}$ & & & \\
Ankerite & $\mathrm{t}$ & & & \\
Stilpnomelane & $\mathrm{a}$ & & & \\
Minnesotaite & $\mathrm{t}$ & & & $\mathrm{S}$ \\
Riebeckite & $\mathrm{t}$ & & $\mathrm{S}$ & \\
Martite & & $\mathrm{M}$ & & $\mathrm{S}$ \\
Kenomagnetite & & $\mathrm{M}$ & $\mathrm{a}$ & \\
Mpl hematite & & & $\mathrm{t}$ & \\
Goethite & & $\mathrm{a}$ & $\mathrm{T}$ & \\
\hline
\end{tabular}

Notes: $\mathrm{S}=$ greater than $40 \%$ abundance; $M=20-40 \%$ abundacne; $a=5-20 \% \mathrm{t}=<$ $5 \%$ abundance; goet = goethtie; hem = hematite; $\mathrm{mt}=$ martite; $\mathrm{mpl}=$ microplaty.

Unaltered BIF is found in drill cores from undeformed regions in the north (e.g., at Wittenoom and Junction Gorges). It consists mostly of incipient chert and euhedral magnetite grains distributed into chert, chert-matrix and magnetite mesobands. Significantly, this BIF contains some primary hematite and small amounts of carbonate and silicate minerals, which occur scattered within the above mesobands or as distinct mesobands. The carbonate and silicate minerals give detectable $\mathrm{CaO}$ and $\mathrm{MgO}$ contents and LOI.

Weathered BIF is found in outcrops across the Hamersley Province (e.g., at Bee Gorge, Weeli Wolli Spring, Mt. Robinson, Pamelia Hill, and Cathedral Gorge). It 
differs from unaltered BIF in two basic regards: (1) most of the magnetite has been converted to martite, kenomagnetite and goethite, and (2) the carbonate and silicate minerals have been either partially leached or replaced by goethite. The loss of carbonates and silicates significantly decreases the $\mathrm{CaO}$ and $\mathrm{MgO}$ contents, as well as LOI. Some process has also consistently increased the $\mathrm{Si} / \mathrm{Fe}$ ratio by of these rocks relative to unaltered $\mathrm{BIF}$ (Table 3.2). Note that the $\mathrm{Fe}_{2} \mathrm{O}_{3} \mathrm{~T}$ content remains nearly the same in unaltered and weathered $\mathrm{BIF}$, despite the partial loss of the 5 to $35 \%$ of mass originally occurring as carbonate and silicate minerals (Table 3.3). Thus, the increase in the $\mathrm{Si} / \mathrm{Fe}$ ratio probably signifies a $5-10 \%$ loss of Fe.

Oxidized BIF is found in outcrop at Fourth West Gorge, and in drill cores and fresh mine faces at Mt. Whaleback. This "altered BIF" (Chapter 2) differs from unaltered BIF and weathered BIF because it contains incipient chert with abundant skeletal martite and relatively common microplaty hematite but lacks kenomagnetite, goethite, carbonates and silicates. The major element chemistry of oxidized and weathered BIF is fairly similar though, because hematite, kenomagnetite and goethite have reasonably close compositions (Table 3.6).

In striking contrast to all BIF, iron ore from drill cores and fresh mine faces at $\mathrm{Mt}$. Whaleback does not contain any quartz, carbonates or silicates. Rather, it is composed almost entirely of subhedral martite grains and aggregates in a porous network of microplaty hematite.

Interestingly, this investigation and previous work (Chapter 2) has not identified the silica-poor, carbonate-rich BIF documented at Mt. Tom Price and Giles Mini (Taylor et al., 2001; Dalstra et al., 2002b). In fact, other than hematite and chert, no other phases have been found in DB-macrobands at Mt. Whaleback.

\subsection{Possible chemical reactions to explain different BIF across the southeast}

So, how and why does the composition and texture of BIF change across the southeastern Hamersley Province? Even in unweathered drill cores from relatively undeformed regions (e.g., Wittenoom and Junction Gorges), the minerals within BIF of 
Table 3.6. Formulas and major element oxide contents (wt\%) of significant minerals found in rocks across the Hamersley Province

\begin{tabular}{|c|c|c|c|c|c|c|c|c|c|c|c|c|}
\hline Mineral & Formula & $\mathrm{SiO}_{2}$ & $\mathrm{Al}_{2} \mathrm{O}_{3}$ & $\mathrm{FeO}$ & $\mathrm{Fe}_{2} \mathrm{O}_{3}$ & $\mathrm{Fe}_{2} \mathrm{O}_{3} \mathrm{~T}$ & $\mathrm{CaO}$ & $\mathrm{Na}_{2} \mathrm{O}$ & $\mathrm{K}_{2} \mathrm{O}$ & $\mathrm{MgO}$ & LOI & Total \\
\hline Ankerite & $\mathrm{CaFe}_{0 s} \mathrm{Mg}_{0 s}\left(\mathrm{CO}_{3}\right)_{2}$ & - & - & 17.9 & - & - & 28.0 & - & - & 10.1 & 44.0 & 100 \\
\hline Goethite & $\mathrm{FeO}(\mathrm{OH})$ & - & $=$ & - & 89.9 & 89.9 & - & - & - & - & 10.1 & 100 \\
\hline Hematite & $\mathrm{Fe}_{2} \mathrm{O}_{3}$ & - & - & - & 100 & 100 & - & - & - & - & - & 100 \\
\hline Magnetite & $\mathrm{Fe}_{3} \mathrm{O}_{4}$ & - & - & 31.0 & 69.0 & 103 & - & - & - & - & -3.50 & 100 \\
\hline Minnesotaite & $\mathrm{Mg}_{1.8} \mathrm{Fe}_{1.2} \mathrm{Si}_{4} \mathrm{O}_{10}(\mathrm{OH})_{2}$ & 57.1 & - & 20.5 & - & - & - & - & - & 17.2 & 4.3 & 100 \\
\hline Quartz & $\mathrm{SiO}_{2}$ & 100 & - & - & - & - & - & - & - & - & - & 100 \\
\hline Siderite & $\mathrm{Fe}_{0.8} \mathrm{Mg}_{0.2} \mathrm{CO}_{3}$ & - & $=$ & 52.4 & - & - & * & $\cdot$ & - & 7.4 & 40.1 & 100 \\
\hline Stilpnomelane* & $\mathrm{K}_{5} \mathrm{Fe}_{34} \mathrm{Mg}_{14} \mathrm{Si}_{64} \mathrm{Al}_{8} \mathrm{O}_{168}(\mathrm{OH})_{45} \cdot 12 \mathrm{H}_{2} \mathrm{O}$ & 48.4 & 5.1 & 30.7 & - & - & - & - & 3.0 & 7.1 & 5.7 & 100 \\
\hline
\end{tabular}

Notes: * Based on average stilpnomelane formula of Miyano and Klein (1989). 
the Dales Gorge Member are not primary sediments. For example, chert most likely crystallized through subaqueous diagenesis of an original opaline or silica gel phase, and stilpnomelane undoubtedly formed through low-grade metamorphism of original clay minerals (e.g., La Berge, 1966; Grubb, 1971; Ayres, 1972; Ewers and Morris, 1981; Morris, 1980, 1993). Probably all rocks across the Hamersley Province experienced post-depositional diagenesis before lithification, and metamorphism during the Ophthalmian Orogeny ca. 2.45-2.2 Ga (Trendall and Blockely, 1970; Grubb, 1971; Ayres, 1972; Ewers and Morris, 1981; Smith et al, 1982). However, if it is assumed, as have others (Ewers and Morris, 1981; Trendall and Blockley, 1970), that these alteration processes affected BIF across the Hamersley Province identically, so that all stratigraphically equivalent BIF horizons had a similar chemical and mineralogical composition at some early age, and that this initial BIF composition across the Hamersley Province was the same as the BIF now observed in cores at Wittenoom and Junction Gorges (Tables 3.2, 3.3), three sets of chemical reactions can be offered to explain weathered BIF, oxidized BIF and iron ore (Table 3.7; Fig. 3.15).

\subsubsection{BIF to weathered BIF}

It is most likely that the alteration of BIF in outcrop across the Hamersley Province (excluding Fourth West Gorge) is primarily due to weathering. Previous investigations (e.g., Morris, 1980; 1983; 1985; Ewers and Morris, 1981) have clearly shown that oxidation, hydration and leaching with/without replacement by goethtite are common processes affecting rocks across the Hamersley Province. This is most evident in the Mesozoic to Tertiary supergene martite-goethite ores that dominate iron ores in the southern Hamersley Province (Harmsworth et al., 1990). In these rocks, all levels of BIF banding are consistently preserved and original magnetite has been replaced by martite, kenomagnetite and goethite and all carbonates and silicates have been pseudomorphed by goethite or leached (Morris, 1985; Harmsworth et al., 1990; Barley et al., 1999). There is no secondary microplaty hematite in this mineralization style.

The first set of reactions describes the conversion of unaltered BIF to weathered 
Reactions 1: Unaltered BLF $\rightarrow$ weathered BIF (outcrops at Bee \& southeastern gorges)

1.1a Hydration of magnetite to goethite

$4 \mathrm{Fe}_{3} \mathrm{O}_{4(\mathrm{~s})}+\mathrm{O}_{2(\mathrm{ag})}+6 \mathrm{H}_{2} \mathrm{O}_{(\mathrm{l})} \rightarrow 12 \mathrm{FeOOH}_{(\mathrm{s})}+4 \mathrm{e}^{-}$

$\left[\mathrm{O}_{2(\mathrm{~g})}+4 \mathrm{H}_{(\mathrm{aq})}^{+}+4 \mathrm{e}^{-} \rightarrow 2 \mathrm{H}_{2} \mathrm{O}_{(0)}\right]$

1.16 Hydration of kenomagnetite to goethite*

$\mathrm{Fe}_{8} \square \mathrm{O}_{12(\mathrm{~s})}+6 \mathrm{H}^{+}$(aq) $\rightarrow 6 \mathrm{FeOOH}_{(\mathrm{s})}+2 \mathrm{Fe}^{3+}$ (aq)

1.Ic Hydration of kenomagnetite to goethite*

$\mathrm{Fe}_{8} \square \mathrm{O}_{12(s)}+6 \mathrm{H}^{+}$(aq) $\rightarrow 6 \mathrm{FeOOH}_{(\mathrm{s})}+2 \mathrm{Fe}^{3+}{ }_{\text {(aq) }}$

1.2 Oxidation of magnetite to martite

$2 \mathrm{Fe}_{3} \mathrm{O}_{4(\mathrm{~s})}+\mathrm{H}_{2} \mathrm{O}_{(\mathrm{aq})} \rightarrow 3 \mathrm{Fe}_{2} \mathrm{O}_{3(\mathrm{~s})}+2 \mathrm{H}_{(\mathrm{aq})}^{+}+2 \mathrm{e}$

$\left[1 / 2 \mathrm{O}_{2(\mathrm{~g})}+2 \mathrm{H}^{+}{ }_{(\mathrm{aq})}+2 \mathrm{e}^{-} \rightarrow \mathrm{H}_{2} \mathrm{O}_{(\mathrm{l})}\right]$

1.3 Hydration of siderite to goethite

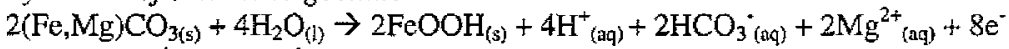

$\left[2 \mathrm{O}_{2(\mathrm{~g})}+8 \mathrm{H}_{(\mathrm{aq})}^{+}+8 \mathrm{e}^{*} \rightarrow 4 \mathrm{H}_{2} \mathrm{O}_{(\mathrm{l})}\right]$

1.4 Incongruent hydrolysis of stilpnometane to goethite

$\mathrm{K}_{5} \mathrm{Fe}_{34} \mathrm{Mg}_{14} \mathrm{Si}_{64} \mathrm{Al}_{8} \mathrm{O}_{168}(\mathrm{OH})_{45} \cdot 12 \mathrm{H}_{2} \mathrm{O}_{(\mathrm{s})}+99 \mathrm{H}_{2} \mathrm{O}_{(\mathrm{aq})}+23 \mathrm{H}^{+}$(aq) $\rightarrow$

$34 \mathrm{FeOOH}_{(\mathrm{aqg})}+5 \mathrm{~K}^{+}{ }_{(\mathrm{aq})}+14 \mathrm{Mg}^{2+}{ }_{(\mathrm{aq})}+8 \mathrm{Al}^{3+}{ }_{(\mathrm{aq})}+64 \mathrm{H}_{4} \mathrm{SiO}_{4(\mathrm{aq})}+34 \mathrm{e}^{-}$

$\left[17 / 2 \mathrm{O}_{2(\mathrm{~g})}+34 \mathrm{H}_{(\mathrm{ag})}^{+}+34 \mathrm{e}^{-} \rightarrow 17 \mathrm{H}_{2} \mathrm{O}_{(\mathrm{l})}\right]$

1.5 Ankerite dissolution

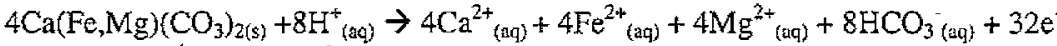

$\left[8 \mathrm{O}_{2(\mathrm{~g})}+32 \mathrm{H}_{(\mathrm{aq})}^{+}+32 \mathrm{e}^{-} \rightarrow 16 \mathrm{H}_{2} \mathrm{O}_{(\mathrm{l})}\right]$

1.6 Minnesotaite dissolution

$\mathrm{Mg}_{9} \mathrm{Fe}_{6} \mathrm{Si}_{20} \mathrm{O}_{50}(\mathrm{OH})_{10(\mathrm{~s})}+20 \mathrm{H}_{2} \mathrm{O}_{(\mathrm{l})}+30 \mathrm{H}_{(\mathrm{aq})}^{+} \rightarrow 9 \mathrm{Mg}^{2+}{ }_{(\mathrm{aq})}+6 \mathrm{Fe}_{(\mathrm{aq})}^{2+}+20 \mathrm{H}_{4} \mathrm{SiO}_{4(\mathrm{aq})}$

Reactions 2: Unaltered BIF $\rightarrow$ oxidized BIF (Fourth West Gorge \& Mt. Whaleback)

2.I Oxidation of magnetite to martite (as above)

2.2 Dissolution and oxidation of siderite to hematite

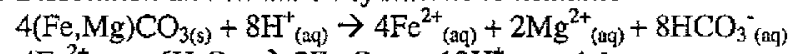

$4 \mathrm{Fe}^{2+}{ }_{(\mathrm{aq})}+6 \mathrm{H}_{2} \mathrm{O}_{\mathrm{ql})} \rightarrow 2 \mathrm{Fe}_{2} \mathrm{O}_{3(\mathrm{~s})}+12 \mathrm{H}^{+}{ }_{(\mathrm{aq})}+4 \mathrm{e}^{-}$

$\left[\mathrm{O}_{2(\mathrm{~g})}+4 \mathrm{H}^{+}(\mathrm{aq})+4 \mathrm{e}^{+} \rightarrow 2 \mathrm{H}_{2} \mathrm{O}_{(0)}\right]$

2.3 Dissolution and oxidation of stilpnomelane to hematite

$2 \mathrm{~K}_{5} \mathrm{Fe}_{34} \mathrm{Mg}_{14} \mathrm{Al}_{8} \mathrm{Si}_{54} \mathrm{O}_{168}(\mathrm{OH})_{45} .12 \mathrm{H}_{2} \mathrm{O}_{(\mathrm{s})}+23 \mathrm{H}_{(\mathrm{qq})}^{+}+82 \mathrm{H}_{2} \mathrm{O}_{(1)} \rightarrow$

$17 \mathrm{Fe}_{2} \mathrm{O}_{3(s)}+5 \mathrm{~K}_{(\mathrm{qq})}^{+}+14 \mathrm{Mg}^{2+}(\mathrm{aq})+8 \mathrm{Al}_{(\mathrm{qq})}^{3+}+64 \mathrm{H}_{4} \mathrm{SiO}_{4(\mathrm{aq})}+34 \mathrm{e}$

$\left[17 / 2 \mathrm{O}_{2(\mathrm{~g})}+34 \mathrm{H}^{+}(\mathrm{aq})+34 \mathrm{e}^{-} \rightarrow 17 \mathrm{H}_{2} \mathrm{O}_{(\mathrm{l})}\right]$

2.4 Crystallisation of microplaty hematite

$2 \mathrm{Fe}^{2+}{ }_{(\mathrm{qq})}+3 \mathrm{H}_{2} \mathrm{O}_{(\mathrm{l})} \rightarrow \mathrm{Fe}_{2} \mathrm{O}_{3(\mathrm{~s})}+6 \mathrm{H}^{*}$ (aq) $+2 \mathrm{e}^{-}$

$\left[1 / 2 \mathrm{O}_{2(\mathrm{~g})}+2 \mathrm{H}^{+}{ }_{(\mathrm{qq})}+2 \mathrm{e}^{-} \rightarrow \mathrm{H}_{2} \mathrm{O}_{(\mathrm{q})}\right]$

2.5 Siderite dissolution

$4(\mathrm{Fe}, \mathrm{Mg})\left(\mathrm{CO}_{3}\right)_{2(\mathrm{~s})}+8 \mathrm{H}_{(\mathrm{aq})}^{+} \rightarrow 4 \mathrm{Fe}^{2+}(\mathrm{aq})+4 \mathrm{Mg}^{2+}{ }_{(\mathrm{aq})}+8 \mathrm{HCO}_{3}(\mathrm{aq})$

2.6 Chert dissolution

$\mathrm{SiO}_{2(\mathrm{~s})}+2 \mathrm{H}_{2} \mathrm{O}_{(\mathrm{j})} \rightarrow \mathrm{H}_{4} \mathrm{SiO}_{4(\mathrm{aq})}$

Reactions 3: Oxidized BIF $\rightarrow$ iron ore (Mt. Whaleback)

3.I Chert dissolution (as above)

3.2 Local iron dissolution and precipitation

$\mathrm{Fe}_{2} \mathrm{O}_{3(\mathrm{~s})}+6 \mathrm{H}^{+}{ }_{\text {(ag) }}+2 \mathrm{e}^{\circ} \rightarrow 2 \mathrm{Fe}^{2+}{ }_{(\text {ag) }}+3 \mathrm{H}_{2} \mathrm{O}_{\text {(l) }}$

$2 \mathrm{Fe}^{2+}{ }_{(\mathrm{qq})}+3 \mathrm{H}_{2} \mathrm{O}_{(\mathrm{l})} \rightarrow \mathrm{Fe}_{2} \mathrm{O}_{3(\mathrm{~s})}+6 \mathrm{H}^{+}{ }_{(\mathrm{qq})}+2 \mathrm{e}^{-}$

Notes: See figure 3.15 for plausible paragenetic sequence. *Morris (1985) suggested that direct bydration of magnetite to goethite (reaction 1.1a) is unlikely as it is energetically more favourable for magnetite to oxidize to hematite. Instead he proposed that kenomagnetite is hydrated to goethite. He suggested this process involved the addition of $\mathrm{H}^{+}$(reaction 1.1 b), as the addition of water (reaction $1.1 \mathrm{c}$ ) would put too much strain on the close-packed oxygen lattice of magnetite. 
a) Weathering of BIF

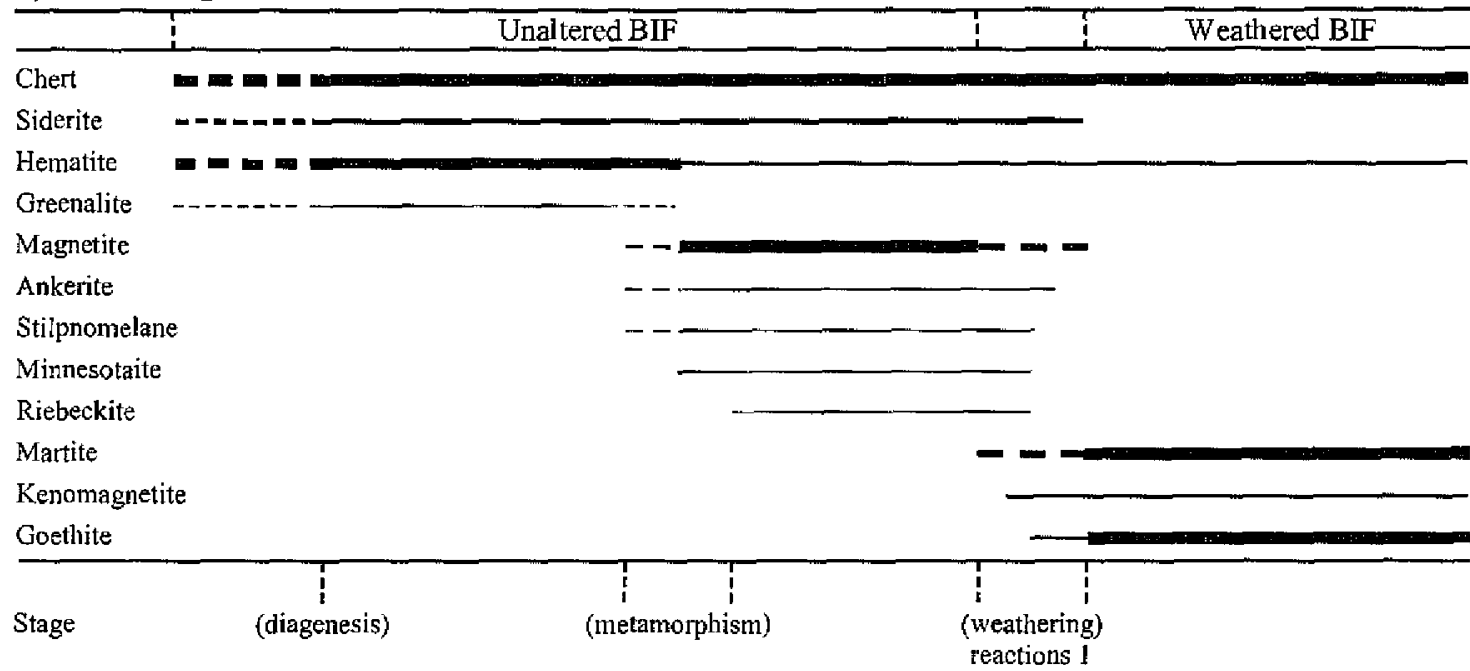

b) Oxidation and mineralization

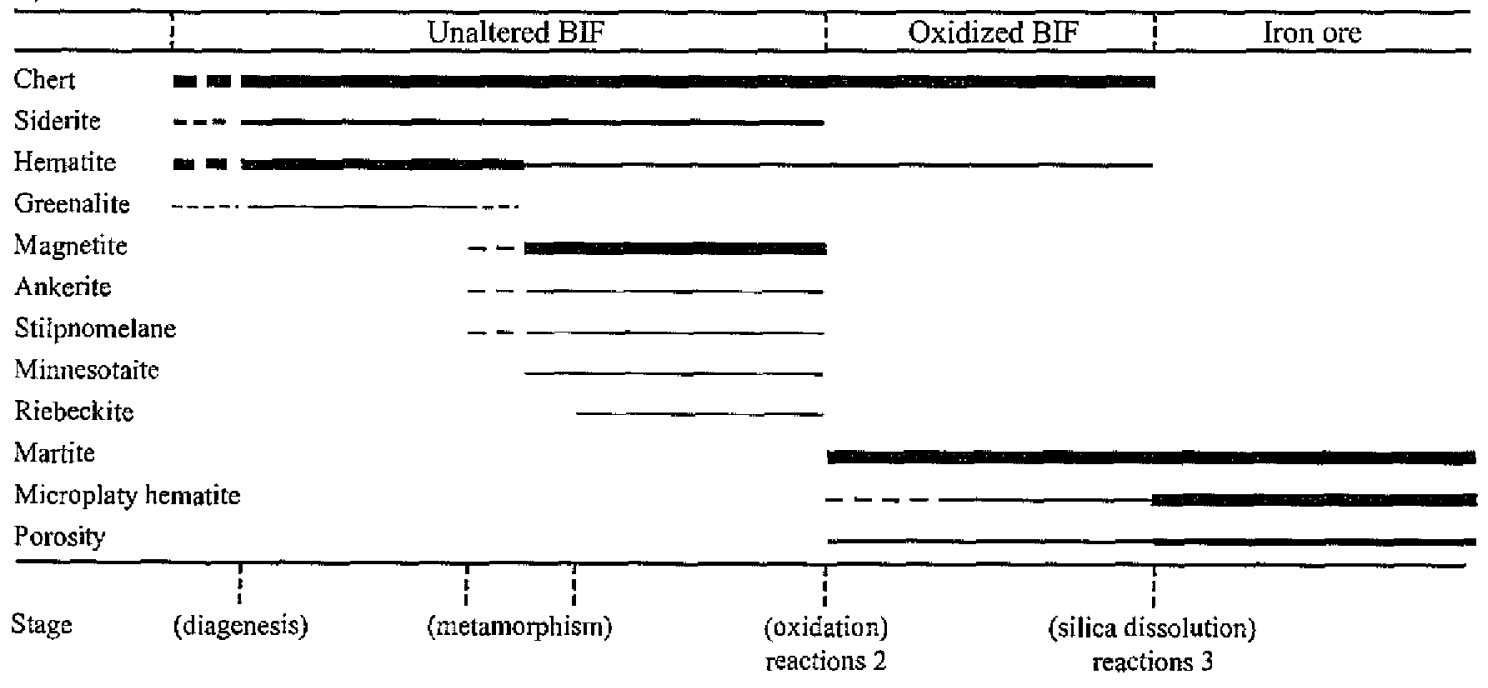

Figure 3.15. Schematic paragenetic sequences for BIF and across the Hamersley Province, (a) Unaltered BIF (Wittenoom and Junction Gorges) to weathered BIF (Bee and southeastern gorges); (b) Unaltered BIF to oxidized BIF (Fourth West Gorge and Mt. Whaleback) to high-grade hematite ore (Mt. Whaleback). Line thicknesses represent relative mineral abundance; dotted lines represent areas of gradational change. Reaction numbers correspond to those listed in table 3.7 .

BIF. During these reactions (reactions 1), magnetite alters to martite, kenomagnetite and goethite, while siderite and stilpnomelane alter incongruently to goethite. As noted by Morris (1985), there is no thermodynamic reason or evidence for direct oxidation and hydration of magnetite to goethite (reaction 1.1a). Instead, mineral textures observed during this and other investigations (Morris, 1980, 1985) strongly suggest that this alteration proceeds through kenomagnetite as an intermediary (reactions $1.1 \mathrm{~b}, \mathrm{c}$ ). Morris (1985) suggested that the intermediate reactions involved addition of $\mathrm{H}+$ 
(reaction 1.1b). However, this implies a release of $\mathrm{Fe}$, for which there is no obvious evidence. The conversion of magnetite to martite is also relatively complex because this can proceed through two different pathways (Morris, 1985): the oxidation of magnetite (reaction 1.2), or the oxidation of kenomagnetite to inversion of maghemite/kenomagnetite. The interlocking grains within weathered BIF (Figs. 3.9b, c) suggest that the former occurs.

The proposed first set of reactions explains most of the chemical and physical differences between unaltered BIF and weathered BIF. The oxidation and hydration of magnetite results in small increases in $\mathrm{Fe}_{2} \mathrm{O}_{3} \mathrm{~T}$ and LOI. However, the replacement of carbonates and silicates by goethite, as well as their partial dissolution (reactions 1.31.6) releases significant amounts of $\mathrm{Ca}^{2+}, \mathrm{K}^{+}, \mathrm{Mg}^{2+}, \mathrm{CO}_{2}$, and $\mathrm{H}_{4} \mathrm{SiO}_{4}$. Consequently, $\mathrm{SiO}_{2}$ contents most likely increase in weathered $\mathrm{BIF}$ through the loss of $\mathrm{K}_{2} \mathrm{O}, \mathrm{MgO}$, $\mathrm{CaO}$, LOI and possibly some minor $\mathrm{Fe}_{2} \mathrm{O}_{3} \mathrm{~T}$. The similar $\mathrm{Al}_{2} \mathrm{O}_{3}$ contents between unaltered and weathered BIF, despite these mass losses, suggest mobilization of $\mathrm{Al}$ or dilution by excess Si. Although it is difficult to quantify either option, the lack of secondary silica or addition of silicates in weathered $\mathrm{BIF}$ implies $\mathrm{SiO}_{2}$ contents increased through the loss of all other major element oxides including $\mathrm{Al}_{2} \mathrm{O}_{3}$ (e.g., reaction 1.4). Also note that the stratigraphic thicknesses of weathered BIF horizons across the southeast are similar or less than unaltered equivalents (see Chapter 5).

\subsubsection{BIF through oxidized BIF to iron ore}

The second and third set of reactions (Table 3.7) are postulated to explain the oxidation of BIF at Fourth West Gorge and Mt. Whaleback and the eventual conversion of these rocks to high-grade hematite ore. The second set of reactions (reactions 2) explains the formation of martite and microplaty hematite, such as observed in the highgrade hematite ore deposits and oxidized BIF. Similar layering and distribution characteristics between unaltered BIF and oxidized BIF suggests original magnetite is converted to martite (reaction 2.1) and microplaty hematite forms from some precursor phase. In contrast to Morris (1985), who suggests microplaty hematite forms from the 
dehydration of goethite, this work suggests incongruent dissolution of siderite and/or silicates (reactions $2.3,2.3$ ) due to the absence of goethite in oxidized BIF. However, the lack of textures showing the direct replacement of gangue by microplaty hematite indicates it may also crystallize directly from solution (reaction 2.4 ) into voids left from the leaching of carbonates, silicates or chert (e.g., reactions $2.5,2.6$ ).

Similar to weathering processes, the conversion of magnetite in unaltered BIF to martite in oxidized BIF results in minimal changes to the major element oxide contents. However, other reactions including the conversion of carbonates and silicates to microplaty hematite as well as their dissolution release $\mathrm{H}_{4} \mathrm{SiO}_{4}, \mathrm{Fe}^{2+}, \mathrm{Al}^{3+}, \mathrm{Mg}^{2+}, \mathrm{Ca}^{2+}$, $\mathrm{K}^{+}$and $\mathrm{HCO}_{3}^{-}$. Thus the small average increase in $\mathrm{Fe}_{2} \mathrm{O}_{3} \mathrm{~T}$ contents of oxidized BIF (particularly Mt. Whaleback BIF) most likely occurred due to the loss of $\mathrm{MgO}, \mathrm{CaO}$, $\mathrm{Al}_{2} \mathrm{O}_{3}$, LOI and some $\mathrm{SiO}_{2}$.

In the third set of reactions, quartz is removed from oxidized BIF to render martite and microplaty hematite (reaction 3.1). The presence of oxidized BIF - with chert, martite, and microplaty hematite - adjacent to high-grade hematite ore suggests that a dominant process of ore formation is the removal of silica. This is not easy to do, except at high temperatures (Walther and Helgeson, 1977). The significant increase of microplaty hematite between oxidized BIF and iron ore, also suggests some local dissolution and precipitation of Fe (reactions 3.2). The final conversion of oxidized BIF to iron ore would result in considerable mass loss. This would be evident as porosity and/or a decrease in stratigraphic thickness. Several investigations have suggested that up to $50 \%$ of BIF volume can be lost during ore formation (Blockley, 1969; Harmsworth et al., 1990; Taylor et al., 2001). Iron ore is also relatively porous suggesting both scenarios have occurred (see Chapter 5).

Deep supergene weathering with meteoric water could provide the necessary fluids for this pervasive oxidation. However, the abundance of microplaty hematite, lack of appreciable goethite and preservation of original layering in these rocks is inconsistent with typical modern day supergene weathering as weathered BIF in outcrop across the southeast generally lacks these characteristics. Moreover, at Mt. Whaleback, 
oxidized BIF often occurs below iron ore implying bedding parallel flow instead of downward migration of fluids. Similarities between oxidized BIF from Fourth West Gorge and Mt. Whaleback suggest such fluids locally affected rocks up to tens of kilometers west of Mt. Whaleback. Importantly, a single process - introduction of acidic, oxidizing fluids - can explain all of the reactions for the conversion of oxidized BIF to high-grade ore.

Although the three sets of reactions described above adequately explain the changes occurring to rocks in the southeastern Hamersley Province, including Mt. Whaleback, they may not describe the correct processes. In particular, the strongly reduced magnetite-carbonate-rich rocks at Mt. Tom Price (Taylor et al., 2001) imply Si may have been removed from BIF prior to its oxidation.

An extensive look at surrounding shales strongly indicated that rocks immediately around Mt. Whaleback have possibly seen two sets of fluids since early diagenesis or low-grade regional metamorphism (Chapter 2):

(1) acidic, mildly reduced fluids, and

(2) pervasive oxidizing fluids.

The first fluid type converted stilpnomelane and $\mathrm{K}$-feldspar in unaltered black shale to clinochlore and muscovite in altered black shale. Importantly these fluids did not dissolve silica or affect the chemistry of surrounding BIF. It was suggested that these fluids were most likely associated with regional metamorphism during the Ophthalmian Orogeny $\left(\mathrm{D}_{2}\right.$, ca 2.45 to $\left.2.2 \mathrm{Ga}\right)$.

The second fluid type transformed altered black shale to red shale, by converting clinochlore to hematite and kaolinite and muscovite. These fluids also dissolved quartz. The coexistence of red shales with oxidized BIF at Mt. Whaleback suggested these fluids were also responsible for oxidizing BIF. Chemical reactions describing this alteration indicated that deep weathering with meteoric water could provide the necessary fluids to drive this pervasive oxidation, although observed bedding-parallel fluid flow is inconsistent with typical supergene fluids that percolate down from above. Importantly carbonate altered BIF and shale has not yet been found at Mt. Whaleback. 


\subsection{Fundamental problems with current ore formation models}

The most basic insight stemming from this work is that the "supergenemetamorphic" model cannot reconcile the coexistence of martite-microplaty hematite and chert because it has Fe-oxidation and chert removal in the same step. BIF from Fourth West Gorge and Mt. Whaleback indicate that oxidation of magnetite to martite can occur independently of silica removal. Oxidized BIF can be found surrounding Mt. Whaleback. This may also occur at Mt. Tom Price. A recent examination of rocks at Mt. Tom Price also discovered microplaty hematite-rich BIF with silica ("jasperoidal BIF"; Taylor et al., 2001). The authors suggested that these rocks are texturally similar to iron ore, except that silica is present in the pore spaces. They proposed that jasperoidal BIF resulted from the oxidation of unaltered BIF by deep circulating heated meteoric fluids associated with the later stages of mineralization. However, they did not consider these rocks precursors to ore. It is thought that jasperoidal BIF best compares to oxidized BIF at Fourth West Gorge and Mt. Whaleback. Interestingly, Morris (1985, 2002) implies that the silica in jasperoidal BIF is secondary as it commonly exhibits infill textures. Such features were not observed in oxidized BIF from Fourth West Gorge or Mt. Whaleback. These rocks indicate:

(1) oxidation can occur independently of silica removal,

(2) microplaty hematite may crystallize directly from solution and in the absence of goethite, and

(3) oxidation was a pervasive process rather than a local process.

According to the supergene-metamorphic model (Morris 1985; Harmsworth et al., 1990), this silica loss occurred together with $\mathrm{Fe}$ oxidation and the formation of microplaty hematite. However, the existence of oxidized BIF, with interlayered incipient chert, martite and microplaty hematite (Figs. 3.14a-c), clearly demonstrates that silica loss was independent of Fe oxidation. However, this does not mean that oxidation and quartz dissolution were not the same product of the same overall fluid flow event. Since quartz solubility is somewhat temperature dependent, the apparent "decoupling" may be due to the palaeothermal regime. It could also be a function of the 
mass of fluid that entered the rocks. For example, relatively small masses of fluid could generate the change from magnetite to hematite but more fluid is required to dissolve quartz. The lack of secondary quartz (or anomalously high $\mathrm{SiO}_{2}$ contents) in oxidized BIF surrounding Mt. Whaleback further indicates that dissolved silica released from chert dissolution was not added to immediately adjacent rocks. Instead, dissolved silica was probably transported over considerable distance, which may imply high temperatures given relationships between silica solubility and temperature (Walther and Helgeson, 1977).

\subsection{Implications for iron ore genesis}

There are three general explanations for the contrasting rocks surrounding Mt. Whaleback and Mt. Tom Price (Chapter 2). Altered BIF at one location:

(1) exists at the other location but has not yet been described or found,

(2) never formed at the other location, or

(3) formed at the other location but was subsequently altered.

The BIF assemblages around Mt. Tom Price can be placed into a relatively straightforward paragenetic sequence that relates to high-grade hematite ore formation (Taylor et al., 2001). On the other hand, the widespread presence of martite-chert BIF at Mt. Whaleback is problematic. The mineralogy and chemistry of these rocks, as well as intervening shale macrobands (Chapter 2), strongly suggest that precursor BIF interacted with acidic, oxidizing fluids (Table 3.7). However, this alteration does not conform to expectations for typical supergene weathering. The hardness, silica and layering of precursor BIF remain and, in many places, the oxidized rocks occur beneath thick sections of reduced black shales with pyrite (Chapter 2). The most congruous explanation for the different rocks around Mt. Whaleback and Mt. Tom Price is that some process has oxidized BIF at the first location.

Multiple deformational events occurred along the southern margin of the Hamersley Province (Tyler and Thorne, 1990; Powell et al., 1999; Taylor et al., 2001; Brown et al., in press). This is pertinent because regional tectonism can drive large- 
scale flow of surface-derived fluids (e.g., Garven and Freeze, 1984; Oliver, 1986). Thus, it is possible that martite-chert BIF at Mt. Whaleback reflects pervasive, northward flow of acidic, oxygenated fluids. In this case, substantial oxidized fluids may not have reached and altered rocks at Mt. Tom Price, which lies $\sim 220 \mathrm{~km}$ northwest of Mt. Whaleback (Fig. 3.1). Structural deformation at Mt. Tom Price is certainly less than at Mt. Whaleback (e.g., Taylor et al., 2001). Variations between Mt. Whaleback and Mt. Tom Price are therefore best explained by different relative fluxes of the second fluid type in the hypogene-meteoric ore genesis model.

\section{CONCLUSION}

The giant high-grade hematite ores of the southern Hamersley Province, Western Australia, occur where deformed sequences of BIF have been altered to martite and microplaty hematite. The widely accepted model for their formation has been questioned in recent years with the appearance of new geochemical, structural, fluid inclusion and geochronological results. However, differing BIF compositions across the Hamersley Province and in particular between the two largest deposits (i.e., Mt. Whaleback and Mt. Tom Price), continue to hinder the development of a consistent genetic model. Changes in chemistry and petrography between rocks across this region suggest BIF can be categorized into four groups: unaltered BIF, weathered BIF, oxidized BIF, and iron ore. A series of chemical reactions indicate that altered BIF in the southeastern Hamersley Province developed primarily from the interaction of unaltered BIF with acidic, oxidizing fluids. In weathered BIF, original textures are superbly preserved by martite, kenomagnetite and goethite, suggesting that these fluids were associated with typical supergene weathering. However, in striking contrast to these rocks, oxidized BIF is characterised by quartz, martite and microplaty hematite, indicating the interaction of unaltered BIF with heated meteoric waters. Oxidized BIF was subsequently converted to high-grade hematite ore through the dissolution of Si. Regionally this sequence may be more complicated as BIF from Mt. Tom Price show an earlier stage involving carbonate replacement of silica prior to oxidation. Assuming the 
hydrothermal alteration of BIF at Mt. Tom Price is pre-ore, the most plausible explanation for the differences between the two deposits is that some process has completely removed any evidence of reduced rocks at Mt. Whaleback. Similarities between oxidized BIF from Mt. Whaleback to equivalent sequences outside the deposit suggest substantial lateral flow of pervasive, acidic, oxygenated fluids across the region, possibly during mineralization. Variations between Mt. Whaleback and Mt. Tom Price are therefore best explained by different relative fluxes of these oxidizing fluids. 
CHAPTER 4

CARBONATE ALTERATION OF THE UPPER MT. McRAE SHALE BENEATH THE MARTITE-MICROPLATY HEMATITE ORE DEPOSIT AT MT. WHALEBACK, WESTERN AUSTRALIA 


\section{ABSTRACT}

The genesis of giant martite-microplaty hematite ore deposits in northwest Australia remains a contentious topic in part because key evidence supporting a unifying genetic model has not been found at all deposits. In particular, recent papers have proposed that carbonate replacement of silica layers in banded iron formation (BIF) by basinal brines is a requisite first step toward ore formation. This initial hypogene stage is inferred primarily from the presence of silica-poor, carbonate-rich BIF found below ore and along normal faults at the Mt. Tom Price and Giles Mini deposits. However, to date, such rocks have not been identified at the largest martitemicroplaty hematite deposit, Mt. Whaleback. In this study, samples of the Mt. McRae Shale are examined for their chemistry, mineralogy and petrography. These samples were collected from several key locations, including within drill core that penetrates an area immediately beneath ore along the Mt. Whaleback fault at Mt. Whaleback. Compared to unaltered black shale from Wittenoom Gorge in the north and altered black and red shale at Mt. Whaleback, reddish-green shale below the Mt. Whaleback deposit is significantly enriched in $\mathrm{MgO}$ and $\mathrm{CaO}$ and depleted in $\mathrm{SiO}_{2}$. Samples of this shale consist predominantly of fine- to medium-grained ferroan-dolomite and ankerite cut by chlorite and carbonate veins, contrasting with unaltered equivalents that contain mostly stilpnomelane, K-feldspar and relatively minor carbonates. This alteration is distinct from assemblages developed during regional metamorphism, and most likely represents hydrothermal alteration after metamorphism. The lack of carbonate-rich, silica-poor rocks in the overlying Dales Gorge Member at Mt. Whaleback is consistent with pervasive oxidation of most rocks in the region during or after the later stages of ore genesis, a process that removed carbonates. Although several questions remain unanswered, these results support models that invoke an early hypogene stage during the formation of the martite-microplaty hematite deposits in the Hamersley Province.

\section{INTRODUCTION}

The Hamersley Province of Western Australia (Fig. 4.1) hosts several large iron 


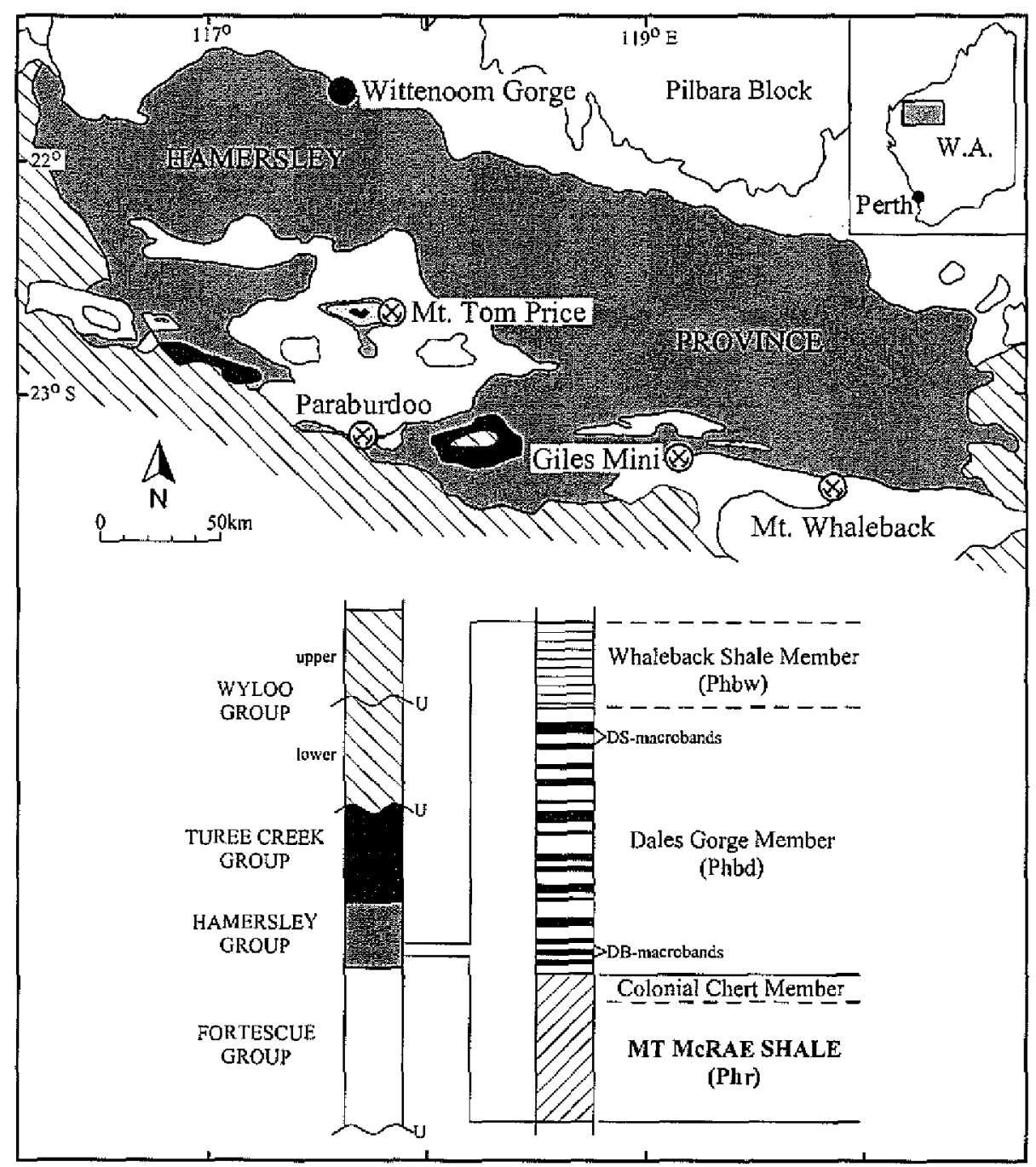

Figure 4.1. Simplified map of the Hamersley Province showing location, regional geology, location of major martite-microplaty hematite deposits and a summary of the lower Hamersley Group stratigraphy (modified from Trendall and Blockley, 1970 and Taylor et al., 2001). DB = Dales Gorge Member BIF macrobands; DS = Dales Gorge Member shale macrobands.

ore deposits (e.g., Mt. Whaleback, Mt Tom Price, Paraburdoo, Giles Mini) where one or more set processes have converted magnetite and chert layers of Proterozoic banded iron-formation (BIF) to martite and microplaty hematite (Fig. 4.2). Despite decades of research on these high-grade iron ore deposits, their formation remains highly controversial (e.g., Dalstra et al., 2002a, b; Kneeshaw and Kepert, 2002; Morris, 2002a,b; Taylor et al., 2001). Many workers have developed and accepted a genetic model that involves Proterozoic supergene weathering of BIF followed by burial metamorphism and uplift (Morris, 1980, 1985, 2002a, b; Harmsworth et al., 1990; Kneeshaw and Kepert, 2002). However, several recent papers have highlighted 


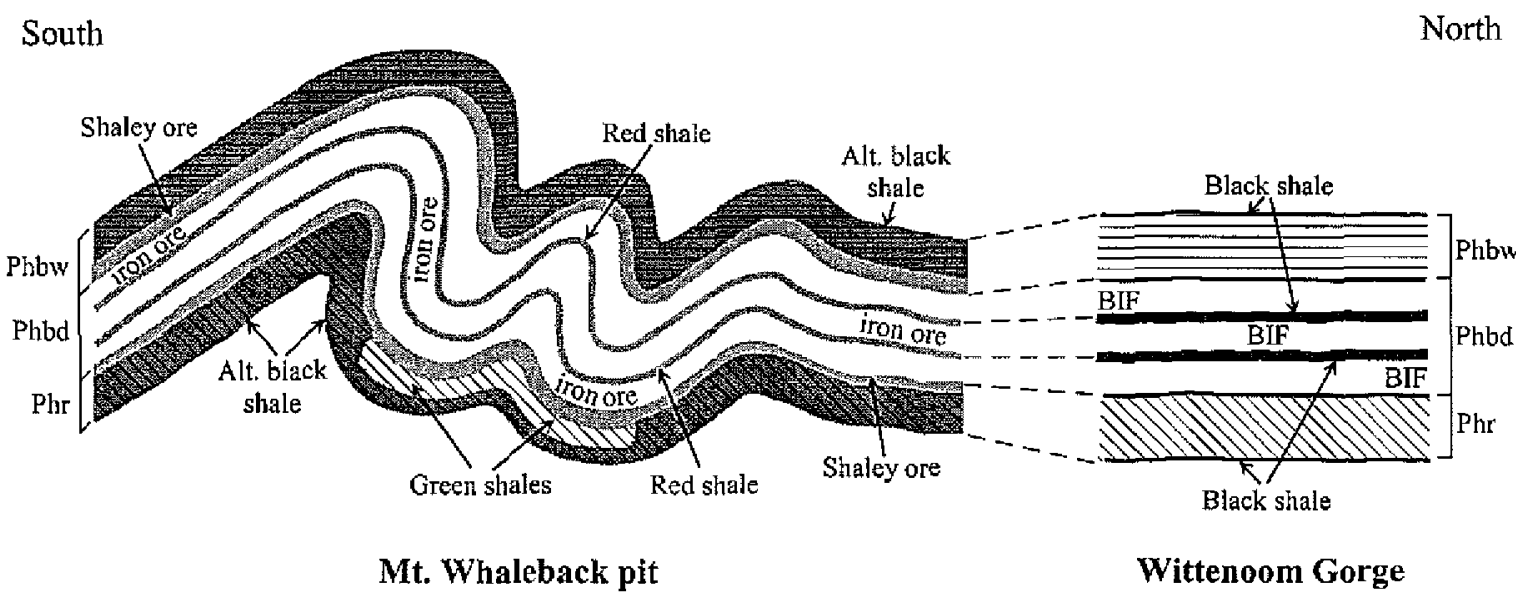

Figure 4.2. Schematic diagram showing the relative stratigraphic position of the Mt. McRae Shale and the different rock types sampled at Wittenoom Gorge (i.e., DDH-47A) and Mi. Whaleback. Note that this diagram does not adequately portray the thickness and porosity changes of the units from north to south caused by deformation and ore genesis (see Chapter 5). Phbw = Mt. Whaleback Shale Member; Phbd = Dales Gorge Members; Phr = Mt. McRae Shale.

fundamental problems with this interpretation (Martin et al., 1998; Barley et al., 1999; Oliver and Dickens, 1999; Powell et al., 1999; Taylor et al., 2001). These papers have generally proposed that the high-grade iron ore deposits must have formed through a succession or combination of high-temperature $\left(>150^{\circ} \mathrm{C}\right)$ alteration and low-temperature oxidation.

An extensive alteration zone underlies the North deposit of the Mt. Tom Price mine area (Taylor et al., 2001). Within this zone, silica-bearing minerals in BIF and surrounding shales have been replaced by $\mathrm{Fe}$ - and $\mathrm{Mg}$-rich carbonates, dolerite dykes have been altered to chlorite and talc, and numerous Fe- and Mg-rich carbonate veins cross-cut host rocks (Taylor et al., 2001; Dalstra et al., 2002b). Given the spatial relationship of these rocks to a prominent normal fault (the Southern Batter Fault), these observations led Taylor et al. (2001) to propose a genetic model for martite-microplaty hematite deposits (Fig. 4.3) whereby the reaction of upward migrating Fe-Mg-carbonate bearing fluids and BIF provides a critical early "hypogene" step to remove silica. Preliminary reports indicate that a similar deep-seated carbonate alteration zone also exists along a normal fault beneath ore at the Giles Mini deposit (Dalstra et al., 2002b). However, no such zone has been previously found at the biggest martite-microplaty 


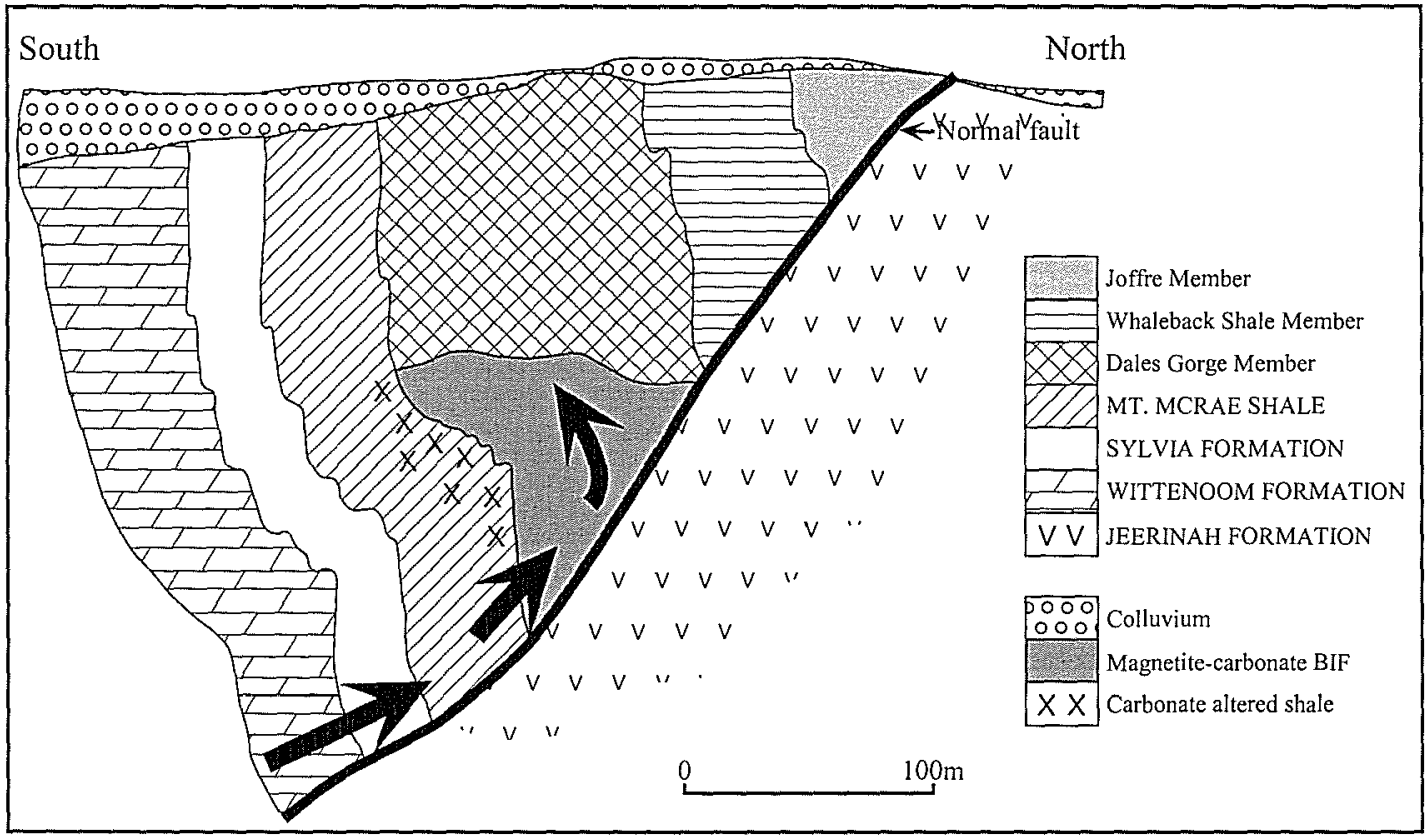

Figure 4.3. Schematic cross-section of Giles Mini showing the "hypogene" step in the formation of a martite-microplaty hematite deposit (modified from Dalstra et al., 2002b) and showing the relative positions of carbonate altered rocks. Note the proximity of carbonate-rich rocks to faults suggests these structures acted as channel ways for the upward migration of basinal brines (arrows).

hematite deposit in the Hamersley Province, Mt. Whaleback (Kneeshaw and Kepert, 2002; Chapters 2, 3). With available information, current literature is forced to conjecture that carbonate replacement of silica is unimportant to high-grade iron ore formation (Kneeshaw and Kepert, 2002; Morris, 2002a, b), or the evidence for this alteration at Mt. Whaleback has been physically removed through tectonism, pervasive oxidation or mining (Taylor et al., 2001; Dalstra et al., 2002a, b; Chapters 2, 3).

The host rocks and the geometric relationships between structure and ore are quite similar at the Giles Mini and Mt. Whaleback deposits (cf. Ronaszecki et al., 1992; Powell et al., 1999; Dalstra et al., 2002a, b). Given the location of carbonate alteration at Giles Mini (Fig. 4.3), it is difficult to envision how this zone could be physically removed through tectonism at Mt. Whaleback if basic aspects of the Tylor et al. (2001) model are correct (Kneeshaw and Kepert, 2002). Indeed, unless affected by post-ore fluids (Chapters 2, 3), the Taylor et al. (2001) model necessarily predicts the occurrence of Fe- and Mg-rich carbonates below ore on the hanging wall of the Mt. Whaleback fault (Figs. 4.3, 4.4). This chapter examines samples of the Mt. McRae shale from 
several key locations, including in core from a drill hole at Mt. Whaleback that penetrated an expected area of carbonate alteration. The results of this study have implications for the genesis of the main Mt. Whaleback orebody, which otherwise lacks the distinct hypogene magnetite-carbonate alteration displayed in lower parts of the Mt. Tom Price orebody.

\section{GEOLOGICAL BACKGROUND AND CORE DDH-409}

The Hamersley Group comprises a 2.5-km-thick package of late Archean to early Proterozoic marine sedimentary and volcanic rocks that cover $\sim 40000 \mathrm{~km}^{2}$ of the Hamersley Province on the southern Pilbara Craton, northwest Western Australia (Fig. 4.1). In the north of the province, these rocks are minimally deformed and weakly metamorphosed (e.g., Trendall and Blockley, 1970; Smith et al., 1982; Chapters 2, 3). However, in the south, they have been strongly folded and moderately metamorphosed in many areas because of multiple north-south collisions between the northern Yilgarn Craton and southern Pilbara Craton (Tyler and Thorne, 1990; Powell at al., 1999; Brown et al., in press).

The Hamersley Group has been divided into several formations and members (Fig. 4.1) on the basis of lithology (Macleod, 1966; Trendall and Blockley, 1970). The Dales Gorge Member of the lower Brockman Iron Formation hosts most of the martitemicroplaty hematite ore deposits at Mt. Whaleback, Mt Tom Price, and Giles Mini (Figs. 4.2-4.4). In the northern Hamersley Province, this member consists of 33 alternating m-scale units (macrobands) of BIF and black shale, with the BIF predominantly comprised of cm-scale layers (mesobands) of magnetite and chert (Morris, 1985; Trendall and Blockley, 1970; Chapters 2, 3). Within the high-grade ore deposits (shown in figure 4.1), these BIF and shale macrobands have been converted to martite-microplaty hematite ore and red shale, respectively (Harmsworth et al,, 1990; Morris, 1985; Chapters 2, 3). The potentially crucial observation at Mt Tom Price and Giles Mini is that macrobands of the Dales Gorge Member beneath ore and along normal faults (Fig. 4.3) can be composed of magnetite-carbonate BIF and greenish 


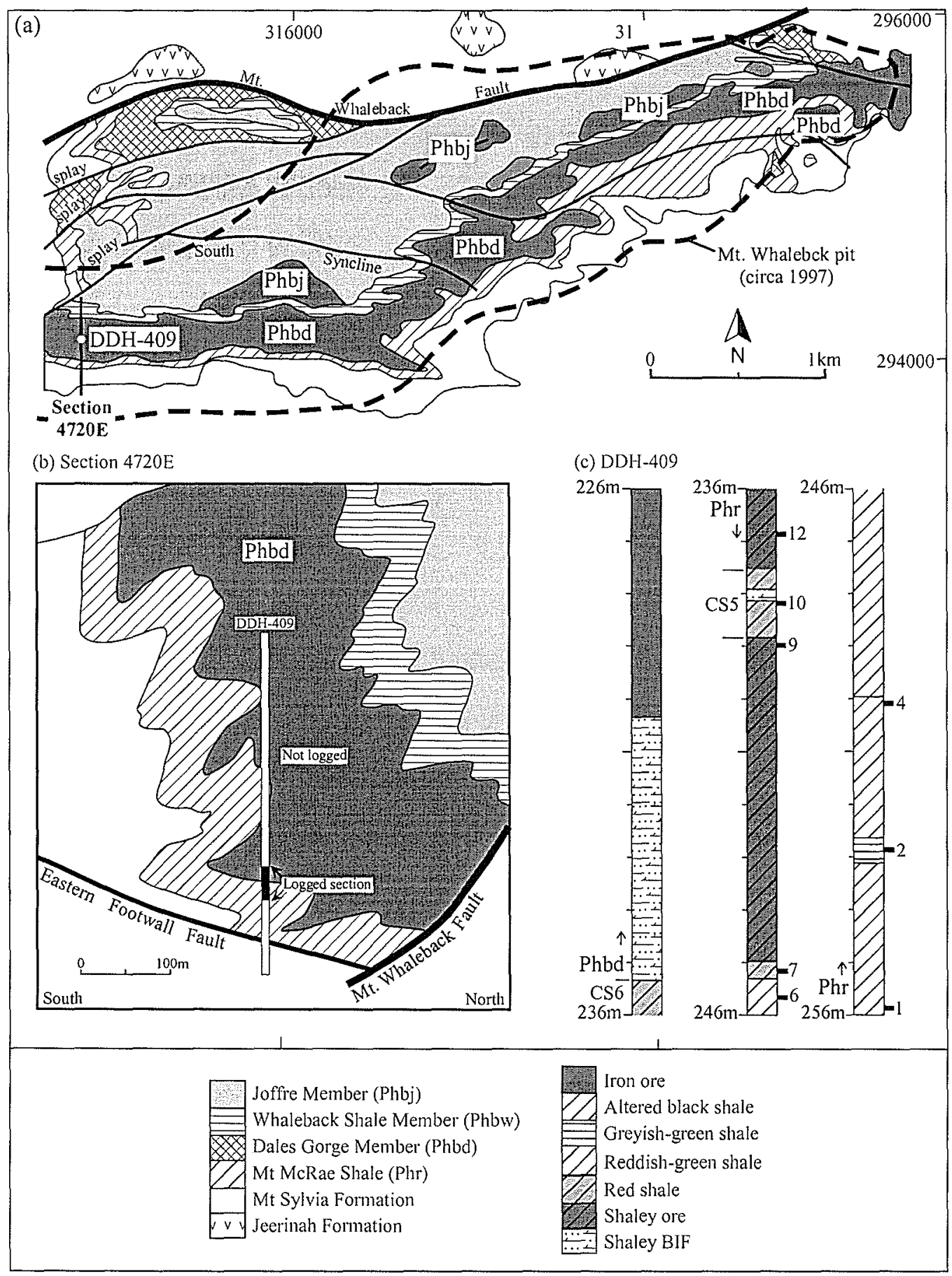

Figure 4.4. (a) Surface geologic plan of the Mt. Whaleback iron ore deposit (from Harmsworth et al., 1990), showing location of cross section 4720E (see fig. b) and outline of Mt. Whaleback pit (circa 1997). (b) Geological cross-section 4720E showing the location of DDH-409 and the region logged and sampled for this study (see fig. 4.4c). Note the close the proximity of this zone to the Mt. Whaleback and Eastern Footwall Faults (compare with figure 4.3) and how it directly underlies martite-microplaty hematite ore. (c) Detailed log of DDH-409 from 226-256m below the surface at Mt. Whaleback showing general geology and sample locations. Note sample locations and corresponding names are shown on the right side of the columns; sample names are prefixed by D409 in tables 4.1 and 4.2 and appendix 3; $\mathrm{Phr}=\mathrm{Mt}$. McRae Shale; CS5 and CS6 are prominent shale bands at the top of the Mt. McRae Shale; Phbd = Dales Gorge Member. 
black silicate-bearing shale (Taylor et al., 2001; Dalstra et al., 2002b). Carbonatebearing macrobands of the Dales Gorge Member have not been found at Mt. Whaleback, despite exhaustive examinations of available mine faces and cores by several workers over many years (Kneeshaw and Kepert, 2002; Chapters 2, 3).

The Colonial Chert Member of the Mt. McRae Shale immediately underlies the Dales Gorge Member (Fig. 4.1). In the northern Hamersley Province, it primarily consists of chert, shaley BIF and black shale, and is clearly identified by two sets of twin shale bands (CS5 and CS6) just below the contact with the Dales Gorge Member (Trendall and Blockley, 1970; Chapter 2). The black shale is mostly a mixture of stilpnomelane, quartz and K-feldspar (Chapter 2). At Mt. Whaleback, the shaley BIF typically has been mineralized to shaley ore, while the original black shale usually has been converted to red shale or an "altered black shale" (Chapter 2). The red shale is mostly a mixture of hematite, kaolinite and chlorite, and the altered black shale is mostly a mixture of chlorite, quartz and muscovite (Chapter 2). In the carbonate alteration zones at Mt. Tom Price, original black shale appears greenish-black, with quartz and phyllosilicate minerals replaced by Fe- and Mg-rich silicates (Taylor et al., 2001). However, shales of the McRae Shale underneath ore at Giles Mini are strongly carbonate altered (Dalstra et al., 2002b). The secondary carbonates in the intervening altered BIF macrobands at both deposits are mostly siderite, ankerite and dolomite (Taylor et al., 2001; Dalstra et al., 2002b).

Diamond drill hole (DDH) 409 was drilled in the western end of the main Mt. Whaleback pit (Fig. 4.4). This core was specifically examined because it comes from one of the few cored holes that penetrates the Colonial Chert Member below martitemicroplaty ore along the hanging wall of the Mt. Whaleback fault; that is, from an area of expected carbonate alteration according to the recent work at other deposits (Fig. 4.3). Although the entire hole was $\sim 320 \mathrm{~m}$ in length, only core from $\sim 9 \mathrm{~m}$ above to $~$ $20 \mathrm{~m}$ below the contact between the Dales Gorge Member and Mt. McRae Shale was logged (Fig. 4.1c).

The lowermost Dales Gorge Member within the logged section consists of typical 
martite-microplaty hematite ore. Much of the Colonial Chert Member in this core also appeared similar to equivalent stratigraphic sections found elsewhere at Mt. Whaleback. However, it also contained a 4-5 m thick interval of reddish-green shale with numerous reddish green and white veins, which clearly contrasts with previous observations.

\section{SAMPLES AND METHODS}

As part of a previous study (Chapter 2), samples of the Mt. McRae Shale were analysed for their powder colour, major element chemistry and mineralogical composition. These samples included 2 examples of black shale from a drill core (DDH-47A*) near Wittenoom Gorge (Fig. 4.1), and 9 examples of red shale, 8 examples of altered black shale, and 2 examples of shaley ore from drill cores and fresh mine faces within the Mt. Whaleback pit. Detailed logs and cross-sections showing the locations of these samples are presented elsewhere (Chapter 2; Appendix 1). Although this suite of samples clearly shows the effects of several alteration processes, none of the samples displayed any evidence for carbonate replacement of silica-bearing minerals (Chapter 2).

This study compares these previously documented carbonate-poor shales with stratigraphic equivalents from DDH-409. Eight 5-10 cm long samples were collected from DDH-409 (Fig. 4.4). These samples include two examples each of "shaley ore", "red shale", and "reddish-green shale", and one example each of "altered black shale" and "greyish-green shale" (Table 4.1; Fig. 4.1c). Splits of these samples were analysed for their powder colour, major element chemistry and mineralogical composition using the same preparation and analytical techniques (Munsell chart, X-ray fluorescence, Xray diffraction) documented in Chapter 2. Representative samples of Mt. McRae Shale from DDH-409 and the other locations noted above were made into polished and standard thin sections for petrography. The chemical compositions of certain minerals in these samples were then determined using a Jeol-840 energy dispersive electron probe microanalyser at the James Cook University Advanced Analytical Centre. Accelerating voltage and beam current were set at $15 \mathrm{kV}$ and $10 \mathrm{nA}$, respectively. 
Reported chemical compositions are the average of at least three microprobe analyses, each forty seconds in duration. Instrumental calibrations were performed on international and in-house standards and analytical precision is approximately \pm 0.6 $\mathrm{wt} \%$ for most elements.

\section{RESULTS}

\subsection{Bulk chemistry and mineralogy of Mt. McRae Shale in DDH-409}

The samples collected from DDH-409 exhibit a wide range in powder colour and major element composition (Table 4.1). The altered black shale sample has a light-grey powder colour, and consists mostly of $\mathrm{SiO}_{2}(51 \%)$, with a moderate amount of $\mathrm{Al}_{2} \mathrm{O}_{3}$ $(20 \%)$ and relatively high $\mathrm{Fe}_{2} \mathrm{O}_{3} \mathrm{~T}(11 \%), \mathrm{MgO}(6.2 \%), \mathrm{K}_{2} \mathrm{O}(5.1 \%)$ and LOI (5.6\%). The two red shale samples are red when powdered, and contain much lower $\mathrm{SiO}_{2}(19 \pm$ $0.6 \%), \mathrm{Al}_{2} \mathrm{O}_{3}(13 \pm 0.6 \%)$ and $\mathrm{K}_{2} \mathrm{O}(0.1 \pm 0.01 \%)$, slightly higher $\mathrm{MgO}(8.7 \pm 1.5 \%)$, and much higher $\mathrm{Fe}_{2} \mathrm{O}_{3} \mathrm{~T}(50 \pm 0.4 \%)$. The two shaley ore samples have a dark red powder colour, contain very low $\mathrm{SiO}_{2}(4.3 \pm 4.5 \%), \mathrm{Al}_{2} \mathrm{O}_{3}(3.8 \pm 4.1 \%), \mathrm{MgO}(0.3 \pm$ $0.0 \%)$ and LOI $(1.9 \pm 1.4 \%)$, but very high $\mathrm{Fe}_{2} \mathrm{O}_{3} \mathrm{~T}(90 \pm 9.8 \%)$. The greyish-green shale, while having a pinkish-grey powder colour, is compositionally fairly similar to altered black shale, being mostly $\mathrm{SiO}_{2}(60 \%)$ and $\mathrm{Al}_{2} \mathrm{O}_{3}(17 \%)$, with significant $\mathrm{Fe}_{2} \mathrm{O}_{3} \mathrm{~T}$ (8.5\%), $\mathrm{MgO}(5.0 \%), \mathrm{K}_{2} \mathrm{O}(4.8 \%)$ and LOI (4.3\%). The reddish-green shales are considerably enriched in $\mathrm{MgO}(14 \pm 3.4 \%), \mathrm{CaO}(18 \pm 8.2 \%)$ and LOI (30 $\pm 10 \%)$, with only moderate amounts of $\mathrm{Fe}_{2} \mathrm{O}_{3} \mathrm{~T}(10 \pm 3.4 \%), \mathrm{SiO}_{2}(20 \pm 20 \%)$ and $\mathrm{Al}_{2} \mathrm{O}_{3}(6.1 \pm$ 4.1\%). Except for the reddish-green shales, the major element chemistry of samples from DDH-409 corresponds closely with results of previous work on Mt. McRae Shale at Mt. Whaleback (Fig. 4.5).

Despite the wide range in colour and chemical composition, only seven minerals were detected at concentrations exceeding $1 \%$ in bulk, individually homogenized samples collected from DDH-409 (Table 4.2). These are quartz, hematite, dolomite, muscovite, chlorite (an Fe- Mg-rich chlorite), goethite and kaolinite. Rocks within DDH-409 are relatively simple mineralogical mixtures of two to four primary minerals. 
Table 4.1. Description and major element composition of rocks from the Mt. McRae Shale at DDH-409 (Mt. Whaleback).

\begin{tabular}{|c|c|c|c|c|c|c|c|c|c|c|c|c|c|c|c|c|c|c|c|}
\hline \multirow{2}{*}{$\frac{\text { Sample }}{\text { D4091 }}$} & \multirow{2}{*}{$\begin{array}{l}\text { Unit } \\
\text { McRae }\end{array}$} & \multirow{2}{*}{$\frac{\text { Location }}{\text { DDH-409 }}$} & \multirow{2}{*}{$\frac{\text { From }}{255.50}$} & \multirow{2}{*}{$\frac{\text { To }}{255.85}$} & Powder Colour & \multirow{2}{*}{$\begin{array}{l}\text { Description } \\
\text { alt. black shale }\end{array}$} & \multirow{2}{*}{$\frac{\mathrm{SiO}_{2}}{51.2}$} & \multirow{2}{*}{$\frac{\mathrm{TiO}_{2}}{0.79}$} & \multicolumn{2}{|c|}{$\mathrm{Al}_{2} \mathrm{O}_{3} \mathrm{Fe}_{2} \mathrm{O}_{3} \mathrm{~T}$} & \multirow{2}{*}{$\begin{array}{r}\mathrm{MnO} \\
0.07\end{array}$} & \multirow{2}{*}{$\frac{\mathrm{MgO}}{6.23}$} & \multirow{2}{*}{$\frac{\mathrm{CaO}}{0.28}$} & \multirow{2}{*}{$\frac{\mathrm{Na}_{2} \mathrm{O}}{0.16}$} & \multirow{2}{*}{$\frac{\mathrm{K}_{2} \mathrm{O}}{5.11}$} & \multirow{2}{*}{$\frac{\mathbf{P}_{2} \mathbf{O}_{5}}{0.20}$} & \multirow{2}{*}{$\frac{\mathbf{S}}{0.01}$} & \multirow{2}{*}{$\begin{array}{l}\text { LOI } \\
5.60\end{array}$} & \multirow{2}{*}{$\frac{\text { SUM }}{100.2}$} \\
\hline & & & & & 10YR 7/1 (light gray) & & & & 19.7 & 10.9 & & & & & & & & & \\
\hline D4092 & McRae & DDH-409 & 252.81 & 252.85 & $7.5 \mathrm{YR} 7 / 2$ (pinkish grey) & greyish-green shal. & 60.2 & 0.54 & 16.8 & 8.50 & - & 4.98 & 0.15 & - & 4.77 & 0.15 & - & 4.30 & 100.4 \\
\hline D4094 & McRae & $\mathrm{DDH}-409$ & 250.06 & 250.10 & 5YR 6/5 (reddish yellow) & reddish-green shal & 34.6 & 0.33 & 9.02 & 7.90 & 0.44 & 11.6 & 11.7 & - & 1.54 & 0.10 & 0.01 & 22.9 & 100.3 \\
\hline D4096 & McRae & DDH-409 & 245.63 & 245.72 & 5YR $6 / 6$ (reddish yellow) & reddish-green shal. & 5.30 & 0.12 & 3.23 & 12.7 & 1.55 & 16.4 & 23.3 & - & 0.01 & 0.08 & 0.01 & 37.3 & 99.9 \\
\hline D4097 & McRae & DDH-409 & 245.10 & 245.15 & $2.5 \mathrm{YR} 4 / 6$ (red) & red shale & 18.6 & 0.40 & 12.5 & 49.9 & 0.24 & 9.78 & 0.75 & 0.20 & 0.05 & 0.32 & 0.02 & 7.20 & 100.1 \\
\hline D4099 & McRae & DDH-409 & 238.96 & 239.02 & 2.5YR $3 / 6$ (dark red) & shaley ore & 1.10 & 0.02 & 0.89 & 97.0 & & 0.25 & 0.11 & - & 0.02 & 0.15 & 0.02 & 0.90 & 100.4 \\
\hline D40910 & McRae & DDH-409 & 238.23 & 238.30 & 2.5 YR $4 / 6(\mathrm{red})$ & red shale & 19.5 & 1.55 & 13.3 & 49.3 & 0.27 & 7.70 & 0.28 & 0.17 & 0.04 & 0.13 & 0.01 & 8.00 & 100.3 \\
\hline D40912 & McRae & DDH-409 & 236.83 & 236.90 & 2.5 YR $3 / 6$ (dark red) & shaley ore & 7.40 & 0.05 & 6.70 & 83.2 & - & - & 0.06 & - & 0.02 & 0.21 & 0.01 & 2.90 & 100.6 \\
\hline \multicolumn{2}{|c|}{ Black shale* } & \multicolumn{2}{|c|}{ Wittenoom Gorge } & & (olive grey to grey) & & 42.1 & 0.63 & 5.72 & 30.9 & 0.10 & 7.99 & 1.18 & 0.46 & 2.60 & 0.05 & 0.56 & 7.66 & 100.0 \\
\hline \multirow{2}{*}{\multicolumn{2}{|c|}{$\begin{array}{l}\text { Alt. black shale* } \\
\text { Red shale* }\end{array}$}} & \multicolumn{2}{|c|}{ Mt. Whaleback pit } & & (brown to black) & & 42.0 & 0.56 & 16.4 & 14.9 & 0.15 & 5.70 & 1.74 & 0.02 & 3.50 & 0.11 & 0.04 & 15.0 & 100.2 \\
\hline & & \multirow{2}{*}{\multicolumn{2}{|c|}{ Mt. Whaleback pit }} & & (yellowish red to red) & & 31.6 & 1.09 & 21.6 & 30.4 & 0.10 & 3.01 & 0.37 & - & 1.95 & 0.41 & - & 9.74 & 100.2 \\
\hline \multicolumn{2}{|c|}{ Shaley ore* } & & & & (red to dark red) & & 7.50 & 0.24 & 6.22 & 75.8 & 0.06 & 2.32 & 2.69 & - & 0.03 & 0.23 & - & 5.90 & 99.8 \\
\hline
\end{tabular}

Notes: $\mathrm{McRae}=*$ Average Mt. McRae Shale chemical compositions and powder colour ranges, from Chapter 2, table 2, see appendix 3; McRae $=\mathrm{Mt} . \mathrm{McRae} \mathrm{Shale} ; \mathrm{DDH}=$ diamond drill hole; alt. $=$ altered; Fe $\mathrm{O}_{3} \mathrm{~T}=$ total iron; ' $-'$ = below detection. From and To refers to vertical distance (m) on log of DDH-409 (see text). Powder colour numbers and letters refer to the Munsell colour attributes of hue, value and chroma (Munsell, 1966). 


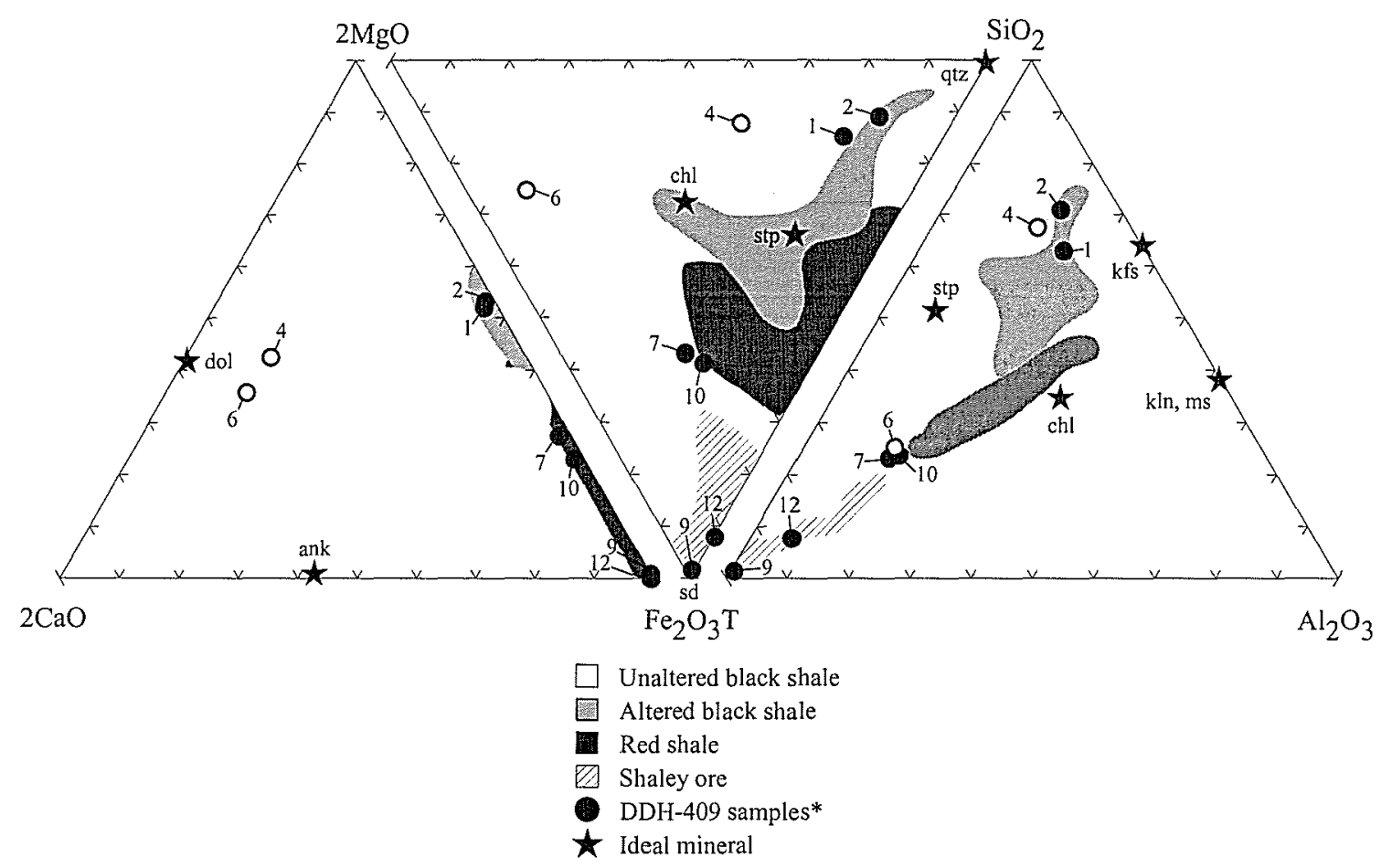

Figure 4.5. Ternary diagrams showing the distribution of $\mathrm{SiO}_{2}, \mathrm{Al}_{2} \mathrm{O}_{3}, \mathrm{Fe}_{2} \mathrm{O}_{3} \mathrm{~T}, \mathrm{MgO}$ and $\mathrm{CaO}$ for shale samples collected from DDH-409 and the relationship of significant mineral phases to the bulk analyses. Note shaded regions represent shales across the Hamersley Province (from Webb et al., 2003). *Open circles represent reddish-green shales from DDH-409; Samples are prefixed by D409 in table 4.1. chl = chlorite; dol = dolomite; $\mathrm{kln}=$ kaolinite; $\mathrm{kfs}=\mathrm{K}$-feldspar; $\mathrm{ms}=$ muscovite; $\mathrm{qtz}=$ quartz; $\mathrm{sd}=$ siderite; $\mathrm{stp}$ $=$ stilpnomelane.

The altered black shale and greyish-green shale are largely comprised of quartz, muscovite and chlorite. The red shale samples contain abundant hematite and chlorite ( \pm kaolinite). The shaley ores are mostly hematite. The reddish-green shales contain chlorite and dolomite (Fig. 4.6), with either quartz and muscovite, or hematite. Again, with the exception of the carbonate-rich reddish-green shales, the mineralogies of samples from DDH-409 are similar to those expected from previous analyses of the Mt. McRae Shale and other shales at Mt. Whaleback (Table 4.2).

\subsection{Petrography of the Upper Mt. McRae Shale across the Hamersley Province}

The mineralogy of stratigraphically equivalent BIF of the Hamersley Group varies significantly across the Hamersley Province (e.g., Trendall and Blockley, 1970; Chapter 2), especially around the high-grade iron ore deposits (e.g., Morris, 1985; Taylor et al., 2001). This is also the case for the Colonial Chert Member of the Mt. McRae Shale. Although samples in this study may not represent the full range of textures within the 
Table 4.2. Semi-quantified mineralogy of rocks from the Mt. McRae Shale at DDH-409 (Mt. Whaleback).

\begin{tabular}{llllcccccccc}
\hline Sample & Unit & Desciption & $\begin{array}{c}\text { Qtz } \\
(\%)\end{array}$ & $\begin{array}{c}\text { Hem } \\
(\%)\end{array}$ & $\begin{array}{c}\text { Dol } \\
(\%)\end{array}$ & $\begin{array}{c}\text { Ms } \\
(\%)\end{array}$ & $\begin{array}{c}\text { ChI } \\
(\%)\end{array}$ & $\begin{array}{c}\text { Goet } \\
(\%)\end{array}$ & $\begin{array}{c}\text { KIn } \\
(\%)\end{array}$ & $\begin{array}{c}\text { Stp } \\
(\%)\end{array}$ & $\begin{array}{c}\text { Py } \\
(\%)\end{array}$ \\
\hline D4091 & McRae & alt. black shale & 24 & & & 41 & 35 & & & \\
D4092 & McRae & greyish-green shale & 40 & & & 36 & 25 & & & \\
D4094 & McRae & reddish-green shale & 21 & & 38 & 11 & 31 & & & \\
D4096 & McRae & reddish-green shale & & 9 & 71 & & 21 & & & \\
D4097 & McRae & red shale & & 41 & & & 59 & & & \\
D4099 & McRae & shaley ore & & 91 & & & & 9 & & \\
D40910 & McRae & red shale & & 42 & & & 39 & & 18 & \\
D40912 & McRae & shaley ore & & 83 & & & & & 17 & & \\
Black shale & & & & & 13 & & & & 87 & \\
Alt. black shale & & 16 & 1 & 2 & 27 & 50 & & & & 4 \\
Red shale $^{2}$ & & & 34 & & & 12 & & 54 & & \\
Shaley ore $^{2}$ & & 80 & & & & & 20 & & \\
\hline
\end{tabular}

Notes: ${ }^{1}$ Average Mt. McRae Shale mineralogy from Chapter $2 ;{ }^{2}$ Average Whaleback Shale Member and Dales Gorge Member mineralogy from Chapter 2, table 6; McRae $=$ Mt. McRae Shale; alt. = altered; $\mathrm{chl}=$ chlorite; dol $=$ dolomite; goet = goethite; hem = hematite; $\mathrm{kfs}=\mathrm{K}$-feldspar; $\mathrm{kln}=$ kaolinite; $\mathrm{ms}=$ muscovite; $\mathrm{py}=$ pyrite; qtz = quartz; $\mathrm{sd}=$ siderite; stp = stilpnomelane.

Colonial Chert Member across the province (or indeed at Mt. Whaleback), they highlight key differences between "unaltered" black shale, altered black shale, red shale, shaley ore and reddish-green shale. Black shale from DDH-47A* near Wittenoom is referred to as "unaltered", even though it clearly has been affected by early diagenesis and low-grade metamorphism (Chapter 2).

Unaltered black shale from DDH-47A* is mostly (>50\%) stilpnomelane and $\mathrm{K}$ feldspar, however it also contains subordinate amounts $(<20 \%)$ of dolomite and quartz, and a highly variable amount $(0-45 \%)$ of siderite, chlorite, pyrite, biotite or muscovite, depending on the sample (Chapter 2) (Figs. 4.7a, b). These minerals are mostly very fine-grained and somewhat aligned into microbands (Figs. 4.7a, b). The pale-green stilpnomelane forms the matrix and typically occurs as laths $\sim 5-20 \mu \mathrm{m}$ in length that form crystal aggregates. These aggregates commonly produce relatively massive bands or partings separated by bands of K-feldspar, chert and carbonates (siderite and dolomite). Most quartz in unaltered black shale is similar in shape and size to that in overlying BIF (Trendall and Blockley, 1970; Chapter 3), and occurs as subhedral, equant grains $\sim 10-20 \mu \mathrm{m}$ across. These grains can form "mosaic chert" aggregates or layers, but are also distributed throughout the matrix. Recrystallized quartz can also be 


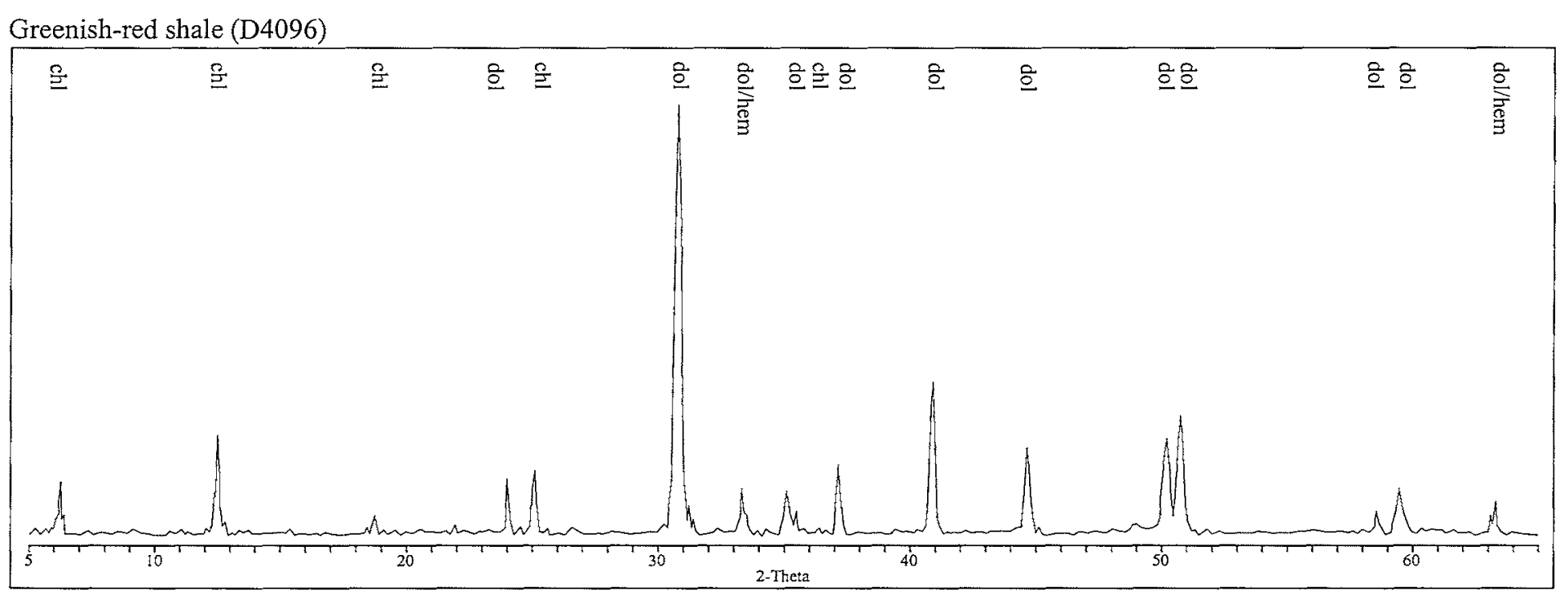

Figure 4.6. XRD trace of sample D4096 with mineral peaks labelled: chl = chlorite; dol = dolmite; hem = hematite. 
Unaltered black shale, sample 4745, Wittenoom Gorge
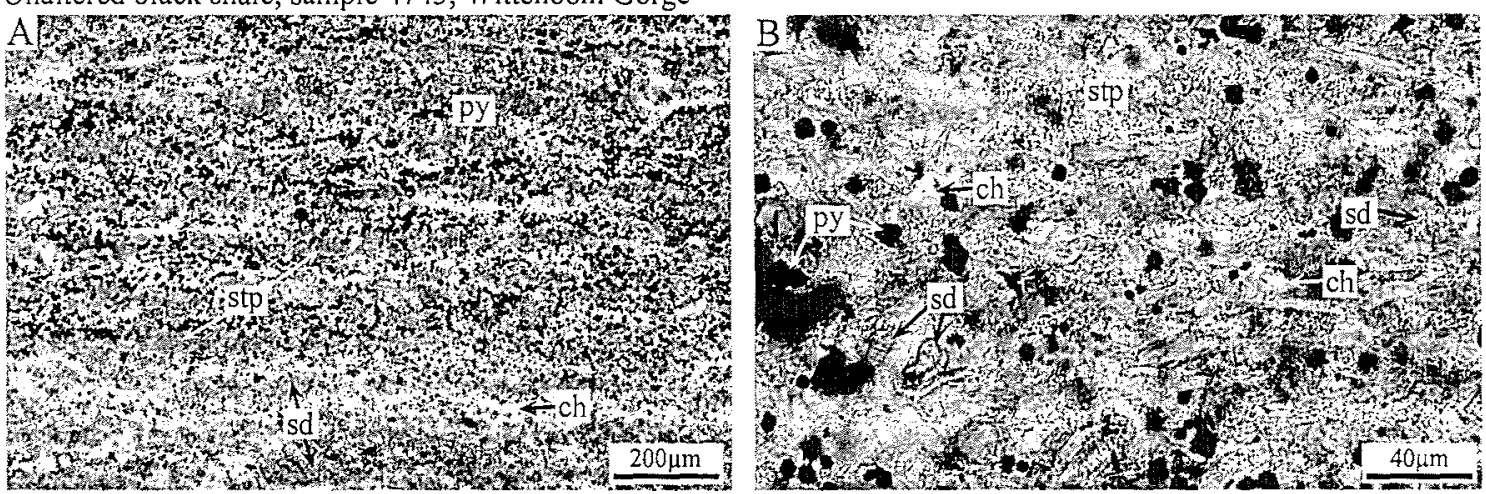

Altered black shale, sample RC, Mt. Whaleback pit
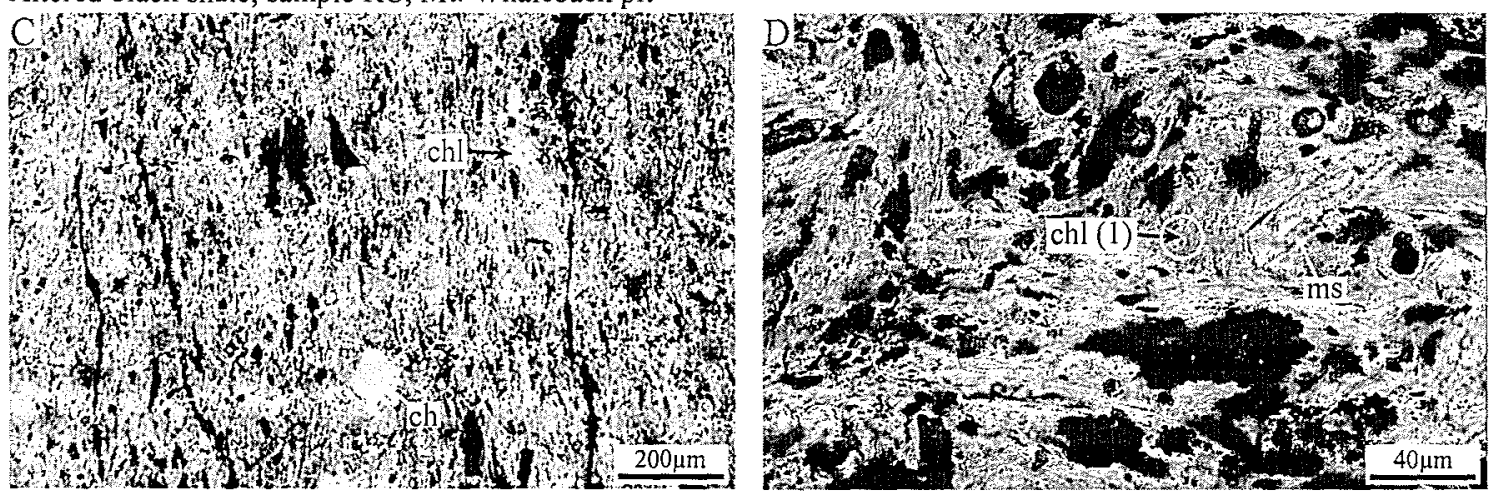

Greyish-green shale, sample D4092, Mt. Whaleback pit
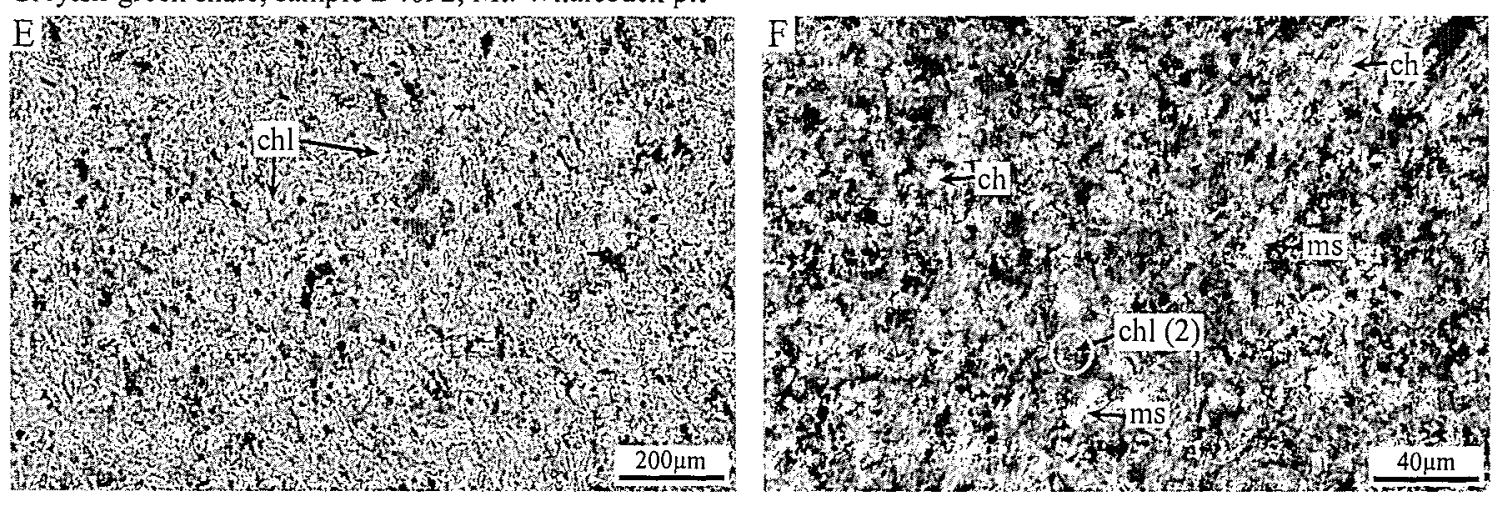

Figure 4.7. Photomicrographs of Mt. McRae Shale across the Hamersley Province showing common textures and locations of microprobe analyses (numbers refer to probe analyses in table 4.3 and appendix 5). ( $a$ and $b$ ) Unaltered black shale consisting of a weakly laminated matrix of very fine-grained stilpnomelane (stp), chert (ch), siderite (sd) and pyrite (py). Plane polarized light. (c and d) Altered black shale consisting of very fine-grained chlorite (chl) and muscovite (ms) with minor chert (ch). Note that black material is possibly a mixture of extremely fine-grained mattered silicate and/or carbon-rich material. Some minor pyrite is also present in these rocks and may account for some opaque phases. Plane polarized light. (e and $f$ ) Greyish-green shale consisting of extremely fine-grained disseminated chlorite (chl), chert (ch) and muscovite (ms). Plane polarized light. 
identified in small fractures, veins, and strain shadows of uncommonly large masses of pyrite. The K-feldspar looks very similar to the mosaic chert, and forms subhedral to anhedral crystals $\sim 5-10 \mu \mathrm{m}$ across, evenly distributed though the matrix. Siderite and dolomite typically occur as subhedral to euhedral shaped grains $\sim 1-20 \mu \mathrm{m}$ in diameter. Importantly, these carbonates are either dispersed throughout the stilpnomelane matrix or grouped into carbonate-rich aggregates or microbands. No large carbonate grains or veins were found in any unaltered black shale sample.

In the altered black shale (and greyish-green shale) of the Colonial Chert Member at Mt. Whaleback, the three dominant minerals - chlorite, muscovite and quartz - are again mostly very fine-grained and somewhat aligned, although microbanding is less obvious (Figs. 4.7c-f). The abundant light to medium-green chlorite typically occurs as scaly or massive aggregates of randomly orientated fibrous grains $\sim 5-30 \mu \mathrm{m}$ long. The muscovite occurs as scattered fine-grained laths 5-10 $\mu \mathrm{m}$ in length, although some can be up to $50 \mu \mathrm{m}$. Most quartz in altered black shale looks similar to that in unaltered black shale. Some minor pyrite is also present in these rocks. The chemical and mineralogical differences between unaltered and altered black shale of the Mt. McRae Shale can mostly be explained by incongruent hydrolysis of stilpnomelane (or its precursor mineral) to chlorite, and K-feldspar to muscovite (Chapter 2). Although the overall distribution of minerals in unaltered and altered black shales may support this contention (Figs. 4.7a-f), direct replacement relationships cannot be seen with methods used in this investigation due to the very small grain sizes. Of crucial interest, no carbonate grains can be found in typical altered black shale, consistent with its very low $\mathrm{CaO}$ contents.

The hematite, chlorite, and kaolinite of red shale occur at micron-sized masses (Figs. 4.8a, b). The hematite generally is found as anhedral to subhedral aggregates of minute $(<2 \mu \mathrm{m})$ bladed crystals closely intergrown with kaolinite. For the most part pseudomorph textures are poorly defined, mainly because of the lack of significant recognisable features in the original shales. However, in some samples mottled or swirling patterns suggest hematite may have replaced silicates such as stilpnomelane or 
Red shale, sample 325E, Mt. Whaleback pit

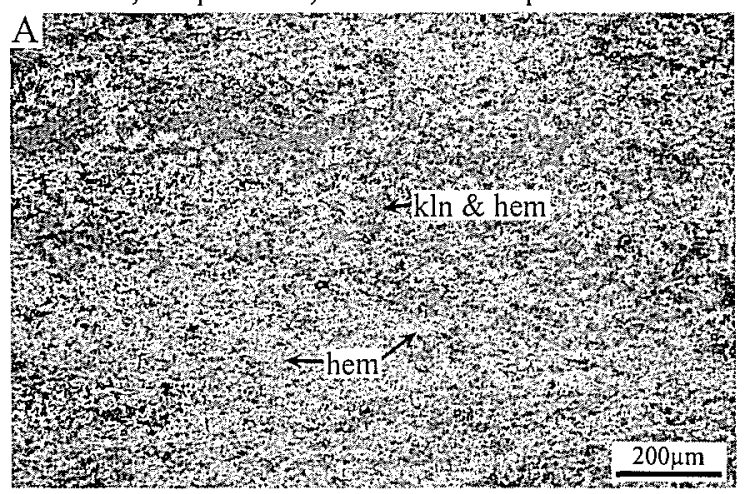

Shaley ore, sample 423, Mt. Whaleback pit

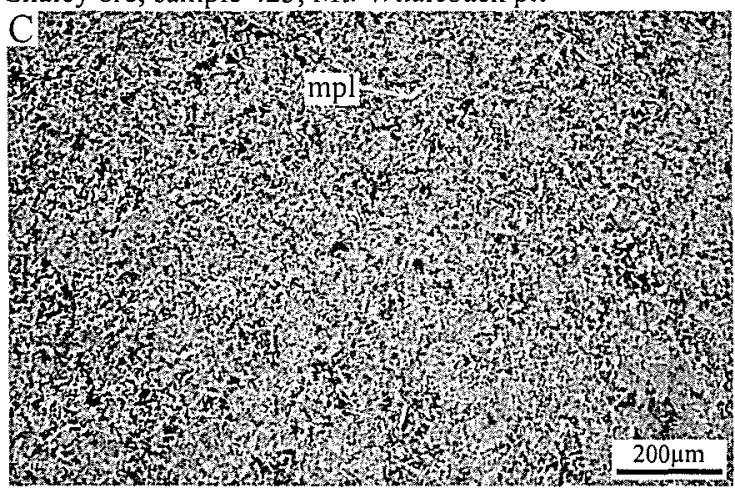

Reddish-green shale, sample D4094, Mt. Whaleback pit

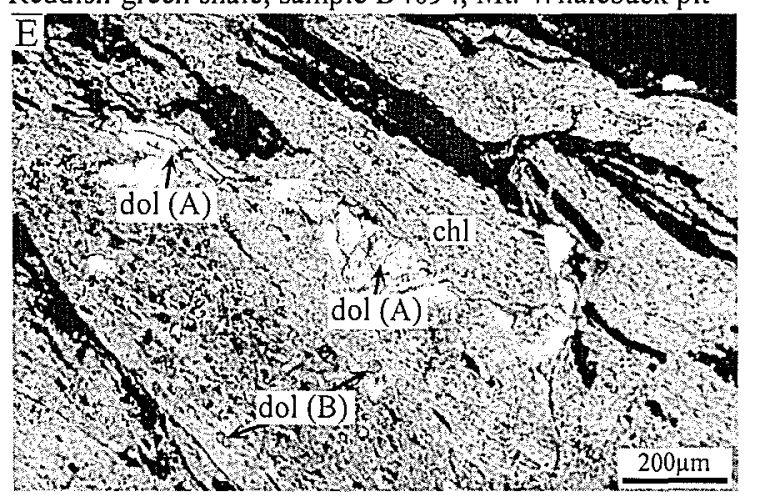

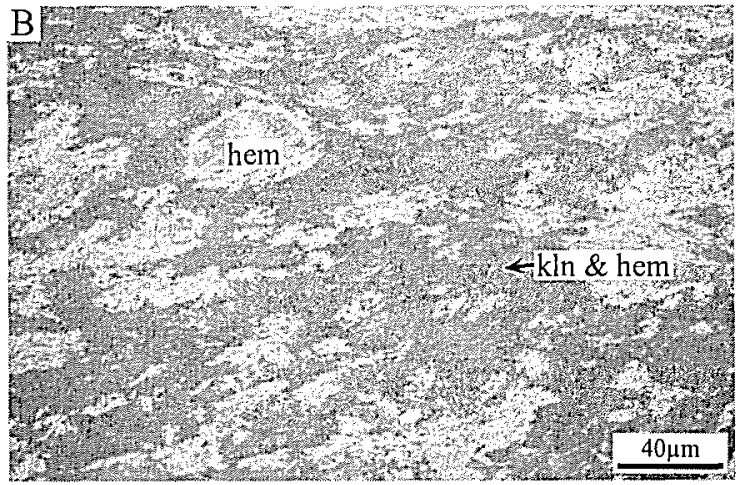
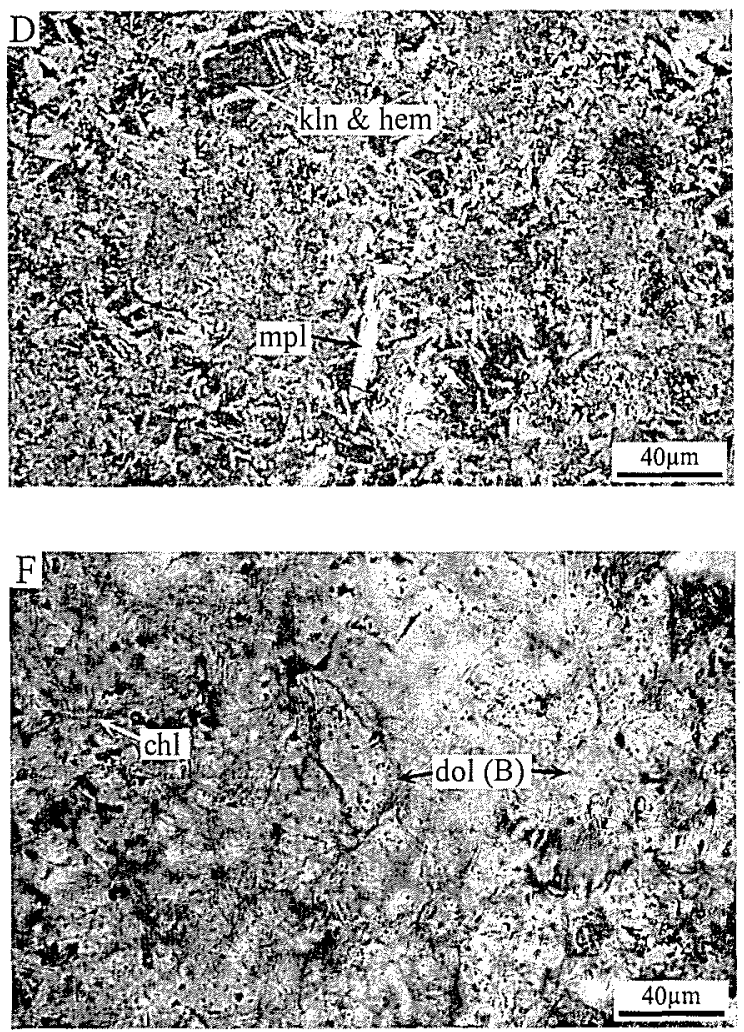

Figure 4.8. Photomicrographs of Mt. McRae Shale from the Mt. Whaleback pit showing common textures at field views of nominally $0.2 \mathrm{~mm}$ and $1 \mathrm{~mm}$. (a and b) Red shale showing very fine-grained hematite (hem) aggregates in a very fine, hematite stained kaolinite matrix. Reflected polarized light. (c and d) Randomly orientated fine-grained microplaty hematite laths $(\mathrm{mpl})$ in shaley ore. Reflected polarized light. (e and f) Reddish-green shale containing relatively coarse dolomite (dol A) in fine-grained chlorite (chl) and dolomite (dol B) matrix. Plane polarized light. Numbers refer to locations of microprobe analyses (Table 4.3; Appendix 5). 
chlorite (Figs. 4.8a, b). More euhedral shaped hematite may indicate the replacement of carbonates and/or pyrite. The kaolinite and chlorite in these rocks were not clearly identified by petrographic methods due to the very fine grain sizes and pervasive red staining caused by iron oxides.

Shaley ore is very similar to red shale except it contains relatively coarser laths of microplaty hematite scattered throughout extremely fine-grained anhedral goethitekaolinite-hematite matrix (Figs. 4.8c, d). Microplaty hematite laths typically range between $5-20 \mu \mathrm{m}$, although some can reach $50 \mu \mathrm{m}$ in length. Generally these laths are much finer than those in ore (Chapter 3).

One of the reddish-green shale samples from DDH-409 has some textural similarities to altered black shale. Sample D4094 contains abundant fine-grained chlorite, quartz and muscovite found in weakly defined microbands (Figs. 4.8e, f). However, this sample also hosts relatively coarse-grained $(\sim 10-100 \mu \mathrm{m})$ subhedral dolomite (dol A) disseminated through the matrix. Fine-grained dolomite (dol B) also occurs sporadically through the matrix in this rock (Fig. 4.8f). The other reddish-green shale sample (D4096) is noticeably different from all other samples of the Mt. McRae shale discussed in this paper. This sample predominantly consists of a very fine-grained dolomite-rich matrix crosscut by numerous carbonate and chlorite veins (Figs. 4.9a-e). Individual carbonate grains in the matrix occur as $5-20 \mu \mathrm{m}$ diameter subhedral to euhedral crystals, although much larger grains up to $2 \mathrm{~mm}$ long occur in and around veins (Figs. 4.9d, e). The abundance of dolomite (and the relative depletion of $\mathrm{SiO}_{2}$ ), along with these textures, suggests dolomite has replaced earlier silica-bearing phases. The carbonate veins contain relatively coarse-grained euhedral ferroan-dolomite and ankerite often with cavities that are filled by later colloform hematite or goethite. Other veins consist mostly of very fine-grained chlorite (Figs. $4.9 \mathrm{a}, \mathrm{c}, \mathrm{d}, \mathrm{e}$ ). Both vein types transect each other, suggesting they developed synchronously. Large (1 to $5 \mathrm{~mm}$ ) euhedral porphyroblasts of fine-grained ferroan-dolomite/ankerite aggregates are spatially associated with both vein types (Figs. $4.9 \mathrm{c}, \mathrm{d}$ ). 
Reddish-green shale, D4096, Mt. Whaleback pit
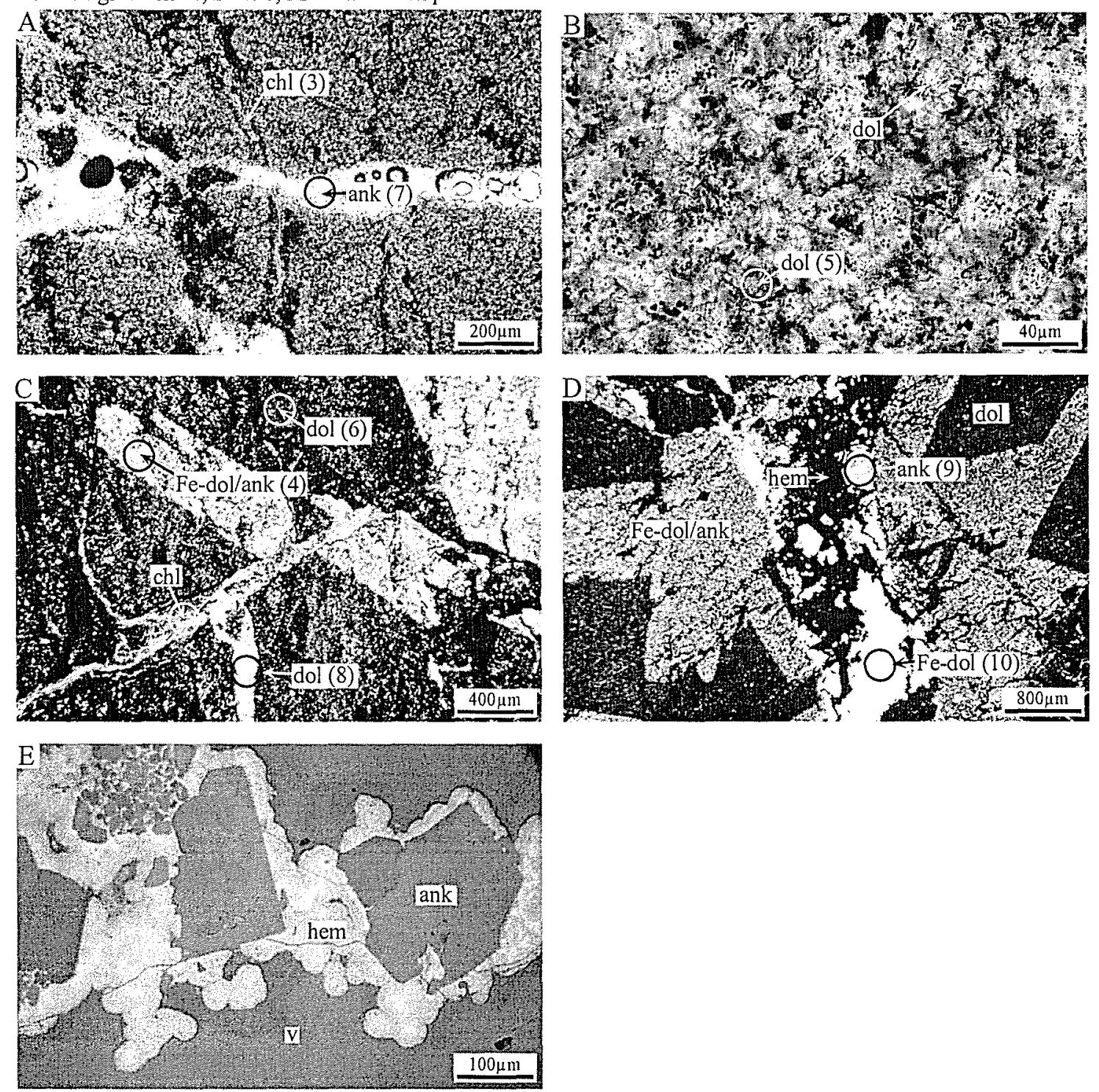

Figure 4.9. Photomicrographs of reddish-green shale from Mt. Whaleback (sample D4096), showing common textures at field views of nominally $0.2 \mathrm{~mm}$ and $1 \mathrm{~mm}$. (a) Clear vein of coarse-grained ankerite (ank) cross-cutting chlorite (chl) vein in relatively fine-grained ferroan-dolomite-rich shale. Plane polarized light. (b) Fine-grained dolomite (dol) matrix in reddish-green shale. (c) Chlorite (chl) vein crosscutting clear dolomite (dol) vein and coarse porphyroblast of fine-grained ferroan-dolomite/ankerite. Plane polarized light. (d) Coarse-grained ferroan-dolomite and ank (Fe-dol and ank) vein cutting large ferroan-dolomite/ankerite porphyroblasts. Note secondary colloform hematite (hem) in the vein. Plane polarized light. (e) Secondary colloform hematite (hem) in coarse-grained ankerite vein. Reflected polarized light. Numbers refer to location of microprobe analyses (Table 4.3; Appendix 5). 


\subsection{Chlorite and carbonate composition}

Microprobe analyses (Table 4.3) demonstrate that fine-grained chlorite in altered black shale and in veins within reddish-green shale have an essentially identical chemical composition. This chlorite consists of $\mathrm{SiO}_{2}$ (26.7-27.4\%), $\mathrm{Al}_{2} \mathrm{O}_{3}$ (17.6$19.5 \%), \mathrm{FeO}(21.7-27.4 \%), \mathrm{MgO}(13.0-14.9 \%)$ and $\mathrm{H}_{2} \mathrm{O}$ (13.2-16.3\%), with all other components less than 1\%. By contrast, the fine-grained and vein-hosted carbonates within the reddish-green shale sample D4096 display a moderate amount of chemical variation. Microprobe analyses show that $\mathrm{FeO}, \mathrm{MnO}$ and $\mathrm{MgO}$ contents of these carbonates range from 2.5 to $10.6 \%, 0.9$ to $3.7 \%$, and 12.9 to $18.9 \%$, respectively. This

Table 4.3. Representative microprobe analyses of silicate and carbonate minerals in Mt. McRae Shale from DDH-409 (Mt. Whaleback).

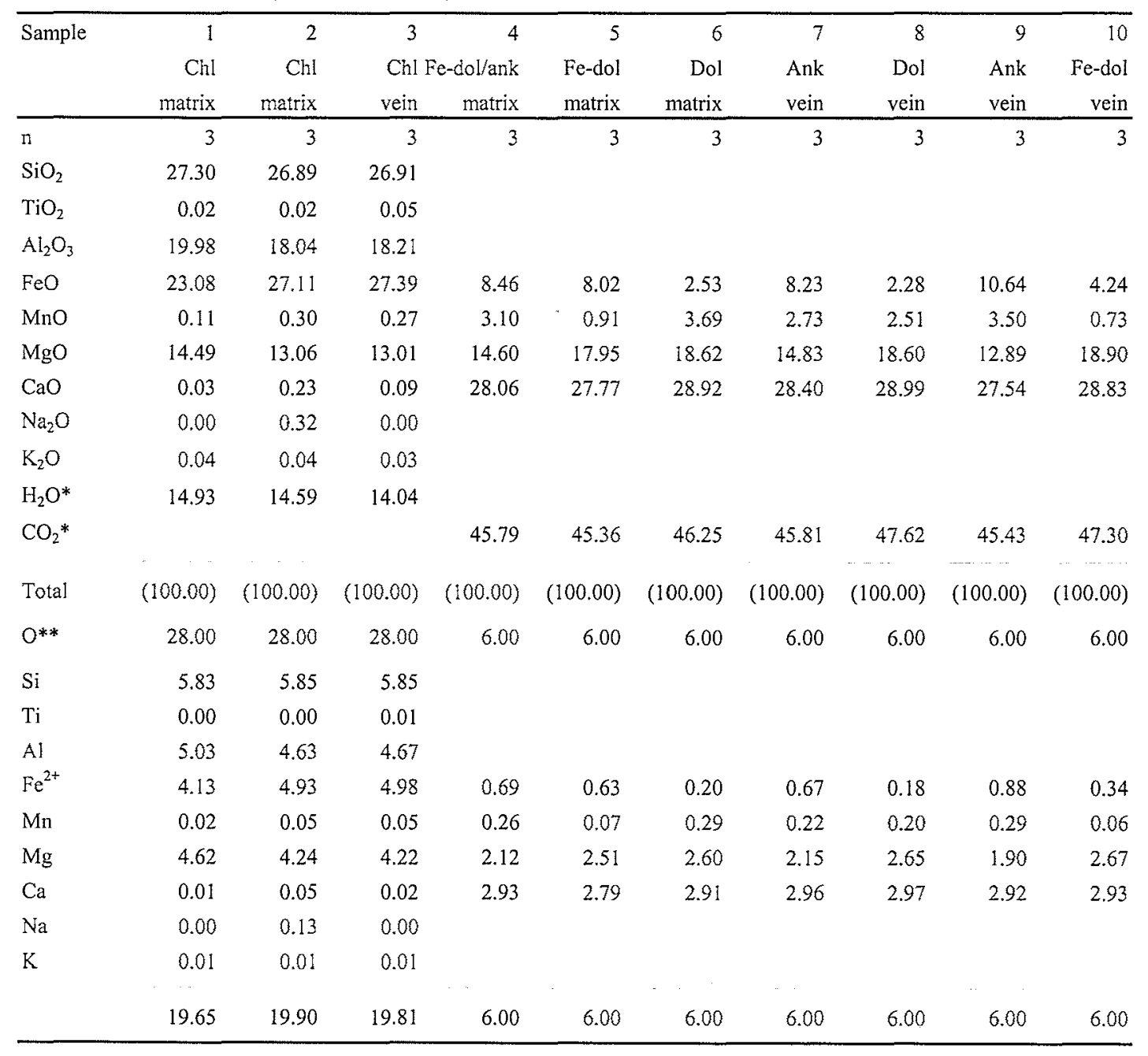

Notes: For corresponding sample numbers and descriptions see Appendix 5.4; total Fe as $\mathrm{Fe}^{2+}$ only; $\mathrm{n}=$ number of analyses (each analysis presented in appendix 5.4). ${ }^{*} \mathrm{H}_{2} \mathrm{O}$ and $\mathrm{CO}_{2}$ data obtained by subtracting electron microprobe total from $100 \%$.

** Number of oxygens used to calculate ions. Ank = ankerite; $\mathrm{Chl}=$ chlorite; Dol = dolomite; Fe-dol = ferroan dolomite. 
variation is probably not "analytical contamination" (i.e., the collection of data from proximal, non-carbonate phases) because all analyses of carbonate have appropriately high $\mathrm{CaO}$ and $\mathrm{CO}_{2}$ contents of 27.5 to $28.9 \%$, and 45.4 to $47.6 \%$, respectively (Table 4.3). The variation is also not obviously related to texture because both fine-grained and vein-hosted carbonates show differences in chemistry. To generalise, the carbonates in the reddish-green shale exhibit solid solution between dolomite and ankerite (Fig. 4.10).

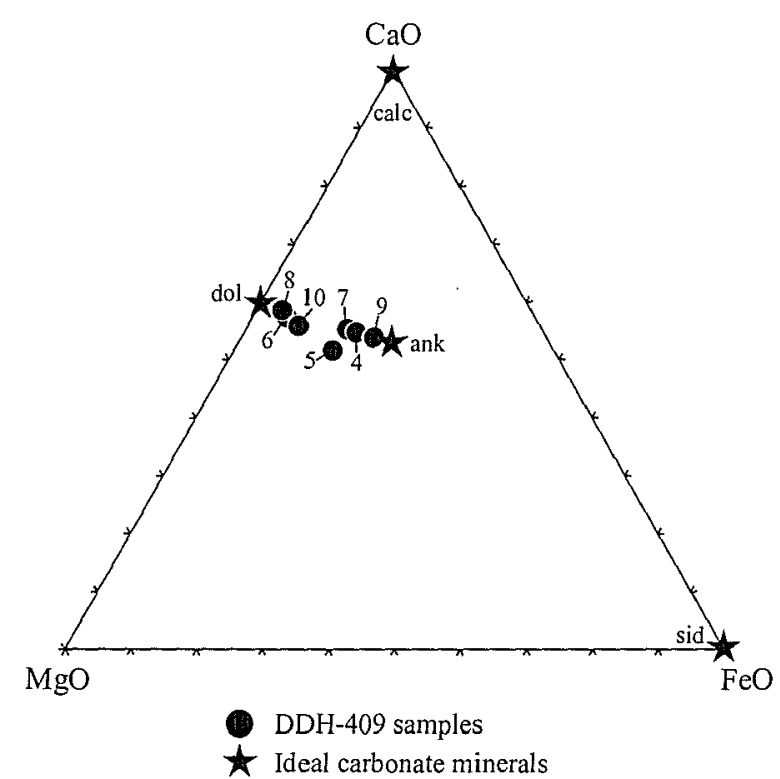

Figure 4.10. Ternary diagram showing chemical compositions of carbonate in red and reddish-green Mt. McRae Shale from DDH-409 using the microprobe and those of end-member carbonate minerals ankerite (ank), calcite (calc), dolomite (dol) and siderite (sid) (from Deer et al., 1998; p.625). Numbers refer to microprobe samples in table 4.3 and locations of microprobe analyses.

\section{DISCUSSION}

The widely cited "supergene-metamorphic" model for high-grade hematite ores of the Hamersley Province proposed the following sequence of events (Morris, 1980, 1985; Harmsworth et al., 1990). During the Ophthalmian Orogeny ca. 2.45 to $2.2 \mathrm{Ga}$, original BIF was uplifted and exposed to near-surface weathering that simultaneously oxidized magnetite layers to martite and replaced chert layers with hydrous iron oxides. Ore was then formed when this altered BIF was buried sometime after the Ophthalmian Orogeny and the hydrous iron oxides were upgraded to microplaty hematite.

Recently acquired geochronological, structural, and geochemical data sets demonstrate several fundamental problems with this model (Martin et al., 1998; Barley 
et al., 1999; Oliver and Dickens, 1999; Powell et al., 1999; Taylor et al., 2001; Chapters 2,3). For example, detrital microplaty hematite clasts can be found in conglomerates of the lower Wyloo Group ( $>2.2 \mathrm{Ga}$ ), suggesting that some high-grade iron ore deposits formed before the second deformation event needed in the supergene model to upgrade the goethite to hematite. More problematical is that BIF surrounding the Mt. Whaleback deposit is composed of martite, microplaty hematite and chert (Chapters 2, 3), clearly showing that some, perhaps all, magnetite oxidation occurred independently of silica removal.

Studies at the Mt. Tom Price and Giles Mini deposits (Fig. 4.1) have documented carbonate alteration zones beneath the high-grade hematite ore. These zones contain BIF and shale where carbonates (both siderite and ankerite) have replaced minerals including magnetite, stilpnomelane and chert (Dalstra et al., 2002b; Taylor et al., 2001). They are also found occur along major normal faults (Fig. 4.3). These observations have led to an alternative "hypogene-meteoric" model for martite-microplaty hematite ore formation (Barley et al., 1999; Taylor et al., 2001). During the first stage, a hightemperature basinal brine moved upward along the normal faults to replace silicabearing phases with carbonate, leaving magnetite-siderite BIF. Moderately hot oxidizing and presumably acidic fluids then oxidized the magnetite-siderite rich assemblages to martite-microplaty hematite-ankerite ore. Subsequent supergene weathering eventually destroyed gangue phases such as ankerite and apatite leaving high-grade, low phosphorous, martite-microplaty hematite ore.

Until this investigation of DDH-409, no evidence of carbonate alteration had been found at Mt. Whaleback. However, the data presented here clearly shows that carbonate replacement of silica-bearing phases occurred within the Mt. McRae Shale beneath the martite-microplaty ore deposit at Mt. Whaleback, thus negating arguments that carbonate replacement observed at Mt. Tom Price and Giles Mini was unimportant to high-grade iron ore formation because of its absence at Mt. Whaleback (e.g., Kneeshaw and Kepert, 2002; Morris, 2002a, b). Reddish-green shale in intervals from DDH-409 are significantly enriched in $\mathrm{MgO}, \mathrm{CaO}$ and LOI and depleted in $\mathrm{SiO}_{2}$ (Table 4.2). The 
rocks consist of abundant dolomite/ankerite, and one sample (i.e., D4096) lacks appreciable quartz (Table 4.3). Texturally, these reddish-green shales are characterised by coarse-grained euhedral ferroan-dolomite porphyroblasts in a fine-grained dolomite matrix that, in places, are cut by chlorite and dolomite/ankerite veins of synchronous age. Chemically and mineralogically, these carbonate-rich shales are distinct from the common altered black shales and red shales at Mt. Whaleback.

Although no magnetite-carbonate BIF has been found in DDH-409 or anywhere at Mt. Whaleback to date, the unusual carbonate alteration of shale occurs in strata immediately beneath ore and adjacent to a major normal fault, placing it in an analogous situation to similar alteration of BIF at Mt. Tom Price and BIF and shale at Giles Mini (Dalstra et al., 2002b; Taylor et al., 2001). Interestingly, carbonate-rich shales are rare at Mt. Tom Price and this may reflect differences in the chemical composition of precursor rocks. However, it is difficult to rigorously argue for or against any explanation with available data. In particular, the lack of detailed mineralogical and chemical data on carbonate-altered shales at Mt. Tom Price and Giles Mini (Dalstra et al., 2002b; Taylor et al., 2001) hampers direct comparison with this work.

Previously work has (Chapter 2) suggested that the conversion of unaltered black shale to altered black shale occurred during regional metamorphism associated with the Ophthalmian Orogeny $\left(\mathrm{D}_{2}\right.$, ca 2.45 to $\left.2.2 \mathrm{Ga}\right)$. This process involved acidic, reducing fluids that changed stilpnomelane (or a precursor clay phase) to chlorite, and K-feldspar to muscovite. Importantly, most carbonates were subject to extensive dissolution (Chapter 2). As altered black shale hosts the carbonate alteration at Mt. Whaleback, the carbonate replacement seen in the reddish-green shales most likely occurred after peak metamorphism. Texturally this is supported by the observation of large laths cutting weak foliation (Fig. 4.9c). This timing coincides with that of ore formation, as well as the activation of normal faults, which are thought to reflect post- $\mathrm{D}_{2}$ uplift and extension (Powell et al., 1999; Taylor et al., 2002).

Assuming that carbonate alteration is a requisite step toward martite-microplaty ore formation, an open issue is why magnetite-carbonate BIF has not been found in 
macrobands of the Dales Gorge Member at Mt. Whaleback. There are two possible explanations. First, these rocks exist but have not yet been documented. Given the enormous size of the Mt. Whaleback deposit, carbonate-rich BIF could lie below current pit dimensions and outside the depths of examined drill cores. Alternatively, these rocks have been altered since forming (Chapter 2). In particular, the ubiquitous martite-chert BIF and red shales of the Dales Gorge Member at Mt. Whaleback suggest that these rocks, unlike the Mt. McRae Shale, have been affected by pervasive oxidation (Chapter 2). In the reddish-green shales such oxidation may be reflected in the late hematite infill that surrounds earlier carbonates and the abundance of ankerite (Fig. 4.9e). This oxidation process, which involves acidic waters, eventually destroys carbonate (Chapters 2,3). Indeed, it is strongly suggested here that martite-microplaty hematite ores occur precisely where carbonate alteration zones in BIF were overprinted by pervasive oxidation.

\section{CONCLUSION}

Several models have been proposed to explain the origin of high-grade hematite ore deposits in the southern Hamersley Province. Most recently, chemical and mineralogical investigations at the Mt. Tom Price and Giles Mini deposits have led to a "hypogene" model where carbonate replacement of silica along normal faults is an important first step in the formation of ore. This study has clearly shown intervals of the Mt. McRae Shale along the Mt. Whaleback fault beneath the Mt. Whaleback ore deposit that may have been affected by fluids that replaced silica-bearing phases with carbonates (dolomite). This is the first good evidence to support a hypogene origin for the Mt. Whaleback deposit and to link martite-microplaty hematite ore deposits across the Hamersley Province to a common genetic model. It is stressed, however, that open issues remain, including the lack of carbonate-rich BIF at Mt. Whaleback and the different composition of $\mathrm{Fe}$-rich carbonates at the various deposits. 


\section{CHAPTER 5}

TRACE ELEMENT CHARACTERISTICS AND MASS-VOLUME CHANGES ASSOCIATED WITH THE ALTFRATION OF BANDED IRON-FORMATION AND SHALE ACROSS THE HAMERSLEY PROVINCE,

WESTERN AUSTRALIA 


\section{ABSTRACT}

Some of the world's largest iron ore deposits are located in deformed parts of the southern Hamersley Province, where banded iron-formation (BIF) of the Dales Gorge Member of the Brockman Iron Formation has been altered to high-grade hematite ore. Several models have been proposed to explain the origin of these ores and most invoke profound changes in chemistry, particularly the significant addition of iron. Earlier major element work indicated profound chemical changes occur between weathered, oxidized and mineralized BIF and shales across the province. However, quantification of the mass differences was hampered by the very low abundances of many trace elements inherited from the precursor rocks and the lack of key trace elements (e.g., rare earth elements) needed to fully assess the geochemical processes. This study utilizes comprehensive trace element chemistry, calculations of mass-volume and thickness changes and previously published major element and paragenetic studies. Statistical analysis of the chemical dataset using principal components analysis suggests three to four main components can explain the bulk of element behaviour in BIF and shale across the province, which correlate with quartz, iron oxide, silicate and carbonate content of the rocks. Rare earth element (REE) patterns of BIF and shale are relatively similar, although REE contents in the latter rocks are considerably higher. Most samples exhibit low to moderate REEs, have positive Eu anomalies, are relatively enriched in HREEs and have slightly negative or absent Ce anomalies. BIF REE patterns suggest iron and REEs were derived from submarine hydrothermal systems, whereas similarities of Hamersley shale REE patterns with typical Archean shales indicate a significant detrital input. Importantly diagenesis, metamorphism, weathering and mineralization did not significantly affect REE contents of rocks across the Hamersley Province. Using a reference frame in which $\mathrm{Al}_{2} \mathrm{O}_{3}, \mathrm{Sc}$ and REEs are relatively immobile, weathered and oxidized $\mathrm{BIF}$ are consistently depleted in $\mathrm{K}_{2} \mathrm{O}$, $\mathrm{MgO}, \mathrm{CaO}, \mathrm{Ba}, \mathrm{Rb}, \mathrm{Sr}$ and $\mathrm{Y}$ and enriched in $\mathrm{Co}, \mathrm{Cr}$ and $\mathrm{Ni}$. All other elements, including $\mathrm{Fe}_{2} \mathrm{O}_{3}$ and $\mathrm{SiO}_{2}$, are relatively immobile. Compared to all $\mathrm{BIF}$, high-grade hematite ore is strongly depleted in $\mathrm{SiO}_{2}, \mathrm{CaO}, \mathrm{P}_{2} \mathrm{O}_{5}$, $\mathrm{Co}$ and $\mathrm{Ni}$. Importantly, $\mathrm{Fe}_{2} \mathrm{O}_{3}$ 
was probably neither lost nor gained during this process. The lack of iron addition during the alteration of BIF is strengthened by its relative immobility during the transformation of surrounding altered black shale to red shale. However, the conversion of altered black shale to recently discovered reduced reddish-green shale deep within the Mt. Whaleback pit suggest some process prior to oxidation may have added $\mathrm{CaO}$ and $\mathrm{MgO}$ to the rocks. This alteration phase could be related to the early silica removal phase of the hypogene-meteoric model for Mt. Tom Price. Measurements of stratigraphic thicknesses of little altered and mineralized equivalents helps to further constrain the otherwise low precision of the geochemically determined mass and volume changes. Regardless of which ore genesis model "stands the test of time" the data confirms that the crucial ore-forming step is silica loss and not widespread iron metasomatism.

\section{INTRODUCTION}

The Hamersley Province of northern Western Australia (Fig. 5.1) is one of the largest iron ore producing regions in the world. Giant premium hematite-rich deposits occur in the south where sequences of banded iron-formation (BIF), originally composed predominantly of magnetite and chert, have been altered to martite and microplaty hematite. Two main models have emerged in the past few decades for the genesis of these high-grade hematite ores. The most widely cited supergenemetamorphic model (Harmsworth et al., 1990; Morris, 1980, 1985, 1998) proposes that Proterozoic subsurface weathering of original BIF simultaneously replaced silica with goethite and oxidized magnetite to martite. High-grade hematite ore formed when subsequent metamorphism associated with burial upgraded the goethite in these altered rocks to microplaty hematite. This model has been questioned in recent years with the advent of new geochronological, structural, fluid inclusion and geochemical results (e.g., Martin et al., 1998; Barley et al., 1999; Oliver and Dickens, 1999; Powell et al., 1999; Taylor et al., 2001; Chapters 2-4). To account for some of these findings these recent investigations have collectively proposed a mixed hypogene-supergene model. 

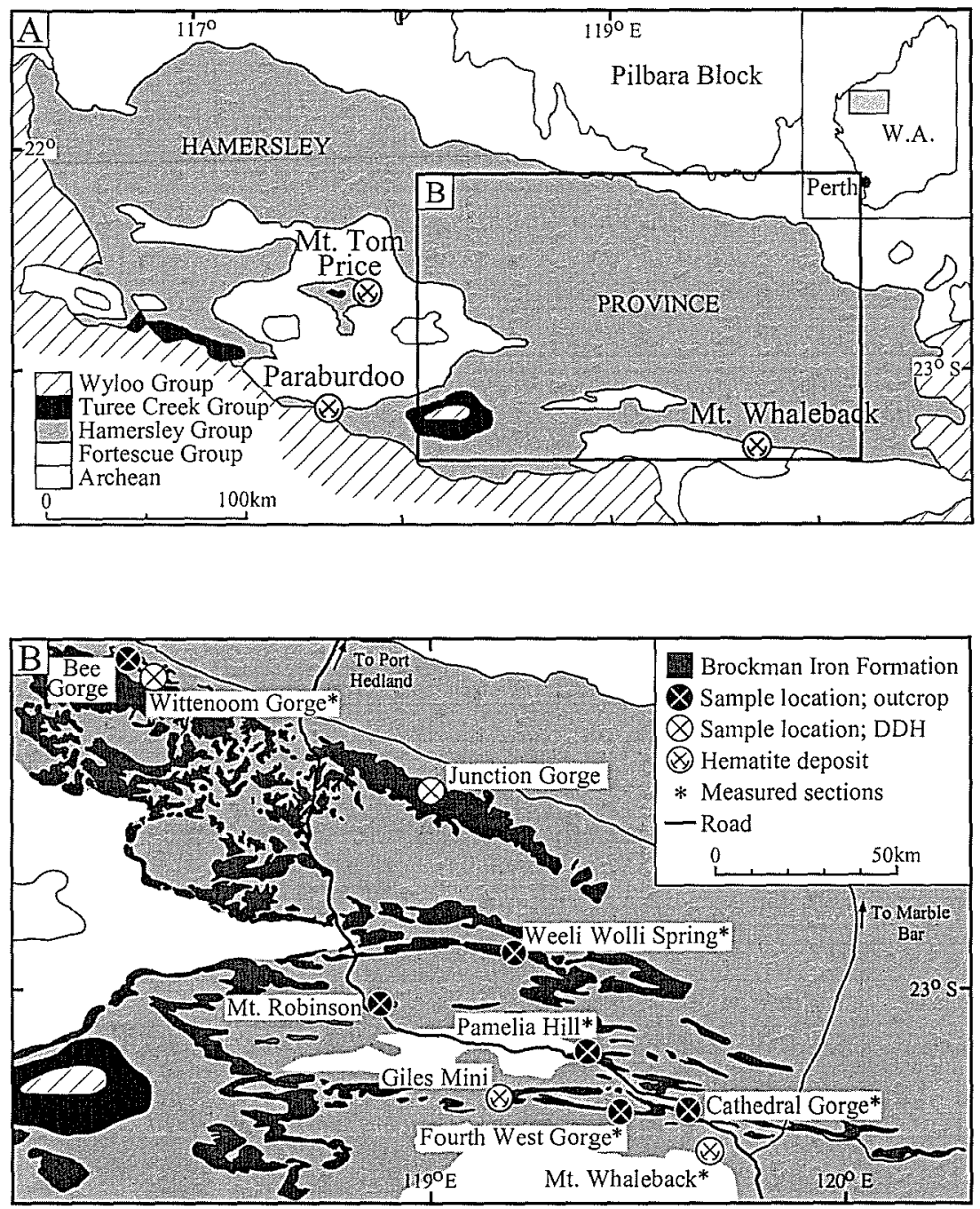

Figure 5.1. Location and simplified geology of the Hamersley Province (modified from Trendall and Blockley, 1970). (a) Location of the Hamersley Province and the three major high-grade hematite deposits. Outlined area is enlarged in (b). (b) General geology of the southeastern Hamersley Province, showing outcrop of Brockman Iron Formation, sample locations and localities of measured stratigraphic sections. DDH = Diamond Drill Hole.

The most detailed of these (i.e., Taylor et al., 2001) suggests high-grade hematite ore formation at Mt. Tom Price initially involved early silica loss at higher temperatures, followed by progressively lower temperature oxidation by heated and/or cool surficial fluids. However, at Mt. Whaleback, oxidation occurred synchronous with or prior to Si loss, although earlier Si loss explains rock types at both deposits (Chapter 2). This has been further strengthened by the discovery of carbonate-rich, silica-poor shales deep within the deposit (Chapter 4). Importantly, most models require the addition of Fe to upgrade original BIF to high-grade hematite ore. In the supergene-metamorphic model 
iron is added to the rocks as goethite during deep weathering (Morris, 1985; Morris et al., 1980). Even in the hypogene-meteoric model some addition of $\mathrm{Fe}$ is required during the carbonate replacement of silica in the early hypogene stage (Taylor et al., 2002).

While many chemical investigations have focussed on broad issues related to BIF and shale deposition (e.g., Holland, 1973; Trendall and Blockley, 1970; Trendall and Pepper, 1976; Anbar and Holland, 1992; Alibert and McCulloch, 1993; Barley et al., 1997), most did not include a sampling strategy amenable to important questions concerning iron ore genesis. Furthermore, only Trendall and Pepper (1976) and Alibert and McCulloch (1993) utilized trace element chemistry. Previous work comparing major element chemistry from unaltered sequences in the north to altered and ultimately mineralized sequences in the south (Chapters 2-4) has suggested that during the alteration of rocks across the Hamersley Province, Fe and other elements were "gained" in some samples while "lost" in others. However, any significant conclusions on the absolute mass differences were hampered by the high variability of the chemical data and in particular, elemental abundances near analytical detection limits (common characteristic of BIF). Furthermore, this previous work lacked trace elements needed to fully assess the geochemical processes.

This study compares equivalent rocks sequences across the Hamersley Province using trace element chemistry in conjunction with calculations of mass, volume and thickness changes as well as the previous major element and paragenetic studies (Chapters 2-4). However unlike earlier research, which has focussed almost exclusively on the chemistry of BIF layers, this investigation will also analyse the chemistry of surrounding shales in order to further constrain BIF. This work will not only better constrain some of the chemical processes involved in iron ore formation, but will also provide an improved understanding of the primary origins of BIF and shale in the Hamersley Province.

\section{GEOLOGICAL VARIATION ACROSS THE HAMERSLEY PROVINCE}

The Proterozoic Hamersley Group (ca. 2.6-2.45 Ga; Barley et al., 1997; Trendall 
et al., 1998) covers approximately $40,000 \mathrm{~km}^{2}$ of the southern Pilbara Craton, Western Australia (Figs. 5.1, 5.2), and is composed of a succession of well-preserved units of BIF, shale, dolomite and volcanic rocks. In the northern Hamersley Province rocks of this group are very gently folded. However, in the south, they are strongly deformed due to Palaeoproterozoic contraction associated with the collision of the Pilbara and Yilgarn Cratons (Tyler and Thorne, 1990; Martin et. al., 1998; Taylor et. al., 2001). Metamorphic grade varies from prehnite-pumpellyite in the north to lowermost greenschist in the south (Smith et al., 1982).

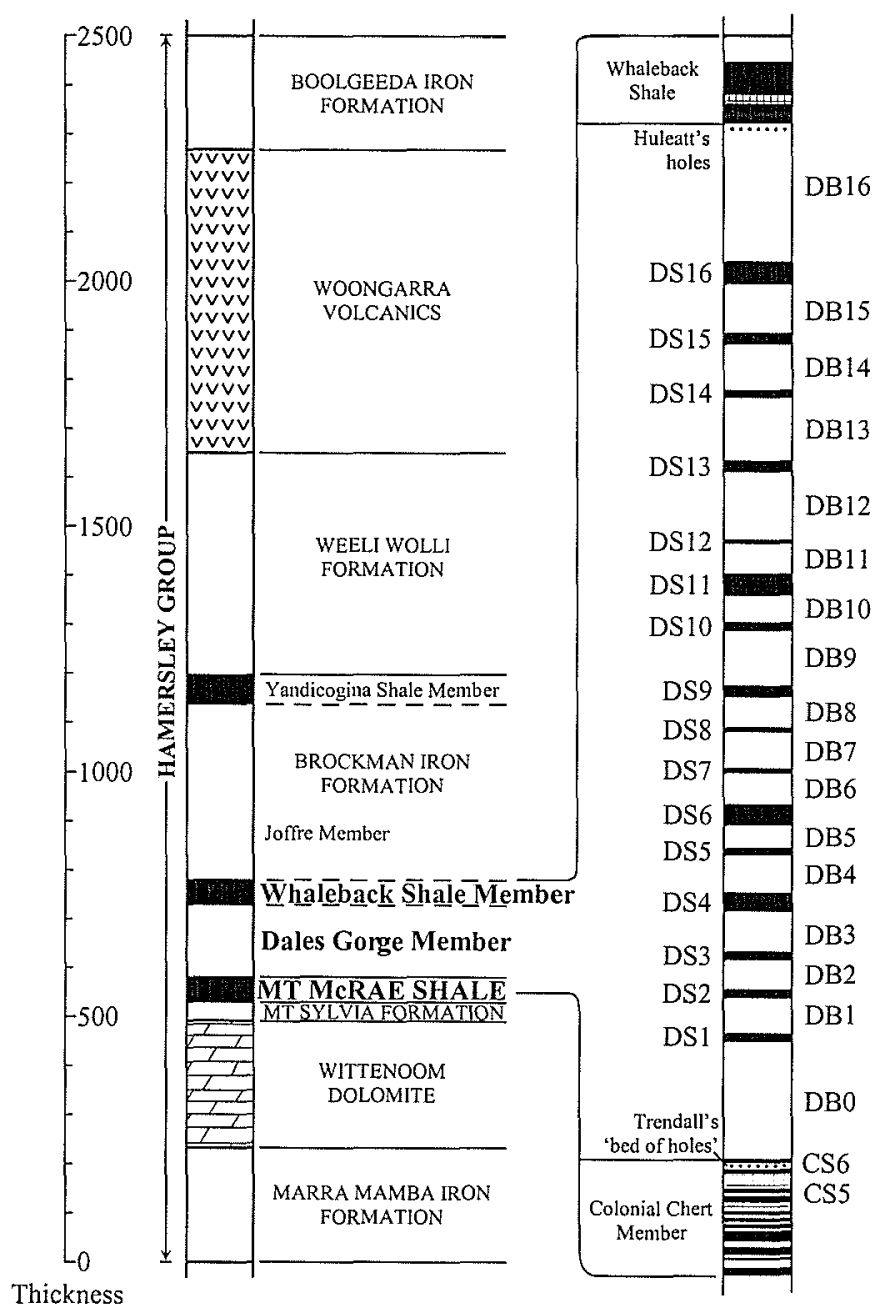

(m)

Figure 5.2. Stratigraphic column of the Hamersley Group, showing detailed stratigraphy of the Whaleback Shale Member, Dales Gorge Member and Colonial Chert Member and relative stratigraphic thicknesses (modified from Harmsworth et al., 1990). Note that Huleatt's "Holes" and Trendall's "Bed of Holes" indicate the top and bottom of the Dales Gorge Member respectively and are excellent marker horizons in the field. $\mathrm{DB}=$ Dales Gorge Member BIF macroband; DS = Dales Gorge Member shale macroband. 
The stratigraphy was first described by Macleod et al. (1963) and has been summarized in detail by Trendall and Blockley (1970) and Harmsworth et al. (1990), the latter of which incorporate the nomenclature used in this study. The lower half of the Hamersley Group consists of BIF, shale and carbonate sequences that were deposited on a slowly subsiding passive continental margin (Trendall and Blockley, 1970; Taylor et. al., 2001). Of these sequences, this study focuses on the Mt. McRae Shale Formation, and Dales Gorge Member and Mt. Whaleback Shale Member of the Brockman Iron Formation (Fig. 5.2), as they host or surround high-grade hematite ore at Mt. Whaleback, Mt. Tom Price, Paraburdoo/Channar and the smaller Giles Mini deposit (Fig. 5.1b). A notable feature of these stratigraphic units is their unique lateral continuity. Individual horizons can be confidently traced from unaltered, undeformed sequences in the north into altered and ultimately mineralized sequences in the deformed south (Trendall and Blockley, 1970; Ewers and Morris, 1981; Chapters 2, 3) (Fig. 5.1b). The high degree of lateral continuity provides an independent benchmark for this geochemical study as it limits the range of possible mass and volume changes attending alteration and mineralization.

\subsection{Mt. McRae Shale}

The Mt. McRae Shale is $\sim 100 \mathrm{~m}$ thick in the north and has been divided into two members based on predominant rock types (Trendall and Blockley, 1970). In undeformed regions the upper Colonial Chert Member (uppermost 10-15 m) consists largely of cherty BIF, black shale and chert and is clearly identified in the field by two sets of twin shale bands (CS5 and CS6) at its top (Fig. 5.2). The lower shale-rich member contains thinly bedded black shale composed of stilpnomelane, carbonates and chert (Chapter 2). In fresh mine faces at Mt. Whaleback and Mt. Tom Price, the upper Colonial Chert Member is typically mineralized to hematite-rich shaley ore (Ewers and Morris, 1981; Harmsworth et a1., 1990; Chapters 2, 4) and the lower shale-rich unit has been converted to mixtures of clinochlore, muscovite and chert informally called altered black shale (Chapters 2,4). However, deep within the Mt. Whaleback pit a small zone 
of upper Colonial Chert Member consists of carbonate-rich, silica-poor shales (Chapter 4). These rocks are cut by synchronous ferroan dolomite and clinochlore veins and are reddish-green in colour instead of the common black or red varieties.

\subsection{Dales Gorge Member}

The Dales Gorge Member (ca. $2470 \pm 4$ Ma; Compston et al., 1981) is $\sim 145 \mathrm{~m}$ thick in the north and consists of an alternating assemblage of 17 BIF (DB) and 16 shale (DS) metre-scale macrobands (Trendall and Blockley, 1968) (Fig. 5.2). The chemistry and petrography of these rocks vary significantly across the Hamersley Province (Chapters 2-4). Based on these changes DB- and DS-macrobands can be classified into eight different types; unaltered BIF, weathered BIF, oxidized BIF and high-grade hematite ore, and black shale, altered black shale and red shale.

Unaltered BIF from the north is characterised by high $\mathrm{SiO}_{2}$ and $\mathrm{Fe}_{2} \mathrm{O}_{3}$, although $\mathrm{MgO}, \mathrm{CaO}$ and loss on ignition (LOI) contents are moderately high (Chapter 2). Relative to these rocks, equivalent weathered sequences from gorges across the southeast contain more $\mathrm{SiO}_{2}$, but lower $\mathrm{MgO}, \mathrm{CaO}$ and LOI (Chapter 3). Likewise, oxidized BIF from Fourth West Gorge and Mt. Whaleback contains less $\mathrm{MgO}, \mathrm{CaO}$ and LOI than unaltered BIF, although $\mathrm{Fe}_{2} \mathrm{O}_{3}$ contents are significantly higher (Chapter 3). In contrast to all BIF samples, high-grade hematite ore at Mt. Whaleback is relatively enriched in $\mathrm{Fe}_{2} \mathrm{O}_{3}$ and relatively depleted in all other major elements, particularly $\mathrm{SiO}_{2}$ (Chapters 2,3).

As for chemistry, the mineralogy of DB-macrobands varies significantly across the province (Chapters 2, 3). Unaltered BIF is mostly comprised of chert, magnetite, siderite, stilpnomelane and hematite. Weathered rocks contain hematite pseudomorphs after magnetite (martite) and goethite pseudomorphs of carbonates and silicates. Chert remains untouched in these rocks. Similarly, oxidized BIF consists mostly of chert and martite, although they also contain abundant microplaty hematite. Importantly these rocks lack any goethite. In striking contrast to all BIF, high-grade hematite ore is entirely martite and microplaty hematite. 
DS-macrobands also show profound differences in chemistry across the province (Chapter 2). Unaltered black shale from drill cores in the north predominantly consist of $\mathrm{SiO}_{2}$ and $\mathrm{Fe}_{2} \mathrm{O}_{3}$ and moderately high contents of $\mathrm{Al}_{2} \mathrm{O}_{3}, \mathrm{MgO}, \mathrm{CaO}, \mathrm{K}_{2} \mathrm{O}$ and LOI. Compared to these rocks, altered black DS-macrobands at Mt. Whaleback are relatively depleted in $\mathrm{SiO}_{2}$ and relatively enriched in $\mathrm{Al}_{2} \mathrm{O}_{3}$. In contrast to all black shales, red DS-macrobands at Mt. Whaleback contain less $\mathrm{MgO}$ and $\mathrm{CaO}$ and higher $\mathrm{Fe}_{2} \mathrm{O}_{3} \mathrm{~T}$ and $\mathrm{Al}_{2} \mathrm{O}_{3}$.

The geochemical changes in shales across the province are matched by distinctive mineralogical differences (Chapter 2). Similar to black shale from the Mt. McRae Shale, black DS-macrobands in the north consist of stilpnomelane, K-feldspar and quartz with subordinate amounts of siderite, dolomite, ankerite, muscovite, biotite, pyrite and chlorite. Altered black DS-macrobands at Mt. Whaleback are rich in quartz, clinochlore and muscovite instead of stilpnomelane, K-feldspar and carbonates. Red DS-macrobands lack any quartz and are entirely composed of very fine hematite and kaolinite.

\subsection{Whaleback Shale Member}

The Whaleback Shale Member is $\sim 65 \mathrm{~m}$ thick in the north (Trendall and Blockley, 1970) and similar to black shale from the Mt. McRae Shale and Dales Gorge Member, consists largely of stilpnomelane, K-feldspar, chert and carbonates (Trendall and Blockley, 1970; Chapter 2). At Mt. Whaleback the Whaleback Shale Member has been converted to altered black shale containing mostly clinochlore, chert and muscovite, although the lower chert-rich section is often enriched to low-grade shaley ore (Ewers and Morris, 1981; Chapter 2).

A series of chemical reactions explaining most of the observed differences in chemistry and mineralogy between samples from these three stratigraphic units suggests that no single process could have produced all of the altered rocks across the Hamersley Province (Chapters 2-4). The conversion of black shale to altered black shale most likely resulted from regional metamorphism (Chapter 2). The alteration of unaltered 
BIF in the north to BIF in gorges across the southeast was due to typical supergene weathering (Chapter 3). However, the alteration of BIF through oxidized BIF to highgrade hematite ore and the conversion of altered black shale to red and reddish-green shales in and around Mt. Whaleback (Chapters 2-4) show distinctive major element and mineralogical changes during mineralization that are examined further below.

\section{SAMPLES AND ANALYTICAL TECHNIQUES}

\subsection{Samples}

In this study, two hundred and thirty-two rock samples were analysed from the Mt. McRae Shale, Dales Gorge Member and Whaleback Shale Member across the Hamersley Province (Fig. 5.1b). These samples were previously collected from three diamond drill holes (DDHs) at Wittenoom Gorge (45 samples), one DDH at Junction Gorge (6 samples), outcrops at Bee Gorge (14 samples), Weeli Wolli Spring (12 samples), Mt. Robinson (16 samples), Pamelia Hill (14 samples), Fourth West Gorge (17 samples) and Cathedral Gorge (17 samples), and six DDHs (91 samples) and six fresh mine faces within the Mt. Whaleback pit (Chapters 2-4). Detailed logs and crosssections showing general geology and sample locations are presented elsewhere (Chapters 2- 4; Appendix 1).

\subsection{Trace element chemistry}

Portions of all 232 samples were crushed with a tungsten carbide-plated hydraulic press and powdered in a clean tungsten carbide bowl using a Rocklabs tema mill. Splits of these homogenized bulk samples were then analysed for trace element chemistry by X-ray fluorescence $(\mathrm{XRF})$ at the James Cook University Advanced Analytical Centre (JCU-AAC). Of these 230 specimens, a second split of selected samples was examined for trace and rare earth element (REE) chemistry using instrumental neutron activation analysis (INAA) at Becquerel Laboratories, Sydney. Reported major element oxide contents of all samples were previously determined using the same preparation and XRF spectrometer (see Chapters 2- 4 for analytical procedures). 
For XRF analyses one split of each sample was made into a pressed powdered pellet and analysed for 13 trace elements using a Siemens SRS-3000 XRF spectrometer (Appendix 3). Trace element contents were obtained by comparing peak positions and intensities to traces of geological standards. Three hundred analyses of 3 different pressed glass disks of the $\mathrm{AGV}-1$ standard consistently resulted in trace element concentrations that were usually within $10 \mathrm{ppm}$ of consensus values (Gladney et al., 1992) (Table 5.1a). Four analyses of the MRG-1 standard resulted in Ba concentrations that were within 2 ppm of the certified value (Gladney \& Roelandts, 1990) (Table 5.1a). New splits of three of samples, 4747 (BIF), E24C (iron ore) and 4718 (black shale) were analysed to evaluate precision. Contents of all trace elements for these samples were within $15 \mathrm{ppm}$ (absolute) of the first analyses (Table 5.1a).

Table 5.1a. Trace element analytical precision (XRF).

\begin{tabular}{|c|c|c|c|c|c|c|c|c|c|c|c|c|c|c|c|}
\hline \multirow{3}{*}{$\begin{array}{l}\text { Element } \\
\text { As }\end{array}$} & \multirow{3}{*}{\begin{tabular}{|l} 
Line \\
$\mathrm{KA} 1,2$
\end{tabular}} & \multicolumn{5}{|c|}{ CRM $\left(\mathrm{AGV}-1^{*}\right)$} & \multicolumn{3}{|c|}{4747 (BIF) } & \multicolumn{3}{|c|}{ E24C (ore) } & \multicolumn{3}{|c|}{4718 (black shale) } \\
\hline & & \multicolumn{2}{|c|}{ Certified $^{\mathrm{a}}$} & \multicolumn{2}{|c|}{ Analysed } & \multirow{2}{*}{$\frac{\mathbf{n}}{300}$} & \multirow{2}{*}{$\frac{\text { Reported }}{2}$} & \multicolumn{2}{|c|}{ Repeats $(\mathrm{n}=11)$} & \multirow{2}{*}{$\frac{\text { Reported }}{-}$} & \multicolumn{2}{|c|}{ Repeats $(\mathrm{n}=11)$} & \multirow{2}{*}{ Reported } & \multicolumn{2}{|c|}{ Repeats $(n=5)$} \\
\hline & & & & 2 & (1) & & & - & - & & - & - & & - & - \\
\hline $\mathrm{Ba}$ & LB1 & 61 & & 62.6 & (1) & 4 & 198 & 200 & (6) & 16 & 21 & (5) & 111 & 115 & (2) \\
\hline $\mathrm{Co}$ & $\mathrm{KA} 1,2$ & 15 & (3.2) & 16 & (1) & 300 & 6 & 3 & (1) & 19 & 6 & (2) & 16 & 12 & (1) \\
\hline $\mathrm{Cr}$ & $\mathrm{KA} 1,2$ & 10 & $(4.8)$ & 13 & (2) & 300 & 3 & 61 & (13) & 98 & 184 & (11) & 54 & 55 & (4) \\
\hline $\mathrm{Nb}$ & KA1 & 15 & (6) & 13 & $(0.6)$ & 300 & - & - & - & 5 & 5 & (1) & 5 & 5 & (1) \\
\hline $\mathrm{Ni}$ & $\mathrm{KA} 1,2$ & 16 & (6) & 22 & $(8)$ & 300 & 9 & 9 & (1) & 14 & 15 & (1) & 31 & 30 & $(0)$ \\
\hline $\mathrm{Pb}$ & LB1 & 36 & (19) & 38 & (2) & 300 & 9 & 6 & (1) & 20 & 21 & (1) & 2 & - & - \\
\hline $\mathrm{Rb}$ & KA1 & 67 & (1.8) & 70 & (4) & 300 & 69 & 65 & (1) & - & - & - & 142 & 144 & (4) \\
\hline $\mathrm{Sc}$ & $\mathrm{KAl}, 2$ & 12.2 & $(2.2)$ & 11 & (2) & 300 & & & & & & & & & \\
\hline $\mathrm{Sr}$ & $\mathrm{KAl}$ & 662 & (18) & 662 & (28) & 300 & 65 & 65 & (0) & 4 & 5 & (1) & 9 & 10 & (0) \\
\hline $\mathrm{Ti}$ & $\mathrm{KAl}, 2$ & 6294 & $(600)$ & 6305 & (146) & 300 & 175 & 176 & (3) & 192 & 193 & (3) & 1644 & 1710 & (12) \\
\hline v & $\mathrm{KAl}, 2$ & 121 & (22) & 108 & (6) & 300 & 8 & 12 & (2) & 127 & 130 & (3) & 52 & 58 & (1) \\
\hline Y & KA1 & 20 & (6) & 20 & $(0.8)$ & 300 & 14 & 13 & (1) & 10 & 8 & (2) & 15 & 14 & (1) \\
\hline $\mathrm{Zn}$ & $\mathrm{KA} 1,2$ & 88 & (18) & 233 & (6) & 300 & 15 & 16 & (1) & 17 & 17 & (1) & 209 & 207 & (5) \\
\hline $\mathrm{Zr}$ & $\mathrm{KAl}$ & 227 & (36) & 233 & (6) & 300 & 3 & 2 & (1) & 10 & 8 & (2) & 64 & 66 & (1) \\
\hline
\end{tabular}

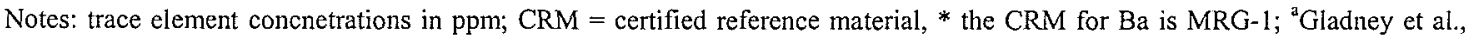
1992; $n=$ number of analyses; standard deviations in brackets; ' - ' = below detection; blank = not reported.

For INAA $\sim 1.0 \mathrm{~g}$ split of 38 selected samples was packed into flat polyethylene bags and analysed for 12 trace elements at the Australian Nuclear Science and Technology Organization's (ANSTO) HIFAR reactor at Lucas Heights (Appendices 3.2 and 3.3). Each sample and their standard flux monitor were irradiated for 10-30 minutes in a neutron flux of $2-4 \times 10^{12} \mathrm{n} \mathrm{cm}^{-2} \mathrm{~s}^{-1}$. The gamma spectrum for each radioactive sample and monitor was then measured simultaneously after seven days 
decay using hyperpure Ge coaxial detectors. A second count was undertaken after a further 7-14 days decay. Spectral data were analysed by an in house program developed by Becquerel Laboratories. Given the long, multiple counts required to achieve the high degree of sensitivity for these samples, it was not possible to determine analytical precision by running duplicate analyses. However, an "in-house" program that compares the first and second halves of the overall count was used to calculate precision. This process effectively provided duplicate analyses for each element from which the mean, standard deviation and precision were calculated. The average standard deviation from counting statistics for $\mathrm{Ce}, \mathrm{Hf}, \mathrm{La}, \mathrm{Lu}, \mathrm{Sm}$ and $\mathrm{Yb}$ was $\pm 5 \%$; for $\mathrm{Cs}, \mathrm{Eu}$ and $\mathrm{Sc}$ it was $\pm 5 \%$; for $\mathrm{Ho}$ and $\mathrm{Nd}$ it was $\pm 15 \%$; and for $\mathrm{Tb}$ it was $\pm 23 \%$ (Table 5.1b).

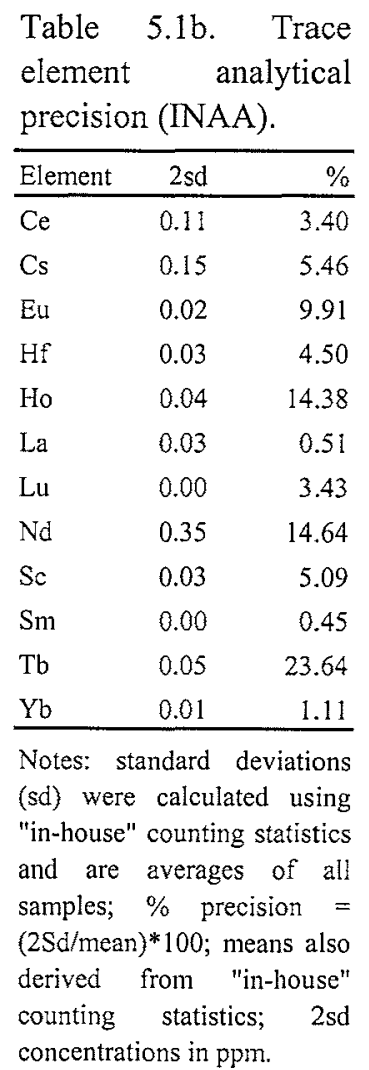

\subsection{Principal components analysis}

Statistical analysis of the chemical dataset using principal components analysis (PCA) was used to identify the main trace element associations within BIF and shale across the Hamersley Province. Principal components analysis is a data reduction technique that enables a large, multivariate dataset to be explained by a relatively small 
number of uncorrelated components or groups. It basically helps to understand the interrelationships between original variables by detecting clusters in data. Principal components analysis is not a "pure" statistical method as it transforms the data with no statistical assumptions (i.e., probability, hypotheses or testing) (Davis, 1986; Reimann et al., 2002). Its effectiveness is simply based on the utility of the results. However, PCA is sensitive to the magnitudes of the measurements, as the element with the greatest variance will have the strongest influence on the outcome (Rienmann et al., 2002). Moreover, geochemical data practically never exhibit a normal distribution (Rienmann and Filzmoser, 2000). To overcome these issues the dataset was logtransformed and standardised prior to PCA following the procedures of Rienmann et al. (2002). Raw-data transformations and PCA were performed using the statistical package SPSS Version 11 (SPSS Inc., 2001)

In order to carry out PCA, element concentrations below the analytical detection limit were replaced with zero. However, changing these values can seriously affect means and standard deviations of the geochemical dataset (e.g., Appendices 3.4 and 3.5) and dramatically influence the correlation between variables (Reimann et al., 2002). Thus, elements containing a large proportion (i.e., over one third) of values below the detection limit were eliminated from the PCA. Note, that REEs were also ignored for PCA as the total number of samples analysed for these elements is less than the number of variables; a situation that provides statistically meaningless correlations (Davis, 1983). Similarly, reddish-green shales were not included in this analysis as only two samples form this group. Previously determined average major element oxide contents of these rocks (Chapters 2-4), were also incorporated into these analyses to aid in the interpretation of the results.

\subsection{Stratigraphic thickness changes and bulk rock densities}

Stratigraphic thicknesses of Dales Gorge Member macrobands were accurately measured at five locations across the Hamersley Province (Appendix 2). The sections were in outcrop at Pamelia Hill, Weeli Wolli Spring, Cathedral Gorge and Fourth West 
Gorge and in three fresh mine faces at the Mt. Whaleback pit (Fig. 5.1b). Due to poor outcrop at Pamelia Hill and Weeli Wolli Spring not all macrobands were measured and the total Dales Gorge Member thickness at these localities could not be determined. Reported macroband thicknesses were typically measured on relatively undeformed limbs (e.g., away from fold hinges etc.) and are the average of at least three separate measurements. Detailed maps showing the relative thicknesses and general geology of these five locations are presented in appendix 1.

Bulk rock densities of samples from the Mt. McRae Shale, Dales Gorge Member and Whaleback Shale Member across the province were calculated from 68 representative samples (Appendix 6). Each sample was accurately weighed to the nearest $0.01 \mathrm{~g}$ using an electronic balance. Volumes were then determined by immersing the sample in water and measuring the amount of displacement $(1 \mathrm{ml}=$ $\left.1 \mathrm{~cm}^{3}\right)$. However, to eliminate water infiltration into pore spaces, each sample was first coated with a very thin film of Saran Resin. Resin solutions were prepared following the procedures of Brasher et al. (1966). The weight and volume of three samples, 472 (BIF), 3EDC (iron ore), 4725 (black shale) were measured 10 separate times to evaluate precision (Table 5.1c). Weights and volumes for these replicates were within 0.02 grams and $0.1 \mathrm{~cm}^{3}$ (absolute) respectively, of the first measurements.

Table 5.1c. Weights, volumes and densities of replicate samples

\begin{tabular}{l|ccc|ccc|ccc}
\hline & \multicolumn{3}{|c|}{$472(B I F)$} & \multicolumn{3}{c|}{3 BEDC (Iron ore) } & \multicolumn{3}{c}{4725 (Black shale) } \\
Repeats & Wt. (g) & Vol $\left(\mathrm{cm}^{3}\right)$ & $\mathrm{D}\left(\mathrm{g} / \mathrm{cm}^{3}\right)$ & Wt. $(\mathrm{g})$ & Vol $\left(\mathrm{cm}^{3}\right)$ & $\mathrm{D}\left(\mathrm{g} / \mathrm{cm}^{3}\right)$ & Wt. $(\mathrm{g})$ & $\mathrm{Vol}\left(\mathrm{cm}^{3}\right)$ & $\mathrm{D}\left(\mathrm{g} / \mathrm{cm}^{3}\right)$ \\
\hline 1 & 232.98 & 75.0 & 3.11 & 283.44 & 61.5 & 4.61 & 72.52 & 28.5 & 2.54 \\
2 & 232.96 & 75.5 & 3.09 & 283.43 & 62.0 & 4.57 & 72.54 & 29.0 & 2.50 \\
3 & 232.98 & 75.0 & 3.11 & 283.43 & 61.5 & 4.61 & 72.52 & 27.5 & 2.64 \\
4 & 232.97 & 74.0 & 3.15 & 283.43 & 62.5 & 4.53 & 72.52 & 27.0 & 2.69 \\
5 & 232.97 & 76.0 & 3.07 & 283.44 & 62.5 & 4.54 & 72.52 & 28.0 & 2.59 \\
6 & 232.98 & 75.5 & 3.09 & 283.44 & 62.0 & 4.57 & 72.54 & 28.5 & 2.55 \\
7 & 232.97 & 75.5 & 3.09 & 283.43 & 62.0 & 4.57 & 72.54 & 28.0 & 2.59 \\
8 & 232.98 & 74.5 & 3.13 & 283.44 & 61.5 & 4.61 & 72.52 & 28.5 & 2.54 \\
9 & 232.98 & 74.0 & 3.15 & 283.43 & 62.0 & 4.57 & 72.52 & 27.5 & 2.64 \\
10 & 232.98 & 76.0 & 3.07 & 283.44 & 62.5 & 4.54 & 72.54 & 28.0 & 2.59 \\
Avg & 232.98 & 75.1 & 3.10 & 283.44 & 62.0 & 4.57 & 72.53 & 28.1 & 2.59 \\
2 SSd & 0.01 & 1.48 & 0.06 & 0.01 & 0.8 & 0.06 & 0.02 & 1.2 & 0.11 \\
\hline
\end{tabular}




\subsection{Geochemical mass changes}

The composition, colour and structure of individual BIF and shale horizons in the north varies significantly in comparison with equivalent layers across the deformed south and into the ore deposits (Ewers and Morris, 1981; Chapters 2-4). Previous work (i.e., Chapters 2-4) and this investigation (see below) has shown that these differences are reflected by variations in the major and trace element chemistry and that certain elements may be enriched in altered rocks, while others are depleted. However, whether this enrichment is real or whether it is residual enrichment due to the depletion of mobile elements is best determined through the isocon method (Grant, 1986).

Isocon diagrams show the concentration of elements for samples that represent relative unaltered and altered equivalents. If an alteration process links two rocks, their immobile element ratios should be fairly constant and this can be used to pin down the actual mass changes. The isocon is defined by elements that show no relative gains or losses in mass during alteration (i.e., immobile) and is graphically represented by generating a "best-fit" line through the immobile elements and the origin (Grant, 1986). The slope of the isocon defines the overall mass change between the rocks, and the deviation of a particular element from this line defines its relative gain or loss. Slopes greater than one indicate an overall mass loss and those less than one indicate mass gain.

By necessity because of the large element variations from sample to sample, averages and standard deviations must be plotted for the data. Average major element oxides (Chapters 2-4) are plotted as percentages while trace elements are plotted in parts per million (ppm) (data from right-hand columns in Appendix 3.4 and 3.5). Individual elements were multiplied or divided by a factor that conveniently distributed them on a unit-less graph from 0 to 10 . As these graphs are essentially ratio diagrams, absolute values are unimportant as long as the same element is multiplied by the same factor for both the unaltered and altered rocks. Paired sample sets comparing equivalent rocks were used to establish average element mobility during the alteration of: unaltered BIF to weathered BIF; unaltered BIF to oxidized BIF; oxidized BIF to high-grade hematite 
ore; unaltered black to altered black shale; altered black shale to red shale; altered black shale to reddish-green shale; and reddish-green shale to red shale.

\subsection{Bulk rock volume changes}

The large variation of most elements in BIF and shale from the Hamersley Province makes it extremely difficult to confidently quantify the bulk rock and elemental mass changes from isocon graphs. To help better constrain this variation, associated volume changes were calculated and compared to stratigraphic thicknesses measured across the region. Using Gresens' (1967) compositional-volume equation, Grant (1986) demonstrated that the relationship between bulk rock mass and volume after $(\mathrm{B})$ and before alteration (A) is:

$$
M^{B} / M^{A}=V^{B} / V^{A} \cdot \rho^{B} / \rho^{A}
$$

where $M^{B} / M^{A}$ is the ratio of bulk rock masses after $\left(M^{B}\right)$ and before $\left(M^{A}\right)$ alteration, $\mathrm{V}^{\mathrm{B}} / \mathrm{V}^{\mathrm{A}}$ is the volume of rock $\mathrm{B}$ after alteration divided by the volume of original rock $\mathrm{A}$ before alteration, and $\rho^{A}$ and $\rho^{B}$ are the densities of the original and altered bulk rocks.

\subsection{Elemental mass changes}

Assuming the calculated volume changes are a common factor to the behaviour of all elements (i.e., alteration was pervasive), individual gains and losses for each element during alteration can be determined using Gresens' (1967) basic mass-volume formula. For the alteration of original rock $A$ to altered rock $B$,

$$
X_{n}=\left[f_{v}\left(\rho^{B} / \rho^{A}\right) C_{n}^{B}-C_{n}^{A}\right] \text {, }
$$

where $X_{n}$ is the amount of component $n$ gained or lost (grams per $100 \mathrm{~g}$ of parent material), $f_{v}$ is the volume factor (the volume of rock $B$ after alteration (in grams) divided by the volume of $100 \mathrm{~g}$ of rock $\mathrm{A}$ before alteration), $\mathrm{C}^{\mathrm{A}}{ }_{\mathrm{n}}$ and $\mathrm{C}^{\mathrm{B}}{ }_{\mathrm{n}}$ are the concentrations (wt. \%) of component $n$ in samples $A$ and $B$, and $\rho^{A}$ and $\rho^{B}$ are the densities of samples A and B. 


\section{RESULTS}

\subsection{Trace element variability across the Hamersley Province}

Similar to major element chemistry and mineralogy (Chapters 2-4), rocks from the Mt. McRae Shale, Dales Gorge Member and Whaleback Shale Member have an exceptionally wide range in trace element composition across the Hamersley Province (Figs. 5.3, 5.4). This variability is best appreciated by comparing mean contents and standard deviations $(1 \sigma)$ (Table 5.2).

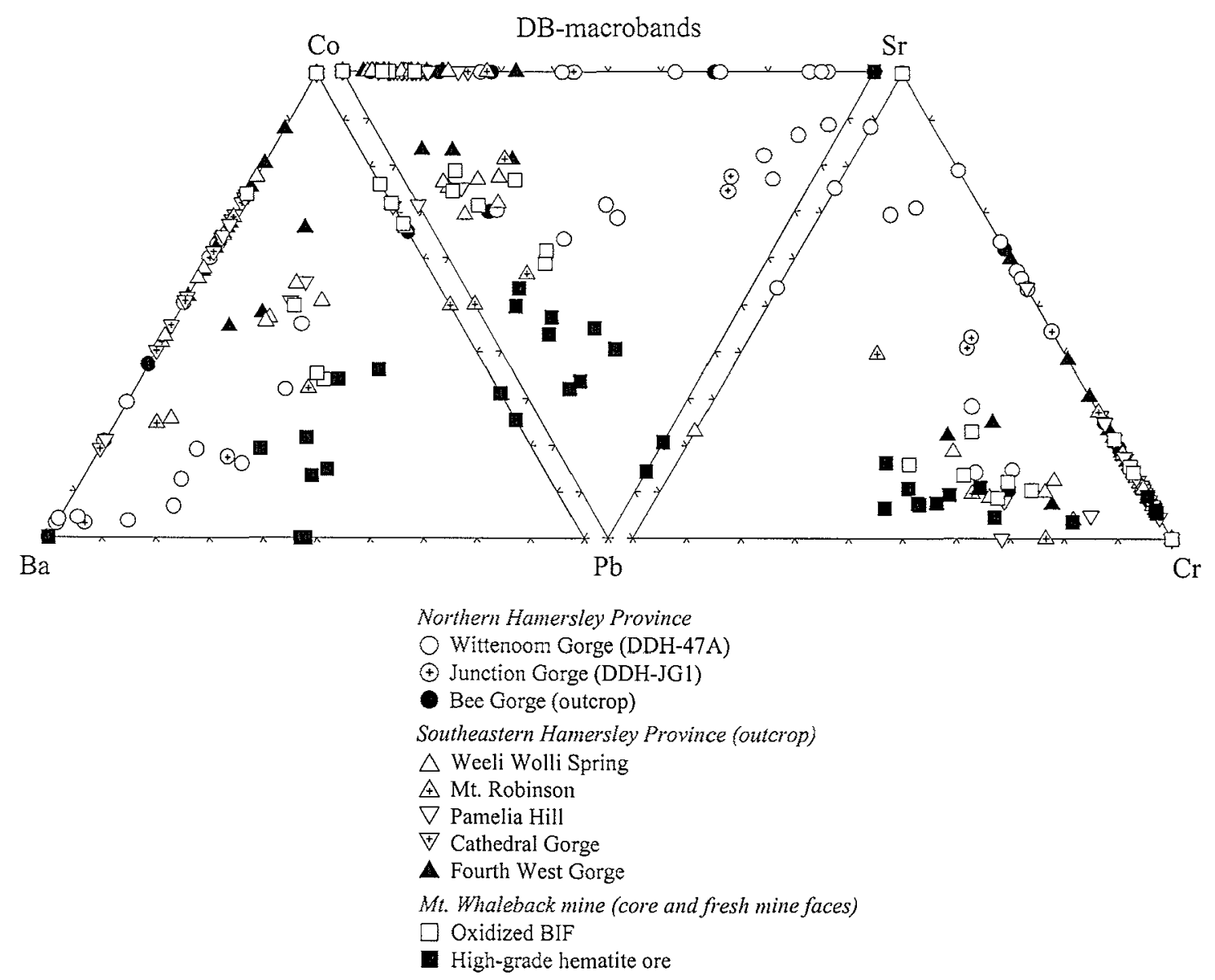

Figure 5.3. Ternary diagrams showing the distribution of $\mathrm{Ba}, \mathrm{Co}, \mathrm{Pb}, \mathrm{Sr}$ and $\mathrm{Cr}$ for $\mathrm{DB}$-macroband samples collected across the Hamersley Province.

\subsubsection{Core and outcrop from undeformed regions}

Unaltered BIF from drill cores at Wittenoom and Junction Gorges in the north contain significant amounts of $\mathrm{Ba}(57 \pm 81 \mathrm{ppm}), \mathrm{Rb}(33 \pm 43 \mathrm{ppm})$ and $\mathrm{Sr}(29 \pm$ $23 \mathrm{ppm})$. Contents of $\mathrm{Co}(13 \pm 10 \mathrm{ppm}), \mathrm{Cr}(12 \pm 11 \mathrm{ppm}), \mathrm{Ni}(8 \pm 3 \mathrm{ppm}), \mathrm{Pb}(5 \pm$ $6 \mathrm{ppm}), \mathrm{V}(4 \pm 7 \mathrm{ppm}), \mathrm{Y}(14 \pm 5 \mathrm{ppm}), \mathrm{Zn}(15 \pm 28 \mathrm{ppm})$ and $\mathrm{Zr}(10 \pm 22 \mathrm{ppm})$ are 

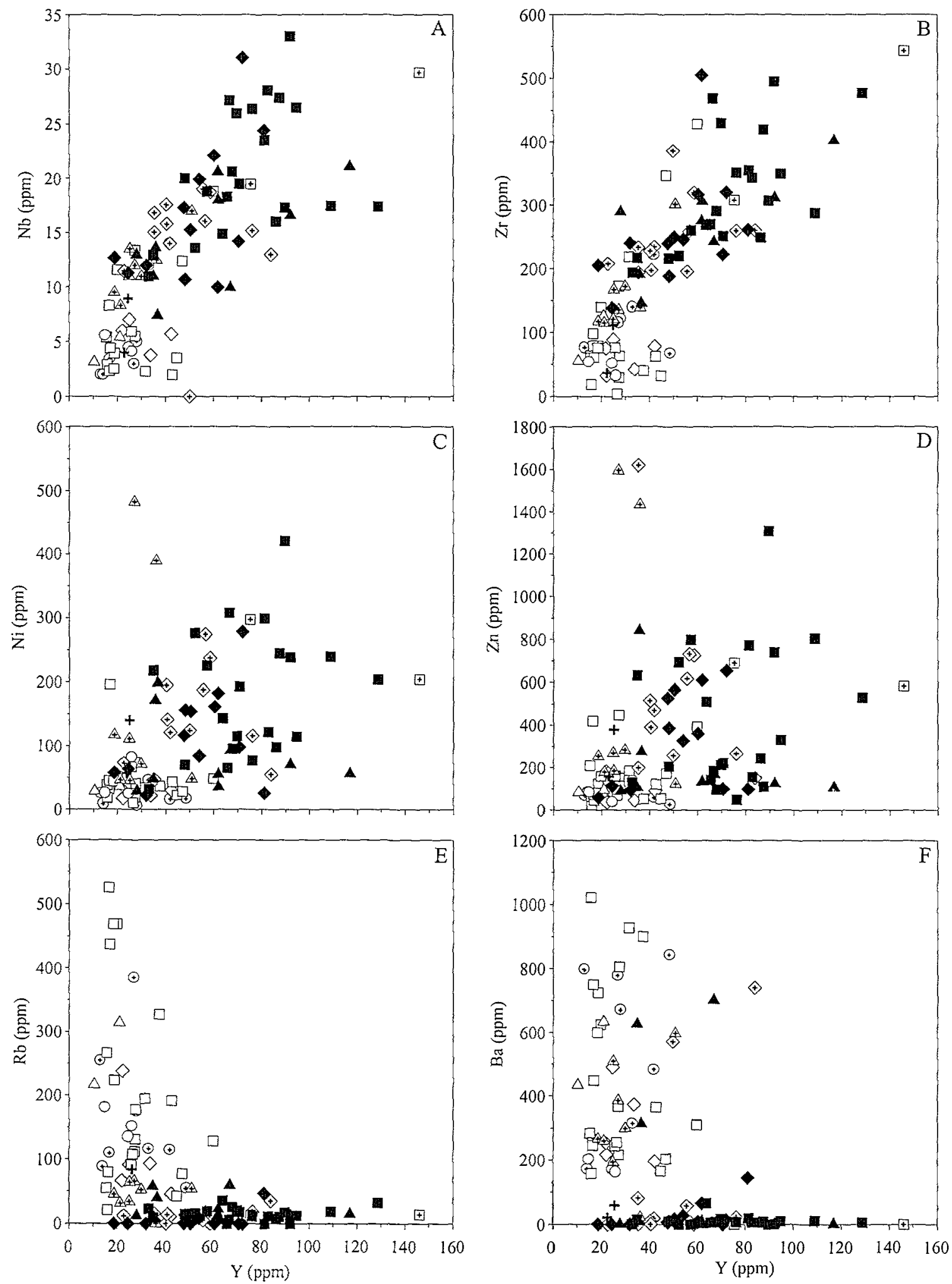

Black shale

$\diamond \square \triangle$ WittenoomGorge $(\diamond \mathrm{Phbw}, \square \mathrm{Phbd}, \triangle \mathrm{Phr})$ Junction Gorge

(๑) Bee Gorge

Altered black shale

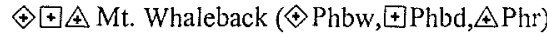

\section{Red shale}

- A Mt. Whaleback ( Phbw, Phbd,APhr)

Reddish-green shale

+ Mt. Whaleback

Figure 5.4. Whole rock trace element contents (ppm) versus whole rock $Y$ contents (ppm) for shales across the Hamersley Province. (a) Nb-Y, (b) Zr-Y, (c) Ni-Y, (d) Zn-Y, (e) Rb-Y and (f) Ba-Y. Note the relatively constant $\mathrm{Y} / \mathrm{Nb}$ and $\mathrm{Y} / \mathrm{Zr}$ ratios and the progressive enrichment of $\mathrm{Nb}, \mathrm{Zr}, \mathrm{Ni}$ and $\mathrm{Zn}$ and depletion of $\mathrm{Rb}$ and $\mathrm{Ba}$ from black shale to red shale. $\mathrm{Y}, \mathrm{Nb}$ and $\mathrm{Zr}$ are inferred to be near-immobile and can be used to constrain mass balance. 
Table 5.2. Average trace element contents and standard deviations of rocks across the Hamersley Province

\begin{tabular}{|c|c|c|c|c|c|c|c|c|c|c|c|c|c|c|c|c|c|}
\hline \multirow[t]{2}{*}{ Sample } & \multirow[t]{2}{*}{$\mathrm{n}$} & \multicolumn{2}{|c|}{ As } & \multicolumn{2}{|c|}{$\mathrm{Ba}$} & \multicolumn{2}{|c|}{$\mathrm{Co}$} & \multicolumn{2}{|c|}{$\mathrm{Cr}$} & \multicolumn{2}{|c|}{$\mathrm{Cs}^{*}$} & \multicolumn{2}{|c|}{$\mathrm{Hf} *$} & \multicolumn{2}{|c|}{$\mathrm{Nb}$} & \multicolumn{2}{|c|}{$\mathrm{Ni}$} \\
\hline & & Avg & Sd & Avg & $\mathrm{Sd}$ & Avg & $\mathrm{Sd}$ & Avg & $\mathrm{Sd}$ & Avg & $\mathrm{Sd}$ & Avg & $\mathrm{Sd}$ & Avg & $\mathrm{Sd}$ & Avg & Sd \\
\hline \multicolumn{18}{|c|}{ Northern Hamersley Province } \\
\hline $\mathrm{BIF}=(,+$, & 21 & - & re & 56.6 & 80.9 & 12.9 & 103 & 117 & 11.3 & 1- & - -2 & (-3 & - & 0.7 & 11 & 7.7 & 2.9 \\
\hline Wittenoom Gorge & 18 & - & - & 52.6 & 78.6 & 13.3 & 11.0 & 9.7 & 10.7 & - & - & - & - & 0.4 & 0.9 & 7.6 & 2.9 \\
\hline Junction Gorge & 3 & - & - & 80.7 & 109.6 & 10.2 & 5.5 & 23.8 & 6.8 & & & & & 2.3 & 0.3 & 8.4 & 3.5 \\
\hline BIF (Bee Gorge) & 6 & & - & 9.0 & 12.5 & 28.8 & 10.6 & 22.3 & 16.6 & & $=$ & 2 & 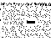 & 0.5 & 1.2 & 6.0 & 0.9 \\
\hline Black shale & 30 & 15.2 & 25.4 & 378.0 & 281.2 & 18.6 & 11.7 & 48.8 & 25.7 & 17,0 & 5.6 & 1.2 & 0.6 & 5.0 & 4.3 & 41.9 & 337 \\
\hline Wittenoom Gorge & 27 & 15.9 & 26.2 & 385.3 & 290.9 & 18.2 & 11.5 & 49.6 & 25.9 & 17.0 & 5.6 & 1.2 & 0.6 & 5.0 & 4.6 & 41.6 & 34.0 \\
\hline Phbw & 5 & 8.2 & 12.4 & 215.6 & 150.8 & 8.9 & 9.0 & 41.6 & 27.3 & 21.4 & 0.0 & 1.1 & 0.0 & 4.5 & 2.8 & 29.2 & 9.7 \\
\hline Phbd & 20 & 18.8 & 29.5 & 413.2 & 315.2 & 20.8 & 11.6 & 49.8 & 25.8 & 12.4 & 2.8 & 1.2 & 0.9 & 5.3 & 5.2 & 45.7 & 38.7 \\
\hline $\mathrm{Phr}$ & 2 & 6.6 & 9.3 & 531.0 & 138.6 & 15.7 & 0.6 & 67.4 & 27.7 & 21.8 & 0.0 & 1.4 & 0.0 & 4.2 & 1.7 & 32.0 & 4.9 \\
\hline Junction Gorge & 3 & 8.6 & 14.8 & 312.0 & 47.1 & 21.9 & 5.5 & 42.1 & 3.1 & & & & & 4.7 & 0.8 & 44.1 & 33.4 \\
\hline Black shale (Bee Gorge) & 8 & 23.9 & 25.9 & 325.1 & 216.8 & 15.5 & 13.6 & $61 \%$ & 35.8 & 8.9 & 12.6 & 4.7 & 2.2 & 5.2 & 5.1 & 28.1 & 22.3 \\
\hline \multicolumn{18}{|c|}{ Southeastern Hamersley Province } \\
\hline $\mathrm{BIF} / \% \uparrow ?$ & 76 & 1 & -2 & 163 & 24.7 & 352 & 15.3 & 28.5 & 15.6 & & -1 & - - & - & 0.6 & 1.1 & 79 & 2.8 \\
\hline Weeli Wolli Spring & 12 & - & - & 18.7 & 19.4 & 28.1 & 4.6 & 31.4 & 16.9 & & & & & - & - & 11.8 & 3.4 \\
\hline Mt. Robinson & 16 & - & - & 12.3 & 32.5 & 32.1 & 17.2 & 21.7 & 13.4 & & & & & 1.1 & 1.3 & 7.5 & 1.5 \\
\hline Pamelia Hill & 14 & - & - & 12.6 & 24.2 & 28.9 & 4.7 & 30.1 & 14.6 & - & - & - & - & - & - & 6.7 & 1.3 \\
\hline Fourth West Gorge & 17 & - & - & 17.5 & 14.4 & 52.3 & 17.8 & 23.9 & 14.5 & - & - & - & - & 1.2 & 1.4 & 6.6 & 1.5 \\
\hline Cathedral Gorge & 17 & - & - & 20.1 & 29.8 & 31.4 & 8.3 & 36.0 & 15.9 & - & - & - & - & 0.5 & 0.9 & 7.9 & 3.0 \\
\hline \multicolumn{18}{|l|}{ Mt. Whaleback pit } \\
\hline $\mathrm{BIF}$ & 12 & & & 4,2 & 62 & 31.2 & 12.9 & 23.8 & 19.3 & & - & -2 & w- & 0.4 & 1.2 & 16.1 & 20.2 \\
\hline Iron Ore & 13 & -1 & - & 18.3 & 113 & 7.5 & 7.2 & 35.5 & 20.8 & -3 & - & 0.1 & 0.2 & 1.9 & 1.7 & 9.4 & 73 \\
\hline Black shale & 22 & 20.4 & 619 & 47.1. & 42.4 & 59.9 & 44.1 & 138.5 & 116.1 & 2.1 & 2.6 & 6.7 & 5.1 & 14.4 & 5.5 & 2063 & 241.9 \\
\hline Phbw & 12 & 6.2 & 10.9 & 23.8 & 20.0 & 72.4 & 50.8 & 126.8 & 113.0 & - & - & 5.9 & 0.1 & 14.4 & 5.0 & 227.1 & 300.5 \\
\hline Phbd & 2 & - & - & 27.5 & 2.1 & 71.7 & 6.4 & 7.1 & 3.6 & - & - & 13.7 & 6.6 & 24.6 & 7.2 & 250.9 & 65.8 \\
\hline $\mathrm{Phr}$ & 8 & 46.7 & 100.2 & 87.0 & 43.5 & 38.3 & 30.6 & 188.9 & 111.0 & 4.2 & 2.0 & 3.6 & 0.7 & 11.9 & 2.7 & 163.9 & 172.1 \\
\hline Red shale. & 42 & 10.0 & 9.0 & 30.2 & 30.6 & 32.3 & 27.4 & 146.5 & 98.7 & 1.4 & 29 & 8.2 & 2.6 & 18.3 & 6.3 & 1419 & 93.4 \\
\hline Phbw & 12 & 12.6 & 8.8 & 12.8 & 27.6 & 32.2 & 29.0 & 189.7 & 104.3 & 0.5 & 0.7 & 6.1 & 1.2 & 16.8 & 6.5 & 116.7 & 74.1 \\
\hline Phbd & 21 & 7.9 & 8.8 & 29.9 & 19.4 & 38.2 & 26.7 & 129.4 & 89.9 & 1.0 & 1.7 & 9.7 & 3.6 & 20.7 & 5.9 & 181.0 & 99.5 \\
\hline $\mathrm{Phr}$ & 9 & 11.2 & 9.7 & 54.3 & 41.3 & 18.6 & 24.8 & 128.7 & 103.9 & 2.2 & 4.4 & 8.1 & 2.0 & 14.6 & 4.8 & 84.2 & 60.5 \\
\hline
\end{tabular}


Table 5.2. (continued)

\begin{tabular}{|c|c|c|c|c|c|c|c|c|c|c|c|c|c|c|c|c|}
\hline \multirow[t]{2}{*}{ Sample } & \multicolumn{2}{|c|}{$\mathrm{Pb}$} & \multicolumn{2}{|c|}{$\mathrm{Rb}$} & \multicolumn{2}{|c|}{ Sc* } & \multicolumn{2}{|c|}{$\mathrm{Sr}$} & \multicolumn{2}{|c|}{$V$} & \multicolumn{2}{|c|}{$Y$} & \multicolumn{2}{|c|}{$\mathrm{Zn}$} & \multicolumn{2}{|c|}{$\mathrm{Zr}$} \\
\hline & Avg & $\mathrm{Sd}$ & Avg & $\mathrm{Sd}$ & Avg & $\mathrm{Sd}$ & Avg & $\mathrm{Sd}$ & Avg & Sd & Avg & $\mathrm{Sd}$ & Avg & $\mathrm{Sd}$ & Avg & $\mathrm{Sd}$ \\
\hline \multicolumn{17}{|c|}{ Northern Hanersley Province } \\
\hline $\mathrm{BIF}$ & 5.3 & 5.7 & 33.3 & 42.6 & 0.4 & 01 & 28.5 & 23.4 & 4.3 & 7.2 & 13.5 & 4.9. & 149 & 27.7 & 95 & 22.4 \\
\hline Wittenoom Gorge & 5.0 & 5.7 & 36.0 & 45.1 & 0.4 & 0.1 & 29.4 & 25.1 & 1.0 & 2.4 & 13.5 & 4.9 & 7.5 & 7.2 & 6.0 & 16.2 \\
\hline Junction Gorge & 7.4 & 6.4 & 17.2 & 20.3 & & & 23.0 & 8.8 & 14.1 & 8.6 & 13.4 & 6.2 & 59.0 & 61.6 & 28.7 & 43.5 \\
\hline $\mathrm{BIF}$ (Bee Gorge) & 2.0 & 4.9 & 5.0 & 6.2 & .02 & 0.0 & 13.2 & 16.1 & - & - & 6.5 & 2.5 & $=-2$ & -2.2 & C- & $1-$ \\
\hline Black shale & 12.8 & 20.4 & 2129 & 127.4 & 6.7 & 2.0 & 37.4 & 36.2 & 59.5 & 22.7 & 26.5 & 11.8 & 131.0 & 114.4 & 92.8 & 93.1 \\
\hline Wittenoom Gorge & 13.4 & 21.0 & 226.6 & 130.3 & 6.7 & 2.0 & 40.0 & 37.4 & 60.9 & 23.0 & 27.0 & 12.0 & 137.5 & 114.0 & 98.0 & 96.0 \\
\hline Phbw & 8.2 & 4.6 & 153.2 & 61.8 & 5.0 & 0.0 & 25.0 & 10.2 & 55.4 & 26.2 & 29.1 & 8.9 & 85.8 & 57.8 & 63.4 & 24.3 \\
\hline Phbd & 16.1 & 23.8 & 240.8 & 142.8 & 7.2 & 3.0 & 45.7 & 41.9 & 61.8 & 23.4 & 27.7 & 12.7 & 155.3 & 125.6 & 107.4 & 109.2 \\
\hline Phr & - & - & 267.3 & 70.9 & 7.3 & 0.0 & 20.9 & 6.8 & 65.3 & 21.4 & 15.8 & 7.4 & 89.0 & 6.8 & 90.6 & 49.6 \\
\hline Junction Gorge & 7.6 & 13.1 & 89.4 & 10.2 & & & 14.1 & 3.9 & 46.9 & 0.6 & 21.7 & 6.0 & 72.0 & 29.8 & 46.1 & 12.2 \\
\hline Black shale (Bee Gorge) & 10.5 & 10.0 & 270.7 & 133.4 & 13.6 & 3.0 & 25.6 & 16.6 & 50.3 & 28.7 & 27.8 & 13.0 & 73.8 & 50.0 & 100.5 & 65.5 \\
\hline \multicolumn{17}{|c|}{ Southeastern Hamersley Province } \\
\hline $\mathrm{BIF}$ & 2.2 & 4.4 & 2 & & 0.9 & 0.6 & 4.3 & 3.4 & 2.7 & 4.6 & 7.6 & 2.8 & & & 0.8 & 2.1 \\
\hline Weeli Wolli Spring & 5.4 & 5.7 & - & - & & & 4.5 & 2.4 & 2.9 & 4.9 & 7.8 & 2.2 & - & - & 1.2 & 2.2 \\
\hline Mt. Robinson & 2.3 & 4.9 & - & - & & & 3.2 & 4.3 & - & - & 6.4 & 2.3 & - & - & 1.6 & 2.8 \\
\hline Pamelia Hill & 2.3 & 4.6 & - & - & 1.3 & 0.0 & 3.6 & 2.0 & - & - & 7.9 & 2.6 & - & - & 0.4 & 1.6 \\
\hline Fourth West Gorge & 1.8 & 4.1 & - & - & 0.6 & 0.1 & 6.6 & 4.1 & 6.8 & 4.9 & 7.8 & 2.7 & - & - & - & - \\
\hline Cathedral Gorge & - & - & - & - & 1.2 & 1.0 & 3.6 & 2.1 & 2.8 & 5.0 & 7.9 & 3.5 & - & - & 0.7 & 2.6 \\
\hline \multicolumn{17}{|l|}{ Mt. Whaleback pit } \\
\hline $\mathrm{BIF}$ & 6.2 & 6.7 & -3 & & 0.4 & 0.1 & 4.0 & 2.5 & 5.4 & 5.0 & 7.8 & 2.8 & 2.4 & 6.6 & 0.3 & 11 \\
\hline Iron Ore & 17.0 & 9.7 & -2 & & 1.4 & 0.4 & 4.4 & 2.0 & 38.1 & 42.3 & 10.7 & 711 & 3.3 & 6.0 & 5.9 & 4.6 \\
\hline Black shale & 4.7 & 10.8 & 92.0 & 118.4 & 20.7 & 6.2 & 30.6 & 33.5 & 116.8 & 55.1 & 47.9 & 28.7 & 532.7 & 458.7 & 2315 & 100.3 \\
\hline Phbw & 2.6 & 4.8 & 63.0 & 126.0 & 26.2 & 6.1 & 28.1 & 27.9 & 119.9 & 50.4 & 49.8 & 17.6 & 509.8 & 406.4 & 248.0 & 56.6 \\
\hline Phbd & - & - & - & - & 24.3 & 6.2 & 6.8 & 0.5 & 33.0 & 3.2 & 110.8 & 49.9 & 638.6 & 74.7 & 426.1 & 165.9 \\
\hline $\mathrm{Phr}$ & 9.0 & 16.7 & 158.7 & 90.5 & 16.2 & 2.7 & 40.3 & 43.2 & 133.1 & 52.8 & 29.3 & 10.2 & 540.6 & 605.7 & 158.1 & 61.7 \\
\hline Red shale & 4.2 & 6.7 & 25.8 & 74.4 & 23.0 & 49 & 24.6 & 36.7 & 85.2 & 57.3 & 647 & 25.1 & 3513 & 293.9 & 290.9 & 92.2 \\
\hline Phbw & 3.3 & 8.0 & 12.3 & 21.3 & 15.5 & 0.9 & 32.6 & 61.5 & 105.5 & 56.5 & 51.8 & 19.3 & 325.0 & 227.3 & 261.2 & 91.7 \\
\hline Phbd & 4.9 & 6.6 & 4.9 & 7.1 & 25.9 & 2.7 & 19.5 & 20.4 & 60.3 & 28.3 & 74.2 & 23.0 & 422.7 & 334.8 & 320.3 & 92.4 \\
\hline $\mathrm{Phr}$ & 3.7 & 5.6 & 92.3 & 145.7 & 24.6 & 2.9 & 25.9 & 22.3 & 116.4 & 84.2 & 59.5 & 29.8 & 220.0 & 239.9 & 262.0 & 78.3 \\
\hline
\end{tabular}

Notes: Concentrations in ppm. $\mathrm{n}=$ number of samples anaylsed by XRF (for number analysed INAA see appendix 3.2); * concentrations determined using INAA; "-" = below detection; blank = not reported; Phbw = Whaleback Shale Member; Phbd = Dales Gorge Member; Phr = Mt. McRae Shale. 
moderately high in one or more samples despite low averages. Contents of As, Cs, Hf, $\mathrm{Ni}, \mathrm{Pb}$ and $\mathrm{Sc}$ are typically near or below detection. Relative to BIF from cores, equivalent rocks from outcrop at Bee Gorge are slightly altered and enriched in Co (29 $\pm 11 \mathrm{ppm})$ and $\mathrm{Cr}(22 \pm 17 \mathrm{ppm})$ and depleted in $\mathrm{Ba}(9 \pm 13 \mathrm{ppm}), \mathrm{Rb}(5 \pm 6 \mathrm{ppm}), \mathrm{Sr}(13$ $\pm 16 \mathrm{ppm}), \mathrm{Pb}(2 \pm 5 \mathrm{ppm})$ and $\mathrm{Y}(7 \pm 2 \mathrm{ppm})$.

Differences also occur between different black shale units from the north. DSmacrobands from drill core at Wittenoom Gorge contain relatively high $\mathrm{Ba}$ (413 \pm $315 \mathrm{ppm}), \mathrm{Rb}(240 \pm 143 \mathrm{ppm})$ and $\mathrm{Zn}(155 \pm 125 \mathrm{ppm})$ contents, with moderate amounts of As $(19 \pm 30 \mathrm{ppm}), \mathrm{Co}(21 \pm 12 \mathrm{ppm}), \mathrm{Cr}(50 \pm 26 \mathrm{ppm}), \mathrm{Cs}(12 \pm 3 \mathrm{ppm}), \mathrm{Ni}(46 \pm$ $39 \mathrm{ppm}), \mathrm{Pb}(16 \pm 24 \mathrm{ppm}), \mathrm{Sr}(46 \pm 42 \mathrm{ppm}), \mathrm{V}(62 \pm 23 \mathrm{ppm}), \mathrm{Y}(28 \pm 13 \mathrm{ppm})$ and $\mathrm{Zr}$ $(107 \pm 109 \mathrm{ppm})$. All other trace element contents are less than or equal to $10 \mathrm{ppm}$. Compared to these rocks, unaltered black shale from the Mt. McRae Shale is enriched in $\mathrm{Ba}(531 \pm 139 \mathrm{ppm}), \mathrm{Cr}(67 \pm 28 \mathrm{ppm})$ and $\mathrm{Cs},(22 \mathrm{ppm})$, and depleted in As $(7 \pm$ $9 \mathrm{ppm}), \mathrm{Co}(16 \pm 0.6 \mathrm{ppm}), \mathrm{Ni}(32 \pm 5 \mathrm{ppm}), \mathrm{Pb}(0 \mathrm{ppm}), \mathrm{Sr}(21 \pm 7 \mathrm{ppm}), \mathrm{Y}(16 \pm 7 \mathrm{ppm})$ and $\mathrm{Zn}(89 \pm 7 \mathrm{ppm})$. Relative to all black shales, rocks from the Whaleback Shale Member are depleted in most trace elements. Black DS-macroband samples from outcrop at Bee Gorge contain significant As (24 $\pm 26 \mathrm{ppm}), \mathrm{Ba}(325 \pm 217 \mathrm{ppm}), \mathrm{Cr}(61$ $\pm 36 \mathrm{ppm}), \mathrm{Ni}(28 \pm 22 \mathrm{ppm}), \mathrm{Rb}(271 \pm 133 \mathrm{ppm}), \mathrm{Sr}(26 \pm 17 \mathrm{ppm}), \mathrm{V}(50 \pm 29 \mathrm{ppm}), \mathrm{Y}$ $(28 \pm 13 \mathrm{ppm}), \mathrm{Zn}(74 \pm 50 \mathrm{ppm})$ and $\mathrm{Zr}(101 \pm 66 \mathrm{ppm})$, although Co (16 $\pm 14 \mathrm{ppm}), \mathrm{Cs}$ (9 $\pm 13 \mathrm{ppm}), \mathrm{Hf}(5 \pm 2 \mathrm{ppm}), \mathrm{Nb}(5 \pm 5 \mathrm{ppm}), \mathrm{Pb}(11 \pm 10 \mathrm{ppm})$ and $\mathrm{Sc}(14 \pm 3 \mathrm{ppm})$ are also moderately high.

\subsubsection{Outcrop from deformed regions}

Weathered BIF samples from outcrop in gorges across the deformed southeast and oxidized BIF from Fourth West Gorge are broadly similar in trace element composition to each other as well as to BIF from Bee Gorge. Compared to unaltered BIF from Wittenoom and Junction Gorges these rocks contain on average more Co $(35 \pm 15 \mathrm{ppm})$ and $\mathrm{Cr}(29 \pm 16 \mathrm{ppm})$ and less $\mathrm{Pb}(2 \pm 4 \mathrm{ppm}), \mathrm{Sr}(4 \pm 3 \mathrm{ppm}), \mathrm{V}(3 \pm 5 \mathrm{ppm}), \mathrm{Y}(8 \pm$ 
$3 \mathrm{ppm})$ and $\mathrm{Zr}(0.8 \pm 2 \mathrm{ppm})$. As, $\mathrm{Cs}, \mathrm{Hf}, \mathrm{Rb}$ and $\mathrm{Zn}$ are below detection.

\subsubsection{Core and outcrop from Mt. Whaleback}

Oxidized BIF at Mt. Whaleback is comparable in trace element chemistry to equivalent sequences from outcrops at Bee Gorge and across the deformed southeast. These rocks contain significant $\mathrm{Co}(31 \pm 13 \mathrm{ppm})$ and $\mathrm{Cr}(24 \pm 19 \mathrm{ppm})$, with subordinate amounts of $\mathrm{Ni}(16 \pm 20 \mathrm{ppm}), \mathrm{Pb}(6 \pm 7 \mathrm{ppm}), \mathrm{V}(5 \pm 5 \mathrm{ppm})$ and $\mathrm{Y}(8 \pm$ 3ppm). Contents of $\mathrm{Ba}, \mathrm{Nb}, \mathrm{Sc}, \mathrm{Sr}, \mathrm{V}, \mathrm{Zn}$ and $\mathrm{Zr}$ are less than or equal to $5 \mathrm{ppm}$ and $\mathrm{As}$, $\mathrm{Cs}, \mathrm{Hf}$ and $\mathrm{Rb}$ are below detection. High-grade hematite ore, in contrast to all $\mathrm{BIF}$ from which it was derived, is relatively enriched in $\mathrm{Cr}(36 \pm 21 \mathrm{ppm}), \mathrm{Pb}(17 \pm 10 \mathrm{ppm})$ and $\mathrm{V}$ $(38 \pm 42 \mathrm{ppm})$.

There is considerable variation in trace element chemistry between different shales at Mt. Whaleback. Relative to altered black shale samples from the Mt. McRae Shale and Whaleback Shale Member in the mine, altered black DS-macrobands contain higher $\mathrm{Hf}(14 \pm 7 \mathrm{ppm}), \mathrm{Nb}(25 \pm 7 \mathrm{ppm}), \mathrm{Y}(110 \pm 50 \mathrm{ppm}), \mathrm{Zn}(639 \pm 75 \mathrm{ppm})$ and $\mathrm{Zr}(426 \pm$ $166 \mathrm{ppm}$ ) and significantly less As (below detection), $\mathrm{Cr}(7 \pm 4 \mathrm{ppm}), \mathrm{Pb}$ (below detection), $\mathrm{Rb}$ (below detection), $\mathrm{Sr}(7 \pm 0.5 \mathrm{ppm})$ and $\mathrm{V}(33 \pm 3 \mathrm{ppm})$. Compared to equivalent units from the north, average altered black shale at Mt. Whaleback is enriched in $\mathrm{Co}(60 \pm 44 \mathrm{ppm}), \mathrm{Cr}(139 \pm 116 \mathrm{ppm}), \mathrm{Nb}(14 \pm 6 \mathrm{ppm}), \mathrm{Ni}(206 \pm 242 \mathrm{ppm})$, Sc $(21 \pm 6 \mathrm{ppm}), \mathrm{V}(117 \pm 55 \mathrm{ppm}), \mathrm{Y}(48 \pm 29 \mathrm{ppm}), \mathrm{Zn}(533 \pm 459 \mathrm{ppm})$ and $\mathrm{Zr}(232 \pm$ $100 \mathrm{ppm})$, and depleted in $\mathrm{Ba}(47 \pm 42 \mathrm{ppm}), \mathrm{Pb}(5 \pm 11 \mathrm{ppm})$ and $\mathrm{Rb}(92 \pm 118 \mathrm{ppm})$. Compared to all black shale samples, average red shale at Mt. Whaleback is enriched in Co (32 $\pm 27 \mathrm{ppm}), \mathrm{Cr},(147 \pm 99 \mathrm{ppm}), \mathrm{Hf}(8 \pm 3 \mathrm{ppm}), \mathrm{Nb}(18 \pm 6 \mathrm{ppm}), \mathrm{Y}(65 \pm 25 \mathrm{ppm})$

$\mathrm{Zr}(291 \pm 92 \mathrm{ppm})$ and depleted in $\mathrm{Ba}(10 \pm 9 \mathrm{ppm}), \mathrm{Rb}(26 \pm 74 \mathrm{ppm})$ and $\mathrm{Sr}(25 \pm$ 37ppm). In striking contrast to all Mt. McRae Shale samples, reddish-green shales are considerably depleted in As (below detection), $\mathrm{Cr}(86 \pm 23 \mathrm{ppm}), \mathrm{Nb}(6 \pm 3 \mathrm{ppm}), \mathrm{Ni}$ $(103 \pm 62 \mathrm{ppm}), \mathrm{Sr}(14 \pm 6 \mathrm{ppm}), \mathrm{Y}(25 \pm 0.7 \mathrm{ppm}), \mathrm{Zn}(271 \pm 142 \mathrm{ppm})$ and $\mathrm{Zr}(72 \pm$ 42ppm) and slightly enriched in $\mathrm{Pb}(9 \pm 2 \mathrm{ppm})$. 


\subsection{Rare earth elements}

Rare earth element contents of BIF and shale show subtle variations in their abundance and nature of Eu and Ce anomalies (Figs. 5.5, 5.6; Table 5.3). REE patterns of BIF samples from across the Hamersley Province, normalized to the North American Shale Composite (NASC) values of Gromet et al. (1984), are almost identical (Fig. 5.5). On average all rocks contain low to moderate REEs, strong positive Eu anomalies $\left(\mathrm{Eu} / \mathrm{Eu}_{\mathrm{N}}{ }_{\mathrm{N}}\right.$ range from 1.6-1.8), depleted LREEs contents compared to HREEs $\left(\mathrm{LREE}_{\mathrm{N}} / \mathrm{HREE}_{\mathrm{N}}\right.$ range from $\left.0.41-0.69\right)$ and either slightly negative or absent Cerium anomalies. However, two oxidized BIF samples from Fourth West Gorge and Mt. Whaleback contain low $\mathrm{Ho}, \mathrm{Yb}$ and $\mathrm{Lu}$ contents and one sample from Fourth West Gorge is depleted in Sm. Compared to all BIF, high-grade hematite ore is slightly enriched in REEs, although one iron ore sample is strongly depleted in $\mathrm{Ho}, \mathrm{Yb}$ and $\mathrm{Lu}$

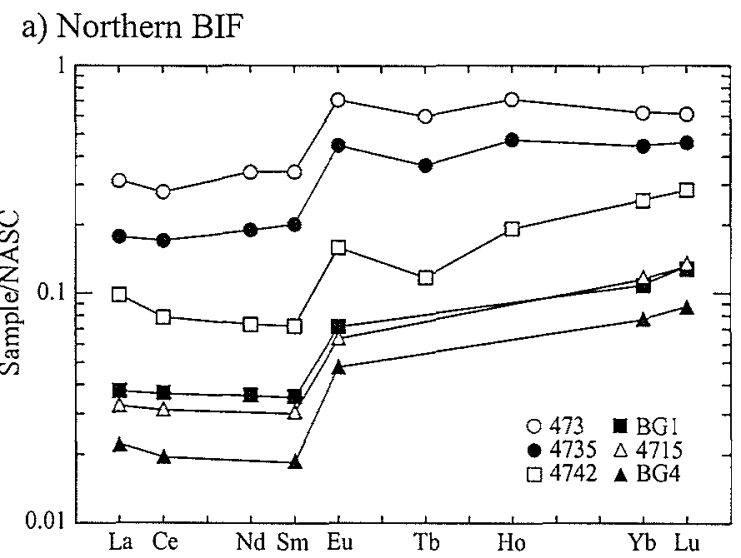

b) Southeastern BIF

c) Mt. Whaleback BIF
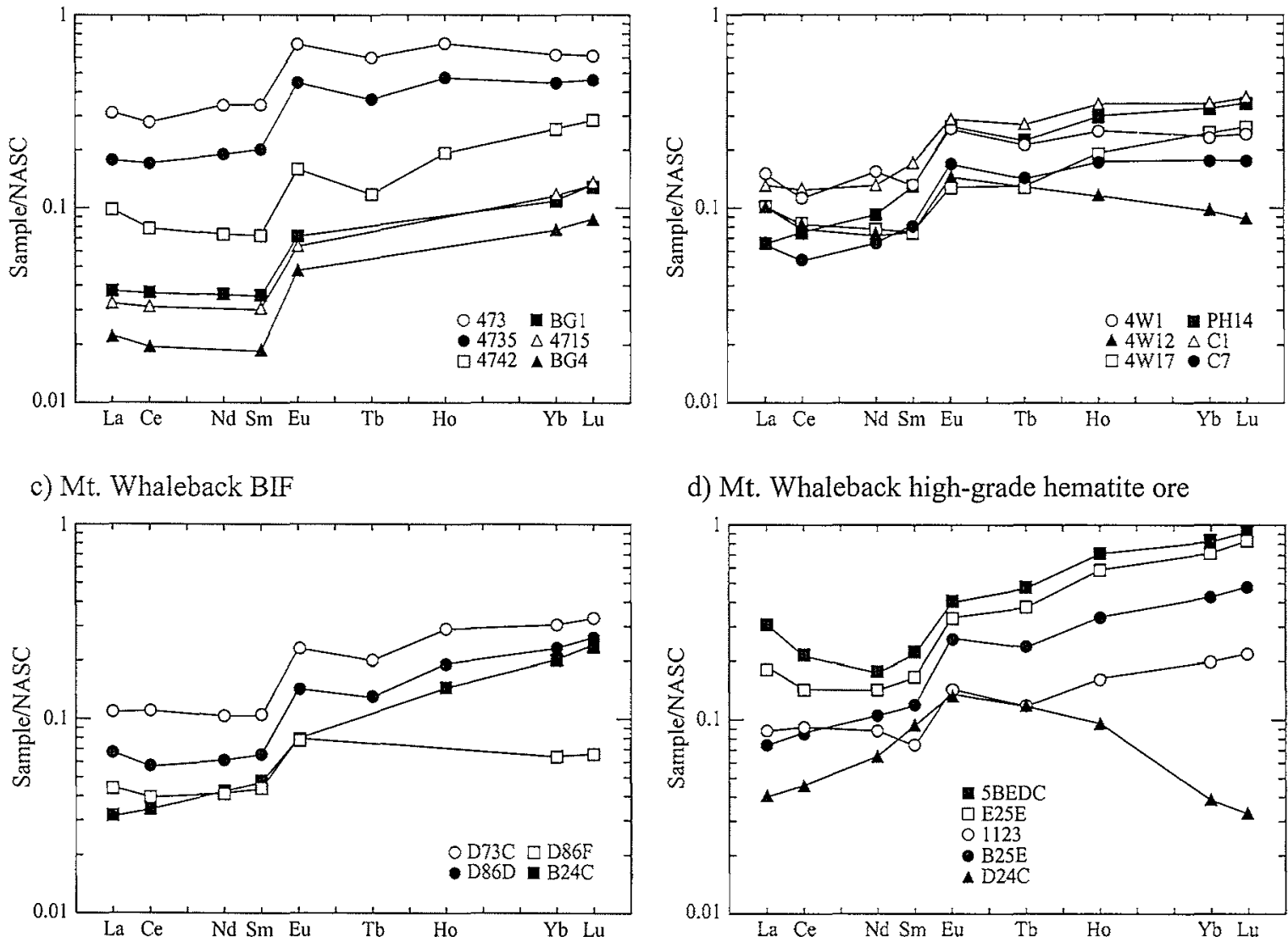

d) Mt. Whaleback high-grade hematite ore

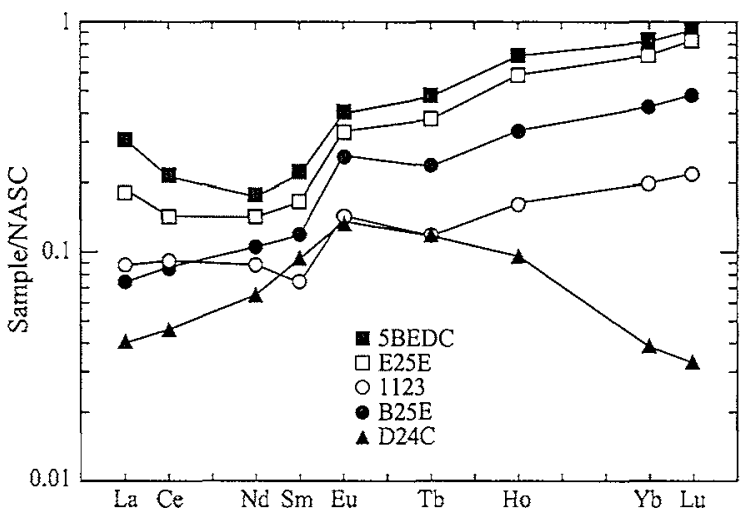

Figure 5.5. REE patterns of selected BIF samples collected across the Hamersley Province, showing low sum REE, positive Eu anomalies and HREE enrichment. (a) Northern BIF from Wittenoom and Bee Gorges, (b) Altered BIF from Pamelia Hill, Cathedral Gorge and Fourth West Gorge, (c) Oxidized BIF from Mt. Whaleback drill core and fresh mine faces, (d) High-grade hematite ore from Mt. Whaleback fresh mine faces. Samples normalized to NASC values of Gromet et al. (1984). 
a) Black shale

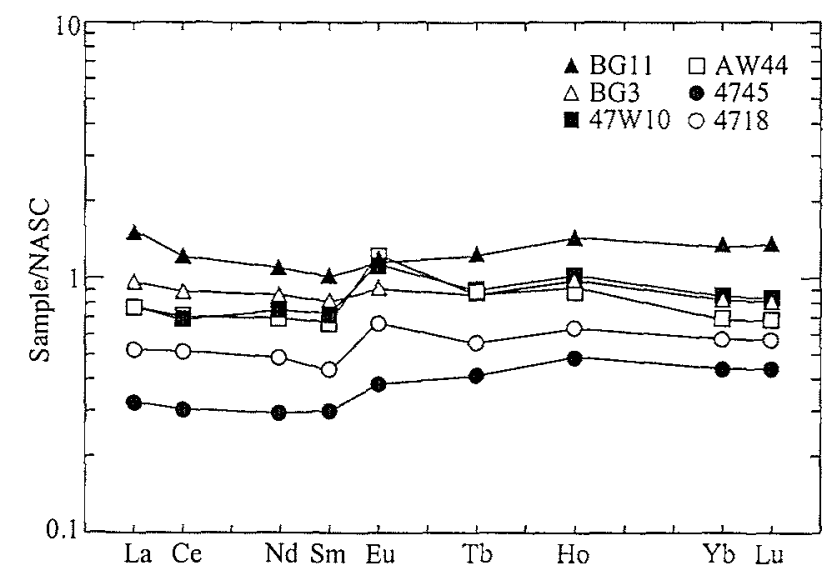

b) Altered black shale

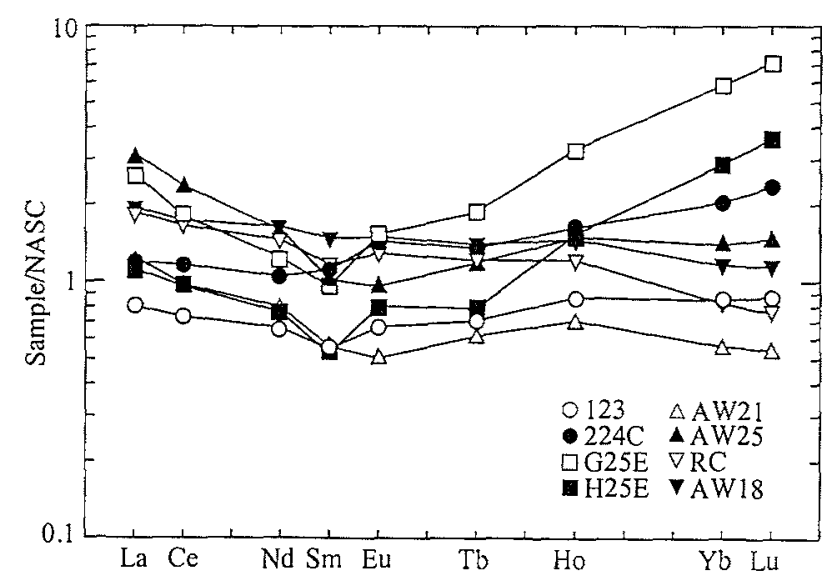

c) Red shale

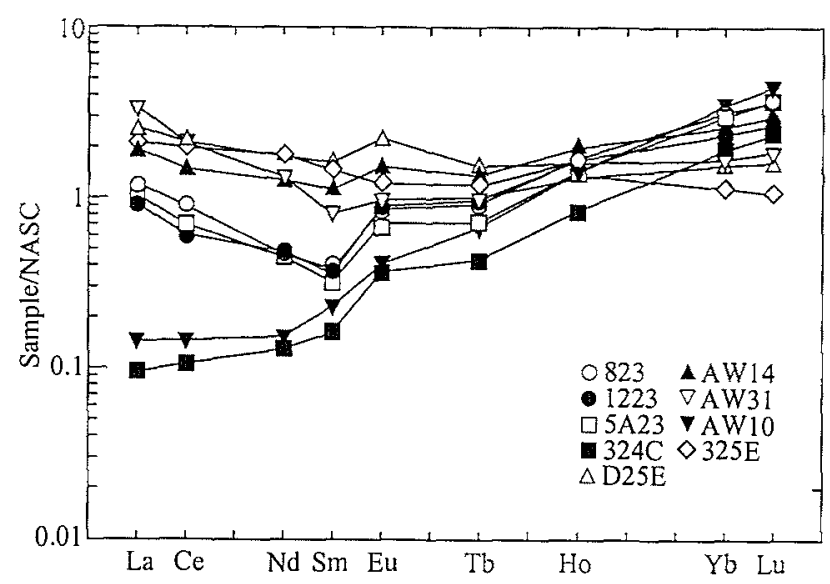

Figure 5.6. The REE patterns of shale across the Hamersley Province, showing low to moderate summ REE, positive Eu anomalies and little or no HREE enrichment. (a) Black shale from Wittenoom and Bee Gorges in the north, (b) Aitered black shale from Mt. Whaleback mine faces, (c) Red shale from Mt. Whaleback mine faces. Samples normalized to NASC values of Gromet et al. (1984). 
Table 5.3. Average rare earth element contents and standard deviations of rocks across the Hamersley Province

\begin{tabular}{|c|c|c|c|c|c|c|c|c|c|c|c|c|c|c|c|c|c|c|c|c|c|c|c|c|}
\hline \multirow[t]{2}{*}{ Sample } & \multirow[t]{2}{*}{$\mathrm{n}$} & \multicolumn{2}{|c|}{$\mathrm{La}$} & \multicolumn{2}{|c|}{$\mathrm{Ce}$} & \multicolumn{2}{|c|}{$\mathrm{Nd}$} & \multicolumn{2}{|c|}{$\mathrm{Sm}$} & \multicolumn{2}{|c|}{$\mathrm{Eu}$} & \multicolumn{2}{|c|}{$\mathrm{Tb}$} & \multicolumn{2}{|c|}{ Ho } & \multicolumn{2}{|c|}{$\overline{\mathrm{Yb}}$} & \multicolumn{2}{|c|}{$\mathrm{Lu}$} & \multirow{2}{*}{$\begin{array}{c}\left(\mathrm{Eu} / \mathrm{Eu}^{*}\right)_{N} \\
\mathrm{Avg}\end{array}$} & \multirow{2}{*}{$\begin{array}{l}\operatorname{LREE}_{N} \\
\text { Avg }\end{array}$} & \multirow{2}{*}{$\begin{array}{l}\mathrm{HREE}_{\mathrm{N}} \\
\mathrm{Avg}\end{array}$} & \multirow{2}{*}{$\begin{array}{l}\mathrm{REE}_{\mathrm{N}} \\
\mathrm{Avg}\end{array}$} & \multirow{2}{*}{$\begin{array}{c}\text { LREE }_{N} / \mathrm{HREE}_{\mathrm{N}} \\
\text { Avg }\end{array}$} \\
\hline & & Avg & $\mathrm{Sd}$ & Avg & $\mathrm{Sd}$ & Avg & $\mathrm{Sd}$ & Avg & $\mathrm{Sd}$ & Avg & $\mathrm{Sd}$ & Avg & $\mathrm{Sd}$ & Avg & $\mathrm{Sd}$ & Avg & $\mathrm{Sd}$ & Avg & $\mathrm{Sd}$ & & & & & \\
\hline \multicolumn{25}{|c|}{ Northern Hamersley Province } \\
\hline BIF (Witt. Gorge) & 3 & 3.2 & 2.3 & 63. & 4.8 & 3.0 & 2.5 & 0.6 & 0.5 & 0.3 & 0.2 & 0.2 & 0.1 & 0.3 & 0.2 & 0.9 & 0.5 & 0.1 & 0.1 & 1.70 & 0.40 & 0.95 & 1.57 & 0.44 \\
\hline BIF (Bee Gorge) & 2 & 0.9 & 0.3 & 19 & 0.8 & 0.8 & 0.4 & 0.2 & 0.1. & $0.1 \%$ & 0.02 & & -2 & & -1 & 0.3. & 0.1 & 0.1 & 0.01 & 1.65 & 0.11 & 0.20 & 0.38 & $0: 54$ \\
\hline Black shale (Witt. Gorge) & 4 & 18.5 & 6.7 & $37: 2$ & 12.5 & 16.9 & 6.3 & 3.2 & 12 & 1.1. & 0.5 & 0.6 & 0.2 & 0.8 & 0.3 & 2,0 & 0.5 & 0.3 & 0.1. & 1.47 & 2.24 & 2.72 & 5.82 & 0.81 \\
\hline Plbw & 1 & 23.9 & - & 46.1 & - & 22.8 & - & 4.3 & - & 1.4 & - & 0.8 & - & 1.1 & - & 2.6 & - & 0.4 & & 1.52 & 2.93 & 3.60 & 7.68 & 0.81 \\
\hline Phbd & 2 & 20.1 & 5.4 & 41.1 & 9.0 & 18.0 & 4.5 & 3.3 & 1.0 & 1.2 & 0.5 & 0.6 & 0.2 & 0.8 & 0.2 & 2.0 & 0.2 & 0.3 & 0.0 & 1.59 & 2.40 & 2.74 & 6.10 & 0.87 \\
\hline Phr & 1 & 10.1 & & 20.5 & & 9.0 & & 1.8 & - & 0.5 & - & 0.4 & - & 0.5 & & 1.4 & & 0.2 & & 1.18 & 1.22 & 1.78 & 3.39 & 0.69 \\
\hline Black shale (Bee Gorge) & 2 & $39: 0$ & 12.7 & 70.7 & 15.6 & 29.9 & 5.2 & $5: 4$ & 0.9 & 1.3 & 0.2 & 0.9 & 0.2 & 1.3 & 0.3 & 3.3 & 1.1. & 0.5 & 0.2 & 1.07 & 4.20 & 4.42 & 9.65 & 0.96 \\
\hline \multicolumn{25}{|c|}{ Southeastern Hamersley Province } \\
\hline $\mathrm{BIF}$ & 66 & 3.2 & 1.1 & 59 & 1.7 & 3.0 & 1.1 & 0.7 & 0.2 & 0.3 & 0.1 & 0.2 & 0.1 & 0.2 & 0.1 & 0.7 & 03 & 0.1 & 0.05 & 1.66 & 0.40 & 0.88 & 1.48 & 0.53 \\
\hline Pamelia Hill & 1 & 2.0 & 0.0 & 5.0 & 0.0 & 2.8 & 0.0 & 0.8 & 0.0 & 0.3 & 0.0 & 0.2 & 0.0 & 0.3 & 0.0 & 1.0 & 0.0 & 0.2 & 0.0 & 1.82 & 0.36 & 1.20 & 1.82 & 0.30 \\
\hline Fourth West Gorge & 3 & 3.7 & 0.9 & 6.1 & 1.3 & 3.1 & 1.4 & 0.6 & 0.2 & 0.2 & 0.1 & 0.1 & 0.1 & 0.2 & 0.1 & 0.6 & 0.3 & 0.1 & 0.04 & 1.65 & 0.40 & 0.69 & 1.27 & 0.69 \\
\hline Cathedral Gorge & 2 & 3.0 & 1.5 & 5.9 & 3.3 & 3.0 & 1.4 & 0.8 & 0.4 & 0.3 & 0.1 & 0.2 & 0.1 & 0.3 & 0.1 & 0.8 & 0.4 & 0.1 & 0.1 & 1.60 & 0.41 & 1.00 & 1.64 & 0.41 \\
\hline \multicolumn{25}{|l|}{ Mt. Whaleback pit } \\
\hline BIF & 4 & 2.0 & 1.1 & 4.1 & 2.3 & 1.9 & 0.9 & 0.4 & 0.2 & 0.2 & 0.1 . & 0.1 & 0.1 & 0.2 & 0.1 & 0.6 & 0.3 & 0.1 & 0.1 & 1.64 & 0.25 & 0.66 & 1.05 & 0.56 \\
\hline Iron Ore & 5 & 4.3 & 3.4 & 7.8 & 4.3 & 3.5 & 1.3 & 0.8 & 0.3 & 0.3 & 0.1 & 0.2 & 0.1 & 0.4 & 0.3 & 1.4 & 1.0 & 0.2 & 0.2 & 1.54 & 0.50 & 1.58 & 2.34 & 0.43 \\
\hline Black shale & 8. & 54.6 & 25.7 & $95: 9$ & 37.5 & 35.2 & 12.0 & 5.5 & 2,1 & 1.4 & 0.5 & 1.0 & 0.4 & 1.6 & 0.8 & 6.1 & 5.5 & 10 & 1.0 & 1.08 & 5.27 & 6.89 & 13.25 & 1.00 \\
\hline Phbw & 2 & 68.3 & 44.0 & 119.0 & 58.0 & 40.4 & 11.9 & 6.4 & 0.4 & 1.5 & 0.4 & 1.1 & 0.1 & 1.6 & 0.1 & 5.4 & 1.4 & 0.9 & 0.3 & 1.02 & 6.37 & 6.51 & 14.08 & 1.04 \\
\hline Phbd & 2 & 58.4 & 33.2 & 92.7 & 40.0 & 30.5 & 10.3 & 4.4 & 1.8 & 1.5 & 0.6 & 1.1 & 0.7 & 2.5 & 1.3 & 13.6 & 6.6 & 2.5 & 1.2 & 1.26 & 5.00 & 13.53 & 19.70 & 0.37 \\
\hline Phr & 4 & 41.8 & 23.8 & 80.6 & 44.5 & 32.4 & 17.3 & 5.2 & 2.7 & 1.2 & 0.6 & 0.8 & 0.3 & 1.1 & 0.3 & 2.6 & 0.0 & 0.4 & 0.0 & 1.11 & 4.85 & 3.76 & 9.61 & 1.29 \\
\hline Red shale & 9 & 46.3 & 342 & $75: 0$ & 540 & 26.5 & 20.4 & 4.3 & 3.3 & 1.3 & 0.7 & 0.8 & 0.3 & 1.5 & 0.3 & 7.2 & 2.5 & 1.3 & 0.5 & 1.41 & 4.20 & 7.53 & 12.75 & 0.65 \\
\hline Phbw & 2 & 54.0 & 72.2 & 73.6 & 93.9 & 22.1 & 25.7 & 2.9 & 2.7 & 0.8 & 0.5 & 0.6 & 0.3 & 1.1 & 0.3 & 5.4 & 0.8 & 0.9 & 0.3 & 1.38 & 4.04 & 5.56 & 10.27 & 0.73 \\
\hline Phbd & 3 & 48.1 & 39.1 & 83.2 & 67.0 & 32.3 & 25.1 & 5.9 & 4.2 & 1.7 & 1.2 & 1.0 & 0.4 & 1.7 & 0.3 & 8.0 & 2.8 & 1.4 & 0.6 & 1.30 & 4.84 & 8.58 & 14.81 & 0.64 \\
\hline Phr & 4 & 41.0 & 16.9 & 69.6 & 41.7 & 24.3 & 20.3 & 3.8 & 3.3 & 1.2 & 0.3 & 0.8 & 0.2 & 1.6 & 0.2 & 7.5 & 2.8 & 1.3 & 0.6 & 1.51 & 3.79 & 7.73 & 12.44 & 0.61 \\
\hline
\end{tabular}

Notes: Concentrations in ppm. $\mathrm{n}=$ number of samples in the group; avg = average; sd = 1 standard deviation; Eu/Eu*, LREE, HREE and REE calculated relative to North American shale composite values of Gromet et al., 1984; "-" = below detection; Phbw = Whaleback Shale Member; Phbd = Dales Gorge Member; Phr = Mt. McRae Shale; Witt. = Wittenoom. 
and two others show depleted Sm contents. For all BIF samples REE patterns, Eu anomalies and $L R E E_{N} / H R E E_{N}$ ratios are very similar.

Rare earth element contents in shales are considerably higher than in BIF. NASCnormalised patterns of most shale samples are relatively similar across the province, although REE contents are progressively higher in altered rocks from Mt. Whaleback (Fig. 5.6). Two altered black shale samples and two red shale samples from Mt. Whaleback are anomalously enriched in HREEs and depleted in LREEs respectively, compared to other rocks within the mine. All shale samples exhibit moderate positive $\mathrm{Eu}$ anomalies $\left(\mathrm{Eu} / \mathrm{Eu}^{*}{ }_{\mathrm{N}}\right.$ range from 1.1-1.5), slight enrichment in HREEs $\left(\mathrm{LREE}_{\mathrm{N}} / \mathrm{HREE}_{\mathrm{N}}\right.$ range from $\left.0.7-1.0\right)$ and slightly negative or absent $\mathrm{Ce}$ anomalies.

Typically, REEs are relatively immobile during post-depositional processes such as diagenesis, metamorphism and hydrothermal alteration (Majumder et al., 1984; McLennan, 1989; Michard, 1989; Bau and Dulski, 1996). Similar REE patterns between BIF and shale samples and their altered equivalents across the Hamersley Province confirm this observation and suggest that REE contents of these rocks primarily reflect the chemistry of the original source material and not subsequent alteration.

\subsection{Principal component analysis}

As emphasized by previous investigations (e.g., Trendall and Pepper, 1977; Alibert and McCulloch, 1993), trace element contents of BIF and surrounding shales vary considerably across the Hamersley Province. However, determination of elemental signatures within the different rock types is hampered by extremely large variations in trace element concentrations. Moreover, many trace elements are at or near analytical detection limits (particularly in BIF samples), making it difficult to determine distribution patterns between stratigraphically equivalent rocks.

Results of the PCA from BIF and shales are presented in tables 5.4a and b. The calculated component loadings may be interpreted similarly to correlation coefficients, with highest absolute loadings onto each component defining a group of variables that 
Table5.4a. Principal Component Analysis matrix* for BIF across the Hamersely Province

\begin{tabular}{|c|c|c|c|c|c|c|c|c|c|c|c|c|c|c|c|c|c|}
\hline \multirow[b]{2}{*}{ Comp. } & \multicolumn{4}{|c|}{ Unaltered $\mathrm{BIF}^{(1)}$} & \multicolumn{4}{|c|}{ Weathered $\mathrm{BIF}^{(2)}$} & \multicolumn{3}{|c|}{ Oxidized BIF $^{(3)}$} & \multicolumn{3}{|c|}{ Oxidized BIF ${ }^{(4)}$} & \multicolumn{3}{|c|}{ High-grade hematite ore ${ }^{(4)}$} \\
\hline & 1 & 2 & 3 & 4 & 1 & 2 & 3 & 4 & 1 & 2 & 3 & 1 & 2 & 3 & 1 & 2 & 3 \\
\hline $\mathrm{SiO}_{2}$ & -0.27 & -0.74 & -0.51 & -0.14 & -0.87 & -0.09 & -0.33 & -0.05 & -0.93 & 0.11 & 0.04 & -0.91 & -0.02 & -0.17 & 0.28 & 0.76 & 0.24 \\
\hline $\mathrm{TiO}_{2}$ & 0.87 & 0.12 & -0.06 & -0.23 & 0.24 & 0.13 & 0.65 & 0.09 & & & & & & & 0.48 & 0.46 & -0.62 \\
\hline $\mathrm{Al}_{2} \mathrm{O}_{3}$ & 0.93 & 0.11 & 0.13 & -0.02 & 0.00 & 0.11 & 0.72 & -0.11 & 0.55 & -0.06 & 0.49 & & & & 0.59 & 0.63 & -0.03 \\
\hline $\mathrm{Fe}_{2} \mathrm{O}_{3} \mathrm{~T}$ & 0.09 & 0.87 & 0.17 & -0.20 & 0.87 & 0.09 & 0.24 & -0.02 & 0.94 & -0.07 & -0.23 & 0.97 & 0.11 & 0.13 & -0.11 & -0.76 & -0.50 \\
\hline $\mathrm{MgO}$ & 0.50 & 0.40 & 0.09 & 0.23 & & & & & & & & & & & & & \\
\hline $\mathrm{CaO}$ & 0.11 & -0.08 & 0.22 & 0.77 & -0.08 & 0.27 & 0.06 & 0.79 & -0.17 & 0.81 & 0.08 & 0.03 & 0.96 & 0.08 & -0.01 & 0.08 & 0.95 \\
\hline $\mathrm{K}_{2} \mathrm{O}$ & 0.81 & 0.27 & 0.24 & 0.24 & 0.14 & 0.85 & -0.02 & 0.22 & -0.20 & 0.11 & 0.81 & 0.21 & 0.94 & 0.00 & 0.09 & 0.34 & 0.67 \\
\hline $\mathrm{P}_{2} \mathrm{O}_{5}$ & 0.24 & -0.46 & 0.55 & 0.07 & 0.07 & -0.27 & 0.64 & 0.10 & -0.02 & 0.80 & -0.36 & 0.30 & 0.29 & 0.74 & -0.03 & 0.74 & 0.03 \\
\hline S & 0.04 & 0.11 & 0.80 & 0.06 & 0.11 & 0.57 & 0.03 & 0.27 & & & & & & & & & \\
\hline $\mathrm{Ba}$ & 0.57 & 0.60 & 0.19 & 0.29 & & & & & 0.64 & 0.25 & 0.28 & & & & 0.37 & -0.36 & 0.05 \\
\hline $\mathrm{Co}$ & -0.09 & -0.42 & -0.69 & -0.34 & -0.72 & 0.18 & 0.18 & 0.07 & -0.82 & -0.29 & 0.21 & -0.32 & -0.53 & -0.56 & 0.79 & -0.08 & 0.02 \\
\hline $\mathrm{Cr}$ & 0.29 & 0.07 & 0.33 & -0.47 & 0.46 & -0.69 & -0.05 & 0.30 & 0.55 & 0.63 & 0.04 & 0.08 & -0.13 & 0.70 & 0.19 & -0.89 & -0.05 \\
\hline $\mathrm{Ni}$ & 0.34 & 0.78 & -0.01 & 0.14 & 0.02 & -0.02 & 0.02 & 0.80 & 0.00 & 0.15 & -0.81 & -0.50 & -0.60 & 0.57 & 0.95 & 0.07 & 0.03 \\
\hline $\mathrm{Rb}$ & 0.54 & 0.55 & 0.34 & 0.36 & & & & & & & & & & & & & \\
\hline $\mathrm{Sr}$ & 0.17 & 0.30 & 0.22 & 0.75 & -0.01 & -0.26 & 0.57 & 0.45 & 0.50 & 0.71 & 0.17 & 0.84 & 0.31 & 0.01 & 0.51 & 0.08 & 0.82 \\
\hline $\mathrm{Y}$ & 0.78 & 0.11 & 0.41 & 0.15 & 0.30 & -0.69 & 0.24 & 0.43 & 0.63 & 0.57 & -0.12 & 0.76 & 0.19 & 0.42 & 0.91 & 0.10 & 0.23 \\
\hline $\mathrm{Zn}$ & 0.39 & 0.29 & 0.60 & 0.10 & & & & & & & & & & & & & \\
\hline Cumul. \% & 43.32 & 54.98 & 65.44 & 72.95 & 24.782 & 41.308 & 55.269 & 65.792 & 39.67 & 57.89 & 73.30 & 47.09 & 66.68 & 81.41 & 73.97 & 56.16 & 73.97 \\
\hline
\end{tabular}

Notes: *Using Varimax factor rotation; (1) Wittenoom and Junction Gorges; (2) Weeli Wolli Spring, Mt. Robinson, Pameilia Hill and Cathedral Gorge; (3) Fourth West Gorge; (4) Mt. Whaleback; Comp. = Component or group; Cumul. = cumulative; bold numbers = highly correlated elements for the particular

component; blank = element eliminated from PCA, see text. 
Table 5.4b. Principal Component Analysis matrix* for shales across the Hamersely Province

\begin{tabular}{|c|c|c|c|c|c|c|c|c|c|}
\hline \multirow[b]{2}{*}{ Comp. } & \multicolumn{3}{|c|}{ Black shale $^{(1)}$} & \multicolumn{3}{|c|}{ Altered black shale $\mathrm{e}^{(2)}$} & \multicolumn{3}{|c|}{ Red shale ${ }^{(2)}$} \\
\hline & 1 & 2 & 3 & 1 & 2 & 3 & 1 & 2 & 3 \\
\hline $\mathrm{SiO}_{2}$ & 0.65 & 0.32 & -0.35 & -0.83 & 0.11 & -0.23 & 0.83 & 0.35 & 0.07 \\
\hline $\mathrm{TiO}_{2}$ & 0.73 & 0.30 & -0.09 & 0.30 & 0.44 & 0.67 & -0.05 & 0.65 & -0.01 \\
\hline $\mathrm{Al}_{2} \mathrm{O}_{3}$ & 0.90 & 0.01 & -0.10 & 0.12 & 0.68 & 0.27 & 0.34 & 0.73 & -0.09 \\
\hline $\mathrm{Fe}_{2} \mathrm{O}_{3} \mathrm{~T}$ & -0.73 & 0.06 & -0.37 & 0.71 & 0.26 & 0.24 & -0.79 & -0.30 & -0.18 \\
\hline $\mathrm{MnO}$ & -0.69 & -0.19 & 0.49 & 0.72 & -0.28 & -0.11 & & & \\
\hline $\mathrm{MgO}$ & 0.09 & -0.49 & -0.47 & 0.71 & 0.01 & -0.23 & 0.15 & -0.39 & 0.85 \\
\hline $\mathrm{CaO}$ & -0.18 & 0.08 & 0.92 & 0.29 & -0.63 & -0.17 & 0.38 & -0.29 & 0.08 \\
\hline $\mathrm{K}_{2} \mathrm{O}$ & 0.72 & 0.47 & 0.22 & -0.84 & -0.25 & -0.37 & 0.91 & -0.28 & -0.03 \\
\hline $\mathrm{P}_{2} \mathrm{O}_{5}$ & -0.62 & -0.09 & 0.06 & 0.00 & 0.04 & 0.78 & 0.00 & -0.01 & -0.78 \\
\hline S & 0.25 & 0.07 & 0.46 & -0.56 & -0.35 & 0.30 & & & \\
\hline $\mathrm{Ba}$ & 0.27 & 0.82 & 0.09 & -0.63 & -0.09 & -0.18 & 0.61 & 0.09 & -0.12 \\
\hline $\mathrm{Co}$ & 0.53 & 0.33 & 0.28 & 0.77 & 0.13 & 0.06 & 0.27 & 0.08 & 0.86 \\
\hline $\mathrm{Cr}$ & 0.71 & 0.01 & -0.06 & -0.29 & -0.45 & 0.14 & 0.04 & -0.35 & 0.04 \\
\hline $\mathrm{Nb}$ & 0.59 & -0.64 & 0.05 & 0.20 & 0.17 & 0.62 & -0.27 & 0.75 & 0.07 \\
\hline $\mathrm{Ni}$ & 0.62 & 0.20 & 0.17 & 0.68 & 0.13 & -0.11 & -0.01 & 0.28 & 0.84 \\
\hline $\mathrm{Rb}$ & 0.39 & 0.79 & -0.02 & -0.75 & -0.33 & -0.41 & 0.79 & -0.23 & 0.23 \\
\hline $\mathrm{Sr}$ & -0.05 & 0.55 & 0.73 & -0.44 & -0.29 & 0.66 & 0.68 & -0.17 & 0.00 \\
\hline V & 0.78 & -0.02 & 0.24 & 0.02 & -0.61 & 0.51 & 0.43 & -0.46 & 0.27 \\
\hline$Y$ & 0.05 & -0.41 & -0.13 & 0.22 & 0.83 & 0.03 & 0.12 & 0.79 & 0.20 \\
\hline $\mathrm{Zn}$ & 0.74 & -0.35 & -0.08 & 0.62 & 0.09 & -0.02 & -0.07 & 0.04 & 0.89 \\
\hline $\mathrm{Zr}$ & 0.82 & -0.13 & -0.22 & 0.13 & 0.86 & 0.09 & -0.07 & 0.85 & 0.15 \\
\hline
\end{tabular}

\begin{tabular}{llllllll|lll}
\hline Cumul. \% & 35.995 & 53.648 & 62.773 & 33.457 & 48.179 & 60.991 & 25.093 & 46.061 & 62.874 \\
\hline
\end{tabular}

Notes: *Using Varimax factor rotation; (1) = Wittenoom and Junction Gorge; (2) Mt. Whaleback; Comp. $=$ Component or group; Cumul, = cumulative; bold numbers $=$ highly correlated elements for the particular component; blank = element eliminated from PCA see text.

are strongly inter-correlated within the dataset. Most of the variation in the chemistry of unaltered $\mathrm{BIF}$ from the north can be described by four main groups; Group 1, $\mathrm{Al}_{2} \mathrm{O}_{3}$, $\mathrm{TiO}_{2}, \mathrm{~K}_{2} \mathrm{O}, \mathrm{Y}$ and $\mathrm{MgO}$; Group 2, $\mathrm{Fe}_{2} \mathrm{O}_{3}, \mathrm{Ni}, \mathrm{Ba}, \mathrm{Rb}$ and minus (-) $\mathrm{SiO}_{2}$; Group 3, S, $\mathrm{Co}, \mathrm{Zn}$ and $\mathrm{P}_{2} \mathrm{O}_{5}$; and Group $4 \mathrm{CaO}, \mathrm{Sr}$ and $\mathrm{Cr}$. For weathered BIF there are four groups; Group 1, $\mathrm{Fe}_{2} \mathrm{O}_{3},-\mathrm{SiO}_{2}$ and -Co; Group 2, $\mathrm{K}_{2} \mathrm{O}$, Cr, Y and S; Group 3, $\mathrm{Al}_{2} \mathrm{O}_{3}$, $\mathrm{TiO}_{2}, \mathrm{P}_{2} \mathrm{O}_{5}$ and $\mathrm{Sr}$; and Group 4, $\mathrm{Ni}$ and $\mathrm{CaO}$. Oxidized BIF from Fourth West Gorge can be explained by three groups; Group $1, \mathrm{Fe}_{2} \mathrm{O}_{3}, \mathrm{Ba}, \mathrm{Y}, \mathrm{Al}_{2} \mathrm{O}_{3},-\mathrm{SiO}_{2}$ and $-\mathrm{Co}$; Group 2, $\mathrm{CaO}, \mathrm{K}_{2} \mathrm{O}$, and $-\mathrm{Ni}$; and Group $3, \mathrm{P}_{2} \mathrm{O}_{5}, \mathrm{Cr}$ and -Co. Similarly oxidized BIF from Mt. Whaleback is described by three groups; Group 1, $\mathrm{Fe}_{2} \mathrm{O}_{3}, \mathrm{Ba}, \mathrm{Y}, \mathrm{Al}_{2} \mathrm{O}_{3},-\mathrm{SiO}_{2}$ and $\mathrm{Co}$; Group 2, $\mathrm{CaO}, \mathrm{P}_{2} \mathrm{O}_{5}, \mathrm{Sr}$ and $\mathrm{Cr}$; and Group 3, $\mathrm{K}_{2} \mathrm{O}$ and -Ni. Iron ore from $\mathrm{Mt}$. Whaleback consists of three main groups; Group 1, Ni, Y, Co and Ba; Group 2, -Cr, - 
$\mathrm{Fe}_{2} \mathrm{O}_{3}, \mathrm{SiO}_{2}, \mathrm{P}_{2} \mathrm{O}_{5}$ and $\mathrm{Al}_{2} \mathrm{O}_{3}$; and Group 3, $\mathrm{CaO}, \mathrm{Sr}, \mathrm{K}_{2} \mathrm{O}$ and $-\mathrm{TiO}_{2}$.

Several dominant groups can also explain variations in shale chemistry across the Hamersley Province. Unaltered black shale from the north consists of 3 groups; Group 1, $\mathrm{Al}_{2} \mathrm{O}_{2}, \mathrm{Zr}, \mathrm{V}, \mathrm{Zn}, \mathrm{TiO}_{2}, \mathrm{~K}_{2} \mathrm{O}, \mathrm{Cr}, \mathrm{SiO}_{2}, \mathrm{Ni}, \mathrm{Ca},-\mathrm{Fe}_{2} \mathrm{O}_{3},-\mathrm{MnO}$ and $-\mathrm{P}_{2} \mathrm{O}_{5}$; Group 2, $\mathrm{Ba}, \mathrm{Rb},-\mathrm{Nb},-\mathrm{MgO}$ and $-\mathrm{Y}$; Group 3, $\mathrm{CaO}, \mathrm{Sr}$ and $\mathrm{S}$. Altered black shale from Mt. Whaleback also consists of three main groups; Group 1, $\mathrm{MnO}, \mathrm{Fe}_{2} \mathrm{O}_{3}, \mathrm{MgO}, \mathrm{Ni}, \mathrm{Zn}$, $\mathrm{K}_{2} \mathrm{O}$, $-\mathrm{SiO}_{2},-\mathrm{Rb}$, - $\mathrm{Ba}$ and $-\mathrm{S}$; Group 2, $\mathrm{Zr}, \mathrm{Y}, \mathrm{Al}_{2} \mathrm{O}_{3},-\mathrm{CaO},-\mathrm{V}$ and $-\mathrm{Cr}$; and Group 3, $\mathrm{P}_{2} \mathrm{O}_{5}, \mathrm{TiO}_{2}$, Sr and $\mathrm{Nb}$. Red shale can be described by three groups; Group $1, \mathrm{~K}_{2} \mathrm{O}$, $\mathrm{SiO}_{2}, \mathrm{Rb}, \mathrm{Sr}, \mathrm{Ba}, \mathrm{CaO}$ and $-\mathrm{Fe}_{2} \mathrm{O}_{3}$; Group 2, $\mathrm{Zr}, \mathrm{Y}, \mathrm{Nb}, \mathrm{Al}_{2} \mathrm{O}_{3}, \mathrm{TiO}_{2},-\mathrm{V}$ and $-\mathrm{Cr}$; and Group 3, $\mathrm{Zn}, \mathrm{Co}, \mathrm{MgO}, \mathrm{Ni}$ and $-\mathrm{P}_{2} \mathrm{O}_{5}$.

\subsection{Dales Gorge Member thickness variations across the Hamersley Province}

Measured stratigraphic thicknesses and relative proportions of BIF and shale in the Dales Gorge Member vary across the Hamersley Province (Table 5.5). In undeformed regions of the north (i.e., DDH-47A at Wittenoom Gorge), the total mean thickness of flat lying unaltered BIF and shale macrobands are $107 \mathrm{~m}$ and $36 \mathrm{~m}$ respectively. In this region BIF layers constitute $75 \%$ of the Dales Gorge Member, whereas shale layers comprise $25 \%$. In deformed and unmineralized regions across the southeast, equivalent layers have been thinned. BIF macrobands at Fourth West and Cathedral Gorges have a total mean thickness of $101 \mathrm{~m}$ and $77 \mathrm{~m}$, respectively, whereas shale macrobands have a total mean thickness of $13 \mathrm{~m}$ and $9 \mathrm{~m}$, respectively. At these localities BIF macrobands form $89 \%$ and shale macrobands form $11 \%$ of the Dales Gorge Member. Variations in total mean thicknesses between BIF macrobands at Fourth West and Cathedral Gorges suggest structural thinning (on $\mathrm{D}_{2}$ fold limbs) has reduced stratigraphic thickness across the deformed southeast. The significant reduction of shale macrobands at these locations indicates these layers took up most of the ductile thinning (e.g., Fig. 5.7). At Mt. Whaleback, stratigraphic thicknesses of BIF and shale macrobands have been further reduced. Compared to undeformed regions in the north the total mean thickness of BIF macrobands is $49 \mathrm{~m}$ and for shales it is $5 \mathrm{~m}$. 
Table 5.5. Average thickness changes of Dales Gorge Member macrobands across the Hamersley Province

\begin{tabular}{|c|c|c|c|c|c|c|c|c|c|c|c|c|c|c|c|c|c|c|c|}
\hline \multirow[t]{2}{*}{ Locality } & \multicolumn{6}{|c|}{ Mean thickness (m) } & \multicolumn{4}{|c|}{ Proportions (\%) } & \multicolumn{3}{|c|}{ Thickness loss (m) } & \multicolumn{3}{|c|}{ Thickness loss (\%) } & \multicolumn{3}{|c|}{ Volume factor $\left(\mathrm{F}_{\mathrm{v}}\right)^{*}$} \\
\hline & BIF & $2 \mathrm{Sd}$ & Shale & $2 \mathrm{Sd}$ & Total & $2 \mathrm{Sd}$ & BIF & $2 \mathrm{Sd}$ & Shale & $2 \mathrm{Sd}$ & $\mathrm{BIF}$ & Shale & Total & $\mathrm{BIF}$ & Shale & Total & $\mathrm{BIF}$ & Shale & Total \\
\hline Wittenoom Gorge ${ }^{(1)}$ & 106.5 & - & 35.6 & - & 142.1 & - & 74.9 & - & 25.1 & - & - & - & - & - & - & - & - & - & \\
\hline Cathedral Gorge ${ }^{(2)}$ & 76.9 & 7.0 & 9.2 & 1.4 & 86.1 & 8.3 & 89.3 & 8.1 & 10.7 & 1.7 & 29.6 & 26.4 & 56.0 & 27.8 & 74.1 & 39.4 & 0.72 & 0.26 & 0.61 \\
\hline Fourth West Gorge ${ }^{\{2\}}$ & 101.2 & 5.7 & 12.7 & 0.7 & 113.9 & 6.5 & 88.8 & 5.0 & 11.1 & 0.6 & 5.3 & 22.9 & 28.2 & 4.9 & 64.4 & 19.8 & 0.95 & 0.36 & 0.80 \\
\hline Mt. Whaleback ore $e^{(2)}$ & 48.5 & 5.6 & 4.9 & 0.9 & 53.4 & 6.5 & 90.8 & 10.4 & 9.2 & 1.7 & 57.9 & 30.7 & 88.7 & 54.4 & 86.2 & 62.4 & 0.46 & 0.14 & 0.38 \\
\hline Mt. Whaleback ore $\mathrm{e}^{(3)}$ & $"$ & $"$ & $"$ & $"$ & $"$ & $"$ & $"$ & $"$ & $"$ & $"$ & 28.4 & 4.3 & 60.5 & 36.9 & 46.9 & 70.3 & 0.63 & 0.53 & 0.62 \\
\hline Mt. Whaleback ore ${ }^{(4)}$ & $"$ & $"$ & $"$ & " & $n$ & $"$ & $"$ & $"$ & $"$ & $"$ & 52.7 & 7.8 & 60.5 & 52.1 & 61.3 & 53.1 & 0.48 & 0.39 & 0.47 \\
\hline
\end{tabular}

Notes: (1) = Dales Gorge Member type-section (i.e., DDH-47A), Trendall and Blockley, 1968; (2) = thickness losses and volume factors relative to the Dales Gorge Member type-section in the north; (3) = thickness losses and volume factors relative to the Dales Gorge Member at Cathedral Gorge; (4) thickness losses and volume factors relative to the Dales Gorge Member at Fourth West Gorge; average thickness losses occur within volume loss ranges calculated using isocons and Gresens ${ }^{2}(1967)$ equation; $* F_{\mathrm{v}}=$ volume factor $=$ the ratio of average altered thickness over average unaltered thickness; " = same as above. 


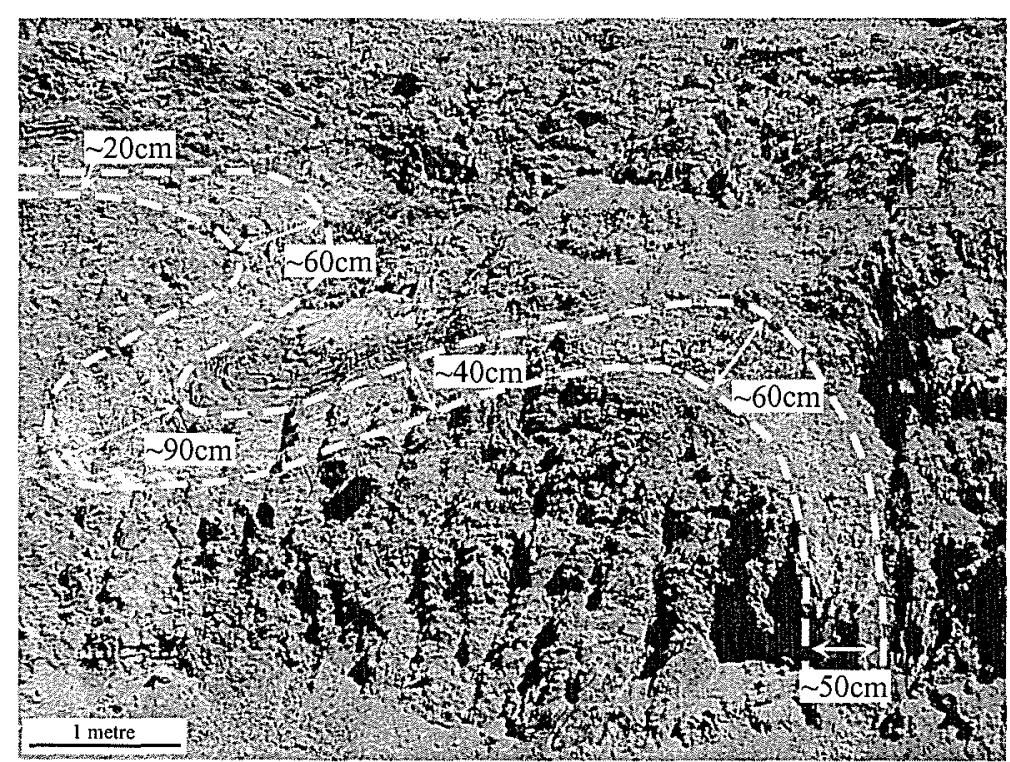

Figure 5.7. Folded DS-macroband (DS16) in high-grade hematite ore showing the effects of pre-ore $\mathrm{D}_{2}$ folding on shale layers. Note thinning of shale band on fold limbs and thickening in hinge region.

Although the shales layers at Mt. Whaleback have been substantially thinned, the most notable change is the significant reduction in the thickness of BIF horizons. Compared to equivalent sequences outside the deposit between $37-54 \%$ of BIF has been lost, suggesting some process other than deformation has thinned these rocks.

\subsection{Bulk rock density variations across the Hamersley Province}

Significant changes in bulk rock densities occur across the Hamersley Province (Table 5.6). Unaltered, weathered and oxidized BIF from core and outcrop across the region has an average bulk density of $3.24 \mathrm{~g} / \mathrm{cm}^{3}$. Similarly, oxidized BIF at Mt. Whaleback has a bulk density of $3.30 \mathrm{~g} / \mathrm{cm}^{3}$. However, in contrast to all BIF, highgrade hematite ore is significantly denser at $4.30 \mathrm{~g} / \mathrm{cm}^{3}$. Assuming iron ore is almost entirely hematite (density $=5.27 \mathrm{~g} / \mathrm{cm}^{3}$ ) (Harmsworth et al., 1990; Chapters 2, 3), this equates to an average porosity of $20 \%$ for high-grade hematite ore.

Black shale from cores in the north is significantly less dense than adjacent BIF sequences averaging $2.70 \mathrm{~g} / \mathrm{cm}^{3}$. However, these rocks are slightly denser than equivalent sequences of altered black, red and reddish-green shale at Mt. Whaleback that have densities of $2.59,2.56$ and $2.57 \mathrm{~g} / \mathrm{cm}^{3}$ respectively. 
Table 5.6. Average mineralogy and density of rocks across the Hamersley Province

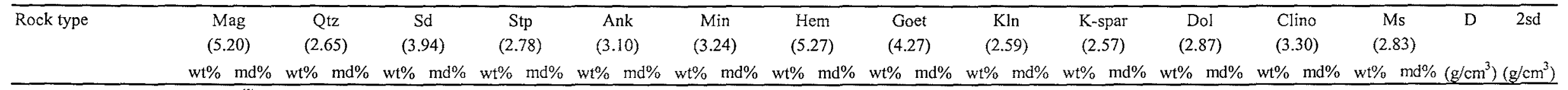

Northern Hamersley Province ${ }^{(1)}$

$\begin{array}{llllllllllllllllllllllllllllllllllllllllll}\text { Unaltered BIF } & 38.0 & 25.6 & 37.0 & 48.9 & 13.0 & 11.5 & 5.0 & 6.3 & 3.0 & 3.4 & 4.0 & 4.32 & - & - & - & - & - & - & - & - & - & - & - & - & - & - & 3.24 & 0.33\end{array}$

$\begin{array}{lllllllllllllllllllllllllllllllllllll}\text { Black shale } & - & - & 12.0 & 13.0 & 10.0 & 7.3 & 33.0 & 34.1 & 7.0 & 6.5 & - & - & - & - & - & - & - & - & 20.0 & 22.3 & 8.0 & 8.0 & 9.0 & 7.8 & 1.0 & 1.0 & 2.70 & 0.27\end{array}$

Southeastern Hamersley Province

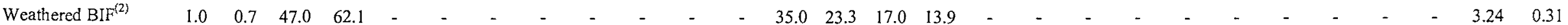

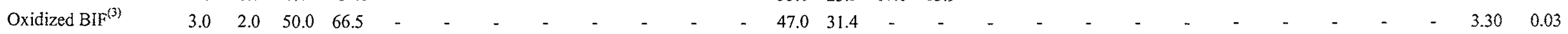

Mt. Whaleback pit

Oxidized BIF

Iron ore

Altered black shale

Red shate

Reddish-green shale

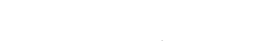

Notes: Average mineral abundances ( $\mathrm{Wt} \%$ ) from Chapters 2 3,4, mineral densities (brackets, $\mathrm{g} / \mathrm{cm}^{3}$ ) from Weast and Astle (1981); (1) Wittenoom (DDH-47A) and Junction (DDH-JO Spring, Mt. Robinson, Pamelia Hill, Cathedral Gorge; (3) Fourth West Gorge; mag = magnetite, $\min =$ minnesotaite; $m s=$ muscovite; qtz $=$ quartz, sd $=$ siderite, stp $=$ stilpnomelane, ank $=$ ankerite, hem $=$ hematite, goet $=$ goethite, $\mathrm{kln}=$ kaolinite, $\mathrm{k}$-spar $=\mathrm{K}$-feldspar, dol $=$ dolomite, clino $=$ clinochlore, $\mathrm{ms}=$ muscovite. $\mathrm{wt} \%=$ weight-percent; $\mathrm{md} \%=$ modal-percent; $\mathrm{D}=\mathrm{average}$ rock density $(\mathrm{calculated}$ from data in appendix $6.1) ; 2 \mathrm{Sd}=2 *$ standard deviation of average densities. 


\subsection{Mass and volume changes}

\subsubsection{Weathering of banded iron-formation}

Mass balance calculations used in this study assumed constant Sc and REEs ( \pm $\mathrm{Al}_{2} \mathrm{O}_{3}$ and $\mathrm{Y}$ ) as these elements are generally considered immobile in low- to mediumtemperature alteration systems (e.g., Bau and Dulski, 1996; Goldschmidt, 1968; McLennan, 1989; Michard, 1989) and were above analytical detection in most BIF samples. On this basis weathering of BIF in gorges across the southeast results in the significant loss of $\mathrm{K}_{2} \mathrm{O}, \mathrm{MgO}, \mathrm{CaO}, \mathrm{Ba}, \mathrm{Rb}, \mathrm{Sr}$ and $\mathrm{Y}$ and gain in $\mathrm{Co}$ and $\mathrm{Cr}$ (Fig. 5.8a). Elements such as $\mathrm{Al}, \mathrm{Ce}, \mathrm{Eu}, \mathrm{Fe}, \mathrm{Ho}, \mathrm{La}, \mathrm{Lu}, \mathrm{Nd}, \mathrm{Ni}, \mathrm{P}, \mathrm{Sc}, \mathrm{Si}, \mathrm{Sm}, \mathrm{Tb}$ and $\mathrm{Yb}$ are relatively immobile.

The large variation of most elements in BIF makes it extremely difficult to confidently quantify the bulk rock and elemental mass changes associated with weathering. The range of isocons taking into account most of the standard deviation suggests that this process could have resulted in bulk rock mass changes ranging from a $43 \%$ loss to a $38 \%$ gain even though the best fit isocon for the averages indicates little mass change (Fig. 5.8a). To better constrain this variation, associated volume changes were calculated and compared to stratigraphic thicknesses measured across the region.

Using equation (1), volume changes accompanying the weathering of unaltered BIF across the southeastern Hamersley Province range from a $43 \%$ loss to a $38 \%$ gain (Fig. 5.8a). However, the lack of measured thickness increases between unaltered Dales Gorge Member BIF and altered equivalents (Table 5.5; Appendix 2) suggests any volume gains are unrealistic data. Moreover, the absence of recrystallised or secondary infill textures in altered BIF and ore (Chapter 3) further excludes a net volume gain. Thus, the minimum and maximum volume losses most likely associated with the weathering of BIF range from $0-43 \%$. These calculated volume changes using the averages concur with average thickness losses determined from measured stratigraphic sections (Table 5.5).

Using the calculated volume losses, bulk rock densities and average chemistry, the transformation of unaltered BIF to weathered BIF across the southeast resulted in the 
a)

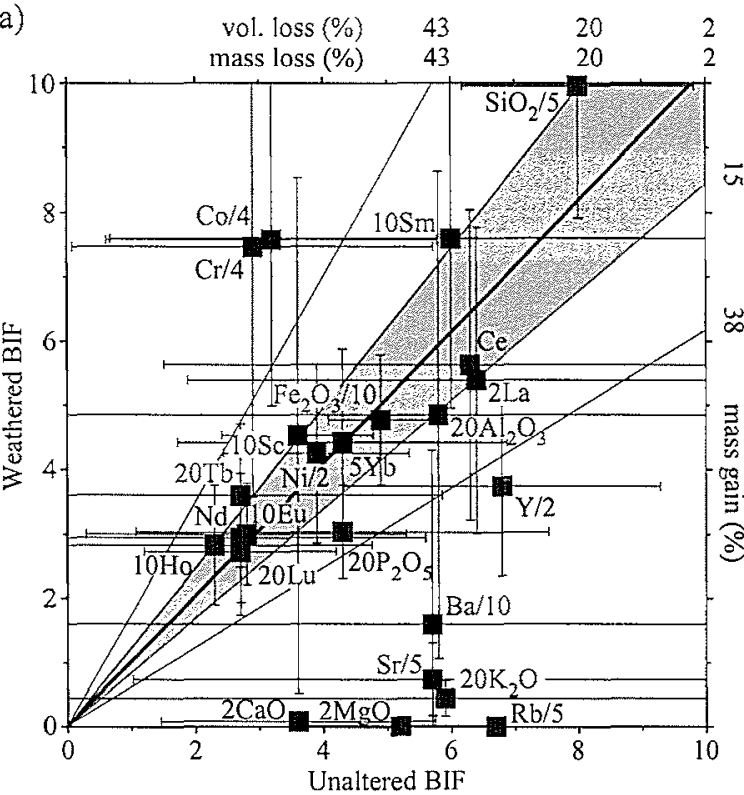

c)

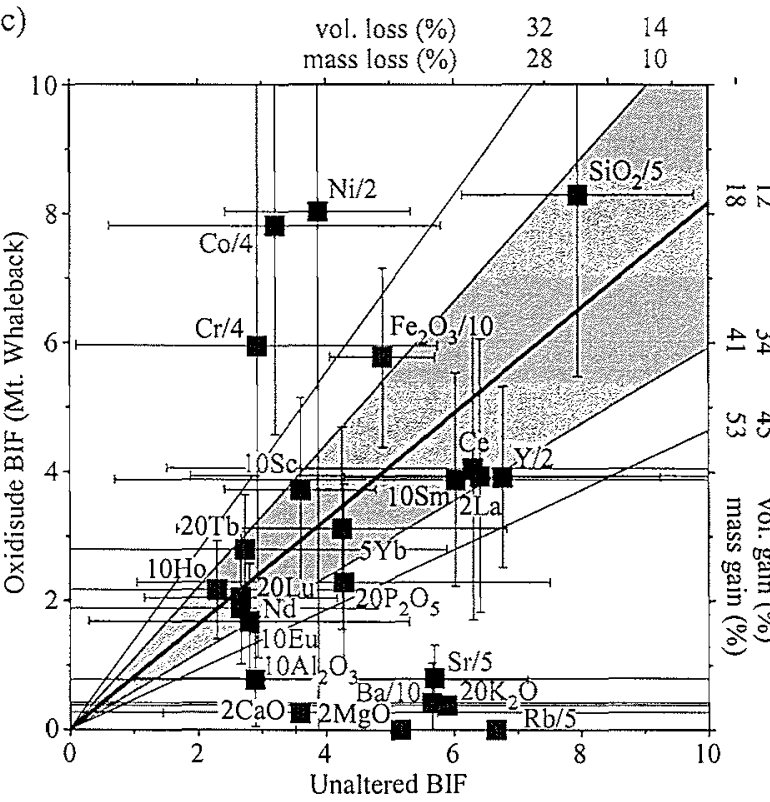

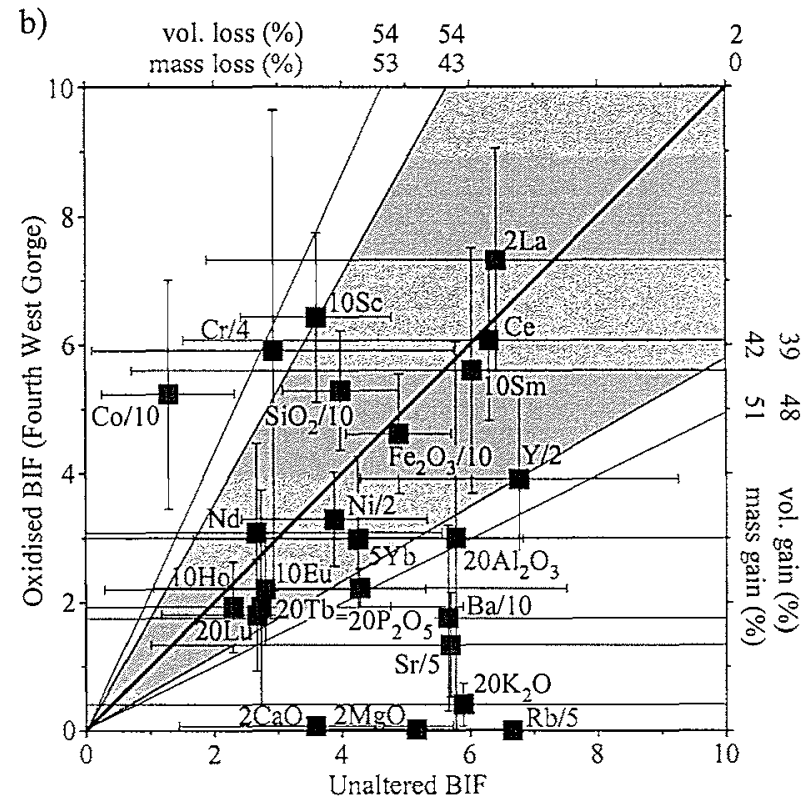

d)

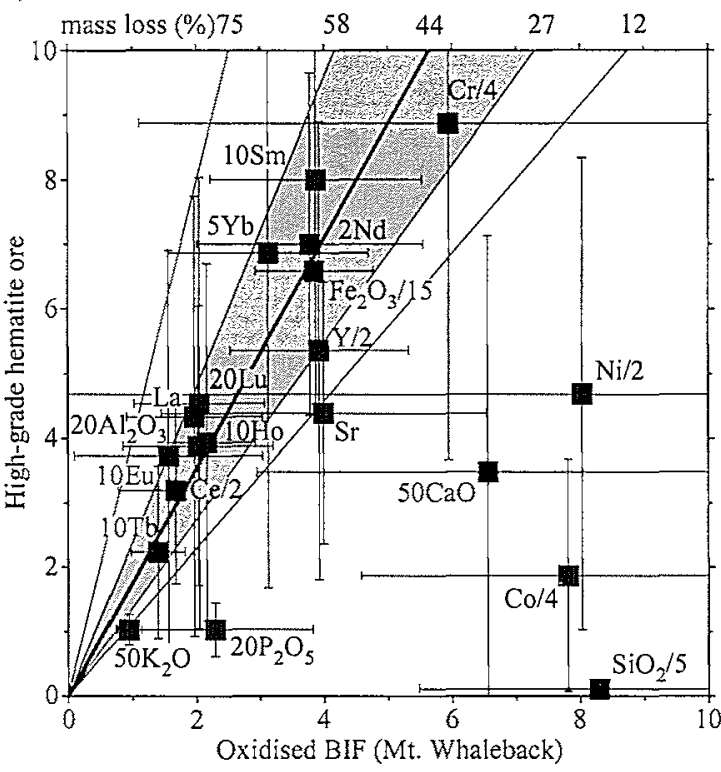

Figure 5.8. Isocon diagrams (after Grant, 1986) showing the representative element changes between (a) unaltered BIF (Wittenoom and Junction Gorges) and weathered BIF (southeastern gorges); (b) unaltered BIF and oxidized BIF (Fourth West Gorge); (c) unaltered BIF and oxidized BIF (Mt. Whaleback); (d) oxidized BIF and high-grade hematite ore (Mt. Whaleback). Average chemistry from right-hand columns in Appendix 3.4 (i.e., values below the lower limit of detection $=0$ ). Note: elements containing a over a third of values below analytical detection were not included in the isocons; major element oxides plotted as wt. \%, trace elements as ppm; dark grey areas represent the broadest range of possible isocons ignoring standard deviations for assumed near immobile elements ( $\mathrm{Sc}$ and $\mathrm{REEs}, \pm \mathrm{Al}_{2} \mathrm{O}_{3}$ and $\mathrm{Y}$ ); the central line represents a visual "best-fit" isocon for the immobile elements; light grey areas represent the broadest range of possible isocons taking into account most of their standard deviations; and bulk rock mass changes (\%) implied for the indicated isocons and the associated calculated volume (vol.) changes (\%) using measured densities are shown along the edges. 
loss of $\mathrm{Fe}_{2} \mathrm{O}_{3} \mathrm{~T}, \mathrm{MgO}, \mathrm{CaO}, \mathrm{K}_{2} \mathrm{O}, \mathrm{Ba}, \mathrm{Rb}$ and $\mathrm{Sr}$ (Fig. 5.9a; Appendix 7) and a slight gain in $\mathrm{Co}$ and $\mathrm{Cr}$. For low assumed volume losses $\mathrm{SiO}_{2}$ may have been added during this process. However, the absence of secondary quartz textures and silicate minerals (Chapter 3) in the weathered rocks suggests it was relatively immobile or even partially removed. Mineralogically, the majority of the mass changes associated with weathering can be explained by the dissolution of carbonates, silicates and minor quartz (Chapter 3).

\subsubsection{Oxidation of banded iron-formation}

Similar to the weathering of BIF, isocons describing the chemical mass changes associated with the conversion of unaltered BIF to oxidized BIF at Fourth West Gorge suggest $\mathrm{K}_{2} \mathrm{O}, \mathrm{MgO}, \mathrm{CaO}, \mathrm{Ba}, \mathrm{Rb}$ and $\mathrm{Sr}$ were lost, although minor Co was gained (Fig. 5.8b). The remaining elements, including $\mathrm{SiO}_{2}$ and $\mathrm{Fe}_{2} \mathrm{O}_{3} \mathrm{~T}$, were essentially immobile during this process. Similarly, isocons for the conversion of unaltered BIF to oxidized BIF at Mt. Whaleback (Fig. 5.8c) indicate the depletion of $\mathrm{K}_{2} \mathrm{O}, \mathrm{MgO}, \mathrm{CaO}, \mathrm{Ba}, \mathrm{Rb}$ and $\mathrm{Sr}$, and enrichment in $\mathrm{Co}, \mathrm{Cr}$ and Ni. Again $\mathrm{Fe}_{2} \mathrm{O}_{3} \mathrm{~T}$ and $\mathrm{SiO}_{2}$ seem to be relatively immobile during this alteration.

Bulk rock chemical mass losses taking into account most of the variation in the datasets suggests the oxidation of BIF at Fourth West Gorge and Mt. Whaleback resulted in changes ranging from $53 \%$ loss to a $53 \%$ mass gain (Figs. $5.8 \mathrm{~b}, \mathrm{c}$ ). This corresponds to volume changes between a $54 \%$ volume loss to $48 \%$ volume gain (Figs. $5.8 \mathrm{~b}, \mathrm{c})$. However, the absence of stratigraphic thickness increases between unaltered Dales Gorge Member BIF and oxidized equivalents at Fourth West Gorge (Table 5.5; Appendix 2) again suggests any volume gains are unlikely during this process. Therefore, the minimum and maximum volume losses associated with the oxidation of BIF at these localities typically range from $0-54 \%$.

Similar to the weathering of BIF across the southeast, the conversion of unaltered BIF to oxidized BIF at Fourth West Gorge resulted in the loss of $\mathrm{SiO}_{2}, \mathrm{MgO}, \mathrm{CaO}$, $\mathrm{K}_{2} \mathrm{O}, \mathrm{Ba}, \mathrm{Rb}$ and $\mathrm{Sr}$ and gain in $\mathrm{Co}, \mathrm{Cr}$ and $\mathrm{Ni}$ (Fig. 5.9b; Appendix 7). Similar 


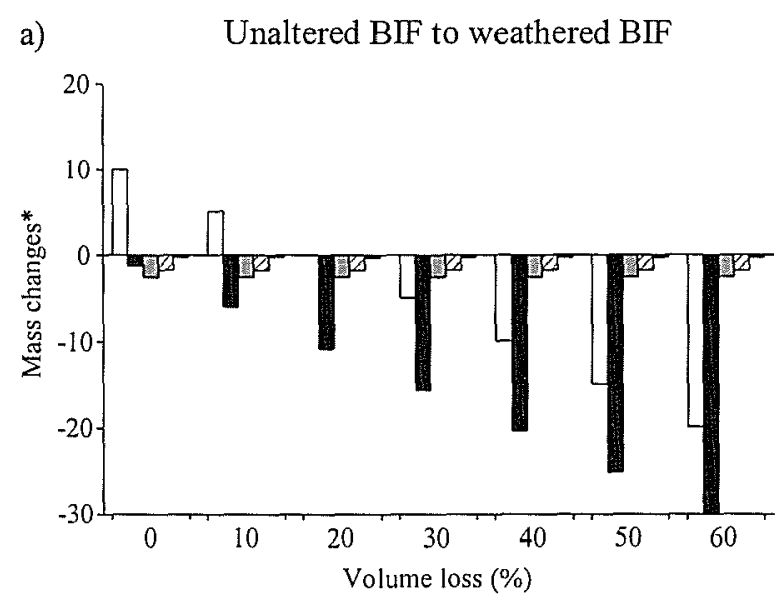

b) Unaltered BIF to oxidized BIF (Fourth West Gorge)

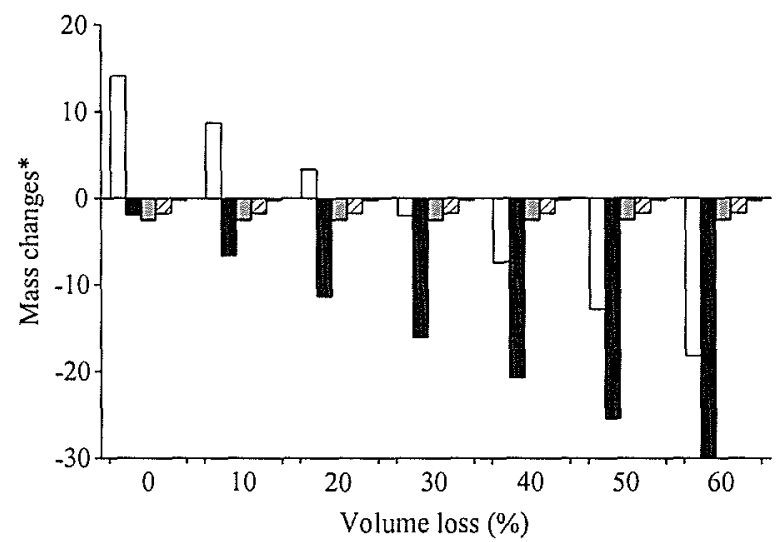

c) Unaltered BIF to oxidized BIF (Mt. Whaleback)
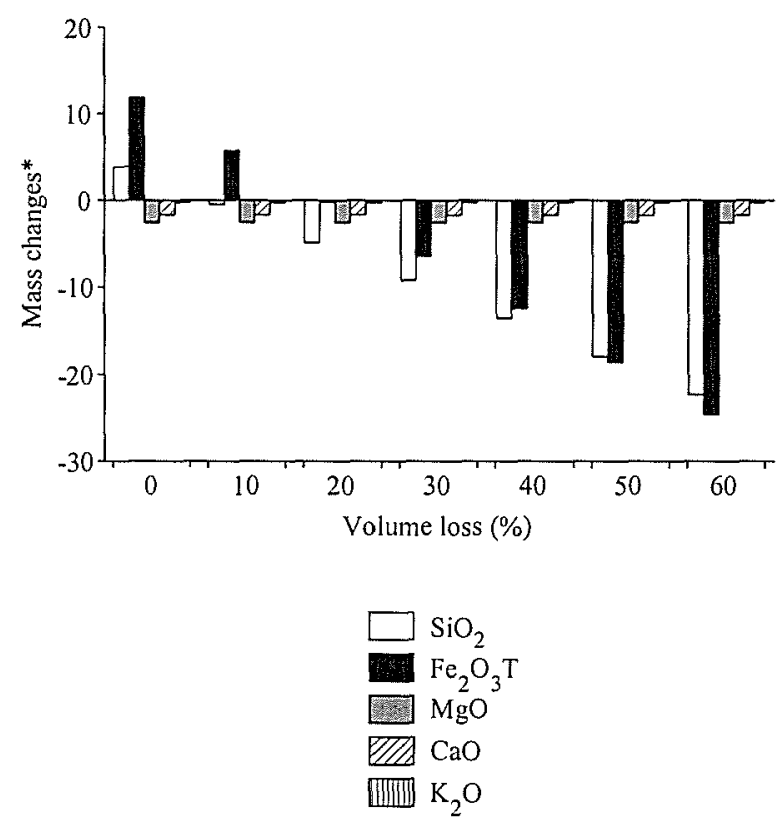

Figure 5.9. Major element oxide mass changes for specific volume losses during the alteration of BIF across the Hamersley Province. (a) Unaltered BIF to weathered BIF; (b) Unaltered BIF to oxidized BIF at Fourth West Gorge; (c) Unaltered BIF to oxidized BIF and Mt. Whaleback. *Elemental mass changes are in grams per 100 grams of parent material. 
elemental changes occurred during the genesis of oxidized BIF at Mt. Whaleback. However, for small-assumed volume losses $(<20 \%), \mathrm{Fe}_{2} \mathrm{O}_{3}$ may have been added to these rocks (Fig. 5.9c). Assuming Mt. Whaleback BIF sequences are not stratigraphically thicker than altered equivalents across the southeast (Table 5.5), somewhat larger volume losses are more likely; indicating $\mathrm{Fe}_{2} \mathrm{O}_{3}$ at the very least was relatively immobile (Fig. 5.9b). The mass losses associated with the oxidation of BIF at Fourth West Gorge and Mt. Whaleback are best explained by the oxidation and dissolution of carbonates and silicates including siderite, ankerite, stilpnomelane and minnesotaite (Chapters 2, 3).

The isocon representing the conversion of Mt. Whaleback BIF to high-grade hematite ore (Fig. 5.8d) suggest the high-grade hematite ore is strongly depleted in $\mathrm{SiO}_{2}, \mathrm{CaO}, \mathrm{P}_{2} \mathrm{O}_{5}$, Co and $\mathrm{Ni}$ compared to the precursor rocks (Fig. 5.8d). Importantly, $\mathrm{Fe}_{2} \mathrm{O}_{3}$ seems to be neither lost nor gained during this process if the average result is used. However, these elemental mass losses resulted in a bulk rock mass loss ranging from $12-75 \%$ if the standard deviations are considered (Fig. 5.8d). The associated volume changes are difficult to determine as variations in iron ore porosity dramatically effect mass/volume calculations (see equation 1). To overcome this issue, normalization of average stratigraphic thicknesses of iron ore horizons to less altered equivalents across the province established the most likely range of volume losses associated with the oxidation of oxidized BIF to iron ore at Mt. Whaleback (Table 5.5; Fig. 5.10). Comparison of this range with the absolute maximum volume loss calculated by assuming all phases removed from BIF are taken up by compaction, indicates iron ore porosity ranges from $9-36 \%$. This is very similar to the average porosity range determined from bulk rock density measurements (Fig. 5.10; Table 5.6) and equates to a density range of $3.4-5.0 \mathrm{~g} / \mathrm{cm}^{3}$. Using this density range and an the average bulk rock mass loss of $44 \%$ calculated from the isocon in equation (1) (Fig. $5.8 \mathrm{~d}$ ), $20-60 \%$ of volume (average $37 \%$ ) was removed during the conversion of oxidized BIF to high-grade hematite ore (Fig. 5.11). This is similar to work by Taylor et al. (2001) who recorded an average porosity of $\sim 30 \%$ and volume loss of $\sim 40 \%$. 


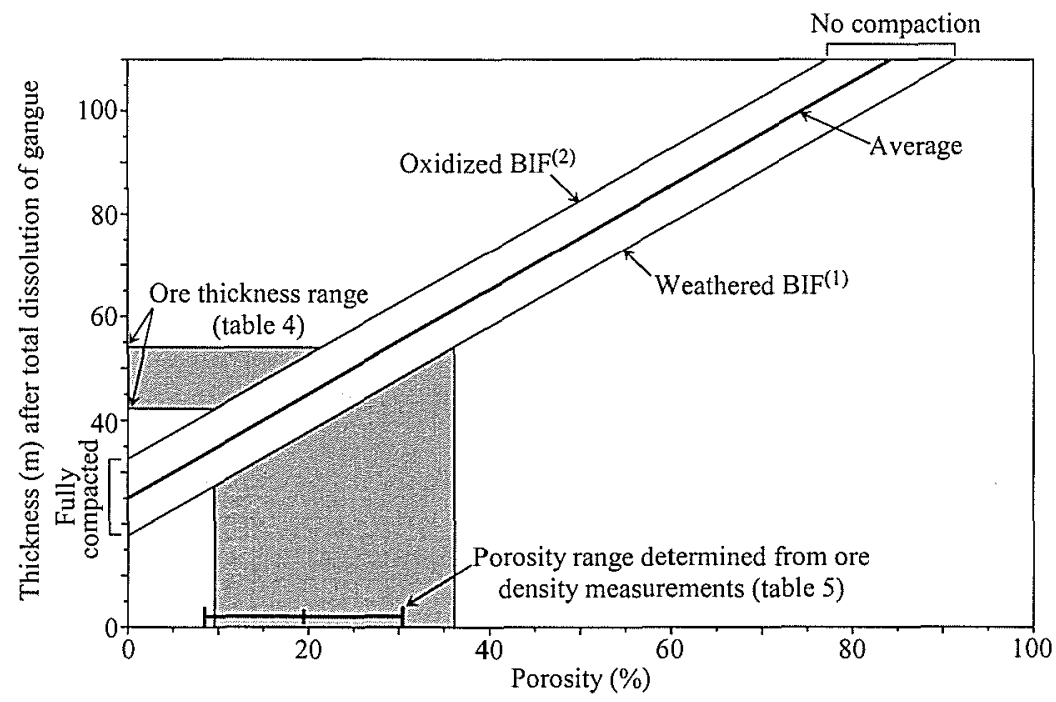

Figure 5.10. Possible porosity range of high-grade hematite ore assuming all phases except iron oxides are removed from the total thickness of Dales Gorge Member BIF macrobands during mineralization. Light grey area shows ideal porosities for any given stratigraphic thickness assuming all phases except iron oxides (Table 5.5) have been removed from precursor rocks across the Hamersley Province; dark grey area represents the broadest possible iron ore porosity range for measured stratigraphic thicknesses. Note the relative iron ore thicknesses take into account the standard deviation of all thickness measurements collected across the province (Table 5.4).

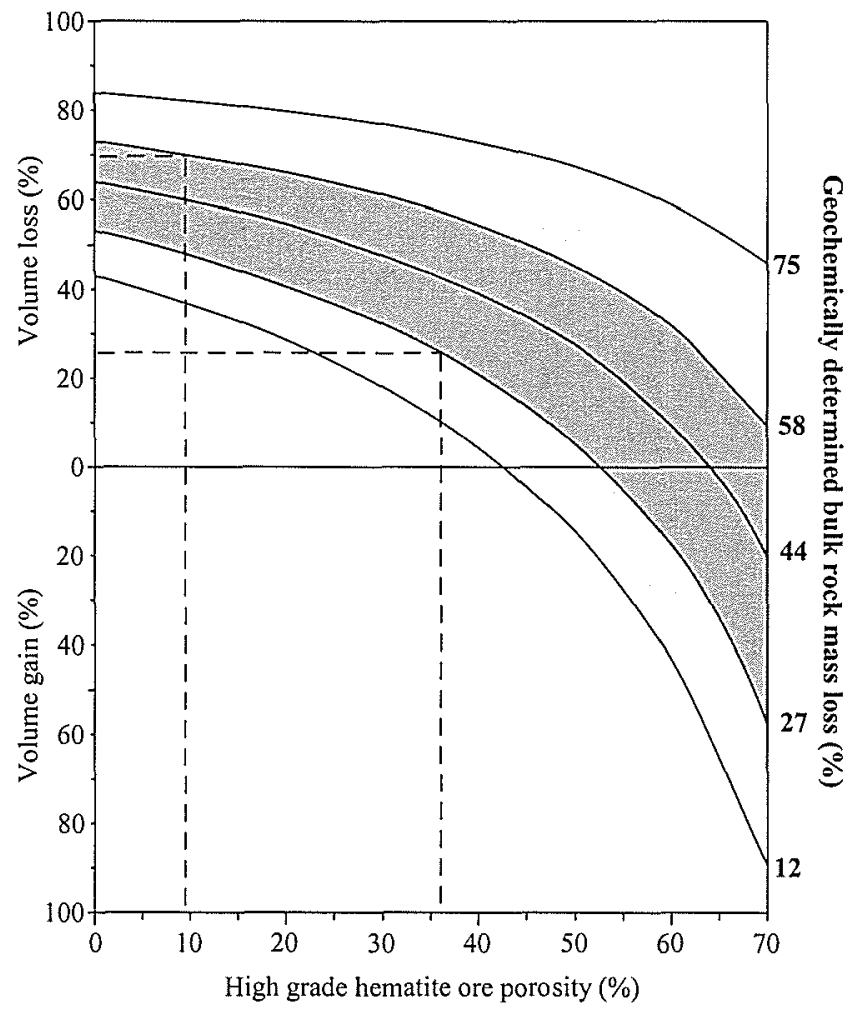

Figure 5.11. Volume losses associated with the conversion of Mt. Whaleback BIF to high-grade hematite ore of varying porosities. Note: geochemical mass losses determined from isocon (Fig. 5.8d); dark grey area represents the most likely bulk rock mass loss range during the conversion of oxidized BIF to highgrade hematite ore (Fig. 5.8d); the central line represents the average bulk rock mass loss during this process and the light grey areas represent the broadest range of possible mass losses taking into account most of the variation; dotted lines indicate the most plausible volume losses associated with the conversion of oxidized BIF to iron ore assuming an average mass loss range calculated from the geochemical data of $27-58 \%$. 
The most dramatic change during the transformation of oxidized BIF to highgrade hematite ore is the significant loss of $\mathrm{SiO}_{2}$ (Fig. 5.12). This considerable mass loss is simply related to the dissolution of quartz (Chapters 2-4). Interpretation of possible iron mass changes is more complex. For a volume loss range of $20-60 \%$, iron can be either added to or lost from the rocks (Fig. 5.12). However, commonly accepted iron ore porosities of 20-40\% (Morris 1985; Taylor et al., 2001; BHPIO staff pers. comm.) and an average volume loss of $37 \%$ suggest iron was relatively immobile. In summary, mass-volume calculations constrained by stratigraphic thickness changes and plausible iron ore porosities are consistent with mass balance constrained by the best-fit average isocon. All these data suggest high-grade hematite ore was produced without significant iron addition.

a)

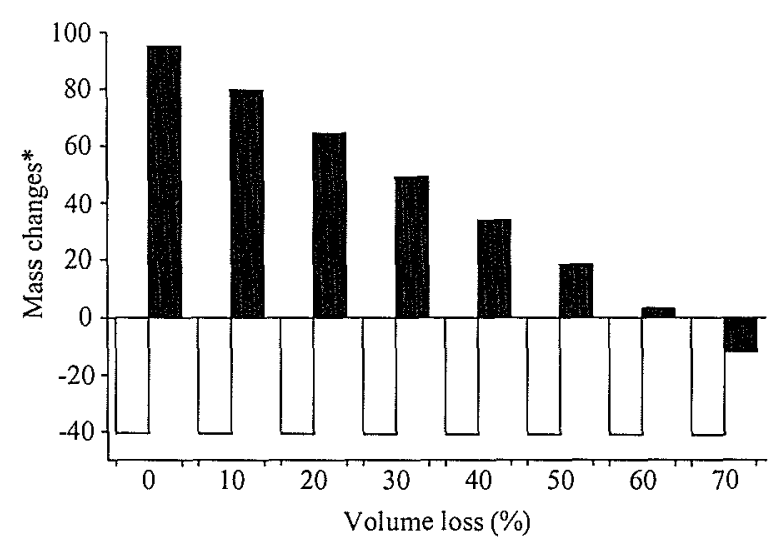

c)

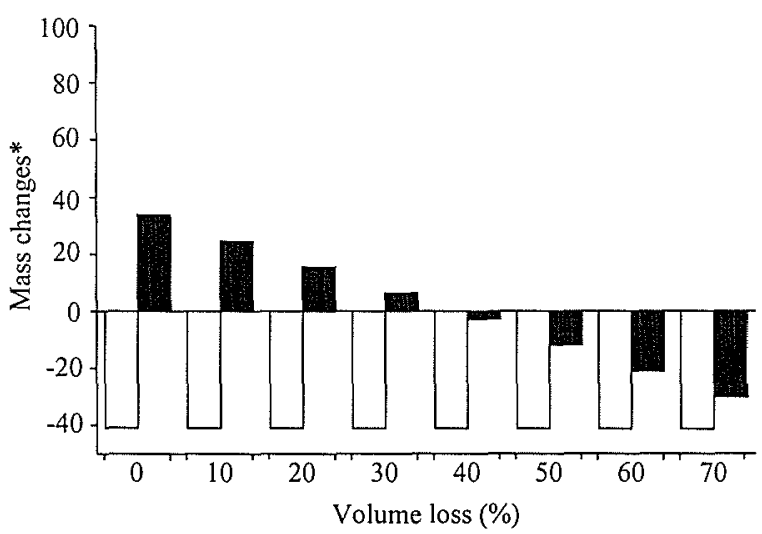

b) $20 \%$ porosity

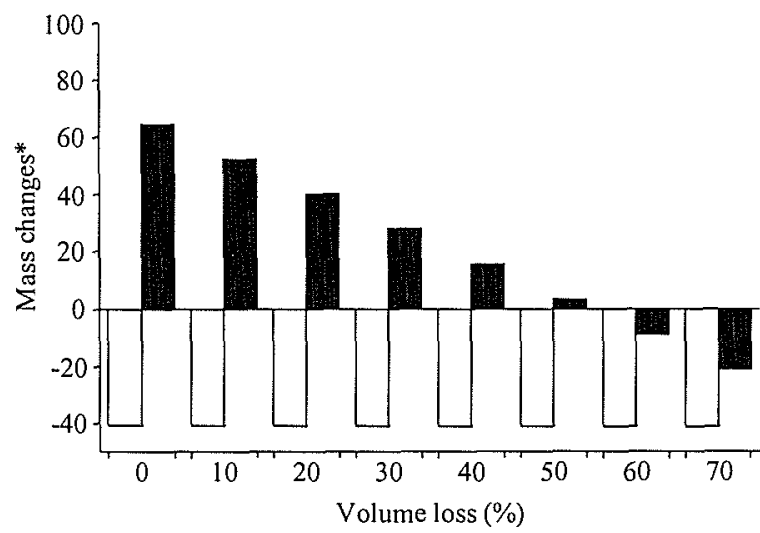

d)

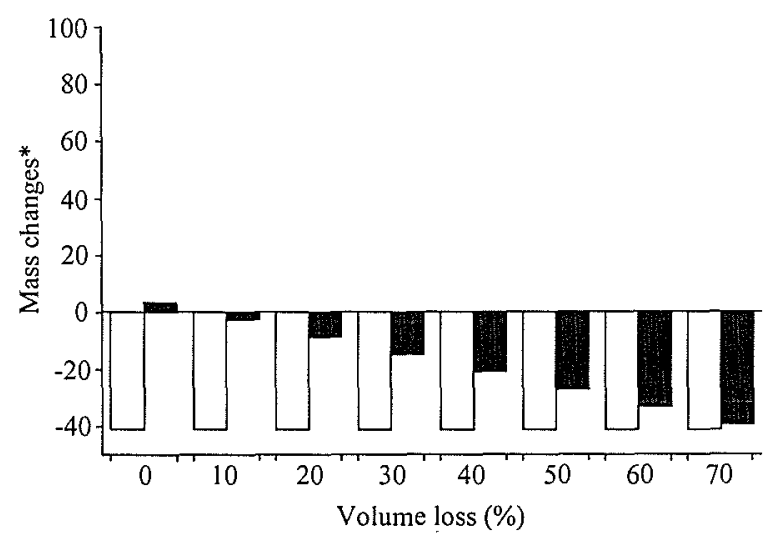

$\square \mathrm{SiO}_{2}$
$\mathrm{Fe}_{2} \mathrm{O}_{3} \mathrm{~T}$

Figure 5.12. $\mathrm{SiO}_{2}$ and $\mathrm{Fe}_{2} \mathrm{O}_{3} \mathrm{~T}$ mass changes associated with the oxidation of BIF at Mt. Whaleback to high-grade hematite ore of varying porosities. (a) $0 \%$ porosity; (b) $20 \%$ porosity; (c) $40 \%$ porosity; (d) $60 \%$ porosity. $*$ Elemental mass changes are in grams per 100 grams of parent material. 


\subsubsection{Conversion of black shale to altered black shale}

Isocon plots for the transformation of black shale through altered black shale to red shale shows a clear trend (Figs. 5.13a, b). Using a reference frame in which $\mathrm{Al}_{2} \mathrm{O}_{3}$, $\mathrm{TiO}_{2}$, Sc and REEs are relatively constant, $35-73 \%$ of shale mass could have been lost during the conversion of unaltered black shale to altered black shale. Thus the enrichment of $\mathrm{Al}_{2} \mathrm{O}_{3}$ and other relatively immobile elements in altered black shale at Mt. Whaleback results through significant loss of $\mathrm{SiO}_{2}, \mathrm{Fe}_{2} \mathrm{O}_{3} \mathrm{~T}, \mathrm{MgO}, \mathrm{CaO}, \mathrm{MnO}, \mathrm{K}_{2} \mathrm{O}$, $\mathrm{P}_{2} \mathrm{O}_{5}, \mathrm{~S}$ and most trace elements (Fig. 5.14a; Appendix 7). These possible mass losses correlate with significant volume reductions of $32-72 \%$. However, by assuming $\mathrm{Al}_{2} \mathrm{O}_{3}$ is the most immobile it is more likely to be $\sim 60-70 \%$ (Fig. 5.14a). Such a significant reduction of volume (and mass) would explain the substantial thinning of shale units at Mt. Whaleback (Table 5.5). Mineralogically, these losses can be explained by the alteration of stilpnomelane and K-feldspar to clinochlore and muscovite and the dissolution of carbonates, as these reactions have been shown to release significant $\mathrm{H}_{4} \mathrm{SiO}_{4}, \mathrm{Fe}^{2+}, \mathrm{Mg}^{2+}, \mathrm{Ca}^{2+}, \mathrm{K}^{+}$and $\mathrm{HCO}_{3}{ }^{-}$into the aqueous phases (Chapter 2).

\subsubsection{Conversion of altered black shale to red shale}

Mass/volume calculations using constant $\mathrm{Al}_{2} \mathrm{O}_{3}$, Sc and REEs suggest an additional $7-41 \%$ of shale mass and $6-40 \%$ of shale volume is lost during the second step of red shale formation (Figs. 5.13c, d). These losses are again due to the significant removal of $\mathrm{SiO}_{2}, \mathrm{MgO}, \mathrm{CaO}, \mathrm{MnO}, \mathrm{K}_{2} \mathrm{O}, \mathrm{P}_{2} \mathrm{O}_{5}, \mathrm{~S}$ and most trace elements (Fig. 5.14b; Appendix 7). However, unlike the black shale reactions, $\mathrm{Fe}_{2} \mathrm{O}_{3}$ is neither lost nor gained over volume losses of $20-30 \%$ (Fig. 5.14b), suggesting it is relatively immobile during this step. Its correlation with other commonly accepted immobile elements such as $\mathrm{TiO}_{2}, \mathrm{Y}$ and $\mathrm{Nb}$ (Goldschmidt, 1967), concurs with this assumption and also suggests some $\mathrm{Al}_{2} \mathrm{O}_{3}$ may have been lost (Figs. 5.13c, 5.14b). Such a loss would explain the increase in the $\mathrm{Fe} / \mathrm{Al}$ ratio between altered black shale and red shale (Chapter 2). The presented mass changes for this second step are most likely related to the conversion of clinochlore and muscovite in altered black shale to kaolinite and 

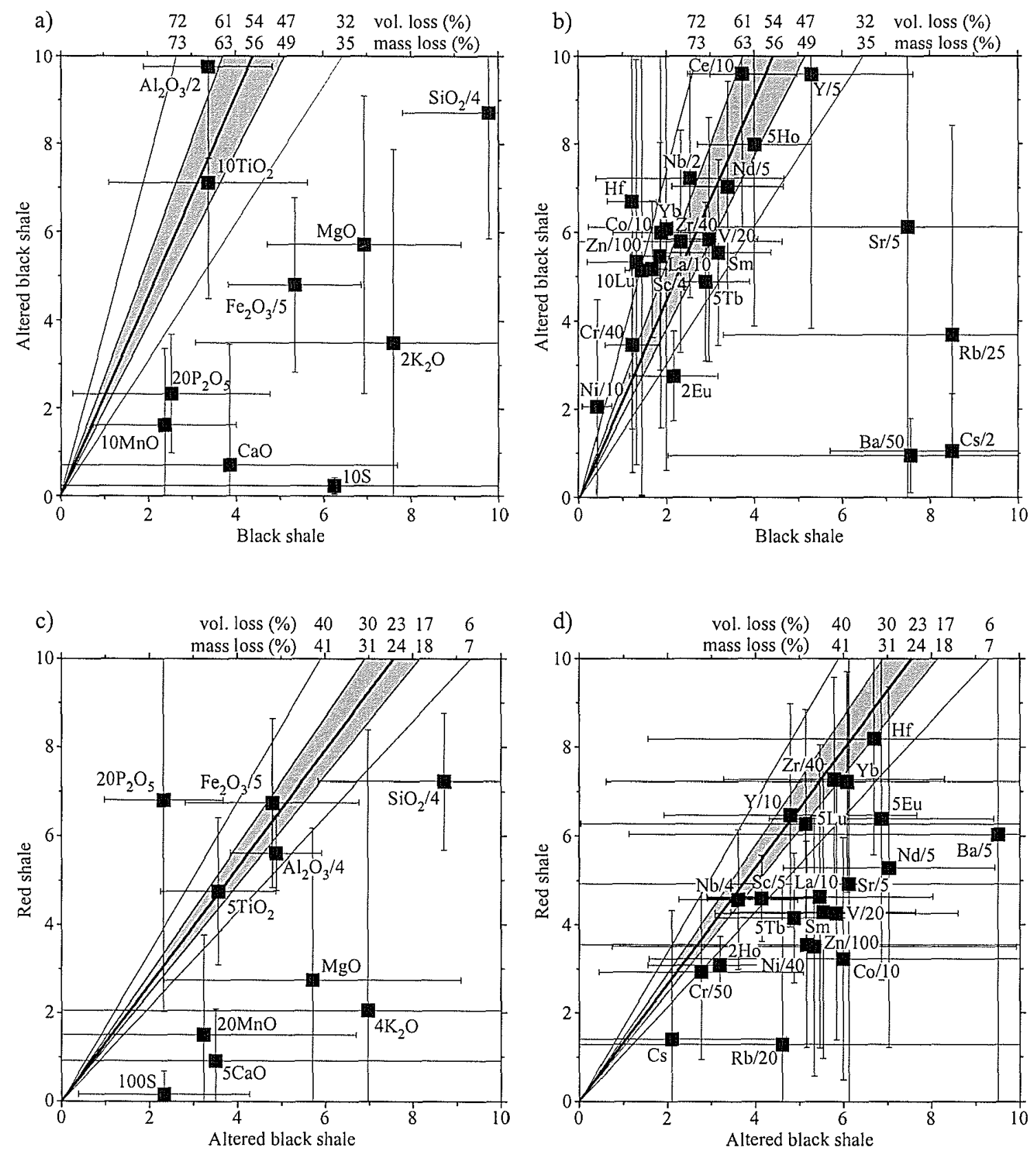

Figure 5.13. Isocon diagrams showing the representative changes between (a) unaltered black shale and altered black shale (major element oxides); (b) unaltered black shale and altered black shale (trace elements); (c) altered black shale and red shale (major element oxides); (d) altered black shale and red shale (trace elements). Note: below analytical detection values were assigned 0 and elements containing over a third of these values were not included in the isocons (see right-hand columns, Appendix 3.5); major element oxides plotted as wt. \%, trace elements are plotted in ppm; dark grey areas represent the broadest range of possible isocons for assumed near immobile elements Sc and REEs, although note the strong correlation of $\mathrm{TiO}_{2}, \mathrm{Al}_{2} \mathrm{O}_{3}$ and $\mathrm{Y}$ with these elements; the central line represents a "best-fit" isocon through these immobile elements; light grey areas represent the broadest range of possible isocons taking into account most of their standard deviations; and the bulk rock mass changes (\%) implied for the indicated isocons and associated volume (vol.) changes (\%) are shown along the edges. 
a)

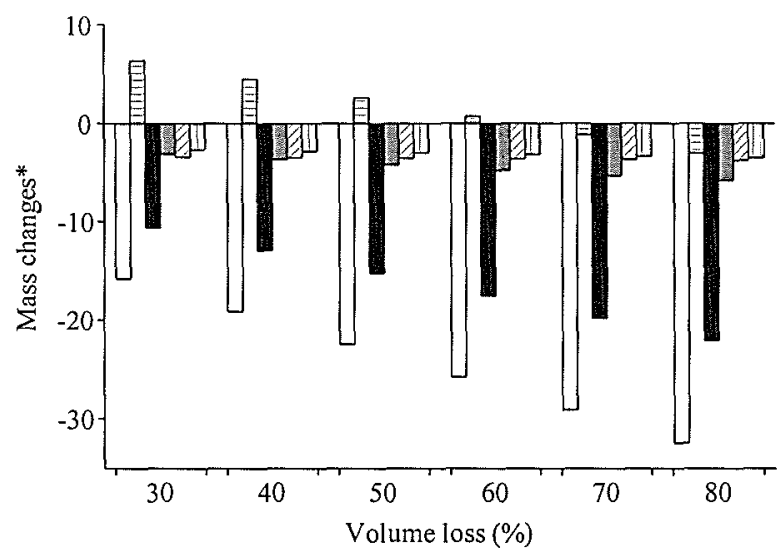

c)

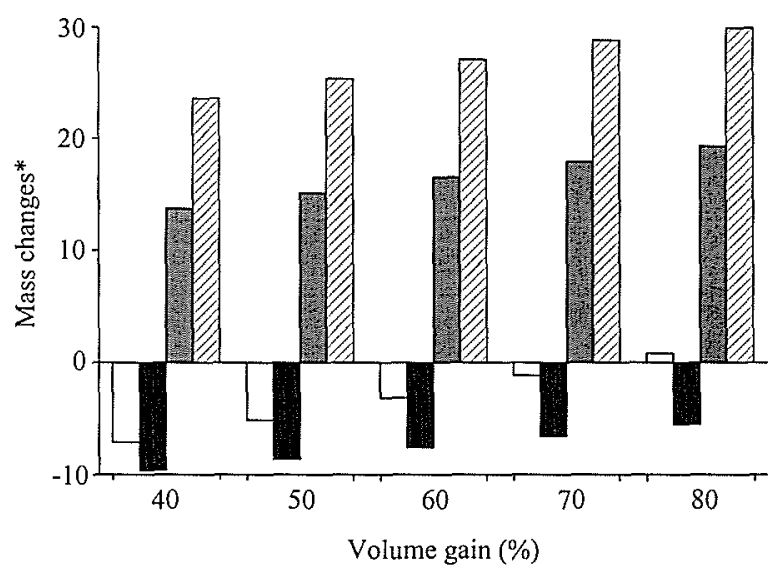

b)

Altered black shale to red shale

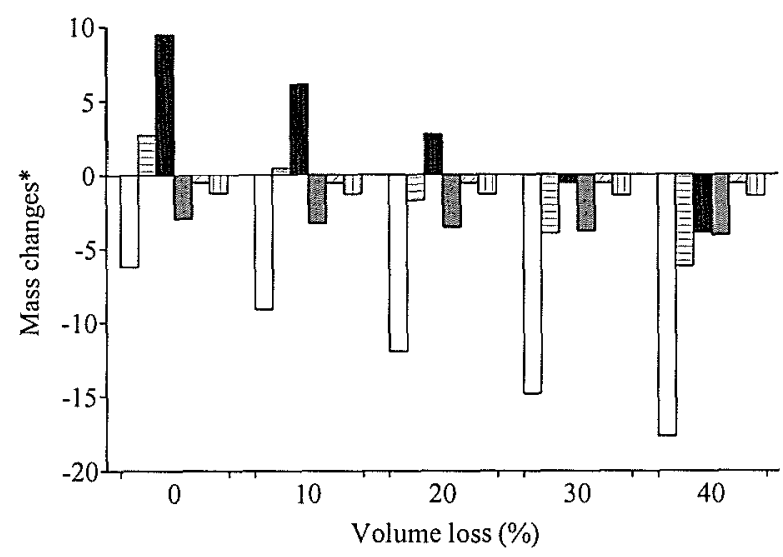

d)

Reddish-green shale to red shale

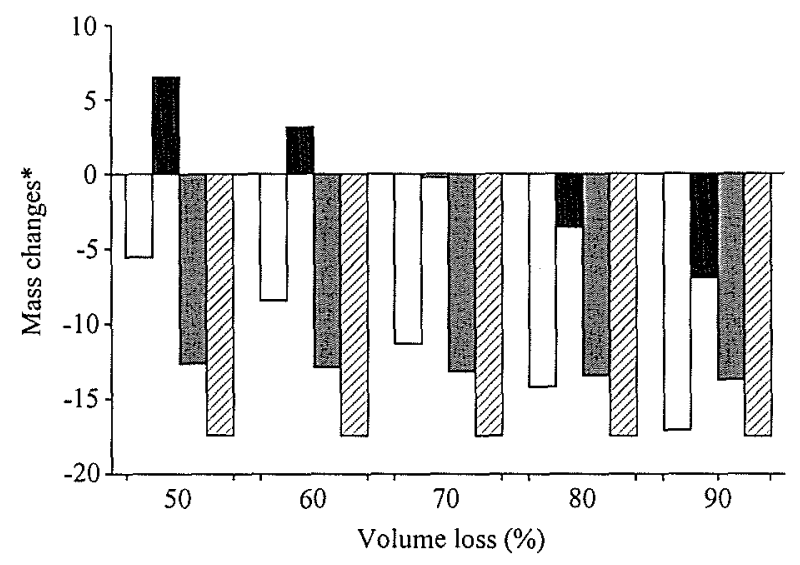

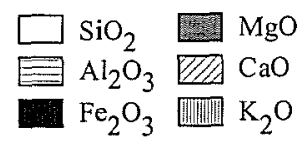

Figure 5.14. Major element oxide mass changes for specific volume losses during the alteration of shale across the Hamersley Province. (a) Black shale to altered black shale; (b) Altered black shale to red shale; (c) Altered black shale to reddish-green shale; (d) reddish-green shale to red shale. *Elemental mass changes are in grams per 100 grams of parent material.

hematite and the dissolution of quartz (Chapter 2).

\subsubsection{Altered black shale to reddish-green shale}

Preliminary mass/volume calculations using constant $\mathrm{Al}_{2} \mathrm{O}_{3}, \mathrm{Nb}$ and $\mathrm{Zr}$ suggest the conversion of altered black shale to reddish-green shale resulted in a mass and volume gain of $48-70 \%$ and $47-78 \%$ respectively (Figs. 5.15a, b). Mass calculations using Gresen's equation indicate such gains are due to the significant addition of $\mathrm{MgO}$, $\mathrm{CaO}$, and $\mathrm{MnO}$ (Fig. 5.14c; Appendix 7), although interestingly $\mathrm{Fe}_{2} \mathrm{O}_{3}$ and $\mathrm{SiO}_{2}$ were 
a)
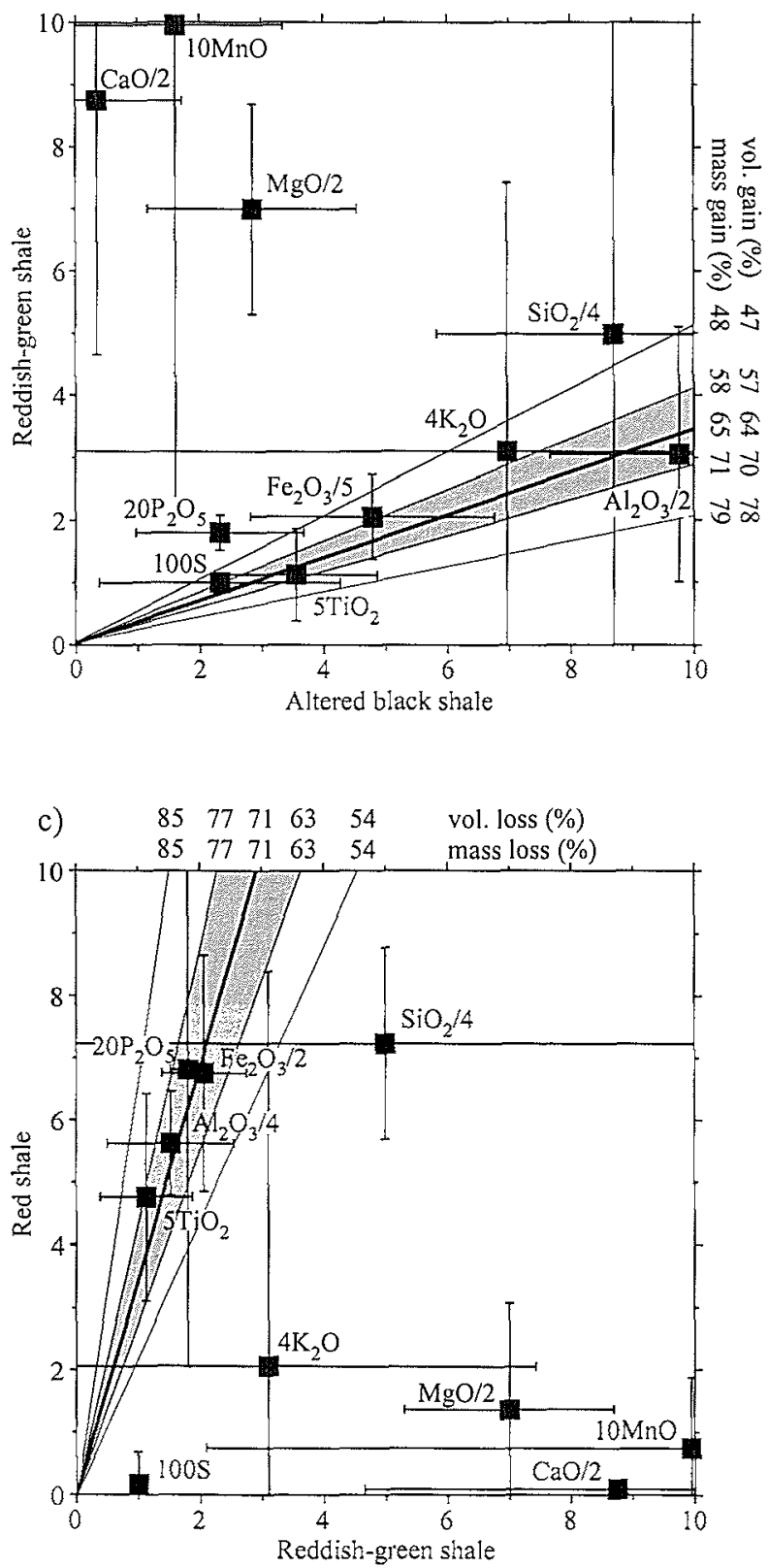

b)
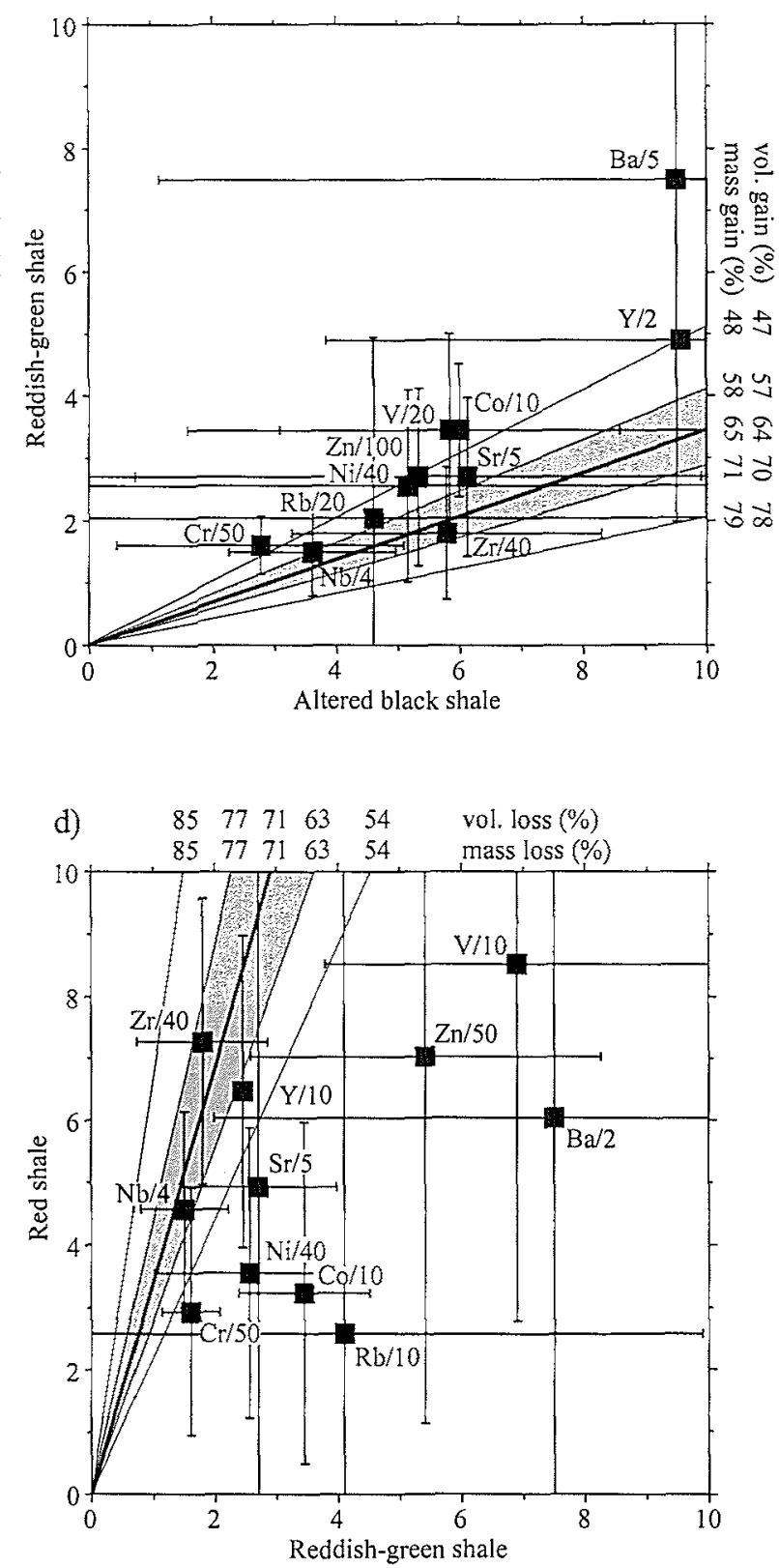

Figure 5.15. Isocon diagrams showing the representative changes between (a) altered black shale and reddish-green shale (major element oxides); (b) altered black shale and reddish-green shale (trace elements); (c) reddish-green shale and red shale (major element oxides); (d) reddish-green shale and red shale (trace elements). Note: major element oxides plotted as wt. $\%$, trace elements are plotted in ppm; dark grey areas represent the broadest range of possible isocons for assumed near immobile elements $\mathrm{Sc}$ and REEs, although note the strong correlation of $\mathrm{TiO}_{2}, \mathrm{Al}_{2} \mathrm{O}_{3}$ and $\mathrm{Y}$ with these elements; the central line represents a "best-fit" isocon through these immobile elements; light grey areas represent the broadest range of possible isocons taking into account most of their standard deviations; and the bulk rock mass changes (\%) implied for the indicated isocons and associated volume (vol.) changes (\%) are shown along the edges. 
most likely lost. It was not possible to measure thickness difference between altered black and reddish-green shale horizons to determine if such a large mass gain is possible. However, at the very least it can be assumed that these rocks represent a significant phase of $\mathrm{CaO}$ and $\mathrm{MgO}$ enrichment. The enrichment of carbonates and lack of silica in these rocks (Chapter 4) suggest reddish-green shales represent a phase of carbonate enrichment and silica removal similar to the early silica removal stage by hydrothermal fluids proposed for mineralization at Mt. Tom Price (Taylor et al., 2001).

\subsubsection{Reddish-green shale to red shale}

Isocons plots using constant $\mathrm{Al}_{2} \mathrm{O}_{3}, \mathrm{Nb}$ and $\mathrm{Zr}$ suggest $54-85 \%$ of mass loss could have been lost during the conversion of reddish-green shale to red shale at Mt. Whaleback (Figs. 5.15c, d). This correlates to a possible volume loss of 54-85\%, with an average of $71 \%$. Using the average volume change calculated from the average isocon representing this process, elements such as $\mathrm{SiO}_{2}, \mathrm{~K}_{2} \mathrm{O}, \mathrm{MgO}, \mathrm{MnO}, \mathrm{CaO}, \mathrm{Ba}$, $\mathrm{Co}, \mathrm{Cr}, \mathrm{Ni}, \mathrm{Rb}, \mathrm{Sr}, \mathrm{V}$ and $\mathrm{Zn}$ are lost (Fig. 5.14d). All other elements including $\mathrm{Fe}_{2} \mathrm{O}_{3}$ are relatively immobile. Such mass changes are possibly due to the conversion of Fedolomite and clinochlore to hematite and kaolinite and most likely represent the major oxidation stage responsible for the conversion of unaltered BIF to oxidized BIF and altered black shale to red shale.

\section{DISCUSSION}

\subsection{Comparisons with previous investigations}

To date only two investigations (i.e., Trendall and Pepper, 1977; Alibert and McCulloch, 1993) have documented the trace element chemistry of BIF and shale across the Hamersley Province. Compared to analyses by Trendall and Pepper (1977), unaltered BIF samples from this study have less $\mathrm{Ba}, \mathrm{Pb}, \mathrm{Sr}, \mathrm{V}$ and $\mathrm{Zn}$, higher $\mathrm{Co}, \mathrm{Cr}$ and $\mathrm{Rb}$ and a large variation in composition (i.e., large standard deviations) (Table 5.7a). Relative to oxidized BIF at Mt. Whaleback, equivalent rocks at Mt. Tom Price and Paraburdoo are depleted in most REEs. There is no distinctive pattern of trace 
Table 5.7a. Average trace element composition of BIF across the Hamersley Province.

\begin{tabular}{|c|c|c|c|c|c|c|c|c|c|c|c|c|c|c|c|c|}
\hline \multirow[t]{2}{*}{$\begin{array}{l}\text { Trace } \\
\text { Element }\end{array}$} & \multicolumn{2}{|c|}{$\begin{array}{l}\text { Wittenoom }^{(1)} \\
(\mathrm{n}=21)\end{array}$} & \multicolumn{2}{|c|}{$\begin{array}{l}\text { Wittenoom }^{(2)} \\
\quad(n=5)\end{array}$} & \multicolumn{2}{|c|}{$\begin{array}{l}\text { Wittenoom }^{(3)} \\
\quad(\mathrm{n}=14)\end{array}$} & \multicolumn{2}{|c|}{$\begin{array}{l}\text { Southeast }^{(4)} \\
(\mathrm{n}=59)\end{array}$} & \multicolumn{2}{|c|}{$\begin{array}{l}\text { Mt. Whaleback }{ }^{(5)} \\
\quad(n=12)\end{array}$} & \multicolumn{2}{|c|}{$\begin{array}{l}\text { Mt. Whaleback } \\
\qquad(\mathrm{n}=13)\end{array}$} & \multicolumn{2}{|c|}{$\begin{array}{l}\text { Tom Price }{ }^{(3)} \\
\quad(n=3)\end{array}$} & \multicolumn{2}{|c|}{$\begin{array}{l}\text { Paraburdoo }^{(3)} \\
\quad(\mathrm{n}=2)\end{array}$} \\
\hline & avg & sd & avg & sd & avg & sd & avg & sd & avg & sd & avg & sd & avg & sd & avg & sd \\
\hline As & - & - & 8.4 & 6.1 & 0.9 & 0.8 & - & - & - & - & - & - & 0.2 & 0.0 & & \\
\hline $\mathrm{Ba}$ & 56.6 & 80.9 & 69.0 & 39.0 & & & 16.0 & 27.0 & 4.2 & 6.2 & 18.3 & 11.3 & & & & \\
\hline $\mathrm{Ce}$ & 6.3 & 4.8 & & & 4.0 & 2.7 & 5.6 & 2.4 & 4.1 & 2.3 & 7.8 & 4.3 & 1.9 & 0.5 & 1.3 & 0.9 \\
\hline $\mathrm{Co}$ & 12.9 & 10.3 & 1.0 & 0.0 & & & 30.3 & 10.3 & 31.2 & 12.9 & 7.5 & 7.2 & & & & \\
\hline $\mathrm{Cr}$ & 11.7 & 11.3 & 9.0 & 4.2 & & & 29.9 & 15.6 & 23.8 & 19.3 & 35.5 & 20.8 & & & & \\
\hline $\mathrm{Cs}$ & - & - & & & & & - & - & - & - & - & - & & & & \\
\hline Eu & 0.3 & 0.2 & & & 0.2 & 0.1 & 0.3 & 0.1 & 0.2 & 0.1 & 0.3 & 0.1 & 0.1 & 0.1 & 0.1 & 0.0 \\
\hline Hf & - & - & & & & & - & - & - & - & 0.1 & 0.2 & & & & \\
\hline Ho & 0.3 & 0.2 & & & & & 0.3 & 0.1 & 0.2 & 0.1 & 0.4 & 0.3 & & & & \\
\hline $\mathrm{La}$ & 3.2 & 2.3 & & & 2.5 & 1.3 & 2.7 & 1.2 & 2.0 & 1.1 & 4.3 & 3.4 & 1.3 & 0.5 & 1.0 & 0.7 \\
\hline $\mathrm{Lu}$ & 0.1 & 0.1 & & & 0.1 & 0.0 & 0.1 & 0.0 & 0.1 & 0.1 & 0.2 & 0.2 & 0.0 & 0.0 & 0.1 & 0.0 \\
\hline $\mathrm{Nb}$ & 0.7 & 1.1 & & & & & 0.4 & 0.9 & 0.4 & 1.2 & 1.9 & 1.7 & & & & \\
\hline $\mathrm{Nd}$ & 3.0 & 2.5 & & & 2.0 & 1.4 & 2.9 & 1.0 & 1.9 & 0.9 & 3.5 & 1.3 & 1.2 & 0.3 & 0.6 & 0.4 \\
\hline $\mathrm{Ni}$ & 7.7 & 2.9 & 8.8 & 3.7 & - & - & 8.5 & 2.8 & 16.1 & 20.2 & 9.4 & 7.3 & - & - & & \\
\hline $\mathrm{Pb}$ & 5.3 & 5.7 & 38.0 & 7.6 & & & 2.3 & 4.6 & 6.2 & 6.7 & 17.0 & 9.7 & & & & \\
\hline $\mathrm{Rb}$ & 33.3 & 42,6 & 16.0 & 12.9 & & & - & - & - & - & - & - & & & & \\
\hline $\mathrm{Sc}$ & 0.4 & 0.1 & & & & & 1.2 & 0.7 & 0.4 & 0.1 & 1.4 & 0.4 & & & & \\
\hline $\mathrm{Sm}$ & 0.6 & 0.5 & & & 0.4 & 0.3 & 0.8 & 0.3 & 0.4 & 0.2 & 0.8 & 0.3 & 0.3 & 0.1 & 0.1 & 0.1 \\
\hline $\mathrm{Sr}$ & 28.5 & 23.4 & 35.0 & 14.1 & & & 3.7 & 2.9 & 4.0 & 2.5 & 4.4 & 2.0 & & & & \\
\hline $\mathrm{Tb}$ & 0.2 & 0.1 & & & & & 0.2 & 0.1 & 0.1 & 0.1 & 0.2 & 0.1 & & & & \\
\hline V & 4.3 & 7.2 & 15.0 & 12.7 & - & - & 0.9 & 2.9 & 5.4 & 5.0 & 38.1 & 42.3 & & & & \\
\hline Y & 13.5 & 4.9 & & & & & 7.5 & 2.8 & 7.8 & 2.8 & 10.7 & 7.1 & & & & \\
\hline $\mathrm{Yb}$ & 0.9 & 0.5 & & & 0.4 & 0.2 & 0.9 & 0.3 & 0.6 & 0.3 & 1.4 & 1.0 & 0.4 & 0.2 & 0.3 & 0.2 \\
\hline $\mathrm{Zn}$ & 14.9 & 27.7 & 36.0 & 7.4 & 8.3 & 2.0 & - & - & 2.4 & 6.6 & 3.3 & 6.0 & 7.0 & 0.0 & & \\
\hline $\mathrm{Zr}$ & 9.5 & 22.4 & & & & & 0.9 & 2.3 & 0.3 & 1.1 & 5.9 & 4.6 & & & & \\
\hline
\end{tabular}

Notes: $(1)=$ Unalterd BIF this study, table 5.2; $(2)=$ Unaltered BIF, Trendall and Pepper (1977), table 4; 3 ) = Unaltered BIF Alibert and McCulloch (1993), tables I \& 3; (4) weathered BIF, this study, table 5.2; (5) = oxidized BIF; (6) = High-grade hematite ore, this study, table $5.2 ; n=$ number of samples; $\mathrm{sd}=$ one standard deviation; "-" = below detection; blank = not reported. 
element distribution between the new and old data and differences most likely reflect the number and size of samples in the different studies, as it is extremely difficult to obtain representative samples of BIF (Trendall and Pepper, 1977; Ewers and Morris, 1981). However, the large number of data collected here may be more representative than previous work because of the (much) larger dataset (Chapter 2).

Black shale from the northern Hamersley Province differs significantly to other "shale" samples from Wittenoom, Tom Price and Paraburdoo (Table 5.7b). They contain more $\mathrm{Ba}, \mathrm{Co}, \mathrm{Cr}, \mathrm{Nd}, \mathrm{Ni}, \mathrm{Pb}, \mathrm{Rb}, \mathrm{V}$ and $\mathrm{Zn}$ and less $\mathrm{As}$ and $\mathrm{Sr}$. Likewise, altered black shale from Mt. Whaleback is relatively enriched in REEs compared to equivalent rocks at Mt. Tom Price and Paraburdoo. Given that shale is often interlayered with chert-siderite bands (Trendall and Blockley, 1970), it is likely that Trendall and Pepper (1977) and Alibert and McCulloch (1993) have incorporated other

Table 5.7b. Average trace element composition of shale across the Hamersley Province.

\begin{tabular}{|c|c|c|c|c|c|c|c|c|c|c|c|c|c|c|}
\hline \multirow[t]{2}{*}{$\begin{array}{l}\text { Trace } \\
\text { Element }\end{array}$} & \multicolumn{2}{|c|}{$\begin{array}{c}\text { Wittenoom }^{(1)} \\
(\mathrm{n}=30)\end{array}$} & \multicolumn{2}{|c|}{$\begin{array}{l}\text { Wittenoom }^{(2)} \\
\qquad(\mathrm{n}=6)\end{array}$} & \multicolumn{2}{|c|}{$\begin{array}{l}\text { Wittenoom }^{(3)} \\
\qquad(\mathrm{n}=6)\end{array}$} & \multicolumn{4}{|c|}{$\begin{array}{l}\text { Mt. Whaleback }{ }^{(4)} \text { Mt. Whaleback } \\
\qquad(\mathrm{n}=22) \\
(\mathrm{n}=42)\end{array}$} & \multicolumn{2}{|c|}{$\begin{array}{l}\text { Mt. Whaleback }{ }^{(6} \\
(n=2)\end{array}$} & \multirow{2}{*}{$\begin{array}{c}\text { Tom Price }^{(3)} \\
(\mathrm{n}=1) \\
\text { avg }\end{array}$} & \multirow{2}{*}{$\begin{array}{c}\text { Paraburdoo }^{(3)} \\
(\mathrm{n}=1) \\
\text { avg }\end{array}$} \\
\hline & avg & sd & avg & sd & avg & sd & avg & sd & avg & sd & avg & sd & & \\
\hline As & 15.2 & 25.4 & 32.0 & 14.4 & 33.0 & 0.0 & 20.4 & 61.9 & 10.0 & 9.0 & - & - & 33.0 & 21.0 \\
\hline $\mathrm{Ba}$ & 378.0 & 281.2 & 262.5 & 149.0 & & & 47.1 & 42.4 & 30.2 & 30.6 & 37.5 & 27.6 & & \\
\hline $\mathrm{Ce}$ & 37.2 & 12.5 & & & 36.5 & 9.7 & 95.9 & 37.5 & 75.0 & 54.0 & & & 59.9 & 45.9 \\
\hline Co & 18.6 & 11.7 & 6.2 & 2.0 & & & 59.9 & 44.1 & 32.3 & 27.4 & 34.5 & 10.6 & & \\
\hline $\mathrm{Cr}$ & 48.8 & 25.7 & 30.0 & 5.5 & & & 138.5 & 116.1 & 146.5 & 98.7 & 80.5 & 23.3 & & \\
\hline $\mathrm{Cs}$ & 17.0 & 5.6 & & & & & 2.1 & 2.6 & 1.4 & 2.9 & & & & \\
\hline $\mathrm{Eu}$ & 1.1 & 0.5 & & & 0.9 & 0.4 & 1.4 & 0.5 & 1.3 & 0.7 & & & 1.1 & 1.3 \\
\hline $\mathrm{Hf}$ & 1.2 & 0.6 & & & & & 6.7 & 5.1 & 8.2 & 2.6 & & & & \\
\hline Ho & 0.8 & 0.3 & & & & & 1.6 & 0.8 & 1.5 & 0.3 & & & & \\
\hline $\mathrm{La}$ & 18.5 & 6.7 & & & 21.6 & 3.2 & 54.6 & 25.7 & 46.3 & 34.2 & & & 27.5 & 22.6 \\
\hline $\mathrm{Lu}$ & 0.3 & 0.1 & & & 0.4 & 0.0 & 1.0 & 1.0 & 1.3 & 0.5 & & & - & - \\
\hline $\mathrm{Nb}$ & 5.0 & 4.3 & & & & & 14.4 & 5.5 & 18.3 & 6.3 & 6.0 & 2.8 & & \\
\hline $\mathrm{Nd}$ & 16.9 & 6.3 & & & 15.4 & 4.0 & 35.2 & 12.0 & 26.5 & 20.4 & & & 26.4 & 21.2 \\
\hline $\mathrm{Ni}$ & 41.9 & 33.7 & 21.2 & 5.0 & 32.8 & 8.8 & 206.3 & 241.9 & 141.9 & 93.4 & 102.5 & 61.5 & 47.0 & 30.0 \\
\hline $\mathrm{Pb}$ & 12.8 & 20.4 & 54.2 & 18.8 & & & 4.7 & 10.8 & 4.2 & 6.7 & 8.5 & 2.1 & & \\
\hline $\mathrm{Rb}$ & 212.9 & 127.4 & 83.3 & 33.4 & & & 92.0 & 118.4 & 25.8 & 74.4 & 41.0 & 58.0 & & \\
\hline $\mathrm{Sc}$ & 6.7 & 2.0 & & & & & 20.7 & 6.2 & 23.0 & 4.9 & & & & \\
\hline $\mathrm{Sm}$ & 3.18 & 1.2 & & & 2.9 & 1.0 & 5.5 & 2.1 & 4.3 & 3.3 & & & 0.3 & 4.1 \\
\hline $\mathrm{Sr}$ & 37.4 & 36.2 & 115.0 & 151.3 & & & 30.6 & 33.5 & 24.6 & 36.7 & 13.5 & 6.4 & & \\
\hline $\mathrm{Tb}$ & 0.6 & 0.2 & & & & & 1.0 & 0.4 & 0.8 & 0.3 & & & & \\
\hline V & 59.5 & 22.7 & 11.7 & 9.8 & 54.0 & 21.1 & 116.8 & 55.1 & 85.2 & 57.3 & 69.0 & 31.1 & 41.0 & 61.0 \\
\hline Y & 26.5 & 11.8 & & & & & 47.9 & 28.7 & 64.7 & 25.1 & 24.5 & 0.7 & & \\
\hline $\mathrm{Yb}$ & 2.0 & 0.5 & & & 2.0 & 0.8 & 6.1 & 5.5 & 7.2 & 2.5 & & & 2.4 & 3.1 \\
\hline $\mathrm{Zn}$ & 131.0 & 114.4 & 82.5 & 33.6 & 89.4 & 42.5 & 532.7 & 458.7 & 351.3 & 293.9 & 270.5 & 142.1 & 67.0 & 86.0 \\
\hline $\mathrm{Zr}$ & 92.8 & 93.1 & & & & & 231.5 & 100.3 & 290.9 & 92.2 & 72.0 & 42.4 & & \\
\hline
\end{tabular}

Notes: $(1)=$ Black shale this study, table $5.2 ;(2)=$ Black shale, Trendall and Pepper (1977), table $4 ;(3)=$ Black shale, Alibert and McCulloch (1993), tables $1 \& 3 ;(4)=$ Altered black shale, this study, table 5.2; (5) Red shale, this study, table 5.2; (6) Reddish-green shale, this study, table $5.2 ; \mathrm{n}=$ number of samples; $\mathrm{sd}=$ one standard deviation; "-" = below detection; blank = not reported. 
rock types into their "shale" samples (Chapter 2). In particular, Trendall and Pepper (1977) sampled entire DS-macrobands, which would definitely mix shale and chertsiderite bands and effectively decrease the average bulk rock trace element compositions due to the very low trace element abundances in the latter layers.

\subsection{Mineralogical control on chemical composition}

Results of the PCA indicate that most of the variation in trace elements can be explained by a few main components (Table 5.4). Although elemental correlations in some components are difficult to explain most relationships can be attributed to variations in mineralogy. Unaltered BIF is characterised by four main components. The strong association of $\mathrm{Al}_{2} \mathrm{O}_{3}, \mathrm{TiO}_{2}, \mathrm{~K}_{2} \mathrm{O}$ and $\mathrm{MgO}, \mathrm{Y}, \mathrm{Ba}$ and $\mathrm{Rb}$ in the first component suggests these elements are most likely related to silicates such as stilpnomelane and minnesotaite. In these minerals $\mathrm{Ba}$ and $\mathrm{Rb}$ may substitute for $\mathrm{K}^{+}$and $\mathrm{Y}$ for $\mathrm{Mg}^{2+}$ (Goldschmidt, 1958). The strong negative correlation between $\mathrm{SiO}_{2}$ and $\mathrm{Fe}_{2} \mathrm{O}_{3}$ in the second component indicates elements in this group are mostly due to variations in Fe-oxides and chert. However, moderate correlations between $\mathrm{Fe}_{2} \mathrm{O}_{3}$, $\mathrm{MgO}, \mathrm{Ba}$ and $\mathrm{Rb}$ suggest carbonates such as dolomite or siderite may also influence the content of these elements in unaltered BIF. The last two components describing element distributions in unaltered BIF are more difficult to explain mineralogically, although the third component may be related to sulphides and the fourth to variations in calcite and dolomite. The weak correlation between $\mathrm{CaO}$ and $\mathrm{P}_{2} \mathrm{O}_{5}$ in the third component suggests apatite may also control abundances of these elements in these rocks.

Compared to unaltered equivalents, elemental associations in altered BIF across the Hamersley Province, including Mt. Whaleback, are generally weak and difficult to explain. This is primarily due to the absence of most major silicate and carbonate phases in these rocks. The only significant "association" in altered BIF is the strong negative correlation between $\mathrm{SiO}_{2}$ and $\mathrm{Fe}_{2} \mathrm{O}_{3}$. These elements are most likely controlled by variations in quartz and iron oxides such as hematite and goethite. There 
is also a strong correlation between $\mathrm{CaO}$ and $\mathrm{P}_{2} \mathrm{O}_{5}$ in oxidized $\mathrm{BIF}$ from Fourth West Gorge. This may indicate apatite controls these elements in oxidized BIF. Interestingly the negative correlation between $\mathrm{P}_{2} \mathrm{O}_{5}$ with $\mathrm{Fe}_{2} \mathrm{O}_{3}$ in iron ore suggests Fe-oxides do not control $\mathrm{P}_{2} \mathrm{O}_{5}$ content. Variable and weak correlations of most trace elements in these rocks are primarily due to their very low abundances and high analytical scatter at levels approaching detection limits.

Compared to BIF, trace element contents are significantly higher in shales across the Hamersley Province and therefore show stronger correlations that can be attributed to variations in mineralogy. In unaltered black shale from the north three components describe most of the element variation. Strong correlations between $\mathrm{Al}_{2} \mathrm{O}_{3}, \mathrm{TiO}_{2}, \mathrm{~K}_{2} \mathrm{O}$, $\mathrm{SiO}_{2}$ and $\mathrm{Zr}$ in the first component suggest these elements are controlled by variations in stilpnomelane, K-feldspar, clinochlore and minor phases such as zircon, ilmenite or anatase. Assuming all $\mathrm{TiO}_{2}, \mathrm{Al}_{2} \mathrm{O}_{3}$ and $\mathrm{Zr}$ in shale are derived from terrigenous material (Alibert and McCulloch, 1993), these elements are probably derived from detrital material related to the weathering of continental rocks (Ewers and Morris, 1981; Khan and Naqvi, 1996). The negative correlation of $\mathrm{Fe}_{2} \mathrm{O}_{3}, \mathrm{MnO}$ and $\mathrm{P}_{2} \mathrm{O}_{5}$ with these elements suggests minerals other than iron silicates control $\mathrm{Fe}_{2} \mathrm{O}_{3}$. Correlated elements in the second and third components of unaltered black shale suggest carbonates control their abundances. However, it is difficult to explain the negative correlation of $\mathrm{Ba}$ and $\mathrm{Rb}$ with $\mathrm{MgO}$ in the second component as these elements commonly substitute for alkali earth metals in most carbonates (Goldschmidt, 1958).

Similar components also describe most of the element distribution in altered black shale from Mt. Whaleback. Silicates and carbonates such as clinochlore, muscovite, siderite, dolomite and calcite can describe all three components. However, for red shale kaolinite controls elements such as $\mathrm{SiO}_{2}, \mathrm{~K}_{2} \mathrm{O}, \mathrm{Rb}, \mathrm{Sr}$, Ba whereas hematite controls $\mathrm{Fe}_{2} \mathrm{O}_{3}$. The other major and trace elements in these rocks are most likely controlled by variations in trace minerals such as zircon or clays. 


\subsection{Rare earth element variation and implications for BIF and shale genesis}

There is a general consensus concerning several basic aspects of BIF and shale origin. Most authors agree that they were deposited in an aqueous environment, that variations in dissolved oxygen are in part responsible for BIF deposition and that BIF chemistry most likely reflects Precambrian ocean composition. However, there is considerable debate over the ultimate source for the material in these rocks. Rare earth elements in sediments have been used for establishing the nature of the source material, process of formation and the environment of deposition (e.g., Holland, 1973; Morris and Howitz, 1983; Klein and Beukes, 1989; Derry and Jacobsen, 1990; Alibert and McCulloch, 1991). They are also good indicators of the major minerals present as certain phases (e.g., aluminosilicates, apatite and zircon) tend to have high to very high REE contents, while others (e.g., quartz) have relatively low concentrations (Goldschmidt, 1958; Graf, 1978).

All rocks from the Hamersley Province share several important features: they all have positive Eu anomalies, all but a few samples are enriched in HREEs and Ce anomalies are either slightly negative or absent. With the exception of $\mathrm{Ce}$ and Eu the overall shape of the REE patterns appear to be relatively similar to modern seawater (Fig. 5.16). However, REE content of seawater cannot solely explain variations in REE abundances of BIF and shale as the strong positive Eu anomalies suggest they were also influenced by the chemical content of the original source material (Graf, 1978).

The ultimate source of REEs in oceanic waters associated with BIF deposition has been the subject of considerable debate (e.g., Holland, 1973; Morris and Howitz, 1983; Klein and Beukes, 1989; Derry and Jacobsen, 1990; Alibert and McCulloch, 1991). REE contents of seawater are generally thought to be due to hydrothermal solutions, river water, detrital sediments or a combination of all three. The absence of obvious clastic sediment in BIF sequences throughout the Hamersley Province (Trendall and Blockley, 1970; Morris, 1985), indicates continental material is possibly not the primary source. Moreover, Nd isotopic differences between BIF samples and typical river sediment preclude the derivation of REEs in BIF from river sources (Derry and 


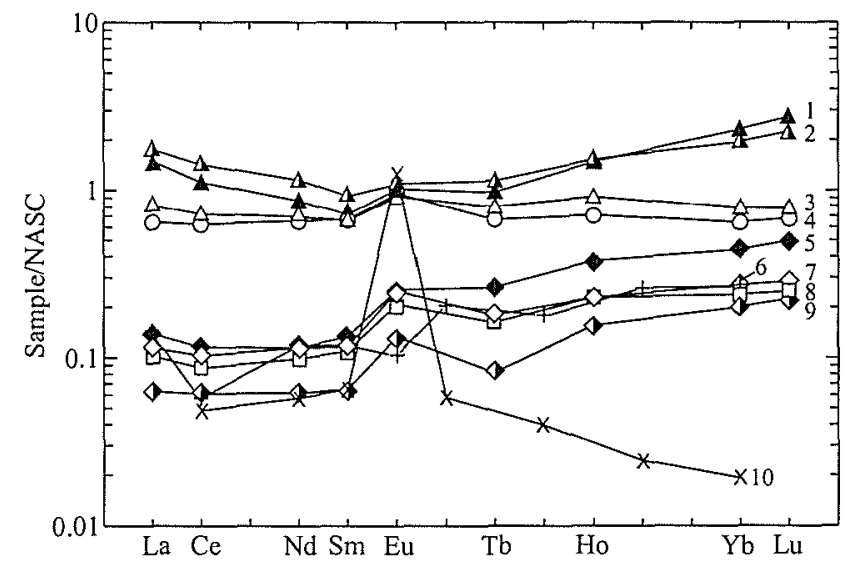

Figure 5.16. REE patterns of average BIF and shale across the Hamersley Province and some potential sources of REEs (normalized to the NASC values of Gromet et al., 1984). (1) Average red shale, this study; (2) Average altered black shale, this study; (3) Average black shale, this study; (4) Average Archean Shale (McLennan and Taylor, 1984); (5) Average high-grade hematite ore, this study; (6) Average seawater (Elderfield and Greaves, 1982); (7) Average BIF, this study; (8) Average weathered BIF, this study; (9) Average oxidized BIF, this study; (10) Hydrothermal water (Michard, 1989). Note: hydrothermal water has a very large Eu anomaly; seawater and BIF have HREE enriched patterns; shales have flat to slightly enriched HREE patterns and moderate Eu anomalies.

Jacobsen, 1990). Interestingly, $\mathrm{Nd}$ isotopic values for BIF are distinct from coeval shale bands (Alibert and McCulloch, 1993), suggesting different sources for REEs ion these rocks despite their relatively similar REE patterns. Seawater alone is the most likely source for REE in BIF. However, modern day seawater does not typically display an Eu anomaly, except near hydrothermal vents (Derry and Jacobsen, 1990) (Fig. 5.16). Thus the strong positive Eu anomalies in BIF samples from the Hamersley Province suggest some REE contents were derived from hydrothermal solutions possibly generated at mid-ocean ridges (Jacobsen and Pimentel-Klose, 1988; Alibert and McCulloch, 1991). Neodymium isotopic evidence from Hamersley BIF (Derry and Jacobsen, 1990; Alibert and McCulloch, 1991) also strongly favours a submarine hydrothermal source.

Despite relatively similar REE patterns between BIF and shale, weaker Eu anomalies and differences in $\mathrm{Nd}$ isotopic compositions (Alibert and McCulloch, 1991) imply hydrothermal fluids were not the primary source for REEs in the latter rocks. The similarity of shale REE patterns to typical Archaean shale (Fig. 5.16) strongly indicates a terrigenous contribution. Moderate HREE enrichment in some samples compared to Archaean Shale (Fig. 5.16) may simply imply a relatively large detrital 
mafic component (Alibert and McCulloch, 1991), although these samples may contain a small BIF fraction.

\subsection{Implications for iron ore genesis}

The supergene-metamorphic model for high-grade hematite ore genesis incorporates specific chemical, structural and fluid flow conditions (Morris, 1980, 1985, 1998; Morris et al., 1980). The model proposes that after a major deformation event in the southern Hamersley Province, rocks of the Dales Gorge Member were uplifted and exposed to supergene enrichment. During this process iron derived from the weathering of BIF migrated downwards to structurally favourable sites where it replaced quartz in unaltered BIF with goethite. During this process magnetite was simultaneously oxidized to martite via deep electrochemical processes. Ore was formed when these rocks were buried during a second deformation phase, which upgraded the goethite to microplaty hematite. The genetic pathway for the supergene model is inconsistent with several observations from this and other recent investigations. In particular, (1) mineralization is essentially a residual enrichment process achieved through the removal of gangue (i.e., quartz, carbonates and silicates), (2) the oxidation of magnetite to martite can occur independently of silica removal (Taylor et al., 2001; Chapter 2), (2) microplaty hematite may crystallize directly in a fluid buffered environment and in the absence of goethite (Chapter 3), and (3) rocks at Mt. Whaleback have been chemically altered numerous times suggesting BIF may have been significantly altered prior to and/or after ore genesis (Chapters 2-4). Furthermore, carbonate-magnetite BIF without silica at Mt. Tom Price (Taylor et al., 2001) and silica-poor carbonate-rich reddishgreen shales at Mt. Whaleback (Chapter 4) suggest some rocks may have seen hightemperature, possibly reducing fluids.

To account for some of these findings Barley et al. (1999), Oliver and Dickens (1999), Powell et al. (1999) and Taylor et al. (2001) have collectively proposed a mixed hypogene-meteoric model for iron ore genesis. The most detailed of these (i.e., Taylor et al., 2001) suggests high-grade hematite mineralization involved early silica loss at 
higher temperatures and reducing conditions, followed by progressively lower temperature oxidation by heated and/or cool surficial fluids. Following criticism by Morris (2002a), Taylor et al. (2002) conceded this model also needed the addition of Fe during earlier Si removal stages. However, they made no attempt to explain the source.

The calculated mass-volume losses between oxidized BIF and iron ore presented here are primarily due to removal of quartz and gangue minerals. One would expect this to be taken up by porosity if ore formation occurred very near the surface. However, the average porosity increase of iron ore relative to BIF is less than calculated or observed volume losses, suggesting either iron addition or compaction during mineralization (Fig. 5.17). Measured stratigraphic sections across the Hamersley Province show iron ore formation led to significant stratigraphic thinning of original

a)

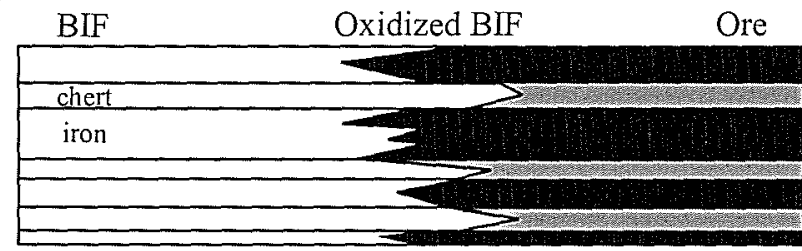

b)

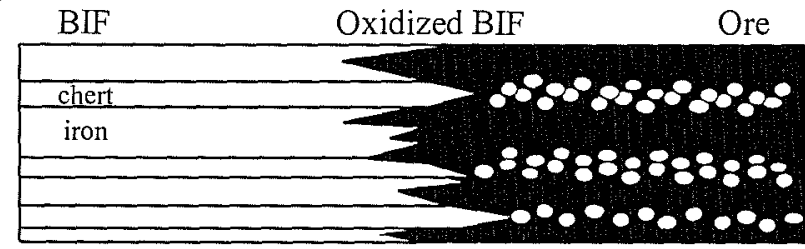

c)

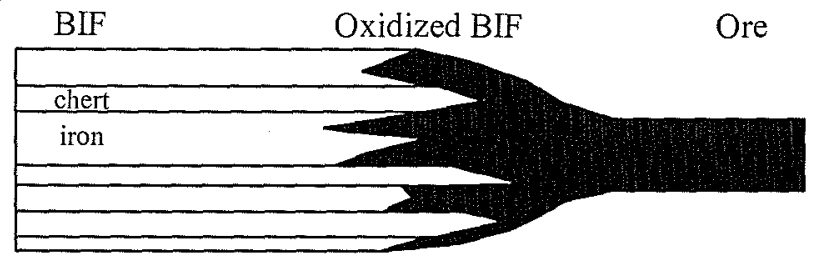

d)

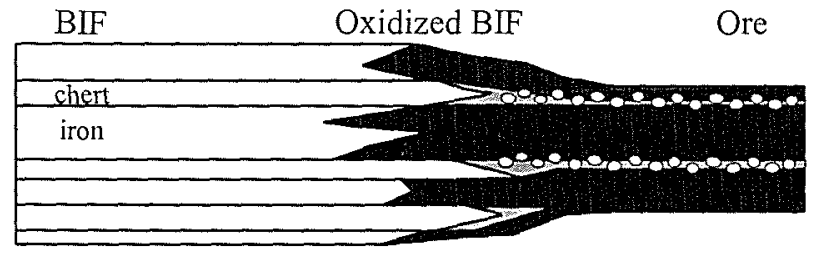

Much Fe added

Much Si lost

No compaction

Ghost stratigraphy preserved

No Fe added

Much Si lost

No compaction

Much porosity created

Ghost stratigraphy preserved

No Fe added

Much Si lost

Significant compaction

Ghost stratigraphy lost

No Fe added

Much Si lost

Much porosity created

Partially compacted

Ghost stratigraphy partially preserved

Figure 5.17.Cartoons representing possible models for oxidized BIF to high-grade hematite ore transitions, regarding the relative changes of volume, mass, $\mathrm{Si}$ and Fe. Note: figures (a), (b) and (c) represent the three possible end members for mineralization; figure (d) represents the most plausible explanation suggesting Si loss accompanied by porosity development and compaction is the key process during iron ore formation, not $\mathrm{Fe}$ addition. 
BIF units, although earlier structural thinning of $\mathrm{D}_{2}$ fold limbs may also have contributed. Of the thousands of drilled sections of enriched horizons, none equal or exceed the average thickness of parent BIF (Morris, 1985). Ore thicknesses at Mt. Whaleback range from about $54 \%$ of BIF at Wittenoom Gorge in the north to about $70 \%$ in other deposits (Blockley, 1969; Baldwin, 1975). Despite the indicated volume losses, addition of iron is still plausible. However, the combined volume losses and typical porosities suggest high-grade hematite ore at best represents only $\sim 35 \%$ of precursor BIF. Assuming original BIF had an iron oxide content of $\sim 20-30 \%$ (Table 5.5), there is sufficient iron in these rocks to account for all the iron in high-grade hematite ore. The lack of iron addition during the conversion of adjacent altered black and reddish-green shale to red shale (Figs. 5.14, 5.15) further supports the immobility of iron during mineralization. The alteration of altered black shale to reddish-green shale suggests some process prior to oxidation added $\mathrm{CaO}$ and $\mathrm{MgO}$. This alteration phase may relate to the early silica removal phase of the hydrothermal-meteoric model for Mt. Tom Price (Taylor et al., 2001). Regardless of which process removed silica, results from this investigation indicate the key process during iron ore formation is its loss accompanied by porosity development and compaction and not iron addition (Fig. 5.17d). The lack of significant iron addition during any process suggests most ore genesis models may need re-evaluation.

\section{CONCLUSION}

Previous work has shown that profound chemical changes occur between weathered, oxidized and mineralized DB-macrobands of the Dales Gorge Member across the Hamersley Province, Western Australia. However, quantification of the actual geochemical mass changes was hampered by the very low abundances of many trace elements in BIF and the lack of certain trace elements needed to fully assess the geochemical processes. This study has utilized comprehensive trace element chemistry, calculations of mass-volume and stratigraphic thickness changes with previously determined major element and paragenetic studies. Using the isocon method of Grant 
(1986) and detailed stratigraphic thickness changes across the province, this work has determined that weathered and oxidized $\mathrm{BIF}$ are depleted in $\mathrm{K}_{2} \mathrm{O}, \mathrm{MgO}, \mathrm{CaO}, \mathrm{Ba}, \mathrm{Rb}$, $\mathrm{Sr}$ and $\mathrm{Y}$ and enriched in $\mathrm{Co}, \mathrm{Cr}$ and $\mathrm{Ni}$. All other elements, including $\mathrm{Fe}$ and $\mathrm{Si}$, were relatively immobile. Compared to oxidized BIF, iron ore is significantly depleted in $\mathrm{SiO}_{2}$. Importantly, $\mathrm{Fe}$ was most likely immobile during this process. The lack of $\mathrm{Fe}$ addition during mineralization is strengthened by its relative immobility during the synchronous transformation of surrounding altered black shale to red shale. However, the conversion of altered black shale to recently discovered reddish-green shale deep within the Mt. Whaleback pit suggest some process prior to oxidation could have added $\mathrm{CaO}$ and $\mathrm{MgO}$ to the rocks. This alteration could be related to the early silica removal phase of the hydrothermal-meteoric model for Mt. Tom Price. Regardless of which model for iron ore genesis is correct the data from this work confirms that the crucial ore-forming step is Si loss and not widespread Fe metasomatism. 


\section{CHAPTER 6}

SUMMARY: A GENERAL GEOCHEMICAL MODEL FOR EXPLAINING ALTERED BANDED IRON-FORMATION, ALTERED SHALES, AND MARTITE-MICROPLATY HEMATITE ORES IN THE HAMERSLEY PROVINCF: 


\section{THE BASIC TRANSITION FROM BANDED IRON-FORMATION TO IRON} ORE

In the northern Hamersley Province, Western Australia, unaltered Proterozoic banded iron-formation (BIF) of the Dales Gorge Member, predominantly consists of an alternating assemblage of $\mathrm{mm}-\mathrm{cm}$ scale layers of magnetite and chert. However, in the several areas across the south (e.g., Mt. Whaleback, Mt. Tom Price, Paraburdoo, Giles Mini), equivalent layers have been deformed, altered and ultimately mineralized to martite-microplaty hematite ore. Over the past two decades, a "supergenemetamorphic" model has been the most widely cited explanation the genesis of these high-grade iron ore deposits in the Hamersley Province (e.g., Morris, 1980, 1985, 1998; Morris et al., 1980; Harmsworth et al., 1990). This model proposes the following:

(1) Uplift during the Ophthalmian Orogeny ca. 2.45-2.2 Ga brought BIF units to near the surface,

(2) During prolonged near-surface exposure and supergene enrichment, magnetite layers in BIF were oxidized to martite, and iron derived from the weathering of overlying BIF migrated downwards to structurally favourable sites where it replaced chert layers in BIF with goethite,

(3) Subsequent burial metamorphism upgraded the goethite to microplaty hematite.

The modern supergene environment in the Hamersley Province rarely exceeds depths of $100 \mathrm{~m}$ (e.g., Morris, 1983, p. 516). Thus, to explain downward penetration of meteoric fluids to depths of $500 \mathrm{~m}$ (approximate depth of mineralization at $\mathrm{Mt}$. Whaleback), this model appeals to a special combination of fluid seepage down former fault zones and electrochemical cells involving BIF and groundwater (Morris et al., 1980).

The "supergene-metamorphic" model incorporates specific chemical, structural and fluid flow conditions, and several authors have commented on fundamental problems. For example, detrital martite-microplaty hematite clasts in conglomerates of the lower Wyloo Group ( $>2.2 \mathrm{Ga}$ ) suggest some high-grade orebodies may have formed 
during the final stages of the Ophthalmian Orogeny (Martin et al., 1998) and silicapoor, magnetite-rich ore at Mt. Tom Price suggests silica may have been leached prior to oxidation (Barley et al., 1999; Taylor et al., 2001).

More recently, a "hypogene-supergene" model for martite-microplaty hematite ores has received attention (Barley et al., 1999; Taylor et al., 2001). This model invokes a four-stage paragenesis for mineralization. First, high temperature, carbonaterich fluids (i.e., hydrothermal conditions) replaced silica with carbonate, leaving carbonate-, magnetite-rich "BIF" with some iron silicates. Heated meteoric fluids then oxidized these assemblages to martite, microplaty hematite and ankerite. Continued oxidation leached remaining carbonates and silicates, leaving a highly porous ore. Finally, supergene weathering with cooler, oxidizing meteoric fluids destroyed remaining minor components such as apatite. Iron and aluminum were conserved during the process. The critical observation in support of this model has been the finding of magnetite-siderite BIF juxtaposed with quartz-hematite-carbonate veins (Barley et al., 1999; Taylor et al., 2001).

The major problem with testing any ore genesis model is the lack of detailed information regarding the composition of Dales Gorge Member BIF, especially in the south and around the orebodies. Apart from earlier work by Ewers and Morris (1981) and this investigation, there has been no systematic study between undeformed sequences in the north and mineralized equivalents in the south. There has also been limited examination of surrounding shales, which should have experienced some effects from fluids involved in ore formation. A proper post-depositional model for these rocks would place fundamental constraints on models describing the alteration of surrounding BIF. Furthermore, previous work describing chemical changes occurring to BIF and shale of the Hamersley Province has not quantified actual chemical mass changes associated with alteration, primarily due the lack of key trace elements (e.g., rare earth elements) needed to fully assess the geochemical processes. 


\section{NEW CONTRIBUTIONS OF THIS THESIS}

This thesis has examined the chemistry, mineralogy and petrology of rocks of the Dales Gorge Member and surrounding shales from undeformed regions in the north into equivalent mineralized sequences at Mt. Whaleback (e.g. Fig. 6.1). The overall purpose was to see how processes in the basin and during ore formation would affect all rocks.

(a)

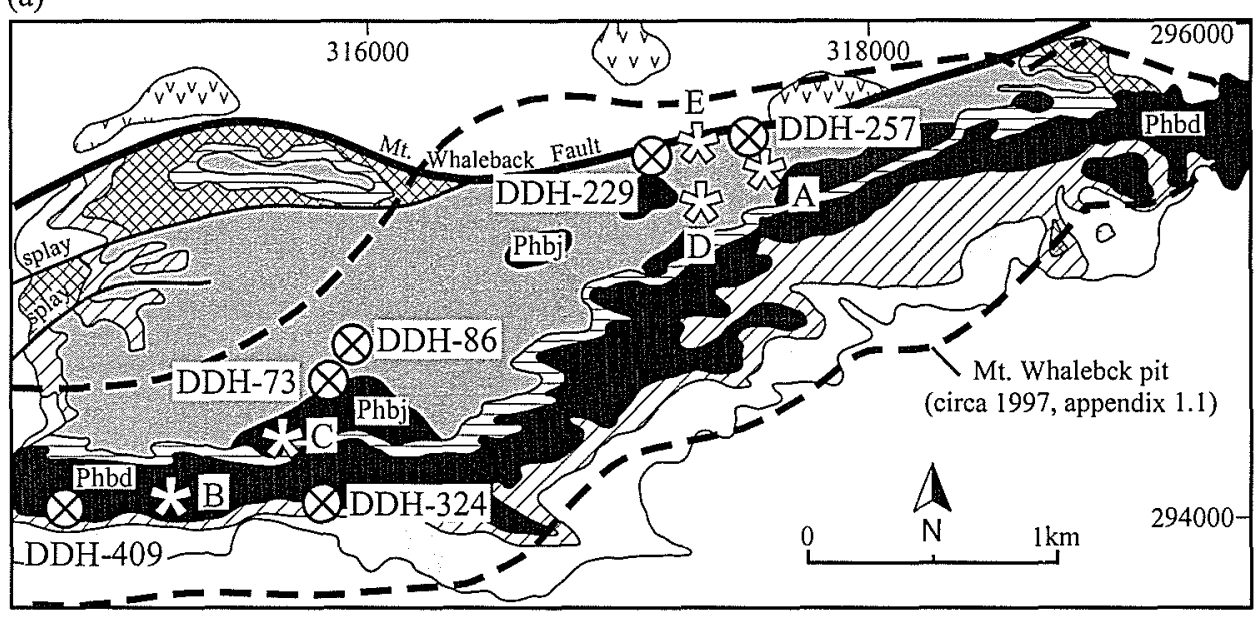

(b)

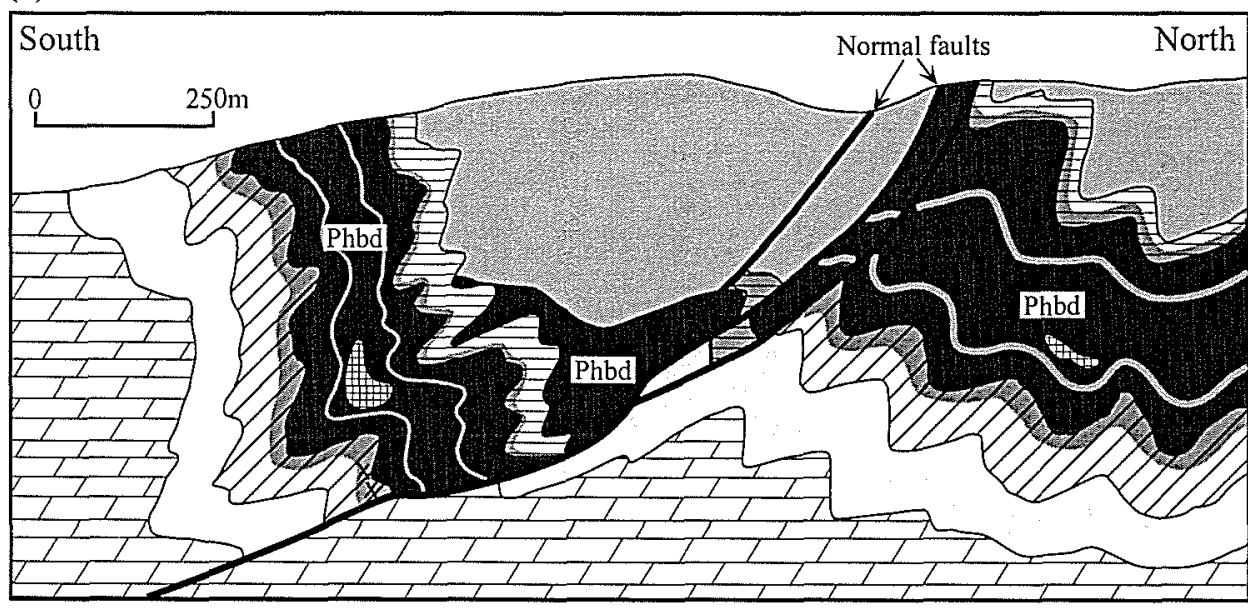

\section{Reference}

Joffre Member (Phbj)
Whaleback Shale Member (Phbw)
Dales Gorge Member (Phbd)
Mt McRae Shale (Phr)
Mt Sylvia Formation
Wittenoom Dolomite

Martite-microplaty hematite ore
Phbw altered black shale
Phr altered black shale
Red shales
Carbonate-rich shale
Oxidized BIF

Figure 6.1. (a) Plan view of the Mt. Whaleback pit showing general geology and sample locations (modified from Harmsworth et al., 1990). (b) Generic cross-section of Mt. Whaleback (approximate mine grid coordinates $315120 \mathrm{E}$ ) showing orebody boundaries and the general distribution of the different rock types analysed in this study (modified from Powell et al., 1999). 
Several key observations resulting from this investigation cannot be reconciled with the "supergene-metamorphic" model for high-grade iron ore genesis. In particular:

(1) the oxidation of magnetite to martite can occur independently of silica removal (Chapters 2, 3),

(2) rocks at Mt. Whaleback have been chemically altered at least 4 times after early diagenesis, suggesting that BIF and surrounding shales may have been significantly changed prior to and/or after ore genesis (Chapter 2),

(3) oxidation, including mineralization, occurred after formation of altered black shales, which probably formed during peak metamorphism $\left(D_{2}\right)$ (Chapter 2),

(4) microplaty hematite can be found in rocks with incipient chert and away from high-grade iron ore deposits (Chapter 3),

(5) silica-poor carbonate-rich shales are found beneath ore at Mt. Whaleback, clearly indicating that some rocks at this location have undergone carbonate alteration processes that may be analogous to processes inferred for other ore deposits (Chapter 4),

(6) mineralization is essentially a residual enrichment process achieved through the removal of gangue (i.e., quartz, carbonates and silicates), not by addition of iron (Chapter 5).

Of these, only the fourth observation cannot be explained by the "hypogene-supergene" model.

Modifying the recent model by Taylor et al. (2001), an internally consistent and testable model to explain rocks at all high-grade iron ore deposits and throughout the southeastern Hamersley Province can be forwarded (Fig. 6.2). Rocks across the region experienced regional metamorphism during the Ophthalmian Orogeny $\left(D_{2}\right)$, although the grade of this metamorphism was greater at Mt. Whaleback. This explains the formation of altered black shale around this deposit. Reduced carbonate-rich fluids flowed up along normal faults during early stages of the collapse and exhumation of the Ophthalmian mountain range after $\mathrm{D}_{2}$ compression, forming carbonate-rich BIF and Mt. McRae Shale at all deposits. Pervasive northward flow of presumably heated, acidic 


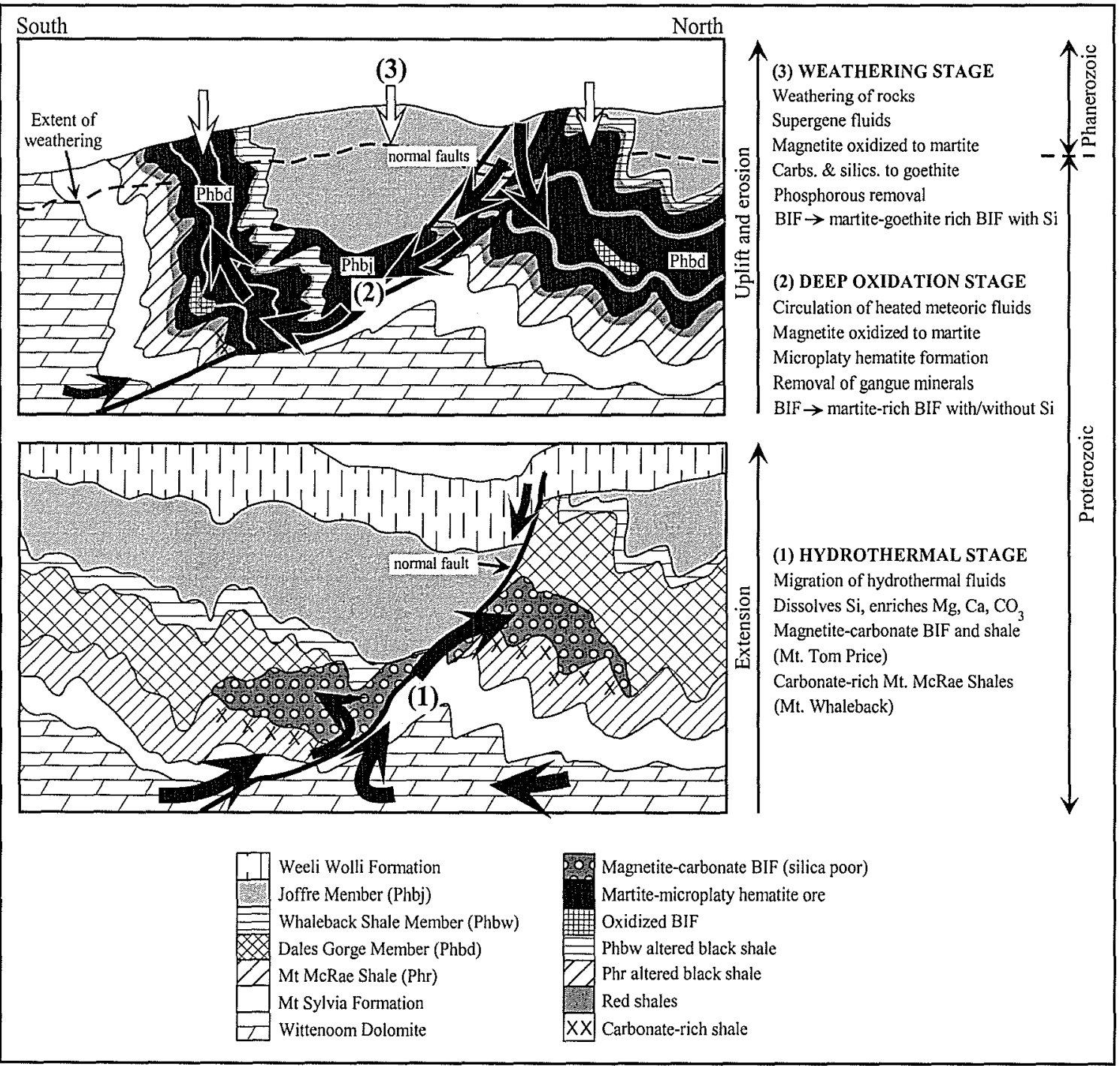

Figure 6.2. Schematic cross-sections showing the evolution of mineralization and alteration at Mt. Whaleback (modified from Ronaszeki, 1997). Note that oxidized BIF developed from deep-seated oxidation of unaltered BIF (syn/post mineralization). Also note the total overprinting of carbonate-rich $\mathrm{BIF}$ and shale by hematite ore and red shale respectively and the preservation of carbonate-rich Mt. McRae Shale at only one location deep within the pit.

oxygenated fluids during continued uplift, subsequently converted magnetite layers in unaltered BIF and carbonate-rich "BIF" to martite, and carbonate to microplaty hematite (Fig. 6.3). This explains the presence of the ore deposits and oxidized BIF at multiple locations (including Fourth West), as well as the general lack of reduced, carbonate-rich, silica-poor rocks at Mt. Whaleback. This also explains why massvolume calculations suggest that $\mathrm{Fe}$ enrichment in the ores was essentially a residual process achieved through the significant removal of gangue. 
Silica deficient, magnetite-carbonate "BIF" has not been found at Mt. Whaleback in this study (Figs. 6.1). Indeed, except for an interval of Mt. McRae Shale from deep within the pit, this investigation did not detect carbonate-rich rocks anywhere in the vicinity of Mt. Whaleback. Given the above model, there are two obvious possible explanations. First, these rocks exist at Mt. Whaleback but have not yet been found. Given the enormous size of the Mt. Whaleback deposit, carbonate-rich "BIF" and "hydrothermal" veins could lie below the current pit and beyond the depths of examined drill cores. Second, the pervasive northward flow of oxidized, acidic waters has greatly affected rocks at Mt. Whaleback, essentially removing these carbonate-rich rocks except in localised pockets within the Mt. McRae Shale (e.g., Fig. 6.3).

\section{FUTURE WORK}

There are three obvious tests of the model outlined here. First, more evidence for carbonate-rich "BIF" and shale should occur below the ore at Mt. Whaleback and other similar deposits across the Hamersley Province. Second, moderate to high temperature fluids might have affected rocks near or around Mt. Whaleback during or after regional metamorphism $\left(\mathrm{D}_{2}\right)$. Third, oxidized chert-rich BIF should occur in locations other than around Mt. Whaleback (e.g., Mt. Tom Price). Although it is difficult to fully assess the first expectation due to limitations related to current dill holes and mine depth, the appearance of carbonate-rich shales deep within the Mt. Whaleback pit and carbonate altered rocks at Giles Mini broadens the likely extent of an early Si removal stage by reduced carbonate-rich fluids. Recent fluid inclusion work has shown that some quartz veins near Mt. Whaleback (Cathedral and Fourth West Gorge) precipitated at high temperature $\left(\sim 300-400^{\circ} \mathrm{C}\right)$ during or after $\mathrm{D}_{2}$ (Oliver and Dickens, 1999; Powell et al., 1999; Brown et al., in press). These inclusions indicate the presence of heated fluids in the region that possibly culminated in hematite mineralization. The extent of this oxidation around Mt. Whaleback suggests "oxidized BIF" should occur in other places across the Hamersley Province. Indeed, the "jasperoidal BIF" at Mt. Tom Price may indicate such rocks exist at other locations away from Mt. Whaleback although it is 
(a) Stage 1: Hydrothermal alteration by carbonate-rich basinal brines (extension)

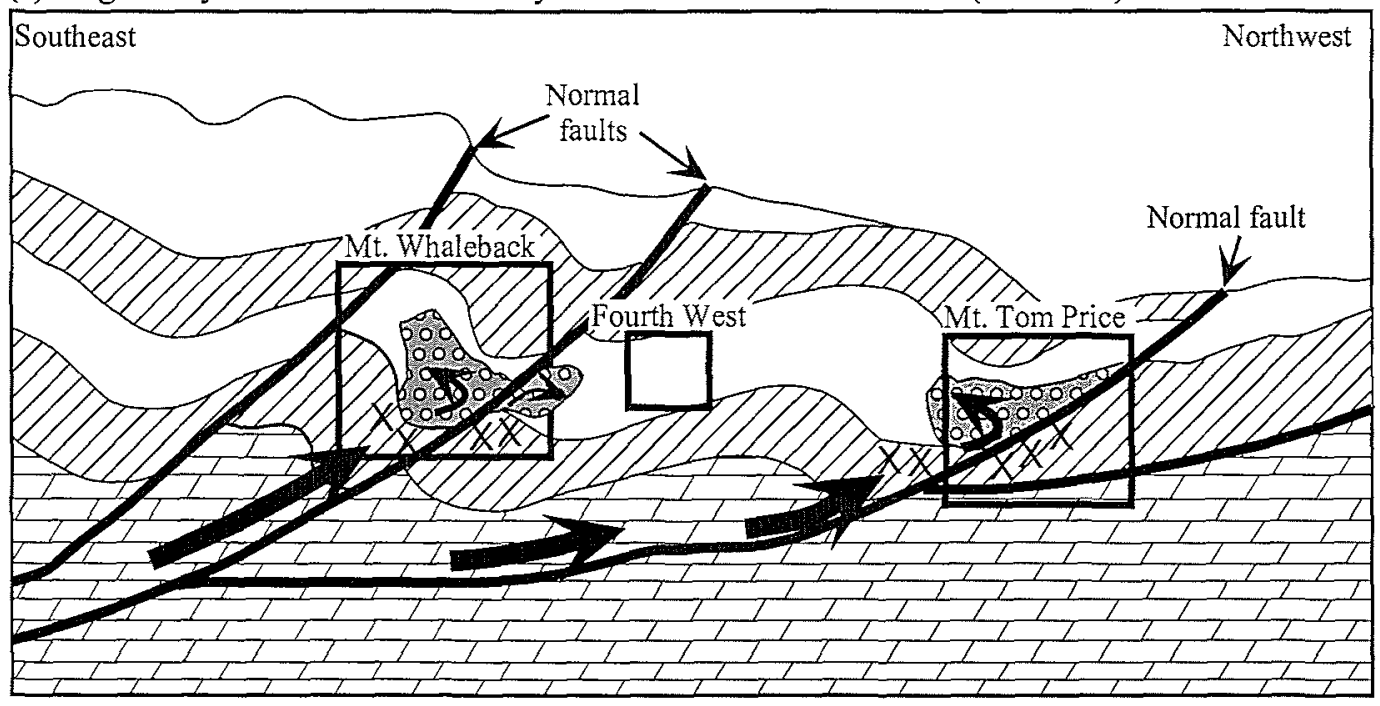

(b) Stage 2: Oxidation by meteoric fluids (uplift and extension)
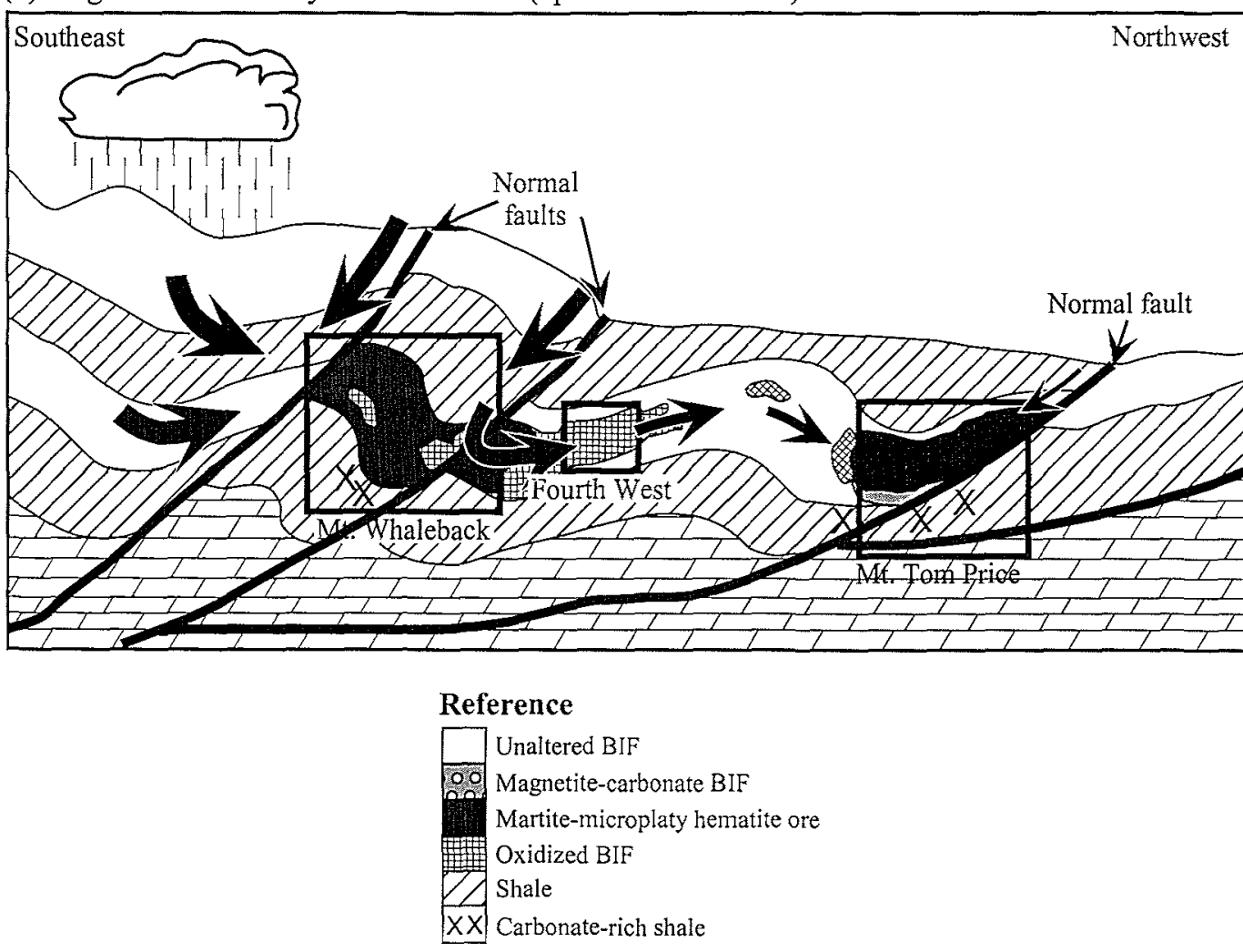

Figure 6.3. Schematic cross-sections showing the regional evolution of mineralization and relative position of altered rocks (primarily BIF) across the Hamersley Province. (a) Development of ores during hydrothermal alteration (Stage 1) by silica undersaturated, carbonate-rich basinal brines (arrows). Note proximity of carbonate ores to normal faults and the absence of hydrothermal alteration at Fourth West Gorge. (b) North/northwestern flow of oxidized fluids during the stage 2 alteration (arrows). Meteoric fluids are expelled into the ex-foreland basin from the uplifted fold and thrust belt. These fluids generally flow laterally away from the mountain belt although normal faults may have acted as recharge paths. Note the strong overprint of reduced rocks at Mt. Whaleback compared to Mt. Tom Price suggesting oxidation was more pervasive in the southeast and the alteration of unaltered BIF between the two major deposits (e.g., Fourth West Gorge). 
difficult to compare these rocks to this work with available information. Either way the relatively high abundance of "oxidized BIF" in and around Mt. Whaleback suggests this oxidation was more pervasive in the southeast.

There are several sampling related problems that should also be addressed in future research into iron ores of the Hamersley Province. The first issue is related to the lack of detailed information regarding the textures and location of reduced rocks at deposits other than Mt. Whaleback. While several investigations have documented these rocks at Mt. Tom Price (e.g., Taylor et al., 2001; Dalstra et al., 2002b; Morris, 2002), the lack of well-constrained and presented data makes it extremely difficult to rigorously compare them to similar rocks from $\mathrm{Mt}$. Whaleback and across the Hamersley Province. This has been a major problem with most work in the Hamersley Province and has caused significant debate over the relative timing of alteration and more importantly, microplaty hematite development (e.g., Morris, 2002; Taylor et al., 2002).

Similarly, although previous work has documented significant differences between unaltered rocks and altered equivalents at various martite-microplaty hematite deposits across the Hamersley Province, no investigation has systematically compared the chemistry of sequences from the different high-grade hematite ore deposits. This is primarily due to the inherent difficulties working in areas owned by different mining companies. Any future research assessing current geochemical ore genesis models should therefore not be company or mine specific.

The large-scale silica dissolution needed to produce hematite-rich ores requires (a) solubility characteristics that favour quartz dissolution and iron oxide precipitation and (b) large fluid volumes. Large $\mathrm{pH}$ changes may affect silica solubility (e.g., Taylor et al., 2001), but as silica has a strong temperature dependant solubility (e.g., Fig. 6.4), temperature gradients may also be crucial. Chemical modelling of the proposed fluidtypes in the hydrothermal-meteoric model may highlight the most plausible scenario. For example, hot basinal brines with high pH (Taylor et al., 2001) are not necessarily the only fluid capable of removing large amounts of silica. Figure 6.4 shows that a 
system involving large-scale silica loss can also be explained by downward flow of near-surface fluid towards deeper and hotter parts of the system. Such a flow path is consistent with the highly oxidizing nature of the fluids and the meteoric stable isotope signature recorded by some of the rocks (cf. Oliver and Dickens, 1999; Powell et al., 1999; Brown et al., in press; Taylor et al., 2001).

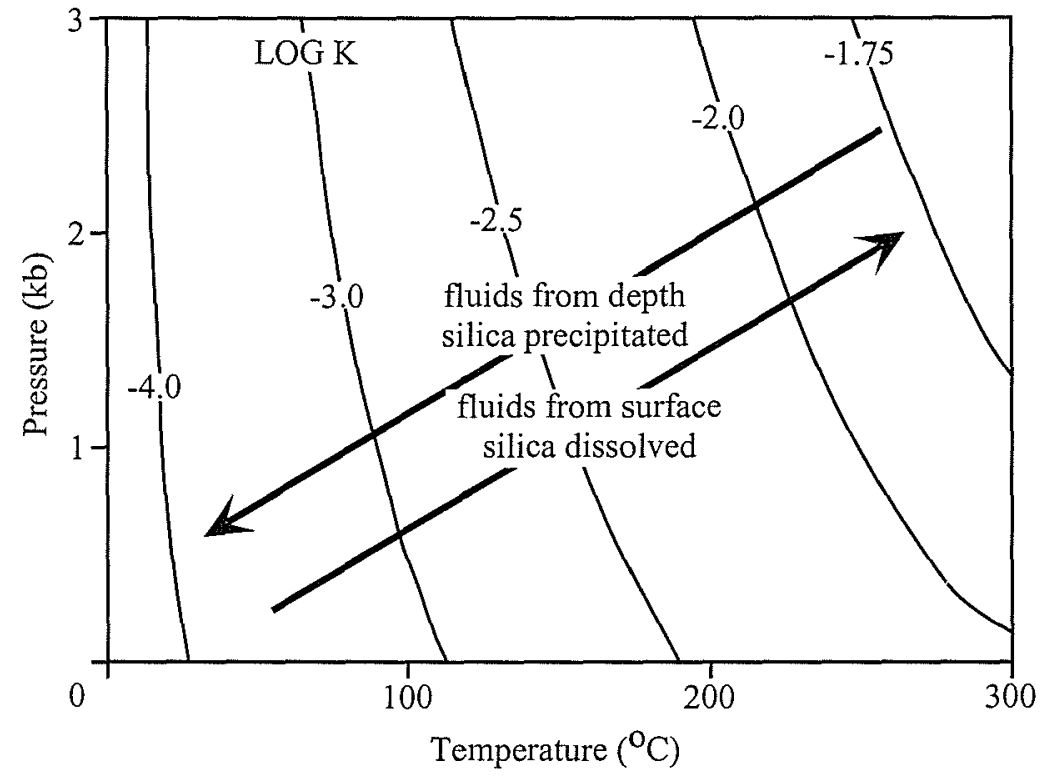

Figure 6.4. Solubility characteristics of silica in water as a function of pressure and temperature (after Walther and Helgeson, 1977). Isopleths of $\log \mathrm{K}$ assume silica solubility is due to the reaction $\mathrm{SiO}_{2(\mathrm{~s})}$ to $\mathrm{SiO}_{2(\mathrm{aq})}$. Note the increasing solubility of quartz as both temperature and pressure increases.

The hydrothermal-meteoric model for iron ore genesis essentially appeals to a very unique texture-preserving process involving two separate stages of significant gangue dissolution and reprecipitation. However, it is possible that these two processes were actually tied together. For example, the removal of silica from unaltered BIF by reduced, $\mathrm{CO}_{2}$, carbonate-bearing fluids, deep within the ore deposit, may have simply acted as a catalyst for mineralization by initially creating extra permeability within the rocks. This may have allowed the significant, focused influx of fluid from the surface needed to oxidize the implied very large volumes of BIF. 
Adams, A.E., Mackenzie, W.S. and Guilford, C., 1984. Atlas of sedimentary rocks under the microscope. Longman, London, pp.1-104.

Alibert, C. and McCulloch, M.T., 1993. Rare earth element and neodymium isotopic compositions of banded iron-formations and associated shales from Hamersley, Western Australia. Geochimica et Cosmochimica Acta, 57: 187-204.

Anbar, A.D. and Holland, H.D., 1992. The photochemistry of manganese and the origin of banded iron-formations. Geochimica et Cosmochimica Acta, 56: 2595-2603.

Ayres, D.E., 1972. Genesis of iron bearing minerals in Banded Iron Formation mesobands in the Dales Gorge Member, Hamersley Group, Western Australia. Economic Geology, 67: 1214-1233.

Baldwin, J.T., 1975. Paraburdoo and Koodaideri iron ore deposits, and comparisons with Tom Price iron ore deposits, Hamersley Iron Province, in Knight, C.L., (Ed.), Economic geology of Australia and Papua New Guinea, 1-metals. Australasian Institute of Mining and Metallurgy Monograph, 5: 898-905.

Barley, M.E., Pickard, A.L., Hagemann, S.G. and Folkert, S.L., 1999. Hydrothermal origin for the 2 billion year old Mount Tom Price giant iron ore deposit, Hamersley Province, Western Australia. Mineralium Deposita, 34: 784-789.

Barley, M.E., Pickard, A.L. and Sylvester, P.J., 1997. Emplacement of a large igneous province as a possible cause of banded iron-formation 2.45 million years age. Nature, 385: 55-58.

Bau, M., and Dulski, P., 1996. Distribution of yttrium and rare-earth elements in the Penge and Kuruman iron-formations, Transvaal Supergroup, South Africa. Precambrian Research, 70: 37-55.

Becker, R.H. and Clayton, R.N., 1976. Oxygen isotope study of Precambrian ironformation, Hamersley Range, Western Australia. Geochimica et Cosmochimica Acta, 40: 1153-1165.

Beukes, N.J., Dorland, H., Gutzmer, J., Nedachi, M. and Ohmoto, H., 2002. Tropical laterites, life on land, and the history of atmospheric oxygen in the Paleoproterozoic. Geology, 30: 491-494. 
Blockley, J.G., 1969. The stratigraphy of the Mount Tom Price ore body and its implication in the genesis of iron ore. Geological Survey of Western Australia Annual Report 1968, pp. 46-49.

Bowers, T.S. and Helgeson, H.C., 1983a, Calculation of the thermodynamic and geochemical consequences of non-ideal mixing in the system $\mathrm{H}_{2} \mathrm{O}-\mathrm{CO}_{2}-\mathrm{NaCl}$ on phase relations in geologic systems: Equation of state for $\mathrm{H}_{2} \mathrm{O}-\mathrm{CO}_{2}-\mathrm{NaCl}$ fluids at high pressures and temperatures, Geochimica et Cosmochimica Acta, 47: 12471275.

Brasher, B.R., Franzmeier, D.P., Valasis, V. and Davidson, S.E., 1966. Use of Saran resin to coat natural soil clods for bulk density and moisture retention measurements. Soil Science Society, 101: 108-110.

Brown, M.C., Oliver, N.H.S. and Dickens, G.R., in press. The characterization and paragenesis of veining and fluid flow in the Mt. Whaleback iron ore district, eastern Hamersley Province, Western Australia. Precambrian Research.

Cameron, E.M. and Garrels, R.M., 1980. Geochemical compositions of some Precambrian shales from the Canadian Shield. Chemical Geology, 28: 181-197.

Canfield, D.E., 1998. A new model for Proterozoic ocean chemistry. Nature, 396: 450452.

Cao, L.-Q, Arculus, R.J. and McKelvey, 1995. Geochemistry and petrology of volcanic ashes recovered from sites 881 through 884: a temporal record of Kamchatka and Kurile volcanism. In Rea, D.K., Basov, I.A., Scholl, D.W., Allan, J.F. (Eds.). Proc. ODP, Scientific Results 145: College Station, TX (Ocean Drilling Program), pp. $345-388$.

Compston, W., Williams, I.S., McCulloch, M.T., Foster, J.J., Arriens, P.A. and Trendall, A.F., 1981. A revised age for the Hamersley Group. Geological Society of Australia Abstracts, 3: 40.

Dalstra, H.J., Harding, A.E. and Taylor, D., 2002a. Genesis of high-grade hematite orebodies of the Hamersley Province, Western Australia - A reply. Economic Geology, 97:174-176. 
Dalstra, H.J., Harding, A.E., Riggs, T. and Taylor, D., 2002b. Banded iron-formation hosted in high-grade hematite deposits, a coherent group? Proceedings of Iron Ore 2002 Conference, 9-11 September 2002, Perth, Western Australia. Special AusIMM Publication Series No. 7/2002, pp. 41-56.

Davis, J.C., 1983. Statistics and data analysis in geology (2nd Edition). John Wiley and Sons, New York, pp. 1-646.

Deer, W.A., Howie, R.A. and Zussman, J., 1992. The rock forming minerals. Longman, London, pp. 1-696.

Department of Mineral and Petroleum Resources, Western Australia, 2001. Iron Ore. Western Australia Mineral and Petroleum Statistics Digest, 2000-2001, pp. 12-14.

Derry, L.A. and Jacobsen, S.B., 1990. The chemical evolution of Precambrian seawater: Evidence from REEs in banded iron-formations. Geochimica et Cosmochimica Acta, 57: 2965-2977.

Dickson, J.A.D., 1965. A modified staining technique for carbonates in thin-sections. Nature, 205: 587.

Dorr, J.V., 1965. High-grade hematite ores of Brazil. Economic Geology, 60: 1-46.

Dunbar, G.B., Dickens, G.R. and Carter, R.M., 2000. Sediment flux across the Great Barrier Reef Shelf to the Queensland Trough over the last 300ky. Sedimentary Geology, 133: 49-92.

Elderfield, H, and Greaves, M.J., 1982. The rare earth elements in seawater. Nature, 296: 214-219.

Ewers, W.E. and Morris, R.C., 1981. Studies of the Dales Gorge Member of the Brockman Iron Formation, Western Australia. Economic Geology, 76: 19291953.

Ewers, W.E., 1983. Chemical factors in the deposition and diagenesis of Banded Iron Formation, in Trendall, A.F. and Morris, R.C. (Eds.), Iron Formation: Facts and Problems, Elsevier, Amsterdam, pp. 491-512.

Faure, G., 1998. Principles and applications of geochemistry. Prentice Hall, New Jersey, pp. 1-600. 
Findlay, D., 1994. Diagenetic boudinage, an analogue model for the control on hematite enrichment iron ores of the Hamersley Iron Province of Western Australia, and a comparison with Krivoi Rog of Ukraine and Nimba Range, Liberia. Ore Geology Reviews, 9: 311-324.

French, B.M., 1973. Mineral assemblages in diagenetic and low-grade metamorphic iron-formation. Economic Geology, 68: 1063-1074.

Garrels, R.M. and Mackenzie, F.T., 1971. Evolution of sedimentary rocks. Norton, New York, pp. 1-397.

Garrels, R.M., Perry, E.A. and Mackenzie, F.T., 1973. Genesis of Precambrian IronFormations and the development of Atmospheric Oxygen. Economic Geology, 68: 1173-1179.

Gladney, E.A., Jones, E.A., Nickell, E.J. and Roelandts, I., 1992. Compilation of elemental concentration data for USGS AVG-1, GSP-1 and G-2. Geostandards Newsletter, 26: 111-300.

Gladney, E.A. and Roelandts, I., 1990. 1988 compilation of chemical concentration data from CCRMP reference rock samples SY-2, SY-3 and MRG-1. Geostandards Newsletter, 14: 373-458.

Garven, G. and Freeze, R.A., 1984. Theoretical analysis of the role of groundwater flow in the genesis of stratabound ore deposits. 1. Mathematical and numerical model. American Journal of Science, 284: 1085-1124.

Gay, A.L. and Grandstaff, D.E., 1980. Chemistry and mineralogy of Precambrian paleosols at Elliot Lake, Ontario, Canada. Precambrian Research, 12: 349-373.

Goldschmidt, V.M., 1958. Geochemistry. Oxford University Press, London, pp. 292302.

Gole, M.J., 1981. Archean Banded Iron Formations, Yilgarn Block, Western Australia. Econ. Geol., 76: 1954-1974.

Graf, J.L., 1978. Rare earth elements, iron formations and sea water. Geochimica et Cosmochimica Acta, 42: 1845-1850.

Grant, J.A., 1986. The isocon diagram - A simple solution to Gresens' Equation for 
metasomatic alteration. Economic Geology, 81: 1976-1982.

Gresens, R.L., 1967. Compositional-volume relationships of metasomatism. Chemical Geology, 2: 47-65.

Gromet, L.P., Dymek, R.F., Haskin, L.A. and Korotev, R.L., 1984. The North American shale composite: its compilation, major and trace element characteristics. Geochimica et Cosmochimica Acta, 48: 2469-2482.

Grubb, P.L.C., 1971. Silicates and their paragenesis in the Brockman Iron Formation of Wittenoom Gorge, Western Australia. Economic Geology, 66: 281-292.

Harmsworth, R.A., Kneeshaw, M., Morris, R.C., Robinson, C.J. and Shrivastava, P.K., 1990. BIF-Derived Iron Ores of the Hamersley Province, in Hughes, F.E., (Ed.), Geology of the mineral deposits of Australia and Papua New Guinea. Australasian Institute of Mining and Metallurgy Monograph 14, Melbourne, pp. 617-642.

Helgeson, H.C., 1967, Solution chemistry and metamorphism, in Abelson, P.H., (Ed.), Researches in Geochemistry. John Wiley and Sons Inc, New York, pp. 362-405.

Holland, D.H., 1973. The Oceans, A possible source of iron in Iron-Formations. Economic Geology, 68: 1169-1172.

Jacobsen, S.B. and Pimentel-Klose, M.R., 1988. A Nd isotopic study of the Hamersley and Michipicoten banded iron-formations: the source of REE and Fe in Archaean oceans. Earth and Planetary Science Letters, 87: 29-44.

Jones, H., Walraven, F. and Knott, G.G., 1973. Natural gamma logging as an aid to iron ore exploration in the Pilbara region of Western Australia, in Western Australian Conference, 1973. Australasian Institute of Mining and Metallurgy, pp. 53-60.

Khan, R.M.K. and Naqvi, S.M., 1996. Geology, geochemistry and genesis of BIF of Kushtagi schist belt, Archaean Dharwar Craton, India. Mineralium Deposita, 31 : 123-133.

Klein, C. and Beukes, N.J., 1989. Geochemistry and sedimentology of a facies transition from limestone to iron-formation deposition in the Early Proterozoic Transvaal Supergroup, South Africa. Economic Geology, 84: 1733-1774. 
Kneeshaw, M. and Kepert, D.A., 2002. Genesis of high-grade hematite orebodies of the Hamersley Province, Western Australia - A discussion. Economic Geology, $97: 173$.

LaBerge, G.L., 1966. Altered Pyroclastic rocks in iron-formation in the Hamersley Range, Western Australia. Economic Geology, 61: 147-161.

Li, Z.X., Powell, C.M. and Bowman, R., 1993. Timing and genesis of Hamersley ironore deposits. Exploration Geophysics, 24: 631-636.

MacLeod, W.N., de la Hunty, L.E., Jones, W.R. and Halligan, R., 1963. A preliminary report on the Hamersley Iron Province, North West Division: Geological Survey of Western Australia Annual Report 1962, pp. 44-54.

Macleod, W.N., 1966. The geology and iron deposits of the Hamersley Range area, Western Australia. Geological Survey of Western Australia Bulletin, 117.

Majumder, T., Whitley, J.E. and Chakraborty, K.L., 1984. Rare-earth elements in the Indian banded iron-formation. Chemical Geology, 45: 203-211.

Martin, D.M., Li, Z.X., Nemchin, A.A. and Powell, C.M., 1998. A pre-2.2 Ga age for giant hematite ores of the Hamersley Province, Australia. Economic Geology, 93: 1084-1090.

McLennan, S.M., 1989. Rare earth elements in sedimentary rocks: Influence of provenance and sedimentary processes, in Lipin, B.R., and McKay, G.A. (Eds.), Geochemistry and mineralogy of rare earth elements. Mineralogical Society of America, Washington, pp. 169-200.

McLennan, S.M. and Taylor, S.R., 1984. Archaean sedimentary rocks and their relation to the composition of the Archaean continental crust, in Kroner, G.N., Hanson, G.N., and Goodwin, A.M. (Eds.), Archaean Geochemistry, Springer-Verlag, Berlin, pp. 47-72.

Michard, A., 1989. Rare earth element systematics in hydrothermal fluids. Geochimica et Cosmochimica Acta, 53: 745-750.

Miyano, T., 1982. Stilpnomelane, iron-rich mica, k-feldspar and hornblende in banded iron-formation assemblages of the Dales Gorge Member, Hamersley Group, 
Western Australia. Canadian Mineralogist, 20: 189-202.

Miyano, T. and Klein, C., 1989. Phase equilibria in the system $\mathrm{K}_{2} \mathrm{O}-\mathrm{FeO}-\mathrm{MgO}-\mathrm{Al}_{2} \mathrm{O}_{3}$ $\mathrm{SiO}_{2}-\mathrm{H}_{2} \mathrm{O}-\mathrm{CO}_{2}$ and the stability limit of stilpnomelane in metamorphosed Precambrian iron-formations. Contributions to Mineralogy and Petrology, 102: $478-491$.

Morris, R.C., 1980. A textural and mineralogical study of the relationship of iron ore to banded iron-formation in the Hamersley Iron Province of Western Australia. Economic Geology, 75: 185-209.

Morris, R.C., 1983. Supergene alteration of banded iron-formation, in Trendall, A.F. and Morris, R.C. (Eds.), Iron Formation, Facts and Problems. Elsevier, Amsterdam, pp. 513-534.

Morris, R.C., 1985. Genesis of iron ore in banded iron-formation by supergene and supergene-metamorphic processes, A conceptual model, in Wolf, K.H. (Ed.), Handbook of strata-bound and stratiform ore deposits, Volume 13, Elsevier Amsterdam, pp. 73-235.

Morris, R.C., 1993. Genetic modeling for banded iron-formation of the Hamersley Group, Pilbara Craton, Western Australia. Precambrian Research, 60: 243-286.

Morris, R.C., 1998. BIF-hosted iron ore deposits-Hamersley style. AGSO Journal of Australian Geology and Geophysics, 17: 207-211.

Morris, R.C., 2002a. Genesis of high-grade hematite orebodies of the Hamersley Province, Western Australia - A discussion. Economic Geology, 97:177-178.

Morris, R.C., 2002b. Iron ore genesis and post-ore metasomatism at Mount Tom Price. Proceedings of Iron Ore 2002 Conference, 9-11 September 2002, Perth, Western Australia. Australasian Institute of Mining and Metallurgy Publication Series No. 7/2002, pp. 3-13.

Morris, R.C., and Horwitz, R.C., 1983. The origin of the iron-formation-rich Hamersley Group of Western Australia-deposition on a platform. Precambrian Research, 21: 273-297.

Morris, R.C., Thornber, M.R. and Ewers, W.E., 1980. Deep-seated iron ores from 
banded iron-formation. Nature, 288: 250-252.

Mozley, P.S. and Burns, S.J., 1993. Oxygen and carbon isotopic composition of marine carbonate concretions: An overview. Journal of Sedimentary Petrology, 63: 7383.

Munsell, A.H., 1966. The Munsell Book of Color. MacBeth Color and Photometry. Kollmorgen Corporation, Newburgh, New York.

Oliver, J., 1986. Fluids expelled tectonically from orogenic belts: Their role in hydrocarbon migration and other geologic phenomena. Geology, 14: 99-102.

Oliver, N.H.S. and Dickens, G.R., 1999. Hematite ores of Australia formed by syntectonic heated meteoric fluids, in Stanley, C. J. et al. (Eds.), Mineral Deposits, Processes to Processing. Balkema, Rotterdam, pp. 889-892.

Panahi, A., Young, G.M. and Rainbird, R.H., 2000. Behaviour of major and trace elements (including REE) during Paleoproterozoic pedogenesis and diagenetic alteration of an Archean granite near Ville Marie, Quebec, Canada. Geochimica et Cosmochimica Acta, 57: 187-204.

Powell, C. McA., Oliver, N.H., Li, Z.X., Martin, D. McB. and Ronaszeki, J., 1999. Synorogenic hydrothermal origin for giant Hamersley iron oxide ore bodies. Geology, 27: 175-178.

Reimann, C. and Filzmoser, P., 2000. Normal and lognormal data distribution in geochemistry: death of a myth. Consequences for the statistical treatment of geochemical and environmenta1 data. Environmental Geology, 39: 1001-1014.

Reimann, C., Filzmoser, P. and Garrett, R.G., 2002. Factor analysis applied to regional geochemical data: problems and possibilities. Applied Geochemistry, 17: 185206.

Ronaszeki, J., 1997. Structural geological setting of the Mt. Whaleback mine, in BHP geology conference field guide, November 19-21, 1997, unpublished field guide, pp. $1-7$.

Rodriguez, N.M., Paul, C.K. and Borowski, W.S., 2000. Zonation of authigenic carbonates within gas-hydrate bearing sedimentary sections of the Blake Ridge: 
Offshore southeastern North America. Proceedings of ODP Scientific Results, 164: 301-312.

Smith, R.E., Perdrix, J.L. and Parks, T.C., 1982. Burial Metamorphism in the Hamersley Basin, Western Australia. Journal of Petrology, 23: 75-102.

Sugitani, K., Horiuchi, Y., Adachi, M. and Sugisaki, R., 1996. Anomalously low $\mathrm{Al}_{2} \mathrm{O}_{3} / \mathrm{TiO}_{2}$ values for Archean cherts from the Pilbara Block, Western Australia possible evidence for extensive chemical weathering on the early earth. Precambrian Research, 80: 49-76.

Taylor, D., Dalstra, H.J., Harding, A.E., Broadbent, G.C. and Barley, M.E., 2001. Genesis of high-grade hematite orebodies of the Hamersley Province, Western Australia. Economic Geology, 96: 837-873.

Taylor, D., Dalstra, H.J. and Harding, A.E., 2002. Genesis of high-grade hematite orebodies of the Hamersley Province, Western Australia - A reply. Economic Geology, 97:179-181.

Taylor, J.C., 1991. Computer programs for standardless quantitative analysis of minerals using the full powder diffraction profile. Powder Diffraction, 6: 2-9.

Taylor, K.G. and Curtis, C.D., 1995. Stability and facies association of early diagenetic mineral assemblages: An example from a Jurassic ironstone-mudstone succession. U.K. Journal of Sedimentary Petrology, 65: 358-368.

Thorne, A.M. and Seymour, D.B., 1991. Geology of the Ashburton Basin, Western Australia. Western Australia Geological Survey Bulletin 139, 141 pp.

Trendall, A.F., 1983. The Hamersley Basin, in Trendall, A.F. and Morris, R.C. (Eds.), Iron Formation, Facts and Problems. Elsevier, Amsterdam, pp. 69-129.

Trendall, A.F. and Blockley, J.G., 1968. Stratigraphy of the Dales Gorge Member of the Brockman Iron Formation, in the Precambrian Hamersley Group of Western Australia. Geological Survey of Western Australia Annual Report 1967, pp. 4862.

Trendall, A.F. and Blockley, J.G., 1970. The iron formations of the Precambrian Hamersley Group, Western Australia, with special reference to the associated 
Crocidolite. Geological Survey of Western Australia Bulletin 119, 1-365.

Trendall, A.F., Nelson, D.R., de Laeter, J.R. and Hassler, S., 1998. Precise zircon U-Pb ages from the Marra Mamba Iron Formation and Wittenoom Formation, Hamersley Group, Western Australia. Australian Journal of Earth Sciences, 45: 137-142.

Trendall, A.F. and Pepper, R.S., 1976. Chemical composition of the Brockman Iron Formation. Geological Survey of Western Australia Record 1976/25, pp. 1-25.

Tyler, I.M., 1994. Geology of the Newman 1:100 000 Sheet. Geological Survey of Western Australia, 1:100 000 Geological Explanatory Notes, pp. 1-36.

Tyler, I.M. and Thorne, A.M., 1990. The northern margin of the Capricorn Orogen, Western Australia - an example of an Early Proterozoic collision zone. Journal of Structural Geology, 12: 685-701.

Walker, C.G., 1984. Suboxic diagenesis in banded iron-formations. Nature, 309: 340342.

Walther, J.V. and Helgeson, G., 1977. Calculation of the thermodynamic properties of aqueous silica and the solubility of quartz and its polymorphs at high pressures and temperatures. American Journal of Science, 277: 1315-1351.

Webb, A.D., Dickens, G.R. and Oliver, N.H.S., 2003. From banded iron-formation to iron ore: geochemical and mineralogical constraints from across the Hamersley Province, Western Australia. Chemical Geology, 197: 215-251.

Wronkiewicz, D.J. and Condie, K.C., 1987. Geochemistry of Archean shales from the Witwatersrand Supergroup, South Africa, Source-area weathering and provenance. Geochimica et Cosmochimica Acta, 51: 2401-2416. 


\section{APPENDIX 1}

SAMPLE LOCATIONS ACROSS THE HAMERSLEY PROVINCE 

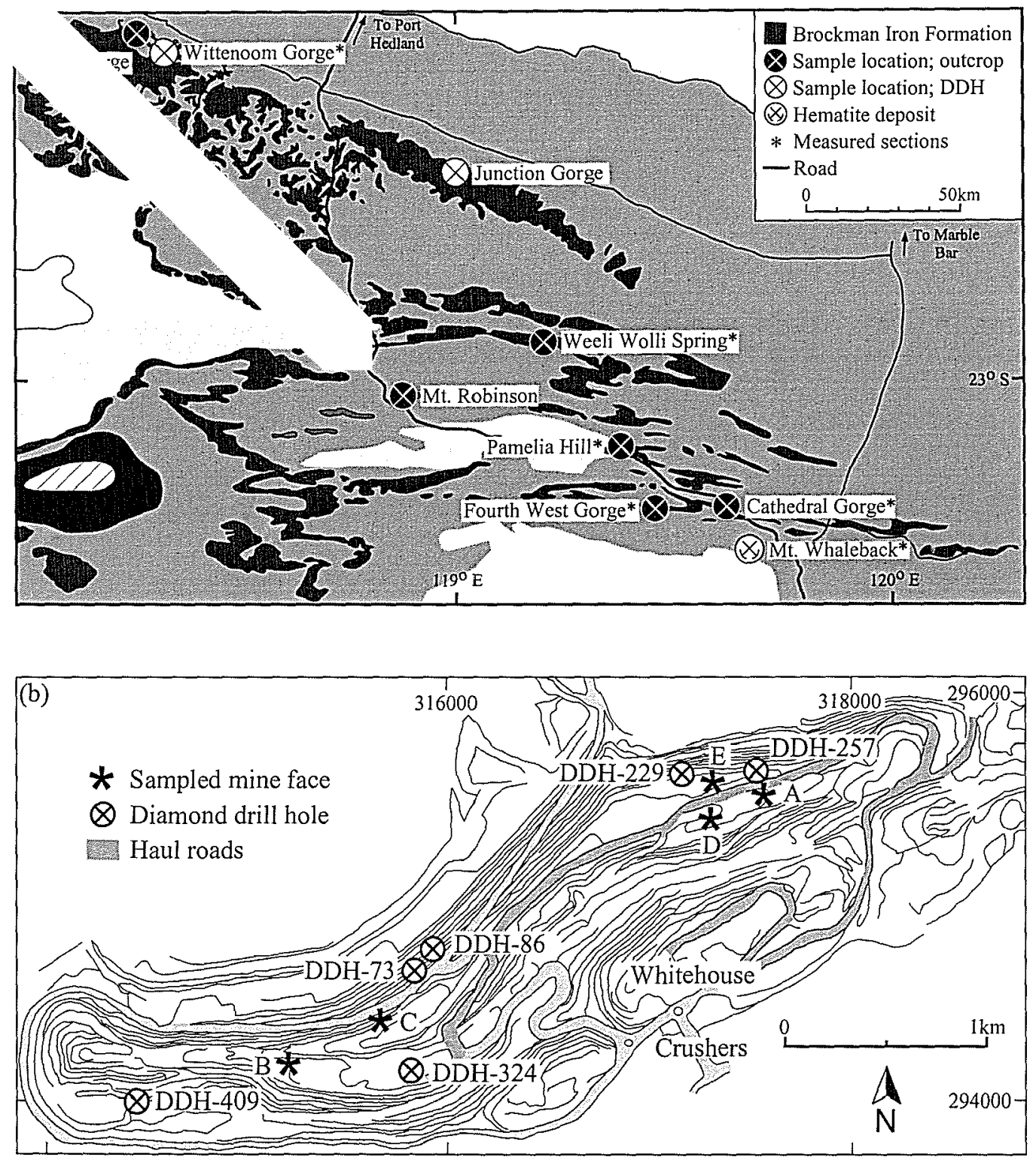

Appendix 1.1. Simplified geology of the southeastern Hamersley Province and mine plan of Mt. Whaleback. (a) Outcrop of Brockman Iron Formation across the southeastern Hamersley Province (modified from Trendall and Blockley, 1970), showing sample locations and position of the Mt. Whaleback iron ore deposit. (b) Locations of sampled diamond drill holes and mine faces within the Mt. Whaleback pit (circa 1997) (after Ronaszeki, 1997). Letters adjacent to face locations correspond to the following maps of mine faces. Phbd $=$ Dales Gorge Member; Phbj = Joffre Member; DDH $=$ diamond drill hole. 
Appendix 1.2. Sample locations across the Hamersley Province

\begin{tabular}{lcccclll}
\hline Site name & Easting (m) & Northing (m) & Map sheet* & 1 & 2 & Stratigraphy & Deformation \\
\hline Junction Gorge & 706010 & 7502490 & Roy Hill SF50-12 & & X & DS1 to DS3 & gentle \\
Bee Gorge & 629980 & 7535390 & Mt. Bruce SF50-11 & X & Phd to Phbw & gentle \\
Weeli Wolli Spring & 725720 & 7463780 & Roy Hill SF50-12 & X & Phr to Phbw & moderate \\
Mt. Robinson & 689660 & 7450760 & Newman SF50-16 & X & Upper Phr to DB16 & moderate \\
Pamelia Hill & 746920 & 7436150 & Newman SF50-16 & X & Upper Phr to DB16 & weak-moderate \\
Cathedral Gorge & 767990 & 7423890 & Newman SF50-16 & X & Phs to Phj & moderate-strong \\
Fourth West Gorge & 757960 & 7422890 & Newman SF50-16 & X & Phr to Phbw & moderate-strong \\
DDH-73 & see appendix 1.1b & Newman SF50-16 & & X & DS16 to lower Phbw & strong \\
DDH-86 & see appendix 1.1b & Newman SF50-16 & & X & DB15 to DS16 & strong \\
DDH-229 & see appendix 1.1b & Newman SF50-16 & & X & Lower Phbw & strong \\
DDH-257 & see appendix 1.1b & Newman SF50-16 & & X & DB16 to lower Phbw & strong \\
DDH-324 & see appendix 1.1b & Newman SF50-16 & & X & Upper Phr to DB0 & strong \\
DDH-409 & see appendix 1.1b & Newman SF50-16 & & X & Phr to lower DB0 & strong \\
Mine face A & 774404 & 7414281 & Newman SF50-16 & X & DB2 to DB10 & strong \\
Mine face B & 771972 & 7412964 & Newman SF50-16 & X & Phr to DB0 & strong \\
Mine face C & 772581 & 7413261 & Newman SF50-16 & X & DB16 to lower Phbw & strong \\
Mine face D & 774206 & 7414241 & Newman SF50-16 & X & DB9 to DB16 & strong \\
Mine face E & 774270 & 7414323 & Newman SF50-16 & X & Lower Phbw & strong \\
\hline
\end{tabular}

Notes: Eastings and northings relate to Zone 50 Australian Map Grid; ${ }^{*}=1: 250000$ scale; 1 = surface exposure; $2=$ diamond drill core; $\mathrm{Phj}=$ Weeli Wolli Formation; Phbw $=$ Whaleback Shale Member; Phbd $=$ Dales Gorge Member;DB $=$ Dales Gorge Member BIF macroband; DS = Dales Gorge Member shale macroband; Phr = Mt. McRae Shale; Phs = Mt. Slvia Member; Phd = Wittenoom Dolomite. 


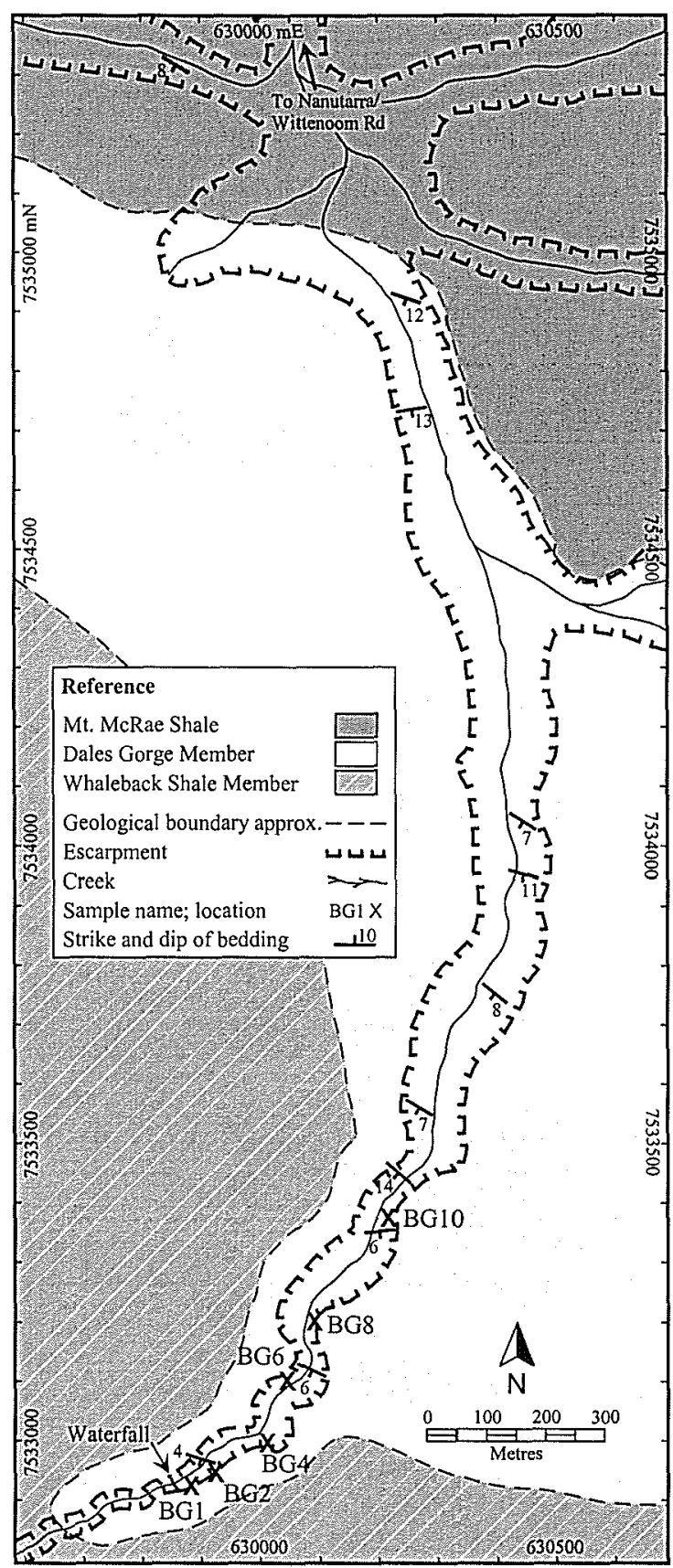

Appendix 1.3. Geological map of the upper reaches of Bee Gorge showing sample locations (crosses). 


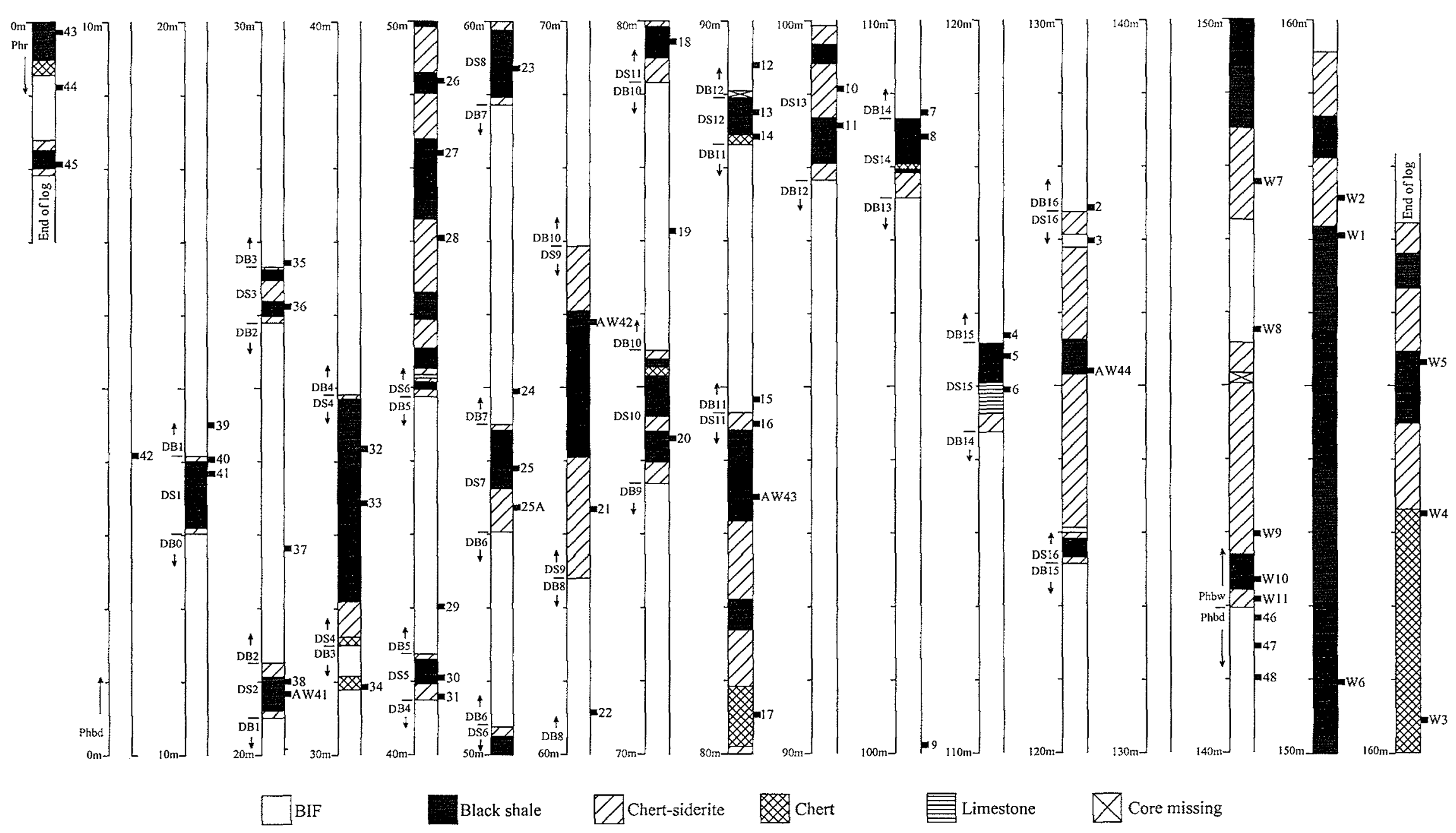

Appendix 1.4. Detailed log of diamond drill hole (DDH) 47A*, Wittenoom region. Note that shale macrobands (DS) are composed of black shale and chertsiderite bands. Black ticks on the right side of the columns indicate sample location and the corresponding sample names are prefixed by " $47^{\text {t" }}$ in Appendix 3. Left-hand scale (in metres) refers to distances above the base of the Dales Gorge Member (similar to Trendall and Blockley, 1968). Phbw $=$ Whaleback Shale Member; Phbd = Dales Gorge Member; DB = Dales Gorge Member BIF macrobands; DS = Dales Gorge Member shale macrobands; Phr = Mt. McRae Shale. 
DDH-JG1

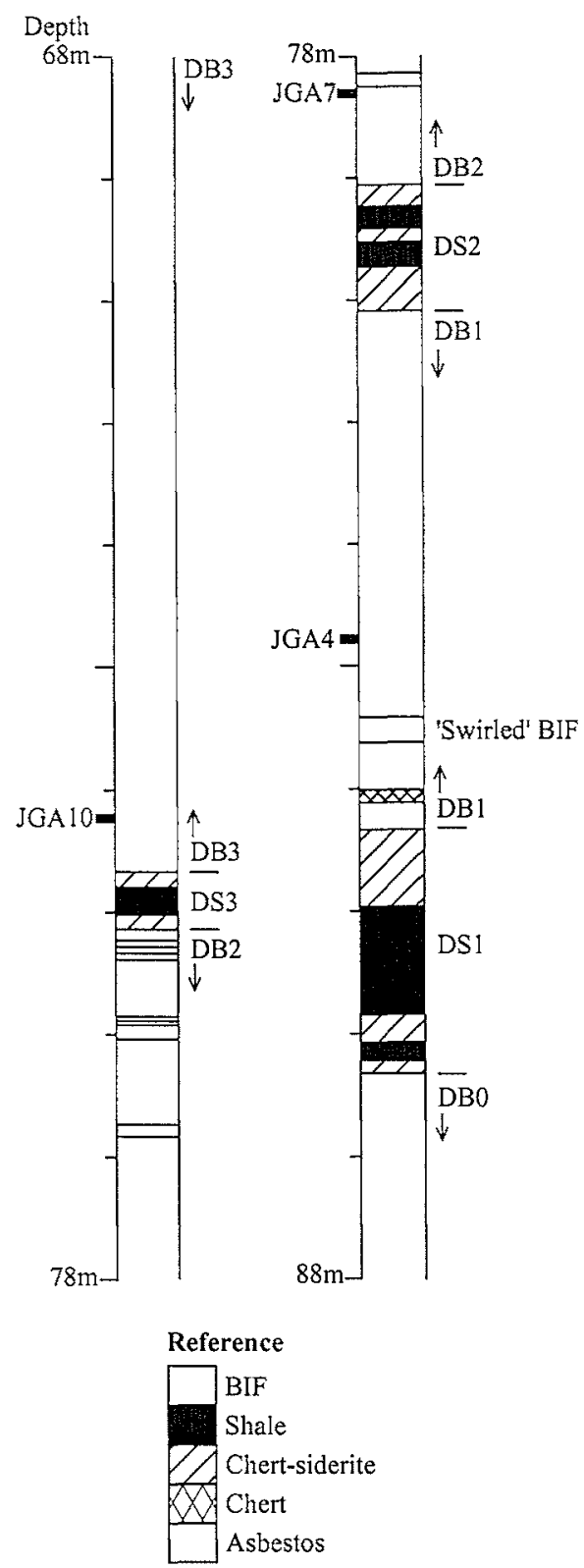

Appendix 1.5. Detailed log of DDH-JG1. Note that shale macrobands are composed of both black shale and chert-siderite bands. Sample names and locations are on the left side of the columns. Phbd = Dales Gorge Member; DB = Dales Gorge Member BIF macroband; DS = Dales Gorge Member shale macroband. 


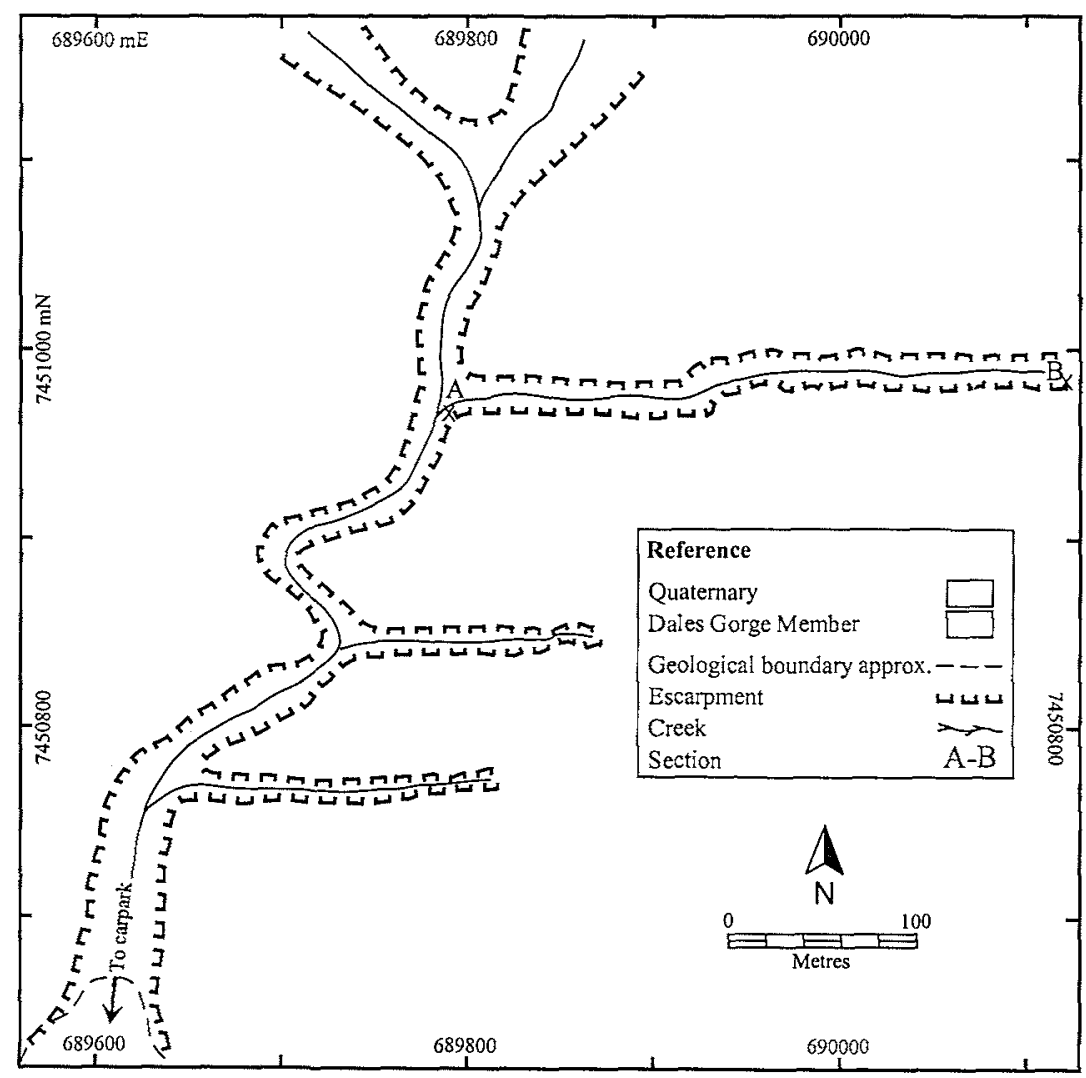

Appendix 1.6. Geological map of Mt. Robinson showing location of sampled section (see next figure). 

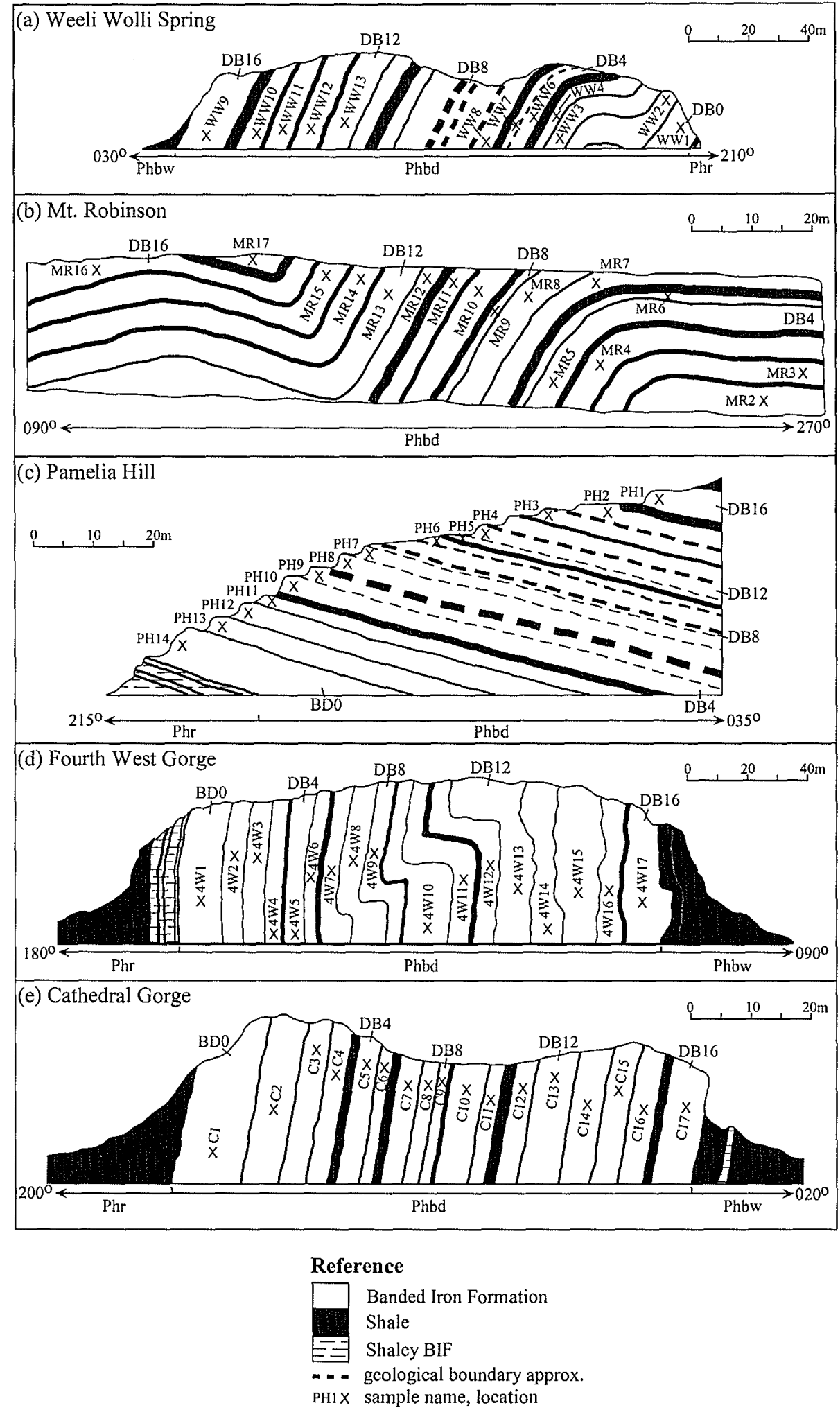

Appendix 1.7. Schematic $x$-sections of gorges from deformed regions across the southeastern Hamersley Province showing general geology and sample locations (crosses). (a) Weeli Wolli Spring; (b) Mt. Robinson; (c) Pamelia Hill; (d) Fourth West Gorge; (e) Cathedral Gorge. Phr = Mt. McRae Shale; Phbd = Dales Gorge Member; DB = Dales Gorge Member BIF macroband; Phbw = Whaleback Shale Member. 
(a) DDH-229

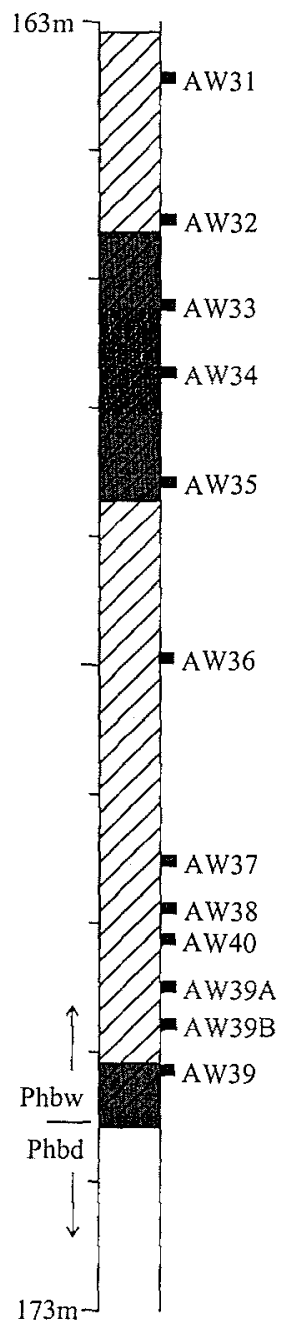

(b) DDH-257

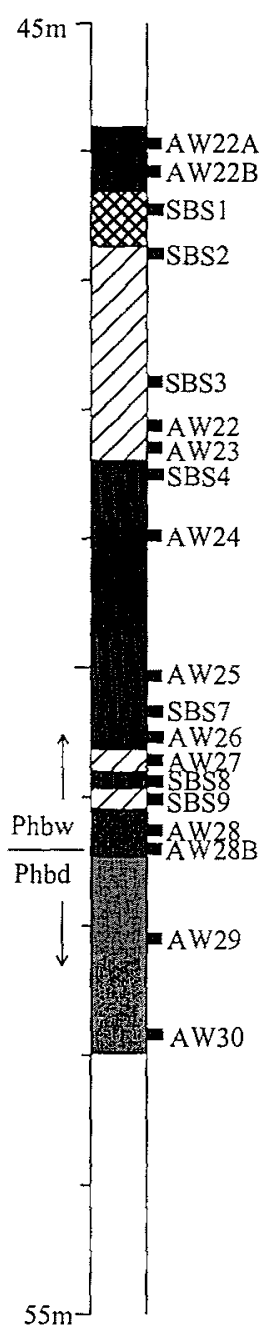

Altered black shale
Red shale
Shaley ore
Iron ore
Chert
Core missing (c) DDH-324

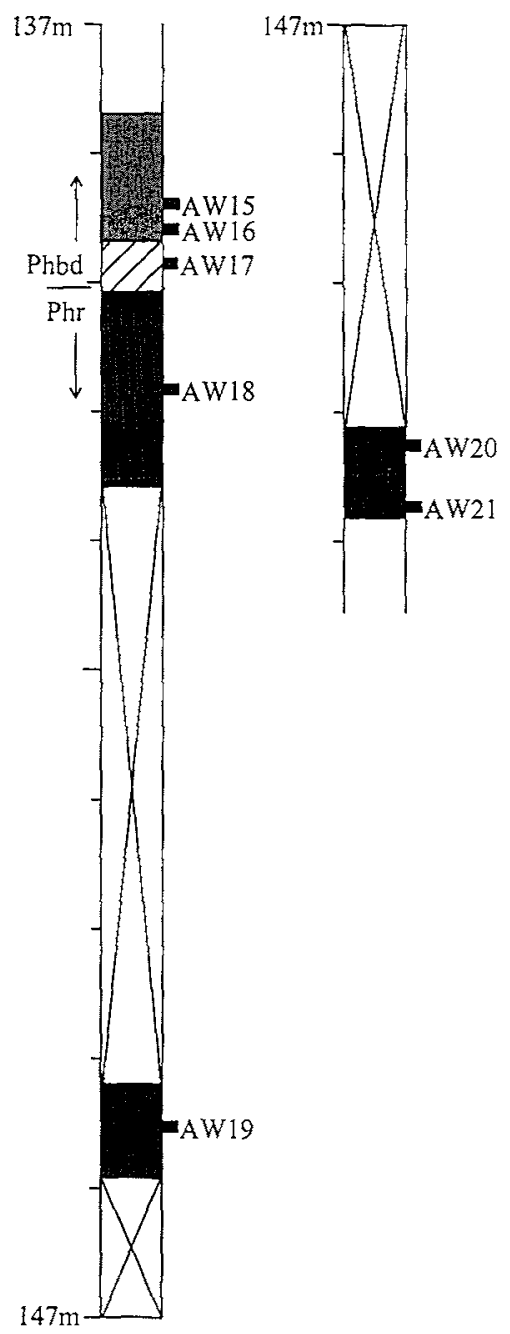

Appendix 1.8. Detailed logs of sampled Mt. Whaleback pit diamond drill holes (DDH). (a) DDH-229; (b) DDH-257; (c) DDH-324. Sample names and locations are on the right-side of the columns. Phbw = Whaleback Shale Member; Phbd = Dales Gorge Member; Phr = Mt. McRae Shale. 
(a) DDH-73

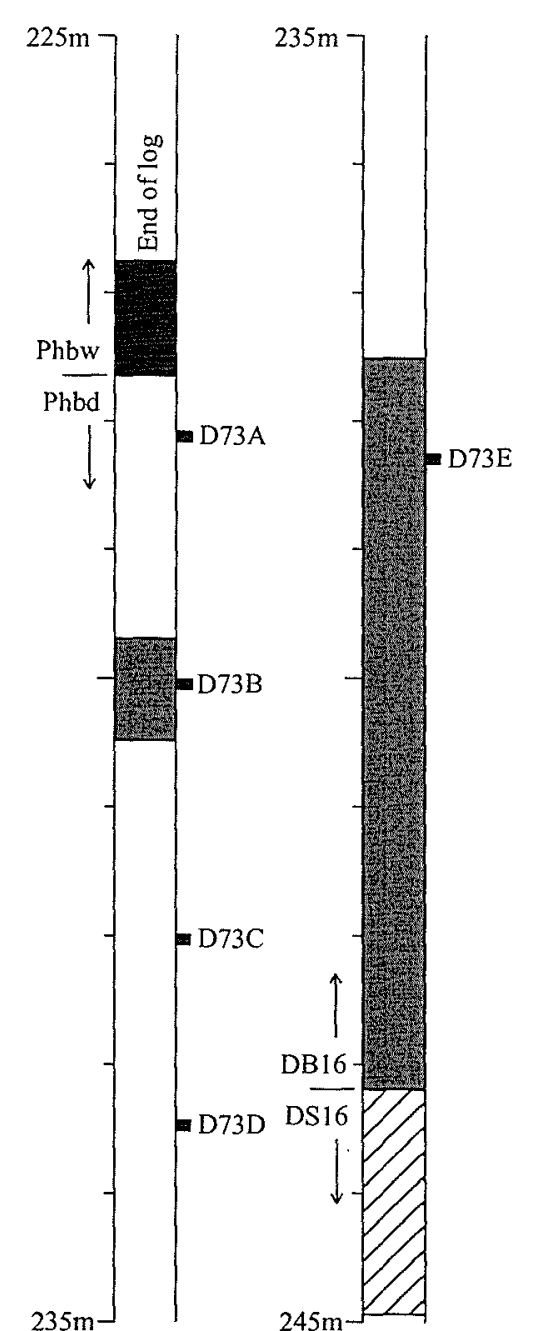

(b) $\mathrm{DDH}-86$

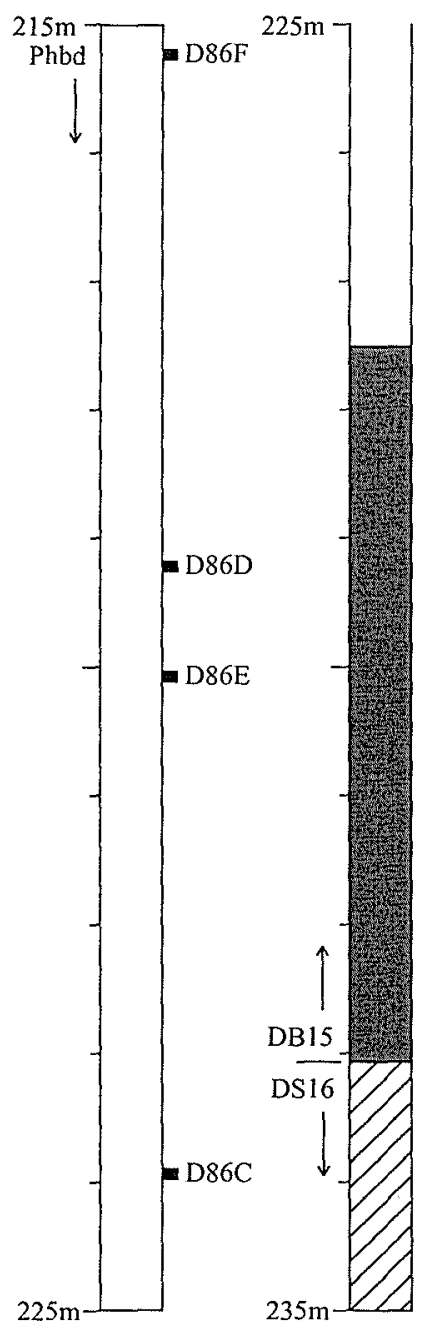

(c) $\mathrm{DDH}-409$

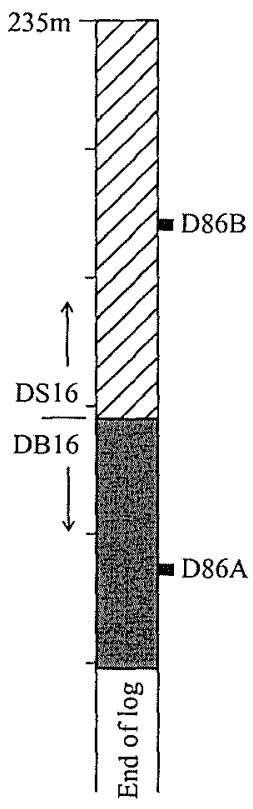

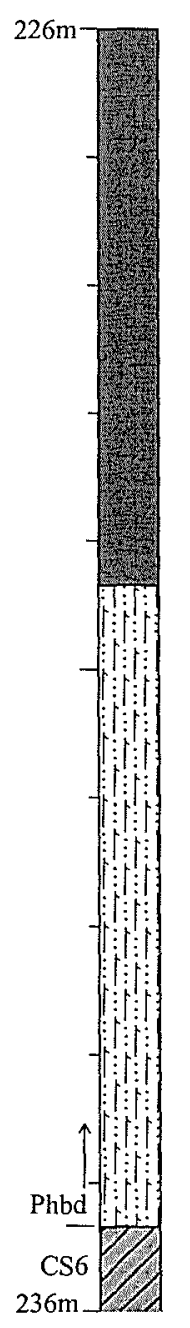

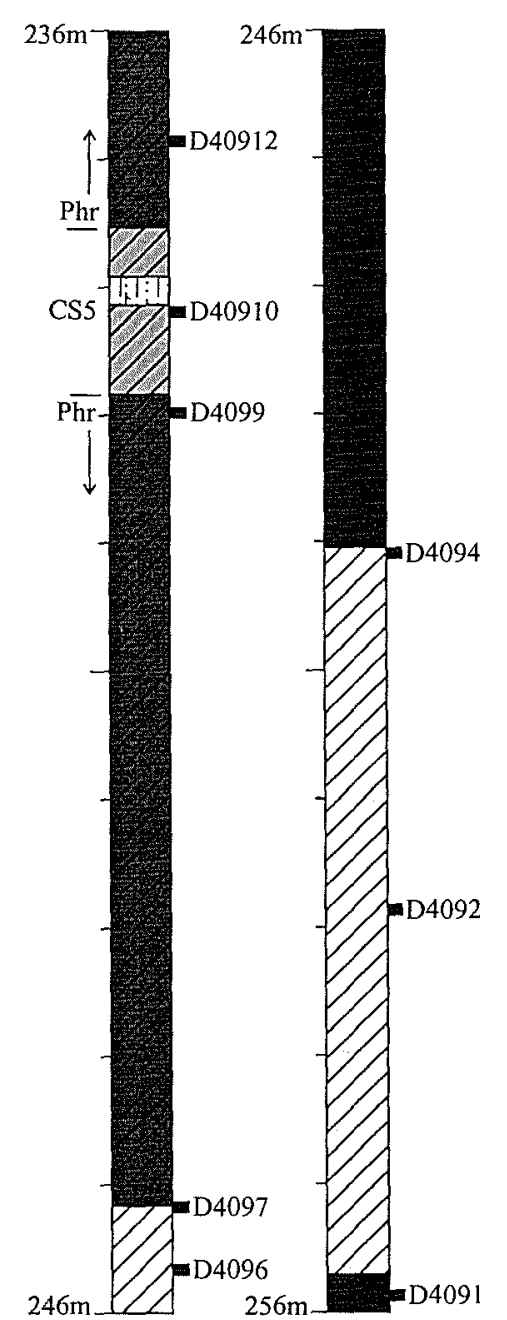

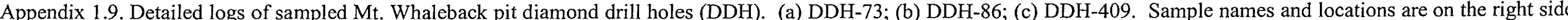

= Mt. McRae Shale. 
a)

b)
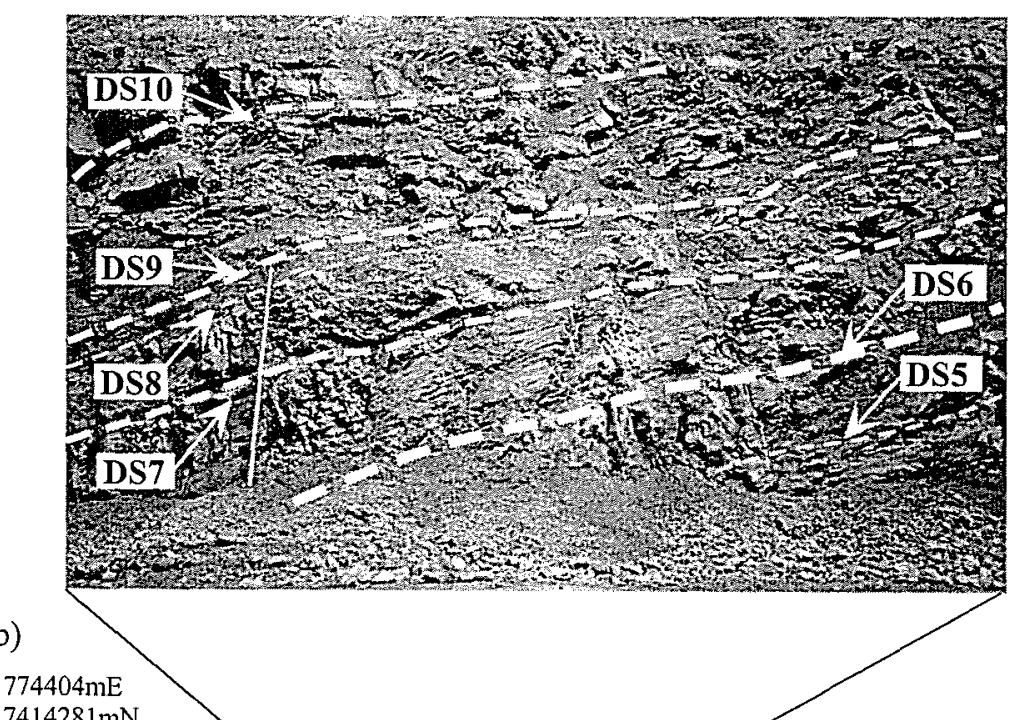

$7414281 \mathrm{mN}$

$15 \mathrm{~m}$
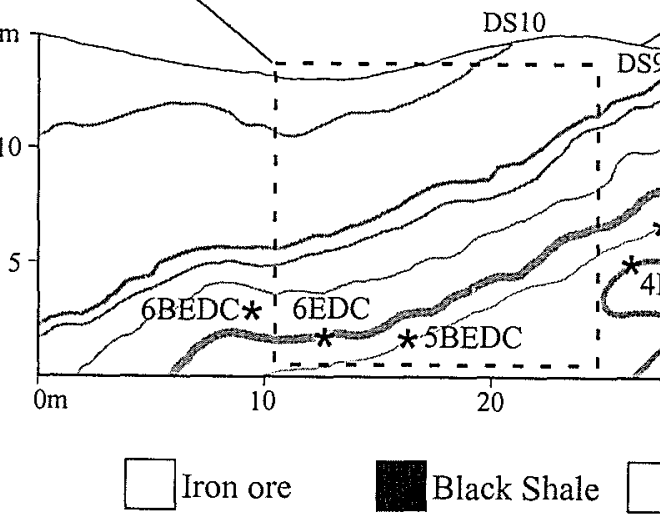

DS8 DS7 DS6 DS5
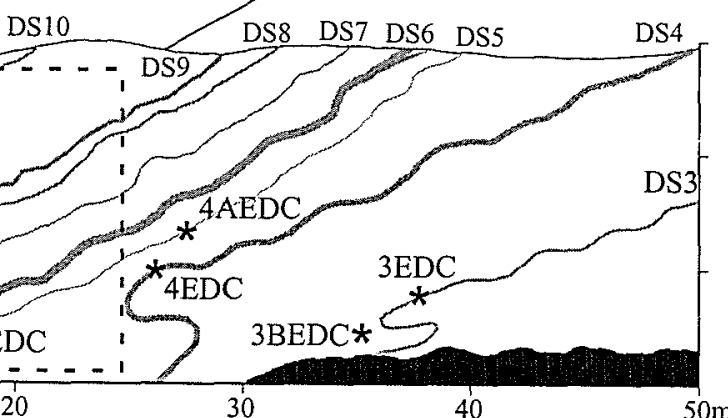

Black Shale

Red shale

Shaley ore

Appendix 1.10. Mine face A at Mt. Whaleback. (a) East facing photograph with shale units labelled according to the BHPBIO classification scheme. (b) Schematic diagram showing sample locations (stars), colour and lithology. 
a)

b)

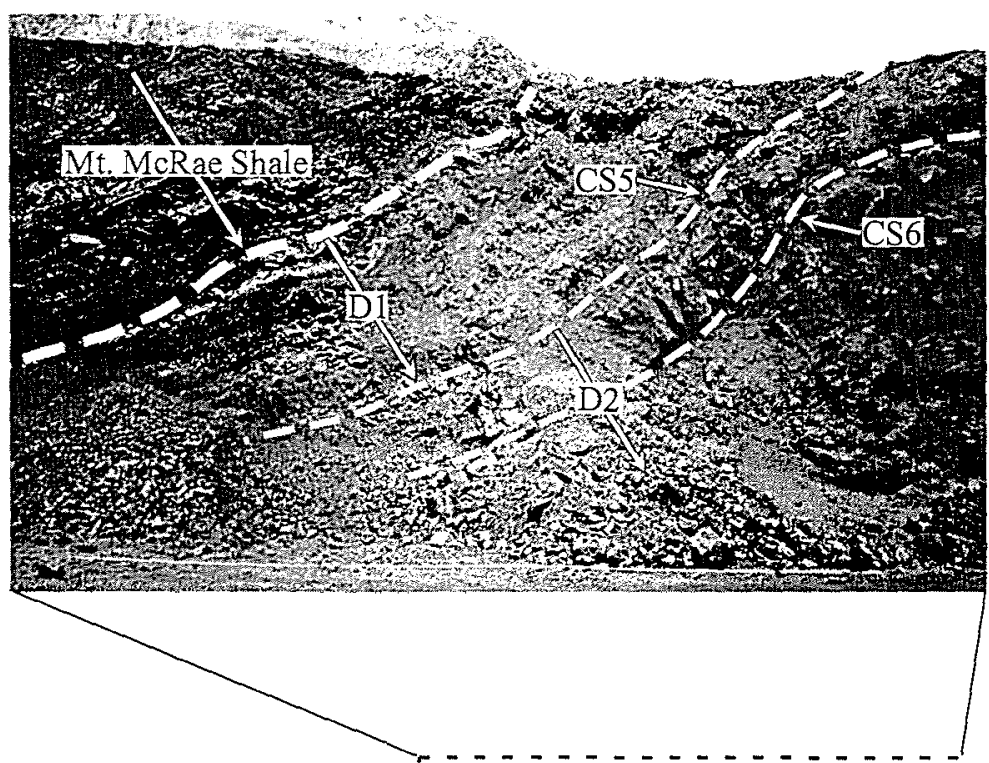

$771972 \mathrm{mE}$

$7412964 \mathrm{mN}$

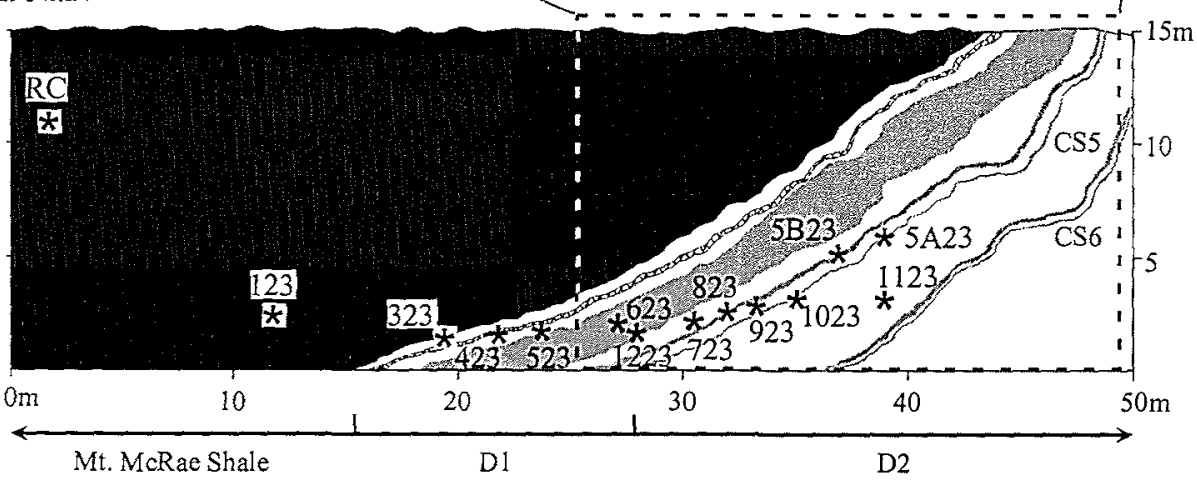

$\square$ Ore

Black Shale

Red shale

Cherty Shale

Appendix 2.11. Mine face B at Mt. Whaleback. (a) West facing photograph with rock units labelled according to the BHPBIO classification scheme (Fig. 2.2). (b) Schematic diagram showing sample locations (stars), colour and lithology. Note the colour transition from black, away from the orebody, to red, close to the orebody. 

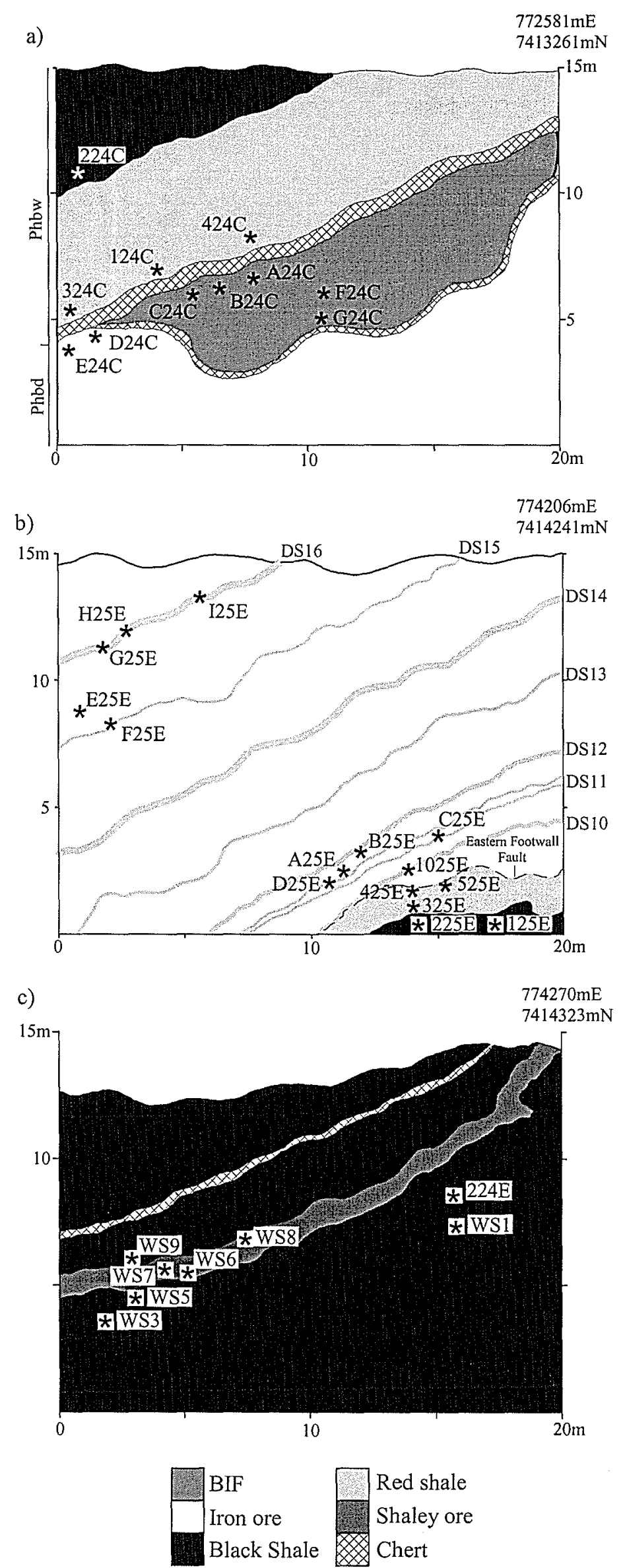

Appendix 1.12. Schematic diagrams of fresh mine faces at Mt. Whaleback showing sample locations (stars), colour and lithology. (a) Face C; (b) Face D; (c) Face E. Letters refer to locations shown in Appendix 1.2. 
APPENDIX 2

STRATIGRAPHIC THICKNESS MEASUREMENTS ACROSS THE

HAMERSLEY PROVINCE 
Appendix 2.1. Measured and reported stratigraphic thicknesses ( $\mathrm{m}$ ) of Dales Gorge Member macrobands across the Hamersley Province

\begin{tabular}{|c|c|c|c|c|c|c|c|c|c|c|c|c|c|c|c|c|c|c|c|c|}
\hline \multirow{2}{*}{$\frac{\text { Macro- }}{\text { bands }}$} & \multicolumn{2}{|c|}{ Northern Hamersley Province } & \multicolumn{18}{|c|}{ Southern Hamersely Province } \\
\hline & \multirow{2}{*}{$\begin{array}{c}\text { Type } \\
\text { section }\end{array}$} & \multirow{2}{*}{$\begin{array}{l}\text { Trendall \& } \\
\text { Blockley }^{(2)}\end{array}$} & \multirow{2}{*}{$\begin{array}{c}\text { Tumer } \\
\text { Syncline }^{(3)}\end{array}$} & \multicolumn{3}{|c|}{ Pamelia Hill $^{(t)}$} & \multicolumn{3}{|c|}{ Weeli Wolli Spring $^{(4)}$} & \multicolumn{3}{|c|}{ Cathedral Gorge ${ }^{(4)}$} & \multicolumn{3}{|c|}{ Fourth West Gorge ${ }^{(d)}$} & \multicolumn{3}{|c|}{ Mt. Whaleback ${ }^{(5)}$} & \multirow{2}{*}{$\begin{array}{c}\text { Tom } \\
\text { Price }\end{array}$} & \multirow[t]{2}{*}{ Paraburdoo $0^{(7)}$} \\
\hline \multicolumn{16}{|c|}{$\frac{1}{\text { Banded iron-formation macrobands }}$} & & & & & \\
\hline $\mathrm{DB} 16$ & 15.06 & 14.08 & 24.00 & 5 & 10.5 & $10.1-11.0$ & & & & 5 & 6.9 & $6.6-7.3$ & 5 & 8.9 & $8.7-9.3$ & 18 & 1.9 & $1.7-2.1$ & & 13.93 \\
\hline DB15 & 7.07 & 7.34 & 14.00 & 3 & 5.5 & $5.0-5.9$ & 3 & 8.0 & $7.6-8.1$ & 5 & 4.2 & $3.9-4.5$ & 6 & 5.4 & $5.1-6.6$ & 16 & 2.7 & $2.6-2.8$ & 27.0 & 6.66 \\
\hline DB14 & 5.79 & 6.55 & 10.00 & 3 & 4.5 & 4.3-4.6 & 4 & 8.3 & $8.1-8.4$ & 5 & 4.0 & $3.8-4.1$ & 6 & 5.3 & $5.0-6.5$ & 20 & 4.9 & $4.6-5.8$ & 36.0 & 5.40 \\
\hline DB13 & 7.88 & 7.68 & 18.00 & & & & 2 & 6.4 & $5.9-6.5$ & 4 & 5.0 & $4.6-5.1$ & 3 & 6.5 & $6.2-6.9$ & 20 & 5.1 & $4.8-5.4$ & 10.5 & 7.68 \\
\hline DB12 & 8.73 & 8.14 & 18.00 & 3 & 5.0 & $4.8-5.2$ & 4 & 9.8 & $9.4-9.9$ & 4 & 6.8 & $6.6-7.0$ & 3 & 7.3 & $7.1-7.8$ & 20 & 2.8 & $2.6-3.5$ & 6.3 & 8.50 \\
\hline DB11 & 3.78 & 4.45 & 6.00 & 4 & 2.3 & $2.0-2.7$ & 5 & 6.5 & $6.2-6.8$ & 5 & 3.0 & $2.8-3.2$ & 4 & 5.4 & $5.0-5.7$ & 15 & 1.3 & $0.9-1.6$ & 3.0 & 3.62 \\
\hline DB10 & 3.52 & 4.24 & 8.00 & 3 & 2.0 & $1.8-2.3$ & 2 & 6.3 & $5.8-6.3$ & 3 & 2.3 & $2.0-2.6$ & 3 & 4.0 & $3.7-4.2$ & 17 & 1.0 & $0.9-1.3$ & 3.0 & 3.37 \\
\hline $\begin{array}{l}\text { DB9 } \\
\text { D. }\end{array}$ & 7.27 & 5.70 & & & & & & & & 3 & 5.6 & $5.4-5.9$ & 3 & 5.9 & $5.6-6.3$ & 20 & 2.6 & $2.0-3.1$ & 7.1 & 6.64 \\
\hline DB8 & 2.29 & 3.81 & 12.00 & & & & & & & 4 & 2.2 & $2.0-2.4$ & 3 & 3.2 & $3.0-3.5$ & 18 & 0.5 & $0.4-0.8$ & 5.1 & 2.39 \\
\hline DB6 & 2.90 & 2.96 & 8.00 & 5 & 3.0 & $2.7-3.2$ & & & & 4 & 3.5 & $3.1-3.7$ & 4 & 3.1 & $2.9-3.3$ & 20 & 1.7 & $1.4-2.4$ & 10.2 & 3.28 \\
\hline DB5 & 3.52 & 4.05 & 6.00 & 4 & 2.9 & $2.8-3.4$ & 4 & 2.2 & $2.1-2.4$ & 5 & 2.1 & $2.0-2.4$ & 5 & 3.0 & $2.7-3.9$ & 20 & 1.5 & $1.1-2.2$ & 1.2 & 3.30 \\
\hline DB4 & 5.70 & 5.43 & 6.00 & 8 & 6.4 & $5.6-6.6$ & 3 & 3.8 & $3.5-4.1$ & 8 & 4.4 & $4.3-4.5$ & 6 & 5.5 & $5.2-6.2$ & 20 & 3.3 & $2.6-4.0$ & 1.7 & 5.28 \\
\hline DB3 & 4.39 & 4.94 & & 6 & 7.4 & $6.9-7.6$ & 5 & 5.5 & $5.3-5.8$ & 8 & 3.6 & $3.2-3.8$ & 8 & 5.8 & $5.6-6.0$ & 19 & 3.0 & $2.8-5.1$ & 4.0 & 5.79 \\
\hline DB2 & $\begin{array}{l}4.91 \\
\end{array}$ & 5.24 & & 8 & 6.5 & $5.9-6.8$ & 5 & 5.4 & $5.2-5.6$ & 8 & 4.3 & $4.1-4.5$ & 8 & 6.9 & $6.5-7.3$ & 19 & 3.4 & $2.9-4.3$ & 5.1 & 4.43 \\
\hline DB1 & 6.07 & 6.10 & & 8 & 7.0 & $6.6-7.3$ & 5 & 6.2 & $6.0-6.3$ & 8 & 5.1 & $4.7-5.2$ & 8 & 6.7 & $6.4-6.8$ & 18 & 3.6 & $3.0-4.3$ & 5.4 & 6.16 \\
\hline DBO & 13.29 & 13.59 & & 10 & 14.6 & $14.2-14.8$ & 6 & 15.6 & $15.6-15.9$ & 8 & 11.1 & $10.8-11.3$ & 8 & 14.6 & $14.2-14.8$ & 17 & 7.5 & $7.0-8.1$ & 14.6 & 13.12 \\
\hline$D B$ total & 106.45 & 108.81 & - & & - & - & & & - & & 76.9 & $72.5-80.5$ & & 101.2 & $96.4-109.9$ & & 48.51 & $42.8-59.4$ & - & 103.78 \\
\hline \multicolumn{21}{|c|}{ Shale macrobands } \\
\hline DSI6 & 4.40 & 4.94 & 6.00 & & & & & & & 8 & 0.82 & $0.81-0.84$ & 6 & 2.10 & $2.00-2.15$ & 20 & 0.3 & $0.2-0.4$ & 1.50 & 2.20 \\
\hline DS15 & 1.11 & 0.70 & 2.00 & & & & & & & 8 & 0.44 & $0.42-0.46$ & 8 & 0.30 & $0.28-0.32$ & 20 & & & 1.50 & 0.28 \\
\hline $\begin{array}{l}\text { DS14 } \\
\text { DS }\end{array}$ & 0.96 & 0.70 & 2.00 & & & & & & & 8 & 0.33 & $0.31-0.35$ & $\begin{array}{l}0 \\
6\end{array}$ & 0.35 & $0.31-0.41$ & 20 & 0.3 & $0.2-0.4$ & 1.50 & 0.28 \\
\hline DS11 & 5.20 & 3.17 & 10.00 & & & & & & & 5 & 1.80 & $1.70-1.90$ & 5 & 2.70 & $2.52-2.81$ & 18 & 0.9 & $0.9-1.1$ & 2.50 & 3.51 \\
\hline DS10 & 1. & 1.3 & & & & & & & & 5 & 0.69 & $0.67-0.73$ & 4 & 0.4 & $0.40-0.51$ & 20 & 0.3 & $0.1-\mathrm{C}$ & 0.08 & 1.09 \\
\hline DS9 & 4.13 & 2.53 & 4.00 & & & & & & & 4 & 0.50 & $0.47-0.52$ & 3 & 1.35 & $1.32-1.40$ & 20 & 0.5 & $0.4-0.6$ & 1.05 & 2.41 \\
\hline DS8 & 1.25 & 0.9 & 2.00 & & & & & & & 5 & 0.28 & $0.26-0.30$ & 4 & 0.5 & $0.51-0.60$ & 20 & 0.3 & $0.2-0.3$ & & 0.92 \\
\hline DS7 & 1.36 & 1.4 & 2.00 & & & & & & & 3 & 0.2 & $0.23-0.27$ & 3 & 0.5 & $0.48-0.59$ & 20 & 0.3 & $0.2-0.4$ & & 0.43 \\
\hline DS6 & 5.47 & 3.32 & 8.00 & & & & & & & 4 & 1.10 & $0.80-1.20$ & 3 & 1.75 & $1.70-1.80$ & 19 & 0.5 & $0.4-0.6$ & 2.45 & 4.28 \\
\hline DS5 & 0.62 & 0.73 & 2.00 & & & & & & & 3 & 0.4 & $0.43-0.48$ & 5 & 0.1 & $0.10-0.15$ & 19 & 0.1 & $0.1-0.2$ & 0.85 & 0.41 \\
\hline DS4 & 3.87 & 2.16 & & 8 & 0.75 & $0.61-0.79$ & 3 & 0.47 & $0.45-0.48$ & 9 & 1.1 & $0.95-1.20$ & 4 & 0.9 & $0.89-0.97$ & 20 & 0.4 & & 0.35 & 0.25 \\
\hline DS3 & 0.76 & 0.64 & & 5 & 0.20 & $0.16-0.22$ & & & & 8 & 0.28 & $0.25-0.30$ & 8 & 0.25 & $0.20-0.30$ & 20 & 0.3 & $0.1-0.3$ & 0.15 & 0.38 \\
\hline DS2 & 0.62 & 0.55 & & 3 & 0.33 & $0.21-0.38$ & & & & 6 & 0.25 & $0.21-0.30$ & 8 & 0.15 & $0.10-0.20$ & 17 & 0.1 & $0.09-0.2$ & 0.28 & 0.31 \\
\hline & 101 & 0.46 & & 5 & 0.15 & $0.10-0.18$ & 2 & 0.3 & $0.25-0.35$ & 8 & 0.23 & $0.20-0.28$ & 8 & 0.10 & $0.05-0.15$ & 17 & 0.1 & $0.06-0.1$ & 0.26 & 0.27 \\
\hline DS total & 35.61 & $\begin{array}{l}0.40 \\
25.68\end{array}$ & - & & & & & & & & 9.22 & $8.38-9.88$ & & 12.67 & $11.79-13.46$ & & 4.85 & $3.65-6.40$ & & 18.65 \\
\hline Total & 142.07 & 134.49 & & & - & & & - & & & 86.1 & $80.9-90.4$ & & 113.9 & $98.2-123.6$ & & 53.4 & $46.5-65.8$ & 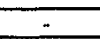 & 122.43 \\
\hline
\end{tabular}

Notes: $(1)=$ Unaltered macrobands (Trendall and Blockley, 1968), figure 11; (2) = Unaltered macrobands (Trendall and Blockley, 1970), table 9; (3) Unaltered macrobands (Taylor et al., 2001), appendix 1; (4) Altered DB- and DS-macrobands, chapter 5; (5) mineralized DB- and DS-macrobands, chapter 5; (6) mineralized macrobands (Taylor et al., 2001), appendix 2; (7) Unaltered macrobands (Ewers and Morris, 1981), table $1 ; \mathrm{n}=$ number of readings; blank = not measured or not reported; $\mathrm{DB}=$ Dales Gorge BIF macrobands; $\mathrm{DS}=$ Dales Gorge shale macrobands 
APPENDIX 3

MAJOR AND TRACE ELEMENT CHEMISTRY OF ROCKS ACROSS THE

HAMERSLEY PROVINCE 
Appendix 3.1. Description and major element composition of rocks across the Hamersley Province.

\begin{tabular}{|c|c|c|c|c|c|c|c|c|c|c|c|c|c|c|c|c|c|}
\hline Sample & Unit & Location & Depth $^{\mathrm{a}} / \mathrm{Face}^{\mathrm{b}}$ & Powder Colour & $\mathrm{SiO}_{2}$ & $\mathrm{TiO}_{2}$ & $\mathrm{Al}_{2} \mathrm{O}_{3}$ & $\mathrm{Fe}_{2} \mathrm{O}_{3} \mathrm{~T}$ & $\mathrm{MnO}$ & $\mathrm{MgO}$ & $\mathrm{CaO}$ & $\mathrm{Na}_{2} \mathrm{O}$ & $\mathbf{K}_{2} \mathbf{O}$ & $\mathrm{P}_{2} \mathrm{O}_{5}$ & $S$ & LOI & SUM \\
\hline \multicolumn{18}{|c|}{ Northern Hamersley Province } \\
\hline \multicolumn{18}{|c|}{ Banded Iron Formation (BIF) } \\
\hline 473 & DB16 & $\mathrm{DDH}-47 \mathrm{~A}^{*}$ & 127.0 & $5 Y 7 / 1$ (light grey) & 22.3 & 0.03 & 0.85 & 42.2 & 0.42 & 3.70 & 8.17 & - & 1.02 & 0.30 & 0.18 & 21.2 & 100.3 \\
\hline 472 & DB16 & $\mathrm{DDH}-47 \mathrm{~A}^{*}$ & 127.4 & 5 Y $5 / 1$ (grey) & 26.8 & 0.02 & 0.39 & 55.8 & 0.13 & 3.18 & 1.57 & - & 1.03 & 0.25 & 0.56 & 9.50 & 99.3 \\
\hline 4748 & DB16 & DDH-47A* & 141.1 & $5 Y 7 / 1$ (light grey) & 38.8 & 0.01 & 0.31 & 41.6 & 0.24 & 3.44 & 1.62 & - & 0.65 & 0.49 & 0.03 & 13.3 & 100.5 \\
\hline 4747 & DB16 & DDH-47A* & 141.5 & 5Y 6.5/1 (light grey) & 43.8 & 0.01 & 0.36 & 40.6 & 0.23 & 3.18 & 3.32 & - & 0.48 & 0.08 & 0.02 & 8.30 & 100.4 \\
\hline 4746 & DB16 & DDH-47A* & 141.9 & 7.5YR 5.5/1 (grey) & 32.4 & 0.01 & 0.43 & 53.0 & 0.37 & 3.55 & 2.53 & 0.51 & 0.70 & 0.05 & 0.01 & 6.77 & 100.4 \\
\hline 474 & DB15 & $\mathrm{DDH}-47 \mathrm{~A}^{*}$ & 115.7 & 7.5YR 6/l (grey) & 46.4 & 0.01 & - & 41.7 & 0.07 & 1.95 & 1.92 & - & 0.09 & 0.18 & 0.02 & 8.30 & 100.6 \\
\hline 477 & $\mathrm{DB} 14$ & $\mathrm{DDH}-47 \mathrm{~A}^{*}$ & 108.7 & 7.5 YR 5/1 (grey) & 37.5 & 0.01 & - & 55.7 & - & 1.18 & 0.53 & - & 0.06 & 0.02 & 0.03 & 5.42 & 100.4 \\
\hline 479 & $\mathrm{DB} 13$ & $\mathrm{DDH}-47 \mathrm{~A}^{*}$ & 100.2 & 7.5R 5/1 (grey) & 34.4 & 0.01 & 0.10 & 58.0 & 0.08 & 2.12 & 1.82 & - & 0.13 & 0.28 & 0.02 & 3.39 & 100.4 \\
\hline 4712 & $\mathrm{DB} 12$ & DDH-47A* & 89.5 & $7.5 \mathrm{R} 5.5 / 6$ (grey) & 66.7 & 0.01 & 0.17 & 29.2 & - & 1.19 & 1.10 & - & 0.04 & 0.40 & 0.00 & 0.37 & 99.2 \\
\hline 4715 & $\mathrm{DB} 11$ & DDH-47A* & 84.8 & 7.5YR 5.5/1 (grey) & 48.9 & 0.01 & - & 38.9 & 0.12 & 3.39 & 0.60 & - & 0.04 & 0.05 & - & 8.56 & 100.6 \\
\hline 4719 & DB10 & $\mathrm{DDH}-47 \mathrm{~A}^{*}$ & 77.3 & 7.5R 4.5/1 (dark grey) & 38.6 & 0.01 & 0.10 & 58.6 & - & 2.55 & 0.56 & - & 0.10 & 0.15 & 0.01 & -0.56 & 100.1 \\
\hline 4722 & DB8 & DDH-47A* & 60.6 & 7.5YR 5/1 (grey) & 37.5 & 0.01 & 0.24 & 48.7 & 0.09 & 3.52 & 2.36 & - & 0.15 & 0.62 & 0.02 & 7.05 & 100.2 \\
\hline 4724 & DB7 & DDH-47A* & 55.1 & 7.5R 5.5/1 (grey) & 54.0 & 0.01 & - & 40.2 & - & 1.16 & 1.65 & - & 0.03 & 0.09 & 0.01 & 3.11 & 100.2 \\
\hline 4729 & DB5 & $\mathrm{DDH}-47 \mathrm{~A}^{*}$ & 42.3 & 7.5YR 4.5/1 (dark grey) & 38.8 & 0.01 & - & 59.5 & - & 2.61 & 0.38 & - & 0.06 & 0.12 & 0.01 & -1.03 & 100.5 \\
\hline 4735 & DB3 & DDH-47A* & 26.8 & 7.5YR 5.5/1 (grey) & 36.3 & 0.01 & 0.06 & 48.4 & 0.15 & 2.77 & 2.22 & - & 0.09 & 0.23 & 0.01 & 10.1 & 100.3 \\
\hline 4737 & $\mathrm{DB} 2$ & $\mathrm{DDH}-47 \mathrm{~A}^{*}$ & 22.8 & $7.5 \mathrm{R} 3.5 / 1$ (very dark grey) & 36.9 & 0.01 & 1.46 & 56.1 & - & 2.85 & 0.20 & 0.18 & 0.87 & 0.12 & 0.01 & 1.12 & 100.2 \\
\hline 4739 & $\mathrm{DB} 1$ & $\mathrm{DDH}-47 \mathrm{~A}^{*}$ & 14.5 & 7.5YR 5.5/1 (grey) & 31.7 & 0.01 & 0.06 & 53.2 & - & 3.46 & 2.79 & - & 0.09 & 0.07 & 0.01 & 9.18 & 100.5 \\
\hline 4740 & DB1 & DDH-47A* & 14.1 & 5 Y 7/2 (light grey) & 32.8 & 0.01 & 0.24 & 45.6 & 0.08 & 2.02 & 1.11 & - & 0.17 & 0.39 & 0.33 & 17.2 & 99.9 \\
\hline 4742 & DBO & $\mathrm{DDH}-47 \mathrm{~A}^{*}$ & 4.1 & 7.5R 4/1.5 (dark grey) & 40.6 & 0.01 & - & 54.2 & - & 2.21 & 1.83 & - & 0.07 & 0.27 & 0.01 & 1.43 & 100.6 \\
\hline JGA 10 & DB3 & DDH-JG1 & 6.2 & & 28.9 & 0.01 & 1.53 & 54.3 & 0.06 & 3.64 & 3.65 & - & 1.02 & 0.32 & 0.15 & 6.25 & 100.5 \\
\hline JGA7 & DB2 & DDH-JG1 & 10.3 & & 36.7 & 0.01 & 0.36 & 52.1 & 0.07 & 1.87 & 3.99 & - & 0.21 & 0.23 & 0.35 & 4.71 & 100.6 \\
\hline JGA4 & DB1 & $\mathrm{DDH}-\mathrm{JG} 1$ & 14.8 & & 47.2 & 0.01 & 0.26 & 42.4 & - & 2.33 & 1.93 & - & 0.11 & 0.08 & 0.01 & 6.26 & 100.6 \\
\hline BGl & DB16 & Bee Gorge & centre & & 56.4 & - & 0.10 & 41.2 & - & - & 0.18 & - & 0.06 & 0.02 & - & 2.02 & 100.0 \\
\hline BG2 & DB14 & Bee Gorge & centre & & 58.6 & 0.01 & 0.09 & 38.6 & - & 1.25 & 0.74 & - & 0.05 & 0.03 & - & 0.82 & 100.1 \\
\hline BG4 & DB13 & Bee Gorge & centre & & 45.2 & - & 0.14 & 49.1 & - & 1.50 & 1.60 & - & 0.08 & 0.09 & 0.02 & 1.87 & 99.6 \\
\hline BG6 & DB12 & Bee Gorge & centre & & 52.2 & 0.01 & 0.09 & 46.0 & - & 0.19 & 0.74 & - & 0.06 & 0.10 & - & 0.86 & 100.2 \\
\hline BG8 & DB11 & Bee Gorge & centre & & 65.4 & - & 0.15 & 31.8 & - & 0.46 & 0.27 & - & 0.05 & 0.10 & - & 1.11 & 99.3 \\
\hline BG10 & DB10 & Bee Gorge & centre & & 34.3 & 0.01 & 0.20 & 63.3 & - & 0.89 & 0.28 & - & 0.07 & 0.11 & - & 1.64 & 100.9 \\
\hline \multicolumn{18}{|c|}{ Black Shale } \\
\hline $47 \mathrm{WI}_{1}$ & Phbw & $\mathrm{DDH}-47 \mathrm{~A}^{*}$ & 142.1 & $5 Y 5 / 2$ (olive grey) & 21.4 & 0.10 & 2.58 & 43.1 & 0.65 & 5.58 & 3.52 & - & 1.70 & 0.24 & 0.02 & 21.3 & 100.2 \\
\hline $47 \mathrm{W10}$ & Phbw & DDH-47A* & 142.4 & $5 Y 5 / 2$ (olive grey) & 30.0 & 0.15 & 4.49 & 34.0 & 0.41 & 7.50 & 3.46 & - & 3.20 & 0.22 & 0.05 & 17.2 & 100.6 \\
\hline
\end{tabular}


Appendix 3.1. (continued)

\begin{tabular}{|c|c|c|c|c|c|c|c|c|c|c|c|c|c|c|c|c|c|}
\hline Sample & Unit & Location & Depth $^{\mathrm{a}} / \mathrm{Face}^{\mathrm{b}}$ & Powder Colour & $\mathrm{SiO}_{2}$ & $\mathrm{TiO}_{2}$ & $\mathrm{Al}_{2} \mathrm{O}_{3}$ & $\mathrm{Fe}_{2} \mathrm{O}_{3} \mathrm{~T}$ & $\mathrm{MnO}$ & MgO & $\mathrm{CaO}$ & $\mathrm{Na}_{2} \mathrm{O}$ & $\mathrm{K}_{2} \mathrm{O}$ & $\mathrm{P}_{2} \mathrm{O}_{5}$ & $\mathbf{S}$ & LOI & SUM \\
\hline $47 \mathrm{~W} 1$ & Phbw & DDH-47A* & 157.1 & 2.5 YR $6 / 0$ (grey) & 27.7 & 0.25 & 6.41 & 13.6 & 0.42 & 10.1 & 13.4 & - & 2.98 & 0.07 & 0.41 & 24.4 & 99.7 \\
\hline $47 \mathrm{~W} 6$ & Phbw & DDH-47A* & 151.0 & 2.5 YR 5/0 (grey) & 39.4 & 0.31 & 8.72 & 14.2 & 0.27 & 6.23 & 7.95 & - & 5.94 & 0.10 & 1.74 & 14.3 & 99.0 \\
\hline $47 \mathrm{~W} 5$ & Phbw & DDH-47A* & 165.3 & $5 Y 5 / 1$ (grey) & 33.1 & 0.26 & 7.12 & 31.9 & 0.46 & 9.98 & 1.39 & 0.22 & 1.42 & 0.25 & 0.49 & 13.7 & 100.3 \\
\hline AW44 & DS16 & DDH-47A* & 125.3 & $5 Y 4 / 2$ (olive grey) & 31.1 & 0.10 & 3.20 & 24.5 & 0.48 & 3.87 & 13.8 & - & 2.52 & 0.21 & 1.03 & 18.1 & 98.8 \\
\hline 475 & DS15 & $\mathrm{DDH}-47 \mathrm{~A}^{*}$ & 115.5 & $5 Y$ 6/1 (light grey) & 41.7 & 0.01 & 7.52 & 21.8 & 0.22 & 6.06 & 4.99 & - & 7.14 & 0.06 & 1.09 & 8.26 & 99.1 \\
\hline 478 & DS14 & DDH-47A* & 108.7 & $5 Y 5 / 1$ (grey) & 46.7 & 0.01 & 9.18 & 23.2 & 0.14 & 6.81 & 1.17 & 0.07 & 7.00 & 0.05 & 0.61 & 5.16 & 100.5 \\
\hline 4711 & DS13 & $\mathrm{DDH}-47 \mathrm{~A}^{*}$ & 98.7 & $5 Y 6 / 1$ (light grey) & 44.2 & 0.01 & 7.71 & 26.2 & 0.18 & 6.83 & 1.85 & 0.18 & 5.63 & 0.09 & 0.59 & 6.25 & 100.0 \\
\hline 4713 & DS12 & $\mathrm{DDH}-47 \mathrm{~A}^{*}$ & 88.7 & $5 Y 5 / 1.5$ (olive grey) & 45.0 & 0.01 & 5.42 & 26.9 & 0.13 & 9.36 & 1.10 & 0.43 & 3.16 & 0.25 & 0.46 & 7.62 & 100.1 \\
\hline $\mathrm{AW} 43$ & DS 11 & $\mathrm{DDH}-47 \mathrm{~A}^{*}$ & 83.2 & 7.5R 3.5/0 (dark grey) & 47.6 & 0.46 & 13.3 & 14.9 & 0.09 & 5.93 & 2.01 & - & 7.48 & 0.10 & 0.58 & 7.01 & 99.5 \\
\hline 4718 & DS11 & DDH-47A* & 79.8 & 5Y 4.5/1 (dark grey) & 42.5 & 0.01 & 5.75 & 29.6 & 0.13 & 9.33 & 0.68 & 0.50 & 1.98 & 0.09 & 0.18 & 8.56 & 99.6 \\
\hline 4720 & DS10 & $\mathrm{DDH}-47 \mathrm{~A}^{*}$ & 74.4 & $5 Y 5 / 2$ (olive grey) & 28.5 & 0.01 & 4.02 & 37.8 & 0.44 & 8.69 & 1.11 & 0.40 & 1.21 & 0.15 & 0.05 & 18.1 & 100.6 \\
\hline AW42 & DS9 & $\mathrm{DDH}-47 \mathrm{~A}^{*}$ & 65.5 & 7.5R 3.5/0 (dark grey) & 57.3 & 0.44 & 13.6 & 11.6 & - & 3.61 & 0.12 & - & 7.86 & 0.09 & 0.10 & 5.26 & 100.0 \\
\hline 4723 & DS8 & $\mathrm{DDH}-47 \mathrm{~A}^{*}$ & 59.4 & $5 Y 5.5 / 1$ (grey) & 41.4 & 0.01 & 11.0 & 23.4 & - & 12.5 & 0.60 & 0.40 & 2.32 & 0.07 & 0.33 & 8.08 & 100.5 \\
\hline 4725 & DS7 & DDH-47A* & 53.9 & $5 Y 5.5 / 1$ (grey) & 40.2 & 0.01 & 8.93 & 29.0 & 0.07 & 9.24 & 1.05 & 0.57 & 2.13 & 0.05 & 0.46 & 7.83 & 100.2 \\
\hline 4726 & DS6 & $\mathrm{DDH}-47 \mathrm{~A}^{*}$ & 49.2 & $5 Y 5 / 2.5$ (olive) & 25.2 & 0.01 & 2.37 & 32.0 & 0.27 & 4.95 & 12.7 & 0.37 & 1.08 & 0.18 & 0.24 & 21.0 & 100.3 \\
\hline 4727 & DS6 & $\mathrm{DDH}-47 \mathrm{~A}^{*}$ & 48.2 & 7.5 YR 4.5/1 (dark grey) & 35.4 & 0.01 & 8.56 & 28.1 & 0.26 & 7.58 & 3.54 & 0.33 & 3.09 & 0.12 & 0.79 & 11.7 & 99.7 \\
\hline 4730 & DS5 & $\mathrm{DDH}-47 \mathrm{~A}^{*}$ & 41.0 & $5 Y 5 / 1.5$ (olive grey) & 40.1 & 0.01 & 5.91 & 31.7 & 0.15 & 7.05 & 2.28 & 0.54 & 3.40 & 0.05 & 0.35 & 8.20 & 99.9 \\
\hline 4732 & DS4 & $\mathrm{DDH}-47 \mathrm{~A}^{*}$ & 34.2 & $5 Y 5 / 1.5$ (olive grey) & 41.1 & 0.01 & 7.75 & 24.4 & 0.29 & 3.30 & 5.56 & 0.34 & 5.69 & 0.04 & 0.33 & 10.6 & 100.1 \\
\hline 4733 & DS4 & $\mathrm{DDH}-47 \mathrm{~A}^{*}$ & 33.4 & 5 Y $5 / 3$ (olive) & 51.1 & 0.01 & 2.68 & 27.9 & 0.40 & 3.34 & 2.39 & 0.22 & 1.35 & 0.58 & 0.02 & 10.3 & 100.2 \\
\hline 4736 & DS3 & DDH-47A* & 26.1 & $5 Y$ 5/1.5 (olive grey) & 39.4 & 0.01 & 5.31 & 33.8 & 0.22 & 5.33 & 2.70 & 0.18 & 3.35 & 0.26 & 0.58 & 8.20 & 99.7 \\
\hline AW41 & DS2 & $\mathrm{DDH}-47 \mathrm{~A}^{*}$ & 20.7 & $5 Y 7 / 1$ (light grey) & 36.5 & 0.97 & 6.64 & 20.5 & 0.23 & 6.43 & 8.28 & 0.29 & 5.17 & 0.06 & 0.17 & 14.7 & 99.9 \\
\hline 4738 & DS2 & $\mathrm{DDH}-47 \mathrm{~A}^{*}$ & 21.0 & 5Y 5.5/1 (grey) & 44.0 & 0.01 & 9.88 & 17.5 & 0.13 & 4.82 & 5.46 & 0.04 & 7.82 & 0.06 & 0.74 & 9.04 & 100.0 \\
\hline 4741 & DS1 & $\mathrm{DDH}-47 \mathrm{~A}^{*}$ & 13.8 & 5Y 6/1 (light grey) & 41.9 & 0.01 & 9.58 & 19.3 & 0.13 & 4.67 & 5.89 & 0.07 & 7.52 & 0.08 & 1.91 & 7.74 & 99.2 \\
\hline 4743 & $\mathrm{Phr}$ & $\mathrm{DDH}-47 \mathrm{~A}^{*}$ & -0.3 & $5 Y 5 / 1.5$ (olive grey) & 44.0 & 0.01 & 6.03 & 30.5 & 0.08 & 8.02 & 0.26 & 0.49 & 2.98 & 0.06 & 0.12 & 7.07 & 100.6 \\
\hline 4745 & $\mathrm{Phr}$ & DDH-47A* & -1.9 & $5 Y 5 / 1$ (grey) & 40.2 & 0.01 & 5.40 & 31.3 & 0.11 & 7.96 & 2.10 & 0.43 & 2.21 & 0.04 & 1.00 & 8.25 & 99.4 \\
\hline \multicolumn{18}{|c|}{ Chert-siderite } \\
\hline $47 \mathrm{~W} 9$ & Phbw & $\mathrm{DDH}-47 \mathrm{~A}^{*}$ & 143.0 & $5 Y$ 6/2 (light olive grey) & 61.2 & 0.03 & 0.92 & 19.8 & 0.22 & 2.72 & 2.67 & - & 0.52 & 0.11 & 0.04 & 11.2 & 99.4 \\
\hline $47 \mathrm{~W} 2$ & Phbw & DDH-47A* & 157.5 & $5 Y 7 / 1$ (light grey) & 29.3 & 0.04 & 0.98 & 35.5 & 0.39 & 7.74 & 0.86 & - & 0.70 & 0.13 & 0.31 & 24.1 & 100.0 \\
\hline 4710 & DS13 & $\mathrm{DDH}-47 \mathrm{~A}^{*}$ & 99.3 & $5 Y 7 / 2$ (light grey) & 60.9 & 0.01 & 0.64 & 22.9 & 0.19 & 2.13 & 1.07 & - & 0.36 & 0.07 & 0.06 & 11.1 & 99.4 \\
\hline 4714 & DS12 & $\mathrm{DDH}-47 \mathrm{~A}^{*}$ & 88.2 & $5 Y 7 / 2$ (light grey) & 72.8 & 0.01 & 0.65 & 10.8 & 0.19 & 2.58 & 3.90 & - & 0.34 & 0.13 & 0.16 & 8.21 & 99.7 \\
\hline 4716 & DS11 & $\mathrm{DDH}-47 \mathrm{~A}^{*}$ & 84.5 & 5Y 8/1 (white) & 65.3 & 0.01 & 0.14 & 18.2 & 0.26 & 2.09 & 1.71 & - & 0.02 & 0.23 & 0.04 & 11.4 & 99.4 \\
\hline 4721 & DS9 & $\mathrm{DDH}-47 \mathrm{~A}^{*}$ & 63.4 & $5 \times 8 / 1$ (white) & 76.4 & 0.01 & 0.13 & 11.5 & 0.15 & 2.76 & 0.30 & - & 0.01 & 0.13 & 0.07 & 7.91 & 99.3 \\
\hline $4725 \mathrm{~A}$ & DS7 & $\mathrm{DDH}-47 \mathrm{~A}^{*}$ & 53.4 & $5 Y 7 / 2$ (light grey) & 69.5 & 0.01 & 1.10 & 12.5 & 0.07 & 2.52 & 4.37 & - & 0.37 & 0.19 & 0.02 & 8.83 & 99.5 \\
\hline
\end{tabular}


Appendix 3.1. (continued)

\begin{tabular}{|c|c|c|c|c|c|c|c|c|c|c|c|c|c|c|c|c|c|}
\hline Sample & Unit & Location & Depth $^{2} /$ Face $^{b}$ & Powder Colour & $\mathrm{SiO}_{2}$ & $\mathrm{TiO}_{2}$ & $\mathrm{Al}_{2} \mathrm{O}_{3}$ & $\mathrm{Fe}_{2} \mathrm{O}_{3} \mathrm{~T}$ & $\mathrm{MnO}$ & $\mathrm{MgO}$ & $\mathrm{CaO}$ & $\mathrm{Na}_{2} \mathrm{O}$ & $\mathrm{K}_{2} \mathrm{O}$ & $\mathrm{P}_{2} \mathrm{O}_{5}$ & $\mathrm{~s}$ & LOI & SUM \\
\hline 4728 & DS6 & $\mathrm{DDH}-47 \mathrm{~A}^{*}$ & 47.0 & $5 Y 7 / 2$ (light grey) & 44.6 & 0.01 & 0.28 & 28.7 & 0.35 & 3.24 & 3.68 & - & 0.15 & 0.10 & 0.05 & 18.2 & 99.3 \\
\hline 4731 & DS5 & DDH-47A* & 40.8 & 5 Y 6.5/1 (light grey) & 70.5 & 0.01 & 0.95 & 12.6 & 0.12 & 2.02 & 4.36 & 0.14 & 0.43 & 0.05 & 0.03 & 8.28 & 99.5 \\
\hline \multicolumn{18}{|c|}{ Shaley BIF } \\
\hline $47 W 8$ & Phbw & $\mathrm{DDH}-47 \mathrm{~A}^{*}$ & 145.8 & 7.5YR 5/1 (grey) & 20.2 & 0.03 & 0.52 & 70.9 & 0.08 & 3.68 & 0.80 & - & 0.52 & 0.31 & 0.01 & 3.37 & 100.4 \\
\hline $47 \mathrm{~W} 7$ & Phbw & $\mathrm{DDH}-47 \mathrm{~A}^{*}$ & 147.9 & $5 Y 7 / 1$ (light grey) & 17.3 & 0.02 & 1.20 & 39.1 & 0.34 & 11.1 & 0.82 & - & 1.02 & 0.15 & 0.07 & 29.4 & 100.5 \\
\hline $47 \mathrm{~W} 3$ & Phbw & $\mathrm{DDH}-47 \mathrm{~A}^{*}$ & 160.4 & 5Y 6/1 (light grey) & 44.9 & 0.01 & 0.44 & 43.4 & - & 4.99 & 0.89 & - & 0.32 & 0.49 & - & 4.96 & 100.4 \\
\hline $47 \mathrm{~W} 4$ & Phbw & $\mathrm{DDH}-47 \mathrm{~A}^{*}$ & 163.4 & 2.5YR 3/1 (very dark grey) & 20.7 & 0.01 & - & 78.8 & - & 0.69 & 0.17 & - & 0.06 & 0.09 & - & -0.29 & 100.2 \\
\hline \multicolumn{18}{|c|}{ Southeastern Hamersley Province } \\
\hline \multicolumn{18}{|c|}{ Banded iron-formation } \\
\hline Ww9 & $\mathrm{DB} 16$ & Weelli Wolli & centre & & 43.1 & 0.01 & 0.17 & 56.3 & - & - & 0.03 & 0.33 & 0.03 & 0.13 & 0.01 & 0.73 & 100.7 \\
\hline WW10 & DB15 & Weelli Wolli & centre & & 46.3 & 0.01 & 0.17 & 51.2 & - & - & 0.05 & 0.36 & 0.03 & 0.14 & 0.01 & 2.53 & 100.9 \\
\hline WW11 & DB 14 & Weelli Wolli & centre & & 52.9 & - & 0.07 & 46.2 & - & - & 0.06 & - & 0.02 & 0.11 & 0.01 & 0.96 & 100.3 \\
\hline WW12 & $\mathrm{DB} 13$ & Weelli Wolli & centre & & 47.9 & 0.03 & 0.15 & 49.9 & - & - & 0.11 & - & 0.01 & 0.15 & - & 1.35 & 99.6 \\
\hline WW13 & $\mathrm{DB} 12$ & Weelli Wolli & centre & & 47.7 & - & 0.09 & 50.4 & - & - & 0.03 & - & 0.02 & 0.14 & 0.02 & 2.09 & 100.6 \\
\hline WW8 & DB6 & Weelli Wolli & centre & & 44.5 & 0.02 & 0.16 & 52.0 & - & - & 0.04 & 0.32 & 0.04 & 0.16 & 0.01 & 2.80 & 100.1 \\
\hline Ww7 & DB5 & Weelli Wolli & centre & & 27.6 & 0.02 & 0.21 & 67.9 & - & - & 0.06 & 0.36 & 0.04 & 0.20 & 0.02 & 2.56 & 99.0 \\
\hline WW6 & DB4 & Weelli Wolli & centre & & 30.7 & 0.02 & 0.32 & 65.7 & - & - & 0.06 & 0.32 & 0.04 & 0.17 & 0.04 & 1.66 & 99.1 \\
\hline WW4 & DB3 & Weelli Wolli & centre & & 41.5 & 0.02 & 0.16 & 55.7 & - & - & 0.06 & 0.36 & 0.04 & 0.15 & 0.01 & 2.26 & 100.2 \\
\hline WW3 & DB2 & Weelli Wolli & centre & & 41.9 & 0.02 & 0.33 & 54.1 & - & - & 0.23 & 0.34 & 0.04 & 0.18 & 0.01 & 2.03 & 99.2 \\
\hline WW2 & $\mathrm{DB} 1$ & Weelli Wolli & centre & & 45.3 & 0.02 & 0.29 & 52.4 & - & - & 0.05 & 0.33 & 0.04 & 0.11 & 0.02 & 1.94 & 100.5 \\
\hline WW1 & $\mathrm{DB} 0$ & Weelli Wolli & centre & & 50.4 & - & 0.14 & 46.8 & - & - & 0.08 & - & 0.02 & 0.13 & - & 2.19 & 99.7 \\
\hline MR17 & DB16 & Mt. Robinson & centre & & 43.9 & 0.01 & 0.42 & 53.0 & - & - & 0.02 & - & 0.01 & 0.15 & - & 2.12 & 99.6 \\
\hline MR16 & $\mathrm{DB} 15$ & Mt. Robinson & centre & & 58.0 & 0.01 & 0.09 & 39.7 & - & - & 0.01 & - & 0.02 & 0.16 & - & 1.47 & 99.5 \\
\hline MRI5 & $\mathrm{DB} 14$ & Mt. Robinson & centre & & 46.8 & 0.01 & 0.16 & 49.7 & - & - & 0.04 & 0.29 & 0.04 & 0.16 & - & 2.02 & 99.2 \\
\hline MR14 & DB13 & Mt. Robinson & centre & & 51.5 & - & 0.13 & 45.6 & - & 0.16 & 0.02 & - & 0.02 & 0.14 & 0.01 & 2.15 & 99.7 \\
\hline MR13 & $\mathrm{DB} 12$ & Mt. Robinson & centre & & 43.5 & - & 0.41 & 52.8 & - & - & 0.03 & 0.17 & 0.04 & 0.12 & - & 2.70 & 99.8 \\
\hline MR12 & DB11 & Mt. Robinson & centre & & 35.5 & 0.02 & 0.24 & 59.6 & - & - & 0.01 & 0.19 & 0.04 & 0.18 & 0.01 & 4.10 & 99.9 \\
\hline MR10 & DB9 & Mt. Robinson & centre & & 58.4 & 0.02 & 0.09 & 38.9 & - & - & 0.03 & 0.47 & 0.06 & 0.11 & 0.01 & 1.48 & 99.6 \\
\hline MR9 & DB8 & Mt. Robinson & centre & & 89.2 & - & 0.17 & 8.1 & - & - & 0.07 & - & 0.01 & 0.12 & - & 1.44 & 99.0 \\
\hline MR8 & DB7 & Mt. Robinson & centre & & 44.2 & - & 0.26 & 50.7 & - & - & 0.03 & - & 0.01 & 0.15 & 0.00 & 4.46 & 99.7 \\
\hline MR7 & DB6 & Mt. Robinson & centre & & 43.7 & 0.02 & 0.25 & 53.2 & - & - & 0.02 & 0.18 & 0.03 & 0.19 & 0.01 & 2.38 & 100.0 \\
\hline MR6 & DB5 & Mt. Robinson & centre & & 63.5 & 0.02 & 0.23 & 33.8 & - & - & 0.03 & 0.18 & 0.03 & 0.15 & 0.02 & 1.82 & 99.8 \\
\hline
\end{tabular}


Appendix 3.1. (continued)

\begin{tabular}{|c|c|c|c|c|c|c|c|c|c|c|c|c|c|c|c|c|c|}
\hline Sample & Unit & Location & Depth $^{2} /$ Face $^{b}$ & Powder Colour & $\mathrm{SiO}_{2}$ & $\mathrm{TiO}_{2}$ & $\mathrm{Al}_{2} \mathrm{O}_{3}$ & $\mathrm{Fe}_{2} \mathrm{O}_{3} \mathrm{~T}$ & $\mathrm{MnO}$ & MgO & $\mathrm{CaO}$ & $\mathrm{Na}_{2} \mathrm{O}$ & $\mathrm{K}_{2} \mathrm{O}$ & $\mathrm{P}_{2} \mathrm{O}_{5}$ & $\mathbf{s}$ & LOI & SUM \\
\hline MR5 & DB4 & Mt. Robinson & centre & & 47.7 & 0.01 & 0.39 & 48.3 & - & - & 0.05 & - & 0.03 & 0.14 & 0.01 & 3.06 & 99.7 \\
\hline MR4 & DB3 & Mt. Robinson & centre & & 43.4 & 0.01 & 0.21 & 54.2 & - & - & 0.02 & - & 0.02 & 0.17 & 0.03 & 1.08 & 99.1 \\
\hline MR3 & DB2 & Mt. Robinson & centre & & 29.3 & 0.02 & 0.73 & 66.9 & - & - & 0.02 & - & 0.02 & 0.26 & - & 2.62 & 99.9 \\
\hline MR2 & $\mathrm{DB} 1$ & Mt. Robinson & centre & & 50.7 & 0.02 & 0.29 & 46.3 & - & - & 0.03 & - & 0.02 & 0.16 & - & 2.35 & 99.9 \\
\hline MRI & DBO & Mt. Robinson & centre & & 66.6 & - & 0.14 & 31.1 & - & - & 0.04 & - & 0.01 & 0.14 & - & 1.45 & 99.5 \\
\hline $\mathrm{PHI}$ & DB16 & Pamelia Hill & centre & & 43.0 & - & 0.13 & 54.8 & - & - & 0.02 & - & 0.01 & 0.17 & - & 1.42 & 99.6 \\
\hline $\mathrm{PH} 2$ & DB15 & Pamelia Hill & centre & & 48.5 & 0.02 & 0.15 & 49.9 & - & - & 0.02 & - & 0.01 & 0.12 & - & 1.32 & 100.1 \\
\hline PH3 & DB14 & Pamelia Hill & centre & & 41.5 & 0.02 & 0.10 & 57.2 & - & - & 0.02 & - & 0.01 & 0.17 & - & 1.10 & 100.2 \\
\hline PH4 & DB12 & Pamelia Hill & centre & & 49.7 & 0.01 & 0.32 & 48.2 & - & - & 0.02 & - & 0.01 & 0.12 & - & 1.47 & 99.9 \\
\hline PH5 & DB11 & Pamelia Hill & centre & & 57.4 & 0.01 & 0.12 & 40.1 & - & - & 0.02 & - & 0.01 & 0.17 & - & 1.72 & 99.6 \\
\hline PH6 & DB10 & Pamelia Hill & centre & & 55.9 & 0.02 & 0.14 & 41.4 & - & - & 0.02 & - & 0.01 & 0.19 & - & 2.05 & 99.7 \\
\hline PH7 & DB7 & Pamelia Hill & centre & & 50.2 & - & 0.07 & 47.4 & - & - & 0.02 & - & 0.01 & 0.13 & 0.01 & 2.12 & 99.9 \\
\hline PH8 & DB6 & Pamelia Hill & centre & & 48.8 & - & 0.07 & 49.7 & - & - & 0.02 & - & 0.01 & 0.15 & - & 0.99 & 99.7 \\
\hline PH9 & DB5 & Pamelia Hill & centre & & 46.7 & 0.01 & 0.47 & 50.1 & - & - & 0.02 & - & 0.01 & 0.30 & - & 2.36 & 99.9 \\
\hline PHIO & DB4 & Pamelia Hill & centre & & 52.3 & 0.01 & 0.23 & 46.2 & - & - & 0.03 & - & 0.01 & 0.14 & - & 0.93 & 99.8 \\
\hline PH11 & DB3 & Pamelia Hill & centre & & 46.5 & 0.02 & 0.18 & 52.3 & - & - & 0.02 & - & 0.01 & 0.11 & - & 0.78 & 99.8 \\
\hline PH12 & DB2 & Pamelia Hill & centre & & 55.1 & 0.01 & 0.13 & 43.3 & - & - & 0.03 & - & 0.02 & 0.16 & - & 1.19 & 99.9 \\
\hline PH13 & DB1 & Pamelia Hill & centre & & 47.6 & 0.01 & 0.19 & 51.0 & - & - & 0.07 & - & 0.02 & 0.15 & - & 0.82 & 99.9 \\
\hline PH14 & DB0 & Pamelia Hill & centre & & 35.4 & 0.01 & 0.19 & 63.1 & - & - & 0.02 & - & 0.01 & 0.14 & - & 1.09 & 100.0 \\
\hline $\mathrm{C} 17$ & DB16 & Cathedral Gorge & centre & & 50.8 & - & 0.16 & 46.6 & - & - & 0.07 & 0.25 & 0.04 & 0.17 & 0.10 & 1.55 & 99.8 \\
\hline $\mathrm{C} 16$ & DB15 & Cathedral Gorge & centre & & 50.6 & 0.02 & 0.09 & 46.4 & - & - & 0.03 & - & 0.01 & 0.17 & - & 2.14 & 99.5 \\
\hline $\mathrm{C} 15$ & $\mathrm{DB} 14$ & Cathedral Gorge & centre & & 44.9 & 0.02 & 0.12 & 53.3 & - & - & 0.03 & - & 0.01 & 0.10 & 0.00 & 1.22 & 99.8 \\
\hline C14 & $\mathrm{DB} 13$ & Cathedral Gorge & centre & & 50.9 & 0.01 & 0.14 & 47.4 & - & - & 0.05 & 0.13 & 0.03 & 0.10 & 0.01 & 0.82 & 99.6 \\
\hline $\mathrm{C} 13$ & $\mathrm{DB} 12$ & Cathedral Gorge & centre & & 52.6 & - & 0.07 & 45.6 & - & - & 0.03 & - & 0.01 & 0.11 & - & 1.29 & 99.7 \\
\hline $\mathrm{C} 12$ & DBII & Cathedral Gorge & centre & & 50.3 & 0.01 & 0.44 & 47.6 & - & - & 0.01 & - & 0.01 & 0.13 & - & 1.66 & 100.1 \\
\hline $\mathrm{C} 11$ & DB10 & Cathedral Gorge & centre & & 55.6 & - & 0.23 & 41.3 & - & - & 0.03 & 0.13 & 0.02 & 0.19 & 0.01 & 2.51 & 100.0 \\
\hline $\mathrm{ClO}$ & DB9 & Cathedral Gorge & centre & & 70.8 & - & 0.33 & 27.0 & - & - & 0.02 & 0.33 & 0.06 & 0.10 & 0.02 & 1.52 & 100.2 \\
\hline $\mathrm{C} 9$ & DB8 & Cathedral Gorge & centre & & 77.8 & - & 0.12 & 18.5 & - & - & 0.04 & - & 0.01 & 0.22 & - & 2.46 & 99.1 \\
\hline $\mathrm{C} 8$ & DB7 & Cathedral Gorge & centre & & 55.7 & 0.02 & 0.10 & 41.2 & - & - & 0.03 & - & 0.02 & 0.13 & 0.01 & 2.40 & 99.6 \\
\hline C7 & DB6 & Cathedral Gorge & centre & & 49.9 & 0.01 & 0.17 & 48.5 & - & - & 0.04 & - & 0.02 & 0.13 & 0.01 & 1.15 & 99.9 \\
\hline C6 & DB5 & Cathedral Gorge & centre & & 56.0 & 0.02 & 0.94 & 42.3 & - & - & 0.03 & - & 0.01 & 0.17 & 0.00 & 1.02 & 100.5 \\
\hline C5 & DB4 & Cathedral Gorge & centre & & 57.1 & - & 0.17 & 40.7 & - & - & 0.04 & 0.16 & 0.02 & 0.16 & 0.01 & 1.83 & 100.2 \\
\hline $\mathrm{C} 4$ & DB3 & Cathedral Gorge & centre & & 53.8 & 0.03 & 0.41 & 43.6 & - & 0.12 & 0.08 & 0.25 & 0.04 & 0.14 & 0.03 & 1.32 & 99.8 \\
\hline
\end{tabular}


Appendix 3.1. (continued)

\begin{tabular}{|c|c|c|c|c|c|c|c|c|c|c|c|c|c|c|c|c|c|}
\hline Sample & Unit & Location & Depth $^{\mathrm{a}} /$ Face $^{\mathrm{t}}$ & Powder Colour & $\mathrm{SiO}_{2}$ & $\mathrm{TiO}_{2}$ & $\mathrm{Al}_{2} \mathrm{O}_{3}$ & $\mathrm{Fe}_{2} \mathrm{O}_{3} \mathrm{~T}$ & MnO & MgO & $\mathrm{CaO}$ & $\mathrm{Na}_{2} \mathrm{O}$ & $\mathrm{K}_{2} \mathrm{O}$ & $\mathrm{P}_{2} \mathrm{O}_{5}$ & $\mathrm{~S}$ & LOI & SUM \\
\hline $\mathrm{C} 3$ & $\mathrm{DB} 2$ & Cathedral Gorge & centre & & 43.7 & 0.02 & 0.53 & 54.5 & - & - & 0.04 & 0.19 & 0.05 & 0.14 & 0.02 & 0.91 & 100.1 \\
\hline $\mathrm{C} 2$ & $\mathrm{DB} 1$ & Cathedral Gorge & centre & & 46.9 & - & 0.39 & 51.1 & - & - & 0.04 & - & 0.02 & 0.16 & - & 1.41 & 100.1 \\
\hline $\mathrm{Cl}$ & DBO & Cathedral Gorge & centre & & 55.6 & 0.02 & 0.99 & 42.4 & - & - & 0.03 & - & 0.02 & 0.17 & - & 0.82 & 100.0 \\
\hline $4 W_{17}$ & DB16 & Fourth West Gorge & centre & & 49.3 & 0.02 & 0.13 & 50.3 & - & - & 0.03 & - & 0.02 & 0.10 & 0.01 & 0.37 & 100.3 \\
\hline $4 W 16$ & $\mathrm{DB} 15$ & Fourth West Gorge & centre & & 60.7 & - & 0.07 & 39.0 & - & - & 0.01 & - & 0.01 & 0.10 & - & 0.25 & 100.2 \\
\hline $4 \mathrm{~W} 15$ & $\mathrm{DB} 14$ & Fourth West Gorge & centre & & 50.4 & - & 0.05 & 49.1 & - & - & 0.02 & - & 0.01 & 0.12 & - & 0.22 & 99.9 \\
\hline $4 W 14$ & DB13 & Fourth West Gorge & centre & & 67.7 & 0.02 & 0.07 & 31.7 & - & - & 0.06 & - & 0.02 & 0.11 & - & 0.17 & 99.8 \\
\hline $4 \mathrm{~W} 13$ & $\mathrm{DB} 12$ & Fourth West Gorge & centre & & 54.4 & - & 0.07 & 45.1 & - & - & 0.04 & - & 0.01 & 0.12 & - & 0.27 & 100.0 \\
\hline $4 W_{12}$ & DB11 & Fourth West Gorge & centre & & 55.3 & - & 0.11 & 43.9 & - & - & 0.04 & - & 0.01 & 0.10 & - & 0.45 & 99.9 \\
\hline $4 W 11$ & $\mathrm{DB} 10$ & Fourth West Gorge & centre & & 49.0 & - & 0.18 & 50.0 & - & - & 0.06 & - & 0.01 & 0.12 & - & 0.60 & 100.0 \\
\hline $4 W 10$ & DB9 & Fourth West Gorge & centre & & 36.5 & 0.01 & 0.22 & 61.6 & - & - & 0.05 & - & 0.03 & 0.10 & 0.02 & 0.52 & 99.1 \\
\hline 4W9 & DB8 & Fourth West Gorge & centre & & 59.5 & 0.02 & 0.10 & 39.9 & - & - & 0.02 & - & 0.00 & 0.10 & - & 0.16 & 99.8 \\
\hline $4 W 8$ & DB7 & Fourth West Gorge & centre & & 36.9 & 0.02 & 0.14 & 61.6 & - & - & 0.02 & - & 0.02 & 0.10 & - & 0.17 & 99.0 \\
\hline $4 W 7$ & DB6 & Fourth West Gorge & centre & & 49.9 & - & 0.04 & 49.7 & - & - & 0.03 & - & 0.00 & 0.12 & - & 0.17 & 99.9 \\
\hline $4 W 6$ & DB5 & Fourth West Gorge & centre & & 66.9 & 0.01 & 0.25 & 31.2 & - & 0.20 & 0.03 & 0.89 & 0.07 & 0.11 & 0.05 & 0.40 & 100.1 \\
\hline 4W5 & DB4 & Fourth West Gorge & centre & & 57.9 & - & 0.13 & 40.2 & - & - & 0.06 & 0.42 & 0.04 & 0.11 & 0.01 & 0.42 & 99.3 \\
\hline $4 \mathrm{~W} 4$ & DB3 & Fourth West Gorge & centre & & 58.4 & 0.04 & 0.10 & 40.1 & - & - & 0.04 & 0.32 & 0.04 & 0.11 & 0.01 & 0.30 & 99.4 \\
\hline $4 \mathrm{~W} 3$ & DB2 & Fourth West Gorge & centre & & 51.6 & 0.02 & 0.15 & 47.3 & - & - & 0.07 & - & 0.01 & 0.16 & 0.01 & 0.44 & 99.8 \\
\hline $4 W 2$ & DB1 & Fourth West Gorge & centre & & 38.1 & 0.02 & 0.69 & 61.3 & - & - & 0.02 & - & 0.02 & 0.11 & 0.01 & 0.14 & 100.4 \\
\hline $4 \mathrm{~W} 1$ & DB0 & Fourth West Gorge & centre & & 56.9 & 0.02 & 0.04 & 42.1 & - & - & 0.03 & 0.15 & 0.02 & 0.11 & 0.01 & 0.32 & 99.7 \\
\hline \multicolumn{18}{|c|}{ Mt. Whaleback pit samples } \\
\hline \multicolumn{18}{|c|}{ Altered $(B I F)$} \\
\hline D73A & $\mathrm{DB} 16$ & DDH-73 & 228.2 & 10R $5 / 4$ (weak red) & 60.5 & 0.01 & 0.13 & 38.8 & - & - & 0.19 & - & 0.02 & 0.05 & - & 0.20 & 99.9 \\
\hline $\mathrm{D} 73 \mathrm{C}$ & DB16 & DDH-73 & 232.0 & 10R 4/3 (weak red) & 38.4 & 0.01 & 0.08 & 61.3 & - & - & 0.18 & - & 0.02 & 0.06 & - & 0.20 & 100.3 \\
\hline D73D & $\mathrm{DB} 16$ & DDH-73 & 233.6 & $10 \mathrm{R} 4 / 3$ (weak red) & 41.0 & 0.01 & 0.13 & 58.6 & 0.08 & - & 0.18 & - & 0.02 & 0.02 & - & 0.24 & 100.3 \\
\hline $\mathrm{A} 24 \mathrm{C}$ & $\mathrm{DB} 16$ & Pit face & $\mathrm{C}$ & 10R $4 / 4$ (weak red) & 60.1 & 0.02 & - & 40.0 & - & - & 0.02 & - & 0.01 & 0.09 & - & 0.23 & 100.4 \\
\hline $\mathrm{B} 24 \mathrm{C}$ & DB16 & Pit face & $\mathrm{C}$ & 10R 4/3 (weak red) & 49.4 & - & - & 51.0 & - & - & 0.04 & - & 0.01 & 0.06 & - & 0.15 & 100.6 \\
\hline $\mathrm{C} 24 \mathrm{C}$ & DB16 & Pit face & $\mathrm{C}$ & 10R 4.5/3 (weak red) & 52.6 & 0.01 & - & 47.6 & - & - & 0.04 & - & 0.01 & 0.07 & - & 0.14 & 100.4 \\
\hline $\mathrm{F} 24 \mathrm{C}$ & DB16 & Pit face & $\mathrm{C}$ & $5 \mathrm{R} 4 / 2$ (weak red) & 19.5 & - & - & 79.9 & - & - & 0.14 & - & 0.02 & 0.14 & - & 0.27 & 100.0 \\
\hline G24C & DB16 & Pit face & $\mathrm{C}$ & $5 \mathrm{R} 4 / 2$ (weak red) & 20.4 & 0.01 & - & 79.4 & - & - & 0.04 & - & 0.02 & 0.12 & - & 0.24 & 100.2 \\
\hline D86C & $\mathrm{DB} 15$ & DDH-86 & 223.9 & 7.5 YR $4 / 4$ (brown) & 24.1 & 0.01 & 0.17 & 73.5 & - & - & 0.19 & - & 0.02 & 0.27 & - & 1.98 & 100.2 \\
\hline D86D & DB15 & DDH-86 & 219.2 & $10 \mathrm{R} 5 / 3$ (weak red) & 47.1 & 0.01 & 0.11 & 51.1 & - & - & 0.18 & - & 0.02 & 0.09 & - & 0.37 & 99.0 \\
\hline $\mathrm{D} 86 \mathrm{E}$ & $\mathrm{DB} 15$ & DDH-86 & 220.1 & 5YR 5/6 (yellowish red) & 39.8 & 0.01 & 0.15 & 58.0 & - & - & 0.19 & - & 0.02 & 0.23 & 0.02 & 1.71 & 100.1 \\
\hline
\end{tabular}


Appendix 3.1. (continued)

\begin{tabular}{|c|c|c|c|c|c|c|c|c|c|c|c|c|c|c|c|c|c|}
\hline Sample & Unit & Location & Depth $^{2} / \mathrm{Face}^{\mathrm{b}}$ & Powder Colour & $\mathrm{SiO}_{2}$ & $\mathrm{TiO}_{2}$ & $\mathrm{Al}_{2} \mathrm{O}_{3}$ & $\mathrm{Fe}_{2} \mathrm{O}_{3} \mathrm{~T}$ & MnO & $\mathrm{MgO}$ & $\mathrm{CaO}$ & $\mathrm{Na}_{2} \mathrm{O}$ & $\mathrm{K}_{2} \mathrm{O}$ & $\mathrm{P}_{2} \mathrm{O}_{5}$ & $\mathrm{~S}$ & LOI & SUM \\
\hline $\mathrm{D} 86 \mathrm{~F}$ & $\mathrm{DB} 15$ & DDH-86 & 215.2 & 5YR 4/6 (yellowish red) & 44.9 & 0.01 & 0.17 & 53.7 & - & - & 0.18 & - & 0.02 & 0.18 & - & 1.15 & 100.3 \\
\hline \multicolumn{18}{|l|}{ Iron Ore } \\
\hline AW 29 & Phbw & DDH-257 & 52.1 & 5R $3.5 / 2$ (dusky red) & 0.77 & - & 0.10 & 98.5 & - & - & 0.06 & - & 0.01 & 0.06 & 0.01 & 0.26 & 99.8 \\
\hline AW30 & Phbw & $\mathrm{DDH}-257$ & 52.8 & 5R $3.5 / 2$ (dusky red) & 0.68 & - & - & 100.9 & - & - & 0.06 & - & 0.01 & 0.03 & & 0.14 & 101.8 \\
\hline WS6 & Phbw & Pit face & $\mathrm{E}$ & $10 \mathrm{R} 4 / 6(\mathrm{red})$ & 1.11 & 0.01 & 0.52 & 96.0 & - & - & 0.14 & - & 0.03 & 0.13 & 0.01 & 1.92 & 99.9 \\
\hline D86A & $\mathrm{DB} 16$ & DDH-86 & 239.3 & 7.5R 4/2 (weak red) & 0.53 & 0.01 & 0.21 & 98.6 & - & - & 0.22 & - & 0.03 & 0.07 & - & 0.35 & 100.1 \\
\hline D73B & DB16 & DDH-73 & 230.1 & 7.5R 4/2 (weak red) & 1.16 & 0.01 & 0.10 & 97.6 & - & - & 0.18 & - & 0.02 & 0.05 & - & 0.27 & 99.3 \\
\hline D73E & DB16 & DDH-73 & 238.3 & 7.5R 4/2 (weak red) & 0.57 & 0.01 & 0.18 & 98.4 & 0.11 & - & 0.19 & - & 0.02 & 0.04 & - & 0.55 & 100.0 \\
\hline $\mathrm{D} 24 \mathrm{C}$ & DB16 & Pit face & $\mathrm{C}$ & 7.5R 3/2 (dusky red) & 1.13 & 0.03 & 0.17 & 99.0 & - & - & 0.03 & - & 0.02 & 0.03 & 0.01 & 0.25 & 100.6 \\
\hline $\mathrm{E} 24 \mathrm{C}$ & DB16 & Pit face & $\mathrm{C}$ & 7.5R 4/2 (weak red) & 0.21 & 0.02 & 0.07 & 99.9 & 0.10 & - & 0.03 & - & 0.01 & 0.02 & - & 0.20 & 100.5 \\
\hline $\mathrm{E} 25 \mathrm{E}$ & DB15 & Pit face & $\mathrm{D}$ & $2.5 Y R \quad 4 / 6(\mathrm{red})$ & 0.40 & 0.01 & 0.29 & 98.9 & - & - & 0.03 & - & 0.02 & 0.07 & - & 0.28 & 100.0 \\
\hline A25E & DBII & Pit face & $\mathrm{D}$ & $2.5 \mathrm{YR} 4 / 6(\mathrm{red})$ & 0.31 & 0.01 & 0.08 & 98.8 & - & - & 0.03 & - & 0.02 & 0.05 & 0.01 & 0.31 & 99.5 \\
\hline $\mathrm{B} 25 \mathrm{E}$ & DB11 & Pit face & $\mathrm{D}$ & $7.5 \mathrm{R} 4 / 2$ (weak red) & 0.33 & 0.01 & 0.06 & 99.3 & - & - & 0.03 & - & 0.02 & 0.05 & - & 0.30 & 100.1 \\
\hline 6BEDC & DB6 & Pit face & A & 5R $3.5 / 2$ (dusky red) & 0.36 & 0.01 & 0.03 & 99.7 & - & - & 0.03 & - & 0.02 & 0.04 & - & 0.19 & 100.3 \\
\hline $5 B E D C$ & DB5 & Pit face & A & 5R $3.5 / 2$ (dusky red) & 0.91 & 0.04 & 0.54 & 98.1 & - & - & 0.04 & - & 0.02 & 0.09 & - & 0.50 & 100.2 \\
\hline 4AEDC & DB4 & Pit face & A & 5R 3.5/2 (dusky red) & 0.69 & 0.02 & 0.45 & 98.0 & - & - & 0.04 & - & 0.02 & 0.07 & - & 0.40 & 99.7 \\
\hline 3BEDC & DB3 & Pit face & A & 7.5R 3.5/2 (dusky red) & 0.46 & 0.02 & 0.19 & 98.8 & - & - & 0.04 & 0.18 & 0.03 & 0.04 & - & 0.22 & 100.0 \\
\hline 1123 & DB0 & Pit face & $\mathrm{B}$ & 5R 4/2 (weak red) & 0.32 & 0.02 & 0.06 & 99.1 & - & - & 0.03 & - & 0.02 & 0.07 & 0.01 & 0.21 & 99.8 \\
\hline AW15 & $\mathrm{Phr}$ & DDH-324 & 138.4 & 5R 3/2 (dusky red) & 1.11 & - & 0.54 & 98.4 & - & - & 0.37 & - & 0.02 & 0.19 & - & 0.64 & 101.3 \\
\hline AW16 & Phr & DDH-324 & 138.7 & 10R 3/6 (dark red) & 1.88 & 0.01 & 0.86 & 97.2 & - & - & 0.83 & - & 0.03 & 0.56 & - & 0.75 & 102.1 \\
\hline 323 & $\mathrm{Phr}$ & Pit face & B & $10 \mathrm{R} 3 / 2$ (dusky red) & 1.10 & - & 0.06 & 97.3 & - & - & 0.04 & - & 0.02 & 0.03 & - & 0.73 & 99.3 \\
\hline 523 & Phr & Pit face & B & $7.5 \mathrm{R} 3.5 / 4$ (dusky red) & 0.59 & 0.02 & 0.19 & 97.6 & - & - & 0.69 & - & 0.02 & 0.49 & - & 0.35 & 100.0 \\
\hline 723 & $\mathrm{Phr}$ & Pit face & B & 5R 4/2 (weak red) & 1.02 & 0.03 & 0.55 & 98.4 & - & - & 0.04 & - & 0.02 & 0.03 & - & 0.48 & 100.6 \\
\hline 923 & Phr & Pit face & B & 10R $3 / 3$ (dusky red) & 0.42 & 0.03 & 0.10 & 98.4 & - & - & 0.04 & - & 0.02 & 0.11 & - & 0.27 & 99.4 \\
\hline \multicolumn{18}{|c|}{ Altered Black Shale } \\
\hline $\mathrm{AW} 22 \mathrm{~A}$ & Phbw & DDH-257 & 45.9 & 10YR $6 / 2$ (light brownish grey) & 33.9 & 0.22 & 24.0 & 23.4 & 0.07 & 8.13 & 0.03 & - & 2.81 & 0.04 & - & 7.96 & 100.6 \\
\hline AW22B & Phbw & DDH-257 & 46.3 & 5YR 3/1 (very dark grey) & 23.7 & 0.78 & 18.8 & 40.2 & 0.17 & 3.71 & 0.11 & - & 0.07 & 0.23 & 0.01 & 12.6 & 100.4 \\
\hline SBS4 & Phbw & DDH-257 & 48.4 & 2.5YR 3/ (very dark grey) & 29.7 & 1.26 & 24.3 & 22.7 & 0.25 & 4.84 & 0.10 & - & 0.09 & 0.08 & - & 17.0 & 100.4 \\
\hline AW24 & Phbw & DDH-257 & 49.0 & 5YR 3/1 (very dark grey) & 29.0 & 0.82 & 24.1 & 29.3 & 0.14 & 5.47 & 0.11 & - & 0.03 & 0.12 & 0.05 & 12.2 & 101.4 \\
\hline AW25 & Phbw & DDH-257 & 50.0 & 5YR 3/1 (very dark grey) & 26.7 & 0.92 & 21.9 & 34.9 & 0.10 & 3.56 & 0.11 & - & 0.04 & 0.18 & 0.01 & 12.5 & 101.0 \\
\hline SBS7 & Phbw & DDH-257 & 50.5 & 2.5YR 3/ (very dark grey) & 28.3 & 0.95 & 23.5 & 28.0 & 0.11 & 3.65 & 0.10 & - & 0.09 & 0.14 & - & 15.5 & 100.4 \\
\hline AW26 & Phbw & DDH-257 & 50.6 & 5YR $2.75 / 1$ (very dark grey) & 31.0 & 1.04 & 25.7 & 24.4 & 0.14 & 4.62 & 0.11 & - & 0.02 & 0.15 & 0.01 & 13.9 & 101.1 \\
\hline $224 \mathrm{C}$ & Phbw & Pit face & $\mathrm{C}$ & $5 Y R 3 / 2$ (dark brown) & 45.9 & 1.01 & 15.7 & 23.2 & - & 2.29 & 0.12 & 0.43 & 0.45 & 0.06 & 0.01 & 11.3 & 100.5 \\
\hline
\end{tabular}


Appendix 3.1. (continued)

\begin{tabular}{|c|c|c|c|c|c|c|c|c|c|c|c|c|c|c|c|c|c|}
\hline Sample & Unit & Location & Depth $^{2} / \mathrm{Face}^{\mathrm{b}}$ & Powder Colour & $\mathrm{SiO}_{2}$ & $\mathrm{TiO}_{2}$ & $\mathrm{Al}_{2} \mathrm{O}_{3}$ & $\mathrm{Fe}_{2} \mathrm{O}_{3} \mathrm{~T}$ & $\mathrm{MnO}$ & MgO & $\mathrm{CaO}$ & $\mathrm{Na}_{2} \mathrm{O}$ & $\mathrm{K}_{2} \mathrm{O}$ & $\mathrm{P}_{2} \mathrm{O}_{5}$ & $\mathrm{~s}$ & LOI & SUM \\
\hline $224 \mathrm{E}$ & Phbw & Pit face & $\mathrm{E}$ & $5 Y 4 / 1$ (dark grey) & 47.6 & 0.34 & 21.4 & 13.8 & 0.06 & 4.89 & 0.08 & - & 5.38 & 0.09 & 0.02 & 6.15 & 99.8 \\
\hline WS1 & Phbw & Pit face & E & $7.5 \mathrm{R} 3.5 / 1$ (very dark grey) & 32.7 & 0.67 & 21.2 & 26.3 & 0.24 & 6.27 & 0.09 & 0.19 & 1.13 & 0.07 & 0.03 & 11.5 & 100.4 \\
\hline WS3 & Phbw & Pit face & $\mathrm{E}$ & $7.5 \mathrm{R} 3.5 / 1$ (very dark grey) & 25.1 & 0.79 & 20.1 & 31.6 & 0.19 & 7.12 & 0.25 & 0.34 & 0.06 & 0.29 & 0.03 & 14.6 & 100.5 \\
\hline WS11 & Phbw & Pit face & E & 10YR 3/1 (very dark grey) & 28.0 & 0.81 & 21.7 & 28.8 & 0.22 & 5.68 & 0.11 & 0.13 & 0.24 & 0.09 & 0.02 & 14.2 & 100.0 \\
\hline G25E & DS16 & Pit face & $\mathrm{D}$ & $5 Y 5 / 1$ (grey) & 27.8 & 1.12 & 22.0 & 30.3 & 0.37 & 7.78 & 0.09 & - & 0.02 & 0.10 & - & 10.7 & 100.2 \\
\hline $\mathrm{H} 25 \mathrm{E}$ & DS16 & Pit face & D & 5Y 5/1 (grey) & 30.4 & 1.13 & 23.7 & 25.4 & 0.17 & 6.75 & 0.11 & - & 0.03 & 0.08 & - & 12.2 & 100.1 \\
\hline AW18 & Phr & DDH-324 & 139.8 & 2.5YR 2.5/ (black) & 26.1 & 0.54 & 16.6 & 23.3 & 0.19 & 15.7 & 0.28 & - & 0.15 & 0.16 & 0.02 & 18.0 & 101.1 \\
\hline AW19 & $\mathrm{Phr}$ & DDH-324 & 145.6 & 2.5YR 3/ (very dark grey) & 56.0 & 0.59 & 16.2 & 8.63 & 0.07 & 4.31 & 0.14 & - & 4.22 & 0.09 & 0.04 & 9.10 & 99.4 \\
\hline $\mathrm{AW} 20$ & $\mathrm{Phr}$ & DDH-324 & 150.2 & 2.5YR 2.5/ (black) & 59.1 & 0.60 & 16.3 & 5.12 & - & 2.26 & 0.10 & - & 5.53 & 0.12 & 0.03 & 10.4 & 99.6 \\
\hline AW21 & $\mathrm{Phr}$ & DDH-324 & 150.7 & 2.5YR 2.5/ (black) & 44.7 & 0.30 & 9.79 & 20.3 & - & 1.10 & 0.06 & - & 3.08 & 0.05 & 0.04 & 20.6 & 100.1 \\
\hline $\mathrm{RC}$ & $\mathrm{Phr}$ & Pit face & B & 2.5 YR $3 /$ (very dark grey) & 47.4 & 0.01 & 14.9 & 17.5 & 0.05 & 3.27 & 0.03 & 0.17 & 3.42 & 0.10 & 0.05 & 13.1 & 100.5 \\
\hline 123 & $\mathrm{Phr}$ & Pit face & B & 7.5 YR $3 / 1$ (very dark grey) & 18.0 & 0.46 & 12.0 & 14.7 & 0.79 & 11.5 & 13.0 & - & 1.77 & 0.06 & 0.03 & 27.2 & 99.4 \\
\hline $125 \mathrm{E}$ & $\mathrm{Phr}$ & Pit face & D & 7.5YR $2 /$ (black) & 39.2 & 0.97 & 23.8 & 10.3 & - & 3.52 & 0.23 & - & 6.92 & 0.23 & 0.08 & 14.4 & 99.7 \\
\hline $225 \mathrm{E}$ & $\mathrm{Phr}$ & Pit face & $\mathrm{D}$ & 7.5 YR $5.5 / 2$ (brown) & 45.6 & 0.49 & 21.3 & 18.9 & 0.07 & 3.90 & 0.06 & - & 2.91 & 0.06 & 0.01 & 7.12 & 100.4 \\
\hline D4091 & Phr & $\mathrm{DDH}-409$ & 255.50 & 10YR $7 / 1$ (light gray) & 51.2 & 0.79 & 19.7 & 10.9 & 0.07 & 6.23 & 0.28 & 0.16 & 5.11 & 0.20 & 0.01 & 5.60 & 100.2 \\
\hline \multicolumn{18}{|c|}{ Greyish-green shale } \\
\hline D4092 & $\mathrm{Phr}$ & $\mathrm{DDH}-409$ & 252.81 & $7.5 Y R$ 7/2 (pinkish gray) & 60.2 & 0.54 & 16.8 & 8.50 & - & 4.98 & 0.15 & - & 4.77 & 0.15 & - & 4.30 & 100.4 \\
\hline \multicolumn{18}{|c|}{ Reddish-green shale } \\
\hline D4094 & $\mathrm{Phr}$ & DDH-409 & 250.06 & 5YR 6/5 (reddish yellow) & 34.6 & 0.33 & 9.02 & 7.90 & 0.44 & 11.6 & 11.7 & - & 1.54 & 0.10 & 0.01 & 22.9 & 100.3 \\
\hline D4096 & $\mathrm{Phr}$ & DDH-409 & 245.63 & 5YR 6/6 (reddish yellow) & 5.30 & 0.12 & 3.23 & 12.7 & 1.55 & 16.4 & 23.3 & - & 0.01 & 0.08 & 0.01 & 37.3 & 99.9 \\
\hline \multicolumn{18}{|c|}{ Red Shale } \\
\hline AW27 & Phibw & DDH-257 & 50.7 & 5YR $3 / 2$ (dark reddish brown) & 24.5 & 0.79 & 19.9 & 41.4 & 0.10 & 2.50 & 0.13 & - & 0.02 & 0.26 & 0.01 & 11.7 & 101.3 \\
\hline SBS9 & Phbw & DDH-257 & 51.0 & 5YR 6/4 (light reddish brown) & 42.7 & 0.04 & 31.7 & 5.08 & - & 5.53 & 0.15 & - & 0.05 & 0.06 & - & 15.3 & 100.6 \\
\hline AW31 & Phbw & DDH-229 & 163.5 & 5YR 4/4 (reddish brown) & 25.4 & 0.54 & 17.5 & 38.6 & 0.20 & 11.0 & 0.21 & - & 0.16 & 0.13 & - & 8.09 & 101.9 \\
\hline AW32 & Phbw & DDH -229 & 164.6 & $2.5 \mathrm{R} 4 / 4$ (reddish brown) & 21.5 & 1.02 & 16.0 & 47.1 & 0.24 & 8.47 & 0.10 & - & 0.02 & 0.06 & - & 6.89 & 101.5 \\
\hline AW36 & Phbw & DDH-229 & 168.0 & 5YR 4.5/2 (reddish grey) & 25.8 & 0.82 & 20.3 & 36.6 & 0.18 & 9.02 & 0.14 & - & 0.02 & 0.09 & - & 8.91 & 101.9 \\
\hline AW37 & Phbw & DDH-229 & 169.5 & 5YR 4.5/2 (reddish grey) & 27.1 & 1.14 & 21.0 & 34.0 & 0.16 & 7.93 & 0.11 & - & 0.03 & 0.09 & 0.02 & 9.75 & 101.4 \\
\hline AW38 & Phbw & DDH-229 & 169.9 & $2.5 Y R 4 / 6(\mathrm{red})$ & 27.0 & 1.15 & 21.6 & 37.2 & 0.08 & 3.49 & 0.14 & - & 0.04 & 0.23 & - & 10.0 & 101.0 \\
\hline AW39A & Phbw & DDH-229 & 170.5 & 5YR 4.5/2 (reddish grey) & 29.9 & 0.58 & 23.2 & 28.7 & 0.12 & 6.25 & 0.11 & - & 0.49 & 0.13 & - & 10.9 & 100.4 \\
\hline AW39B & Phbw & DDH-229 & 170.8 & 4.5YR 4/6 (red) & 28.1 & 1.11 & 23.8 & 36.0 & - & 0.16 & 0.09 & - & 0.02 & 0.44 & - & 10.4 & 100.1 \\
\hline AW40 & Phbw & $\mathrm{DDH}-229$ & 170.1 & $10 \mathrm{R} 4 / 8(\mathrm{red})$ & 32.6 & 0.89 & 25.5 & 29.1 & - & 0.50 & 0.16 & - & 1.68 & 0.51 & 0.01 & 9.51 & 100.4 \\
\hline $124 \mathrm{C}$ & Phbw & Pit face & $\mathrm{C}$ & $2.5 Y R \quad 4 / 8(\mathrm{red})$ & 26.5 & 0.41 & 21.9 & 39.2 & - & 0.16 & 0.10 & - & 0.02 & 0.42 & - & 10.9 & 99.6 \\
\hline $324 \mathrm{C}$ & Phbw & Pit face & $\mathrm{C}$ & 2.5 YR $4 / 8(\mathrm{red})$ & 24.3 & 0.70 & 20.5 & 42.2 & - & 0.11 & 0.09 & - & 0.02 & 0.49 & - & 10.3 & 98.7 \\
\hline
\end{tabular}


Appendix 3.1. (continued)

\begin{tabular}{|c|c|c|c|c|c|c|c|c|c|c|c|c|c|c|c|c|c|}
\hline Sample & Unit & Location & Depth $^{\mathrm{n}} /$ Face $^{\mathrm{b}}$ & Powder Colour & $\mathrm{SiO}_{2}$ & $\mathrm{TiO}_{2}$ & $\mathrm{Al}_{2} \mathrm{O}_{3}$ & $\mathrm{Fe}_{2} \mathrm{O}_{3} \mathrm{~T}$ & Mno & $\mathrm{MgO}$ & $\mathrm{CaO}$ & $\mathrm{Na}_{2} \mathrm{O}$ & $\mathbf{K}_{2} \mathbf{O}$ & $\mathbf{P}_{2} \mathbf{O}_{5}$ & $\mathrm{~s}$ & LOI & SUM \\
\hline $424 \mathrm{C}$ & Phbw & Pit face & $\mathrm{C}$ & 2.5 YR $4 / 8$ (red) & 24.8 & 0.41 & 21.3 & 41.4 & - & 0.12 & 0.09 & 0.18 & 0.02 & 0.56 & - & 10.6 & 99.5 \\
\hline WS5 & Phbw & Pit face & $\mathrm{E}$ & 5YR $3 / 2$ (dark reddish brown) & 21.7 & 0.80 & 17.4 & 43.9 & 0.20 & 3.88 & 0.13 & 0.25 & 0.04 & 0.15 & 0.02 & 11.9 & 100.3 \\
\hline WS9 & Phbw & Pit face & $\mathrm{E}$ & 5YR 5/3 (reddish brown) & 26.5 & 0.72 & 20.8 & 32.3 & 0.30 & 9.83 & 0.06 & 0.13 & 0.03 & 0.04 & 0.01 & 9.66 & 100.4 \\
\hline D86B & DS16 & DDH-86 & 236.6 & 2.5 YR $4 / 6(\mathrm{red})$ & 21.9 & 0.01 & 17.6 & 46.8 & 0.06 & 0.14 & 0.22 & - & 0.03 & 0.90 & - & 11.8 & 100.0 \\
\hline AW 14 & DS16 & Pit face & $\mathrm{O}$ & $2.5 \mathrm{YR} 4 / 8(\mathrm{red})$ & 29.0 & 0.71 & 25.0 & 35.2 & - & - & 0.13 & - & 0.02 & 0.64 & 0.01 & 10.3 & 100.8 \\
\hline $125 \mathrm{E}$ & DS16 & Pit face & D & 5YR 5/2 (reddish grey) & 29.2 & 0.83 & 22.9 & 28.6 & 0.11 & 5.99 & 0.12 & 0.14 & 0.03 & 0.13 & - & 12.3 & 100.3 \\
\hline AW13 & DS15 & Pit face & $\mathrm{O}$ & $2.5 \mathrm{YR} 4 / 7$ (red) & 32.8 & 0.91 & 28.1 & 27.0 & 0.11 & - & 0.13 & - & 0.02 & 0.38 & - & 11.2 & 100.7 \\
\hline AW12 & DS14 & Pit face & o & $2.5 Y R 5 / 6$ (red) & 32.9 & 1.09 & 28.3 & 25.9 & 0.07 & 0.11 & 0.12 & - & 0.01 & 0.45 & 0.01 & 11.6 & 100.6 \\
\hline AW11 & DS13 & Pit face & O & $2.5 Y R 4 / 8(\mathrm{red})$ & 32.3 & 1.35 & 27.3 & 28.1 & - & 0.12 & 0.11 & - & 0.02 & 0.21 & - & 11.2 & 100.7 \\
\hline $\mathrm{AW} 10$ & DS12 & Pit face & 0 & 2.5 YR $4.5 / 8$ (red) & 37.6 & 1.07 & 31.8 & 17.1 & - & - & 0.09 & - & 0.01 & 0.16 & - & 12.3 & 100.2 \\
\hline $\mathrm{C} 25 \mathrm{E}$ & DS11 & Pit face & $\mathrm{D}$ & 2.5 YR $4 / 4$ (reddish brown) & 28.9 & 0.92 & 21.7 & 30.2 & 0.10 & 4.65 & 0.16 & - & 0.04 & 0.14 & - & 13.4 & 100.2 \\
\hline D25E & DS11 & Pit face & D & 2.5 YR $4 / 4$ (reddish brown) & 29.1 & 0.97 & 21.9 & 31.6 & 0.06 & 3.77 & 0.17 & 0.18 & 0.84 & 0.17 & - & 11.3 & 100.0 \\
\hline AW9 & DS11 & Pit face & $\mathrm{O}$ & $2.5 \mathrm{YR} 4 / 7(\mathrm{red})$ & 27.7 & 0.95 & 22.6 & 40.1 & - & - & 0.10 & - & 0.02 & 0.16 & - & 9.08 & 100.8 \\
\hline $1025 \mathrm{E}$ & DS10 & Pit face & $\mathrm{D}$ & 5 YR $4.5 / 3$ (reddish brown) & 33.9 & 1.03 & 25.9 & 19.2 & 0.20 & 4.88 & 0.16 & - & 0.15 & 0.11 & - & 14.3 & 99.8 \\
\hline AW8 & DS10 & Pit face & $\mathrm{O}$ & $2.5 Y R$ 3/6 (dark red) & 27.1 & 0.91 & 22.5 & 39.9 & - & - & 0.15 & - & 0.04 & 0.53 & - & 9.50 & 100.6 \\
\hline AW6 & DS9 & Pit face & 0 & 2.5 YR $3.5 / 6$ (red) & 27.3 & 0.62 & 22.1 & 40.7 & - & 0.64 & 0.15 & - & 0.12 & 0.28 & 0.01 & 9.01 & 101.0 \\
\hline AW5 & DS8 & Pit face & 0 & 2.5YR 3.5/4 (reddish brown) & 23.0 & 0.66 & 18.3 & 49.5 & - & 0.29 & 0.17 & - & 0.02 & 0.51 & - & 8.34 & 100.7 \\
\hline AW4 & DS7 & Pit face & 0 & 2.5YR 4/4 (reddish brown) & 27.3 & 0.85 & 22.4 & 38.7 & - & 0.38 & 0.18 & - & 0.02 & 0.77 & - & 10.2 & 100.8 \\
\hline AW3 & DS6 & Pit face & $\mathrm{O}$ & 2.5YR $3 / 4$ (dark reddish brown) & 22.5 & 0.74 & 17.6 & 45.3 & 0.12 & 6.30 & 0.16 & - & 0.04 & 0.15 & - & 8.49 & 101.4 \\
\hline $6 \mathrm{EDC}$ & DS6 & Pit face & A & $2.5 \mathrm{YR} 4 / 6(\mathrm{red})$ & 28.6 & 1.30 & 22.4 & 31.3 & 0.08 & 3.57 & 0.14 & - & 0.03 & 0.20 & 0.01 & 11.9 & 99.6 \\
\hline AW2 & DS5 & Pit face & $\mathrm{O}$ & $2.5 \mathrm{YR} 4 / 7$ (red) & 26.3 & 0.91 & 23.8 & 38.0 & - & - & 0.12 & - & 0.01 & 0.61 & - & 10.9 & 100.6 \\
\hline AW1 & DS4 & Pit face & $\mathrm{o}$ & $2.5 \mathrm{YR} 3.5 / 6$ (red) & 24.4 & 1.55 & 19.1 & 42.6 & 0.16 & 3.58 & 0.17 & - & 0.04 & 0.33 & - & 9.20 & 101.2 \\
\hline $4 E D C$ & DS4 & Pit face & A & 10R $5 / 3$ (weak red) & 33.8 & 1.06 & 26.5 & 20.7 & 0.12 & 3.49 & 0.14 & 0.16 & 0.04 & 0.22 & 0.02 & 13.3 & 99.5 \\
\hline $3 \mathrm{EDC}$ & DS3 & Pit face & A & 5YR 6/4 (light reddish brown) & 36.9 & 1.63 & 29.7 & 16.4 & - & 0.70 & 0.08 & - & 0.02 & 0.12 & 0.01 & 13.0 & 98.6 \\
\hline AW 17 & $\mathrm{Phr}$ & DDH-324 & 139.0 & 5YR 4/6 (yellowish red) & 24.6 & 0.53 & 19.3 & 34.0 & 0.64 & 12.2 & 1.06 & - & 0.02 & 0.07 & - & 8.85 & 101.2 \\
\hline $5 \mathrm{~A} 23$ & $\mathrm{Phr}$ & Pit face & B & $2.5 Y R 4 / 6$ (red) & 26.6 & 1.41 & 22.1 & 36.8 & - & 0.18 & 0.13 & - & 0.02 & 0.41 & - & 12.1 & 99.7 \\
\hline $5 \mathrm{~B} 23$ & $\mathrm{Phr}$ & Pit face & B & $2.5 Y R$ 4/6 (red) & 24.6 & 1.38 & 20.6 & 40.4 & 0.11 & 0.12 & 0.13 & - & 0.02 & 0.47 & - & 12.3 & 100.2 \\
\hline 823 & Phr & Pit face & B & $2.5 Y R \quad 4 / 6$ (red) & 24.9 & 1.73 & 21.1 & 39.9 & 0.07 & 0.15 & 0.22 & - & 0.02 & 0.57 & - & 11.8 & 100.4 \\
\hline 1023 & $\mathrm{Phr}$ & Pit face & B & $2.5 Y R \quad 4 / 6$ (red) & 24.9 & 1.55 & 21.3 & 38.2 & - & 0.14 & 0.12 & - & 0.02 & 0.63 & - & 12.8 & 99.6 \\
\hline 1223 & $\mathrm{Phr}$ & Pit face & B & $2.5 \mathrm{YR} 4 / 6$ (red) & 27.4 & 0.99 & 22.9 & 37.7 & - & 0.16 & 0.11 & - & 0.01 & 0.44 & - & 10.7 & 100.4 \\
\hline $325 \mathrm{E}$ & Phr & Pit face & $\mathrm{D}$ & 5YR $6.5 / 2$ (pinkish grey) & 56.1 & 0.85 & 21.0 & 8.12 & - & 2.70 & 0.08 & - & 6.64 & 0.08 & - & 4.46 & 99.9 \\
\hline $425 \mathrm{E}$ & Phr & Pit face & D & 2.5 YR $5 / 4$ (reddish brown) & 41.4 & 0.82 & 24.1 & 14.1 & - & 3.68 & 1.35 & - & 7.33 & 0.99 & - & 5.98 & 99.8 \\
\hline $525 \mathrm{E}$ & $\mathrm{Phr}$ & Pit face & D & 5YR 4/6 (yellowish red) & 33.5 & 0.58 & 21.7 & 24.4 & 0.10 & 7.77 & 0.10 & - & 3.48 & 0.06 & - & 8.69 & 100.4 \\
\hline
\end{tabular}


Appendix 3.1. (continued)

\begin{tabular}{|c|c|c|c|c|c|c|c|c|c|c|c|c|c|c|c|c|c|}
\hline Sample & Unit & Location & Depth $^{2} /$ Face $^{6}$ & Powder Colour & $\mathrm{SiO}_{2}$ & $\mathrm{TiO}_{2}$ & $\mathrm{Al}_{2} \mathrm{O}_{3}$ & $\mathrm{Fe}_{2} \mathrm{O}_{3} \mathrm{~T}$ & $\mathrm{MnO}$ & $\mathrm{MgO}$ & $\mathrm{CaO}$ & $\mathrm{Na}_{2} \mathrm{O}$ & $\mathrm{K}_{2} \mathrm{O}$ & $\mathrm{P}_{2} \mathrm{O}_{5}$ & $\mathrm{~S}$ & LOI & SUM \\
\hline D4097 & Phr & DDH-409 & 245.10 & 2.5 YR $4 / 6$ (red) & 18.6 & 0.40 & 12.5 & 49.9 & 0.24 & 9.78 & 0.75 & 0.20 & 0.05 & 0.32 & 0.02 & 7.20 & 100.1 \\
\hline D40910 & $\mathrm{Phr}$ & DDH -409 & 238.23 & 2.5 YR 4/6 (red) & 19.5 & 1.55 & 13.3 & 49.3 & 0.27 & 7.70 & 0.28 & 0.17 & 0.04 & 0.13 & 0.01 & 8.00 & 100.3 \\
\hline \multicolumn{18}{|c|}{ Shaley Ore } \\
\hline SBS2 & Phbw & DDH-257 & 47.0 & 2.5 YR 3/6 (dark red) & 6.90 & 0.01 & 0.60 & 90.3 & - & 0.30 & 0.22 & - & 0.04 & 0.22 & - & 1.64 & 100.2 \\
\hline SBS3 & Phbw & $\mathrm{DDH}-257$ & 47.8 & 10R 3/2 (dusky red) & 5.10 & 0.03 & 1.30 & 87.9 & - & 1.60 & 0.22 & - & 0.06 & 0.27 & 0.01 & 2.43 & 99.0 \\
\hline $\mathrm{AW} 22$ & Phbw & DDH-257 & 48.1 & 2.5YR $3 / 4$ (dark reddish brown) & 6.54 & 0.39 & 4.51 & 84.7 & - & 0.58 & 0.17 & - & 0.03 & 0.32 & - & 4.35 & 101.6 \\
\hline AW 23 & Phbw & DDH-257 & 48.3 & 5YR 3/2 (dark reddish brown) & 13.6 & 2.18 & 10.4 & 63.7 & 0.10 & 1.36 & 0.14 & - & 0.02 & 0.32 & - & 9.44 & 101.3 \\
\hline SBS8 & Phbw & DDH-257 & 50.8 & 10R $3 / 6$ (dark red) & 5.20 & 0.14 & 3.50 & 88.5 & - & - & 0.09 & - & 0.08 & 0.15 & - & 2.69 & 100.3 \\
\hline AW28 & Phbw & $\mathrm{DDH}-257$ & 51.3 & 10YR $4 / 4$ (dark yellowish brown) & 8.49 & 0.62 & 10.8 & 64.0 & 3.03 & 0.66 & 0.14 & - & 0.09 & 1.09 & - & 12.1 & 101.0 \\
\hline AW28B & Phbw & DDH-257 & 51.4 & 5YR 3/4 (dark reddish brown) & 9.86 & 1.15 & 12.1 & 62.8 & 1.07 & 0.25 & 0.26 & - & 0.03 & 1.41 & - & 10.7 & 99.6 \\
\hline AW33 & Phbw & DDH-229 & 165.2 & 10R $3.5 / 6$ (red) & 10.2 & 0.15 & 7.93 & 76.8 & 0.22 & 2.98 & 0.09 & - & 0.02 & 0.06 & - & 3.39 & 101.9 \\
\hline AW34 & Phbw & $\mathrm{DDH}-229$ & 165.8 & 10R 3/6 (dark red) & 2.80 & 0.01 & 1.90 & 75.7 & - & 0.56 & 11.2 & - & 0.02 & 8.15 & - & 1.02 & 101.3 \\
\hline AW35 & Phbw & $\mathrm{DDH}-229$ & 166.6 & $2.5 \mathrm{YR} 3 / 6$ (dark red) & 15.8 & 0.76 & 11.8 & 61.7 & 0.17 & 5.69 & 0.11 & - & 0.02 & 0.13 & 0.01 & 5.72 & 101.9 \\
\hline AW39 & Phbw & DDH-229 & 171.2 & 5YR 5/2 (reddish grey) & 6.32 & 0.13 & 4.79 & 84.9 & 0.21 & - & 1.29 & - & 0.03 & 0.34 & 0.02 & 2.65 & 100.6 \\
\hline WS7 & Phbw & Pit face & $E$ & 2.5YR 3/6 (dark red) & 3.46 & 0.06 & 2.22 & 93.3 & - & 0.32 & 0.09 & - & 0.03 & 0.13 & - & 0.57 & 100.2 \\
\hline WS8 & Phbw & Pit face & $\mathrm{E}$ & 2.5YR 3/6 (dark red) & 2.36 & 0.04 & 1.56 & 92.9 & - & 0.14 & 0.49 & 0.38 & 0.04 & 0.41 & - & 1.40 & 99.8 \\
\hline D73F & DS16 & DDH-73 & 244.0 & 2.5 YR $4 / 4$ (reddish brown) & 16.5 & 0.01 & 13.0 & 55.9 & 1.91 & 0.15 & 0.24 & - & 0.03 & 0.83 & - & 9.75 & 99.3 \\
\hline F25E & DS15 & Pit face & $\mathrm{D}$ & 2.5 YR $4.5 / 2$ (weak red) & 7.59 & 0.08 & 6.43 & 80.3 & 0.10 & 1.78 & 0.07 & - & 0.02 & 0.18 & - & 3.18 & 99.7 \\
\hline 423 & Phr & Pit face & B & 10R $3 / 6$ (dark red) & 0.78 & 0.03 & 0.29 & 83.5 & - & 2.32 & 5.31 & - & 0.02 & 0.25 & . & 6.46 & 99.0 \\
\hline 623 & $\mathrm{Phr}$ & Pit face & $\mathrm{B}$ & $2.5 \mathrm{YR} 4 / 6$ (red) & 14.2 & 0.44 & 12.1 & 68.1 & 0.06 & - & 0.07 & - & 0.04 & 0.22 & - & 5.33 & 100.6 \\
\hline D4099 & $\mathrm{Phr}$ & $\mathrm{DDH}-409$ & 238.96 & 2.5 YR $3 / 6$ (dark red) & 1.10 & 0.02 & 0.89 & 97.0 & - & 0.25 & 0.11 & - & 0.02 & 0.15 & 0.02 & 0.90 & 100.4 \\
\hline D40912 & $\mathrm{Phr}$ & DDH-409 & 236.83 & 2.5 YR $3 / 6$ (dark red) & 7.40 & 0.05 & 6.70 & 83.2 & - & - & 0.06 & - & 0.02 & 0.21 & 0.01 & 2.90 & 100.6 \\
\hline
\end{tabular}

Notes: Phbw = Whaleback Shale Member; $\mathrm{DB}=$ Dales Gorge BIF macroband; DS = Dales Gorge shale macroband; Phr = Mt. McRae Shale; $\mathrm{DDH}=$ diamond drill hole; Weeli Wolli $=$ Welli Wolli Spring; Fe $\mathrm{O}_{3} \mathrm{~T}=$ total iron; ' -1 ' = below detection ${ }^{2}$ blank $=$ not deternined. Depth ${ }^{a}$ refers to vertical distance $(\mathrm{m})$ on detailed logs in appendix 1 ; Face ${ }^{b}$ refers to the face locations shown in appendix 1.1 . Powder colour numbers and letters refer to the Munsell colour attributes of hue, value and chroma (Munsell, 1966). 
Appendix 3.2. Trace element composition of rocks across the Hamersley Province

\begin{tabular}{|c|c|c|c|c|c|c|c|c|c|c|c|c|c|c|c|c|c|c|}
\hline Sample & Unit & Location & As & $\mathrm{Ba}$ & Co & $\mathrm{Cr}$ & $\mathrm{Cs}^{*}$ & $\mathrm{Hf}^{*}$ & $\mathrm{Nb}$ & $\mathrm{Ni}$ & $\mathrm{Pb}$ & $\mathrm{Rb}$ & $\mathrm{Sc}^{*}$ & $\mathrm{Sr}$ & $\mathrm{V}$ & $\mathrm{Y}$ & $\mathrm{Zn}$ & $\mathrm{Zr}$ \\
\hline \multicolumn{19}{|c|}{ Northern Hamersley Province } \\
\hline \multicolumn{19}{|c|}{ Banded iron-formation (BIF) } \\
\hline 473 & $\mathrm{DB} 16$ & $\mathrm{DDH}-47 \mathrm{~A}$ & - & 117.0 & - & 20.0 & & & - & 9.7 & - & 108.0 & & 57.3 & - & 23.9 & 22.8 & 8.7 \\
\hline 472 & DB16 & $\mathrm{DDH}-47 \mathrm{~A}$ & - & 44.0 & 4.0 & - & & & - & 9.9 & 12.0 & 119.0 & & 36.2 & - & 20.2 & 14.0 & 4.8 \\
\hline 4748 & DB16 & $\mathrm{DDH}-47 \mathrm{~A}$ & - & 69.0 & 2.8 & 22.0 & & & - & 10.7 & - & 99.7 & & 25.3 & - & 24.3 & 14.6 & 4.3 \\
\hline 4747 & DB16 & $\mathrm{DDH}-47 \mathrm{~A}$ & - & 198.0 & 6.2 & - & & & - & 8.7 & - & 69.2 & & 65.1 & - & 14.1 & 15.4 & - \\
\hline 4746 & DB16 & $\mathrm{DDH}-47 \mathrm{~A}$ & - & 70.0 & 3.0 & - & & & - & 10.0 & 11.0 & 110.0 & & 84.0 & - & 17.0 & 12.0 & 8.0 \\
\hline 474 & DB15 & $\mathrm{DDH}-47 \mathrm{~A}$ & - & 35.0 & 14.4 & - & & & - & 7.1 & - & 13.0 & & 35.2 & - & 9.1 & - & - \\
\hline 477 & DB14 & $\mathrm{DDH}-47 \mathrm{~A}$ & - & 36.0 & 10.9 & - & & & - & 5.3 & 10.4 & 9.2 & & 12.0 & - & 7.1 & - & - \\
\hline 479 & DB13 & $\mathrm{DDH}-47 \mathrm{~A}$ & - & 44.0 & 8.0 & 8.9 & & & - & 7.2 & 11.8 & 15.0 & & 46.9 & - & 11.1 & 7.3 & 3.0 \\
\hline 4712 & DB12 & $\mathrm{DDH}-47 \mathrm{~A}$ & - & - & 44.4 & 5.8 & & & 2.3 & - & - & - & & 7.8 & - & 13.3 & - & - \\
\hline 4715 & DB11 & $\mathrm{DDH}-47 \mathrm{~A}$ & - & - & 19.7 & - & - & - & 3.0 & 6.3 & - & - & 0.2 & - & - & 7.9 & 10.2 & - \\
\hline 4719 & DB10 & $\mathrm{DDH}-47 \mathrm{~A}$ & - & 14.0 & 21.6 & 22.0 & & & - & 10.3 & 11.4 & 9.8 & & 5.5 & - & 12.2 & - & 4.1 \\
\hline 4722 & DB8 & DDH-47A & - & 10.0 & 17.0 & - & & & - & 7.8 & - & 16.0 & & 12.0 & - & 14.4 & - & 5.1 \\
\hline 4724 & DB7 & $\mathrm{DDH}-47 \mathrm{~A}$ & - & - & 31.2 & - & & & - & 7.2 & - & - & & 11.0 & - & 7.3 & - & - \\
\hline 4729 & DB5 & $\mathrm{DDH}-47 \mathrm{~A}$ & - & 16.0 & 12.8 & 32.0 & & & - & 5.7 & 11.3 & 10.0 & & 7.5 & - & 12.3 & 11.0 & - \\
\hline 4735 & DB3 & $\mathrm{DDH}-47 \mathrm{~A}$ & - & 34.0 & 8.9 & 17.0 & - & - & - & 7.8 & - & 11.0 & 0.4 & 64.0 & - & 13.6 & 5.2 & - \\
\hline 4737 & DB2 & $\mathrm{DDH}-47 \mathrm{~A}$ & - & 310.0 & 14.4 & 24.0 & & & 1.6 & 13.7 & 11.3 & 123.0 & & 14.0 & - & 23.1 & 10.0 & 66.0 \\
\hline 4739 & DB1 & DDH-47A & - & 21.0 & 6.0 & 15.0 & & & - & 6.8 & 10.5 & 15.0 & & 61.9 & - & 12.2 & 12.0 & - \\
\hline 4740 & DB1 & $\mathrm{DDH}-47 \mathrm{~A}$ & - & 32.0 & - & 9.5 & & & - & 5.8 & - & 21.6 & & 16.6 & - & 12.4 & 23.8 & - \\
\hline 4742 & DBO & $\mathrm{DDH}-47 \mathrm{~A}$ & - & 14.0 & 14.3 & 19.0 & - & - & - & 7.3 & - & 6.1 & 0.5 & 23.9 & - & 12.0 & - & - \\
\hline JGA10 & DB3 & DDH-JG1 & - & 207.0 & 6.9 & 28.3 & & & 2.6 & 12.4 & 11.9 & 39.5 & & 27.9 & 20.2 & 19.8 & 54.1 & 78.7 \\
\hline IGA7 & DB2 & DDH-JG1 & - & 24.0 & 7.2 & 27.0 & & & 2.1 & 7.2 & 10.2 & 12.0 & & 28.2 & 8.0 & 13.0 & 123.0 & 7.3 \\
\hline JGA4 & DB1 & DDH-JG1 & - & 11.0 & 16.6 & 16.0 & & & 2.2 & 5.7 & - & - & & 12.8 & - & 7.3 & - & - \\
\hline BGI & DB15 & Bee Gorge & - & 12.0 & 21.0 & 45.0 & - & - & - & 6.0 & - & 14.0 & 0.2 & 4.0 & - & 9.0 & - & - \\
\hline $\mathrm{BG} 2$ & DB14 & Bee Gorge & - & - & 46.0 & - & & & - & 7.0 & - & 5.0 & & 18.0 & - & 3.0 & - & - \\
\hline BG4 & DB13 & Bee Gorge & - & 32.0 & 19.0 & 27.0 & - & - & - & 7.0 & - & 11.0 & 0.2 & 44.0 & - & 7.0 & - & - \\
\hline BG6 & DB12 & Bee Gorge & - & 10.0 & 27.0 & 25.0 & & & - & 6.0 & - & - & & 6.0 & - & 7.0 & - & - \\
\hline BG8 & DB11 & Bee Gorge & - & - & 37.0 & 6.0 & & & 3.0 & 5.0 & - & - & & 2.0 & - & 4.0 & - & - \\
\hline BG10 & DB10 & Bee Gorge & - & - & 23.0 & 31.0 & & & - & 5.0 & 12.0 & - & & 5.0 & $\sim$ & 9.0 & - & - \\
\hline \multicolumn{19}{|c|}{ Black shale } \\
\hline $47 \mathrm{~W} 11$ & Phbw & DDH-47A & - & 476.0 & - & - & & & - & 17.0 & 10.0 & 109.0 & & 29.4 & 18.0 & 22.2 & 35.7 & 33.0 \\
\hline $47 \mathrm{~W} 10$ & Phbw & DDH-47A & - & 189.0 & - & 27.9 & 21.4 & 1.1 & 3.8 & 21.9 & 10.0 & 187.1 & 5.0 & 34.7 & 42.0 & 33.8 & 44.9 & 42.2 \\
\hline
\end{tabular}


Appendix 3.2. (continued).

\begin{tabular}{|c|c|c|c|c|c|c|c|c|c|c|c|c|c|c|c|c|c|c|}
\hline Sample & Unit & Location & As & $\mathrm{Ba}$ & $\mathrm{Co}$ & $\mathrm{Cr}$ & $\mathrm{Cs}^{*}$ & $\mathrm{Hf} *$ & $\mathrm{Nb}$ & $\mathrm{Ni}$ & $\mathrm{Pb}$ & $\mathrm{Rb}$ & $\mathrm{Sc}^{*}$ & $\mathrm{Sr}$ & $\mathrm{V}$ & $\mathrm{Y}$ & $\mathrm{Zn}$ & $\mathrm{Zr}$ \\
\hline $47 \mathrm{WI}$ & Phbw & $\mathrm{DDH}-47 \mathrm{~A}$ & 13.0 & 135.0 & 13.0 & 65.0 & & & 6.0 & 37.0 & 10.0 & 127.0 & & 31.0 & 79.0 & 22.0 & 181.0 & 75.0 \\
\hline $47 \mathrm{~W} 6$ & Phbw & $\mathrm{DDH}-47 \mathrm{~A}$ & 28.0 & 185.0 & 21.0 & 60.0 & & & 7.0 & 40.0 & 11.0 & 245.0 & & 21.0 & 80.0 & 25.0 & 76.0 & 89.0 \\
\hline $47 \mathrm{~W} 5$ & Phbw & $\mathrm{DDH}-47 \mathrm{~A}$ & - & 92.9 & 10.5 & 55.2 & & & 5.7 & 29.9 & - & 98.0 & & 9.1 & 58.0 & 42.4 & 91.2 & 77.8 \\
\hline AW44 & DS16 & DDH-47A & 68.5 & 263.0 & 27.0 & 12.4 & 10.4 & 0.5 & 5.5 & 18.4 & 11.7 & 108.4 & 5.1 & 161.2 & 102.5 & 27.4 & 148.4 & 29.4 \\
\hline 475 & DS 15 & $\mathrm{DDH}-47 \mathrm{~A}$ & - & 355.0 & 29.8 & 39.3 & & & - & 40.3 & - & 403.6 & & 71.8 & 47.1 & 27.6 & 112.0 & 63.1 \\
\hline 478 & DS14 & $\mathrm{DDH}-47 \mathrm{~A}$ & - & 389.0 & 22.6 & 44.4 & & & 2.3 & 33.8 & 13.9 & 463.6 & & 32.9 & 69.2 & 31.6 & 184.3 & 218.7 \\
\hline 4711 & DS13 & $\mathrm{DDH}-47 \mathrm{~A}$ & - & 447.0 & 24.9 & 41.7 & & & 3.9 & 38.3 & - & 363.3 & & 24.2 & 63.7 & 18.8 & 124.0 & 78.4 \\
\hline 4713 & DS12 & $\mathrm{DDH}-47 \mathrm{~A}$ & 15.3 & 383.0 & 27.9 & 33.4 & & & 2.0 & 43.5 & 15.3 & 182.7 & & 10.5 & 52.0 & 42.9 & 121.0 & 62.0 \\
\hline AW43 & DS11 & DDH-47A & 36.8 & 257.8 & 10.2 & 72.5 & & & 18.8 & 48.4 & 19.3 & 155.6 & & 20.6 & 74.7 & 60.0 & 394.4 & 428.3 \\
\hline 4718 & DS11 & $\mathrm{DDH}-47 \mathrm{~A}$ & - & 111.0 & 15.5 & 54.2 & 14.4 & 1.8 & 5.4 & 30.5 & - & 142.4 & 9.3 & 9.3 & 52.3 & 15.4 & 208.5 & 64.3 \\
\hline 4720 & DS10 & DDH-47A & - & 85.4 & - & 20.6 & & & 3.5 & 22.6 & - & 83.8 & & 8.0 & 32.0 & 44.8 & 53.1 & 32.3 \\
\hline AW42 & DS9 & DDH-47A & 110.7 & 224.5 & 3.5 & 85.3 & & & 13.4 & 73.7 & 85.4 & 184.1 & & 14.2 & 65.7 & 27.3 & 448.5 & 172.6 \\
\hline 4723 & DS8 & $\mathrm{DDH}-47 \mathrm{~A}$ & 18.7 & 156.0 & 25.7 & 22.9 & & & 12.4 & 27.5 & 30.1 & 102.0 & & 9.3 & 47.5 & 47.1 & 170.6 & 346.7 \\
\hline 4725 & DS? & $\mathrm{DDH}-47 \mathrm{~A}$ & 20.5 & 161.0 & 11.1 & 98.4 & & & 8.3 & 31.8 & 40.8 & 123.0 & & 6.9 & 99.3 & 16.5 & 418.7 & 98.6 \\
\hline 4726 & DS6 & $\mathrm{DDH}-47 \mathrm{~A}$ & - & 43.0 & 5.8 & 25.0 & & & 2.9 & 17.9 & - & 79.0 & & 46.3 & 22.0 & 15.9 & 23.1 & 19.0 \\
\hline 4727 & DS6 & DDH-47A & 33.7 & 183.0 & 24.3 & 47.2 & & & 5.9 & 67.1 & 68.7 & 122.0 & & 26.8 & 64.3 & 25.8 & 161.3 & 75.8 \\
\hline 4730 & DS5 & $\mathrm{DDH}-47 \mathrm{~A}$ & - & 534.0 & 14.1 & 45.6 & & & - & 37.9 & - & 510.6 & & 25.7 & 50.1 & 15.7 & 61.9 & 60.4 \\
\hline 4732 & DS4 & $\mathrm{DDH}-47 \mathrm{~A}$ & 53.2 & 874.0 & 36.8 & 29.1 & & & 4.4 & 196.3 & - & 224.7 & & 59.3 & 64.4 & 17.0 & 45.6 & 60.4 \\
\hline 4733 & DS4 & $\mathrm{DDH}-47 \mathrm{~A}$ & - & 216.0 & 16.8 & 43.0 & & & - & 10.3 & - & 128.0 & & 43.5 & 41.0 & 26.5 & 69.4 & 3.9 \\
\hline 4736 & DS3 & $\mathrm{DDH}-47 \mathrm{~A}$ & - & 655.0 & 14.8 & 55.0 & & & - & 36.5 & 12.7 & 451.0 & & 65.8 & 54.5 & 37.6 & 51.3 & 40.2 \\
\hline AW41 & DS2 & $\mathrm{DDH}-47 \mathrm{~A}$ & - & 938.1 & 25.1 & 105.8 & & & 11.6 & 51.2 & - & 313.0 & & 131.1 & 113.5 & 19.9 & 158.4 & 139.3 \\
\hline 4738 & DS2 & $\mathrm{DDH}-47 \mathrm{~A}$ & - & 1050.0 & 37.7 & 77.1 & & & 2.3 & 44.8 & 13.0 & 375.6 & & 80.9 & 78.9 & 16.7 & 72.1 & 78.5 \\
\hline 4741 & DS1 & $\mathrm{DDH}-47 \mathrm{~A}$ & 18.1 & 938.0 & 42.8 & 42.4 & & & 2.5 & 43.8 & 10.3 & 300.3 & & 65.5 & 42.0 & 18.5 & 80.4 & 75.3 \\
\hline 4743 & Phr & DDH-47A & - & 629.0 & 16.1 & 87.0 & & & 5.4 & 35.5 & - & 317.4 & & 16.1 & 80.4 & 21.0 & 93.8 & 125.6 \\
\hline 4745 & Phr & DDH-47A & 13.2 & 433.0 & 15.3 & 47.8 & 21.8 & 1.4 & 3.1 & 28.5 & - & 217.2 & 7.3 & 25.7 & 50.1 & 10.5 & 84.2 & 55.5 \\
\hline \multicolumn{19}{|c|}{ Southeastern Hamersley Province } \\
\hline \multicolumn{19}{|c|}{ Banded iron-formation (BIF) } \\
\hline WW9 & DB16 & Weeli Wolli Spring & - & 65.0 & 26.0 & 46.0 & & & - & 8.0 & 10.0 & - & & 8.0 & - & 8.0 & - & - \\
\hline WW10 & DB15 & Weeli Wolli Spring & - & 16.0 & 22.0 & 25.0 & & & - & 11.0 & - & - & & 3.0 & - & 6.0 & - & - \\
\hline WW11 & DB14 & Weeli Wolli Spring & - & 19.0 & 24.0 & 31.0 & & & - & 15.0 & - & - & & 3.0 & - & 6.0 & - & - \\
\hline WW12 & DB13 & Weeli Wolli Spring & - & 47.0 & 36.0 & 50.0 & & & - & 9.0 & - & - & & 9.0 & - & 10.0 & - & - \\
\hline WW13 & DB12 & Weeli Wolli Spring & - & - & 34.0 & 30.0 & & & - & 8.0 & - & - & & 2.0 & - & 6.0 & - & - \\
\hline WW8 & DB6 & Weeli Wolli Spring & - & - & 27.0 & 25.0 & & & - & 14.0 & - & - & & 4.0 & - & 8.0 & - & 4.0 \\
\hline
\end{tabular}




\begin{tabular}{|c|c|c|c|c|c|c|c|c|c|c|c|c|c|c|c|c|c|c|}
\hline Sample & Unit & Location & As & $\mathrm{Ba}$ & $\mathrm{Co}$ & $\mathrm{Cr}$ & $\mathrm{Cs}^{*}$ & $\mathrm{Hf}^{*}$ & $\mathrm{Nb}$ & $\mathrm{Ni}$ & $\mathrm{Pb}$ & $\mathrm{Rb}$ & Sc* & $\mathrm{Sr}$ & $\mathrm{V}$ & $\mathrm{Y}$ & $\mathrm{Zn}$ & $\mathrm{Zr}$ \\
\hline WW? & DB5 & Weeli Wolli Spring & - & - & 24.0 & 59.0 & & & - & 13.0 & 12.0 & - & & 3.0 & - & 12.0 & - & - \\
\hline WW6 & DB4 & Weeli Wolli Spring & - & 12.0 & 26.0 & 50.0 & & & - & 8.0 & 13.0 & - & & 7.0 & - & 10.0 & - & 4.0 \\
\hline WW4 & DB3 & Weeli Wolli Spring & - & 14.0 & 29.0 & 21.0 & & & - & 13.0 & 10.0 & - & & 3.0 & 9.0 & 7.0 & - & 6.0 \\
\hline WW3 & DB2 & Weeli Wolli Spring & - & 21.0 & 27.0 & 16.0 & & & - & 13.0 & 10.0 & - & & 6.0 & 11.0 & 7.0 & - & - \\
\hline WW2 & DB 1 & Weeli Wolli Spring & - & 20.0 & 27.0 & - & & & - & 10.0 & 10.0 & - & & 3.0 & - & 4.0 & - & - \\
\hline WW1 & DB0 & Weeli Wolli Spring & - & 10.0 & 35.0 & 24.0 & & & - & 19.0 & - & - & & 3.0 & - & 9.0 & - & - \\
\hline MR17 & DB16 & Mt. Robinson & - & 11.0 & 10.0 & 18.0 & & & - & 7.0 & 10.0 & - & & 3.0 & - & 4.0 & - & 3.0 \\
\hline MR16 & DB 15 & Mt. Robinson & - & - & 36.0 & 7.0 & & & 2.0 & 9.0 & - & - & & - & - & 5.0 & - & - \\
\hline MR15 & DB14 & Mt. Robinson & - & - & 24.0 & 26.0 & & & - & 8.0 & - & - & & 2.0 & - & 5.0 & - & - \\
\hline MR14 & DB13 & Mt. Robinson & - & - & 24.0 & 37.0 & & & - & 5.0 & - & - & & - & - & 5.0 & - & - \\
\hline MR 13 & $\mathrm{DB} 12$ & Mt. Robinson & - & 22.0 & 16.0 & 29.0 & & & - & 9.0 & - & - & & - & - & 7.0 & - & 6.0 \\
\hline MR12 & DB11 & Mt. Robinson & - & - & 11.0 & 36.0 & & & - & 5.0 & 11.0 & - & & - & - & 10.0 & - & - \\
\hline MR10 & DB9 & Mt. Robinson & - & - & 53.0 & 8.0 & & & 3.0 & 10.0 & - & - & & - & - & 4.0 & - & - \\
\hline MR9 & DB8 & Mt. Robinson & - & - & 52.0 & 22.0 & & & 2.0 & 6.0 & - & - & & 3.0 & - & 7.0 & - & 9.0 \\
\hline MR8 & DB7 & Mt. Robinson & - & - & 8.0 & 18.0 & & & - & 8.0 & - & - & & 3.0 & - & 6.0 & - & - \\
\hline MR7 & DB6 & Mt. Robinson & - & - & 22.0 & 39.0 & & & 2.0 & 7.0 & - & - & & 3.0 & - & 9.0 & - & - \\
\hline MR6 & DB5 & Mt. Robinson & - & - & 53.0 & - & & & 4.0 & 7.0 & - & - & & - & - & 4.0 & - & - \\
\hline MR5 & DB4 & Mt. Robinson & - & - & 28.0 & 15.0 & & & - & 10.0 & - & - & & 4.0 & - & 8.0 & - & 5.0 \\
\hline MR4 & DB3 & Mt. Robinson & - & 18.0 & 40.0 & 27.0 & & & 2.0 & 8.0 & - & - & & 6.0 & - & 7.0 & - & - \\
\hline MR3 & DB2 & Mt. Robinson & - & 131.0 & 48.0 & 11.0 & & & - & 7.0 & 15.0 & - & & 17.0 & - & 7.0 & - & - \\
\hline MR2 & DBI & Mt. Robinson & - & 15.0 & 28.0 & 46.0 & & & - & 8.0 & - & - & & 7.0 & - & 11.0 & - & 3.0 \\
\hline MR1 & DBO & Mt. Robinson & - & - & 60.0 & 8.0 & & & 2.0 & 6.0 & - & - & & 3.0 & - & 3.0 & - & - \\
\hline PH1 & DB16 & Pameilia Hill & - & 12.0 & 27.0 & 24.0 & & & - & 6.0 & 10.0 & - & & 3.0 & - & 5.0 & - & - \\
\hline $\mathrm{PH} 2$ & DB15 & Pameilia Hill & - & 14.0 & 26.0 & 35.0 & & & - & 5.0 & - & - & & 5.0 & - & 7.0 & - & - \\
\hline $\mathrm{PH} 3$ & $\mathrm{DB} 14$ & Pameilia Hill & - & 15.0 & 26.0 & 66.0 & & & - & 6.0 & 10.0 & - & & 4.0 & - & 10.0 & - & - \\
\hline PH4 & DB12 & Pameilia Hill & - & - & 20.0 & 29.0 & & & - & 7.0 & - & - & & 3.0 & - & 5.0 & - & - \\
\hline PH5 & DB11 & Pameilia Hill & - & - & 26.0 & 38.0 & & & - & 8.0 & - & - & & 3.0 & - & 9.0 & - & - \\
\hline PH6 & DB10 & Pameilia Hill & - & - & 28.0 & 9.0 & & & - & 7.0 & - & - & & 3.0 & - & 6.0 & - & - \\
\hline PH7 & DB7 & Pameilia Hill & - & - & 32.0 & 32.0 & & & - & 7.0 & - & - & & - & - & 7.0 & - & - \\
\hline PH8 & DB6 & Pameilia Hill & - & 11.0 & 30.0 & 21.0 & & & - & 5.0 & - & - & & 3.0 & - & 6.0 & - & - \\
\hline PH9 & DB5 & Pameilia Hill & - & 14.0 & 29.0 & 38.0 & & & - & 8.0 & - & - & & 4.0 & - & 12.0 & - & - \\
\hline PH10 & DB4 & Pameilia Hill & - & 17.0 & 31.0 & 27.0 & & & - & 9.0 & - & - & & 5.0 & - & 13.0 & - & - \\
\hline PH1 1 & DB3 & Pameilia Hill & - & - & 36.0 & 42.0 & & & - & 6.0 & - & - & & 5.0 & - & 9.0 & - & - \\
\hline
\end{tabular}




\begin{tabular}{|c|c|c|c|c|c|c|c|c|c|c|c|c|c|c|c|c|c|c|}
\hline Sample & Unit & Location & As & $\mathrm{Ba}$ & $\mathrm{Co}$ & $\mathrm{Cr}$ & $\mathrm{Cs}^{*}$ & $\mathrm{Hf}^{*}$ & $\mathrm{Nb}$ & $\mathrm{Ni}$ & $\mathrm{Pb}$ & $\mathrm{Rb}$ & $\mathrm{Sc}^{*}$ & $\mathrm{Sr}$ & $\mathrm{V}$ & $Y$ & $\mathrm{Zn}$ & $\mathrm{Zr}$ \\
\hline $\mathrm{PH} 12$ & DB2 & Pameilia Hill & - & - & 39.0 & 28.0 & & & - & 8.0 & - & - & & 6.0 & - & 8.0 & - & - \\
\hline PH13 & DB1 & Pameilia Hill & - & 93.0 & 25.0 & 6.0 & & & - & 7.0 & - & - & & 7.0 & - & 5.0 & - & - \\
\hline PH14 & DBO & Pameilia Hill & - & - & 30.0 & 26.0 & - & - & - & 5.0 & 12.0 & - & 1.3 & - & - & 9.0 & - & 6.0 \\
\hline $\mathrm{C} 17$ & DB16 & Cathederal Gorge & - & 11.0 & 31.0 & 23.0 & & & - & 8.0 & - & - & & 3.0 & - & 6.0 & - & - \\
\hline $\mathrm{C} 16$ & DB15 & Cathederal Gorge & - & - & 26.0 & 33.0 & & & - & 9.0 & - & - & & 3.0 & - & 8.0 & - & - \\
\hline $\mathrm{C} 15$ & $\mathrm{DB} 14$ & Cathederal Gorge & - & - & 32.0 & 47.0 & & & - & 7.0 & - & - & & 3.0 & 8.0 & 9.0 & - & - \\
\hline $\mathrm{C} 14$ & $\mathrm{DB} 13$ & Cathederal Gorge & - & 12.0 & 31.0 & 40.0 & & & - & 9.0 & - & - & & 4.0 & - & 6.0 & - & - \\
\hline $\mathrm{C} 13$ & DB12 & Cathederal Gorge & - & 12.0 & 26.0 & 43.0 & & & - & 7.0 & - & - & & 3.0 & - & 7.0 & - & - \\
\hline $\mathrm{C} 12$ & DB11 & Cathederal Gorge & - & - & 24.0 & 66.0 & & & - & 7.0 & - & - & & - & - & 11.0 & - & - \\
\hline $\mathrm{Cl1}$ & $\mathrm{DB} 10$ & Cathederal Gorge & - & - & 24.0 & 41.0 & & & 2.0 & 10.0 & - & - & & 3.0 & - & 7.0 & - & - \\
\hline $\mathrm{C} 10$ & DB9 & Cathederal Gorge & - & - & 57.0 & - & & & 2.0 & 4.0 & - & - & & - & - & - & - & - \\
\hline $\mathrm{C} 9$ & $\mathrm{DB} 8$ & Cathederal Gorge & - & - & 41.0 & 31.0 & & & 2.0 & 14.0 & - & - & & 4.0 & 9.0 & 18.0 & - & 10.0 \\
\hline $\mathrm{C} 8$ & DB7 & Cathederal Gorge & - & 15.0 & 24.0 & 40.0 & & & - & 6.0 & - & - & & 3.0 & - & 7.0 & - & - \\
\hline $\mathrm{C} 7$ & DB6 & Cathederal Gorge & - & 14.0 & 29.0 & 24.0 & - & - & - & 9.0 & - & - & 0.4 & 5.0 & - & 5.0 & - & - \\
\hline $\mathrm{C} 6$ & DB5 & Cathederal Gorge & - & 18.0 & 41.0 & 27.0 & & & - & 8.0 & - & - & & 3.0 & - & 8.0 & - & - \\
\hline $\mathrm{C} 5$ & DB4 & Cathederal Gorge & - & 25.0 & 26.0 & 63.0 & & & - & 9.0 & - & - & & 3.0 & - & 9.0 & - & - \\
\hline $\mathrm{C} 4$ & DB3 & Cathederal Gorge & - & 46.0 & 31.0 & 22.0 & & & - & 9.0 & - & - & & 6.0 & - & 7.0 & - & - \\
\hline $\mathrm{C} 3$ & DB2 & Cathederal Gorge & - & 38.0 & 32.0 & 48.0 & & & 2.0 & 8.0 & - & - & & 6.0 & - & 10.0 & - & - \\
\hline $\mathrm{C} 2$ & $\mathrm{DB} 1$ & Cathederal Gorge & - & 28.0 & 30.0 & 39.0 & & & - & 11.0 & - & - & & 3.0 & - & 8.0 & - & - \\
\hline $\mathrm{Cl}$ & DB0 & Cathederal Gorge & - & 122.0 & 29.0 & 25.0 & - & - & - & - & - & - & 1.9 & 9.0 & 14.0 & 9.0 & - & - \\
\hline 4 W17 & DB16 & Fourth West Gorge & - & 23.0 & 38.0 & 43.0 & - & - & - & 5.0 & - & - & 0.7 & 5.0 & 12.0 & 11.0 & - & - \\
\hline $4 \mathrm{~W} 16$ & DB15 & Fourth West Gorge & - & 44.0 & 83.0 & 4.0 & & & 3.0 & 6.0 & - & - & & 6.0 & - & 6.0 & - & - \\
\hline $4 \mathrm{~W} 15$ & DB 14 & Fourth West Gorge & - & 11.0 & 46.0 & 23.0 & & & - & 9.0 & - & - & & 6.0 & - & 9.0 & - & - \\
\hline 4 W14 & DB13 & Fourth West Gorge & - & - & 83.0 & 8.0 & & & 3.0 & 4.0 & - & - & & 5.0 & - & 4.0 & - & - \\
\hline $4 \mathrm{~W} 13$ & $\mathrm{DB} 12$ & Fourth West Gorge & - & - & 59.0 & 13.0 & & & - & 8.0 & - & - & & 4.0 & - & 7.0 & - & - \\
\hline $4 \mathrm{~W} 12$ & DB11 & Fourth West Gorge & - & 20.0 & 42.0 & 38.0 & - & - & - & 7.0 & - & - & 0.8 & 7.0 & - & 7.0 & - & - \\
\hline $4 \mathrm{~W} 11$ & DBio & Fourth West Gorge & - & 17.0 & 34.0 & 40.0 & & & - & 7.0 & - & - & & 8.0 & 8.0 & 11.0 & - & - \\
\hline $4 \mathrm{~W} 10$ & DB9 & Fourth West Gorge & - & 44.0 & 46.0 & 17.0 & & & - & 5.0 & 11.0 & - & & 8.0 & 9.0 & 10.0 & - & - \\
\hline 4W9 & DB8 & Fourth West Gorge & - & - & 59.0 & - & & & 3.0 & 8.0 & - & - & & - & - & 2.0 & - & - \\
\hline $4 \mathrm{~W} 8$ & DB7 & Fourth West Gorge & - & 13.0 & 46.0 & 40.0 & & & 2.0 & 6.0 & 10.0 & - & & 4.0 & 9.0 & 10.0 & - & - \\
\hline $4 \mathrm{~W} 7$ & DB6 & Fourth West Gorge & - & 12.0 & 37.0 & 25.0 & & & - & 6.0 & - & - & & 7.0 & - & 8.0 & - & - \\
\hline $4 W 6$ & DB5 & Fourth West Gorge & - & 11.0 & 82.0 & 8.0 & & & 3.0 & 5.0 & - & - & & 5.0 & - & 4.0 & - & - \\
\hline $4 \mathrm{~W} 5$ & DB4 & Fourth West Gorge & - & 36.0 & 39.0 & 39.0 & & & - & 6.0 & - & - & & 9.0 & 11.0 & 9.0 & - & - \\
\hline
\end{tabular}




\begin{tabular}{|c|c|c|c|c|c|c|c|c|c|c|c|c|c|c|c|c|c|c|}
\hline Sample & Unit & Location & As & $\mathrm{Ba}$ & $\mathrm{Co}$ & $\mathrm{Cr}$ & $\mathrm{Cs}^{*}$ & $\mathrm{Hf}^{*}$ & $\mathrm{Nb}$ & $\mathrm{Ni}$ & $\mathrm{Pb}$ & $\mathrm{Rb}$ & $\mathrm{Sc}^{*}$ & $\mathrm{Sr}$ & $\mathrm{V}$ & $\mathrm{Y}$ & $\mathrm{Zn}$ & $\mathrm{Zr}$ \\
\hline $4 \mathrm{~W} 4$ & DB3 & Fourth West Gorge & - & - & 73.0 & 16.0 & & & 3.0 & 8.0 & - & - & & 3.0 & 11.0 & 9.0 & - & - \\
\hline $4 \mathrm{~W} 3$ & DB2 & Fourth West Gorge & - & 29.0 & 39.0 & 43.0 & & & - & 9.0 & - & - & & 19.0 & - & 12.0 & - & - \\
\hline $4 \mathrm{~W} 2$ & DB1 & Fourth West Gorge & - & 23.0 & 31.0 & 26.0 & & & 2.0 & 6.0 & 10.0 & - & & 12.0 & - & 7.0 & - & - \\
\hline $4 \mathrm{~W} 1$ & DB0 & Fourth West Gorge & - & 15.0 & 52.0 & 23.0 & - & - & 2.0 & 7.0 & - & - & 0.5 & 5.0 & 8.0 & 7.0 & - & - \\
\hline \multicolumn{19}{|c|}{ Mt. Whaleback pit } \\
\hline \multicolumn{19}{|c|}{ Banded iron-formation (BIF) } \\
\hline D73A & DB16 & $\mathrm{DDH}-73$ & - & - & 57.0 & 8.0 & & & 4.0 & 9.0 & - & - & & - & - & 3.0 & - & - \\
\hline D73C & DB16 & DDH-73 & - & - & 32.0 & 33.0 & - & - & - & 5.0 & 10.0 & - & 0.6 & 5.0 & - & 12.0 & - & - \\
\hline D73D & DB16 & DDH-73 & - & 14.0 & 24.0 & 20.0 & & & - & 8.0 & 10.0 & - & & 9.0 & 10.0 & 7.0 & - & - \\
\hline $\mathrm{A} 24 \mathrm{C}$ & $\mathrm{DBI} 6$ & Pit face & - & - & 43.3 & 76.4 & & & - & 78.1 & - & - & & - & - & 5.5 & - & - \\
\hline $\mathrm{B} 24 \mathrm{C}$ & $\mathrm{DB} 16$ & Pit face & - & - & 31.8 & - & - & - & - & 8.3 & - & - & 0.2 & 2.9 & - & 4.7 & - & - \\
\hline $\mathrm{C} 24 \mathrm{C}$ & DB16 & Pit face & - & - & 34.4 & 18.0 & & & - & 25.3 & - & - & & 3.3 & - & 5.3 & - & - \\
\hline $\mathrm{F} 24 \mathrm{C}$ & DB16 & Pit face & - & - & 31.5 & 16.0 & & & - & 9.0 & 15.1 & - & & 5.9 & - & 8.3 & - & 3.5 \\
\hline $\mathrm{G} 24 \mathrm{C}$ & DB16 & Pit face & - & - & 39.9 & 35.0 & & & - & 8.1 & 15.5 & - & & 4.8 & - & 11.3 & - & - \\
\hline D86C & DB15 & DDH-86 & - & 13.0 & 14.0 & 24.0 & & & - & 13.0 & 14.0 & - & & 6.0 & 9.0 & 10.0 & 22.0 & - \\
\hline D86D & DB15 & DDH-86 & - & 13.0 & 37.0 & 18.0 & - & - & - & 7.0 & - & - & 0.3 & 3.0 & - & 9.0 & - & - \\
\hline D86E & DB15 & DDH-86 & - & 10.0 & 11.0 & 26.0 & & & - & 12.0 & 10.0 & - & & 5.0 & 8.0 & 10.0 & 4.0 & - \\
\hline $\mathrm{D} 86 \mathrm{~F}$ & $\mathrm{DB} 15$ & DDH-86 & - & - & 19.0 & 11.0 & - & - & - & 10.0 & - & - & 0.4 & 3.0 & - & 8.0 & - & - \\
\hline \multicolumn{19}{|c|}{ Iron Ore } \\
\hline D86A & $\mathrm{DB} 16$ & DDH-86 & - & 23.0 & 7.0 & 43.0 & & & 2.0 & 4.0 & 22.0 & - & & 8.0 & 14.0 & 14.0 & - & 7.0 \\
\hline D73B & DB16 & $\mathrm{DDH}-73$ & - & - & 10.0 & 19.0 & & & - & 7.0 & 22.0 & - & & 8.0 & 9.0 & 9.0 & - & 6.0 \\
\hline D73E & DB16 & DDH-73 & - & 26.0 & - & 34.0 & & & 3.0 & 6.0 & 23.0 & - & & 6.0 & 17.0 & 10.0 & - & 9.0 \\
\hline D24C & DB16 & Pit face & - & - & 6.9 & 17.5 & - & - & 3.7 & 7.0 & 20.1 & - & 1.6 & 2.6 & 122.0 & 10.0 & - & 4.9 \\
\hline E24C & DB16 & Pit face & - & 16.0 & 19.0 & 98.2 & & & 5.0 & 14.1 & 20.4 & - & & 4.4 & 127.0 & 9.8 & 17.0 & 10.0 \\
\hline E25E & DB15 & Pit face & - & 24.0 & - & 25.2 & - & - & - & 16.9 & 22.0 & - & 1.2 & 3.7 & 10.0 & 20.1 & 5.3 & 7.8 \\
\hline A $25 \mathrm{E}$ & DB11 & Pit face & - & 18.0 & - & 35.5 & & & - & - & - & - & & 2.3 & 15.0 & - & - & - \\
\hline B25E & DBil & Pit face & - & 25.0 & - & 39.0 & - & - & - & - & - & - & 0.9 & 2.3 & 13.0 & - & - & - \\
\hline 6BEDC & DB6 & Pit face & - & 10.0 & 17.9 & 45.4 & & & 2.3 & 14.1 & 21.4 & - & & 3.2 & 29.0 & 16.4 & - & 5.4 \\
\hline $5 \mathrm{BEDC}$ & DB5 & Pit face & - & 21.0 & 7.7 & 26.0 & - & 0.5 & 2.9 & 18.3 & 23.0 & - & 2.0 & 4.0 & 54.3 & 19.9 & 15.0 & 16.6 \\
\hline 4AEDC & $\mathrm{DB} 4$ & Pit face & - & 40.0 & 15.2 & 24.6 & & & 2.8 & 20.3 & 23.4 & - & & 5.8 & 31.0 & 14.1 & 5.9 & 5.5 \\
\hline 3BEDC & DB3 & Pit face & - & 26.0 & 13.7 & 31.0 & & & 3.2 & 14.1 & 23.5 & - & & 4.5 & 16.0 & 15.9 & - & 3.9 \\
\hline 1123 & DB0 & Pit face & - & - & - & 23.0 & - & - & - & - & - & - & 1.1 & 2.3 & - & - & - & - \\
\hline$A W 15$ & $\mathrm{Phr}$ & $\mathrm{DDH}-324$ & - & 29.1 & 8.3 & 25.3 & & & 3.0 & 11.0 & - & - & & 1.5 & 17.3 & 7.6 & 5.5 & 10.2 \\
\hline
\end{tabular}


Appendix 3.2. (continued).

\begin{tabular}{|c|c|c|c|c|c|c|c|c|c|c|c|c|c|c|c|c|c|c|}
\hline Sample & Unit & Location & As & $\mathrm{Ba}$ & $\mathrm{Co}$ & $\mathrm{Cr}$ & $\mathrm{Cs}^{*}$ & $\mathrm{Hf}^{*}$ & $\mathrm{Nb}$ & $\mathrm{Ni}$ & $\mathrm{Pb}$ & $\mathrm{Rb}$ & Sc* & $\mathrm{Sr}$ & $\mathrm{V}$ & $\mathrm{Y}$ & $\mathrm{Zn}$ & $\mathrm{Zr}$ \\
\hline AW16 & Phr & DDH-324 & - & 37.4 & - & 531.1 & & & 2.6 & 10.3 & - & - & & 6.9 & 26.5 & 27.8 & 18.5 & 10.7 \\
\hline 323 & $\mathrm{Phr}$ & Pit face & - & 12.0 & - & 33.1 & & & - & 10.3 & 21.0 & - & & 4.0 & 9.9 & 8.4 & - & 4.7 \\
\hline 523 & $\mathrm{Phr}$ & Pit face & - & 20.0 & - & 32.0 & & & 2.6 & 11.6 & 22.3 & - & & 6.6 & 7.4 & 11.7 & - & 7.3 \\
\hline 723 & $\mathrm{Phr}$ & Pit face & - & 17.0 & - & 74.5 & & & 2.2 & 15.6 & 22.4 & - & & 3.2 & 41.0 & 16.2 & - & 13.5 \\
\hline 923 & $\mathrm{Phr}$ & Pit face & - & 22.0 & 13.6 & 13.0 & & & - & 17.0 & 22.1 & - & & 6.4 & 40.0 & 17.1 & - & 9.2 \\
\hline \multicolumn{19}{|c|}{ Black shale } \\
\hline AW22A & Phbw & Pit face & - & 12.0 & 40.0 & 36.0 & & & - & 124.0 & - & 286.0 & & 3.0 & 40.0 & 50.0 & 257.0 & 386.0 \\
\hline AW22B & Phbw & Pit face & - & 21.0 & 107.0 & 74.0 & & & 14.0 & 121.0 & 11.0 & 9.0 & & 31.0 & 120.0 & 42.0 & 469.0 & 234.0 \\
\hline AW24 & Phbw & Pit face & 15.3 & - & 67.7 & 225.1 & & & 18.7 & 237.6 & - & - & & 21.6 & 198.5 & 58.6 & 726.7 & 320.1 \\
\hline AW25 & Phbw & Pit face & 35.2 & - & 51.8 & 289.9 & - & 5.9 & 17.6 & 195.0 & - & 5.0 & 30.5 & 52.3 & 216.0 & 40.3 & 514.3 & 227.9 \\
\hline AW26 & Phbw & Pit face & 11.1 & 36.3 & 54.7 & 336.5 & & & 16.1 & 274.4 & 10.2 & 4.2 & & 51.1 & 133.2 & 56.7 & 732.1 & 258.8 \\
\hline $224 \mathrm{C}$ & Phbw & Pit face & - & 11.0 & 71.8 & 66.7 & - & 6.0 & 19.0 & 187.5 & - & 28.8 & 21.9 & 6.9 & 98.6 & 55.7 & 616.8 & 195.9 \\
\hline $224 \mathrm{E}$ & Phbw & Pit face & - & 72.0 & 23.0 & 50.0 & & & 13.0 & 55.0 & - & 371.0 & & 9.0 & 53.0 & 84.0 & 152.0 & 260.0 \\
\hline WS1 & Phbw & Pit face & - & 32.0 & 43.0 & 75.9 & & & 15.0 & 47.0 & - & 40.8 & & 45.7 & 133.0 & 35.4 & 199.5 & 233.3 \\
\hline WS3 & Phbw & Pit face & - & 29.0 & 88.0 & - & & & 15.8 & 141.0 & - & - & & 92.9 & 132.0 & 40.8 & 389.0 & 197.7 \\
\hline WS11 & Phbw & Pit face & 12.8 & 37.0 & 69.7 & 55.0 & & & 15.2 & 116.0 & - & 11.0 & & 3.8 & 109.0 & 76.2 & 267.6 & 259.6 \\
\hline G25E & DS16 & Pit face & - & 29.0 & 67.1 & 9.6 & - & 18.4 & 29.7 & 204.3 & - & - & 28.6 & 6.4 & 30.7 & 146.1 & 585.8 & 543.4 \\
\hline $\mathrm{H} 25 \mathrm{E}$ & DS16 & Pit face & - & 26.0 & 76.2 & 4.6 & - & 9.0 & 19.5 & 297.4 & - & - & 19.9 & 7.1 & 35.2 & 75.5 & 691.4 & 308.8 \\
\hline AW18 & $\mathrm{Phr}$ & Pit face & - & - & 75.9 & 185.0 & 1.4 & 3.3 & 12.5 & 389.8 & - & 10.9 & 18.6 & 4.7 & 165.9 & 36.2 & 1435.6 & 138.8 \\
\hline AW19 & $\mathrm{Phr}$ & Pit face & - & 132.6 & 5.2 & 178.0 & & & 12.0 & 482.2 & - & 193.7 & & 9.8 & 142.0 & 27.2 & 1595.6 & 134.9 \\
\hline AW20 & $\mathrm{Phr}$ & Pit face & 23.5 & 129.2 & - & 205.0 & & & 13.5 & 45.6 & 10.1 & 254.9 & & 49.8 & 124.8 & 25.2 & 184.7 & 166.7 \\
\hline AW21 & $\mathrm{Phr}$ & Pit face & 291.9 & 90.6 & 25.1 & 86.3 & 5.7 & 2.8 & 9.5 & 117.2 & 47.9 & 133.3 & 13.6 & 27.4 & 61.0 & 18.8 & 255.0 & 116.9 \\
\hline $\mathrm{RC}$ & $\mathrm{Phr}$ & Pit face & 42.0 & 106.0 & 68.0 & 100.0 & 5.7 & 4.5 & 11.0 & 71.0 & - & 150.0 & 18.4 & 9.0 & 126.0 & 30.0 & 284.0 & 172.0 \\
\hline 123 & Phr & Pit face & - & 67.0 & 73.0 & 136.0 & 4.1 & 3.7 & 11.0 & 111.0 & - & 97.0 & 14.0 & 28.0 & 121.0 & 25.0 & 269.0 & 120.0 \\
\hline $125 \mathrm{E}$ & $\mathrm{Phr}$ & Pit face & 16.0 & 108.0 & 21.0 & 443.0 & & & 17.0 & 48.0 & 14.0 & 299.0 & & 136.0 & 87.0 & 51.0 & 123.0 & 301.0 \\
\hline $225 \mathrm{E}$ & $\mathrm{Phr}$ & Pit face & - & 63.0 & 38.2 & 178.0 & & & 8.3 & 45.9 & - & 130.5 & & 57.5 & 237.0 & 21.3 & 178.1 & 114.7 \\
\hline D4091 & Phr & DDH-409 & - & 60.0 & 36.0 & 261.0 & & & 13.0 & 265.0 & - & 266.0 & & 7.0 & 136.0 & 52.0 & 360.0 & 251.0 \\
\hline \multicolumn{19}{|c|}{ Greyish-green shale } \\
\hline D4092 & Phr & DDH-409 & - & 122.0 & 22.0 & 468.0 & & & 9.0 & 108.0 & - & 240.0 & & 5.0 & 130.0 & 25.0 & 180.0 & 148.0 \\
\hline \multicolumn{19}{|c|}{ Reddish-green shale } \\
\hline D4094 & $\mathrm{Phr}$ & DDH-409 & - & 57.0 & 42.0 & 97.0 & & & 8.0 & 146.0 & 10.0 & 82.0 & & 9.0 & 91.0 & 25.0 & 371.0 & 102.0 \\
\hline D4096 & $\mathrm{Phr}$ & DDH-409 & - & 18.0 & 27.0 & 64.0 & & & 4.0 & 59.0 & - & - & & 18.0 & 47.0 & 24.0 & 170.0 & 42.0 \\
\hline
\end{tabular}




\begin{tabular}{|c|c|c|c|c|c|c|c|c|c|c|c|c|c|c|c|c|c|c|}
\hline Sample & Unit & Location & As & $\mathrm{Ba}$ & Co & $\mathrm{Cr}$ & $\mathrm{Cs}^{*}$ & $\mathrm{Hf}^{*}$ & $\mathrm{Nb}$ & $\mathrm{Ni}$ & $\mathrm{Pb}$ & $\mathrm{Rb}$ & $\mathrm{Sc}^{*}$ & $\mathrm{Sr}$ & $\mathrm{V}$ & $\mathrm{Y}$ & $\mathrm{Zn}$ & $\mathrm{Zr}$ \\
\hline \multicolumn{19}{|c|}{ Red shale } \\
\hline AW27 & Phbw & Pit face & 24.5 & 27.4 & 45.5 & 437.5 & & & 10.7 & 155.8 & 24.5 & 4.8 & & 66.8 & 273.3 & 48.3 & 386.6 & 188.5 \\
\hline AW31 & Phbw & Pit face & 13.1 & 17.8 & 37.3 & 196.2 & 1.1 & 7.0 & 19.9 & 84.5 & - & 13.7 & 14.8 & 18.8 & 68.5 & 54.1 & 328.2 & 245.8 \\
\hline AW32 & Phbw & Pit face & 14.6 & - & 57.0 & 259.2 & & & 22.1 & 162.0 & - & 3.9 & & 9.7 & 90.5 & 60.4 & 362.0 & 317.2 \\
\hline AW36 & Phbw & Pit face & 22.8 & - & 51.1 & 178.7 & & & 17.3 & 115.7 & - & 3.4 & & 9.1 & 131.7 & 47.7 & 526.9 & 239.7 \\
\hline AW37 & Phbw & Pit face & 11.2 & - & 47.1 & 230.1 & & & 15.3 & 153.9 & - & 8.1 & & 8.2 & 113.4 & 50.5 & 566.7 & 249.8 \\
\hline AW38 & Phbw & Pit face & 15.8 & - & 42.0 & 222.0 & & & 31.1 & 278.4 & - & 7.4 & & 15.0 & 68.8 & 72.1 & 654.6 & 321.1 \\
\hline AW39A & Phbw & Pit face & - & 13.0 & 90.0 & 41.0 & & & 10.0 & 183.0 & - & 33.0 & & 14.0 & 60.0 & 62.0 & 613.0 & 505.0 \\
\hline AW39B & Phbw & Pit face & 22.0 & - & - & 100.0 & & & 12.0 & 22.0 & - & - & & 6.0 & 94.0 & 32.0 & 95.0 & 240.0 \\
\hline AW40 & Phbw & Pit face & 16.6 & 95.4 & 16.2 & 153.7 & & & 24.4 & 26.4 & 15.1 & 73.2 & & 220.7 & 85.3 & 81.1 & 98.0 & 261.2 \\
\hline $124 \mathrm{C}$ & Phbw & Pit face & 10.6 & - & - & 63.2 & & & 14.2 & 97.7 & - & - & & 5.9 & 86.7 & 70.6 & 97.5 & 222.4 \\
\hline $324 \mathrm{C}$ & Phbw & Pit face & - & - & - & 236.0 & - & 5.3 & 12.7 & 57.6 & - & - & 16.1 & 6.7 & 87.8 & 18.7 & 58.2 & 205.9 \\
\hline $424 \mathrm{C}$ & Phbw & Pit face & - & - & - & 159.0 & & & 11.3 & 63.7 & - & - & & 10.0 & 106.0 & 24.4 & 113.0 & 138.1 \\
\hline WS5 & Phbw & Pit face & - & 25.0 & 36.3 & 240.0 & & & 11.5 & 72.3 & 10.6 & - & & 20.1 & 101.0 & 22.7 & 173.9 & 208.2 \\
\hline WS9 & Phbw & Pit face & - & 10.0 & 215.6 & 72.2 & & & 16.8 & 1155.0 & - & - & & - & 104.0 & 35.5 & 1620.0 & 194.0 \\
\hline D86B & DS16 & Pit face & - & 47.0 & - & 90.0 & & & 11.0 & 32.0 & 11.0 & - & & 28.0 & 17.0 & 33.0 & 129.0 & 194.0 \\
\hline AW14 & DS16 & Pit face & 22.8 & 16.0 & 19.0 & 162.1 & - & 7.1 & 16.0 & 98.5 & - & 2.9 & 22.8 & 10.0 & 98.0 & 86.3 & 243.7 & 249.0 \\
\hline I25E & DS16 & Pit face & - & 32.0 & 76.8 & 37.5 & & & 13.6 & 276.1 & - & - & & 9.9 & 46.5 & 52.4 & 694.8 & 221.0 \\
\hline AW13 & DS15 & Pit face & 17.2 & 35.9 & 16.0 & 147.3 & & & 19.5 & 193.4 & - & 3.6 & & 11.3 & 41.7 & 70.8 & 221.0 & 251.9 \\
\hline AW 12 & DS14 & Pit face & 15.0 & 23.1 & 17.0 & 248.2 & & & 28.1 & 121.6 & - & 2.9 & & 7.0 & 61.1 & 82.8 & 155.8 & 344.4 \\
\hline AW11 & $\mathrm{DS} 13$ & Pit face & - & 22.5 & 20.1 & 227.9 & & & 27.4 & 244.8 & 13.0 & 4.4 & & 15.5 & 51.1 & 87.5 & 110.8 & 420.1 \\
\hline AW10 & DS12 & Pit face & - & 12.6 & 12.3 & 151.7 & - & 13.8 & 27.2 & 307.9 & - & 3.2 & 27.9 & 4.0 & 71.8 & 66.7 & 185.0 & 468.1 \\
\hline $\mathrm{C} 25 \mathrm{E}$ & DS11 & Pit face & - & 38.0 & 70.1 & 73.2 & & & 18.8 & 225.9 & - & 0.0 & & 8.8 & 101.0 & 57.4 & 797.7 & 259.7 \\
\hline D25E & DSIl & Pit face & - & 72.0 & 41.4 & 58.7 & 2.9 & 8.0 & 14.9 & 143.0 & 16.9 & 33.6 & 27.0 & 97.8 & 98.9 & 63.9 & 510.4 & 268.7 \\
\hline AW9 & DS11 & Pit face & - & 23.4 & 20.2 & 236.7 & & & 26.4 & 77.0 & - & 3.3 & & 8.6 & 72.1 & 76.3 & 49.1 & 351.4 \\
\hline $1025 \mathrm{E}$ & DS10 & Pit face & - & 65.1 & 98.4 & - & & & 17.4 & 204.8 & - & 2.8 & & 43.3 & 107.0 & 128.8 & 530.6 & 477.4 \\
\hline AW8 & DSio & Pit face & 15.8 & 51.1 & 22.3 & 174.2 & & & 20.6 & 95.7 & 12.2 & 3.8 & & 16.9 & 29.0 & 67.9 & 96.5 & 290.4 \\
\hline AW6 & DS9 & Pit face & 11.4 & 41.3 & 23.6 & 56.2 & & & 26.0 & 114.9 & 11.4 & 8.3 & & 22.3 & 34.4 & 69.8 & 212.9 & 429.8 \\
\hline AW5 & DS8 & Pit face & 17.8 & 29.6 & 23.8 & 112.8 & & & 20.0 & 69.7 & 15.2 & 4.4 & & 15.3 & 41.4 & 48.2 & 205.5 & 216.3 \\
\hline AW4 & DS7 & Pit face & 20.6 & 24.9 & 24.6 & 118.4 & & & 26.5 & 114.8 & - & 5.2 & & 19.2 & 36.0 & 94.7 & 331.1 & 349.8 \\
\hline AW3 & DS6 & Pit face & 13.9 & 19.0 & 58.1 & 147.2 & & & 12.9 & 217.6 & 10.0 & 7.0 & & 10.8 & 63.0 & 35.0 & 634.8 & 216.8 \\
\hline $6 \mathrm{EDC}$ & DS6 & Pit face & - & 39.0 & 59.1 & - & & & 17.5 & 240.1 & 14.0 & 5.6 & & 33.3 & 78.9 & 109.0 & 803.6 & 287.0 \\
\hline AW2 & DS5 & Pit face & 16.5 & - & 21.3 & 136.8 & & & 18.3 & 64.7 & - & 2.9 & & 9.2 & 36.0 & 65.7 & 141.7 & 270.7 \\
\hline
\end{tabular}




\begin{tabular}{|c|c|c|c|c|c|c|c|c|c|c|c|c|c|c|c|c|c|c|}
\hline Sample & Unit & Location & As & $\mathrm{Ba}$ & $\mathrm{Co}$ & $\mathrm{Cr}$ & $\mathrm{Cs}^{*}$ & Hf* & $\mathrm{Nb}$ & $\mathrm{Ni}$ & $\mathrm{Pb}$ & $\mathrm{Rb}$ & $\mathrm{Sc}^{*}$ & $\mathrm{Sr}$ & V & $\mathrm{Y}$ & $\mathrm{Zn}$ & $\mathrm{Zr}$ \\
\hline AW1 & DS4 & Pit face & 15.6 & - & 47.1 & 159.2 & & & 23.5 & 298.9 & - & 9.7 & & 12.5 & 94.9 & 81.4 & 773.1 & 355.9 \\
\hline $4 \mathrm{EDC}$ & DS4 & Pit face & - & 35.0 & 81.5 & 22.1 & & & 17.3 & 420.2 & - & - & & 20.5 & 67.5 & 89.7 & 1309.0 & 308.0 \\
\hline $3 \mathrm{EDC}$ & DS3 & Pit face & - & - & 50.0 & 358.0 & & & 33.0 & 239.0 & - & - & & 6.0 & 19.0 & 92.0 & 741.0 & 495.0 \\
\hline AW 17 & $\mathrm{Phr}$ & Pit face & 12.7 & 14.6 & 57.5 & 171.2 & & & 13.6 & 171.7 & - & 3.8 & & 6.5 & 100.9 & 35.9 & 842.3 & 191.4 \\
\hline $5 \mathrm{~A} 23$ & $\mathrm{Phr}$ & Pit face & 12.8 & 25.0 & - & 23.0 & - & 9.5 & 16.6 & 70.8 & - & - & 23.2 & 8.9 & 80.2 & 92.2 & 126.0 & 312.6 \\
\hline $5 B 23$ & $\mathrm{Phr}$ & Pit face & - & 25.0 & - & 221.0 & & & 13.0 & 29.1 & 10.1 & - & & 12.4 & 47.3 & 28.0 & 89.0 & 289.8 \\
\hline 823 & $\mathrm{Phr}$ & Pit face & 28.0 & 46.0 & - & 68.0 & - & 8.7 & 18.0 & 55.0 & - & 5.0 & 23.4 & 30.0 & 75.0 & 62.0 & 133.0 & 307.0 \\
\hline 1023 & Phr & Pit face & 13.9 & 31.0 & - & - & & & 21.1 & 56.3 & - & - & & 5.3 & 54.3 & 117.0 & 106.0 & 402.0 \\
\hline 1223 & $\mathrm{Phr}$ & Pit face & - & 28.0 & - & - & - & 9.0 & 20.6 & 35.3 & 13.3 & - & 22.7 & 12.0 & 49.9 & 62.0 & 133.0 & 275.6 \\
\hline $325 \mathrm{E}$ & Phr & Pit face & 13.0 & 117.0 & 25.0 & 230.0 & 8.8 & 5.2 & 11.0 & 48.0 & - & 314.0 & 28.9 & 58.0 & 124.0 & 35.0 & 106.0 & 191.0 \\
\hline $425 \mathrm{E}$ & $\mathrm{Phr}$ & Pit face & 20.0 & 121.0 & 27.0 & 252.0 & & & 10.0 & 93.0 & 10.0 & 351.0 & & 62.0 & 268.0 & 67.0 & 168.0 & 243.0 \\
\hline $525 \mathrm{E}$ & $\mathrm{Phr}$ & Pit face & - & 80.7 & 58.0 & 189.0 & & & 7.4 & 198.4 & - & 157.0 & & 38.3 & 248.0 & 36.7 & 276.4 & 145.7 \\
\hline D4097 & Phr & $\mathrm{DDH}-409$ & 3.0 & 30.0 & 45.0 & 2574.0 & & & 10.0 & 92.0 & 13.0 & bd & & 8.0 & 85.0 & 14.0 & 402.0 & 130.0 \\
\hline D40910 & $\mathrm{Phr}$ & DDH-409 & 3.0 & 63.0 & 53.0 & 253.0 & & & 14.0 & 69.0 & 16.0 & $b d$ & & 25.0 & 33.0 & 35.0 & 384.0 & 284.0 \\
\hline
\end{tabular}

Notes: Phbw $=$ Whaleback Shale Member; DB $=$ Dales Gorge Member BIF macroband; DS $=$ Dales Gorge Member shale macroband; Phr $=$ Mt. McRae Shale; DDH $=$ diamond drill hole; all trace element contents in ppm; * concentrations determined using neutron activation analysis; "-" $=$ below detection; blank = not reported. 
Appendix 3.3. Rare earth element contents of rocks across the Hamersley Province

\begin{tabular}{|c|c|c|c|c|c|c|c|c|c|c|c|c|c|c|}
\hline Sample & $\mathrm{La}$ & $\mathrm{Ce}$ & $\mathrm{Nd}$ & $\mathrm{Sm}$ & $\mathrm{Eu}$ & $\mathrm{Tb}$ & Ho & $\mathrm{Yb}$ & Lu & $(\mathrm{Eu} / \mathrm{Eu} *)_{N}$ & $\mathrm{LREE}_{\mathrm{N}}$ & $\mathrm{HREE}_{\mathrm{N}}$ & $\mathrm{REE}_{\mathrm{N}}$ & $\mathrm{LREE}_{\mathrm{N}} / \mathrm{HREE}_{\mathrm{I}}$ \\
\hline \multicolumn{15}{|c|}{ Northern Hamersley Province } \\
\hline \multicolumn{15}{|c|}{ Banded iron-formation } \\
\hline $4715^{\top}$ & 1.0 & 2.1 & 0.9 & 0.2 & 0.1 & - & - & 0.4 & 0.1 & 1.5 & 0.12 & 0.25 & 0.44 & 0.50 \\
\hline 4735 & 5.5 & 11.5 & 5.8 & 1.2 & 0.6 & 0.3 & 0.5 & 1.4 & 0.2 & 1.7 & 0.74 & 1.74 & 2.93 & 0.42 \\
\hline 4742 & 3.1 & 5.3 & 2.2 & 0.4 & 0.2 & 0.1 & 0.2 & 0.8 & 0.1 & 1.9 & 0.32 & 0.85 & 1.34 & 0.38 \\
\hline BG1 & 1.2 & 2.5 & 1.1 & 0.2 & 0.1 & - & - & 0.3 & 0.1 & 1.5 & 0.15 & 0.24 & 0.46 & 0.60 \\
\hline $\mathrm{BG} 4^{\dagger}$ & 0.7 & 1.3 & 0.6 & 0.1 & 0.1 & - & - & 0.2 & 0.0 & 1.8 & 0.08 & 0.16 & 0.29 & 0.48 \\
\hline \multicolumn{15}{|c|}{ Black shale } \\
\hline $47 \mathrm{~W} 10$ & 23.9 & 46.1 & 22.8 & 4.3 & 1.4 & 0.8 & 1.1 & 2.6 & 0.4 & 1.5 & 2.93 & 3.60 & 7.68 & 0.81 \\
\hline AW44 & 23.9 & 47.4 & 21.2 & 4.0 & 1.6 & 0.7 & 1.0 & 2.1 & 0.3 & 1.8 & 2.84 & 3.15 & 7.24 & 0.90 \\
\hline BG3 & 30.0 & 59.7 & 26.2 & 4.8 & 1.1 & 0.7 & 1.0 & 2.6 & 0.4 & 1.1 & 3.52 & 3.47 & 7.90 & 1.02 \\
\hline 4718 & 16.2 & 34.7 & 14.8 & 2.6 & 0.8 & 0.5 & 0.7 & 1.8 & 0.3 & 1.4 & 1.96 & 2.34 & 4.96 & 0.84 \\
\hline BG11 & 47.9 & 81.7 & 33.5 & 6.1 & 1.5 & 1.0 & 1.5 & 4.1 & 0.6 & 1.0 & 4.87 & 5.36 & 11.39 & 0.91 \\
\hline 4745 & 10.1 & 20.5 & 9.0 & 1.8 & 0.5 & 0.4 & 0.5 & 1.4 & 0.2 & 1.2 & 1.22 & 1.78 & 3.39 & 0.69 \\
\hline \multicolumn{15}{|c|}{ Southeastern Hamersley Province } \\
\hline \multicolumn{15}{|c|}{ Banded iron-formation } \\
\hline PH14 & 2.0 & 5.0 & 2.8 & 0.8 & 0.3 & 0.2 & 0.3 & 1.0 & 0.2 & 1.8 & 0.36 & 1.20 & 1.82 & 0.30 \\
\hline $\mathrm{C} 7$ & 2.0 & 3.6 & 2.0 & 0.5 & 0.2 & 0.1 & 0.2 & 0.6 & 0.1 & 1.8 & 0.27 & 0.67 & 1.10 & 0.40 \\
\hline $\mathrm{Cl}$ & 4.1 & 8.3 & 4.0 & 1.0 & 0.4 & 0.2 & 0.4 & 1.1 & 0.2 & 1.4 & 0.56 & 1.34 & 2.18 & 0.42 \\
\hline $4 \mathrm{~W} 17$ & 3.2 & 5.5 & 2.4 & 0.5 & 0.2 & 0.1 & 0.2 & 0.8 & 0.1 & 1.5 & 0.34 & 0.83 & 1.29 & 0.41 \\
\hline $4 \mathrm{~W} 12$ & 3.2 & 5.2 & 2.2 & 0.5 & 0.2 & - & 0.1 & 0.3 & 0.0 & 1.7 & 0.33 & 0.30 & 0.77 & 1.09 \\
\hline $4 W 1$ & 4.7 & 7.5 & 4.7 & 0.8 & 0.3 & 0.2 & 0.3 & 0.7 & 0.1 & 1.8 & 0.55 & 0.94 & 1.74 & 0.58 \\
\hline \multicolumn{15}{|c|}{ Mt. Whaleback pit } \\
\hline \multicolumn{15}{|c|}{ Banded iron-formation } \\
\hline $\mathrm{D} 73 \mathrm{C}$ & 3.4 & 7.4 & 3.2 & 0.6 & 0.3 & 0.2 & 0.3 & 1.0 & 0.2 & 1.9 & 0.43 & 1.12 & 1.78 & 0.38 \\
\hline$B 24 C$ & 1.4 & 2.7 & 1.3 & 0.3 & 0.1 & - & - & 0.2 & 0.0 & 1.3 & 0.17 & 0.13 & 0.38 & 1.30 \\
\hline $\mathrm{D} 86 \mathrm{D}$ & 2.1 & 3.8 & 1.9 & 0.4 & 0.2 & 0.1 & 0.2 & 0.7 & 0.1 & 1.8 & 0.25 & 0.82 & 1.21 & 0.31 \\
\hline $\mathrm{D} 86 \mathrm{~F}$ & 1.0 & 2.3 & 1.3 & 0.3 & 0.1 & - & 0.2 & 0.6 & 0.1 & 1.5 & 0.16 & 0.59 & 0.82 & 0.26 \\
\hline \multicolumn{15}{|c|}{ Iron Ore } \\
\hline $\mathrm{D} 24 \mathrm{C}$ & 1.2 & 3.1 & 2.0 & 0.6 & 0.2 & 0.1 & 0.1 & 0.1 & 0.0 & 1.4 & 0.24 & 0.29 & 0.67 & 0.86 \\
\hline E25E & 5.8 & 9.6 & 4.3 & 1.0 & 0.4 & 0.3 & 0.6 & 2.2 & 0.4 & 1.5 & 0.64 & 2.51 & 3.49 & 0.25 \\
\hline B25E & 2.3 & 5.8 & 3.2 & 0.7 & 0.3 & 0.2 & 0.4 & 1.3 & 0.2 & 1.6 & 0.38 & 1.48 & 2.13 & 0.26 \\
\hline 5BEDC & 9.6 & 14.3 & 5.3 & 1.3 & 0.5 & 0.4 & 0.7 & 2.6 & 0.4 & 1.4 & 0.91 & 2.93 & 4.24 & 0.31 \\
\hline 1123 & 2.7 & 6.1 & 2.7 & 0.4 & 0.2 & 0.1 & 0.2 & 0.6 & 0.1 & 1.7 & 0.34 & 0.70 & 1.18 & 0.49 \\
\hline \multicolumn{15}{|c|}{ Black shale } \\
\hline AW25 & 99.4 & 160.0 & 48.8 & 6.1 & 1.2 & 1.0 & 1.6 & 4.4 & 0.7 & 0.8 & 8.22 & 5.61 & 14.80 & 1.46 \\
\hline $224 \mathrm{C}$ & 37.2 & 78.0 & 32.0 & 6.7 & 1.8 & 1.2 & 1.7 & 6.4 & 1.1 & 1.2 & 4.52 & 7.40 & 13.37 & 0.61 \\
\hline G25E & 81.8 & 121.0 & 37.8 & 5.7 & 1.9 & 1.6 & 3.4 & 18.3 & 3.3 & 1.2 & 6.64 & 18.24 & 26.41 & 0.36 \\
\hline $\mathrm{H} 25 \mathrm{E}$ & 34.9 & 64.4 & 23.2 & 3.1 & 1.0 & 0.7 & 1.6 & 9.0 & 1.7 & 1.3 & 3.37 & 8.82 & 13.00 & 0.38 \\
\hline AW18 & 61.1 & 117.0 & 50.4 & 8.9 & 1.9 & 1.2 & 1.5 & 3.6 & 0.5 & 1.0 & 6.86 & 5.22 & 13.60 & 1.31 \\
\hline AW21 & 39.0 & 66.0 & 24.4 & 3.4 & 0.6 & 0.5 & 0.7 & 1.8 & 0.3 & 0.9 & 3.61 & 2.45 & 6.57 & 1.47 \\
\hline $\mathrm{RC}$ & 58.6 & 112.0 & 44.6 & 7.1 & 1.6 & 1.0 & 1.3 & 2.6 & 0.4 & 1.1 & 6.20 & 4.05 & 11.56 & 1.53 \\
\hline 123 & 25.0 & 49.1 & 20.1 & 3.3 & 0.8 & 0.6 & 0.9 & 2.6 & 0.4 & 1.1 & 2.75 & 3.31 & 6.72 & 0.83 \\
\hline \multicolumn{15}{|c|}{ Red shale } \\
\hline AW31 & 105.0 & 140.0 & 40.3 & 4.8 & 1.2 & 0.9 & 1.4 & 4.9 & 0.7 & 1.1 & 7.60 & 5.51 & 14.08 & 1.38 \\
\hline $324 \mathrm{C}$ & 3.0 & 7.1 & 3.9 & 1.0 & 0.5 & 0.4 & 0.9 & 5.9 & 1.1 & 1.7 & 0.49 & 5.60 & 6.46 & 0.09 \\
\hline AW14 & 59.7 & 98.9 & 38.7 & 6.7 & 1.9 & 1.2 & 2.1 & 8.1 & 1.4 & 1.2 & 5.79 & 8.95 & 16.27 & 0.65 \\
\hline AW10 & 4.5 & 9.8 & 4.6 & 1.4 & 0.5 & 0.6 & 1.5 & 10.8 & 2.1 & 1.3 & 0.67 & 10.10 & 11.18 & 0.07 \\
\hline $\mathrm{D} 25 \mathrm{E}$ & 80.0 & 141.0 & 53.6 & 9.7 & 2.8 & 1.3 & 1.7 & 5.2 & 0.9 & 1.4 & 8.05 & 6.70 & 16.99 & 1.20 \\
\hline $5 \mathrm{~A} 23$ & 32.3 & 46.8 & 13.6 & 1.9 & 0.9 & 0.6 & 1.5 & 9.3 & 1.7 & 1.8 & 2.51 & 8.94 & 12.15 & 0.28 \\
\hline 823 & 37.5 & 60.0 & 14.2 & 2.3 & 1.1 & 0.8 & 1.8 & 9.8 & 1.7 & 1.6 & 2.95 & 9.49 & 13.31 & 0.31 \\
\hline 1223 & 28.5 & 40.7 & 14.6 & 2.2 & 1.1 & 0.8 & 1.7 & 7.3 & 1.2 & 1.8 & 2.36 & 7.72 & 10.97 & 0.31 \\
\hline $325 \mathrm{E}$ & 65.8 & 131.0 & 54.7 & 8.7 & 1.5 & 1.0 & 1.4 & 3.6 & 0.5 & 0.9 & 7.33 & 4.79 & 13.32 & 1.53 \\
\hline
\end{tabular}

Notes: Concentrations in ppm. Eu/Eu*, LREE and HREE calculated relative to North American Shale Composite (NASC) values of Gromet et al., 1984. Eu* $=(\mathrm{Sm}+\mathrm{Tb})_{N} / 2 ;{ }^{\dagger} \mathrm{Nd}$ concentrations are interpolated values; "-" = below detection; $\mathrm{REE}=$ rare earth element; $\mathrm{L}=$ light; $\mathrm{H}=$ heavy 
Appendix 3.4. Statistical summary of Dales Gorge Member BIF across the Hamersley Province

\begin{tabular}{|c|c|c|c|c|c|c|c|c|c|c|c|c|c|c|c|c|c|c|c|c|c|c|}
\hline & \multirow[b]{3}{*}{ DL } & \multicolumn{7}{|c|}{ Unaltered $B F^{(1)}(\mathrm{n}=21)$} & \multicolumn{7}{|c|}{ Weathered $\mathrm{BIF}^{(2)}(\mathrm{n}=59)$} & \multicolumn{7}{|c|}{ Oxidized BIF (Fourth West Gorge) $(\mathrm{n}=17)$} \\
\hline & & \multirow[b]{2}{*}{$<\mathrm{DL}$} & \multicolumn{2}{|c|}{$>\mathrm{DL}^{(3)}$} & \multicolumn{2}{|c|}{$\mathrm{DL}=0.5 \mathrm{DL}^{(4)}$} & \multicolumn{2}{|c|}{$\mathrm{DL}=0^{(5)}$} & & \multicolumn{2}{|c|}{$>\mathrm{DL}^{(3)}$} & \multicolumn{2}{|c|}{$\mathrm{DL}=0.5 \mathrm{DL}^{(4)}$} & \multicolumn{2}{|c|}{$\mathrm{DL}=0^{(5)}$} & \multirow[b]{2}{*}{$<D L$} & \multicolumn{2}{|c|}{$>\mathrm{DL}^{\{3\rangle}$} & \multicolumn{2}{|c|}{$\mathrm{DL}=0.5 \mathrm{DL}^{(4)}$} & \multicolumn{2}{|c|}{$\mathrm{DL}=0^{(5)}$} \\
\hline & & & avg & sd & avg & sd & avg & $\mathrm{sd}$ & $<\mathrm{DL}$ & avg & sd & avg & $\mathrm{sd}$ & avg & sd & & avg & $\mathrm{sd}$ & avg & sd & avg & sd \\
\hline$\overline{\mathrm{SiO}_{2}}$ & 0.10 & 0 & 39.77 & 9.09 & 39.77 & 9.09 & 39.77 & 9.09 & 0 & 49.79 & 10.25 & 49.79 & 10.25 & 49.79 & 10.25 & 0 & 52.91 & 9.30 & 52.91 & 9.30 & 52.91 & 930 \\
\hline $\mathrm{TiO}_{2}$ & 0.01 & 33 & 0.10 & 0.21 & 0.07 & 0.18 & 0.07 & 0.18 & 31 & 0.02 & 0.00 & 0.01 & 0.01 & 0.01 & 0.01 & 41 & 0.02 & 0.01 & 0.01 & 0.01 & 0.01 & 0.01 \\
\hline $\mathrm{Al}_{2} \mathrm{O}_{3}$ & 0.03 & 29 & 0.40 & 0.46 & 0.29 & 0.42 & 0.29 & 0.43 & 0 & 0.24 & 0.19 & 0.24 & 0.19 & 0.24 & 0.19 & 0 & 0.15 & 0.15 & 0.15 & 0.15 & 0.15 & 0.15 \\
\hline $\mathrm{Fe}_{2} \mathrm{O}_{3} \mathrm{~T}$ & 0.02 & 0 & 48.94 & 8.15 & 48.94 & 8.15 & 48.94 & 8.15 & 0 & 47.68 & 10.12 & 47.68 & 10.12 & 47.68 & 10.12 & 0 & 46.12 & 9.28 & 46.12 & 9.28 & 46.12 & 9.28 \\
\hline $\mathrm{MnO}$ & 0.01 & 43 & 0.14 & 0.10 & 0.08 & 0.10 & 0.08 & 0.10 & 100 & 0.00 & 0.00 & 0.01 & 0.00 & 0.00 & 0.00 & 100 & 0.00 & 0.00 & 0.01 & 0.00 & 0.00 & 0.00 \\
\hline $\mathrm{MgO}$ & 0.02 & 0 & 2.58 & 0.82 & 2.58 & 0.82 & 2.58 & 0.82 & 95 & 0.13 & 0.02 & 0.02 & 0.03 & 0.01 & 0.03 & 94 & 0.20 & 0.00 & 0.02 & 0.05 & 0.01 & 0.05 \\
\hline $\mathrm{CaO}$ & 0.005 & 0 & 1.79 & 1.07 & 1.79 & 1.07 & 1179 & 1.07 & 0 & 0.04 & 0.03 & 0.04 & 0.03 & 0.04 & 0.03 & 0 & 0.04 & 0.02 & 0.04 & 0.02 & 0.04 & 0.02 \\
\hline $\mathrm{Na}_{2} \mathrm{O}$ & 0.05 & 90 & 0.35 & 0.24 & 0.06 & 0.11 & 0.03 & 0.12 & 64 & 0.27 & 0.09 & 0.11 & 0.13 & 0.10 & 0.14 & 76 & 0.44 & 0.32 & 0.12 & 0.23 & 0.10 & 0.24 \\
\hline $\mathrm{K}_{2} \mathrm{O}$ & 0.004 & 0 & 0.29 & 0.34 & 0.29 & 0.34 & 0.29 & 0.34 & 0 & 0.02 & 0.01 & 0.02 & 0.01 & 0.02 & 0.01 & 0 & 0.02 & 0.02 & 0.02 & 0.02 & 0.02 & 0.02 \\
\hline $\mathrm{P}_{2} \mathrm{O}_{5}$ & 0.004 & 0 & 0.21 & 0.16 & 0.21 & 0.16 & 0.21 & 0.16 & 0 & 0.15 & 0.04 & 0.15 & 0.04 & 0.15 & 0.04 & 0 & 0.11 & 0.01 & 0.11 & 0.01 & 0.11 & 0.01 \\
\hline $\mathrm{s}$ & 0.01 & 33 & 0.11 & 0.17 & 0.08 & 0.15 & 0.08 & 0.15 & 73 & 0.02 & 0.02 & 0.01 & 0.01 & 0.01 & 0.02 & 71 & 0.01 & 0.00 & 0.01 & 0.01 & 0.00 & 0.01 \\
\hline As & 10 & 100 & 0.00 & 0.00 & 5.00 & 0.00 & 0.00 & 0.00 & 100 & 0.00 & 0.00 & 5.00 & 0.00 & 0.00 & 0.00 & 100 & 0.00 & 0.00 & 5.00 & 0.00 & 0.00 & 0.00 \\
\hline $\mathrm{Ba}$ & 10 & 14 & 66.06 & 83.92 & 57.33 & 80.41 & 56.62 & 80.92 & 44 & 28.67 & 30.83 & 18.24 & 25.79 & 16.03 & 27.03 & 24 & 22.92 & 11.92 & 18.71 & 12.96 & 17.53 & 14.39 \\
\hline $\mathrm{Ce}^{*}$ & 0.50 & 0 & 6.30 & 4.78 & 6.30 & 4.78 & 6.30 & 4.78 & 0 & 5.63 & 2.41 & 5.63 & 2.41 & 5.63 & 2.41 & 0 & 6.07 & 1.25 & 6.07 & 1.25 & 6.07 & 1.25 \\
\hline Co & 2 & 5 & 13.50 & 10.18 & 12.90 & 10.29 & 12.86 & 10.35 & 0 & 30.32 & 10.34 & 30.32 & 10.34 & 30.32 & 10.34 & 0 & 52.29 & 17.84 & 52.29 & 17.84 & 52.29 & 1784 \\
\hline $\mathrm{Cr}$ & 5 & 38 & 18.96 & 7.95 & 12.69 & 10.25 & 11.74 & 11.27 & 2 & 30.38 & 15.20 & 29.86 & 15.58 & 29.86 & 15.58 & 12 & 26.80 & 12.79 & 23.94 & 14.43 & 23.65 & 14.91 \\
\hline $\mathrm{Cs}^{*}$ & 0.50 & 100 & 0.00 & 0.00 & 0.25 & 0.00 & 0.00 & 0.00 & 100 & 0.00 & 0.00 & 0.25 & 0.00 & 0.00 & 0.00 & 100 & 0.00 & 0.00 & 0.25 & 0.00 & 0.00 & 0.00 \\
\hline $\mathrm{Eu}^{*}$ & 0.05 & 0 & 0.28 & 0.25 & 0.28 & 0.25 & 0.28 & 0.25 & 0 & 0.30 & 0.08 & 0.30 & 0.08 & 0.30 & 0.08 & 0 & 0.22 & 0.09 & 0.22 & 0.09 & 0.22 & 0.09 \\
\hline $\mathrm{Hf}^{*}$ & 0.20 & 100 & 0.00 & 0.00 & 0.10 & 0.00 & 1000 & 0.00 & 100 & 0.00 & 0.00 & 0.10 & 0.00 & 0.00 & 0.00 & 100 & 0.00 & 0.00 & 0.10 & 0.00 & 0.00 & 0.00 \\
\hline $\mathrm{Ho}^{*}$ & 0.10 & 33 & 0.35 & 0.21 & 0.25 & 0.22 & 0.23 & 0.25 & 0 & 0.28 & 0.09 & 0.28 & 0.09 & 0.28 & 0.09 & 0 & 0.19 & 0.07 & 0.19 & 0.07 & 019 & 0.07 \\
\hline $\mathrm{La}^{*}$ & 0.05 & 0 & 3.20 & 2.26 & 3.20 & 2.26 & 3.20 & 2.26 & 0 & 2.70 & 1.19 & 2.70 & 1.19 & 2.70 & 1.19 & 0 & 3.66 & 0.87 & 3.66 & 0.87 & 3.66 & 0.87 \\
\hline $\mathrm{Lu} *$ & 0.01 & 0 & 0.13 & 0.08 & 0.13 & 0.08 & 0.13 & 0.08 & 0 & 0.14 & 0.05 & 0.14 & 0.05 & 0.14 & 0.05 & 0 & 0.12 & 0.01 & 0.08 & 0.06 & 0.09 & 0.04 \\
\hline $\mathrm{Nb}$ & 2 & 76 & 2.43 & 0.34 & 1.42 & 0.63 & 0.58 & 1.07 & 81 & 2.27 & 0.65 & 1.24 & 0.57 & 0.42 & 0.93 & 53 & 2.63 & 0.52 & 1.76 & 0.90 & 1.24 & 139 \\
\hline $\mathrm{Nd}^{*}$ & 1.00 & 33 & 3.99 & 2.49 & 2.83 & 2.68 & 2.66 & 2.90 & 0 & 2.94 & 1.00 & 2.94 & 1.00 & 2.94 & 1.00 & 0 & 3.08 & 1.39 & 3.08 & 1.39 & 3.08 & 139 \\
\hline $\mathrm{Ni}$ & 3 & 5 & 8.15 & 2.34 & 7.83 & 2.71 & 7.76 & 2.89 & 0 & 8.49 & 2.79 & 8.49 & 2.79 & 8.49 & 2.79 & 0 & 6.59 & 1.46 & 6.59 & 1.46 & 6.59 & 146 \\
\hline $\mathrm{Pb}$ & 10 & 48 & 11.05 & 0.71 & 8.17 & 3.14 & 5.79 & 5.68 & 80 & 11.08 & 1.62 & 6.24 & 2.57 & 2.25 & 4.55 & 82 & 10.33 & 0.58 & 5.94 & 2.11 & 1.82 & 4.07 \\
\hline $\mathrm{Rb}$ & 2 & 19 & 41.12 & 43.91 & 33.48 & 42.47 & 33.29 & 42.62 & 100 & 0.00 & 0.00 & 1.00 & 0.00 & 0.00 & 0.00 & 100 & 0.00 & 0.00 & 1.00 & 0.00 & 0.00 & 0.00 \\
\hline $\mathrm{Sc}^{*}$ & 0.10 & 0 & 0.36 & 0.12 & 0.36 & 0.12 & 0.36 & 0.12 & 0 & 1.20 & 0.73 & 1.20 & 0.73 & 1.20 & 0.73 & 0 & 0.72 & 0.06 & 0.64 & 0.13 & 0.64 & 0.13 \\
\hline $\mathrm{Sm}^{*}$ & 0.01 & 0 & 0.60 & 0.53 & 0.60 & 0.53 & 0.60 & 0.53 & 0 & 0.76 & 0.27 & 0.76 & 0.27 & 0.76 & 0.27 & 0 & 0.56 & 0.19 & 0.56 & 0.19 & 0.56 & 0.19 \\
\hline $\mathrm{S}_{\Gamma}$ & 2 & 5. & 29.89 & 23.03 & 28.51 & 23.32 & 28.47 & 23.38 & 17 & 4.43 & 2.54 & 3.85 & 2.65 & 3.68 & 2.86 & 0 & 6.71 & 4.04 & 6.71 & 4.04 & 16.71 & 4.04 \\
\hline $\mathrm{Tb}^{*}$ & 0.10 & 33 & 0.21 & 0.15 & 0.15 & 0.14 & 014 & 016 & 0 & 0.18 & 0.06 & 0.18 & 0.06 & 0.18 & 0.06 & 33 & 0.15 & 0.05 & 0.11 & 0.07 & 010 & 0.09 \\
\hline V & 8 & 86 & 11.90 & 7.19 & 5.13 & 3.63 & 170 & 4.84 & 92 & 10.20 & 2.39 & 4.53 & 1.85 & 088 & 2.93 & 59 & 9.71 & 1.60 & 6.35 & 3.06 & 4.00 & 5,02 \\
\hline Y & 2 & 0 & 13.53 & 4.96 & 13.53 & 4.96 & 1353 & 4.96 & 2 & 7.60 & 2.62 & 7.49 & 2.73 & 7.47 & 2.78 & 0 & 7.82 & 2.74 & 7.82 & 2.74 & 782 & 2.74 \\
\hline $\mathrm{Yb}^{*}$ & 0.03 & 0 & 0.85 & 0.52 & 0.85 & 0.52 & 0.85 & 0.52 & 0 & 0.88 & 0.29 & 0.88 & 0.29 & 0.88 & 0.29 & 33 & 0.60 & 0.26 & 0.60 & 0.26 & 0.60 & 0.26 \\
\hline $\mathrm{Zn}$ & 3 & 38 & 24.05 & 32.20 & 15.46 & 27.35 & 14.89 & 27.67 & 100 & 0.00 & 0.00 & 1.50 & 0.00 & 0.00 & 0.00 & 100 & 0.00 & 0.00 & 1.50 & 0.00 & 0.00 & 0.00 \\
\hline $\mathrm{Zr}$ & 3 & 62 & 22.29 & 31.12 & 9.42 & 21.12 & 8.49 & 21.49 & 83 & 5.60 & 2.37 & 2.19 & 1.81 & 0.95 & 2.32 & 100 & 0.00 & 0.00 & 1.50 & 0.00 & 0.00 & 0.00 \\
\hline
\end{tabular}


Appendix 3.4. (continued)

\begin{tabular}{|c|c|c|c|c|c|c|c|c|c|c|c|c|c|c|c|}
\hline & \multirow[b]{3}{*}{$\mathrm{DL}$} & \multicolumn{7}{|c|}{ Oxidized BIF (Mt. Whaleback) $(\mathrm{n}=12)$} & \multicolumn{7}{|c|}{ High-grade hemaite ore $(\mathrm{n}=13)$} \\
\hline & & \multirow[b]{2}{*}{$<\mathrm{DL}$} & \multicolumn{2}{|c|}{$>\mathrm{DL}^{(3)}$} & \multicolumn{2}{|c|}{$\mathrm{DL}=0.5 \mathrm{DL}^{(4)}$} & \multicolumn{2}{|c|}{$\mathrm{DL}=0^{(5)}$} & \multirow[b]{2}{*}{$\leq \mathrm{DL}$} & \multicolumn{2}{|c|}{$>\mathrm{DL}^{(3)}$} & \multicolumn{2}{|c|}{$\mathrm{DL}=0.5 \mathrm{DL}^{(4)}$} & \multicolumn{2}{|c|}{$\mathrm{DL}=0^{(5)}$} \\
\hline & & & avg & sd & avg & sd & avg & sd & & avg & $\mathrm{sd}$ & avg & sd & avg & sd \\
\hline$\overline{\mathrm{SiO}_{2}}$ & 0.10 & 0 & 41.47 & 14.08 & 41.47 & 14.08 & 41.47 & 14.08 & 0 & 0.57 & 0.32 & 0.57 & 0.32 & 0.57 & 0.32 \\
\hline $\mathrm{TiO}_{2}$ & 0.01 & 58 & 0.01 & 0.00 & 0.01 & 0.00 & 0.01 & $0.01 /$ & 0 & 0.02 & 0.01 & 0.02 & 0.01 & 0.02 & 0.01 \\
\hline $\mathrm{Al}_{2} \mathrm{O}_{3}$ & 0.03 & 42 & 0.13 & 0.03 & 0.08 & 0.07 & 0.08 & 0.07 & 0 & 0.19 & 0.16 & 0.19 & 0.16 & 0.19 & 0.16 \\
\hline $\mathrm{Fe}_{2} \mathrm{O}_{3} \mathrm{~T}$ & 0.02 & 0 & 57.73 & 13.85 & 57.73 & 13.85 & 57.73 & 13.85 & 0 & 98.77 & 0.66 & 98.77 & 0.66 & 98.77 & 0.66 \\
\hline $\mathrm{MnO}$ & 0.01 & 92 & 0.08 & 0.00 & 0.01 & 0.02 & 0.01 & 0.02 & 85 & 0.10 & 0.01 & 0.02 & 0.04 & 0.02 & 0.04 \\
\hline $\mathrm{MgO}$ & 0.02 & 100 & 0.00 & 0.00 & 0.01 & 0.00 & 0.00 & 0.00 & 100 & 0.00 & 0.00 & 0.01 & 0.00 & 0.00 & 0.00 \\
\hline $\mathrm{CaO}$ & 0.005 & 0 & 0.13 & 0.07 & 0.13 & 0.07 & 0.13 & 0.07 & 0 & 0.07 & 0.07 & 0.0 & 0.07 & 0.07 & 0.07 \\
\hline $\mathrm{Na}_{2} \mathrm{O}$ & 0.05 & 100 & 0.00 & 0.00 & 0.03 & 0.00 & 0.00 & 0.00 & 92 & 0.18 & 0.00 & 0.04 & 0.04 & 0.01 & 0.05 \\
\hline $\mathrm{K}_{2} \mathrm{O}$ & 0.004 & 0 & 0.02 & 0.00 & 0.02 & 0.00 & 0.02 & 0.00 & 0 & 0.02 & 0.00 & 0.0 & 0.00 & 0.02 & 0.00 \\
\hline $\mathrm{P}_{2} \mathrm{O}_{5}$ & 0.004 & 0 & 0.11 & 0.08 & 0.11 & 0.08 & 0.11 & 0.08 & 0 & 0.05 & 0.02 & 0.0 & 0.02 & 0.05 & 0.02 \\
\hline $\mathrm{s}$ & 0.01 & 92 & 0.04 & 0.00 & 0.01 & 0.01 & 0.00 & 0.01 & 77 & 0.01 & 0.00 & 0.0 & 0.00 & 0.00 & 0.00 \\
\hline As & 10 & 100 & & 0.00 & 5.00 & 0.00 & 0.00 & 0.00 & 100 & 0.00 & 0.0 & & 0. & 0.00 & 0.00 \\
\hline $\mathrm{Ba}$ & 10 & 67 & & 1.7 & 7.50 & 3.80 & 4.17 & 6.2 & 15 & 21.65 & 8.5 & 18. & 10.40 & 1832 & 11.27 \\
\hline $\mathrm{Ce}^{*}$ & 0.50 & 0 & & 2.35 & 4.06 & 2.35 & 4.06 & 2.35 & 0 & 7.77 & 4 & 7. & 4.33 & 7.77 & 4.33 \\
\hline $\mathrm{Co}$ & 2 & 0 & & 12.93 & 31.24 & 12.93 & 31.24 & 12.93 & 38 & 12.17 & 4.9 & 7. & $6 .{ }^{\circ}$ & 7.49 & 722 \\
\hline $\mathrm{Cr}$ & 5 & 8 & .95 & 18.67 & 23.99 & 19.05 & 23.78 & 19.32 & 0 & 35.49 & 20.79 & 35.4 & 20.79 & 35.49 & 20.79 \\
\hline $\mathrm{Cs}^{*}$ & 0.50 & 100 & & 0.00 & 0.25 & 0.00 & 0.00 & 0.00 & 100 & 0.00 & 0.00 & 0.2 & 0.00 & 0.00 & 0.00 \\
\hline $\mathrm{Eu}^{*}$ & & 0 & & 0.0 & 0.17 & 0.09 & 0.17 & 0.09 & 0 & 0.32 & 0.1 & & 0.1 & 0.32 & 0.15 \\
\hline $\mathrm{Hf}^{*}$ & & 100 & & 0.0 & 0.10 & 0.00 & 0.00 & 0.00 & 80 & 0.45 & 0.00 & 0. & 0. & 0.09 & 0.20 \\
\hline $\mathrm{Ho}^{*}$ & 0.1 & 25 & 0.2 & 0.08 & 0.18 & 0.10 & 0.22 & 0.08 & 0 & 0.3 & 0.2 & 0. & 0.28 & 0.39 & 0.28 \\
\hline $\mathrm{La}^{*}$ & 0.05 & 0 & 1.97 & 1.06 & 1.97 & 1.06 & 1.97 & 1.06 & ( & 4.34 & 3.4 & 4.3 & 3.41 & 4.34 & 3.41 \\
\hline $\mathrm{Lu}^{*}$ & 0.01 & 0 & 0.10 & 0.05 & 0.10 & 0.05 & 0.10 & 0.05 & 0 & 0.23 & 0.1 & 0.2 & 0.1 & 0.23 & 0.17 \\
\hline $\mathrm{Nb}$ & 2 & 75 & & & & 0.87 & 0.61 & 124 & 38 & 3.1 & 0.92 & 2.3 & 1.28 & 192 & 1.73 \\
\hline $\mathrm{Nd}^{*}$ & 1.00 & 0 & & 0.88 & & 0.88 & 1.89 & 0.88 & 0 & 3.50 & 1.3 & & 1.32 & 3.50 & 132 \\
\hline $\mathrm{Ni}$ & 3 & 0 & 16.06 & 20.20 & 16.06 & 20.20 & 16.06 & 20.20 & 23 & 12.18 & 5.7 & 9.7 & 6.8 & 9.37 & 7.29 \\
\hline $\mathrm{Pb}$ & 10 & 50 & & & & 4.29 & 6.22 & 6.75 & 23 & 22. & & 18. & 7. & 16.98 & 9,74 \\
\hline $\mathrm{Rb}$ & 2 & 100 & & 0.0 & & 0.00 & 0.00 & 0.00 & 100 & $0 . c$ & $0 . C$ & 1. & 0.00 & 0.00 & 0.00 \\
\hline $\mathrm{Sc}^{*}$ & 0.10 & 0 & & 0.14 & 0.37 & 0.14 & 0.37 & 0.14 & 0 & 1.37 & 0.44 & 1.37 & 0.44 & 137 & 0.44 \\
\hline $\mathrm{Sm}^{*}$ & 0.01 & 0 & 0.39 & 0.17 & 0.39 & 0.17 & 0.39 & 0.17 & 0 & 0.80 & 0.3 & 0.8 & 0.35 & 0.80 & 0.35 \\
\hline $\mathrm{Sr}$ & 2 & 17 & & 1.91 & 4.16 & 2.2 & 3.99 & 2.54 & 0 & 4.39 & 2.0 & 4.3 & 2.02 & 4.39 & 2.02 \\
\hline $\mathrm{Tb}^{*}$ & 0.10 & 50 & 0.14 & 0.04 & 0.10 & 0.06 & 0.14 & 0.04 & 0 & 0.22 & 0.13 & 0.22 & 0.13 & 0.22 & 0.13 \\
\hline V & 8 & 75 & 9.00 & 1.00 & 5.25 & 2.30 & 2.25 & 4.09 & 0 & 35.65 & 41.43 & 35.65 & 41.43 & 35.65 & 41.43 \\
\hline$Y$ & 2 & 0 & 7.84 & 2.80 & 7.84 & 2.80 & 784 & 2.80 & 23 & 13.92 & 4.16 & 10.94 & 6.72 & 10.71 & 7.09 \\
\hline $\mathrm{Yb}^{*}$ & 0.03 & 0 & & 0.31 & 0.63 & 0.31 & 0.63 & 0.31 & 0 & 1.37 & 1.03 & 1.37 & 1.03 & 1.37 & 1.03 \\
\hline $\mathrm{Zn}$ & 3 & 83 & 13.00 & 12.73 & 3.42 & 5.90 & 2.17 & 6.35 & 69 & 10.80 & 6.06 & 4.36 & 5.40 & 3.32 & 6.01 \\
\hline $7 \pi$ & & 67 & & & & 069 & & & 32 & & 368 & 620 & & & \\
\hline
\end{tabular}

Notes: BIF = banded iron-formaiton; $\mathrm{n}=$ number of samples in the group (for number analysed by neutron activation see appendix 1 ); (1) = Wittenoom and Junction Gorges; (2) = Weeli Wolli Spring, Mt. Robinson, Pamelia Hill and Cathedral Gorge; (3) values below the lower limit of detection were ignored; (4) values below the lower limit of detection were assigned values half of the detection limit; (5) values below the lower limit of detection were assigned 0 ; grey areas highlight average values used in PCA and mass-volume calculations (chapter 5 ); *analysed by instrumental neutron activation analysis; DL $=$ detection limit,$\angle \mathrm{DL}=\%$ of samples below the detection limit; avg = average; sd = standard deviation; major element oxide and trace element concentrations as $\mathrm{wt} \%$ and ppm respectively. 


\begin{tabular}{|c|c|c|c|c|c|c|c|c|c|c|c|c|c|c|c|c|c|c|c|c|c|c|}
\hline & \multirow[b]{3}{*}{ DL } & \multicolumn{7}{|c|}{ Black shate $^{(1)}(n=30)$} & \multicolumn{7}{|c|}{ Altered black shale ${ }^{(2)}(n=22)$} & \multicolumn{7}{|c|}{ Red shale $^{(2)}(n=42)$} \\
\hline & & \multirow[b]{2}{*}{$<\mathrm{DL}$} & \multicolumn{2}{|c|}{$>\mathrm{DL}^{(3)}$} & \multicolumn{2}{|c|}{$\mathrm{DL}=0.5 \mathrm{DL}^{(4)}$} & \multicolumn{2}{|c|}{$\mathrm{DL}=0^{(5)}$} & \multirow[b]{2}{*}{$<\mathrm{DL}$} & \multicolumn{2}{|c|}{$>\mathrm{DL}^{(3)}$} & \multicolumn{2}{|c|}{$\mathrm{DL}=0.5 \mathrm{DL}^{(4)}$} & \multicolumn{2}{|c|}{$\mathrm{DL}=0^{(5)}$} & \multirow[b]{2}{*}{$<\mathrm{DL}$} & \multicolumn{2}{|c|}{$>\mathrm{DL}^{(3)}$} & \multicolumn{2}{|c|}{$\mathrm{DL}=0.5 \mathrm{DL}^{(4)}$} & \multicolumn{2}{|c|}{$\mathrm{DL}=0^{(5)}$} \\
\hline & & & avg & sd & avg & $\mathrm{sd}$ & avg & $\mathrm{sd}$ & & avg & sd & avg & sd & avg & sd & & avg & sd & & & avg & sd \\
\hline$\overline{\mathrm{SiO}_{2}}$ & 0.10 & 0 & 39.12 & 7.88 & 39.12 & 7.88 & 39.12 & 7.88 & 0 & 34.83 & 11.48 & 34.8 & 11.48 & 3483 & 111.48 & 0 & 28.91 & 6.14 & 28.91 & 6.14 & 28.91 & 6.14 \\
\hline $\mathrm{TiO}_{2}$ & 0.01 & 0 & 0.34 & 0.23 & 0.34 & 0.23 & 0.34 & 0.23 & 0 & 0.71 & 0.26 & 0.7 & 0.26 & 0.71 & 0.26 & 0 & 0.95 & 0.33 & 0.95 & 0.33 & 0.95 & 0.33 \\
\hline $\mathrm{Al}_{2} \mathrm{O}_{3}$ & 0.03 & 0 & 6.72 & 2.95 & 6.72 & 2.95 & 6.72 & 2.95 & 0 & 19.52 & 4.18 & 19.5 & 4.18 & 19.52 & 4.18 & 0 & 22.48 & 3.36 & 22.48 & 3.36 & 22.48 & 3.36 \\
\hline $\mathrm{Fe}_{2} \mathrm{O}_{3} \mathrm{~T}$ & 0.02 & 0 & 26.68 & 7.62 & 26.68 & 7.62 & 26.68 & 7.62 & 0 & 23.93 & 9.89 & 23.9 & 9.89 & 23.93 & $9: 89$ & 0 & 33.76 & 9.50 & 33.76 & 9.50 & 33.76 & 9.50 \\
\hline $\mathrm{MnO}$ & 0.01 & 7 & 0.25 & 0.15 & 0.24 & 0.16 & 0.24 & 0.16 & 18 & 0.20 & 0.17 & 0.2 & 0.17 & 0.16 & 017 & 48 & 0.14 & 0.12 & 0.08 & 0.11 & 0.08 & 0.11 \\
\hline $\mathrm{MgO}$ & 0.02 & 0 & 6.93 & 2.22 & 6.93 & 2.22 & 6.93 & 2.22 & 0 & 5.71 & 3.38 & 5.7 & 3.38 & 5.71 & 13.38 & 12 & 3.12 & 3.49 & 2.75 & 3.43 & 2.75 & 3.43 \\
\hline $\mathrm{CaO}$ & 0.005 & 0 & 3.85 & 3.84 & 3.85 & 3.84 & 3.85 & 3.84 & 0 & 0.70 & 2.75 & 0.7 & 2.75 & 1070 & 2.75 & 0 & 0.18 & 0.24 & 0.18 & 0.24 & 0.18 & 0.24 \\
\hline $\mathrm{Na}_{2} \mathrm{O}$ & 0.05 & 30 & 0.30 & 0.16 & 0.23 & 0.19 & 0.22 & 0.19 & 68 & 0.23 & 0.12 & 0.1 & 0.12 & 0.07 & 0.13 & 90 & 0.16 & 0.02 & 0.04 & 0.04 & 0.02 & 0.05 \\
\hline $\mathrm{K}_{2} \mathrm{O}$ & 0.004 & 0 & 3.80 & 2.26 & 3.80 & 2.26 & 3.80 & 2.26 & 0 & 1.74 & 2.19 & 1.7 & 2.19 & 174 & 2.19 & 0 & 0.52 & 1.58 & 0.52 & 1.58 & 0.52 & 1.58 \\
\hline $\mathrm{P}_{2} \mathrm{O}_{5}$ & 0.004 & 0 & 0.13 & 0.11 & 0.13 & 0.11 & 0.13 & 0.11 & 0 & 0.12 & 0.07 & 0.1 & 0.07 & 0.12 & 0007 & 0 & 0.34 & 0.24 & 0.34 & 0.24 & 0.34 & 0.24 \\
\hline $\mathrm{s}$ & 0.01 & 0 & 0.62 & 0.64 & 0.62 & 0.64 & 0.62 & 0.64 & 14 & 0.03 & 0.02 & 0.0 & 0.02 & 0.02 & 0.02 & 90 & 0.02 & 0.01 & 0. & 0.00 & 0.00 & 0.01 \\
\hline As & 10 & 57 & 35.02 & 28.03 & 18.01 & 23.54 & 15.18 & 25.23 & 64 & 55.98 & 95.97 & 23.5 & 60.83 & 20.36 & 61.88 & 40 & 16.72 & 4.56 & 11.98 & 6.79 & 9.95 & 9.01 \\
\hline $\mathrm{Ba}$ & 10 & 0 & 377.99 & 276.61 & 377.99 & 276.61 & 377.99 & 276.61 & 9 & 52.31 & 40.96 & 48.0 & 41.37 & 47.56 & 41.89 & 26 & 39.67 & 29.22 & 31.41 & 29.47 & 30.22 & 30.62 \\
\hline $\mathrm{Co}$ & 2 & 7 & 19.99 & 10.11 & 18.72 & 10.88 & 18.65 & 10.99 & 5 & 62.78 & 43.05 & 60.0 & 44.03 & 59.93 & 44.09 & 24 & 42.38 & 23.54 & & 27.15 & 32.29 & 27.44 \\
\hline $\mathrm{Cr}$ & 5 & 3 & 50.50 & 23.22 & 48.90 & 24.44 & 48.81 & 24.61 & 5 & 145.09 & 114.70 & 138.6 & 115.99 & 138.49 & 116.13 & 10 & 161.81 & 90.86 & 146.64 & 98.44 & 146.40 & 98.80 \\
\hline $\mathrm{Nb}$ & 2 & 13 & 5.83 & 4.07 & 5.19 & 4.14 & 5.06 & 4.29 & 0 & 14.45 & 5.41 & 14.4 & 5.41 & 14.45 & 541 & 0 & 18.29 & 6.30 & 18.29 & 6.30 & 18.29 & 6.30 \\
\hline $\mathrm{Ni}$ & 3 & 0 & 41.89 & 33.40 & 41.89 & 33.40 & 41.89 & 33.40 & 0 & 206.28 & 241.90 & 206.3 & 241.90 & 206.28 & 24190 & 0 & 141.88 & 93.36 & 141.88 & 93.36 & 141.88 & 93.36 \\
\hline $\mathrm{Pb}$ & 10 & 43 & 23.20 & 22.11 & 15.31 & 18.81 & 13.15 & 20.16 & 73 & 17.30 & 15.07 & 8.4 & 9.25 & 4.72 & 10.78 & 67 & 13.34 & 3.92 & 7.78 & 4.55 & 4.45 & 6.73 \\
\hline $\mathrm{Rb}$ & 2 & 0 & 212.86 & 130.35 & 212.86 & 130.35 & 212.86 & 13035 & 23 & 119.23 & 122.28 & 92.4 & 118.17 & 92.13 & 11835 & 31 & 36.07 & 86.26 & 26.05 & 74.30 & 25.76 & 74.40 \\
\hline $\mathrm{Sr}$ & 2 & 0 & 37.43 & 36.28 & 37.43 & 36.28 & 37.43 & 36.28 & 5 & 32.04 & 33.60 & 30.6 & 33.45 & 30.59 & 33.50 & 0 & 24.63 & 36.71 & 24.63 & 36.71 & 24.63 & 36.71 \\
\hline V & 8 & 0 & 59.50 & 22.22 & 59.50 & 22.22 & 59.50 & 22.22 & 0 & 116.76 & 55.11 & 116.8 & 55.11 & 116.6 & 55.11 & 0 & 85.23 & 57.28 & 85.23 & 57.28 & 85.23 & 57.28 \\
\hline Y & 2 & 0 & 26.50 & 11.57 & 26.50 & 11.57 & 26.50 & 1157 & 0 & 47.92 & 28.73 & 47.9 & 28.73 & 4792 & 28.73 & 0 & 64.69 & 25.15 & 64.69 & 25.15 & 64.69 & 25.15 \\
\hline $\mathrm{Zn}$ & 3 & 0 & 130.99 & 110.05 & 130.99 & 110.05 & 13099 & 110.05 & 0 & 532.73 & 458.72 & 532.7 & 458.72 & 532.73 & 458.72 & 0 & 351.35 & 293.90 & 351.35 & 293.90 & 351.35 & 293.90 \\
\hline $\mathrm{Zr}$ & 3 & 0 & 92.78 & 92.28 & 92.78 & 92.28 & 92.78 & 92.28 & 0 & 231.48 & 100.34 & 231.5 & 100.34 & 231.48 & 100.34 & 0 & 290.91 & 92.18 & 290.91 & 92.18 & 290.91 & 92.18 \\
\hline $\mathrm{Ce}^{*}$ & 0.50 & 0 & 37.18 & 12.50 & 37.18 & 12.50 & 37.18 & 12.50 & 50 & 95.94 & 37.49 & 95.9 & 37.49 & 95.94 & 37.49 & 67 & 75.04 & 54.02 & 75.04 & 54.02 & 75.04 & 54.02 \\
\hline $\mathrm{Cs}^{*}$ & 0.50 & 0 & 17.00 & 5.56 & 17.00 & 5.56 & 17.00 & 5.56 & 0 & 4.19 & 2.01 & 2.2 & 2.49 & 2,10 & 2.60 & 0 & 4.23 & 4.02 & 1.58 & 2.83 & 1.41 & 2.92 \\
\hline $\mathrm{Eu} *$ & 0.05 & 0 & 1.08 & 0.51 & 1.08 & 0.51 & 1.08 & 0.51 & 0 & 1.37 & 0.51 & 1.4 & 0.5 & 1.37 & 0.51 & & 1.2 & 0.7 & 1.2 & 0.73 & 1.28 & 0.73 \\
\hline $\mathrm{HF}^{*}$ & 0.20 & 0 & 1.21 & 0.56 & 1.21 & 0.56 & 1.21 & 0.56 & 0 & 6.69 & 5.14 & 6.7 & 5.14 & 6.69 & 5.14 & 0 & 8. & 2.6 & 8. & 2.60 & 8.18 & 2.60 \\
\hline $\mathrm{Ho}^{*}$ & 0.10 & 0 & 0.80 & 0.26 & 0.80 & 0.26 & 0.80 & 0.26 & 0 & 1.60 & 0.82 & 1.6 & 0.82 & 1.60 & 0.82 & 0 & 1.54 & 0.33 & 1.54 & 0.33 & 1.54 & 0.33 \\
\hline $\mathrm{La}^{*}$ & 0.05 & 0 & 18.53 & 6.69 & 18.53 & 6.69 & 18.53 & 6.69 & 0 & 54.63 & 25.68 & 54.6 & 25.68 & 54.63 & 25.68 & 0 & 46.25 & 34.20 & 46.25 & 34.20 & 46.25 & 34.20 \\
\hline $\mathrm{Lu}^{*}$ & 0.01 & 0 & 0.29 & 0.08 & 0.29 & 0.08 & 0.29 & 0.08 & 0 & 1.03 & 1.02 & 1.0 & 1.02 & 1003 & 102 & 0 & & 0.51 & 1.25 & 0.51 & 125 & 0,51 \\
\hline $\mathrm{Nd}^{*}$ & 1.00 & 0 & 16.94 & 6.34 & 16.94 & 6.34 & 16.94 & 6.34 & 0 & 35.16 & 12.01 & 35.2 & 12.01 & 35.16 & 12.01 & 0 & 26.47 & 20.36 & 26.47 & 20.36 & 26.47 & 20.36 \\
\hline $\mathrm{Sc}^{*}$ & 0.10 & 0 & 6.67 & 2.04 & 6.67 & 2.04 & 6.67 & $2: 04$ & 0 & 20.69 & 6.16 & 20.7 & 6.16 & $20.69 \%$ & 616 & 0 & 22.98 & 4.87 & 22.98 & 4.87 & 22.98 & 4.87 \\
\hline $\mathrm{Sm}^{*}$ & 0.01 & 0 & 3.18 & 1.20 & 3.18 & 1.20 & 3.18 & 120 & 0 & 5.54 & 2.10 & 5.5 & 2.10 & 5.54 & 2.10 & 0 & 4.29 & 3.32 & 4.29 & 3.32 & 4.29 & 3.32 \\
\hline $\mathrm{Tb}^{*}$ & 0.10 & 0 & 0.58 & 0.20 & 0.58 & 0.20 & 0.58 & 0.20 & 0 & 0.98 & 0.36 & 1.0 & 0.36 & 0.98 & 0.36 & 0 & 0.83 & 0.29 & 0.83 & 0.29 & 0.83 & 0.29 \\
\hline $\mathrm{Yb}^{*}$ & 0.03 & 0 & 1.99 & 0.54 & 1.99 & 0.54 & 1.99 & 0.54 & 0 & 6.08 & 5.47 & 6.1 & 5.47 & 6.08 & 5.47 & 0 & 7.22 & 2.48 & 7.22 & 2.48 & 7.22 & 2.48 \\
\hline
\end{tabular}

Notes: $n=$ number of samples in the group (for number of samples analysed by neutron activation see appendix 1); (1) Wittenoom and Junction Gorges; (2) Mt. Whaleback; (3) = values below the lower limit of detection were igniored; (4) values below the lower limit of detection were assigned values half of the detection limit; (5) values below the lower limit of detection were assigned 0 ; grey areas highlight average values used in PCA and mass-volume calculations (chapter 5); *analysed by instrumental neutron activation analysis; DL $=$ detection limit, $\angle \mathrm{DL}=\%$ of samples below the detection limit; avg $=$ average; sd = standard 
APPENDIX 4

MINERALOGY OF BULK ROCKS 
Appendix 4.1. Semi-quantified mineralogy of rocks from the Hamersley Province*.

\begin{tabular}{|c|c|c|c|c|c|c|c|c|c|c|c|c|c|c|c|c|c|c|c|}
\hline Sample & Unit & Desciption & $\begin{array}{l}\text { Qtz } \\
(\%) \\
\end{array}$ & $\begin{array}{c}\text { Mag } \\
(\%)\end{array}$ & $\begin{array}{c}\text { Hem } \\
(\%)\end{array}$ & $\begin{array}{l}\text { Stp } \\
(\%)\end{array}$ & $\begin{array}{c}\text { Sd } \\
(\%) \\
\end{array}$ & $\begin{array}{l}\text { Dol } \\
(\%) \\
\end{array}$ & $\begin{array}{c}\text { Ank } \\
(\%) \\
\end{array}$ & $\begin{array}{l}\text { Kfs } \\
(\%) \\
\end{array}$ & $\begin{array}{l}\text { Ms } \\
(\%) \\
\end{array}$ & $\begin{array}{l}\text { Bio } \\
(\%) \\
\end{array}$ & $\begin{array}{l}\mathrm{Py} \\
(\%) \\
\end{array}$ & $\begin{array}{c}\text { Clino } \\
(\%)\end{array}$ & $\begin{array}{c}\text { Goet } \\
(\%) \\
\end{array}$ & $\begin{array}{l}\text { TIc } \\
(\%) \\
\end{array}$ & $\begin{array}{l}\text { KIn } \\
(\%) \\
\end{array}$ & $\begin{array}{l}\text { Apa } \\
(\%) \\
\end{array}$ & $\begin{array}{c}\text { Pyr } \\
(\%) \\
\end{array}$ \\
\hline \multicolumn{20}{|c|}{ Wittenoon Gorge (DDH-47A) } \\
\hline 4748 & DB16 & BIF & 35 & 17 & & & 38 & & & & & & & & & 10 & & & \\
\hline 477 & DB14 & BIF & 39 & 48 & & & 13 & & & & & & & & & & & & \\
\hline 4715 & DB11 & BIF & 49 & 23 & & & 22 & & & & & & & & & 5 & & & \\
\hline 4719 & DB10 & $\mathrm{BIF}$ & 34 & 57 & & 3 & & & & & & & & & & 6 & & & \\
\hline 4722 & DB8 & BIF & 33 & 39 & & 7 & 7 & & 8 & & & & & & & 4 & & & \\
\hline 4735 & DB3 & $\mathrm{BIF}$ & 38 & 32 & & 4 & 19 & & 7 & & & & & & & & & & \\
\hline 4739 & DBI & BIF & 28 & 40 & & 10 & 9 & & 9 & & & & & & & 5 & & & \\
\hline 4742 & $\mathrm{DB} 0$ & BIF & 41 & 50 & & 4 & & & 2 & & & & & & & 3 & & & \\
\hline $47 \mathrm{~W}_{1}$ & Whale & black shale & 14 & & & & & 41 & & 14 & 4 & & & 26 & & & & & \\
\hline $47 \mathrm{~W} 10$ & Whale & black shale & 5 & & & 30 & 34 & 13 & & 8 & & 9 & & & & & & & \\
\hline AW44 & DS16 & black shale & 12 & & & 24 & & & 48 & 16 & & & & & & & & & \\
\hline 475 & DS15 & black shale & 4 & & & 26 & & 17 & & 24 & & 28 & & & & & & & \\
\hline AW43 & DS11 & black shale & 7 & & & 16 & & & & 56 & & & & 21 & & & & & \\
\hline AW42 & DS9 & black shale & 27 & & & & & & & 48 & & & 7 & 18 & & & & & \\
\hline 4723 & DS8 & black shale & 2 & & & 53 & & 2 & & 2 & & & & 41 & & & & & \\
\hline 4730 & DS5 & black shale & & & & 55 & & 6 & & & & 39 & & & & & & & \\
\hline 4733 & DS4 & black shale & 35 & & & 36 & 21 & 8 & & & & & & & & & & & \\
\hline AW41 & DS2 & black shale & & & & 40 & & & 34 & 26 & & & & & & & & & \\
\hline 4738 & DS2 & black shale & 1 & & & 34 & & 5 & & 45 & & 15 & & & & & & & \\
\hline 4743 & McRae & black shale & & & & 87 & & & & & 13 & & & & & & & & \\
\hline 4710 & DS13 & chert-siderite & 57 & & & 5 & 33 & 4 & & & 2 & & & & & & & & \\
\hline 4721 & DS9 & chert-siderite & 75 & & & & 22 & 2 & & & & & & & & & & & \\
\hline $47 \mathrm{~W} 2$ & Whale & chert-siderite & 29 & & & & 62 & 5 & & & & & & & & 3 & & & \\
\hline $47 \mathrm{~W} 8$ & Whale & cherty BIF & 11 & 72 & & 5 & & & & & 5 & & & & & 6 & & 1 & \\
\hline $47 \mathrm{~W} 7$ & Whale & cherty BIF & 12 & 2 & & 10 & 71 & & & 6 & & & & & & & & & \\
\hline \multicolumn{20}{|c|}{ Weeli Wolli Spring } \\
\hline WW9 & $\mathrm{DB} 16$ & weathered BIF & 43 & 0 & 50 & & & & & & & & & & 7 & & & & \\
\hline WW13 & $\mathrm{DB} 12$ & weathered $\mathrm{BIF}$ & 48 & 0 & 32 & & & & & & & & & & 21 & & & & \\
\hline WW6 & DB4 & weathered BIF & 31 & 0 & 53 & & & & & & & & & & 16 & & & & \\
\hline WW3 & DB2 & weathered BIF & 42 & 0 & 39 & & & & & & & & & & 19 & & & & \\
\hline WWI & DB0 & weathered BIF & 51 & 0 & 29 & & & & & & & & & & 21 & & & & \\
\hline
\end{tabular}


Appendix 4.1. (continued)

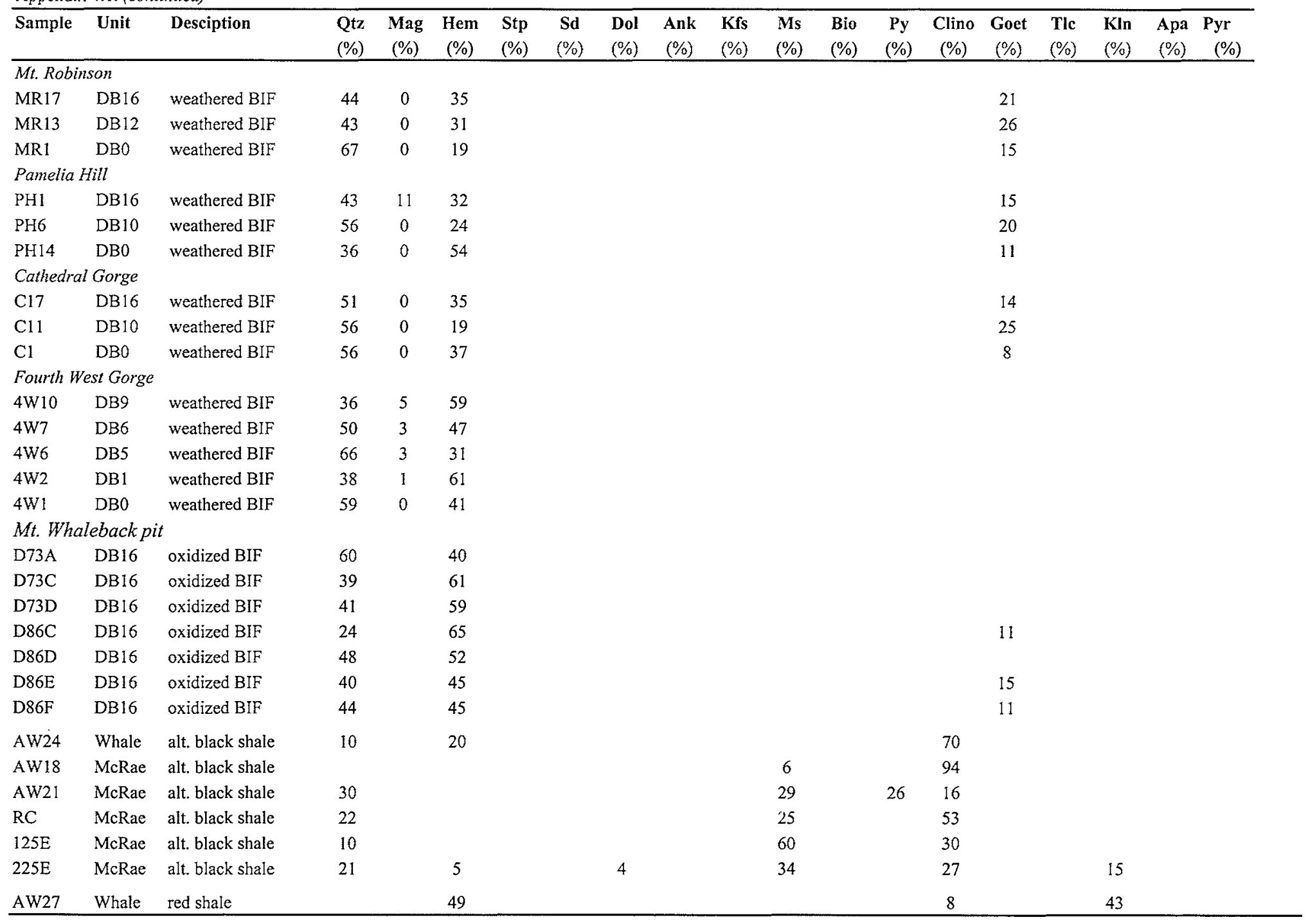




\begin{tabular}{|c|c|c|c|c|c|c|c|c|c|c|c|c|c|c|c|c|c|c|c|}
\hline Sample & Unit & Desciption & $\begin{array}{l}\text { Qtz } \\
(\%)\end{array}$ & $\begin{array}{c}\text { Mag } \\
(\%)\end{array}$ & $\begin{array}{c}\text { Hem } \\
(\%)\end{array}$ & $\begin{array}{l}\text { Stp } \\
(\%)\end{array}$ & $\begin{array}{c}\text { Sd } \\
(\%)\end{array}$ & $\begin{array}{l}\text { DoI } \\
(\%)\end{array}$ & $\begin{array}{c}\text { Ank } \\
(\%)\end{array}$ & $\begin{array}{l}\text { Kfs } \\
(\%)\end{array}$ & $\begin{array}{l}\text { Ms } \\
(\%)\end{array}$ & $\begin{array}{l}\text { Bio } \\
(\%)\end{array}$ & $\begin{array}{l}\text { Py } \\
(\%)\end{array}$ & $\begin{array}{c}\text { Clino } \\
(\%)\end{array}$ & $\begin{array}{l}\text { Goet } \\
(\%)\end{array}$ & $\begin{array}{l}\text { TIc } \\
(\%)\end{array}$ & $\begin{array}{l}\text { Kln } \\
(\%)\end{array}$ & $\begin{array}{l}\text { Apa } \\
(\%)\end{array}$ & $\begin{array}{c}\text { Pyr } \\
(\%)\end{array}$ \\
\hline AW31 & Whale & red shale & & & 40 & & & & & & & & & 16 & & & 44 & & \\
\hline AW36 & Whale & red shale & & & 36 & & & & & & & & & 18 & & & 46 & & \\
\hline $\mathrm{D} 86 \mathrm{~B}$ & DS16 & red shale & & & 48 & & & & & & & & & 11 & & & 41 & & \\
\hline AW14 & DS16 & red shale & & & 43 & & & & & & & & & & & & 57 & & \\
\hline AW10 & DS12 & red shale & & & 22 & & & & & & & & & & & & 78 & & \\
\hline AW6 & DS9 & red shale & & & 54 & & & & & & & & & 6 & & & 40 & & \\
\hline AW1 & DS4 & red shale & & & 44 & & & & & & & & & 39 & & & 17 & & \\
\hline D4091 & McRae & alt. black shale & 24 & & & & & & & & 41 & & & 35 & & & & & \\
\hline D4092 & McRae & greyish-green shale & 40 & & & & & & & & 36 & & & 25 & & & & & \\
\hline D4094 & McRae & reddish-green shale & 21 & & & & & 38 & & & 11 & & & 31 & & & & & \\
\hline D4096 & McRae & reddish-green shale & & & 9 & & & 71 & & & & & & 21 & & & & & \\
\hline D4097 & McRae & red shale & & & 41 & & & & & & & & & 59 & & & & & \\
\hline D4099 & McRae & shaley ore & & & 91 & & & & & & & & & & 9 & & & & \\
\hline D40910 & McRae & red shale & & & 42 & & & & & & & & & 39 & & & 18 & & \\
\hline D40912 & McRae & shaley ore & & & 83 & & & & & & & & & & & & 17 & & \\
\hline AW29 & Whale & iron ore & & & 98 & & & & & & & & & & & & 2 & & \\
\hline E24C & DB16 & iron ore & & & 100 & & & & & & & & & & & & & & \\
\hline AW 15 & McRae & iron ore & & & 99 & & & & & & & & & & & & 1 & & \\
\hline AW22 & Whale & shaley ore & & & 85 & & & & & & & & & & & & 15 & & \\
\hline AW28 & Whale & shaley ore & & & 5 & & & & & & & & & & 74 & & 18 & & 4 \\
\hline AW34 & Whale & shaley ore & & & 73 & & & & & & & & & & & & 6 & 21 & \\
\hline AW39 & Whale & shaley ore & & & 87 & & & & & & & & & & & & 13 & & \\
\hline D73F & DS16 & shaley ore & & & 57 & & & & & & & & & & & & 40 & & 3 \\
\hline
\end{tabular}

Notes: * XRD traces of each samples on accompanying compact disk (File XRD traces.pdf); Whale $=$ Whaleback Shale Member; McRae $=$ Mt. McRae Shale; BIF $=$ banded iron-formation; ank = ankerite; apa = apatite; bio = biotite; clino = clinochlore; dol = dolomite; goet = goethite; hem $=$ hematite; kln $=$ kaolinite; $\mathrm{Kfs}=\mathrm{K}$-feldspar; mag $=$ magnetite; $m s=$ muscovite; $p y=$ pyrite; pyr $=$ pyrophyllite; $q \mathrm{tz}=$ quartz; $\mathrm{sd}=$ siderite; $\mathrm{stp}=$ stilpnomelane; tle $=$ tale 

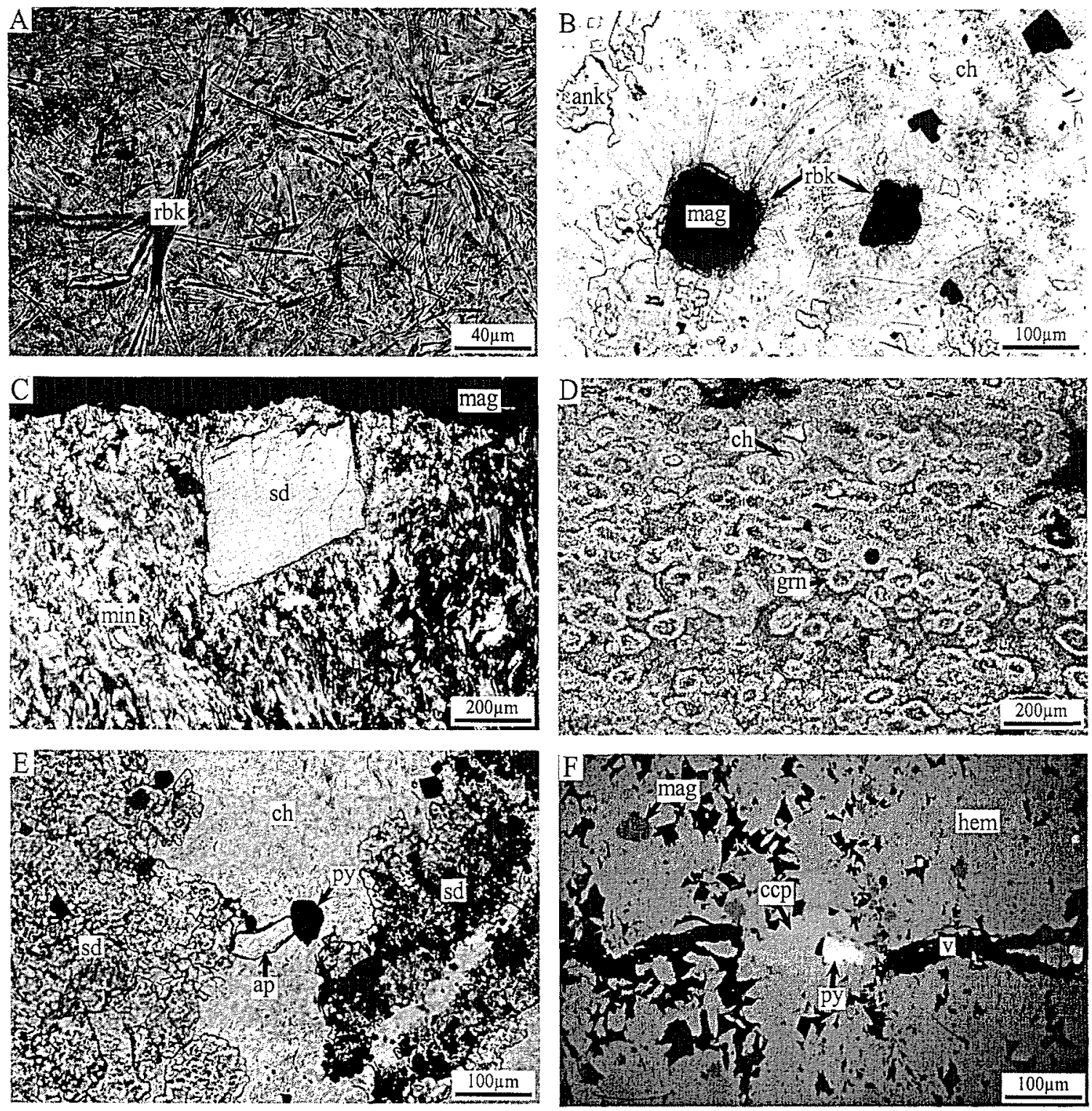

Appendix 4.2. Photomicrographs of minor phases in unaltered BIF from the northern Hamersley Province. (a) Relatively long, randomly orientated fibrous riebeckite ( $\mathrm{rbk}$ ) laths in chert-martix mesoband (sample 4724, Wittenoom Gorge). Plane polarized light. (b) Riebeckite (rbk) laths nucleating on magnetite euhedra (sample JGA7, Junction Gorge). Plane polarized light. (c) Felted masses of minnesotaite (min) between magnetite $(\mathrm{mt})$ microbands. Note replacement by coarse-grained euhedral siderite (sd) (sample 4722, Wittenoom Gorge). Crossed polarized light. (d) Extremely fine-grained spherical greenalite (grn) structures in chert. Note chert (ch) inclusions in some grains. (Sample 473, Wittenoom Gorge). Plane polarized light. (e) Fine-grained subhedral apatite (ap) grain in chert-matrix mesoband (sample 477, Wittenoom Gorge). Note relatively high relief of apatite compared to carbonates. (f) Rare pyrite (py) and calcopyrite (ccp) as infill on late cross cutting vein (sample 4722, Wittenoom Gorge). 
APPENDIX 5

MINERAL CHEMISTRY 
Appendix 5.1. Average chemical composition of silicate minerals in BIF from the Dales Gorge Member

\begin{tabular}{lrrrrrrrrrrrr}
\hline Sample & 1 & 2 & 3 & 4 & 5 & 6 & 7 & 8 & 9 & 10 & 11 & 12 \\
& Stp & Stp & Stp & Stp & Stp & Stp & Stp & Min & Min & Rbk & Rbk & Grn \\
\hline $\mathrm{SiO}_{2}$ & 44.60 & 41.26 & 44.36 & 45.20 & 48.89 & 46.37 & 45.34 & 58.17 & 55.24 & 50.79 & 50.54 & 36.02 \\
$\mathrm{TiO}_{2}$ & 0.07 & 0.05 & 0.05 & 0.17 & 0.14 & 0.09 & - & 0.01 & 0.01 & 0.06 & 0.05 & 0.02 \\
$\mathrm{Al}_{2} \mathrm{O}_{3}$ & 3.73 & 2.47 & 2.87 & 3.72 & 3.07 & 3.41 & 2.88 & 0.02 & - & - & - & - \\
$\mathrm{FeO}$ & 26.72 & 35.52 & 31.28 & 24.87 & 25.03 & 26.69 & 23.75 & 20.87 & 18.71 & 23.09 & 25.89 & 48.18 \\
$\mathrm{MnO}$ & 0.06 & 0.09 & 0.02 & 0.10 & 0.04 & - & 0.01 & - & 0.07 & 0.04 & 0.11 & - \\
$\mathrm{MgO}$ & 6.82 & 3.84 & 3.04 & 7.86 & 9.76 & 7.33 & 8.74 & 16.32 & 16.37 & 5.34 & 5.80 & 1.91 \\
$\mathrm{CaO}$ & 0.05 & - & - & 0.04 & - & 0.12 & 0.85 & 0.03 & 0.03 & 0.05 & 0.13 & 0.01 \\
$\mathrm{Na} 2 \mathrm{O}$ & 0.19 & 0.12 & 0.05 & 0.44 & - & 0.14 & 0.17 & 0.24 & - & 4.56 & 4.02 & 0.06 \\
$\mathrm{~K}_{2} \mathrm{O}$ & 5.72 & 4.27 & 2.36 & 5.98 & 0.83 & 2.22 & 3.02 & - & 0.02 & 0.72 & 0.36 & 0.03 \\
$\mathrm{H}_{2} \mathrm{O} *$ & 12.04 & 12.37 & 15.98 & 11.62 & 12.21 & 13.65 & 15.25 & 4.33 & 9.54 & 15.34 & 13.11 & 13.77 \\
& & & & & & & & & & & \\
$\mathrm{Tot}$. & $(100.00)$ & $(100.00)$ & $(100.00)$ & $(100.00)$ & $(100.00)$ & $(100.00)$ & $(100.00)$ & $(100.00)$ & $(100.00)$ & $(100.00)$ & $(100.00)$ & $(100.00)$ \\
$\mathrm{O}^{* *}$ & 23.81 & 23.81 & 23.81 & 23.81 & 23.81 & 23.81 & 23.81 & 11 & 11 & 24 & 24 & 14 \\
$\mathrm{Si}$ & 8.02 & 7.84 & 8.38 & 8.03 & 8.34 & 8.25 & 8.20 & 4.04 & 4.03 & 9.10 & 8.93 & 4.37 \\
$\mathrm{Ti}$ & 0.01 & 0.01 & 0.01 & 0.02 & 0.02 & 0.01 & - & 0.00 & 0.00 & 0.01 & 0.01 & 0.00 \\
$\mathrm{Al}$ & 0.79 & 0.55 & 0.64 & 0.78 & 0.62 & 0.71 & 0.61 & 0.00 & - & - & - & - \\
$\mathrm{Fe}$ & 4.02 & 5.64 & 4.94 & 3.69 & 3.57 & 3.97 & 3.59 & 1.21 & 1.14 & 3.46 & 3.83 & 4.89 \\
$\mathrm{Mn}$ & 0.01 & 0.02 & 0.00 & 0.02 & 0.01 & - & 0.00 & - & 0.00 & 0.01 & 0.02 & - \\
$\mathrm{Mg}$ & 1.83 & 1.09 & 0.85 & 2.08 & 2.48 & 1.94 & 2.36 & 1.69 & 1.78 & 1.43 & 1.53 & 0.35 \\
$\mathrm{Ca}$ & 0.01 & - & - & 0.01 & - & 0.02 & 0.17 & 0.00 & 0.00 & 0.01 & 0.02 & 0.00 \\
$\mathrm{Na}$ & 0.07 & 0.05 & 0.02 & 0.15 & - & 0.05 & 0.06 & 0.03 & - & 1.59 & 1.38 & 0.01 \\
$\mathrm{~K}$ & 1.33 & 1.04 & 0.57 & 1.35 & 0.18 & 0.50 & 0.69 & - & 0.00 & 0.17 & 0.08 & 0.00 \\
& 16.09 & 16.23 & 15.40 & 16.13 & 15.24 & 15.47 & 15.68 & 6.98 & 6.97 & 15.77 & 15.79 & 9.63 \\
\hline & & & & & & & & & & &
\end{tabular}

Sample descriptions

1. Fine-grained ferrostilpnomelane associated with chert and siderite (sample 4735)

2. Fine-grained ferrostilpnomelane lath in chert (sample 473)

3. Fine-grained green/brown stilpnomelane rosette (sample 477)

4. Green/brown stilpnomelane replacing siderite (sample 4735)

5. Brown ferristilpnomelane replacing siderite (sample 4722)

6. Coarse ferristilpnomelane lath associated with recrystallised quartz (sample 4715)

7. Dark brown ferristilpnomelane associated with coarse-grained siderite (sample 479)

8. Micaceous minnesotaite in vein (sample 4722)

9. Colourless subhedral minnesotaite associated with stilpnomelane (sample 4722)

10. Riebeckite lath nucleating off magnetite (sample 4737)

11. Disseminated riebeckite crystal in chert-matrix mesoband (sample 4737)

12. Fine-grained greenalite (sample 473 )

Notes: $* \mathrm{H}_{2} \mathrm{O}$ data obtained by subtracting electron microprobe total from $100 \%$;**number of oxygens used to calculate ions; total Fe as Fe2+ only; '-' = below detection; results represent the average of three separate analyses (appendix 5.3) 
Appendix 5.2. Average chemical composition of carbonate minerals in BIF from the Dales Gorge Member

\begin{tabular}{|c|c|c|c|c|c|c|c|c|c|c|}
\hline \multirow[t]{2}{*}{ Sample } & 13 & 14 & 15 & 16 & 17 & 18 & 19 & 20 & 21 & 22 \\
\hline & $\mathrm{Sd}$ & $\mathrm{Sd}$ & Sd & $\mathrm{Sd}$ & $\mathrm{Sd}$ & $\mathrm{Sd}$ & $\mathrm{Sd}$ & Ank & Ank & Ank \\
\hline $\mathrm{FeO}$ & 57.09 & 49.96 & 48.64 & 50.54 & 46.97 & 51.59 & 44.14 & 19.55 & 15.71 & 15.97 \\
\hline $\mathrm{MnO}$ & - & 0.56 & 0.27 & 0.27 & 0.35 & 0.13 & 0.16 & 0.17 & 0.22 & 0.33 \\
\hline $\mathrm{MgO}$ & 2.63 & 7.87 & 7.43 & 7.40 & 9.62 & 6.76 & 11.55 & 8.20 & 11.11 & 9.82 \\
\hline $\mathrm{CaO}$ & 0.20 & 0.38 & 0.94 & 0.37 & 0.20 & 0.42 & 0.11 & 27.05 & 27.02 & 28.53 \\
\hline $\mathrm{CO}_{2} *$ & 40.08 & 41.23 & 42.72 & 41.41 & 42.85 & 41.10 & 44.03 & 45.03 & 45.94 & 45.35 \\
\hline Total & $(100.00)$ & $(100.00)$ & $(100.00)$ & $(100.00)$ & $(100.00)$ & $(100.00)$ & $(100.00)$ & $(100.00)$ & $(100.00)$ & $(100.00)$ \\
\hline \multicolumn{11}{|c|}{ Cations calculated on the the basis of 6 oxygens (total $\mathrm{Fe}$ as $\mathrm{Fe}^{2+}$ only) } \\
\hline $\mathrm{Fe}^{2+}$ & 5.52 & 4.61 & 4.61 & 4.70 & 4.35 & 4.81 & 4.07 & 1.70 & 1.34 & 1.36 \\
\hline $\mathrm{Mn}$ & - & 0.05 & 0.03 & 0.03 & 0.03 & 0.01 & 0.02 & 0.01 & 0.02 & 0.03 \\
\hline $\mathrm{Mg}$ & 0.45 & 1.29 & 1.25 & 1.23 & 1.59 & 1.12 & 1.90 & 1.27 & 1.69 & 1.49 \\
\hline \multirow[t]{2}{*}{$\mathrm{Ca}$} & 0.02 & 0.04 & 0.11 & 0.04 & 0.02 & 0.05 & 0.01 & 3.01 & 2.95 & 3.12 \\
\hline & 6.00 & 6.00 & 6.00 & 6.00 & 6.00 & 6.00 & 6.00 & 6.00 & 6.00 & 6.00 \\
\hline
\end{tabular}

Sample descriptions

13. Fine siderite in chert-matrix mesoband (sample 477)

14. Cigar shaped siderite in chert mesoband (sample 4715)

15 Recrystallised elongated siderite associated with fibrous quartz (sample 4735)

16 Recrystallised anhedral siderite with chert (sample 4735)

17. Coarse euhedral siderite associated with minnesotaite (sample 4722)

18. Coarse-grained siderite replacing ferristilpnomelane (sample 4722)

19. Siderite being partially replaced by ferristilpnomelane (sample 4722)

20. Recrystallised elongated ankerite associated with fibrous quartz (sample 4735)

21. Coarse ankerite rhomb in chert-matrix (sample 4742)

22. Coarse subhedral ankerite associated with ferristilpnomelane (sample 479)

Notes: * $\mathrm{CO}_{2}$ data obtained by subtracting electron microprobe total from $100 \%$; total $\mathrm{Fe}$ as Fe $2+$ only; '-' = below detection; results represent the average of three separate analyses (appendix 5.3) 
Appendix 5.3. Chemical composition of silicates and carbonates in unaltered BIF from the northern Hamersley Province.

\begin{tabular}{|c|c|c|c|c|c|c|c|c|c|c|c|c|c|c|c|c|c|c|}
\hline $\begin{array}{l}\text { Sample }^{1} \\
\text { Mineral } \\
\end{array}$ & $\begin{array}{r}\text { 1a } \\
\text { stp } \\
\end{array}$ & $\begin{array}{r}1 b \\
\text { stp }\end{array}$ & $\begin{array}{r}1 \mathrm{c} \\
\text { stp }\end{array}$ & $\begin{array}{r}2 a \\
\text { stp } \\
\end{array}$ & $\begin{array}{l}2 b \\
\text { stp }\end{array}$ & $\begin{array}{r}2 \mathrm{c} \\
\mathrm{stp}\end{array}$ & $\begin{array}{r}3 a \\
\text { stp } \\
\end{array}$ & $\begin{array}{r}3 b \\
\text { stp }\end{array}$ & $\begin{array}{r}3 \mathrm{c} \\
\text { stp }\end{array}$ & $\begin{array}{r}4 a \\
\text { stp } \\
\end{array}$ & $\begin{array}{r}4 \mathrm{~b} \\
\text { stp } \\
\end{array}$ & $\begin{array}{r}4 \mathrm{c} \\
\text { stp } \\
\end{array}$ & $\begin{array}{r}5 a \\
\text { stp } \\
\end{array}$ & $\begin{array}{r}5 b \\
\text { stp } \\
\end{array}$ & $\begin{array}{r}5 \mathrm{c} \\
\text { stp } \\
\end{array}$ & $\begin{array}{r}6 \mathrm{a} \\
\text { stp } \\
\end{array}$ & $\begin{array}{r}6 b \\
\text { stp } \\
\end{array}$ & $\begin{array}{r}6 c \\
\text { stp } \\
\end{array}$ \\
\hline \multicolumn{19}{|c|}{ Oxide weight percent } \\
\hline $\mathrm{SiO}_{2}$ & 45.74 & 40.84 & 47.22 & 39.62 & 40.96 & 43.21 & 45.48 & 43.43 & 44.18 & 44.77 & 45.12 & 45.72 & 48.62 & 49.20 & 48.85 & 47.24 & 45.93 & 45.94 \\
\hline $\mathrm{TiO}_{2}$ & 0.13 & - & 0.08 & 0.10 & - & 0.04 & 0.05 & - & 0.09 & - & 0.11 & 0.41 & 0.20 & 0.23 & - & 0.15 & 0.11 & - \\
\hline $\mathrm{Al}_{2} \mathrm{O}_{3}$ & 3.80 & 3.56 & 3.83 & 2.47 & 2.41 & 2.52 & 2.43 & 3.01 & 3.17 & 3.89 & 3.40 & 3.87 & 3.01 & 3.19 & 3.01 & 3.82 & 3.02 & 3.39 \\
\hline $\mathrm{FeO}$ & 26.63 & 25.11 & 28.43 & 34.53 & 35.90 & 36.13 & 30.83 & 30.96 & 32.04 & 25.31 & 23.69 & 25.60 & 24.84 & 24.29 & 25.96 & 27.18 & 26.85 & 26.03 \\
\hline $\mathrm{MnO}$ & - & - & 0.19 & 0.28 & - & - & 0.05 & - & - & 0.29 & 0.01 & - & - & 0.11 & - & - & - & - \\
\hline $\mathrm{MgO}$ & 7.09 & 6.44 & 6.93 & 3.71 & 4.31 & 3.50 & 3.10 & 2.91 & 3.10 & 8.24 & 7.85 & 7.48 & 9.28 & 10.33 & 9.66 & 7.45 & 7.11 & 7.42 \\
\hline $\mathrm{CaO}$ & - & 0.14 & - & - & - & - & - & - & - & - & 0.11 & - & - & - & - & 0.22 & 0.02 & 0.11 \\
\hline $\mathrm{Na}_{2} \mathrm{O}$ & 0.25 & 0.31 & - & 0.23 & 0.14 & - & 0.08 & - & 0.06 & 0.43 & 0.85 & 0.05 & - & - & - & 0.42 & - & - \\
\hline $\mathrm{K}_{2} \mathrm{O}$ & 7.40 & 8.20 & 1.55 & 4.62 & 4.51 & 3.69 & 2.17 & 2.62 & 2.30 & 5.95 & 7.68 & 4.31 & 0.83 & 0.66 & 1.00 & 2.00 & 2.57 & 2.08 \\
\hline $\mathrm{H}_{2} \mathrm{O}^{*}$ & 8.96 & 15.40 & 11.77 & 14.44 & 11.77 & 10.91 & 15.81 & 17.07 & 15.06 & 11.12 & 11.18 & 12.56 & 13.18 & 11.94 & 11.50 & 11.52 & 14.39 & 15.03 \\
\hline \multicolumn{19}{|l|}{$\mathrm{CO}_{2}{ }^{*}$} \\
\hline Total & 91.04 & 84.60 & 88.23 & 85.56 & 88.23 & 89.09 & 84.19 & 82.93 & 84.94 & 88.88 & 88.82 & 87.44 & 86.82 & 88.06 & 88.50 & 88.48 & 85.61 & 84.97 \\
\hline \multicolumn{19}{|c|}{ Number of atoms recalculated on the basis of** } \\
\hline & 23.8 & 23.8 & 23.8 & 23.8 & 23.8 & 23.8 & 23.8 & 23.8 & 23.8 & 23.8 & 23.8 & 23.8 & 23.8 & 23.8 & 23.8 & 23.8 & 23.81 & 23.81 \\
\hline $\mathrm{Si}$ & 8.00 & 7.83 & 8.23 & 7.76 & 7.76 & 7.99 & 8.51 & 8.33 & 8.28 & 7.94 & 8.03 & 8.11 & 8.39 & 8.33 & 8.32 & 8.20 & 8.28 & 8.28 \\
\hline $\mathrm{Ti}$ & 0.02 & - & 0.01 & 0.01 & - & 0.01 & 0.01 & - & 0.01 & - & 0.01 & 0.05 & 0.03 & 0.03 & - & 0.02 & 0.01 & - \\
\hline Al & 0.78 & 0.80 & 0.79 & 0.57 & 0.54 & 0.55 & 0.54 & 0.68 & 0.70 & 0.81 & 0.71 & 0.81 & 0.61 & 0.64 & 0.60 & 0.78 & 0.64 & 0.72 \\
\hline $\mathrm{Fe}^{2+}$ & 3.89 & 4.02 & 4.14 & 5.66 & 5.69 & 5.59 & 4.82 & 4.97 & 5.02 & 3.75 & 3.53 & 3.80 & 3.58 & 3.44 & 3.70 & 3.94 & 4.05 & 3.92 \\
\hline Mn & - & - & 0.03 & 0.05 & - & - & 0.01 & - & - & 0.04 & 0.00 & - & - & 0.02 & - & - & - & - \\
\hline $\mathrm{Mg}$ & 1.85 & 1.84 & 1.80 & 1.08 & 1.22 & 0.97 & 0.86 & 0.83 & 0.87 & 2.18 & 2.08 & 1.98 & 2.39 & 2.61 & 2.45 & 1.93 & 1.91 & 1.99 \\
\hline $\mathrm{Ca}$ & - & 0.03 & - & - & - & - & - & - & - & - & 0.02 & - & - & - & - & 0.04 & 0.00 & 0.02 \\
\hline $\mathrm{Na}$ & 0.08 & 0.12 & - & 0.09 & 0.05 & - & 0.03 & - & 0.02 & 0.15 & 0.29 & 0.02 & - & - & - & 0.14 & - & - \\
\hline \multirow[t]{2}{*}{$\mathrm{K}$} & 1.65 & 2.00 & 0.34 & 1.15 & 1.09 & 0.87 & 0.52 & 0.64 & 0.55 & 1.35 & 1.74 & 0.98 & 0.18 & 0.14 & 0.22 & 0.44 & 0.59 & 0.48 \\
\hline & 16.27 & 16.64 & 15.35 & 16.37 & 16.35 & 15.97 & 15.30 & 15.46 & 15.45 & 16.21 & 16.43 & 15.74 & 15.19 & 15.21 & 15.30 & 15.49 & 15.49 & 15.41 \\
\hline
\end{tabular}


Appendix 5.3. (continued)

\begin{tabular}{|c|c|c|c|c|c|c|c|c|c|c|c|c|c|c|c|c|c|c|}
\hline $\begin{array}{l}\text { Sample }^{1} \\
\text { Mineral }\end{array}$ & $\begin{array}{r}7 \mathrm{a} \\
\text { stp }\end{array}$ & $\begin{array}{r}7 \mathrm{~b} \\
\text { stp }\end{array}$ & $\begin{array}{r}7 \mathrm{c} \\
\text { stp }\end{array}$ & $\begin{array}{r}8 a \\
\min \end{array}$ & $\begin{array}{r}8 b \\
\min \end{array}$ & $\begin{array}{r}8 c \\
\min \\
\end{array}$ & $\begin{array}{r}9 a \\
\min \\
\end{array}$ & $\begin{array}{r}9 b \\
\text { min } \\
\end{array}$ & $\begin{array}{r}9 \mathrm{c} \\
\min \\
\end{array}$ & $\begin{array}{l}10 \mathrm{a} \\
\mathrm{rbk}\end{array}$ & $\begin{array}{l}10 \mathrm{~b} \\
\mathrm{rbk}\end{array}$ & $\begin{array}{l}10 \mathrm{c} \\
\mathrm{rbk}\end{array}$ & $\begin{array}{l}11 \mathrm{a} \\
\mathrm{rbk} \\
\end{array}$ & $\begin{array}{l}11 \mathrm{~b} \\
\mathrm{rbk}\end{array}$ & $\begin{array}{l}11 \mathrm{c} \\
\mathrm{rbk}\end{array}$ & $\begin{array}{l}12 \mathrm{a} \\
\mathrm{gen}\end{array}$ & $\begin{array}{l}12 b \\
\text { grn }\end{array}$ & $\begin{array}{l}12 \mathrm{c} \\
\mathrm{gm}\end{array}$ \\
\hline \multicolumn{19}{|c|}{ Oxide weight percent } \\
\hline $\mathrm{SiO}_{2}$ & 45.97 & 46.02 & 44.03 & 57.35 & 58.63 & 58.52 & 55.90 & 55.72 & 54.09 & 50.42 & 52.25 & 49.69 & 51.90 & 48.65 & 51.07 & 35.94 & 35.47 & 36.66 \\
\hline $\mathrm{TiO}_{2}$ & - & - & - & - & - & 0.02 & - & - & 0.04 & - & 0.02 & 0.15 & 0.14 & - & - & 0.05 & - & - \\
\hline $\mathrm{Al}_{2} \mathrm{O}_{3}$ & 3.03 & 2.88 & 2.72 & - & - & 0.06 & - & - & - & - & - & - & 0.00 & - & - & - & - & - \\
\hline $\mathrm{FeO}$ & 23.99 & 24.24 & 23.01 & 21.13 & 18.93 & 22.56 & 19.00 & 19.23 & 17.91 & 25.16 & 20.58 & 23.54 & 24.41 & 26.92 & 26.33 & 48.66 & 48.25 & 47.63 \\
\hline $\mathrm{MnO}$ & 0.04 & - & - & - & - & - & 0.03 & 0.05 & 0.12 & 0.13 & - & - & 0.14 & - & 0.19 & - & - & - \\
\hline $\mathrm{MgO}$ & 8.76 & 8.67 & 8.79 & 15.59 & 17.50 & 15.88 & 16.46 & 16.39 & 16.27 & 5.21 & 4.86 & 5.94 & 5.75 & 5.62 & 6.03 & 2.05 & 1.80 & 1.89 \\
\hline $\mathrm{CaO}$ & - & 0.18 & 2.36 & 0.07 & - & 0.03 & - & 0.09 & - & 0.09 & 0.07 & - & 0.10 & 0.23 & 0.05 & - & - & 0.04 \\
\hline $\mathrm{Na}_{2} \mathrm{O}$ & - & 0.51 & - & 0.16 & 0.56 & - & - & - & - & 4.59 & 4.31 & 4.79 & 3.78 & 4.34 & 3.94 & - & 0.18 & - \\
\hline $\mathrm{K}_{2} \mathrm{O}$ & 2.17 & 4.40 & 2.49 & - & - & 0.01 & 0.05 & 0.02 & - & 0.17 & 0.76 & 1.24 & 0.57 & 0.30 & 0.21 & - & 0.01 & 0.07 \\
\hline $\mathrm{H}_{2} \mathrm{O}^{*}$ & 16.04 & 13.10 & 16.60 & 5.70 & 4.38 & 2.92 & 8.56 & 8.50 & 11.57 & 14.23 & 17.15 & 14.65 & 13.21 & 13.94 & 12.18 & 13.30 & 14.29 & 13.71 \\
\hline Total & 83.96 & 86.90 & 83.40 & 94.30 & 95.62 & 97.08 & 91.44 & 91.50 & 88.43 & 85.77 & 82.85 & 85.35 & 86.79 & 86.06 & 87.82 & 86.70 & 85.71 & 86.29 \\
\hline \multicolumn{19}{|c|}{ Number of atoms recalculated on the basis of $f^{* *}$} \\
\hline & 23.81 & 23.81 & 23.81 & 11.00 & 11.00 & 11.00 & 11.00 & 11.00 & 11.00 & 24.00 & 24.00 & 24.00 & 24.00 & 24.00 & 24.00 & 14.00 & 14.00 & 14.00 \\
\hline $\mathrm{Si}$ & 8.30 & 8.19 & 8.11 & 4.05 & 4.04 & 4.03 & 4.04 & 4.03 & 4.03 & 9.00 & 9.38 & 8.93 & 9.08 & 8.79 & 8.93 & 4.35 & 4.35 & 4.42 \\
\hline $\mathrm{Ti}$ & - & - & - & - & - & 0.00 & - & - & 0.00 & - & 0.00 & 0.02 & 0.02 & - & - & 0.00 & - & - \\
\hline $\mathrm{Al}$ & 0.64 & 0.60 & 0.59 & - & - & 0.00 & - & - & - & - & - & - & 0.00 & - & - & - & - & - \\
\hline $\mathrm{Fe}^{2+}$ & 3.62 & 3.61 & 3.54 & 1.25 & 1.09 & 1.30 & 1.15 & 1.16 & 1.12 & 3.76 & 3.09 & 3.54 & 3.57 & 4.07 & 3.85 & 4.92 & 4.95 & 4.80 \\
\hline $\mathrm{Mn}$ & 0.01 & - & - & - & - & - & 0.00 & 0.00 & 0.01 & 0.02 & - & - & 0.02 & - & 0.03 & - & - & - \\
\hline $\mathrm{Mg}$ & 2.36 & 2.30 & 2.41 & 1.64 & 1.80 & 1.63 & 1.77 & 1.77 & 1.81 & 1.39 & 1.30 & 1.59 & 1.50 & 1.51 & 1.57 & 0.37 & 0.33 & 0.34 \\
\hline $\mathrm{Ca}$ & - & 0.03 & 0.47 & 0.01 & - & 0.00 & - & 0.01 & - & 0.02 & 0.01 & - & 0.02 & 0.04 & 0.01 & - & - & 0.01 \\
\hline $\mathrm{Na}$ & - & 0.18 & - & 0.02 & 0.07 & - & - & - & - & 1.59 & 1.50 & 1.67 & 1.28 & 1.52 & 1.34 & - & 0.04 & - \\
\hline \multirow[t]{2}{*}{$\mathrm{K}$} & 0.50 & 1.00 & 0.58 & - & - & 0.00 & 0.00 & 0.00 & - & 0.04 & 0.17 & 0.28 & 0.13 & 0.07 & 0.05 & - & 0.00 & 0.01 \\
\hline & 15.44 & 15.91 & 15.70 & 6.96 & 7.00 & 6.97 & 6.96 & 6.97 & 6.97 & 15.81 & 15.46 & 16.03 & 15.61 & 16.00 & 15.76 & 9.65 & 9.67 & 9.58 \\
\hline
\end{tabular}


Appendix 5.3. (continued)

\begin{tabular}{|c|c|c|c|c|c|c|c|c|c|c|c|c|c|c|c|c|c|c|}
\hline Sample $^{1}$ & $13 a$ & $13 b$ & $13 \mathrm{c}$ & $14 \mathrm{a}$ & $14 b$ & $14 c$ & $15 \mathrm{a}$ & $15 b$ & $15 \mathrm{c}$ & $16 \mathrm{a}$ & $16 \mathrm{~b}$ & $16 \mathrm{c}$ & $17 \mathrm{a}$ & $17 \mathrm{~b}$ & $17 \mathrm{c}$ & $18 \mathrm{a}$ & $18 \mathrm{~b}$ & $18 \mathrm{c}$ \\
\hline Mineral & $\mathrm{sd}$ & sd & sd & sd & $\mathrm{sd}$ & $\mathrm{sd}$ & $\mathrm{sd}$ & $\mathrm{sd}$ & $\mathrm{sd}$ & $\mathrm{sd}$ & sd & $\mathrm{sd}$ & $\mathrm{sd}$ & $\mathrm{sd}$ & $\mathrm{sd}$ & sd & sd & sd \\
\hline \multicolumn{19}{|c|}{ Oxide weight percent } \\
\hline \multicolumn{19}{|c|}{$\mathrm{SiO}_{2}$} \\
\hline \multicolumn{19}{|l|}{$\mathrm{TiO}_{2}$} \\
\hline \multicolumn{19}{|l|}{$\mathrm{Al}_{2} \mathrm{O}_{3}$} \\
\hline $\mathrm{FeO}$ & 56.13 & 57.14 & 57.99 & 50.11 & 50.34 & 49.42 & 49.23 & 48.82 & 47.88 & 51.39 & 50.21 & 50.03 & 47.11 & 46.43 & 47.38 & 52.40 & 52.91 & 49.45 \\
\hline $\mathrm{MnO}$ & - & - & - & 0.62 & 0.58 & 0.48 & 0.33 & 0.16 & 0.33 & 0.08 & 0.29 & 0.45 & 0.33 & 0.54 & 0.19 & 0.06 & 0.15 & 0.19 \\
\hline $\mathrm{MgO}$ & 2.76 & 2.62 & 2.51 & 7.99 & 7.61 & 8.02 & 6.96 & 7.49 & 7.83 & 6.92 & 7.43 & 7.86 & 10.30 & 9.35 & 9.22 & 7.00 & 6.59 & 6.69 \\
\hline $\mathrm{CaO}$ & 0.22 & 0.04 & 0.33 & 0.48 & 0.28 & 0.37 & 1.15 & 0.81 & 0.86 & 0.26 & 0.28 & 0.56 & 0.14 & 0.18 & 0.29 & 0.38 & 0.41 & 0.48 \\
\hline \multicolumn{19}{|l|}{$\mathrm{Na}_{2} \mathrm{O}$} \\
\hline \multicolumn{19}{|l|}{$\mathrm{K}_{2} \mathrm{O}$} \\
\hline \multicolumn{19}{|l|}{$\mathrm{H}_{2} \mathrm{O}^{*}$} \\
\hline $\mathrm{CO}_{2}{ }^{*}$ & 40.89 & 40.20 & 39.16 & 40.80 & 41.19 & 41.71 & 42.33 & 42.72 & 43.10 & 41.35 & 41.79 & 41.10 & 42.12 & 43.50 & 42.92 & 40.16 & 39.94 & 43.19 \\
\hline Total & $(100.00)$ & $(100.00)$ & $(100.00)$ & $(100.00)$ & $(100.00)$ & $(100.00)$ & $(100.00)$ & $(100.00)$ & $(100.00)$ & $(100.00)$ & $(100.00)$ & $(100.00)$ & $(100.00)$ & $(100.00)$ & $(100.00)$ & $(100.00)$ & $(100.00)$ & $(100.00)$ \\
\hline \multicolumn{19}{|c|}{ Number of atoms recalculated on the basis of ${ }^{* *}$} \\
\hline & 6.00 & 6.00 & 6.00 & 6.00 & 6.00 & 6.00 & 6.00 & 6.00 & 6.00 & 6.00 & 6.00 & 6.00 & 6.00 & 6.00 & 6.00 & 6.00 & 6.00 & 6.00 \\
\hline \multicolumn{19}{|l|}{$\mathrm{Si}$} \\
\hline \multicolumn{19}{|l|}{$\mathrm{Ti}$} \\
\hline \multicolumn{19}{|l|}{$\mathrm{Al}$} \\
\hline $\mathrm{Fe}^{2+}$ & 5.49 & 5.54 & 5.53 & 4.58 & 4.66 & 4.58 & 4.66 & 4.62 & 4.54 & 4.81 & 4.70 & 4.60 & 4.28 & 4.36 & 4.42 & 4.81 & 4.86 & 4.77 \\
\hline $\mathrm{Mn}$ & - & - & - & 0.06 & 0.05 & 0.05 & 0.03 & 0.02 & 0.03 & 0.01 & 0.03 & 0.04 & 0.03 & 0.05 & 0.02 & 0.01 & 0.01 & 0.02 \\
\hline $\mathrm{Mg}$ & 0.48 & 0.45 & 0.43 & 1.30 & 1.26 & 1.33 & 1.17 & 1.26 & 1.32 & 1.15 & 1.24 & 1.29 & 1.67 & 1.57 & 1.53 & 1.14 & 1.08 & 1.15 \\
\hline $\mathrm{Ca}$ & 0.03 & 0.00 & 0.04 & 0.06 & 0.03 & 0.04 & 0.14 & 0.10 & 0.10 & 0.03 & 0.03 & 0.07 & 0.02 & 0.02 & 0.03 & 0.04 & 0.05 & 0.06 \\
\hline \multicolumn{19}{|l|}{$\mathrm{Na}$} \\
\hline K & & & & & & & & & & & & & & & & & & \\
\hline & 6.00 & 6.00 & 6.00 & 6.00 & 6.00 & 6.00 & 6.00 & 6.00 & 6.00 & 6.00 & 6.00 & 6.00 & 6.00 & 6.00 & 6.00 & 6.00 & 6.00 & 6.00 \\
\hline
\end{tabular}


Appendix 5.3. (continued)

\begin{tabular}{|c|c|c|c|c|c|c|c|c|c|c|c|c|}
\hline $\begin{array}{l}\text { Sample }{ }^{I} \\
\text { Mineral }\end{array}$ & $\begin{array}{r}19 \mathrm{a} \\
\mathrm{sd}\end{array}$ & $\begin{array}{r}19 b \\
s d\end{array}$ & $\begin{array}{r}19 \mathrm{c} \\
\text { sd }\end{array}$ & $\begin{array}{l}20 \mathrm{a} \\
\text { ank }\end{array}$ & $\begin{array}{l}20 \mathrm{~b} \\
\text { ank }\end{array}$ & $\begin{array}{l}20 c \\
\text { ank }\end{array}$ & $\begin{array}{l}2 \mathrm{la} \\
\text { ank }\end{array}$ & $\begin{array}{l}21 b \\
\text { ank }\end{array}$ & $\begin{array}{l}21 \mathrm{c} \\
\text { ank }\end{array}$ & $\begin{array}{l}22 \mathrm{a} \\
\text { ank }\end{array}$ & $\begin{array}{l}22 \mathrm{~b} \\
\text { ank }\end{array}$ & $\begin{array}{l}22 \mathrm{c} \\
\text { ank }\end{array}$ \\
\hline \multicolumn{13}{|c|}{ Oxide weight percent } \\
\hline \multicolumn{13}{|c|}{$\mathrm{SiO}_{2}$} \\
\hline \multicolumn{13}{|l|}{$\mathrm{TiO}_{2}$} \\
\hline \multicolumn{13}{|l|}{$\mathrm{Al}_{2} \mathrm{O}_{3}$} \\
\hline $\mathrm{FeO}$ & 43.86 & 44.34 & 44.23 & 19.48 & 19.98 & 19.19 & 15.77 & 17.06 & 14.30 & 12.29 & 17.64 & 17.97 \\
\hline $\mathrm{MnO}$ & 0.21 & - & 0.28 & 0.30 & - & 0.21 & 0.01 & 0.26 & 0.39 & 0.40 & 0.29 & 0.30 \\
\hline $\mathrm{MgO}$ & 11.15 & 11.90 & 11.61 & 7.82 & 8.42 & 8.37 & 11.70 & 10.43 & 11.20 & 13.20 & 8.14 & 8.12 \\
\hline $\mathrm{CaO}$ & - & 0.22 & 0.12 & 26.92 & 26.80 & 27.42 & 27.52 & 26.86 & 26.68 & 27.80 & 28.70 & 29.09 \\
\hline \multicolumn{13}{|l|}{$\mathrm{Na}_{2} \mathrm{O}$} \\
\hline \multicolumn{13}{|l|}{$\mathrm{K}_{2} \mathrm{O}$} \\
\hline \multicolumn{13}{|l|}{$\mathrm{H}_{2} \mathrm{O}^{*}$} \\
\hline $\mathrm{CO}_{2} *$ & 44.78 & 43.54 & 43.76 & 45.48 & 44.80 & 44.81 & 45.00 & 45.39 & 47.43 & 46.31 & 45.23 & 44.52 \\
\hline Total & $(100.00)$ & $(100.00)$ & $(100.00)$ & $(100.00)$ & $(100.00)$ & $(100.00)$ & $(100.00)$ & $(100.00)$ & $(100.00)$ & $(100.00)$ & $(100.00)$ & $(100.00)$ \\
\hline \multicolumn{13}{|c|}{ Number of atoms recalculated on the basis of** } \\
\hline & 6.00 & 6.00 & 6.00 & 6.00 & 6.00 & 6.00 & 6.00 & 6.00 & 6.00 & 6.00 & 6.00 & 6.00 \\
\hline \multicolumn{13}{|l|}{$\mathrm{Si}$} \\
\hline \multicolumn{13}{|l|}{$\mathrm{Ti}$} \\
\hline \multicolumn{13}{|l|}{$\mathrm{Al}$} \\
\hline $\mathrm{Fe}^{2+}$ & 4.11 & 4.04 & 4.06 & 1.71 & 1.73 & 1.66 & 1.32 & 1.46 & 1.25 & 1.03 & 1.53 & 1.54 \\
\hline $\mathrm{Mn}$ & 0.02 & - & 0.03 & 0.03 & - & 0.02 & 0.00 & 0.02 & 0.03 & 0.03 & 0.03 & 0.03 \\
\hline $\mathrm{Mg}$ & 1.87 & 1.93 & 1.90 & 1.23 & 1.30 & 1.29 & 1.74 & 1.59 & 1.74 & 1.97 & 1.26 & 1.24 \\
\hline $\mathrm{Ca}$ & - & 0.03 & 0.01 & 3.03 & 2.97 & 3.03 & 2.94 & 2.94 & 2.98 & 2.97 & 3.19 & 3.19 \\
\hline \multicolumn{13}{|l|}{$\begin{array}{l}\mathrm{Na} \\
\mathrm{K}\end{array}$} \\
\hline $\mathrm{K}$ & & & & & & & & & & & & \\
\hline & 6.00 & 6.00 & 6.00 & 6.00 & 6.00 & 6.00 & 6.00 & 6.00 & 6.00 & 6.00 & 6.00 & 6.00 \\
\hline
\end{tabular}

Notes: Total $\mathrm{Fe}$ as $\mathrm{FeO}$ only; ank = ankerite; $\mathrm{grn}=$ greenalite; $\mathrm{min}=$ minnesotaite; $\mathrm{rbk}=$ riebeckite; $\mathrm{sd}=$ siderite; $\mathrm{stp}=$ stilpnomelane; ${ }^{*} \mathrm{H}_{2} \mathrm{O}$ and $\mathrm{CO}_{2}$ data obtained by subtracting electron microprobe total from $100 \%$;*Number of oxygens used to calculate ions; ' $\because$ = below detection; 'Sample numbers correspond to descriptions in appendices 5.1 and 5.2 ; letters represent the separate analyses of the same sample and are averaged in appendices 5.1 and 5.2 . 
Appendix 5.4. Chemical composition of silicate and carbonate minerals in altered Mt. McRae Shale from Mt. Whaleback.

\begin{tabular}{|c|c|c|c|c|c|c|c|c|c|c|c|c|c|c|c|}
\hline Sample & $1 \mathrm{a}$ & $1 \mathrm{~b}$ & lc & $2 \mathrm{a}$ & $2 \mathrm{~b}$ & $2 \mathrm{c}$ & $3 a$ & $3 b$ & $3 c$ & $4 a$ & $4 b$ & $4 c$ & $5 a$ & $5 \mathrm{~b}$ & 50 \\
\hline Mineral & Chl & Chl & Ch1 & Chl & Chl & Chl & $\mathrm{Chl}$ & Chl & Chl & Ank & Fe-dol & Ank & Dol & Dol & Ank \\
\hline \multicolumn{16}{|c|}{ Oxide weight percent } \\
\hline $\mathrm{SiO}_{2}$ & 27.35 & 27.48 & 27.07 & 26.68 & 26.72 & 27.27 & 27.18 & 26.45 & 27.10 & & & & & & \\
\hline $\mathrm{TiO}_{2}$ & 0.03 & 0.00 & 0.04 & 0.00 & 0.04 & 0.02 & 0.09 & 0.00 & 0.06 & & & & & & \\
\hline $\mathrm{Al}_{2} \mathrm{O}_{3}$ & 19.48 & 20.13 & 20.34 & 17.60 & 17.72 & 18.80 & 18.58 & 18.09 & 17.95 & & & & & & \\
\hline $\mathrm{FeO}$ & 21.65 & 23.66 & 23.94 & 27.36 & 27.36 & 26.62 & 26.66 & 27.90 & 27.61 & 9.54 & 5.59 & 10.24 & 3.52 & 1.8 & 18.74 \\
\hline $\mathrm{MnO}$ & 0.26 & 0.08 & 0.00 & 0.15 & 0.42 & 0.32 & 0.30 & 0.46 & 0.06 & 3.63 & 1.42 & 4.24 & 1.09 & 0.66 & 0.97 \\
\hline $\mathrm{MgO}$ & 14.87 & 14.51 & 14.08 & 12.92 & 12.44 & 13.81 & 13.96 & 12.42 & 12.65 & 12.93 & 17.63 & 13.24 & 18.93 & 18.41 & 16.51 \\
\hline $\mathrm{CaO}$ & 0.06 & 0.00 & 0.04 & 0.28 & 0.05 & 0.35 & 0.05 & 0.10 & 0.11 & 27.71 & 28.44 & 28.03 & 29.22 & 30.41 & 23.67 \\
\hline $\mathrm{Na}_{2} \mathrm{O}$ & 0.00 & 0.00 & 0.00 & 0.00 & 0.95 & 0.00 & 0.00 & 0.00 & 0.00 & & & & & & \\
\hline $\mathrm{K}_{2} \mathrm{O}$ & 0.01 & 0.03 & 0.09 & 0.04 & 0.07 & 0.02 & 0.02 & 0.07 & 0.00 & & & & & & \\
\hline $\mathrm{H}_{2} \mathrm{O}^{*}$ & 16.29 & 14.11 & 14.40 & 14.97 & 14.23 & 12.79 & 13.16 & 14.51 & 14.46 & & & & & & \\
\hline $\mathrm{CO}_{2}{ }^{*}$ & & & & & & & & & & 46.19 & 46.92 & 44.25 & 47.24 & 48.72 & 40.11 \\
\hline Total & 100.0 & 100.0 & 100.0 & 100.0 & 100.0 & 100.0 & 100.0 & 100.0 & 100.0 & 100.0 & 100.0 & 100.0 & 100.0 & 100.0 & 100.0 \\
\hline \multicolumn{16}{|c|}{ Number of atoms recalculated on the basis of ${ }^{* *}$} \\
\hline & 28.0 & 28.0 & 28.0 & 28.0 & 28.0 & 28.0 & 28.0 & 28.0 & 28.0 & 6.0 & 6.0 & 6.0 & 6.0 & 6.0 & 6.0 \\
\hline $\mathrm{Si}$ & 5.90 & 5.83 & 5.77 & 5.88 & 5.86 & 5.81 & 5.82 & 5.82 & 5.92 & & & & & & \\
\hline $\mathrm{Ti}$ & 0.00 & 0.00 & 0.01 & 0.00 & 0.01 & 0.00 & 0.01 & 0.00 & 0.01 & & & & & & \\
\hline $\mathrm{Al}$ & 4.95 & 5.03 & 5.11 & 4.57 & 4.58 & 4.72 & 4.69 & 4.69 & 4.62 & & & & & & \\
\hline $\mathrm{Fe}^{2+}$ & 3.91 & 4.20 & 4.27 & 5.04 & 5.02 & 4.75 & 4.77 & 5.13 & 5.04 & 0.80 & 0.45 & 0.83 & 0.28 & 0.15 & 1.41 \\
\hline $\mathrm{Mn}$ & 0.05 & 0.01 & 0.00 & 0.03 & 0.08 & 0.06 & 0.05 & 0.09 & 0.01 & 0.31 & 0.12 & 0.35 & 0.09 & 0.05 & 0.07 \\
\hline $\mathrm{Mg}$ & 4.78 & 4.59 & 4.48 & 4.24 & 4.07 & 4.39 & 4.46 & 4.07 & 4.12 & 1.93 & 2.52 & 1.91 & 2.67 & 2.65 & 2.22 \\
\hline $\mathrm{Ca}$ & 0.01 & 0.00 & 0.01 & 0.07 & 0.01 & 0.08 & 0.01 & 0.02 & 0.03 & 2.97 & 2.92 & 2.91 & 2.96 & 3.15 & 2.29 \\
\hline $\mathrm{Na}$ & 0.00 & 0.00 & 0.00 & 0.00 & 0.40 & 0.00 & 0.00 & 0.00 & 0.00 & & & & & & \\
\hline \multirow[t]{2}{*}{$\mathrm{K}$} & 0.00 & 0.01 & 0.02 & 0.01 & 0.02 & 0.01 & 0.01 & 0.02 & 0.00 & & & & & & \\
\hline & 19.62 & 19.66 & 19.68 & 19.84 & 20.05 & 19.82 & 19.82 & 19.85 & 19.76 & 6.00 & 6.00 & 6.00 & 6.00 & 6.00 & 6.00 \\
\hline
\end{tabular}


Appendix 5.4. (continued)

\begin{tabular}{|c|c|c|c|c|c|c|c|c|c|c|c|c|c|c|c|}
\hline Sample & $6 a$ & $6 \mathrm{~b}$ & $6 \mathrm{c}$ & $7 a$ & $7 \mathrm{~b}$ & $7 \mathrm{c}$ & $8 \mathrm{a}$ & $8 b$ & $8 \mathrm{c}$ & $9 \mathrm{a}$ & $9 b$ & $9 \mathrm{c}$ & $10 \mathrm{a}$ & $10 \mathrm{~b}$ & $10 \mathrm{c}$ \\
\hline Mineral & Dol & Dol & Dol & Ank & Ank & Ank & Dol & Dol & Dol & Ank & Ank & Ank & Fe-dol & Dol & Fe-dol \\
\hline \multicolumn{16}{|c|}{ Oxide weight percent } \\
\hline \multicolumn{16}{|c|}{$\mathrm{SiO}_{2}$} \\
\hline \multicolumn{16}{|l|}{$\mathrm{TiO}_{2}$} \\
\hline \multicolumn{16}{|l|}{$\mathrm{Al}_{2} \mathrm{O}_{3}$} \\
\hline $\mathrm{FeO}$ & 1.46 & 4.7 & 1.44 & 9.07 & 6.99 & 8.64 & 3.63 & 2.03 & 1.19 & 9.28 & 9.80 & 12.85 & 3.76 & 2.35 & 6.62 \\
\hline $\mathrm{MnO}$ & 3.69 & 1.7 & 5.67 & 1.91 & $3.5 \mathrm{I}$ & 2.77 & 2.58 & 0.42 & 4.52 & 3.63 & 3.33 & 3.54 & 0.45 & 0.34 & 1.39 \\
\hline $\mathrm{MgO}$ & 18.89 & 19.02 & 17.94 & 15.11 & 15.08 & 14.29 & 17.89 & 19.88 & 18.04 & 13.61 & 13.64 & 11.42 & 19.57 & 20.41 & 16.72 \\
\hline $\mathrm{CaO}$ & 29.11 & 28.57 & 29.07 & 28.43 & 28.57 & 28.19 & 28.98 & 29.03 & 28.95 & 28.72 & 27.06 & 26.83 & 29.10 & 29.03 & 28.36 \\
\hline \multicolumn{16}{|l|}{$\mathrm{Na}_{2} \mathrm{O}$} \\
\hline \multicolumn{16}{|l|}{$\mathrm{K}_{2} \mathrm{O}$} \\
\hline \multicolumn{16}{|l|}{$\mathrm{H}_{2} \mathrm{O}^{*}$} \\
\hline $\mathrm{CO}_{2}{ }^{*}$ & 46.85 & 46.01 & 45.88 & 45.48 & 45.85 & 46.11 & 46.92 & 48.64 & 47.30 & 44.76 & 46.17 & 45.36 & 47.12 & 47.87 & 46.91 \\
\hline Total & 100.0 & 100.0 & 100.0 & 100.0 & 100.0 & 100.0 & 100.0 & 100.0 & 100.0 & 100.0 & 100.0 & 100.0 & 100.0 & 100.0 & 100.0 \\
\hline \multicolumn{16}{|c|}{ Number of atoms recalculated on the basis of** } \\
\hline & 6.0 & 6.0 & 6.0 & 6.0 & 6.0 & 6.0 & 6.0 & 6.0 & 6.0 & 6.0 & 6.0 & 6.00 & 6.00 & 6.00 & 6.00 \\
\hline \multicolumn{16}{|l|}{$\mathrm{Si}$} \\
\hline \multicolumn{16}{|l|}{$\mathrm{Ti}$} \\
\hline \multicolumn{16}{|l|}{$\mathrm{Al}$} \\
\hline $\mathrm{Fe}^{2+}$ & 0.12 & 0.37 & 0.11 & 0.73 & 0.57 & 0.71 & 0.29 & 0.16 & 0.10 & 0.75 & 0.81 & 1.08 & 0.30 & 0.18 & 0.54 \\
\hline Mn & 0.29 & 0.13 & 0.45 & 0.16 & 0.29 & 0.23 & 0.21 & 0.03 & 0.37 & 0.30 & 0.28 & 0.30 & 0.04 & 0.03 & 0.11 \\
\hline $\mathrm{Mg}$ & 2.65 & 2.64 & 2.51 & 2.17 & 2.18 & 2.09 & 2.54 & 2.83 & 2.57 & 1.97 & 2.02 & 1.72 & 2.74 & 2.86 & 2.41 \\
\hline $\mathrm{Ca}$ & 2.94 & 2.85 & 2.92 & 2.94 & 2.97 & 2.97 & 2.96 & 2.97 & 2.97 & 2.98 & 2.88 & 2.90 & 2.93 & 2.93 & 2.94 \\
\hline \multicolumn{16}{|l|}{$\mathrm{Na}$} \\
\hline \multicolumn{16}{|l|}{$\mathrm{K}$} \\
\hline & 6.00 & 6.00 & 6.00 & 6.00 & 6.00 & 6.00 & 6.00 & 6.00 & 6.00 & 6.00 & 6.00 & 6.00 & 6.00 & 6.00 & 6.00 \\
\hline
\end{tabular}

Notes: (1) Fine-grained chlorite matrix in altered black shale (sample RC); (2) Fine-grained chlorite matrix in greyish-green shale (sample D4092); (3) Chlorite vein in reddishgreen shale (sample D4096); (4) Medium-grained Fe-dolomite/ankerite in carbonate porphyroblast (sample D4096); (5) Fine-grained dolomite in reddish-green shale (sample D4096); (6) Fine-grained dolomite in reddish-green shale (sample D4097); (7) Coarse-grained ankerite vein in reddish-green shale (sample D4096); (8) Coarse-grained dolomite vein in reddish-green shale (sample D4096); (9) Coarse-grained ankerite vein in reddish-green shale (sample D4096); (10) Coarse-grained dolomite vein in reddish-green shale (sample D4096). Total Fe as Fe2+ only. ${ }^{*} \mathrm{H} 2 \mathrm{O}$ and $\mathrm{CO} 2$ data obtained by subtracting electron microprobe total from $100 \%$. ${ }^{* *}$ Number of oxygens used to calculate ions. Sample numbers refer to microprobe locations in figures 4.7-4.9. Sample letters represent separate analyses of the same mineral and are averaged in table 4.3 . ank $=$ ankerite; chl $=$ chlorite; dol = dolomite; Fe-dol $=$ ferroan dolomite. 
APPENDIX 6

BULK ROCK DENSITIES 
Appendix 6.1. Rock densities across the Hamersley Province

\begin{tabular}{|c|c|c|c|c|c|}
\hline \multirow{2}{*}{\multicolumn{2}{|c|}{$\begin{array}{l}\text { Sample } \quad \text { Location } \\
\text { Northern Hamersley Province }\end{array}$}} & Unit & Weight (g) & \multicolumn{2}{|c|}{ Volume $\left(\mathrm{cm}^{3}\right)$ Density $\left(\mathrm{g} / \mathrm{cm}^{3}\right)$} \\
\hline & & & & & \\
\hline \multicolumn{6}{|c|}{ Banded iron-formation } \\
\hline 472 & Witt. Gorge (DDH-47A) & DB16 & 232.98 & 75.0 & 3.11 \\
\hline 4748 & Witt. Gorge (DDH-47A) & DB16 & 54.32 & 17.0 & 3.20 \\
\hline 474 & Witt. Gorge (DDH-47A) & DB 15 & 130.34 & 37.5 & 3.48 \\
\hline 477 & Witt. Gorge (DDH-47A) & DB14 & 57.30 & 18.0 & 3.18 \\
\hline 479 & Witt. Gorge (DDH-47A) & DB13 & 34.02 & 11.0 & 3.09 \\
\hline 4722 & Witt. Gorge (DDH-47A) & DB8 & 63.60 & 20.5 & 3.10 \\
\hline 4724 & Witt. Gorge (DDH-47A) & DB7 & 100.46 & 32.5 & 3.09 \\
\hline JGA7 & Junct. Gorge (DDH-JG1) & DB2 & 166.38 & 51.5 & 3.23 \\
\hline JGA4 & Junct. Gorge (DDH-JG1) & DB1 & 111.04 & 32.5 & 3.42 \\
\hline 4742 & Witt. Gorge (DDH-47A) & DBO & 62.92 & 18.0 & 3.50 \\
\hline \multicolumn{6}{|c|}{ Black shale } \\
\hline 4718 & Witt. Gorge (DDH-47A) & DS11 & 66.84 & 25.5 & 2.62 \\
\hline 4725 & Witt. Gorge (DDH-47A) & DS7 & 72.52 & 28.5 & 2.54 \\
\hline 4726 & Witt. Gorge (DDH-47A) & DS6 & 65.66 & 25.0 & 2.63 \\
\hline 4727 & Witt. Gorge (DDH-47A) & DS6 & 58.28 & 20.0 & 2.91 \\
\hline 4730 & Witt. Gorge (DDH-47A) & DS5 & 24.78 & 9.5 & 2.61 \\
\hline 4733 & Witt. Gorge (DDH-47A) & DS4 & 73.58 & 28.0 & 2.63 \\
\hline 4736 & Witt. Gorge (DDH-47A) & DS3 & 50.16 & 19.0 & 2.64 \\
\hline JGA9 & Junct. Gorge (DDH-JG1) & DS3 & 102.04 & 35.0 & 2.92 \\
\hline 4738 & Witt. Gorge (DDH-47A) & DS2 & 19.78 & 7.0 & 2.83 \\
\hline JGA2 & Junct. Gorge (DDH-JG1) & DS1 & 83.06 & 30.5 & 2.72 \\
\hline \multicolumn{6}{|c|}{ Southeastern Hamersley Province } \\
\hline \multicolumn{6}{|c|}{ Banded iron-formation } \\
\hline WW11 & Weeli Wolli Spring & $\mathrm{DB} 14$ & 289.28 & 86.0 & 3.36 \\
\hline WW1 & Weeli Wolli Spring & DB0 & 189.02 & 59.5 & 3.18 \\
\hline MR14 & Mt. Robinson & $\mathrm{DB} 13$ & 260.62 & 81.5 & 3.20 \\
\hline MR7 & Mt. Robinson & DB6 & 217.50 & 66.0 & 3.30 \\
\hline $\mathrm{PH} 2$ & Pamelia Hill & DB15 & 403.32 & 117.5 & 3.43 \\
\hline PH8 & Pamelia Hill & DB6 & 285.28 & 87.5 & 3.26 \\
\hline $\mathrm{C} 10$ & Cathedral Gorge & DB9 & 194.96 & 67.5 & 2.89 \\
\hline $\mathrm{Cl}$ & Cathedral Gorge & DB0 & 139.08 & 42.0 & 3.31 \\
\hline $4 \mathrm{~W} 16$ & Fourth West Gorge & $\mathrm{DB} 15$ & 253.04 & 76.5 & 3.31 \\
\hline $4 \mathrm{~W} 12$ & Fourth West Gorge & DB 11 & 144.56 & 44.0 & 3.29 \\
\hline \multicolumn{6}{|c|}{ Mt. Whaleback pit } \\
\hline \multicolumn{6}{|c|}{ Banded iron-formation } \\
\hline D73A & DDH-73 & DB16 & 108.48 & 29.5 & 3.68 \\
\hline D73C & DDH-73 & DB16 & 140.70 & 37.0 & 3.80 \\
\hline $\mathrm{F} 24 \mathrm{C}$ & Fresh mine face & $\mathrm{DB} 15$ & 239.68 & 78.0 & 3.07 \\
\hline $\mathrm{A} 24 \mathrm{C}$ & Fresh mine face & DB15 & 303.80 & 91.5 & 3.32 \\
\hline $\mathrm{C} 24 \mathrm{C}$ & Fresh mine face & DB 15 & 74.34 & 23.5 & 3.16 \\
\hline $\mathrm{B} 24 \mathrm{C}$ & Fresh mine face & $\mathrm{DB} 15$ & 453.32 & 143.0 & 3.17 \\
\hline $\mathrm{G} 24 \mathrm{C}$ & Fresh mine face & $\mathrm{DB} 15$ & 126.24 & 34.0 & 3.71 \\
\hline D85D & Fresh mine face & $\mathrm{DB} 15$ & 97.08 & 29.0 & 3.35 \\
\hline \multicolumn{6}{|l|}{ Iron ore } \\
\hline D24C & Fresh mine face & DB16 & 292.25 & 73.0 & 4.00 \\
\hline $\mathrm{E} 24 \mathrm{C}$ & Fresh mine face & DB16 & 211.01 & 49.0 & 4.31 \\
\hline $\mathrm{E} 25 \mathrm{E}$ & Fresh mine face & $\mathrm{DB} 15$ & 343.48 & 81.5 & 4.21 \\
\hline $\mathrm{A} 25 \mathrm{E}$ & Fresh mine face & DB11 & 275.73 & 63.5 & 4.34 \\
\hline B25E & Fresh mine face & $\mathrm{DB} 11$ & 236.73 & 59.0 & 4.01 \\
\hline 6BEDC & Fresh mine face & DB6 & 375.87 & 75.0 & 5.01 \\
\hline 5BEDC & Fresh mine face & DB5 & 188.62 & 46.5 & 4.06 \\
\hline 4AEDC & Fresh mine face & DB4 & 269.00 & 60.0 & 4.48 \\
\hline 3BEDC & Fresh mine face & DB3 & 283.44 & 61.5 & 4.61 \\
\hline 1123 & Fresh mine face & DB0 & 262.42 & 65.5 & 4.01 \\
\hline
\end{tabular}


Appendix 6.1. (continued)

\begin{tabular}{llcrcr}
\hline \multicolumn{2}{l}{ Sample } & & Unit & Weight $(\mathrm{g})$ & Volume $\left(\mathrm{cm}^{3}\right)$ Density $\left(\mathrm{g} / \mathrm{cm}^{3}\right)$ \\
\hline \multicolumn{1}{l}{ Alteied black shale } & & & & \\
AW22A & Fresh mine face & Phbw & 133.06 & 51.5 & 2.58 \\
224E & Fresh mine face & Phbw & 225.74 & 84.0 & 2.69 \\
AW18 & Fresh mine face & Phr & 221.98 & 83.0 & 2.67 \\
AW19 & Fresh mine face & Phr & 229.4 & 93.5 & 2.45 \\
AW20 & Fresh mine face & Phr & 153.52 & 62.5 & 2.46 \\
123 & Fresh mine face & Phr & 206.58 & 82.0 & 2.52 \\
125E & Fresh mine face & Phr & 511.44 & 202.0 & 2.53 \\
225E & Fresh mine face & Phr & 254.3 & 91.0 & 2.79 \\
Red shale & & & & & \\
324C & Fresh mine face & Phbw & 102.24 & 40.5 & 2.52 \\
424C & Fresh mine face & Phbw & 113.56 & 50.0 & 2.27 \\
AW9 & Fresh mine face & DS11 & 103.06 & 39.0 & 2.64 \\
1025E & Fresh mine face & DSl0 & 104.51 & 43.0 & 2.43 \\
6EDC & Fresh mine face & DS6 & 83.26 & 34.5 & 2.41 \\
4EDC & Fresh mine face & DS4 & 65.65 & 28.0 & 2.34 \\
AW17 & Fresh mine face & Phr & 200.75 & 68.5 & 2.93 \\
5A23 & Fresh mine face & Phr & 87.93 & 36.5 & 2.41 \\
425E & Fresh mine face & Phr & 65.38 & 23.5 & 2.78 \\
525E & Fresh mine face & Phr & 172.02 & 60.0 & 2.87 \\
Reddish-green shaie & & & & \\
D4094 & DDH-409 & Phr & 114.49 & 44.5 & 2.57 \\
D4096 & DDH-409 & Phr & 120.34 & 46.8 & 2.57 \\
\hline
\end{tabular}

Notes: Phbw $=$ Whaleback Shale Member; DB = Dales Gorge BIF macroband; DS = Dales Gorge shale macroband; $\mathrm{Phr}=$ Mt. McRae Shale; Witt. $=$ Wittenoom; Junct. $=$ Junction; DDH $=$ diamond drill hole. 
APPENDIX 7

CHEMICAL MASS CHANGES ACROSS THE HAMERSLEY PROVINCE 
Appendix 7.1. Elemental mass changes* as a function of volume and porosity for the alteration of BIF across the Hamersley Province

\begin{tabular}{|c|c|c|c|c|c|c|c|c|c|c|}
\hline Vol. loss ${ }^{\dagger}$ & 0 & 10 & 20 & 30 & 40 & 50 & 60 & 70 & 80 & 90 \\
\hline \multicolumn{11}{|c|}{ Unaltered BIF to Weathered BIF } \\
\hline $\mathrm{SiO}_{2}$ & 10.01 & 5.03 & 0.05 & -492 & 9.90 & -14.88 & -19.86 & -24.84 & -29.82 & -34.80 \\
\hline $\mathrm{Al}_{2} \mathrm{O}_{3}$ & -0.05 & -0.07 & -0.09 & $=0.12$ & -0.14 & -0.17 & -0.19 & -0.22 & -0.24 & -0.26 \\
\hline $\mathrm{Fe}_{2} \mathrm{O}_{3} \mathrm{~T}$ & -1.26 & -6.03 & 1079 & 15.56 & -2033 & -25.10 & -29.87 & -34.63 & -39.40 & -44.17 \\
\hline $\mathrm{MgO}$ & -2.57 & -2.57 & -2.57 & -2.57 & 2.57 & -2.58 & -2.58 & -2.58 & -2.58 & -2.58 \\
\hline $\mathrm{CaO}$ & -1.76 & -1.76 & -1.76 & -1.77 & -1.77 & -1.77 & -1.78 & -1.78 & -1.79 & -1.79 \\
\hline $\mathrm{K}_{2} \mathrm{O}$ & -0.27 & -0.27 & 0.28 & -0.28 & 0.28 & -0.28 & -0.29 & -0.29 & -0.29 & -0.29 \\
\hline $\mathrm{P}_{2} \mathrm{O}_{5}$ & -0.06 & -0.08 & -0.09 & 0.11 & -0.12 & -0.14 & -0.15 & -0.17 & -0.18 & -0.20 \\
\hline S & -0.07 & -0.07 & -0.07 & 0.07 & -0.07 & -0.07 & -0.07 & -0.07 & -0.07 & -0.07 \\
\hline $\mathrm{Ba}$ & -40.59 & -42.19 & -43.79 & -45.40 & -47.00 & -48.60 & -50.21 & -51.81 & -53.41 & -55.02 \\
\hline Co & 1747 & 14.43 & 11.40 & 8.37 & 5.34 & 2.30 & -0.73 & -3.76 & -6.79 & -9.82 \\
\hline $\mathrm{Cr}$ & 18.13 & 15.14 & 12.15 & 9.17 & 6.18 & 3.19 & 0.21 & -2.78 & -5.77 & -8.75 \\
\hline $\mathrm{Ni}$ & 0.73 & 0.12 & -0.97 & -1.82 & -2.66 & -3.51 & -4.36 & -5.21 & -6.06 & -6.91 \\
\hline $\mathrm{Pb}$ & -3.53 & -3.76 & -3.99 & -4.21 & -4.44 & -4.66 & -4.89 & -5.11 & -5.34 & -5.56 \\
\hline $\mathrm{Rb}$ & 33.29 & 33.29 & -33.29 & -33.29 & -33.29 & -33.29 & -33.29 & -33.29 & -33.29 & -33.29 \\
\hline $\mathrm{Sr}$ & 24.79 & -25.16 & -25.52 & -25.89 & -26.26 & -26.63 & -27.00 & -27.36 & -27.73 & -28.10 \\
\hline V & $=0.84$ & -0.92 & -1.01 & -1.09 & -1.18 & -1.27 & -1.35 & -1.44 & -1.53 & -1.61 \\
\hline Y & -6.06 & -6.80 & -7.55 & -8.30 & -9.05 & -9.79 & -10.54 & -11.29 & -12.04 & -12.78 \\
\hline $\mathrm{Zn}$ & 14.89 & -14.89 & -14.89 & -14.89 & -14.89 & -14.89 & -14.89 & -14.89 & -14.89 & -14.89 \\
\hline $\mathrm{Zr}$ & -7.54 & -7.64 & -7.73 & -7.83 & $-7,92$ & -8.01 & -8.11 & -8.20 & -8.30 & -8.39 \\
\hline $\mathrm{Ce}$ & -0.67 & -123 & -1.80 & -2.36 & -2.92 & -3.49 & -4.05 & -4.61 & -5.17 & -5.74 \\
\hline $\mathrm{Eu}$ & 0.02 & -0.01 & -0.04 & -0.07 & 0.10 & -0.13 & -0.16 & -0.19 & -0.22 & -0.25 \\
\hline Hf & 0.00 & 0.00 & 0.00 & 0.00 & 0.00 & 0.00 & 0.00 & 0.00 & 0.00 & 0.00 \\
\hline Ho & 0.05 & 0.03 & 0.00 & 0.03 & -0.06 & -0.09 & -0.12 & -0.15 & -0.17 & -0.20 \\
\hline $\mathrm{La}$ & -0.51 & -0.78 & -1.05 & -1.32 & -1.59 & -1.86 & -2.12 & -2.39 & -2.66 & -2.93 \\
\hline $\mathrm{Lu}$ & 0.00 & 0.01 & -0.02 & -0.04 & -0.05 & -0.07 & -0.08 & -0.09 & -0.11 & -0.12 \\
\hline Nd & 0.28 & -0.02 & -0.31 & $=0.60$ & -0.90 & -1.19 & -1.49 & -1.78 & -2.07 & -2.37 \\
\hline $\mathrm{Sc}$ & 0.84 & 0.72 & 0.60 & 0.48 & 0.36 & 0.24 & 0.12 & 0.00 & -0.12 & -0.24 \\
\hline $\mathrm{Sm}$ & 0.16 & 0.08 & 0.00 & -0.07 & $=0.15$ & -0.22 & -0.30 & -0.38 & -0.45 & -0.53 \\
\hline $\mathrm{Tb}$ & 0.04 & 0.03 & 0.01 & -0.01 & -0.03 & -0.05 & -0.06 & -0.08 & -0.10 & -0.12 \\
\hline $\mathrm{Yb}$ & 0.03 & -0.05 & $=0.14$ & -0.23 & -0.32 & -0.41 & -0.50 & -0.59 & -0.67 & -0.76 \\
\hline \multicolumn{11}{|c|}{ Unaltered BIF to oxidized BIF (Fourth West Gorge) } \\
\hline $\mathrm{SiO}_{2}$ & 14.11 & 8.72 & 3.33 & 2.05 & -7.44 & -12.83 & -18.22 & -23.61 & -29.00 & -34.39 \\
\hline $\mathrm{Al}_{2} \mathrm{O}_{3}$ & -0.14 & 0.15 & -0.17 & -0.18 & -0.20 & -0.21 & -0.23 & -0.24 & -0.26 & -0.27 \\
\hline $\mathrm{Fe}_{2} \mathrm{O}_{3} \mathrm{~T}$ & -1.97 & 6.66 & -11.36 & -16.06 & -20.75 & 25.45 & -30.15 & -34.85 & -39.54 & -44.24 \\
\hline $\mathrm{MgO}$ & -2.57 & -2.57 & -2.57 & -2.57 & -2.57 & $=-2.57$ & -2.57 & -2.58 & -2.58 & -2.58 \\
\hline $\mathrm{CaO}$ & -1.76 & -1.76 & -1.76 & -1.77 & -1.77 & -1.78 & -1.78 & -1.78 & -1.79 & -1.79 \\
\hline $\mathrm{K}_{2} \mathrm{O}$ & -0.27 & -0.28 & -0.28 & -0.28 & -0.28 & $=0.28$ & -0.29 & -0.29 & -0.29 & -0.29 \\
\hline $\mathrm{P}_{2} \mathrm{O}_{5}$ & -0.10 & -0.11 & -0.12 & $=0.13$ & -0.15 & -0.16 & -0.17 & -0.18 & -0.19 & -0.20 \\
\hline $\mathrm{S}$ & -0.07 & 0.07 & -0.07 & -0.07 & 0.07 & -0.07 & -0.07 & -0.07 & -0.07 & -0.07 \\
\hline $\mathrm{Ba}$ & -38.77 & -40.55 & -42.34 & -44.12 & 45.91 & -47.69 & -49.48 & -51.26 & -53.05 & -54.83 \\
\hline Co & 40.41 & 35.08 & 29.75 & 24.43 & 19.10 & 13.77 & 8.45 & 3.12 & -2.20 & -7.53 \\
\hline $\mathrm{Cr}$ & 12.35 & 9.94 & 7.53 & 5.12 & 2.71 & 0.30 & -2.10 & -4.51 & -6.92 & -9.33 \\
\hline $\mathrm{Ni}$ & -1.05 & -1.72 & -2.39 & -3.06 & -3.73 & -4.40 & -5.08 & -5.75 & -6.42 & -7.09 \\
\hline $\mathrm{Pb}$ & -3.93 & $-4,12$ & -4.30 & -4.49 & -4.67 & -4.86 & -5.05 & -5.23 & -5.42 & -5.60 \\
\hline $\mathrm{Rb}$ & -33.29 & -33.29 & -33.29 & -33.29 & -33.29 & -33.29 & -33.29 & -33.29 & -33.29 & -33.29 \\
\hline $\mathrm{Sr}$ & -2164 & -22.32 & -23.00 & -23.69 & -24.37 & 25.05 & -25.73 & -26.42 & -27.10 & -27.78 \\
\hline V & 2.37 & 1.97 & 1.56 & 1.15 & 0.74 & 0.34 & -0.07 & -0.48 & -0.89 & -1.29 \\
\hline Y & -5.56 & -6.36 & -7.16 & -7.95 & -8.75 & -9.55 & -10.34 & -11.14 & -11.94 & -12.73 \\
\hline $\mathrm{Zn}$ & 14.89 & -14.89 & 14.89 & -1489 & -14.89 & -14.89 & -14.89 & -14.89 & -14.89 & -14.89 \\
\hline $\mathrm{Zr}$ & -8.49 & -8.49 & -8.49 & -8.49 & -8.49 & $=8.49$ & -8.49 & -8.49 & -8.49 & -8.49 \\
\hline $\mathrm{Ce}$ & -0.12 & -0.74 & 1.35 & -1.97 & -2.59 & 3.21 & -3.83 & -4.45 & -5.06 & -5.68 \\
\hline Eu & -0.06 & 0.08 & -0.10 & -0.12 & 0.15 & -0.17 & -0.19 & -0.21 & -0.24 & -0.26 \\
\hline $\mathrm{Hf}$ & 0.00 & 0.00 & 0.00 & 0.00 & 0.00 & 0.00 & 0.00 & 0.00 & 0.00 & 0.00 \\
\hline Ho & -0.03 & -0.05 & -0.07 & -0.09 & -0.11 & 0.13 & -0.15 & -0.17 & -0.19 & -0.21 \\
\hline $\mathrm{La}$ & 0.52 & 0.15 & -0.22 & -0.59 & -0.97 & -1.34 & -1.71 & -2.09 & -2.46 & -2.83 \\
\hline $\mathrm{Lu}$ & 0.04 & -0.05 & -0.06 & 0.07 & -0.08 & 0.09 & -0.10 & -0.11 & -0.12 & -0.12 \\
\hline $\mathrm{Nd}$ & 0.48 & 0.17 & -0.15 & -0.46 & -0.78 & -1.09 & -1.40 & -1.72 & -2.03 & -2.35 \\
\hline $\mathrm{Sc}$ & 0.30 & 0.23 & 0.16 & 0.10 & 0.03 & 0.03 & -0.10 & -0.16 & -0.23 & -0.29 \\
\hline
\end{tabular}




\begin{tabular}{|c|c|c|c|c|c|c|c|c|c|c|}
\hline Vol. loss ${ }^{\dagger}$ & 0 & 10 & 20 & 30 & 40 & 50 & 60 & 70 & 80 & 90 \\
\hline $\mathrm{Sm}$ & 0.03 & 0.09 & 0.15 & $=0.20$ & 0.26 & -0.32 & -0.38 & -0.43 & -0.49 & -0.55 \\
\hline $\mathrm{Tb}$ & -0.04 & -0.05 & -0.06 & -0.07 & -0.08 & $=0.09$ & -0.10 & -0.11 & -0.12 & -0.13 \\
\hline $\mathrm{Yb}$ & -0.24 & -0.30 & -0.36 & -0.42 & -0.49 & 0.55 & -0.61 & -0.67 & -0.73 & -0.79 \\
\hline \multicolumn{11}{|c|}{ Unaltered BIF to oxidized BIF (Mt. Whaleback) } \\
\hline $\mathrm{SiO}_{2}$ & 3.87 & 0.49 & -4.86 & -9.22 & -13.59 & -17.95 & -22.32 & -26.68 & -31.05 & -35.41 \\
\hline $\mathrm{Al}_{2} \mathrm{O}_{3}$ & -0.21 & $=0.21$ & -0.22 & 0.23 & -0.24 & -0.25 & -0.26 & -0.26 & -0.27 & -0.28 \\
\hline $\mathrm{Fe}_{2} \mathrm{O}_{3} \mathrm{~T}$ & 11.83 & 5.75 & -0.33 & 6.40 & -12.48 & -18.56 & -24.63 & -30.71 & -36.78 & -42.86 \\
\hline $\mathrm{MgO}$ & 2.58 & -2.58 & -2.58 & -2.58 & -2.58 & -2.58 & -2.58 & -2.58 & -2.58 & -2.58 \\
\hline $\mathrm{CaO}$ & -1.66 & 1.67 & -1.68 & -1.70 & -1.71 & -1.72 & -1.74 & -1.75 & -1.77 & -1.78 \\
\hline $\mathrm{K}_{2} \mathrm{O}$ & -0.27 & -0.28 & -0.28 & 0.28 & -0.28 & -0.28 & -0.29 & -0.29 & -0.29 & -0.29 \\
\hline $\mathrm{P}_{2} \mathrm{O}_{5}$ & -0.09 & -0.11 & -0.12 & -0.13 & -0.14 & -0.15 & -0.17 & -0.18 & -0.19 & -0.20 \\
\hline S & -0.07 & -0.07 & -0.07 & -0.07 & -0.07 & -0.07 & -0.07 & -0.07 & -0.07 & -0.07 \\
\hline $\mathrm{Ba}$ & -52.23 & 52.67 & 53.11 & 53.55 & -53.99 & -54.43 & -54.86 & -55.30 & -55.74 & -56.18 \\
\hline Co & 20.02 & 16.73 & 13.45 & 10.16 & 6.87 & 3.58 & 0.29 & -2.99 & -6.28 & -9.57 \\
\hline $\mathrm{Cr}$ & 13.29 & 10.79 & 8.29 & 5.78 & 3.28 & 0.78 & -1.73 & -4.23 & -6.73 & -9.23 \\
\hline $\mathrm{Ni}$ & 9.15 & 7.46 & 5.77 & 4.07 & 2.38 & 0.69 & -1.00 & -2.69 & -4.38 & -6.07 \\
\hline $\mathrm{Pb}$ & 0.75 & 0.10 & -0.55 & -1.21 & -1.86 & -2.52 & -3.17 & -3.83 & -4.48 & -5.13 \\
\hline $\mathrm{Rb}$ & -33.29 & -33.29 & -33.29 & -33.29 & -33.29 & -33.29 & -33.29 & -33.29 & -33.29 & -33.29 \\
\hline $\mathrm{Sr}$ & -24.27 & 24.69 & 25.11 & 25.53 & -25.95 & -26.37 & -26.79 & -27.21 & -27.63 & -28.05 \\
\hline V & 0.67 & 0.43 & 0.19 & -0.04 & -0.28 & -0.52 & -0.75 & -0.99 & -1.23 & -1.46 \\
\hline Y & -5.27 & -6.10 & -6.93 & -7.75 & -8.58 & -9.40 & -10.23 & -11.05 & -11.88 & -12.70 \\
\hline $\mathrm{Zn}$ & -12.61 & -12.83 & -13.06 & 13.29 & -13.52 & -13.75 & -13.97 & -14.20 & -14.43 & -14.66 \\
\hline $\mathrm{Zr}$ & -7.92 & -7.98 & 8.03 & $=8.09$ & -8.15 & -8.20 & -8.26 & -8.32 & -8.38 & -8.43 \\
\hline $\mathrm{Ce}$ & -2.03 & -2.45 & -2.88 & -3.31 & -3.74 & -4.16 & -4.59 & -5.02 & -5.45 & -5.87 \\
\hline $\mathrm{Eu}$ & 0.10 & 0.12 & -0.14 & -0.16 & -0.17 & -0.19 & -0.21 & -0.23 & -0.24 & -0.26 \\
\hline Hf & 0.00 & 0.00 & 0.00 & 0.00 & 0.00 & 0.00 & 0.00 & 0.00 & 0.00 & 0.00 \\
\hline Ho & 0.00 & 0.02 & -0.05 & 0.07 & -0.09 & -0.12 & -0.14 & -0.16 & -0.18 & -0.21 \\
\hline $\mathrm{La}$ & -1.13 & -1.34 & -1.54 & -1.75 & -1.96 & -2.17 & -2.37 & -2.58 & -2.79 & -3.00 \\
\hline $\mathrm{Lu}$ & 0.03 & -0.04 & 0.05 & -0.06 & -0.07 & -0.08 & -0.09 & -0.10 & -0.11 & -0.12 \\
\hline $\mathrm{Nd}$ & 0.67 & -0.87 & -1.07 & -1.27 & -1.47 & -1.67 & -1.86 & -2.06 & -2.26 & -2.46 \\
\hline $\mathrm{Sc}$ & 0.03 & -0.01 & -0.05 & 0.09 & -0.12 & -0.16 & -0.20 & -0.24 & -0.28 & -0.32 \\
\hline $\mathrm{Sm}$ & -0.20 & -0.24 & -0.28 & -0.32 & -0.36 & -0.40 & -0.44 & -0.48 & -0.52 & -0.56 \\
\hline $\mathrm{Tb}$ & 0.01 & 0.00 & -0.02 & 0.03 & -0.05 & -0.06 & -0.08 & -0.09 & -0.11 & -0.12 \\
\hline $\mathrm{Yb}$ & -0.19 & -0.26 & $=0.32$ & -0.39 & -0.46 & -0.52 & -0.59 & -0.65 & -0.72 & -0.78 \\
\hline \multicolumn{11}{|c|}{ Mt. Whaleback BIF to high-grade hematite ore (0\% porosity) } \\
\hline $\mathrm{SiO}_{2}$ & -40.59 & -40.68 管 & -4077 & 40.86 & 40.94 & -41.03 & 41.12 & -41.21 & -41.29 & -41.38 \\
\hline $\mathrm{TiO}_{2}$ & 0.02 & 0.02 & 0.01 & 0.01 & 0.01 & 0.01 & 0.00 & 0.00 & 0.00 & 0.00 \\
\hline $\mathrm{Al}_{2} \mathrm{O}_{3}$ & 0.21 & 0.18 & 0.15 & 0.12 & 0.09 & 0.07 & 0.04 & 0.01 & -0.02 & -0.05 \\
\hline $\mathrm{Fe}_{2} \mathrm{O}_{3} \mathrm{~T}$ & 94.92 & 79.65 & 64.39 & 49.12 & 33.86 & 18.59 & 3.33 & -11.94 & -27.20 & $-42,47$ \\
\hline $\mathrm{CaO}$ & -0.02 & -0.03 & -0.05 & $=0.06$ & 0.07 & 0.08 & -0.09 & -0.10 & -0.11 & -0.12 \\
\hline $\mathrm{P}_{2} \mathrm{O}_{5}$ & -0.03 & -0.04 & -0.05 & -0.06 & 0.07 & -0.07 & -0.08 & -0.09 & -0.10 & -0.11 \\
\hline Co & -19.66 & -20.82 & 21.98 & -23.13 & -24.29 & 25.45 & -26.61 & -27.77 & -28.92 & -30.08 \\
\hline $\mathrm{Cr}$ & 31.07 & 25.58 & 20.10 & 14.61 & 9.13 & 3.64 & -1.84 & -7.33 & -12.81 & -18.30 \\
\hline $\mathrm{Ni}$ & -1.58 & -3.03 & -4.48 & -5.92 & -7.37 & 8.82 & -10.27 & -11.72 & -13.17 & -14.61 \\
\hline $\mathrm{Sr}$ & 2.80 & 2.12 & 1.44 & 0.76 & 0.08 & -0.60 & $-1,28$ & -1.96 & -2.63 & -3.31 \\
\hline Y & 8.71 & 7.05 & 5.40 & 3.74 & 2.09 & 0.43 & -1.22 & -2.88 & -4.53 & -6.19 \\
\hline $\mathrm{Eu}$ & 0.33 & 0.28 & 0.23 & 0.18 & 0.13 & 0.08 & 0.03 & -0.02 & -0.07 & -0.12 \\
\hline $\mathrm{Lu}$ & 0.25 & 0.21 & 0.18 & 0.14 & 0.11 & 0.07 & 0.04 & 0.00 & -0.03 & -0.07 \\
\hline Nd & 3.52 & 2.98 & 2.44 & 1.90 & 1.36 & 0.81 & 0.27 & -0.27 & -0.81 & -1.35 \\
\hline $\mathrm{Sc}$ & 1.74 & 1.53 & 1.32 & 1.11 & 090 & 0.69 & 0.47 & 0.26 & 0.05 & -0.16 \\
\hline $\mathrm{Sm}$ & 0.85 & 0.73 & 0.60 & 0.48 & 0.35 & 0.23 & 0.11 & -0.02 & -0.14 & -0.26 \\
\hline $\mathrm{Yb}$ & 1.50 & 1.28 & 1.07 & 0.86 & 0.65 & 0.44 & 0.22 & 0.01 & -0.20 & -0.41 \\
\hline \multicolumn{11}{|c|}{ Mt. Whaleback BIF to high-grade hematite ore ( $10 \%$ porosity) } \\
\hline $\mathrm{SiO}_{2}$ & -40.68 & -40.76 & -40.84 & -40.92 & 41,00 筑 & 41.08 & 41.15 & -41.23 & -41.31 & -41.39 \\
\hline $\mathrm{TiO}_{2}$ & 0.02 & 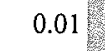 & 0.01 & 0.01 & 0.01 & 0.01 & 0.00 & 0.00 & 0.00 & 0.00 \\
\hline $\mathrm{Al}_{2} \mathrm{O}_{3}$ & 0.18 & 0.16 & 0.13 & 0.10 & 0.08 & 0.05 & 0.03 & 0.00 & -0.03 & -0.05 \\
\hline $\mathrm{Fe}_{2} \mathrm{O}_{3} \mathrm{~T}$ & 79.56 & 65.83 & 52.10 & 38.37 & 24.64 & 10.91 & -2.82 & -16.54 & -30.27 & -44.00 \\
\hline $\mathrm{CaO}$ & -0.03 & -0.04 & -0.05 & 0.06 & -0.07 & -0.08 & 0.09 & -0.10 & -0.11 & -0.12 \\
\hline $\mathrm{P}_{2} \mathrm{O}_{5}$ & -0.04 & -0.05 & -0.06 & -0.06 & -0.07 & -0.08 & $=0.09$ & -0.09 & -0.10 & -0.11 \\
\hline Co & -20.82 & -21.87 & -22.91 & -23.95 & 24.99 & 26.03 & 2707 & -28.11 & -29.16 & -30.20 \\
\hline $\mathrm{Cr}$ & 25.55 & 20.62 & 15.68 & 10.75 & 5.82 & 0.88 & 4.05 & -8.98 & -13.92 & -18.85 \\
\hline
\end{tabular}


Appendix 7.1. (continued)

\begin{tabular}{|c|c|c|c|c|c|c|c|c|c|c|}
\hline Vol. $\operatorname{loss}^{\dagger}$ & 0 & 10 & 20 & 30 & 40 & 50 & 60 & 70 & 80 & 90 \\
\hline $\mathrm{Ni}$ & -3.04 & -4.34 & 5.64 & 6.94 & 8.25 & -9.55 & -10.85 & -12.15 & -13.46 & -14.76 \\
\hline $\mathrm{Sr}$ & 2.11 & 1.50 & 0.89 & 0.28 & 0.33 & -0.94 & -1.55 & -2.16 & -2.77 & -3.38 \\
\hline Y & 7.04 & 5.55 & 4.06 & 2.58 & 1.09 & -0.40 & -1.89 & -3.38 & -4.87 & -6.36 \\
\hline $\mathrm{Eu}$ & 0.28 & 0.23 & 0.19 & 0.14 & 0.10 & 0.05 & 0.01 & -0.03 & -0.08 & -0.12 \\
\hline $\mathrm{Lu}$ & 0.21 & 0.18 & 0.15 & 0.12 & 0.09 & 0.06 & 0.02 & -0.01 & -0.04 & -0.07 \\
\hline $\mathrm{Nd}$ & 2.98 & 2.49 & 2.00 & 1.52 & 1.03 & 0.54 & 0.06 & -0.43 & -0.92 & -1.40 \\
\hline $\mathrm{Sc}$ & 1.53 & 1.34 & 1.15 & 0.96 & 0.77 & 0.58 & 039 & 0.20 & 0.01 & -0.18 \\
\hline $\mathrm{Sm}$ & 0.72 & 0.61 & 0.50 & 0.39 & 0.28 & 0.17 & 0.06 & -0.05 & -0.17 & -0.28 \\
\hline $\mathrm{Yb}$ & 1.28 & 1.09 & 0.90 & 0.71 & 0.52 & 0.33 & 0.14 & -0.05 & -0.24 & -0.43 \\
\hline \multicolumn{11}{|c|}{ Mt. Whaleback BIF to high-grade hematite ore (20\% porosity) } \\
\hline $\mathrm{SiO}_{2}$ & -40.77 & -40.84 & -40.91 & -40.98 & -41.05 & 4.12 & -41.19 & -41.26 & -41.33 & -41.40 \\
\hline $\mathrm{TiO}_{2}$ & 0.01 & 0.01 & 0.01 & 0.01 & 0.01 & 0.00 & 0,00 & 0.00 & 0.00 & 0.00 \\
\hline $\mathrm{Al}_{2} \mathrm{O}_{3}$ & 0.15 & 0.13 & 0.11 & 0.08 & 0.06 & 0.04 & 0.01 & -0.01 & -0.03 & -0.06 \\
\hline $\mathrm{Fe}_{2} \mathrm{O}_{3} \mathrm{~T}$ & 64.50 & 52.28 & 40.05 & 27.83 & 15.61 & 3.38 & 8.84 & -21.06 & -33.29 & -45.51 \\
\hline $\mathrm{CaO}$ & -0.04 & -0.05 & -0.06 & -0.07 & $=0.08$ & -0.09 & $=0.10$ & -0.11 & -0.11 & -0.12 \\
\hline $\mathrm{P}_{2} \mathrm{O}_{5}$ & -0.05 & -0.06 & 0.06 & 0.07 & 0.08 & 0.08 & -0.09 & -0.10 & -0.10 & -0.11 \\
\hline $\mathrm{Co}$ & -21.97 & -22.89 & 23.82 & -24.75 & -25.68 & 26,60 & -2753 & -28.46 & -29.38 & -30.31 \\
\hline $\mathrm{Cr}$ & 20.14 & 15.75 & 11.36 & 6.96 & 2.57 & -1.82 & -6.21 & -10.61 & -15.00 & -19.39 \\
\hline $\mathrm{Ni}$ & -4.46 & -5.62 & -6.78 & -7.94 & -9.10 & -10.26 & -11.42 & -12.58 & -13.74 & -14.90 \\
\hline $\mathrm{Sr}$ & 1.44 & 0.90 & 0.36 & $=0.19$ & -0.73 & -1.27 & -1.82 & -2.36 & -2.90 & -3.45 \\
\hline $\mathrm{Y}$ & 5.41 & 4.08 & 2.76 & 1.43 & 0.11 & -1.22 & -2.54 & -3.87 & -5.19 & -6.52 \\
\hline $\mathrm{Eu}$ & 0.23 & 0.19 & 0.15 & 0.11 & 0.07 & 0.03 & -0.01 & -0.05 & -0.09 & -0.13 \\
\hline $\mathrm{Lu}$ & 0.18 & 0.15 & 0.12 & 0.09 & 0.07 & 0.04 & 0.01 & -0.02 & -0.05 & -0.07 \\
\hline $\mathrm{Nd}$ & 2.44 & 2.01 & 1.58 & 1.14 & 0.71 & 0.28 & -0.16 & -0.59 & -1.02 & -1.46 \\
\hline $\mathrm{Sc}$ & 1.32 & 1.15 & 0.98 & 0.81 & 0.64 & 0.48 & 0.31 & 0.14 & -0.03 & -0.20 \\
\hline Sm & 0.60 & 0.50 & 0.40 & 0.31 & 0.21 & 0.11 & 0.01 & -0.09 & -0.19 & -0.29 \\
\hline $\mathrm{Yb}$ & 1.07 & 0.90 & 0.73 & 0.56 & 0.39 & 0.22 & 0.05 & -0.12 & -0.29 & -0.46 \\
\hline \multicolumn{11}{|c|}{ Mt. Whaleback BIF to high-grade hematite ore (30\% porosity) } \\
\hline $\mathrm{SiO}_{2}$ & -40.86 & -40.92 & 40.98 & -41.04 & 41.10 & 4116 & 41.22 & -41.29 & -41.35 & -41.41 \\
\hline $\mathrm{TiO}_{2}$ & 0.01 & 0.01 & 0.01 & 0.01 & 0.00 & 0.00 & 0.00 & 0.00 & 0.00 & 0.00 \\
\hline $\mathrm{Al}_{2} \mathrm{O}_{3}$ & 0.12 & 0.10 & 0.08 & 0.06 & 0.04 & 0.02 & 0.00 & -0.02 & -0.04 & -0.06 \\
\hline $\mathrm{Fe}_{2} \mathrm{O}_{3} \mathrm{~T}$ & 49.15 & 38.46 & 27.77 & 17.08 & 6.40 & -4.29 & 14.98 & -25.67 & -36.36 & -47.05 \\
\hline $\mathrm{CaO}$ & -0.06 & -0.06 & -0.07 & -0.08 & -0.09 & -0.09 & $=010$ & -0.11 & -0.12 & -0.12 \\
\hline $\mathrm{P}_{2} \mathrm{O}_{5}$ & -0.06 & -0.06 & -0.07 & -0.08 & -0.08 & -0.09 & -0.09 & -0.10 & -0.10 & -0.11 \\
\hline Co & -23.13 & -23.94 & 24.75 & $-25,56$ & -26.37 & -27.19 & 28.00 & -28.81 & -29.62 & -30.43 \\
\hline $\mathrm{Cr}$ & 14.62 & 10.78 & 6.94 & 3.10 & -0.74 & -4.58 & -8.42 & -12.26 & -16.10 & -19.94 \\
\hline $\mathrm{Ni}$ & -5.92 & -6.94 & -7.95 & 8.96 & 9.98 & -10.99 & -12.01 & -13.02 & -14.03 & -15.05 \\
\hline $\mathrm{Sr}$ & 0.76 & 0.29 & -0.19 & 0.66 & -1.14 & -1.62 & 2.09 & -2.57 & -3.04 & -3.52 \\
\hline$Y$ & 3.74 & 2.59 & 1.43 & 0.27 & -0.89 & -2.05 & -3.21 & -4.37 & -5.53 & -6.69 \\
\hline Eu & 0.18 & 0.14 & 0.11 & 0.07 & 0.04 & 0.01 & $=0.03$ & -0.06 & -0.10 & -0.13 \\
\hline $\mathrm{Lu}$ & 0.14 & 0.12 & 0.09 & 0.07 & 0.04 & 0.02 & 0.00 & -0.03 & -0.05 & -0.08 \\
\hline $\mathrm{Nd}$ & 1.90 & 1.52 & 1.14 & 0.76 & 0.38 & 0.00 & -0.38 & -0.75 & -1.13 & -1.51 \\
\hline $\mathrm{Sc}$ & 1.11 & 0.96 & 0.81 & 0.67 & 0.52 & 0.37 & 0.22 & 0.07 & -0.08 & -0.22 \\
\hline $\mathrm{Sm}$ & 0.48 & 0.39 & 0.31 & 0.22 & 0.13 & 0.05 & -0.04 & -0.13 & -0.21 & -0.30 \\
\hline $\mathrm{Yb}$ & 0.86 & 0.71 & 0.56 & 0.41 & 0.27 & 0.12 & -0.03 & -0.18 & -0.33 & -0.48 \\
\hline \multicolumn{11}{|c|}{ Mt. Whaleback BIF to high-grade hematite ore (40\% porosity) } \\
\hline $\mathrm{SiO}_{2}$ & -40.94 & -41.00 & -41.05 & 41.10 & -41.15 & 41.21 & -41.26 & -41.31 & -41.36 & -41.42 \\
\hline $\mathrm{TiO}_{2}$ & 0.01 & 0.01 & 0.01 & 0.00 & 0.00 & 0.00 & 0.00 & 0.00 & 0.00 & 0.00 \\
\hline $\mathrm{Al}_{2} \mathrm{O}_{3}$ & 0.09 & 0.08 & 0.06 & 0.04 & 0.03 & 0.01 & -0.01 & -0.03 & -0.04 & -0.06 \\
\hline $\mathrm{Fe}_{2} \mathrm{O}_{3} \mathrm{~T}$ & 33.80 & 24.64 & 15.49 & 6.34 & -2.82 & -11.97 & -21.12 & -30.27 & -39.43 & -48.58 \\
\hline $\mathrm{CaO}$ & -0.07 & -0.07 & $=0.08$ & -0.09 & -0.09 & $=0.10$ & -0.11 & -0.11 & -0.12 & -0.12 \\
\hline $\mathrm{P}_{2} \mathrm{O}_{5}$ & -0.07 & -0.07 & -0.08 & 0.08 & -0.09 & 0.09 & $=0.10$ & -0.10 & -0.11 & -0.11 \\
\hline $\mathrm{Co}$ & -24.30 & -24.99 & -25.68 & 26.38 & -27.07 & 27.77 & 28.46 & -29.16 & -29.85 & -30.54 \\
\hline $\mathrm{Cr}$ & 9.11 & 5.82 & 2.53 & -0.76 & -4.05 & -7.34 & 10.63 & -13.92 & -17.21 & -20.49 \\
\hline $\mathrm{Ni}$ & -7.38 & -8.25 & -9.12 & 9.98 & -10.85 & 11.72 & -12.59 & -13.46 & -14.33 & -15.19 \\
\hline $\mathrm{Sr}$ & 0.08 & -0.33 & -0.74 & -1.14 & -1.55 & -1.96 & 2.36 & -2.77 & -3.18 & -3.58 \\
\hline Y & 2.08 & 1.09 & 0.10 & -0.90 & -1.89 & -2.88 & -3.87 & -4.87 & -5.86 & -6.85 \\
\hline $\mathrm{Eu}$ & 0.13 & 0.10 & 0.07 & 0.04 & 0.01 & $=0.02$ & $=0.05$ & -0.08 & -0.11 & -0.14 \\
\hline $\mathrm{Nd}$ & 1.35 & 1.03 & 0.70 & 0.38 & 0.06 & -0.27 & $-0,59$ & -0.92 & -1.24 & -1.57 \\
\hline Sc & 0.90 & 0.77 & 0.64 & 0.52 & 0.39 & 0.26 & 0.14 & 0.01 & -0.12 & -0.25 \\
\hline $\mathrm{Lu}$ & 0.11 & 0.09 & 0.07 & 0.04 & 0.02 & 0.00 & 0.02 & -0.04 & -0.06 & -0.08 \\
\hline
\end{tabular}




\begin{tabular}{|c|c|c|c|c|c|c|c|c|c|c|}
\hline Vol. loss ${ }^{\dagger}$ & 0 & 10 & 20 & 30 & 40 & 50 & 60 & 70 & 80 & 90 \\
\hline $\mathrm{Sm}$ & 0.35 & 0.28 & 0.21 & 0.13 & 0.06 & -0.02 & 0.09 & -0.17 & -0.24 & -0.31 \\
\hline $\mathrm{Yb}$ & 0.65 & 0.52 & 0.39 & 0.26 & 0.14 & 0.01 & -0.12 & -0.24 & -0.37 & -0.50 \\
\hline \multicolumn{11}{|c|}{ Mt. Whaleback BIF to high-grade hematite ore (50\% porosity) } \\
\hline $\mathrm{SiO}_{2}$ & -41.03 & -41.07 & -41.2 & 4116 & -41.21 & -41.25 & -41.29 & -41.34 & -41.38 & -41.43 \\
\hline $\mathrm{TiO}_{2}$ & 0.01 & 0.01 & 000 & 0.00 & 0.00 & 0.00 & 0.00 & 0.00 & 0.00 & 0.00 \\
\hline $\mathrm{Al}_{2} \mathrm{O}_{3}$ & 0.07 & 0.05 & 0.04 & 0.02 & 0.01 & 0.01 & $=0.02$ & -0.04 & -0.05 & -0.06 \\
\hline $\mathrm{Fe}_{2} \mathrm{O}_{3} \mathrm{~T}$ & 18.74 & 11.09 & 3.44 & $-4,21$ & 11.85 & 19.50 & 2715 & -34.79 & -42.44 & -50.09 \\
\hline $\mathrm{CaO}$ & -0.08 & -0.08 & -0.09 & -0.09 & $=0.10$ & 0.10 & 0.17 & -0.11 & -0.12 & -0.13 \\
\hline $\mathrm{P}_{2} \mathrm{O}_{5}$ & -0.07 & -0.08 & -0.08 & -0.09 & 0.09 & 0.09 & 0.10 & -0.10 & -0.11 & -0.11 \\
\hline $\mathrm{Co}$ & -25.44 & -26.02 & -26.60 & 27.18 & -2776 & 28.34 & 28.92 & -29.50 & -30.08 & -30.66 \\
\hline $\mathrm{Cr}$ & 3.69 & 0.95 & -180 & -4.55 & -730 & -10.04 & 1279 & -15.54 & -18.29 & -21.04 \\
\hline $\mathrm{Ni}$ & -8.81 & -9.53 & -1026 & 210.98 & 11.71 & $-12,44$ & -13.16 & -13.89 & -14.61 & -15.34 \\
\hline $\mathrm{Sr}$ & -0.59 & -0.93 & -1.27 & -161 & -1.95 & -2.29 & -2.63 & -2.97 & -3.31 & -3.65 \\
\hline Y & 0.45 & -0.38 & -121 & 2.04 & -2.87 & -3.70 & -4.53 & -5.36 & -6.19 & -7.02 \\
\hline Eu & 0.08 & 0.06 & 0.03 & 0.01 & -0.02 & -0.04 & -0.07 & -0.09 & -0.12 & -0.14 \\
\hline Lu & 0.07 & 0.06 & 0.04 & 0.02 & 0.00 & -0.01 & $=0.03$ & -0.05 & -0.07 & -0.08 \\
\hline $\mathrm{Nd}$ & 0.82 & 0.55 & 0.28 & 0.01 & 0.26 & $=0.54$ & 0.81 & -1.08 & -1.35 & -1.62 \\
\hline Sc & 0.69 & 0.58 & 0.48 & 0.37 & 0.26 & 0.16 & 0.05 & -0.05 & -0.16 & -0.27 \\
\hline $\mathrm{Sm}$ & 0.23 & 0.17 & 0.11 & 0.05 & 0.02 & $=0.08$ & -0.14 & -0.20 & -0.26 & -0.33 \\
\hline $\mathrm{Yb}$ & 0.44 & 0.33 & 0.22 & 0.12 & 0.01 & 0.09 & 020 & -0.31 & -0.41 & -0.52 \\
\hline \multicolumn{11}{|c|}{ Mt. Whaleback BIF to high-grade hematite ore (60\% porosity) } \\
\hline $\mathrm{SiO}_{2}$ & -41.12 & -41.15 & 41.19 & -41.22 & -4126 & 4129 & 4133 & -41.36 & -41.40 & -41.44 \\
\hline $\mathrm{TiO}_{2}$ & 0.00 & 0.00 & 0.00 & 0.00 & 0.00 & 0.00 & 0.00 & 0.00 & 0.00 & 0.00 \\
\hline $\mathrm{Al}_{2} \mathrm{O}_{3}$ & 0.04 & 0.03 & 0.01 & 0.00 & -0.01 & $=0.02$ & -0.03 & -0.04 & -0.06 & -0.07 \\
\hline $\mathrm{Fe}_{2} \mathrm{O}_{3} \mathrm{~T}$ & 3.38 & -2.73 & 8.84 & -1495 & -21.06 & 27.18 & -33.29 & -39.40 & -45.51 & -51.62 \\
\hline $\mathrm{CaO}$ & -0.09 & -0.09 & 010 & 0.10 & -0.11 & -0.11 & -0.11 & -0.12 & -0.12 & -0.13 \\
\hline $\mathrm{P}_{2} \mathrm{O}_{5}$ & -0.08 & -0.09 & 0.09 & -0.09 & -0.10 & -0.10 & $=0.10$ & -0.11 & -0.11 & -0.11 \\
\hline $\mathrm{Co}$ & -26.60 & -27.07 & 27.53 & -2799 & 28,46 & -28.92 & 29.38 & -29.85 & -30.31 & -30.78 \\
\hline $\mathrm{Cr}$ & -1.82 & -4.02 & -6.21 & -8.41 & -10.61 & -1280 & 15.00 & -17.19 & -19.39 & -21.59 \\
\hline $\mathrm{Ni}$ & -10.26 & -10.84 & -11.42 & 12.00 & 1258 & -1316 & 1374 & -14.32 & -14.90 & -15.48 \\
\hline $\mathrm{Sr}$ & -1.27 & -1.55 & -1.82 & -2.09 & 2,36 & 22.63 & -2.90 & -3.18 & -3.45 & -3.72 \\
\hline$Y$ & -1.22 & -1.88 & -2.54 & -3.21 & -3.87 & -4.53 & -5.19 & -5.86 & -6.52 & -7.18 \\
\hline $\mathrm{Eu}$ & 0.03 & 0.01 & -0.01 & -0.03 & -0.05 & -0.07 & 0.09 & -0.11 & -0.13 & -0.15 \\
\hline $\mathrm{Lu}$ & 0.04 & 0.02 & 0.01 & 0.00 & $=0.02$ & -0.03 & $=0.05$ & -0.06 & -0.07 & -0.09 \\
\hline $\mathrm{Nd}$ & 0.28 & 0.06 & 0.16 & 0.37 & 0.59 & -0.81 & -1.02 & -1.24 & -1.46 & -1.67 \\
\hline $\mathrm{Sc}$ & 0.48 & 0.39 & 031 & 0.22 & 0.14 & 0.05 & -0.03 & -0.12 & -0.20 & -0.29 \\
\hline $\mathrm{Sm}$ & 0.11 & 0.06 & 0.01 & 0.04 & -0.09 & -0.14 & -0.19 & -0.24 & -0.29 & -0.34 \\
\hline $\mathrm{Yb}$ & 0.22 & 0.14 & 0.05 & 0.03 & $=0.12$ & -0.20 & $\begin{array}{r}-0.29 \\
\end{array}$ & -0.37 & -0.46 & -0.54 \\
\hline
\end{tabular}

Notes: ${ }^{*}$ mass changes in grams and $10^{-5}$ grams per 100 grams of parent rock for major element oxides and trace elements respectively; light gray areas represenet the plausible volume losses based on geochemical mass/volume calculations and stratigraphic thickness mesurements; $\dagger=$ volume (vol.) loss in percent; volume factor $\left(f_{\mathrm{v}}\right)=$ the ratio of altered volume/unaltered volume (ie., (100 - vol. loss)/100); '-' = mass loss, no sign signifies mass gain. 
Appendix 7.2. Elemental mass changes* as a function of volume for the alteration of shale across the Hamersley Province

\begin{tabular}{|c|c|c|c|c|c|c|c|c|c|c|}
\hline $\mathrm{Voll} \mathrm{loss}^{\dagger}$ & 0 & 10 & 20 & 30 & 40 & 50 & 60 & 70 & 80 & 90 \\
\hline \multicolumn{11}{|c|}{ Black shale to altered black shale } \\
\hline $\mathrm{SiO}_{2}$ & -5.80 & -9.13 & -12.46 & 15.80 & 19.13 & 22.46 & -25.79 & 29.12 & $-32,46$ & -35.79 \\
\hline $\mathrm{TiO}_{2}$ & 0.34 & 0.28 & 0.21 玹 & 0.14 & 0.07 & 0.00 & $-0,06$ & 0.13 & -0.20 & -0.27 \\
\hline $\mathrm{Al}_{2} \mathrm{O}_{3}$ & 11.96 & 10.09 & 8.22 & 635 & 4.48 & 2.62 & 0.75 & -12 & -2.99 & -4.85 \\
\hline $\mathrm{Fe}_{2} \mathrm{O}_{3} \mathrm{~T}$ & -3.78 & -6.07 & -8.36 & 10.65 & 12.94 & 15.23 & -1752 & 19.81 & -22.10 & -24.39 \\
\hline $\mathrm{MnO}$ & -0.08 & -0.10 & -0.11 & 0.13 & -0.14 & 0.16 & 0.18 & 2019 & -0.21 & -0.22 \\
\hline $\mathrm{MgO}$ & -1.47 & -2.02 & -2.56 & -3.11 & 3.66 & $4: 20$ & 4.75 & -529 & -5.84 & -6.39 \\
\hline $\mathrm{CaO}$ & -3.18 & -3.25 & -3.31 & -3.38 & 3.45 & -3.51 & -3.58 & -3.65 & -3.72 & -3.78 \\
\hline $\mathrm{K}_{2} \mathrm{O}$ & -2.13 & -2.30 & -2.47 & 2.63 & -2.80 & -2.97 & -3.13 & -3.30 & -3.47 & -3.63 \\
\hline $\mathrm{P}_{2} \mathrm{O}_{5}$ & -0.01 & -0.03 & -0.04 & 0.05 & -0.06 & -0.07 & 0.08 & -0.09 & -0.10 & -0.11 \\
\hline S & -0.60 & -0.60 & -0.61 & 0.61 & 0.61 & 0.61 & -0.62 & 0.62 & -0.62 & -0.62 \\
\hline $\mathrm{Ba}$ & -332.49 & -337.04 & -341.59 & 346.14 & 350.69 & -355.24 & -359.79 & -364.34 & -368.89 & -373.44 \\
\hline $\mathrm{Co}$ & 38.68 & 32.95 & 27.21 & 2148 & 15.75 & 10.01 & 4.28 & -1.45 & -7.19 & -12.92 \\
\hline $\mathrm{Cr}$ & 83.68 & 70.43 & 57.18 & 4393 & 30.68 & 1744 & 419 & -9.06 & -22.31 & -35.56 \\
\hline $\mathrm{Nb}$ & 8.77 & 7.38 & 6.00 & 4.62 & 3.24 & 186 & 0.47 & 0.91 & -2.29 & -3.67 \\
\hline $\mathrm{Ni}$ & 155,46 & 135.73 & 115.99 & 96.25 & 76.52 & 56.78 & 37.05 & 1731 & -2.42 & -22.16 \\
\hline $\mathrm{Rb}$ & -124.71 & -133.53 & -142.34 & 15116 & 159.97 & -168.78 & 177.60 & 186.41 & -195.23 & -204.04 \\
\hline $\mathrm{Sr}$ & -8.17 & -11.10 & -14.02 & -16.95 & 19.88 & -2280 & 25.73 & -28.65 & -31.58 & -34.51 \\
\hline V & 52.21 & 41.04 & 29.87 & 18.70 & 7.53 & -3.64 & 14.81 & 2598 & -37.15 & -48.33 \\
\hline Y & 19.34 & 14.76 & 10.17 & 5.59 & 1.00 & -3.58 & -8.17 & -12.75 & -17.34 & -21.92 \\
\hline$Z_{n}$ & 378.68 & 327.72 & 276.75 & 225.78 & 174.81 & 123.85 & 72.88 & 21.91 & -29.05 & -80.02 \\
\hline $\mathrm{Zr}$ & 128.68 & 106.54 & 84.39 & 62.24 & 40.10 & 1795 & -4.19 & $=26.34$ & -48.49 & -70.63 \\
\hline $\mathrm{Ce}$ & 54.61 & 45.43 & 36.25 & 27.07 & 17.90 & 8.72 & $=0.46$ & -9.64 & -18.82 & -28.00 \\
\hline $\mathrm{Cs}$ & -14.99 & -15.20 & -15.40 & 15.60 & 15.80 & -16.00 & 16.20 & -1640 & -16.60 & -16.80 \\
\hline $\mathrm{Eu}$ & 0.24 & 0.10 & -0.03 & $=0.16$ & -0.29 & -0.42 & -0.55 & 0.68 & -0.81 & -0.95 \\
\hline $\mathrm{Hf}$ & 5.19 & 4.55 & 3.91 & 3.27 & 2.63 & 199 & 135 & 0.71 & 0.07 & -0.57 \\
\hline Ho & 0.73 & 0.57 & 0.42 & 0.27 & 0.12 & 0.04 & 0.19 & 0.34 & -0.49 & -0.65 \\
\hline $\mathrm{La}$ & 33.74 & 28.51 & 23.28 & 18.06 & 12.83 & (6.61 & 2.38 & -2.85 & -8.07 & -13.30 \\
\hline Lu & 0.70 & 0.60 & 0.50 & 0.40 & 0.30 & 0.20 & 0.11 & 0.01 & -0.09 & -0.19 \\
\hline $\mathrm{Nd}$ & 16.70 & 13.34 & 9.97 & 6.61 & 3.24 & $=012$ & 3.48 & 6.85 & -10.21 & -13.58 \\
\hline Sc & 13.12 & 11.14 & 9.16 & 7.18 & 5.20 & 3.22 & 124 & -0.73 & -2.71 & -4.69 \\
\hline $\mathrm{Sm}$ & 2,12 & 1.59 & 1.06 & 0053 & 0.00 & -0.53 & -1.06 & -1.59 & -2.12 & -2.65 \\
\hline $\mathrm{Tb}$ & 0.36 & 0.26 & 0.17 & 0.08 & -0.02 & $=0.11$ & -0.20 & -0.30 & -0.39 & -0.48 \\
\hline $\mathrm{Yb}$ & 3.83 & 3.25 & 2.67 & 2.09 & 1.50 & 0.92 & 034 & -0.24 & -0.82 & -1.41 \\
\hline \multicolumn{11}{|c|}{ Altered black shale to red shale } \\
\hline $\mathrm{SiO}_{2}$ & -6.23 & -9.09 & 1195 & 14.81 & -1767 & -20.53 & -23.39 & -26.25 & -29.11 & -31.97 \\
\hline $\mathrm{TiO}_{2}$ & 0.23 & 0.14 & 0.04 & 0.05 & 0.15 & -0.24 & -0.33 & -0.43 & -0.52 & -0.62 \\
\hline $\mathrm{Al}_{2} \mathrm{O}_{3}$ & 2.72 & 0.49 & -1.73 & -3.95 & 618 & -8.40 & -10.63 & -12.85 & -15.07 & -17.30 \\
\hline $\mathrm{Fe}_{2} \mathrm{O}_{3} \mathrm{~T}$ & 9.47 & 6.13 & 2.79 & 0.55 & -3.89 & -7.23 & -10.57 & -13.91 & -17.25 & -20.59 \\
\hline $\mathrm{MnO}$ & -0.09 & 0.09 & 0.10 & 0.11 & -0.12 & -0.12 & -0.13 & -0.14 & -0.15 & -0.15 \\
\hline $\mathrm{MgO}$ & -2.99 & -3.26 & -3.53 & 3.80 & -4.08 & -4.35 & -4.62 & -4.89 & -5.16 & -5.44 \\
\hline $\mathrm{CaO}$ & -0.52 & -0.54 & 0.55 & -0.57 & 0.59 & -0.61 & -0.63 & -0.65 & -0.66 & -0.68 \\
\hline $\mathrm{K}_{2} \mathrm{O}$ & -1.23 & $=128$ & -1.33 & -1.39 & -1.44 & -1.49 & -1.54 & -1.59 & -1.64 & -1.69 \\
\hline $\mathrm{P}_{2} \mathrm{O}_{5}$ & 0.22 & 0.19 & 015 & 0.12 & 0.09 & 0.05 & 0.02 & -0.02 & -0.05 & -0.08 \\
\hline $\mathrm{S}$ & -0.02 & -0.02 & $=0.02$ & -0.02 & 0002 & -0.02 & -0.02 & -0.02 & -0.02 & -0.02 \\
\hline $\mathrm{Ba}$ & -17.66 & -20.65 & -23.64 & -26.63 & 29.62 & -32.61 & -35.60 & -38.59 & -41.58 & -44.57 \\
\hline $\mathrm{Co}$ & -27.98 & -31.17 & 3437 & -3756 & $-40,76$ & -43.95 & -47.15 & -50.34 & -53.54 & -56.73 \\
\hline $\mathrm{Cr}$ & 6.35 & 8.13 & -22.62 & 3710 & -51.59 & -66.07 & -80.55 & -95.04 & -109.52 & -124.01 \\
\hline $\mathrm{Nb}$ & 3.64 & 1.83 & 0.03 & -1.78 & -3.59 & -5.40 & -7.21 & -9.02 & -10.83 & -12.64 \\
\hline $\mathrm{Ni}$ & -65.92 & 79.95 & 93.99 & 108.03 & 122.06 & -136.10 & -150.14 & -164.17 & -178.21 & -192.25 \\
\hline $\mathrm{Rb}$ & -66.65 & 69.19 & $-71,74$ & 74.29 & -76.84 & -79.39 & -81.94 & -84.49 & -87.03 & -89.58 \\
\hline $\mathrm{Sr}$ & -6.22 & 8.66 & 1109 & 1353 & -15.97 & -18.40 & -20.84 & -23.28 & -25.71 & -28.15 \\
\hline V & -32.44 & 40.87 & 4930 & -57.74 & -66.17 & -74.60 & -83.03 & -91.47 & -99.90 & -108.33 \\
\hline Y & 16.08 & 9.68 & 3.28 & -3.12 & -9.52 & -15.92 & -22.32 & -28.72 & -35.12 & -41.52 \\
\hline $\mathrm{Zn}$ & -185.14 & 219.89 & 254.65 & -289.41 & $-324,17$ & -358.93 & -393.69 & -428.45 & -463.21 & -497.97 \\
\hline $\mathrm{Zr}$ & 56.32 & 27.54 & $-1,24$ & -30.02 & -58.80 & -87.58 & -116.36 & -145.14 & -173.92 & -202.70 \\
\hline $\mathrm{Cs}$ & -0.70 & -0.84 & -0.98 & -1.12 & $=1126$ & -1.40 & -1.54 & -1.68 & -1.82 & -1.96 \\
\hline $\mathrm{Eu}$ & -0.11 & -0.23 & -0.36 & -0.49 & $=0.61$ & -0.74 & -0.87 & -0.99 & -1.12 & -1.25 \\
\hline Hf & 1.40 & 0.59 & 0.22 & -1.03 & 2. -1.84 & -2.65 & -3.46 & -4.27 & -5.08 & -5.88 \\
\hline Ho & -0.07 & $=0.22$ & -0.37 & -0.53 & -0.68 & -0.83 & -0.99 & -1.14 & -1.29 & -1.44 \\
\hline $\mathrm{La}$ & -8.87 & -13.44 & -18.02 & 22.59 & 27,17 & -31.75 & -36.32 & -40.90 & -45.47 & -50.05 \\
\hline $\mathrm{Lu}$ & 0.21 & 0.09 & -0.03 & $=0.16$ & 0.28 & -0.41 & -0.53 & -0.66 & -0.78 & -0.90 \\
\hline
\end{tabular}


Appendix 7.2. (coninued)

\begin{tabular}{|c|c|c|c|c|c|c|c|c|c|c|}
\hline $\mathrm{Vol}_{\mathrm{loss}}{ }^{\dagger}$ & 0 & 10 & 20 & 30 & 40 & 50 & 60 & 70 & 80 & 90 \\
\hline $\mathrm{Nd}$ & -8.97 & 11.59 & -14.21 & 1683 & 19,45 & -22.07 & -24.69 & -27.30 & -29.92 & -32.54 \\
\hline Sc & 2.04 & -0.23 & -2.50 & $=4.77$ & 47,05 & -9.32 & -11.59 & -13.87 & -16.14 & -18.41 \\
\hline $\mathrm{Sm}$ & -1.29 & -1.72 & -2.14 & -2.57 & 2.99 & -3.41 & -3.84 & -4.26 & -4.69 & -5.11 \\
\hline $\mathrm{Tb}$ & -0.15 & -0.23 & -0.32 & -0.40 & 0.48 & -0.56 & -0.65 & -0.73 & -0.81 & -0.89 \\
\hline $\mathrm{Yb}$ & 1.06 & 0.34 & -0.37 & -1.08 & $-180^{\circ}$ & -2.51 & -3.23 & -3.94 & -4.65 & -5.37 \\
\hline
\end{tabular}

Reddish-green shale to red shale

$\begin{array}{lllll}\mathrm{SiO}_{2} & 8.85 & 5.97 & 3.09 & 0.21\end{array}$

$\begin{array}{llllll}\mathrm{TiO}_{2} & 0.72 & 0.63 & 0.53 & 0.44\end{array}$

$\begin{array}{lllll}\mathrm{Al}_{2} \mathrm{O}_{3} & 16.27 & 14.03 & 11.79 & 9.55\end{array}$

$\begin{array}{lllll}\mathrm{Fe}_{2} \mathrm{O}_{3} \mathrm{~T} & 23.33 & 19.96 & 16.60 & 13.24\end{array}$

$\mathrm{MnO} \quad-0.92 \quad-0.93 \quad-0.93 \quad-0.94$

$\begin{array}{lllll}\mathrm{MgO} & -11.26 & -11.54 & -11.81 & -12.08\end{array}$

$\begin{array}{lrrrr}\mathrm{CaO} & -17.32 & -17.33 & -17.35 & -17.37 \\ \mathrm{~K}_{2} \mathrm{O} & -0.26 & -0.31 & -0.36 & -0.42\end{array}$

$\begin{array}{lllll}\mathrm{P}_{2} \mathrm{O}_{5} & 0.25 & 0.22 & 0.18 & 0.15\end{array}$

$\begin{array}{lllll}S & -0.01 & -0.01 & -0.01 & -0.01\end{array}$

$\begin{array}{lllll}\mathrm{Ba} & -7.40 & -10.41 & -13.42 & -16.43\end{array}$

$\begin{array}{lllll}\mathrm{Co} & -2.33 & -5.55 & -8.77 & -11.98\end{array}$

$\begin{array}{lllll}\mathrm{Cr} & 65.33 & 50.75 & 36.17 & 21.58\end{array}$

$\begin{array}{lllrr}\mathrm{No} & 12.22 & 10.39 & 8.57 & 6.75\end{array}$

$\begin{array}{lllll}\mathrm{Ni} & 38.83 & 24.70 & 10.56 & -3.57\end{array}$

$\mathrm{Rb} \quad-15.34 \quad-17.90 \quad-20.47 \quad-23.04$

$\begin{array}{lllll}\text { Sr } & 11.03 & 8.58 & 6.13 & 3.67\end{array}$

$\begin{array}{lllll}\mathrm{V} & 15.90 & 7.41 & -1.08 & -9.57\end{array}$

$\begin{array}{lllll}\mathrm{Y} & 39.94 & 33.50 & 27.05 & 20.6\end{array}$

$\begin{array}{lllll}\mathrm{Zn} & 79.48 & 44.48 & 9.48 & -25.52\end{array}$

$\begin{array}{lllll}\mathrm{Zr} & 217.78 & 188.80 & 159.82 & 130.84\end{array}$

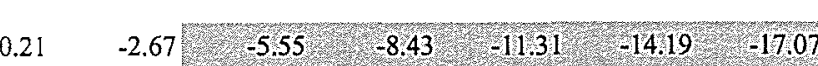

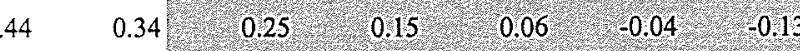

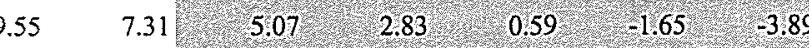

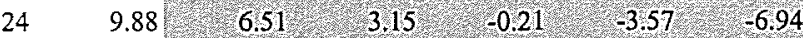

$-0.95 / 40.96 \div 0.96 \% 0.97 \% 0.98 \% 0.99$

$-12.36,-12.63 \times-12.91 \times 13.18 \times 1345 \% 13.73$

$-17.39 \mathrm{~m}-17.41 \times-17.43-17.44 \times-1746)-1748$

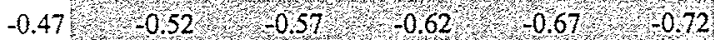

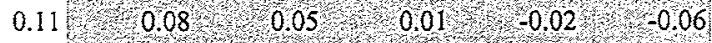

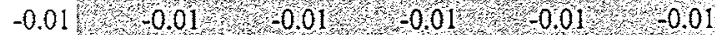

$\begin{array}{llllll}-19.44 & -22.45 & -25.46 & -28.47 & 31.48 & -34.49\end{array}$

$-15.20 \div-18.42 \quad-21.63 \quad-24.85 \quad-28.07 \quad-31.28$

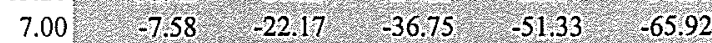

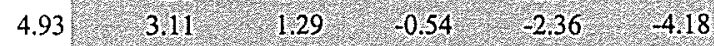

$\begin{array}{lllll}-17.70 & -31.84 & -45.97 & -60.10 & -74.23\end{array}-88.37$

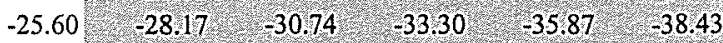

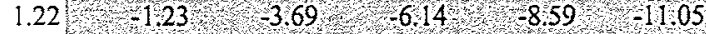

$-18.06 \mathrm{~W}-26.55,-35.04 \times-4353 \times-52.02,-60.51$

$14.16 \mathrm{~m}, 7,2,1.28,-5,17,11.61 \mathrm{~W}, 18.06$

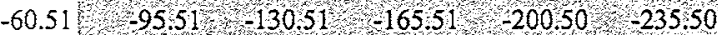

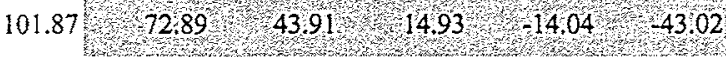

Altered black shale to reddish-green shale

\begin{tabular}{|c|c|c|c|c|c|c|c|c|c|c|}
\hline Vol gain $^{\dagger}$ & 0 & 10 & 20 & 30 & 40 & 50 & 60 & 70 & 80 & 90 \\
\hline $\mathrm{SiO}_{2}$ & -15.03 & -13.05 & -11.07 & -9.09 & -7.11 & -5.13 & -3.15 & -1.17 & 0.81 & 2.79 \\
\hline $\mathrm{TiO}_{2}$ & -0.49 & -0.47 & -0.44 & -0.42 & 20.40 & $=0.38$ & 0.35 & -0.33 & 0.31 & -0.29 \\
\hline $\mathrm{Al}_{2} \mathrm{O}_{3}$ & -13.44 & -12.84 & -12.23 & -11.62 & -11.01 & -10.41 & -9.80 & -919 & -8.58 & -7.97 \\
\hline $\mathrm{Fe}_{2} \mathrm{O}_{3} \mathrm{~T}$ & -13.71 & -12.69 & -11.66 & -10.64 & -9.62 & -8.60 & -7.57 & -6.55 & -5.53 & -4.51 \\
\hline $\mathrm{MnO}$ & 0.83 & 0.92 & 1.02 & 1.12 & 1.22 & -132 & 1.42 & 1,52 & 1.62 & 1.71 \\
\hline $\mathrm{MgO}$ & 8.18 & 9.57 & 10.96 & 12.35 & 1374 & 1513 & 16.52 & 1791 & 1930 & 20.69 \\
\hline $\mathrm{CaO}$ & 16.66 & 18.40 & 20.14 & 21.87 & 23.61 & 2535 & 2708 & 28,82 & 30.56 & 32.29 \\
\hline $\mathrm{K}_{2} \mathrm{O}$ & -0.97 & -0.90 & -0.82 & -0.74 & -0.67 & 0.59 & -0.51 & 0.44 & 036 & -0.28 \\
\hline $\mathrm{P}_{2} \mathrm{O}_{5}$ & -0.03 & -0.02 & -0.01 & 0.00 & 0.01 & 0.02 & 0.03 & 0.04 & 0.04 & 0.05 \\
\hline S & -0.01 & -0.01 & -0.01 & -0.01 & 0,01 & 0.01 & -0.01 & 0.01 & -0.01 & 0.00 \\
\hline $\mathrm{Ba}$ & -10.35 & -6.62 & -2.90 & 0.82 & 4.54 & 8.26 & 11.98 & 15.70 & 19.42 & 23.14 \\
\hline $\mathrm{Co}$ & -25.69 & -22.27 & -18.85 & -15.42 & 12.00 & $=8.58$ & -5.15 & -1.73 & 1.69 & 5.12 \\
\hline $\mathrm{Cr}$ & -58.61 & -50.62 & -42.64 & -34.65 & 26.66 & -18.67 & 10.69 & -2.70 & 5.29 & 13.28 \\
\hline $\mathrm{Nb}$ & -8.49 & -7.90 & -7.30 & -6.71 & -6.11 & -5.52 & -4.92 & -4.33 & -3.73 & -3.14 \\
\hline $\mathrm{Ni}$ & -104.58 & -94.41 & -84.23 & -74.06 & -63.89 & -53.72 & -43.55 & 33.38 & -23.21 & -13.04 \\
\hline $\mathrm{Rb}$ & -51.45 & -47.38 & -43.31 & -39.24 & -35.18 & -31.11 & 27.04 & -2297 & -18.90 & -14.83 \\
\hline $\mathrm{Sr}$ & -17.19 & -15.85 & -14.51 & -13.17 & -1183 & 10.49 & -915 & 7.81 & -6.48 & -5.14 \\
\hline $\mathrm{V}$ & -48.30 & -41.45 & -34.60 & -27.76 & 2091 & 14,06 & -722 & 037 & 6,48 & 13.32 \\
\hline $\mathrm{Y}$ & -23.61 & -21.18 & -18.75 & -16.31 & 13.88 & -11.45 & 9.02 & -6.59 & 4,16 & -1.73 \\
\hline $\mathrm{Zn}$ & -264.32 & -237.48 & -210.64 & -183.80 & 156.95 & 13011 & 10327 & 76,43 & 49.59 & -22.75 \\
\hline $\mathrm{Zr}$ & -160.04 & -152.89 & -145.75 & -138.60 & -131446 & -124.32 & -11717 & 110.03 & 10288 & -95.74 \\
\hline
\end{tabular}

Notes: *mass changes in grans and $10^{-5}$ grams per 100 grams of parent rock for major element oxides and trace elements respectively; light gray areas represenet the plausible volume losses based on geochemical mass/volume calculations and stratigraphic thickness mesurements; $\dagger=$ volume (vol.) changes in percent; volume factor $\left(f_{v}\right)=$ the ratio of altered volume/unaltered volume (ie., (100 - vol. loss)/100); "' = mass loss, no sign signifies mass gain. 
APPENDIX 8

JAMES COOK UNIVERSITY CATALOGUE NUMBERS 
Appendix 8.1. Catalogue of James Cook University sample numbers

\begin{tabular}{|c|c|c|c|c|c|c|c|c|c|c|c|c|c|}
\hline Sample & JCU no. & Location & Unit & & nple & ype & Sample & JCU no. & Location & Unit & & nple & \\
\hline & & & & Pd & Ts & $\mathbf{R k}$ & & & & & Pd & Ts & $\mathrm{Rk}$ \\
\hline Norther & n Hamersl & ley Province & & & & & 4738 & 68547 & $\mathrm{DDH}-47 \mathrm{~A}^{*}$ & DS2 & $\mathrm{X}$ & & $\mathrm{x}$ \\
\hline Banded & iron-format & tion & & & & & 4741 & 68548 & DDH-47A* & DS1 & $\mathrm{x}$ & & \\
\hline 473 & 68496 & $\mathrm{DDH}-47 \mathrm{~A}^{*}$ & DB16 & $\mathrm{x}$ & $\mathrm{X}$ & $\mathrm{X}$ & 4743 & 68549 & $\mathrm{DDH}-47 \mathrm{~A}^{*}$ & McRae & $\mathrm{X}$ & $\mathrm{X}$ & $\mathrm{X}$ \\
\hline 472 & 68497 & $\mathrm{DDH}-47 \mathrm{~A}^{*}$ & DB16 & $\mathrm{x}$ & & $\mathrm{X}$ & 4745 & 68550 & $\mathrm{DDH}-47 \mathrm{~A}^{*}$ & McRae & $\mathrm{X}$ & $\mathrm{X}$ & \\
\hline 4748 & 68498 & DDH-47A* & DB16 & $\mathrm{X}$ & & & Chert-sic & derite & & & & & \\
\hline 4747 & 68499 & $\mathrm{DDH}-47 \mathrm{~A}^{*}$ & DB16 & $\mathrm{X}$ & & & 47W9 & 68551 & $\mathrm{DDH}-47 \mathrm{~A}^{*}$ & Whale & $\mathrm{x}$ & & $X$ \\
\hline 4746 & 68500 & $\mathrm{DDH}-47 \mathrm{~A}^{*}$ & DB16 & $\mathrm{X}$ & & & $47 \mathrm{~W} 2$ & 68552 & DDH-47A* & Whale & $\mathrm{X}$ & & $\mathrm{X}$ \\
\hline 474 & 68501 & $\mathrm{DDH}-47 \mathrm{~A}^{*}$ & DB15 & $x$ & & $x$ & 4710 & 68553 & DDH-47A* & DS13 & $\mathrm{X}$ & & $\mathrm{X}$ \\
\hline 477 & 68502 & $\mathrm{DDH}-47 \mathrm{~A}^{*}$ & DB14 & $\mathrm{x}$ & $X$ & $x$ & 4714 & 68554 & DDH-47A* & $\mathrm{DS} 12$ & $\mathrm{x}$ & & $\mathrm{X}$ \\
\hline 479 & 68503 & $\mathrm{DDH}-47 \mathrm{~A}^{*}$ & DB13 & $\mathrm{X}$ & $\mathrm{X}$ & $\mathrm{X}$ & 4716 & 68555 & $\mathrm{DDH}-47 \mathrm{~A}^{*}$ & DS11 & $X$ & & $\mathrm{X}$ \\
\hline 4712 & 68504 & DDH-47A* & DB12 & $\mathrm{X}$ & & & 4721 & 68556 & $\mathrm{DDH}-47 \mathrm{~A}^{*}$ & DS9 & $\mathrm{x}$ & $\mathrm{x}$ & $\mathrm{X}$ \\
\hline 4715 & 68505 & $\mathrm{DDH}-47 \mathrm{~A}^{*}$ & DBII & $\mathrm{X}$ & $\mathrm{X}$ & $\mathrm{x}$ & $4725 \mathrm{~A}$ & 68557 & DDH-47A* & DS7 & $\mathrm{X}$ & & $\mathrm{X}$ \\
\hline 4719 & 68506 & $\mathrm{DDH}-47 \mathrm{~A}^{*}$ & DB10 & $\mathrm{x}$ & & $\mathrm{X}$ & 4728 & 68558 & $\mathrm{DDH}-47 \mathrm{~A}^{*}$ & DS6 & $\mathrm{x}$ & & $\mathrm{X}$ \\
\hline 4722 & 68507 & $\mathrm{DDH}-47 \mathrm{~A}^{*}$ & DB8 & $\mathrm{x}$ & $X$ & $\mathrm{x}$ & 4731 & 68559 & DDH-47A* & DS5 & $\mathrm{x}$ & $\mathrm{X}$ & $\mathrm{X}$ \\
\hline 4724 & 68508 & DDH-47A* & DB7 & $\mathrm{X}$ & & $\mathrm{x}$ & Shaley $B$ & & & & & & \\
\hline 4729 & 68509 & DDH-47A* & DB5 & $\mathrm{x}$ & & & $47 \mathrm{~W} 8$ & 68560 & $\mathrm{DDH}-47 \mathrm{~A}^{*}$ & Whale & $\mathrm{x}$ & $\mathrm{x}$ & $\mathrm{x}$ \\
\hline 4735 & 68510 & DDH-47A* & DB3 & $\mathrm{x}$ & $\mathrm{x}$ & $\mathrm{X}$ & $47 \mathrm{~W} 7$ & 68561 & $\mathrm{DDH}-47 \mathrm{~A}^{*}$ & Whale & $\mathrm{X}$ & & $\mathrm{x}$ \\
\hline 4737 & 68511 & $\mathrm{DDH}-47 \mathrm{~A}^{*}$ & DB2 & $\mathrm{x}$ & $\mathrm{X}$ & $\mathrm{x}$ & $47 \mathrm{~W} 3$ & 68562 & $\mathrm{DDH}-47 \mathrm{~A}^{*}$ & Whale & $\mathrm{x}$ & & $\mathrm{X}$ \\
\hline 4739 & 68512 & $\mathrm{DDH}-47 \mathrm{~A}^{*}$ & DBI & $\mathrm{X}$ & & & $47 \mathrm{~W} 4$ & 68563 & DDH-47A* & Whale & $\mathrm{x}$ & $\mathrm{X}$ & $\mathrm{X}$ \\
\hline 4740 & 68513 & DDH-47A* & DB1 & $\mathrm{X}$ & & $\mathrm{X}$ & Southea & stern Ham & aersely Provine & & & & \\
\hline 4742 & 68514 & $\mathrm{DDH}-47 \mathrm{~A}^{*}$ & DB0 & $\mathrm{x}$ & $\mathrm{X}$ & $\mathrm{x}$ & Weather & ed BIF & & & & & \\
\hline JGA10 & 68515 & DDH-JGI & DB3 & $\mathrm{X}$ & $\mathrm{X}$ & $\mathrm{X}$ & WW9 & 68564 & Weelli Wolli & DB16 & $x$ & $\mathrm{x}$ & \\
\hline JGA7 & 68516 & DDH-JGI & $\mathrm{DB} 2$ & $\mathrm{X}$ & $\mathrm{x}$ & $x$ & WW10 & 68565 & Weelli Wolli & DB15 & $\mathrm{x}$ & & \\
\hline JGA4 & 68517 & DDH-JGI & DBI & $\mathrm{X}$ & & & WW11 & 68566 & Weelli Wolli & DB14 & $\mathrm{x}$ & $\mathrm{X}$ & $\mathrm{x}$ \\
\hline BG1 & 68518 & Bee Gorge & DB16 & $\mathrm{X}$ & $\mathrm{X}$ & & WW12 & 68567 & Weelli Wolli & DB13 & $\mathrm{x}$ & & \\
\hline BG2 & 68519 & Bee Gorge & DB14 & $\mathrm{X}$ & $X$ & & WW13 & 68568 & Weelli Wolli & $\mathrm{DB} 12$ & $\mathrm{X}$ & & \\
\hline BG4 & 68520 & Bee Gorge & DB13 & $\mathrm{X}$ & $\mathrm{x}$ & & WW8 & 68569 & Weelli Wolli & DB6 & $\mathrm{X}$ & & \\
\hline BG6 & 68521 & Bee Gorge & $\mathrm{DB} 12$ & $\mathrm{X}$ & $\mathrm{X}$ & & WW7 & 68570 & Weelli Wolli & DB5 & $\mathrm{X}$ & & \\
\hline BG8 & 68522 & Bee Gorge & DB11 & $\mathrm{X}$ & & & WW6 & 68571 & Weelli Wolli & DB4 & $\mathrm{X}$ & $X$ & $X$ \\
\hline BG10 & 68523 & Bee Gorge & DB10 & $\mathrm{X}$ & & & WW4 & 68572 & Weelli Wolli & DB3 & $\mathrm{X}$ & & \\
\hline Black sh & iale & & & & & & WW3 & 68573 & Weelli Wolli & $\mathrm{DB} 2$ & $x$ & & \\
\hline $47 W 11$ & 68524 & DDH-47A* & Whale & $X$ & & $\mathrm{X}$ & WW2 & 68574 & Weelli Wolli & $\mathrm{DB} 1$ & $X$ & & \\
\hline $47 W 10$ & 68525 & $\mathrm{DDH}-47 \mathrm{~A}^{*}$ & Whale & $X$ & & & WW1 & 68575 & Weelli Wolli & DB0 & $X$ & $\mathrm{X}$ & $\mathrm{X}$ \\
\hline $47 \mathrm{Wl}$ & 68526 & $\mathrm{DDH}-47 \mathrm{~A}^{*}$ & Whale & $\mathrm{x}$ & & $x$ & MR17 & 68576 & Mt. Robinson & DB16 & $X$ & & \\
\hline $47 \mathrm{~W} 6$ & 68527 & $\mathrm{DDH}-47 \mathrm{~A}^{*}$ & Whale & $x$ & $\mathrm{X}$ & $\mathrm{x}$ & MR16 & 68577 & Mt. Robinson & $\mathrm{DB} 15$ & $\mathrm{X}$ & & \\
\hline $47 \mathrm{~W} 5$ & 68528 & DDH-47A* & Whale & $\mathrm{x}$ & & $\mathrm{x}$ & MR15 & 68578 & Mt. Robinson & DB 14 & $X$ & & \\
\hline AW44 & 68529 & DDH-47A* & DS16 & $\mathrm{x}$ & & & MR 14 & 68579 & Mt. Robinson & DB13 & $x$ & $x$ & $\mathrm{X}$ \\
\hline 475 & 68530 & $\mathrm{DDH}-47 \mathrm{~A}^{*}$ & DS15 & $\mathrm{X}$ & & $X$ & MR13 & 68580 & Mt. Robinson & $\mathrm{DB} 12$ & $X$ & & \\
\hline 478 & 68531 & DDH-47A* & DS14 & $\mathrm{X}$ & & & MR12 & 68581 & Mt. Robinson & DB 11 & $X$ & $\mathrm{X}$ & \\
\hline 4711 & 68532 & DDH-47A* & DS13 & $x$ & & & MRIO & 68582 & Mt. Robinson & DB9 & $X$ & & \\
\hline 4713 & 68533 & DDH-47A* & DS 12 & $\mathrm{X}$ & & & MR9 & 68583 & Mt. Robinson & DB8 & $X$ & & \\
\hline AW43 & 68534 & DDH-47A* & DS11 & $\mathrm{X}$ & & & MR8 & 68584 & Mt. Robinson & DB7 & $X$ & & \\
\hline 4718 & 68535 & $\mathrm{DDH}-47 \mathrm{~A}^{*}$ & DSI1 & $x$ & & $X$ & MR7 & 68585 & Mt. Robinson & DB6 & $\mathrm{X}$ & $\mathrm{X}$ & $X$ \\
\hline 4720 & 68536 & $\mathrm{DDH}-47 \mathrm{~A}^{*}$ & DS 10 & $x$ & & & MR6 & 68586 & Mt. Robinson & DB5 & $\mathrm{X}$ & & \\
\hline AW42 & 68537 & DDH-47A* & DS9 & $\mathrm{X}$ & & & MR5 & 68587 & Mt. Robinson & DB4 & $\mathrm{X}$ & & \\
\hline 4723 & 68538 & DDH-47A* & DS8 & $X$ & & & MR4 & 68588 & Mt. Robinson & DB3 & $\mathrm{X}$ & $X$ & \\
\hline 4725 & 68539 & DDH-47A* & DS7 & $\mathrm{X}$ & & & MR3 & 68589 & Mt. Robinson & $\mathrm{DB} 2$ & $x$ & & \\
\hline 4726 & 68540 & $\mathrm{DDH}-47 \mathrm{~A}^{*}$ & DS6 & $\mathrm{x}$ & & $\mathrm{x}$ & MR2 & 68590 & Mt. Robinson & DB1 & $\mathrm{X}$ & & \\
\hline 4727 & 68541 & $\mathrm{DDH}-47 \mathrm{~A}^{*}$ & DS6 & $\mathrm{x}$ & $\mathrm{x}$ & $x$ & MR1 & 68591 & Mt. Robinson & DB0 & $\mathrm{x}$ & $\mathrm{X}$ & $\mathrm{x}$ \\
\hline 4730 & 68542 & $\mathrm{DDH}-47 \mathrm{~A}^{*}$ & DS5 & $x$ & & $\mathrm{x}$ & $\mathrm{PH} 1$ & 68592 & Pamelia Hill & DB16 & $\mathrm{X}$ & & \\
\hline 4732 & 68543 & $\mathrm{DDH}-47 \mathrm{~A}^{*}$ & DS4 & $\mathrm{X}$ & $\mathrm{x}$ & $\mathrm{x}$ & $\mathrm{PH} 2$ & 68593 & Pamelia Hill & $\mathrm{DB} 15$ & $\mathrm{X}$ & $X$ & $\mathrm{X}$ \\
\hline 4733 & 68544 & $\mathrm{DDH}-47 \mathrm{~A}^{*}$ & DS4 & $\mathrm{x}$ & & $\mathrm{x}$ & PH3 & 68594 & Pamelia Hill & $\mathrm{DB} 14$ & $\mathrm{x}$ & & \\
\hline 4736 & 68545 & DDH-47A* & DS3 & $x$ & & $\mathrm{X}$ & PH4 & 68595 & Pamelia Hill & DB12 & $\mathrm{X}$ & & \\
\hline AW41 & 68546 & $\mathrm{DDH}-47 \mathrm{~A}^{*}$ & $\mathrm{DS} 2$ & $\mathrm{X}$ & & & PH5 & 68596 & Pamelia Hill & DB11 & $X$ & $x$ & \\
\hline
\end{tabular}


Appendix 8.1. (continued)

\begin{tabular}{|c|c|c|c|c|c|c|}
\hline \multirow[t]{2}{*}{ Sample } & \multirow[t]{2}{*}{ JCU no. } & \multirow[t]{2}{*}{ Location } & \multirow[t]{2}{*}{ Unit } & \multicolumn{3}{|c|}{ Sample type } \\
\hline & & & & $\mathbf{P d}$ & Ts & $\mathbf{R k}$ \\
\hline PH6 & 68597 & Pamelia Hill & $\mathrm{DB} 10$ & $\mathrm{X}$ & & \\
\hline PH7 & 68598 & Pamelia Hill & DB7 & $\mathrm{X}$ & & \\
\hline PH8 & 68599 & Pamelia Hill & DB6 & $\mathrm{X}$ & $\mathrm{X}$ & \\
\hline PH9 & 68600 & Pamelia Hill & DB5 & $X$ & & \\
\hline PH10 & 68601 & Pamelia Hill & DB4 & $X$ & & \\
\hline PH11 & 68602 & Pamelia Hill & DB3 & $\mathrm{X}$ & $\mathrm{X}$ & \\
\hline PH12 & 68603 & Pamelia Hill & DB2 & $X$ & & \\
\hline PH13 & 68604 & Pamelia Hill & $\mathrm{DB} 1$ & $\mathrm{X}$ & & \\
\hline PH14 & 68605 & Pamelia Hill & DBO & $\mathrm{X}$ & $X$ & $\mathrm{X}$ \\
\hline $\mathrm{C} 17$ & 68606 & Cathedral & DB16 & $\mathrm{X}$ & $\mathrm{X}$ & \\
\hline $\mathrm{C} 16$ & 68607 & Cathedral & DB15 & $\mathrm{X}$ & $x$ & $\mathrm{x}$ \\
\hline $\mathrm{C} 15$ & 68608 & Cathedral & DB14 & $\mathrm{X}$ & & \\
\hline $\mathrm{C} 14$ & 68609 & Cathedral & DB13 & $X$ & & \\
\hline $\mathrm{C} 13$ & 68610 & Cathedral & $\mathrm{DB} 12$ & $\mathrm{X}$ & & \\
\hline $\mathrm{C} 12$ & 68611 & Cathedral & DB11 & $\mathrm{X}$ & $\mathrm{X}$ & \\
\hline $\mathrm{C} 11$ & 68612 & Cathedral & DB10 & $\mathrm{X}$ & & \\
\hline $\mathrm{ClO}$ & 68613 & Cathedral & DB9 & $X$ & $\mathrm{X}$ & $\mathrm{x}$ \\
\hline $\mathrm{C} 9$ & 68614 & Cathedral & DB8 & $\mathrm{X}$ & $X$ & \\
\hline $\mathrm{C} 8$ & 68615 & Cathedral & DB7 & $\mathrm{X}$ & & \\
\hline $\mathrm{C} 7$ & 68616 & Cathedral & DB6 & $\mathrm{X}$ & $\mathrm{X}$ & \\
\hline $\mathrm{C} 6$ & 68617 & Cathedral & DB5 & $\mathrm{X}$ & & \\
\hline $\mathrm{C} 5$ & 68618 & Cathedral & DB4 & $\mathrm{X}$ & & \\
\hline $\mathrm{C} 4$ & 68619 & Cathedral & DB3 & $x$ & $\mathrm{X}$ & \\
\hline $\mathrm{C} 3$ & 68620 & Cathedral & DB2 & $\mathrm{X}$ & & \\
\hline $\mathrm{C} 2$ & 68621 & Cathedral & DB1 & $\mathrm{X}$ & & \\
\hline $\mathrm{C} 1$ & 68622 & Cathedral & DB0 & $x$ & $\mathrm{X}$ & $\mathrm{x}$ \\
\hline \multicolumn{7}{|c|}{ Oxidized BIF } \\
\hline $4 W 17$ & 68623 & Fourth West & DB16 & $\mathrm{X}$ & $\mathrm{X}$ & \\
\hline $4 W 16$ & 68624 & Fourth West & DB15 & $\mathrm{X}$ & $X$ & $\mathrm{x}$ \\
\hline $4 W 15$ & 68625 & Fourth West & DB14 & $\mathrm{X}$ & & \\
\hline $4 W 14$ & 68626 & Fourth West & DB13 & $X$ & & \\
\hline $4 W 13$ & 68627 & Fourth West & DB12 & $\mathrm{X}$ & & $\mathrm{x}$ \\
\hline $4 W 12$ & 68628 & Fourth West & DB11 & $\mathrm{X}$ & $\mathrm{X}$ & \\
\hline $4 W 11$ & 68629 & Fourth West & DB10 & $\mathrm{X}$ & & \\
\hline $4 W 10$ & 68630 & Fourth West & DB9 & $\mathrm{X}$ & & \\
\hline 4W9 & 68631 & Fourth West & DB8 & $\mathrm{X}$ & & \\
\hline $4 W 8$ & 68632 & Fourth West & DB7 & $\mathrm{X}$ & & \\
\hline $4 \mathrm{~W} 7$ & 68633 & Fourth West & DB6 & $\mathrm{X}$ & & \\
\hline $4 \mathrm{~W} 6$ & 68634 & Fourth West & DB5 & $\mathrm{X}$ & & \\
\hline 4 W5 & 68635 & Fourth West & DB4 & $\mathrm{X}$ & & \\
\hline $4 \mathrm{~W} 4$ & 68636 & Fourth West & DB3 & $\mathrm{X}$ & & \\
\hline $4 \mathrm{~W} 3$ & 68637 & Fourth West & DB2 & $\mathrm{X}$ & & \\
\hline $4 \mathrm{~W} 2$ & 68638 & Fourth West & DBl & $\mathrm{X}$ & & \\
\hline $4 \mathrm{~W} 1$ & 68639 & Fourth West & DB0 & $\mathrm{X}$ & & \\
\hline \multicolumn{7}{|c|}{ Mt. Whaleback pit } \\
\hline \multicolumn{7}{|c|}{ Oxidized BIF } \\
\hline D73A & 68640 & DDH-73 & DB16 & $\mathrm{x}$ & $\mathrm{x}$ & $\mathrm{X}$ \\
\hline D73C & 68641 & DDH-73 & DB16 & $\mathrm{X}$ & $\mathrm{x}$ & $\mathrm{x}$ \\
\hline D73D & 68642 & DDH-73 & DB16 & $\mathrm{X}$ & & \\
\hline D86C & 68643 & DDH-86 & $\mathrm{DB} 15$ & $\mathrm{X}$ & & \\
\hline D86D & 68644 & DDH-86 & $\mathrm{DB} 15$ & $\mathrm{X}$ & $\mathrm{X}$ & \\
\hline D86E & 68645 & DDH-86 & DB15 & $\mathrm{X}$ & & \\
\hline D86F & 68646 & DDH-86 & DB15 & $\mathrm{X}$ & & \\
\hline $\mathrm{A} 24 \mathrm{C}$ & 68647 & Pit face & DB16 & $\mathrm{X}$ & $\mathrm{X}$ & $X$ \\
\hline $\mathrm{B} 24 \mathrm{C}$ & 68648 & Pit face & DB16 & $\mathrm{X}$ & $\mathrm{X}$ & $\mathrm{X}$ \\
\hline
\end{tabular}

\begin{tabular}{|c|c|c|c|c|c|c|}
\hline \multirow[t]{2}{*}{ Sample } & \multirow[t]{2}{*}{ JCU no. } & \multirow[t]{2}{*}{ Location } & \multirow[t]{2}{*}{ Unit } & \multicolumn{3}{|c|}{ Sample type } \\
\hline & & & & Pd & Ts & $\mathbf{R k}$ \\
\hline $\mathrm{C} 24 \mathrm{C}$ & 68649 & Pit face & $\mathrm{DB} 16$ & $x$ & $\mathrm{X}$ & \\
\hline F24C & 68650 & Pit face & DB16 & $x$ & $\mathrm{X}$ & $\mathrm{x}$ \\
\hline $\mathrm{G} 24 \mathrm{C}$ & 68651 & Pit face & DB16 & $\mathrm{X}$ & & \\
\hline \multicolumn{7}{|c|}{ Iron Ore } \\
\hline D73B & 68652 & DDH-73 & $\mathrm{DB} 16$ & $\mathrm{x}$ & & \\
\hline D73E & 68653 & DDH-73 & DB16 & $\mathrm{x}$ & & \\
\hline D86A & 68654 & DDH-86 & DBl6 & $\mathrm{X}$ & & \\
\hline AW29 & 68655 & DDH-257 & Whale & $\mathrm{X}$ & & \\
\hline AW30 & 68656 & DDH-257 & Whale & $\mathrm{X}$ & & \\
\hline AW 15 & 68657 & DDH-324 & McRae & $\mathrm{x}$ & & \\
\hline AWI6 & 68658 & DDH-324 & McRae & $x$ & & \\
\hline WS6 & 68659 & Pit face & Whale & $x$ & & \\
\hline D24C & 68660 & Pit face & DBI6 & $\mathrm{X}$ & & $\mathrm{X}$ \\
\hline $\mathrm{E} 24 \mathrm{C}$ & 68661 & Pit face & DB16 & $\mathrm{X}$ & $\mathrm{X}$ & $X$ \\
\hline $\mathrm{E} 25 \mathrm{E}$ & 68662 & Pit face & DB15 & $\mathrm{X}$ & $\mathrm{X}$ & $\mathrm{x}$ \\
\hline A25E & 68663 & Pit face & DB11 & $\mathrm{X}$ & & $\mathrm{X}$ \\
\hline $\mathrm{B} 25 \mathrm{E}$ & 68664 & Pit face & DB11 & $x$ & & $\mathrm{X}$ \\
\hline 6BEDC & 68665 & Pit face & DB6 & $\mathrm{x}$ & & $\mathrm{X}$ \\
\hline SBEDC & 68666 & Pit face & DB5 & $\mathrm{X}$ & $\mathrm{X}$ & $\mathrm{X}$ \\
\hline 4AEDC & 68667 & Pit face & DB4 & $\mathrm{x}$ & & $\mathrm{X}$ \\
\hline 3BEDC & 68668 & Pit face & DB3 & $x$ & & $x$ \\
\hline 1123 & 68669 & Pit face & DB0 & $x$ & $\mathrm{X}$ & $\mathrm{x}$ \\
\hline 323 & 68670 & Pit face & McRae & $\mathrm{X}$ & & \\
\hline 523 & 68671 & Pit face & McRae & $\mathrm{x}$ & & \\
\hline 723 & 68672 & Pit face & McRae & $\mathrm{X}$ & & \\
\hline 923 & 68673 & Pit face & McRae & $\mathrm{X}$ & & \\
\hline \multicolumn{7}{|c|}{ Altered Black Shale } \\
\hline AW22A & 68674 & DDH-257 & Whale & $\mathrm{x}$ & & $\mathrm{X}$ \\
\hline AW22B & 68675 & DDH-257 & Whale & $\mathrm{X}$ & & \\
\hline SBS4 & 68676 & DDH-257 & Whale & $\mathrm{x}$ & & \\
\hline $\mathrm{AW} 24$ & 68677 & DDH-257 & Whale & $\mathrm{X}$ & & \\
\hline AW25 & 68678 & DDH-257 & Whale & $\mathrm{X}$ & & \\
\hline SBS7 & 68679 & DDH-257 & Whale & $\mathrm{X}$ & & \\
\hline AW26 & 68680 & DDH-257 & Whale & $\mathrm{X}$ & & \\
\hline AW 18 & 68681 & DDH-324 & McRae & $\mathrm{x}$ & & $\mathrm{X}$ \\
\hline AW19 & 68682 & DDH-324 & McRae & $\mathrm{x}$ & & $\mathrm{X}$ \\
\hline AW20 & 68683 & DDH-324 & McRae & $\mathrm{X}$ & & $\mathrm{X}$ \\
\hline AW21 & 68684 & DDH-324 & McRae & $\mathrm{x}$ & & \\
\hline $224 \mathrm{C}$ & 68685 & Pit face & Whale & $\mathrm{x}$ & & \\
\hline $224 \mathrm{E}$ & 68686 & Pit face & Whale & $\mathrm{x}$ & & $x$ \\
\hline WSI & 68687 & Pit face & Whale & $\mathrm{x}$ & & \\
\hline WS3 & 68688 & Pit face & Whale & $\mathrm{x}$ & & \\
\hline WS11 & 68689 & Pit face & Whale & $x$ & & \\
\hline G25E & 68690 & Pit face & DS16 & $\mathrm{x}$ & & \\
\hline $\mathrm{H} 25 \mathrm{E}$ & 68691 & Pit face & DS16 & $\mathrm{x}$ & $\mathrm{X}$ & \\
\hline $\mathrm{RC}$ & 68692 & Pit face & McRae & $\mathrm{x}$ & $\mathrm{X}$ & \\
\hline 123 & 68693 & Pit face & McRae & $\mathrm{x}$ & & $\mathrm{x}$ \\
\hline $125 \mathrm{E}$ & 68694 & Pit face & McRae & $\mathrm{X}$ & & \\
\hline $225 \mathrm{E}$ & 68695 & Pit face & McRae & $\mathrm{x}$ & $\mathrm{X}$ & $\mathrm{X}$ \\
\hline \multicolumn{7}{|c|}{ Red Shale } \\
\hline D86B & 68696 & DDH-86 & DS16 & $\mathrm{x}$ & $\mathrm{X}$ & \\
\hline AW31 & 68697 & DDH-229 & Whale & $\mathrm{x}$ & & \\
\hline AW32 & 68698 & DDH-229 & Whale & $\mathrm{x}$ & & \\
\hline AW36 & 68699 & DDH-229 & Whale & $\mathrm{X}$ & & \\
\hline AW37 & 68700 & DDH-229 & Whale & $\mathrm{x}$ & & \\
\hline
\end{tabular}


Appendix 8.1. (continued)

\begin{tabular}{|c|c|c|c|c|c|c|c|c|c|c|c|c|}
\hline \multirow[t]{2}{*}{ Sample } & \multirow[t]{2}{*}{ JCU no. } & \multirow[t]{2}{*}{ Location } & \multirow[t]{2}{*}{ Unit } & \multicolumn{2}{|c|}{ Sample type } & \multirow{2}{*}{\multicolumn{2}{|c|}{ Sample JCU no. }} & \multirow[t]{2}{*}{ Location } & \multirow[t]{2}{*}{ Unit } & \multicolumn{3}{|c|}{ Sample type } \\
\hline & & & & $\mathbf{P d}$ & Ts $\quad R k$ & & & & & Pd & Ts & Rk \\
\hline AW38 & 68701 & DDH-229 & Whale & $\mathrm{X}$ & & 823 & 68735 & Pit face & McRae & $\mathrm{X}$ & & \\
\hline AW39A & 68702 & DDH-229 & Whale & $x$ & & 1023 & 68736 & Pit face & McRae & $\mathrm{X}$ & $x$ & \\
\hline AW39B & 68703 & DDH-229 & Whale & $X$ & & 1223 & 68737 & Pit face & McRae & $\mathrm{X}$ & & \\
\hline AW40 & 68704 & DDH-229 & Whale & $\mathrm{X}$ & & $325 \mathrm{E}$ & 68738 & Pit face & McRae & $x$ & $X$ & \\
\hline AW27 & 68705 & DDH-257 & Whale & $X$ & & $425 \mathrm{E}$ & 68739 & Pit face & McRae & $X$ & & $X$ \\
\hline SBS9 & 68706 & $\mathrm{DDH}-257$ & Whale & $\mathrm{X}$ & & $525 \mathrm{E}$ & 68740 & Pit face & McRae & $\mathrm{X}$ & & $\mathrm{X}$ \\
\hline AW17 & 68707 & DDH-324 & McRae & $\mathrm{X}$ & $\mathrm{X}$ & Shaley 0 & & & & & & \\
\hline $124 \mathrm{C}$ & 68708 & Pit face & Whale & $X$ & & D73F & 68741 & DDH-73 & DS 16 & $X$ & & \\
\hline $324 \mathrm{C}$ & 68709 & Pit face & Whale & $\mathrm{x}$ & $\mathrm{x}$ & AW33 & 68742 & DDH-229 & Whale & $X$ & & \\
\hline $424 \mathrm{C}$ & 68710 & Pit face & Whale & $\mathrm{X}$ & $\mathrm{x}$ & AW34 & 68743 & DDH-229 & Whale & $x$ & & \\
\hline WS5 & 68711 & Pit face & Whale & $\mathrm{X}$ & & AW35 & 68744 & DDH-229 & Whale & $\mathrm{X}$ & & \\
\hline WS9 & 68712 & Pit face & Whale & $\mathrm{x}$ & & AW39 & 68745 & DDH-229 & Whale & $\mathrm{x}$ & & \\
\hline AW 14 & 68713 & Pit face & DS16 & $\mathrm{x}$ & & SBS2 & 68746 & DDH-257 & Whale & $\mathrm{X}$ & & \\
\hline $\mathrm{I} 25 \mathrm{E}$ & 68714 & Pit face & DS16 & $x$ & & SBS3 & 68747 & DDH-257 & Whale & $\mathrm{X}$ & & \\
\hline AW13 & 68715 & Pit face & DS15 & $\mathrm{x}$ & & AW22 & 68748 & DDH-257 & Whale & $\mathrm{x}$ & & \\
\hline$A W_{12}$ & 68716 & Pit face & DS14 & $\mathrm{x}$ & & AW23 & 68749 & DDH-257 & Whale & $\mathrm{X}$ & & \\
\hline AW11 & 68717 & Pit face & $\mathrm{DS} 13$ & $\mathrm{x}$ & & SBS8 & 68750 & DDH-257 & Whale & $\mathrm{x}$ & & \\
\hline $\mathrm{AW} 10$ & 68718 & Pit face & $\mathrm{DS} 12$ & $\mathrm{x}$ & & AW28 & 68751 & DDH-257 & Whale & $\mathrm{x}$ & & \\
\hline $\mathrm{C} 25 \mathrm{E}$ & 68719 & Pit face & DS11 & $\mathrm{X}$ & & AW28B & 68752 & DDH-257 & Whale & $\mathrm{X}$ & & \\
\hline $\mathrm{D} 25 \mathrm{E}$ & 68720 & Pit face & DS11 & $\mathrm{X}$ & & WS7 & 68753 & Pit face & Whale & $\mathrm{X}$ & & \\
\hline AW9 & 68721 & Pit face & DS11 & $\mathrm{X}$ & $X$ & WS8 & 68754 & Pit face & Whale & $x$ & & \\
\hline $1025 \mathrm{E}$ & 68722 & Pit face & DS10 & $\mathrm{X}$ & $\mathrm{X}$ & F25E & 68755 & Pit face & DS15 & $\mathrm{x}$ & & \\
\hline AW8 & 68723 & Pit face & DS10 & $X$ & & 423 & 68756 & Pit face & McRae & $\mathrm{X}$ & & \\
\hline AW6 & 68724 & Pit face & DS9 & $\mathrm{X}$ & & 623 & 68757 & Pit face & McRae & $x$ & & \\
\hline AW5 & 68725 & Pit face & DS8 & $X$ & & Mt. McR & Rae Shale & & & & & \\
\hline AW4 & 68726 & Pit face & DS7 & $x$ & & D4091 & 68758 & DDH-409 & McRae & $X$ & & \\
\hline AW3 & 68727 & Pit face & DS6 & $\mathrm{X}$ & & D4092 & 68759 & DDH-409 & McRae & $\mathrm{x}$ & $\mathrm{X}$ & $X$ \\
\hline $6 \mathrm{EDC}$ & 68728 & Pit face & DS6 & $\mathrm{x}$ & $\mathrm{X}$ & D4094 & 68760 & DDH-409 & McRae & $x$ & $x$ & $X$ \\
\hline AW2 & 68729 & Pit face & DS5 & $\mathrm{X}$ & & D4096 & 68761 & $\mathrm{DDH}-409$ & McRae & $\mathrm{X}$ & $\mathrm{X}$ & $X$ \\
\hline $\mathrm{AWl}$ & 68730 & Pit face & DS4 & $x$ & & D4097 & 68762 & DDH-409 & McRae & $\mathrm{X}$ & $\mathrm{X}$ & $X$ \\
\hline 4EDC & 68731 & Pit face & DS4 & $\mathrm{X}$ & $\mathrm{x}$ & D4099 & 68763 & DDH-409 & McRae & $X$ & & \\
\hline $3 \mathrm{EDC}$ & 68732 & Pit face & DS3 & $\mathrm{X}$ & & D40910 & 68764 & DDH-409 & McRae & $X$ & & \\
\hline $5 \mathrm{~A} 23$ & 68733 & Pit face & McRae & $X$ & $x$ & D40912 & 68765 & DDH-409 & McRae & $X$ & & \\
\hline
\end{tabular}

Notes: No. $=$ number; $\mathrm{Pd}=$ Powder; $\mathrm{Ts}=$ thin-section; $\mathrm{Rk}=$ rock; Whale $=$ Whaleback Shale Member; $\mathrm{DB}=$ Dales Gorge BIF macroband; DS = Dales Gorge Shale macroband; McRae = Mt. McRae Shale; Pit face $=$ fresh mine faces in Mt. Whaleback. 